Minnet av

\title{
BENGT NORDBERG
}

ÄGNAS DETTA NUMMER AV

SPRÅK OCH STIL 



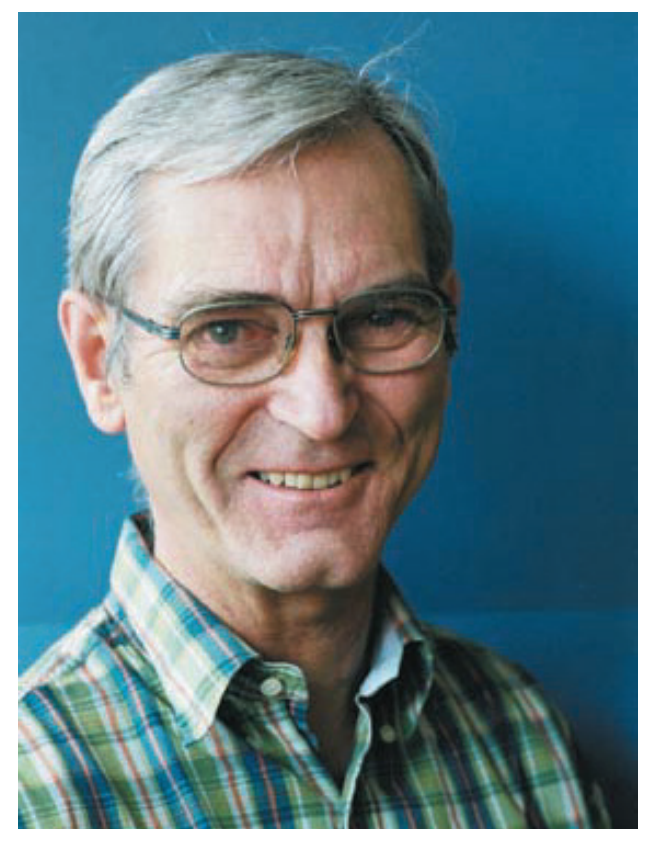

BENGT NORDBERG

* 8.8.1936 +27.9 .2019$ 

Språk och stil

\author{
TIDSKRIFT FÖR \\ SVENSK SPRÅKFORSKNING
}

eddy.se $a b$

e-post: order@bokorder.se 


\title{
Utgiven med stöd av Vetenskapsrådet
}

\author{
Utgiven med stöd av \\ Ares \\ SLS SVenska litteratursällskapet I FinLAND \\ Dingrid, Margit och Henrik Höijers donationsfond II
}

Språk och stils redaktion tar hjälp av externa manusgranskare för att avgöra vilka bidrag som ska antas till publicering. Inför bearbetningen av sina manus har också artikelförfattarna fått ta del av referenternas utlåtanden. Redaktionen tackar följande personer för värdefulla referentinsatser under arbetet på Språk och stil 29:

Memet Aktürk-Drake, Peter Andersson, Björn Bihl, Anders Björkvall, Maria Bylin, Marja Etelämäki, Erik Falk, Britt-Louise Gunnarsson, Saara Haapamäki, Fred Karlsson, Leelo Keevalik, Håkan Landqvist, Jannika Lassus, Hanna Lehti-Eklund, Lena Lind Palicki, Katarina Lundin, Karin Milles, Marie Nelson, Lina Nyroos, Claes Ohlsson, Åsa Palviainen, Beatrice Silén, Jan Svanlund, Marie Sörlin, Sofia Tingsell, Orla Vigsø, Karolina Wirdenäs, Jan-Ola Östman.

De engelska sammanfattningarna har språkgranskats av fil.dr Donald MacQueen.

(C) Författarna och Språk och stil

ISSN 1101-1165

Textgruppen i Uppsala AB, Uppsala 2019 


\section{Innehåll}

Martina Huhtamäki, Inga-Lill Grahn, Jan Lindström, Jenny Nilsson, Catrin Norrby \& Camilla Wide: Frasformade instruktioner med uppföljningar

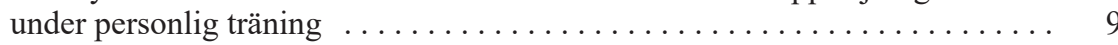

Ingela Tykesson, Linda Kahlin \& Mihaela Oana Romanitan: Utvecklingen av interaktionell kompetens hos läkare som lär sig svenska. Mönster i fråge-

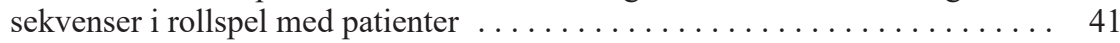

Klara Bertils \& Simon Magnusson: Att koka ihop ett beslut. En multimodal interaktionsanalys av gemensamt beslutsfattande $\mathrm{i}$ vardagen $\ldots \ldots \ldots \ldots . \ldots 73$

Per Ledin \& David Machin: Att rädda planeten genom konsumtionsval. Oatlys antagonistiska och lekfulla marknadskommunikation . . . . . . . . . . . 99

Ulla Stroh-Wollin: Gällande gällande och andra avseendemarkörer . . . . . . . . 134

Joel Olofsson: Frekvens som mått på produktivitet. En konstruktionsgrammatisk undersökning av förflyttningskonstruktioner i svenskan . . . . . . 168

Jenny Nilsson \& Susanne Nylund Skog: Dialekter, platser och identiteter. Språk- och kulturvetenskapliga förklaringar till språklig förändring och stabilitet i Torsby och Edsbyn . . . . . . . . . . . . . . . . . . . 203

Per Klang: Perspektiv på paradigm. Kuhns paradigmbegrepp och språkveten-

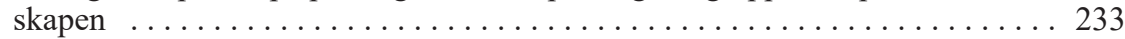

Smärre bidrag

Olof Eriksson: Legend och legendar - reflektioner kring en lexikal kon-

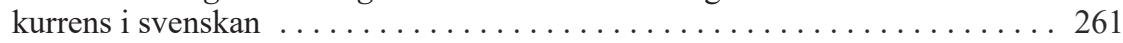

\section{Recensioner}

Fremer, Maria: Tilltal i reklamfilm. Du-reformen i ett historiskt perspektiv (2018). Rec. av Björn Melander

Loenheim, Lisa: Att tolka det sammansatta. Befästning och mönster i förstaoch andraspråkstalares tolkning av sammansättningar (2019). Rec. av Steffen Höder . . . . . . . . . . . . . . . . . . . . . . . . . . . . . . . . . . . . . . . 271

Lundin, Katarina: Att utbildas till svensklärare i teori och praktik (2018). Rec. av Catharina Nyström Höög . . . . . . . . . . . . . . . . 275

McCulloch, Gretchen: Because Internet. Understanding the New Rules of Language (2017). Rec. av Susanna Karlsson . . . . . . . . . . . . . . . . . . . 279

Norrby, Catrin \& Håkansson, Gisela: Samtal om svenska. Förhandling, positionering och känslosvall (2018). Rec. av Maria Bylin \& Marie Sörlin . . . 282 
Författarna i detta nummer 


\title{
Frasformade instruktioner med uppföljningar under personlig träning
}

\author{
Av MARTINA HUHTAMÄKI, INGA-LILL GRAHN, JAN \\ LINDSTRÖM, JENNY NILSSON, CATRIN NORRBY \& \\ CAMILLA WIDE
}

\begin{abstract}
Huhtamäki, Martina, martina.huhtamaki@helsinki.fi, Post Doctoral Fellow, Department of Finnish, Finno-Ugrian and Scandinavian Studies, University of Helsinki; Inga-Lill Grahn, ingalill.grahn@svenska.gu.se, Senior Lecturer, Department of Swedish Language, University of Gothenburg; Jan Lindström, jan.k.lindstrom@helsinki.fi, Professor, Department of Finnish, Finno-Ugrian and Scandinavian Studies, University of Helsinki; Jenny Nilsson, jenny.nilsson@sprakochfolkminnen.se, Associate Professor, The Institute for Language and Folklore, Gothenburg; Catrin Norrby, catrin.norrby@su.se, Professor, Department of Swedish Language and Multilingualism, Stockholm University; CamillaWide, camilla.wide@utu.fi, Professor, Department of Scandinavian Languages, University of Turku: "Phrasal instructions with follow-ups during personal training”. Språk och stil NF 29, 2019, pp. 9-40.
\end{abstract}

Personal training is a new form of institutional interaction that has not been extensively studied as regards language. Still, alongside embodied interaction, language is central in this activity. In this paper, phrasal utterances are studied as a resource for instructing in personal training. The data consist of $7 \mathrm{~h} 23 \mathrm{~min}$ of video recordings of training sessions with Swedish-speaking participants from Finland and Sweden, which are supplemented with field notes. The theoretical-methodological framework includes interactional linguistics, ethnography of communication, and variational pragmatics. Results show that participants use all semiotic information at hand when they produce and understand phrasal instructions during personal training. This process involves the overall activity, the participants' institutional roles as trainer and client, their body positions and movements, and trajectories of earlier interaction and embodied elements of the instructions themselves. Phrasal instructions are short; thus, they are focused and easily integrated into the ongoing physical activity. Certain differences are observed between the data from Finland and from Sweden, e.g., Finnish data have more phrasal instructions, whereas the Swedish data have more third-turn follow-ups, which may indicate cultural differences in this domain. The article concludes that phrasal utterances are not only useful as instructions in personal training but also well-suited for the activity type.

Keywords: phrasal utterances, instructions, personal training, interactional linguistics, ethnography of communication, variational pragmatics, Finland Swedish, Sweden Swedish. 
Den grammatiska formen hos ett yttrande hjälper oss ibland att förstå vilken språkhandling en talare avser att uttrycka. Exempelvis kopplas imperativa satser ihop med funktionen direktiv (SAG 1999, 1 s. 41-42, 2, s. 549, 4 s. 705 ff., Lindström m.fl. 2017). Det förekommer samtidigt att flera olika satstyper kan utföra samma språkhandling. En fråga som Vill du stänga fönstret? kan fungera som uppmaning, och en deklarativ sats som Du kommer hit sedan? kan fungera som fråga. Talare anses kunna använda bland annat prosodiska drag för att förtydliga funktionen hos yttranden som inte har den typiska syntaxen för språkhandlingen, exempelvis kan deklarativa frågor och uppmaningar ha stigande intonation (se Gårding 1998 s. 121-122, SAG 1999, 4 s. 677). Studier av frågor med deklarativ syntax i finlandssvensk interaktion har ändå visat att dessa frågor inte har stigande intonation i någon större utsträckning än frågor med interrogativ syntax (t.ex. Huhtamäki 2014).

Det finns även yttranden där den grammatiska formen ger ytterst litet information om vilken typ av språkhandling som avses. Detta gäller fraser som $a ̊ a x-$ larna, två till och explosivt upp, vilka alla saknar finit verb och subjekt som skulle ge oss mer information om vad någon ska göra med vems axlar, vad som ska ges eller tas två till av, och vem som ska röra vad uppåt på ett explosivt sätt. Tagna ur sitt sammanhang skulle vi knappast förstå att de nämnda yttrandena är instruktioner. Om vi däremot vet att yttrandena uttalas av en personlig tränare under ett träningspass kan vi få en aning om deras innebörd. Ifall vi dessutom vet vad den aktuella övningen går ut på förstår vi ännu mer. Om vi därtill håller på att utföra övningen och är den person som uppmaningen riktas till skulle vi i de flesta fall förstå uppmaningens exakta betydelse. I fråga om dessa yttranden är det alltså kontexten som skapar betydelsen tillsammans med den lingvistiska formen.

I exempel 1 nedan ser vi ett utdrag från en träningssession med en personlig tränare (PT) och en motionär (MO). I utdraget fungerar nominalfrasen hälen (r. 16), adverbfrasen å ut (r. 19) och imperationen stopp (r. 23) som instruktioner, liksom imperativsatsen å sen sträck (r. 25). I övningen ligger motionären på rygg, medan tränaren sitter bredvid henne. Övningen går ut på att motionären ska dra benet mot sig, fälla ut knäet och sedan sträcka ut benet, hela tiden med foten i golvet. Tränaren har introducerat övningen genom att först visa den själv, sedan förklara den med ord och därefter genom att styra motionären med sina händer. Under största delen av övningen tittar tränaren på motionärens ben, medan motionären ser upp i taket. För tolkning av symbolerna, se Transkriptionsnyckel i slutet av artikeln. 


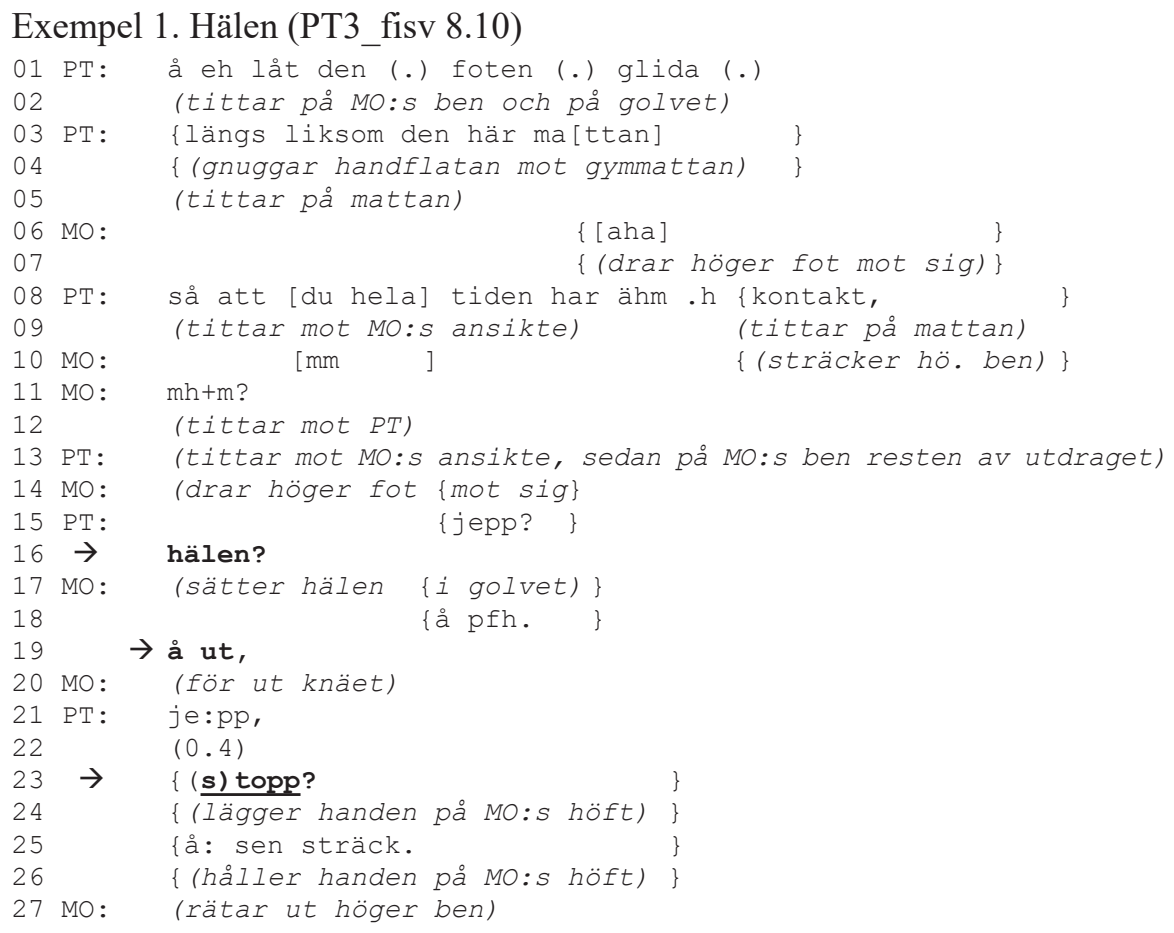

I början av utdraget påpekar tränaren att motionären ska ha sin fot $\mathrm{i}$ golvet (r. $1,3,8)$, och motionären visar med responspartiklar att hon förstått (r. 6, 10). Hon prövar också att dra upp och sträcka benet en gång medan tränaren förkla$\operatorname{rar}($ r. 7, 10). Därefter drar motionären benet mot sig igen (r. 14), vilket tränaren bekräftar med uppföljningen jepp (r. 15). Efter detta påminner tränaren om att hälen ska vara i golvet genom att säga hälen (r. 16). Lite senare säger tränaren å ut (r. 19), vilket motionären reagerar på genom att föra knäet ut från kroppen (r. 20). Tränaren bekräftar även denna rörelse med jepp (r. 21). Därefter säger tränaren stopp, samtidigt som hon lägger handen på motionärens höft (r. 23, 24). Påföljande instruktion utgörs av en imperativsats, å sen sträck, varefter motionären rätar ut höger ben (r. 25, 27). Vi ser att motionären tolkar tränarens yttranden som instruktioner eftersom hon följer dem, och tränaren godkänner hennes fysiska prestationer som adekvata i sammanhanget genom att producera uppföljningar och gå vidare i övningen.

Syftet med denna studie är att undersöka vilken typ av resurs frasformade yttranden utgör i instruerande aktiviteter: hur frasformade yttranden används och förstås som instruktioner samt hur de följs upp under personlig träning. 
Tyngdpunkten i vår undersökning ligger på sekventiella analyser av interaktionen, som vi kompletterat med etnografiska studier av den institutionella kontexten. Eftersom vårt material innehåller såväl finlandssvenska som sverigesvenska träningssessioner har vi också ett kontrastivt perspektiv på användning av frasformade instruktioner, och studerar skillnader och likheter varieteterna emellan.

I teori och forskningsbakgrund nedan diskuterar vi definitionen av frasformade yttranden med instruerande funktion samt behandlar relevant forskning om språklig utformning av instruktioner och liknande yttranden. Sedan beskriver vi material och metoder. Därefter redogör vi för resultaten i undersökningen och slutligen sammanfattar och diskuterar vi resultaten.

\section{Teori och forskningsbakgrund}

Den teoretiska och metodologiska referensramen för undersökningen utgörs av en kombination av interaktionell lingvistik, variationspragmatik och kommunikationsetnografi. Interaktionell lingvistik är en forskningsinriktning där språkliga drag studeras med samtalsanalytisk metodik samtidigt som de förankras i en grammatisk analys (Couper-Kuhlen \& Selting 2001, 2018). Samtalsanalys är en induktiv metod med fokus på språkliga, sociala handlingar och deras sekventiella organisation i naturligt förekommande interaktion (Sidnell 2013). Inom variationspragmatiken studeras variation i kommunikativa mönster hos olika varieteter av samma språk (Schneider \& Barron 2008). Exempelvis kan man studera geografisk variation i hur folk hälsar, tackar eller ber om något (Placencia 2008, Grahn 2017, Nilsson m.fl. 2018). Kommunikationsetnografi innebär i sin tur att man studerar förhållandet mellan kommunikationsmönster och kultur (Saville-Troike 2003). För att förstå den kultur som språket är en del av ingår ofta fältarbete (Blommaert \& Jie 2010).

\subsection{Definition av frasformade yttranden med instruerande funk- tion}

De yttranden vi undersöker är frasformade och har instruerande funktion. Denna typ av yttranden är frekventa i personlig träning och således ett centralt element i verksamheten. Frasformade yttranden är en term som används av 
Lindström (2008 s. 70-71) om yttranden som saknar finit verb, i motsättning till satsformade yttranden, såsom imperativsatser. Frasformade yttranden kan utgöras av nominalfraser, verbfraser, adjektivfraser, interjektionsfraser eller prepositionsfraser. De består antingen av enbart ett huvudord, eller av ett huvudord med bestämningar.

Svenska Akademiens grammatik (SAG 1999, 4 s. 783 ff.) kallar yttranden som saknar predikatsled (finit verb) och subjekt för icke satsformade meningar. Sådana kan utgöras av interjektionsfraser, t.ex. stopp, vokativfraser, t.ex. $d u$, eller huvudsatsekvivalenter, t.ex. Hitåt! (alla exempel från SAG). SAG (1999, 4 s. 814) tar upp även militära kommandon som exempel på huvudsatsekvivalenter, såsom Lediga! Enligt SAG skapas huvudsatsekvivalenternas betydelse med hjälp av talsituationen, kontexten och intonationen, medan den grammatiska strukturen spelar en mindre roll (SAG 1999, 4 s. 810). De yttranden vi undersöker motsvarar främst icke satsformade huvudsatsekvivalenter i SAG:s beskrivning. Vi använder dock termen frasformande yttranden i stället för icke satsformade meningar, eftersom den senare antyder en skriftspråklig slagsida; i talspråket finns inte samma förväntan på satsform hos yttranden som i skriftspråket. Dessutom slipper vi definiera en företeelse genom vad den inte är.

Vi har inte undersökt samtliga frasformade yttranden i materialet, utan valt ut dem som har en instruerande funktion. Med instruerande funktion avser vi yttranden som relevantgör en fysisk handling och som också följs av en sådan (se nedan). Funktionen hos yttrandena kunde även beskrivas som uppmaning, direktiv eller begäran om en handling, men vi skiljer inte mellan dessa funktioner, eftersom det inte är relevant för vår undersökning att utreda en sådan distinktion. Det viktiga är alltså att de frasformade yttrandena skapar förväntningar på en fysisk respons hos mottagaren.

\subsection{Forskning om instruktioner och uppmaningar i olika kontexter}

I föreliggande artikel undersöker vi alltså en språkhandling där någon uppmanar någon annan att utföra en fysisk handling och personen utför denna handling. Tidigare forskning har visat att den grammatiska utformningen av sådana yttranden hänger samman med de rättigheter och skyldigheter talaren respektive mottagaren har. Curl \& Drew (2008) fann att talare använde former som Can you i vardagliga samtal då mottagaren har lätt att uppfylla deras önskemål, medan de började sin begäran med I wonder if när de i patientroll begärde något av en läkare. Couper-Kuhlen (2014) har visat hur engelskspråkiga talare väljer 
mellan olika språkliga former för att framföra en begäran beroende på vem som drar nytta av handlingen och vem som förväntas utföra den. Sorjonen \& Raevaara (2014) fann att på finska används nominalfraser ofta när en kund begär att få köpa cigaretter i en kiosk. Den korta formen hänger ihop med den fysiska närheten till varan samt den rutinartade och snabba transaktionen. Enligt Stevanovic \& Peräkylä (2012) behöver talare som har stor deontisk auktoritet, dvs. rätt att bestämma om kommande handlingar, inte förklara eller motivera sina direktiv för att få andra att göra som de vill. I den aktivitet vi undersöker har tränaren rättighet att ge instruktioner och motionären förväntas följa dem. Det är motionären som drar nytta av att följa instruktionerna, t.ex. genom att komma i bättre form. Men det är också bra att motionären förstår vad en viss instruktion syftar till $i$ träningen, vilket kommer fram $i$ att vissa mer utbyggda instruktioner följs upp av tränarens motiveringar (Lindström m.fl. u.u.).

Det har utförts många studier av instruktioner, speciellt inom undervisningskontexter. Den personliga tränarens expertroll påminner om den hos läraren i en undervisningskontext. Lärarens yttranden förväntas generera en (verbal) respons hos eleven, liksom tränarens yttranden förväntas generera en (fysisk) respons hos motionären. Denna respons kan sedan utvärderas av läraren/tränaren. I många undervisningskontexter utgår forskarna därför från en så kallad IRU-struktur ( $I=$ initiering, $R=$ respons, $U=$ uppföljning) eller IRE-struktur $(E=$ evaluering) (se t.ex. Sinclair \& Coulthard 1975, Mehan 1979, Macbeth 2003). Enligt IRU-strukturen uppmanas en person göra något, utför sedan en viss handling och utvärderas därefter enligt ett lokalt operativt kriterium (se Lindwall, Lymer \& Greiffenhagen 2015). I vårt material utgörs initieringen av tränarens uppmaning, responsen av en fysisk prestation, och i vissa fall sker en verbal uppföljning av tränaren.

I en svenskspråkig undervisningskontext har Henricson \& Nelson (2017) funnit skillnader i hur handledare ger råd och hur studenter tar emot råden i Finland och Sverige. Vid högskolorna i Finland framförs råden mer direkt, medan det förekommer fler förmildrande uttryck i Sverige. Råden tas emot med mer uppgraderade uppbackningar i Sverige än i Finland.

En specifik undervisningskontext som är relevant för vår studie är körlektioner. Under körlektioner ska mottagaren i vissa fall reagera på en instruktion med en fysisk handling i nuet, liksom i personlig träning. Inom körlektioner har De Stefani \& Gazin (2014) funnit att frasformade yttranden används som s.k. kontrollinstruktioner. De Stefani och Gazin, som undersökt italiensk interaktion i Schweiz, påpekar att den sekventiella strukturen hos instruktioner under 
körlektioner är mer komplicerad än IRU-strukturen låter förstå. Mer övergripande instruktioner (navigeringsinstruktioner) följs av sekvenser med instruktioner som berör kontroll av fordonet och trafiken (kontrollinstruktioner). Kontrollinstruktioner saknar ofta finit verb och får en fysisk respons, medan navigeringsinstruktionerna utgörs av fullständiga satser och får en verbal respons.

Deppermann (2018) studerade den syntaktiska utformningen av instruktioner under körlektioner på tyska. Även han fann en uppdelning mellan den syntaktiska formen hos instruktioner och de kontexter de används i. Medan deklarativer används som navigeringsinstruktioner används imperativer för att korrigera en pågående handling eller insistera på en handling som borde ha utförts. Jämfört med deklarativerna är imperativerna korta och kan vid behov produceras snabbt. De frasformade instruktionerna i vårt material påminner i detta avseende om imperativerna.

När det gäller svenskspråkig interaktion har forskare påvisat en arbetsfördelning mellan yttranden med olika grammatisk utformning i en vårdkontext. Även vårdkontexter påminner om personlig träning, eftersom det är fråga om en expert som ska hjälpa en person med det fysiska välbefinnandet. Lindström m.fl. (2017) har i en undersökning av imperativer under läkarbesök på svenska i Finland och Sverige visat att läkaren i början och slutet av besöket använder modifierande element tillsammans med imperativer (adverb/partiklar: berätta lite eller artighetsfraser: varsego ta på skjortan), medan läkaren under den fysiska undersökningen använder raka imperativer. En förklaring är att imperativerna i undersökningen är starkare knutna till den fysiska aktiviteten, ofta inbäddade i serier av direktiva handlingar. I vår undersökning kan vi förvänta oss att de frasformade instruktionerna hör mycket nära ihop med den fysiska aktiviteten.

Förutom att använda verbala instruktioner är det även möjligt att använda sin kropp för att ge instruktioner och uppmaningar. Detta är speciellt relevant när den fysiska aktiviteten är i förgrunden, såsom i personlig träning. Keevallik (2013) har visat hur danslärare använder instruktioner som består av en verbal syntaktisk del (dvs. en sats) som projicerar en fortsättning, och en fysisk del som fullbordar projektionen. Exempelvis säger dansläraren vid ett tillfälle: för om killarna gör och utför en kroppslig demonstration, och fortsätter: så kommer ju tjejerna att göra och utför en ny demonstration (s. 8). Cekaite (2010) beskriver i sin tur hur föräldrar i svenska medelklassfamiljer styr sina barn genom verbala, kroppsliga och rumsliga praktiker. Föräldrar kan ta tag i sina barn, svänga deras kroppar och fösa dem dit de borde röra sig för att till exempel borsta tänderna. Föremålen i hemmet begränsar vart barnet kan röra sig. De 
återkommande aktiviteterna och den gemensamma förståelsen av situationen bidrar till att de kroppsliga direktiven fungerar. Nishizaka (2016) pekar också på hur yttrandets syntaktiska form spelar en roll för hur deltagare koordinerar verbala och fysiska handlingar under massage.

Lundin (2018) har studerat språkbruket under idrottsträningar för barn med hjälp av funktionell grammatik. Hon fann fem typer av yttranden med uppmanande funktion: enkelt presens, presens med det modala hjälpverbet $s k a$, imperativ, frågesats eller »icke-verbburen exklamativ» (s. 158). Icke-verbburna exklamativer är detsamma som vi kallar frasformade instruktioner. Hon ger exemplet Upp med knäna! men säger inte något mera om dessa uppmaningar. Tidigare studier att nämna i angränsande områden är t.ex. Martin \& Sahlström 2010 som undersöker lärande i fysioterapeutisk behandling.

Vad vi vet finns det inte några tidigare undersökningar av svensk interaktion om just frasformade yttranden som fungerar som instruktioner, förutom en pilotstudie av Grahn \& Huhtamäki (2019). Vår undersökning bidrar således till kunskapen om hur frasformade yttranden används och förstås som instruktioner i den institutionella verksamhet som personlig träning utgör. Vi ser vår studie både som ett bidrag till hur språkliga resurser används interaktionellt och till hur språket är en integrerad del av en viss verksamhet, här den hittills tämligen outforskade friskvårdsdomänen. Därtill bidrar vår jämförelse av frasformade instruktioner i finlandssvenska och sverigesvenska till ökad kunskap om svenskan som pluricentriskt språk.

\section{Material och metoder}

Undersökningen utgör en delstudie inom forskningsprogrammet Interaktion och variation i pluricentriska språ $k^{1}$ vars syfte är att jämföra kommunikationsmönster i svenskan i Finland och svenskan i Sverige inom olika domäner (jfr Schneider \& Barron 2008). Således utgörs hälften av vårt material av videoinspelningar från Finland och andra hälften av inspelningar från Sverige med personliga tränare och motionärer. Som kompletterande material används fältan-

\footnotetext{
${ }^{1}$ Programmet Interaktion och variation i pluricentriska språk är finansierat av Riksbankens Jubileumsfond (M12-0137:1) och pågår 2013-2020. Inom programmet samarbetar forskare från Stockholms, Helsingfors och Åbo universitet samt Institutet för språk och folkminnen i Göteborg. Se Norrby m.fl. 2012, 2014 och http://www.su.se/svefler/ivip. Vi tackar Riksbankens Jubileumsfond för stöd till forskningsprogrammet och Klara Skogmyr Marian för hjälp med analysen av uppföljningarna.
} 
teckningar vi tagit vid besöken på inspelningsplatserna, som hjälper oss att förstå aktiviteten personlig träning och den kontext där den äger rum (jfr Saville-Troike 2003, Blommaert \& Jie 2010; se avsn. 3 nedan).

Inspelningarna utfördes under träningspass som hade ägt rum oberoende av vår undersökning. Vi kontaktade de personliga tränarna och de frågade i sin tur motionärerna. Samtliga tränare och motionärer har tränat tillsammans tidigare och vissa känner varandra väl. Både tränarna och motionärerna var medvetna om att vi undersöker språk och interaktion och hade gått med på att vi spelade in dem. Alla personnamn och annan information som skulle göra det möjligt att identifiera personerna har anonymiserats i samtalsutdragen och på bilderna. Projektet har godkänts av etiknämnder i respektive länder.

Inspelningarna utgör sammanlagt 7 timmar och 23 minuter, relativt jämnt fördelat mellan Finland och Sverige (se tabell 1). I materialet ingår fyra träningspass med tre olika tränare från Finland och tre träningspass med två olika tränare från Sverige. Antalet olika motionärer är fyra i både Finland och Sverige. Vanligen deltar en tränare och en motionär i träningspassen, men i Sverige utgörs ett pass av gruppträning med en tränare och tre motionärer. I rubriken till transkriptionerna betecknas inspelningarna med nummer och landskod, exempelvis syftar PT1_fisv på den första inspelningen från Finland.

Tabell 1. Materialöversikt.

\begin{tabular}{lccccc}
\hline & Inspelningslängd & $\begin{array}{c}\text { Ant. } \\
\text { träningspass }\end{array}$ & Ant. tränare & $\begin{array}{c}\text { Ant. } \\
\text { motionärer }\end{array}$ & $\begin{array}{c}\text { Ant. } \\
\text { frasformade instr. }\end{array}$ \\
\hline Finland & 3 tim. $47 \mathrm{~min}$ & 4 & 3 & 4 & $406^{2}$ \\
Sverige & $3 \mathrm{tim} .36 \mathrm{~min}$ & 3 & 2 & 4 & 211 \\
Totalt & 7 tim. 23 min & 7 & 5 & 8 & 617 \\
\hline
\end{tabular}

I inspelningarna har vi excerperat 617 sekvenser där ett frasformat yttrande från en deltagare direkt följs av en fysisk handling från en annan. ${ }^{3}$ Den utförda fysiska handlingen visar hur det aktuella yttrandet förstås som en instruktion, eller kanske uppmaning, i situationen. I vissa sekvenser följer också en avslutande uppföljning av motionärens prestation från tränaren, vilka också ges plats i analysen. Urvalskriterierna tar därmed hänsyn till både form (se punkt 1 och 2), sekventiell placering (se punkt 2 och 3 ) och funktion (se punkt 2 och 3 ):

\footnotetext{
${ }^{2}$ I Grahn \& Huhtamäki (2019) anges att det finns 399 frasformade instruktioner i det finländska delmaterialet, men en fördjupad analys ger denna summa.

${ }^{3} \mathrm{Vi}$ har inte utfört någon jämförelse mellan frasformade och andra typer av instruktioner i vårt material, men de frasformade är mycket frekventa och varvas med deklarativa och imperativa satser.
} 
1) Yttrandena saknar finit verb, dvs. de utgörs av frasformade yttranden (se Lindström 2008 s. 70-71, jfr SAG 1999, 4 s. 783; se avsnitt 1.1 ovan).

2) Yttrandena utgör självständiga syntaktiska, prosodiska och pragmatiska enheter i sin kontext (se Sacks m.fl. 1974 s. 720-721, Ford \& Thomson 1996, Bockgård 2007).

3) Yttrandena fälls under pågående fysisk aktivitet och följs direkt av en fysisk handling.

Vi har enbart excerperat yttranden som inte är syntaktiskt beroende av en språklig konstruktion i en tidigare tur, dvs. elliptiska yttranden. Detta innebär att vi har uteslutit fraser som parasiterar på ett finit verb i en föregående tur, såsom frasen hela vägen nu som följer på den imperativa satsen kom igen $\mathrm{i}$ den föregående turen (ex. 2):

\section{Exempel 2: kom igen / hela vägen $n u$}

Vi behandlar motionärernas fysiska respons som en bekräftelse på att de förstått tränarens instruktion (se Sacks \& Schegloff 1973, Mondada 2011). Ibland är den fysiska responsen tydlig, såsom när motionären lyfter benen, men ibland är det fråga om utifrån sett mer subtila förändringar, såsom att spänna magmusklerna eller ändra kroppshållningen en smula (jfr Martin 2004 om modifierade rörelser som respons). Även om motionärens fysiska aktivitet inte alltid utgör en respons på en instruktion, utan i stället är en fortsättning av övningen, hänger de två så nära ihop att det i vissa fall är omöjligt att skilja dem åt. Exempel på sådana fall är räkning som fungerar som instruktion. I en del fall följs den fysiska responsen av tränarens godkännande uppföljning, som ytterligare bekräftar att motionären har tolkat instruktionen rätt.

I enlighet med samtalsanalytiska principer utför vi sekventiella analyser av de utdrag ur inspelningarna där de frasformade instruktionerna ingår (se Sidnell 2013). I dessa beaktar vi vilken verbal information som föregår instruktionen och hur den fysiska prestationen följs upp. Vi studerar den lexikala, syntaktiska och prosodiska utformningen av den frasformade instruktionen samt kroppslig (visuell och taktil) information som kombineras med den. För presentationen av exemplen har vi transkriberat utdrag ur inspelningarna enligt principerna för transkription av samtalsmaterial (Lindström 2008, Hepburn \& Bolden 2013). I de utvalda sekvenserna utförs så gott som hela tiden fysiska övningar, och för att transkriptionerna ska bli läsbara har vi begränsat återgivningen till metakommentarer av för analysen relevanta multimodala drag. 
Överlappande tal betecknas med [ ], medan fysisk aktivitet som överlappar tal betecknas med \{ \}. Fullständig transkriptionsnyckel återfinns sist i artikeln. Vi bifogar även bilder för att hjälpa läsaren att få en uppfattning om deltagarnas kroppspositioner under övningen.

\section{Personlig träning som institutionell verksamhet}

Den verksamhet som vårt material är hämtat från kan beskrivas som institutionell eftersom en av deltagarna, tränaren, utövar sin yrkesroll och det finns ett tydligt mål för verksamheten (se Drew \& Heritage 1992 s. 3-4, Heritage 1997, Linell 2011 s. 109). Den omfattar både fysisk aktivitet och samtal, som deltagarna koordinerar i sin interaktion. Personlig träning är en relativt ny näringsgren som George (2008) klassificerar som servicearbete på expertbasis. Enligt henne kännetecknas branschen av att en standardiserad utbildning för personliga tränare saknas, vilket gör att tränarna måste visa sin expertis extra tydligt $\mathrm{i}$ interaktionen med motionärerna. Våra analyser visar dock att tränaren i de flesta fall har en självklar auktoritet i förhållande till motionären.

Deltagarnas institutionella roller innebär asymmetri gällande kunskap samt rättigheter och skyldigheter (jfr Drew \& Heritage 1992 s. 3-4, Linell 2011 s. 109). Till tränarens roll hör att instruera, undervisa och uppmuntra motionären (se George 2008). Motionären förväntas i sin tur ta emot råd och utföra övningarna (jfr De Stefani \& Gazin 2014, Lundin 2018). I de flesta inspelningarna förekommer även avsnitt där tränaren och motionären småpratar med varandra (jfr George 2008). De personliga tränarna bär ofta t-skjorta med gymmets logo, vilket innebär att de är lätta att identifiera som tränare. Till deltagarramen bidrar i hög grad tränarens och motionärens kroppspositioner och rörelser (jfr t.ex. Goffman 1981, Goodwin 2000). Tränares instruerande roll syns på att de ofta intar en övervakande kroppsposition i förhållande till motionärerna.

Den fysiska miljön är i de allra flesta fall ett gym, det vill säga en halvoffentlig miljö där motionären måste betala för att fă träna. ${ }^{4}$ Motionären betalar också för den personliga tränarens tjänster, så det är alltså fråga om en kundrelation. Även i den fysiska miljön förekommer instruktioner och uppmaningar i skriven

${ }^{4}$ Ett undantag är en av inspelningarna som skedde i motionärens hem, PT3_fisv. 
form av olika storlek och formalitet. Dessa förstärker den institutionella kontexten och deltagarramen, eftersom instruktionerna endast gäller motionären. Det kan vara fråga om instruktioner för hur motionärerna ska handla här och nu, såsom att torka av träningsmaskinen med en trasa efter användning, instruktioner för hur övningarna ska utföras på rätt sätt och tips för hur de kan stretcha samt uppmaningar som också kan appliceras på livet utanför gymmet, exempelvis Believe in yourself, you are stronger than you think!

Föremålen på gymmet styr in verksamheten på en viss typ av träning. Motionärens kropp och rörelser avgränsas av vissa föremål, såsom gymmattor, träningsmaskiner och olika redskap (jfr Cekaite 2010). Motionären kan exempelvis ligga på en gymmatta med benen på en stor boll, vilket möjliggör en begränsad uppsättning rörelser. Träffarna mellan personliga tränare och motionärer är ofta upplagda enligt ett relativt fast program som vanligen inkluderar uppvärmning och övningar (jfr Lundin 2018 s. 155).

De frasformade instruktionerna används alltså under en aktivitet där de institutionella rollerna är tydliga och i en miljö som är utformad för fysisk träning. Det finns således många element både i omgivningen, aktiviteten, deltagarramen och i den kroppsliga och verbala kommunikationen som skapar betydelser för deltagarna (se Goodwin 2000).

\section{Frasformade instruktioner under träningspassen}

I detta avsnitt ger vi först en överblick över semantiskt innehåll och grammatisk form hos de frasformade yttrandena vi undersökt. Därefter presenteras en analys av fyra sekvenser som illustrerar hur yttrandena används och tas emot under träningspassen.

De frasformade instruktionerna används för att finjustera och korrigera motionärens prestation samt för att uppmuntra motionären att göra sitt bästa. De förekommer både under själva övningen och vid inledningen till en övning när motionären ska inta rätt position. Som exempelanalyserna visar varvas de frasformade instruktionerna med instruktioner som har deklarativ eller imperativ syntax. De kombineras ibland med visuella eller taktila instruktioner, och denna typ av instruktioner kan även förekomma utan verbala element.

De frasformade instruktioner vi studerat hänvisar till situerade element $\mathrm{i}$ aktiviteten. Vi har identifierat två huvudsakliga typer av element som före- 
kommer i materialen från både Finland och Sverige. Huvudtyperna utgörs av 1) räkning före en prestation (ex. nu sista) och 2) referens till kropp eller riktning (ex. å sen vaden; å sen ner), eventuellt tillsammans. Den förstnämnda typen hjälper motionären att orientera sig tidsmässigt i övningen och den andra anger vilken kroppsdel de ska röra på och/eller vartåt de ska röra på den.

Grammatiskt sett utgörs de undersökta yttrandena av nominalfraser, verbfraser, adjektivfraser, interjektionsfraser eller prepositionsfraser. Därtill förekommer en frastyp som vi benämner räkneordsfraser. Fraserna består av ett huvudord, med eventuella bestämningar (jfr Lindström 2008 s. 71). Omnämnande av kropp utgörs grammatiskt sett ofta av nominalfraser som anger vilken kroppsdel motionären ska fokusera på, exempelvis hälen (se ex. 1 ovan). Omnämnande av riktning består i stor utsträckning av adverbfraser som anger vartåt motionären ska röra en viss kroppsdel, exempelvis å ut (se ex. 1). Kropp och riktning kan också kombineras i en instruktion, till exempel adverbfrasen upp med bröstet (se ex. 5). Räkneordsfraserna utgörs av räkneord, ibland även med bestämning, såsom två till (se ex. 3). De instruktioner som hänförs till övriga refererar bland annat till sättet på vilket en övning ska utföras, exempelvis adjektivfraserna stark och lugn å fin, eller av nominalfraser som benämner en rörelse eller ett moment i övningen, såsom inandning och å: paus.

\subsection{Frasformad instruktion som utgörs av räkning}

I vårt material finns många exempel på när tränaren använder räkneordsfraser för att leda motionären genom övningen, det vill säga uttalar en siffra som anger vilken repetition i ordningen som motionären just utför eller utfört. Vi har kallat detta fenomen för medräkning, och dessa yttranden utgör inte instruktioner eftersom de uttalas samtidigt med eller strax efter den handling de refererar till. De räkneordsfraser som vi bedömt har en instruerande funktion uttalas istället före den fysiska handling som refereras till och kan därmed anses projicera denna handling. Ofta förekommer både medräkning och instruerande räkning i samma sekvens, vilket visas i exempel 3. Före utdraget har tränaren visat utgångspositionen och berättat vad övningen går ut på: att hålla händerna i golvet, ena benet böjt framför sig och det andra rakt bakåt, och sedan föra det bakre benet mot armbågen tio gånger. Tränaren sitter först på knä bredvid motionärens huvud och ställer sig sedan upp. Under sekvensen iakttar tränaren hela tiden motionären, som tittar i golvet. 
Exempel 3. Två till (PT3_svsv 11.20)

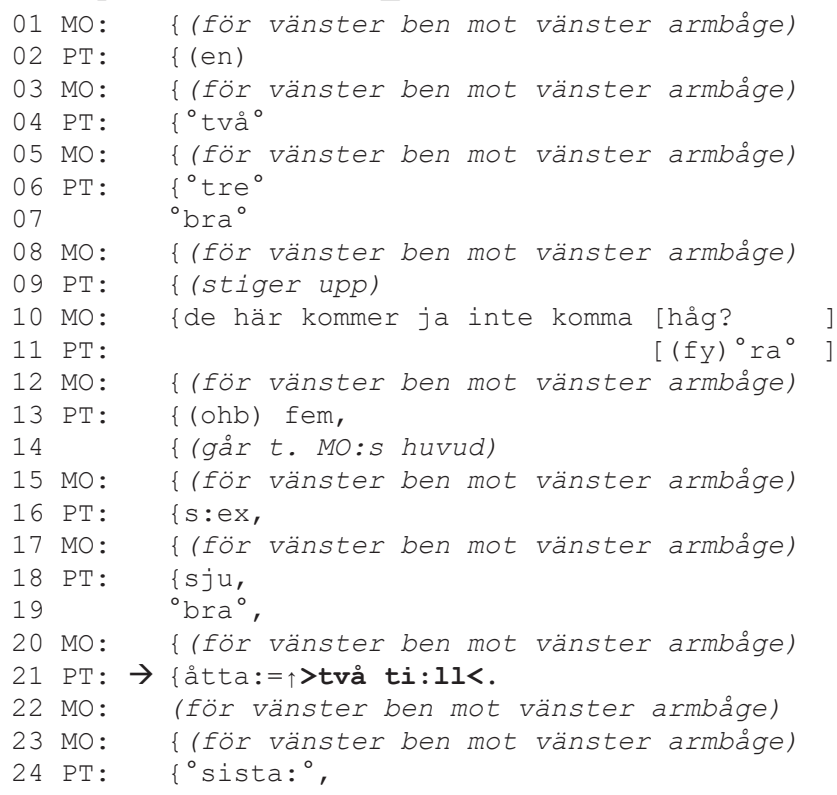

Före utdraget kontrollerar motionären att hon är i rätt position (se bild 1; pilarna betecknar blickriktning) och har förstått övningen på rätt sätt, vilket tränaren bekräftar. Sedan börjar motionären utföra övningen (från r. 1; se bild 2). Tränaren hjälper motionären att räkna de repetitioner hon utför genom att säga en siffra med låg ljudstyrka samtidigt med varje repetition (t.ex. r. 2). Hon gör även ett par positiva evalueringar med låg ljudstyrka (r. $7,19)$.

Direkt efter att ha sagt åtta (r. 21) ökar tränaren taltempot och säger två $t i: l l$. Frasen $t v a ̊$ till sägs just innan motionären hunnit påbörja nästa repetition och pekar på vad motionären ska göra härnäst, vilket ger frasen en instruerande funktion. Den skiljer sig prosodiskt från de tidigare medräkningarna och uppföljningarna genom en aningen ökad ljudstyrka och tonhöjd. Talhastigheten hos $t v a ̊$ till är snabbare jämfört med åtta, vilket innebär att den inte bryter rytmen hos repetitionerna, utan tränaren hinner säga frasen just innan motionären ska utföra nästa repetition. Motionären utför repetition nummer nio och tio och medan hon utför den sista säger tränaren ett prosodiskt nertonat sista: (r. 24), vilket fungerar som medräkning. Tränaren signalerar genom att gå vidare i programmet att sekvensen genomförts på det sätt som var tänkt. 


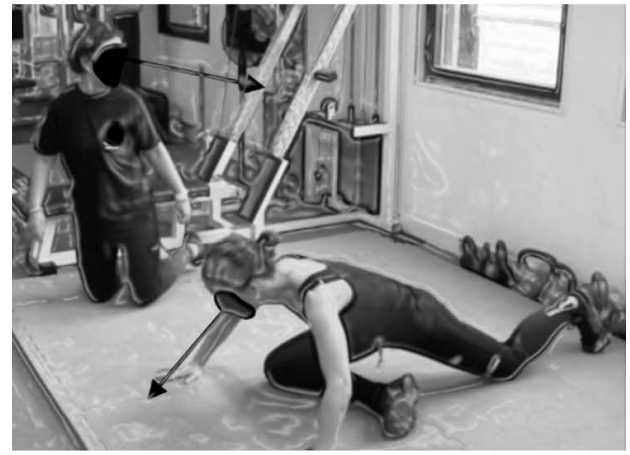

Bild 1. Utgångsposition.

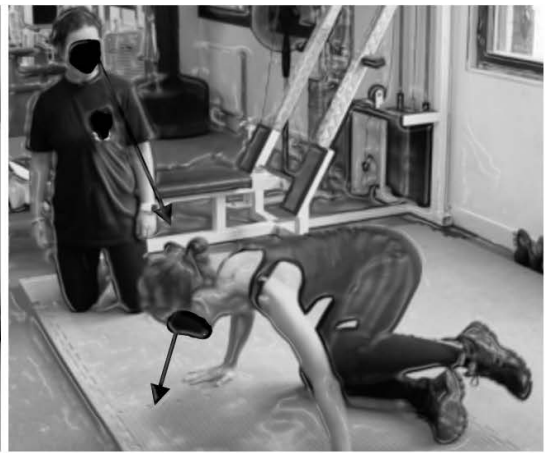

Bild 2. Övningen utförs.

Räkneordfraserna i vårt material har en uppmuntrande och motiverande funktion, genom att de hjälper motionärerna att hålla reda på var de befinner sig $\mathrm{i}$ övningen och därmed ge dem möjlighet att kanalisera sina krafter därefter. Detta gäller även de räkneordsfraser som uttalas före en repetition, men dessa har samtidigt drag av instruktion eftersom de projicerar en direkt fysisk handling.

\subsection{Frasformade instruktioner som refererar till kroppsdel och/ eller riktning}

I exempel 4 används två frasformade instruktioner som anger både kroppsdel och riktning: opp me benen tibaks (r. 4) och ansikte lite hitåt (r. 7). Båda instruktionerna åtföljs av taktila demonstrationer, dvs. tränaren anger genom beröring vilken kroppsdel motionären ska röra på respektive i vilken riktning. Utdraget är från början av en övning då tränaren ger anvisningar om positionen. Övningen går ut på att ligga på rygg med ett gymblock mellan knäna och benen i nittio graders vinkel och röra benen (se bild 3). Motionären blundar under övningen. Hon har nyss avslutat en annan övning som också utfördes på rygg. Tränaren sitter på knä till vänster om henne. Först följer tränaren upp motionärens tidigare prestation, de gick jättefint (r. 1). Uppföljningen utgörs av en evaluering av högre positiv grad, det vill säga, den utvärderar motionärens prestation starkt positivt (jfr avsnitt 4.4 nedan). 


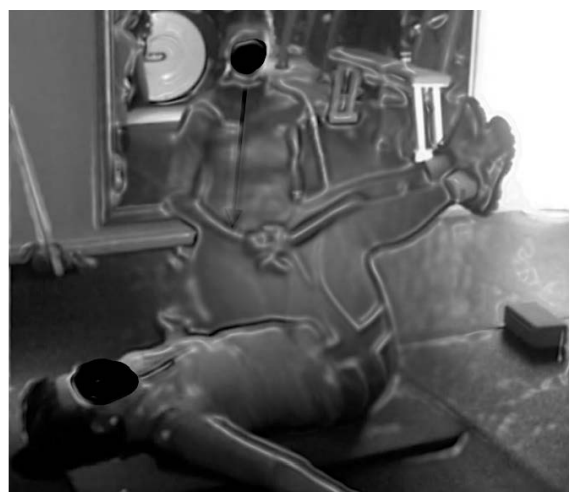

Bild 3. Utgångsposition.

Exempel 4. Upp med benen tillbaka (PT1_fisv 38.52)

01 PT: de gick jättefint.

$02 \quad(0.3)$

$03 \quad \mathrm{~mm}$ ?

$04 \rightarrow$ >opp me benen $\{$ tibaks $<$.

$05 \quad\{(k l a p p a r 2$ ggr på MO:s vänstra ben) \}

$06 \mathrm{MO}: \quad$ (lyfter upp benen)

$07 \mathrm{PT}: \rightarrow$ ansikte lite hitåt?

\{(rör med höger hand på MO:s vänstra axel) \}

09 MO: (vrider huvudet aningen mot vänster, skakar lätt på axlarna)

10 PT: okej håll.

Därefter säger tränaren opp me benen tibaks (r. 4), snabbt och med fallande slutintonation. Adverbet opp anger riktning för rörelsen, prepositionsfrasen me benen tillsammans med beröringen i slutet av instruktionen anger vilken kroppsdel rörelsen gäller och adverbet tibaks 'tillbaka' hänvisar till den föregående övningen (jfr Torpo 1998 om finitlösa direktiv under aerobiclektioner på finska). Motionären lyfter upp benen som respons.

Sedan säger tränaren ansikte lite hitåt (r. 7), och lägger för ett ögonblick höger hand på motionärens vänstra axel. Denna instruktion produceras med stigande slutintonation. Det frasformade yttrandet refererar till en kroppsdel, ansikte $(t)^{5}$, en riktning, hitåt, och en gradering, lite. Genom beröringen anger tränaren vad det deiktiska adverbet hitåt syftar på. Motionären responderar genom att vrida huvudet en aning åt vänster. Därefter bekräftar tränaren motionärens position med okej och ger utan paus en ny instruktion med imperativet håll (r. 10).

${ }^{5}$ Det går inte att avgöra om substantivet ansikte används i bestämd eller obestämd form utifrån hur ordet uttalas, eftersom det saknar slut-t i båda fallen i talad finlandssvenska. 
De verbala instruktionerna är finkoordinerade med beröringar som därmed också blir instruerande. Beröringarna framhäver och preciserar de verbala instruktionerna, men vore inte ensamma tillräckliga för att motionären skulle kunna inta rätt position. Beröringarna är speciellt viktiga i denna sekvens eftersom motionären inte är tillgänglig för synintryck. Genom att tränaren går vidare i programmet efter motionärens fysiska respons (r. 7) signalerar hon att motionären responderat på ett förväntat sätt. Efter motionärens fysiska respons på den andra instruktionen producerar tränaren därtill den bekräftande uppföljningen okej (r. 10), vilket visar att motionärens respons är korrekt. Därefter produceras nästa instruktion utan paus, vilket tyder på att uppföljningen dessutom fungerar som övergångssignal.

Exempel 5 visar en sekvens med fyra frasformade instruktioner som refererar till en kroppsdel och/eller riktning. I detta utdrag används de frasformade instruktionerna för att hjälpa motionären att inta rätt position i början av en övning och stödja honom $\mathrm{i}$ att göra rörelserna på ett korrekt sätt. Övningen går ut på att i lätt framåtböjd position lyfta en skivstång från knähöjd upp till höfthöjd. Tränaren står till vänster om motionären under utdraget och övervakar hans rörelser.

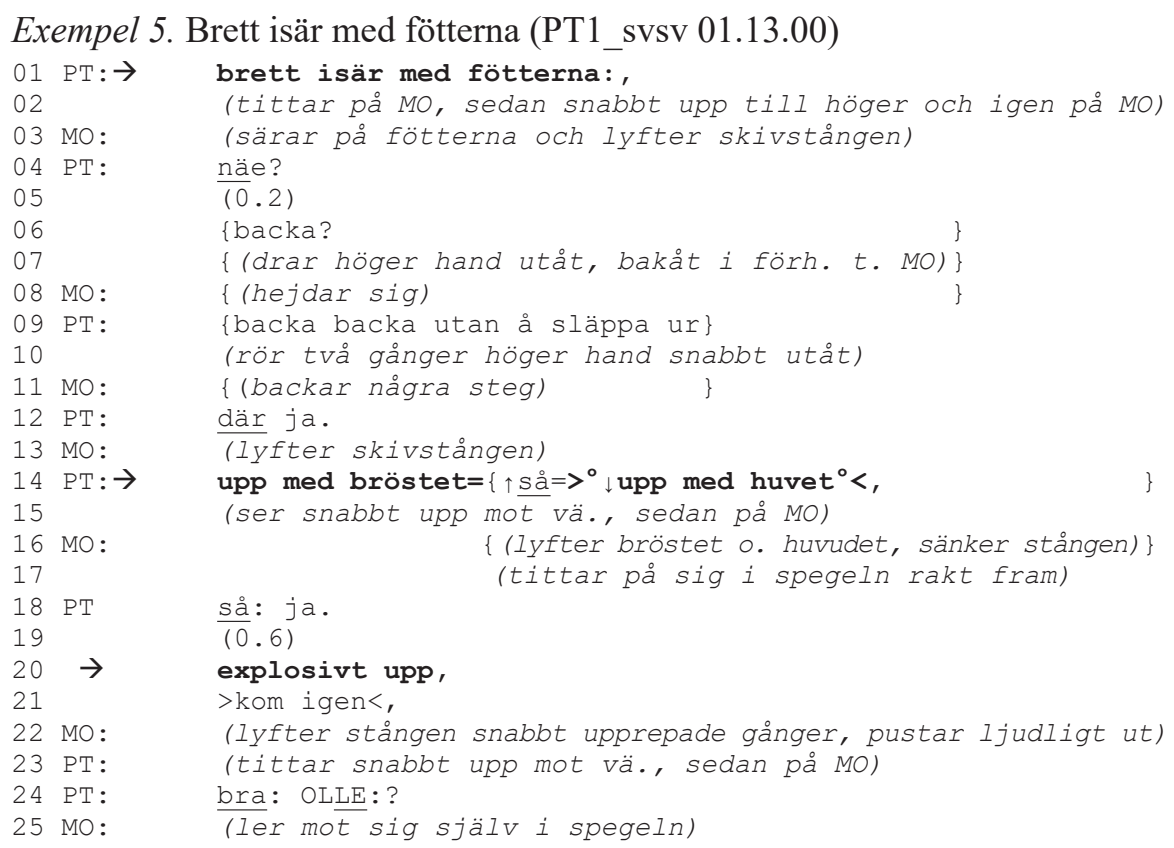


Den första frasformade instruktionen utgörs, liksom de tre andra, av en adverbfras: brett isär med fötterna (r. 1). Tränaren uttalar den sista stavelsen förlängd och med jämn slutton (jfr Karlsson 2010 om platåintonation i listor). Motionären flyttar isär fötterna en aning och påbörjar övningen, men tränaren ger en negerande respons på hans prestation och en ny, korrigerande instruktion i imperativ: näe (0.2) backa backa backa utan å släppa ur samtidigt som han med höger hand gör en gest mot det som är bakåt ur motionärens synvinkel (r. 4-7, 9-10). Upprepningen av backa kan signalera brådska (jfr De Stefani \& Gazin 2014 s. 68), vilket verkar vara fallet här då skivstången är tung och motionärens aktivitet ska korrigeras omedelbart. Motionären hejdar sig i lyftet och backar med skivstången. Efter det producerar tränaren uppföljningen där ja (r. 12).

Motionären börjar lyfta skivstången igen, men tränaren korrigerar återigen hans position med två frasformade instruktioner med ett kort godkännande $s a ̊$ mellan: upp med bröstet så upp med huvet (r. 14). Den senare frasen, upp med huvet uttalas snabbt, med låg ljudstyrka och jämn slutintonation. Motionären responderar genom att lyfta bröstet och huvudet (se bild 4). Därefter sänker han stången till utgångsläget. Tränaren godkänner motionärens position med så ja med stigande-fallande intonation (r. 18), och övergår sedan till att ge en ny frasformad instruktion, explosivt upp (r. 20), följt av ett lexikaliserat uppmuntrande uttryck i imperativ, kom igen (r. 21). Båda instruktionerna har jämn slutintonation och kom igen uttalas mycket snabbt.

Koordineringen av instruktionerna med motionärens rörelse är extra viktig här eftersom skivstångens tyngd gör att han riskerar att skada sig ifall han missförstår dem. Motionären lyfter stången kraftfullt ett antal gånger, varefter tränaren evaluerar hans prestation positivt, bra: OLLE: (r. 24). Denna uppföljning som till sin lexikala utformning är en evaluering av lägre positiv grad (se avsn. 4.4 nedan), får ökad tyngd genom att den uttalas med förlängning, ökad ljudstyrka och stigande slutintonation. Uppföljningen kan alltså beskrivas som prosodiskt uppgraderad jämfört med den föregående instruktionen (se Curl 2002, Ogden 2006), och mer framträdande än de andra uppföljningarna i sekvensen. Under denna sekvens följer tränaren upp den fysiska prestationen efter varje instruktion, så att en IRU/IRE-sekvens bildas (jfr Sinclair \& Coulthard 1975, Mehan 1979, Macbeth 2003; jfr Schegloff 2007 s. 118, 124 om sequence-closing thirds). I de flesta fall bekräftar tränaren att motionären uppfattat instruktionen rätt, men i ett fall säger tränaren att motionären gör fel. 
Bild 4. Korrigerad position.

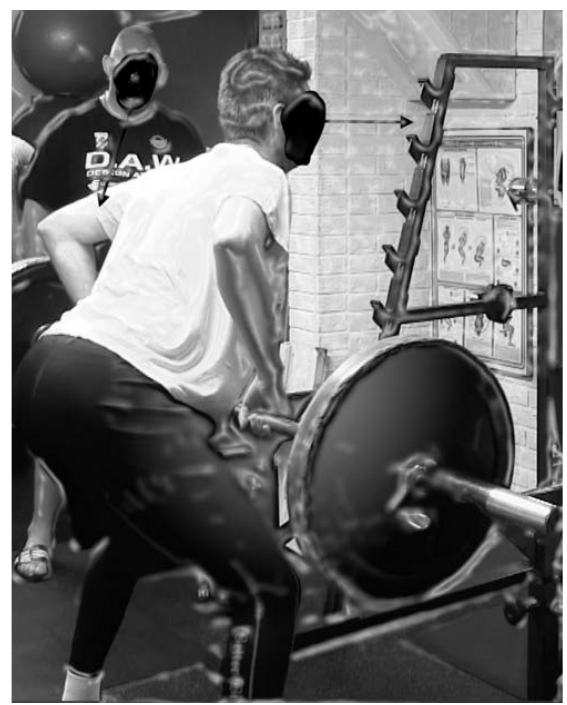

\subsection{Koordineringen av en frasformad instruktion och en fysisk demonstration}

Det är mindre vanligt att tränaren gör en övning samtidigt med motionären, men detta sker i följande exempel där frasen å axlarna (r. 20) kombineras med att tränaren visar övningen. I exemplet skapas motionärens förståelse av den frasformade instruktionen i hög grad genom koordinationen med tränarens fysiska rörelser. Tränaren och motionären står mitt emot varandra och håller $\mathrm{i}$ varsin gymnastikpinne med ett brett grepp. Övningen går ut på att föra pinnen ovanför huvudet, andas ut och föra ner den igen. Detta är en ny övning, och tränaren har inte gett några instruktioner före övningen utan instruerar den stegvis. Utdraget är från början av övningen: rad 1-6 utgör slutet av den första repetitionen, rad 11-22 den andra repetitionen. Att röra på axlarna introduceras i slutet av den andra repetitionen.

Exempel 6. Och axlarna (PT2_fisv 17.02)
01 PT:
\{å så får du andas ut.
$02 \mathrm{PT}+\mathrm{MO}$ :
\{(håller pinnen ovanför huvudet med brett handgrepp)\}
03 PT: $\mathrm{PFHHH}$.
04 PT:
\{å så får du släppa ${ }^{\circ}$ ner ${ }^{\circ}$. \}
\{ (sänker sin pinne)
(sänker \{sin pinne)
\{ja måst ju ha andats in före ja kan andas ut. 


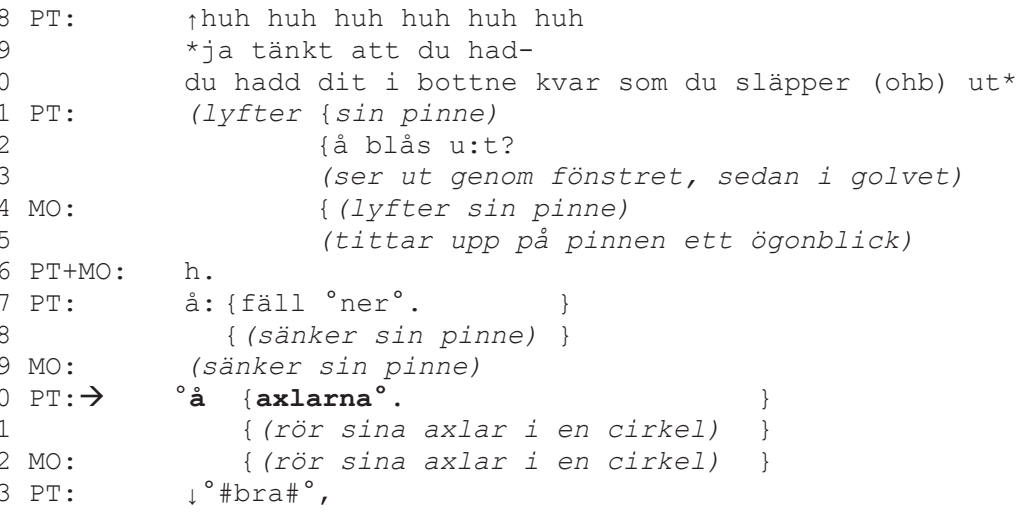

I utdraget ger tränaren en rad instruktioner, både i form av deklarativa satser (r. 1,4), imperativa satser (r. 12, 17) och i form av en fras (r. 20). Samtliga instruktioner inleds med konjunktionen $a$ ' 'och', som här binder ihop element med instruerande funktion och hänvisar till en institutionell agenda (jfr Heritage \& Sorjonen 1994). Motionären svarar enbart fysiskt på instruktionerna, med undantag av rad 7 där hon skämtsamt protesterar mot att tränaren gett bristfälliga instruktioner.

Genom placeringen mitt emot varandra kan tränaren se vad motionären gör och vice versa. De har ögonkontakt nästan hela tiden och i transkriptionen anges bara när de inte har det. Ögonkontakten är en förutsättning för att motionären ska veta hur övningen går till. Tränaren koordinerar sina verbala instruktioner med såväl sina egna som med motionärens rörelser och varje instruktion kommer precis när motionären är redo att följa den. Exempelvis både påbörjar och avslutar tränaren sin fysiska rörelse och verbala instruktion samtidigt på rad 4 och 5 , och påbörjar nästa verbala instruktion på rad 12 när pinnen är nästan uppe. Den fysiska demonstration som äger rum på rad 11 föregås inte av någon verbal sådan, utan tränaren lyfter bara sin pinne och motionären följer.

Efter att båda två har sänkt sina pinnar på rad 18 och 19 producerar tränaren den frasformade instruktionen å axlarna samtidigt som hon för sina axlar i en cirkel (r. 20, 21; se bild 5). Motionären svarar genom att omedelbart göra en liknande rörelse (r. 22). Nominalfrasen å axlarna fäster motionärens uppmärksamhet vid den kroppsdel som är central vid detta moment i övningen (jfr Rantala-Ekholm 1999 om substantiv under ishockeyträningar på finska; Sorjonen \& Raevaara 2014 om substantiv i servicesituationer på finska). Ljudstyrkan och tonhöjden i frasen är lägre än i tidigare instruktioner, och röstkvaliteten en 
Bild 5. Positionerna när å axlarna produceras. Motionären till vänster.

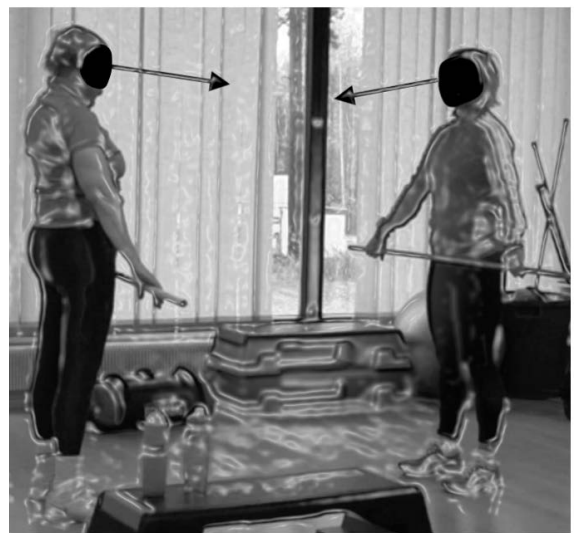

aning knarrig, vilket bidrar till att instruktionen framstår som den sista i en serie av flera instruktioner (jfr Huhtamäki 2012).

Därefter producerar tränaren uppföljningen bra (r. 23), vilket är en evaluering av lägre positiv grad. Den kan beskrivas som prosodiskt nertonad, eftersom den börjar på en lägre tonhöjd än föregående tur och är mycket tyst (jfr Curl 2002, Ogden 2006). Samtidigt fungerar dessa prosodiska drag, tillsammans med en knarrig röstkvalitet, slutsignalerande. Med evalueringen uttrycker tränaren att motionärens prestation är tillräcklig, och att denna repetition är slut.

Både det frasformade yttrandet å axlarna och den visuella demonstrationen är viktiga för att motionären ska kunna utföra detta moment. Till skillnad från de instruktioner Keevallik (2013) undersökt produceras den verbala och den fysiska delen av instruktionen nästan samtidigt. Deltagarnas placering mitt emot varandra är av stor betydelse för att motionären ska förstå instruktionen och tränaren producera den vid exakt rätt tidpunkt. Till motionärens förståelse av frasen bidrar också hennes kännedom om aktiviteten och deltagarnas roller. Likaså skapar raden av tidigare instruktioner, inledda med ett additivt $\stackrel{a}{a}$, förväntningar på att också detta yttrande ska fungera som en instruktion. Det frasformade yttrandet bidrar därtill till rytmen i övningen, genom att ange exakt när rörelsen ska utföras.

Utdragen ovan illustrerar hur frasformade yttranden används och förstås som instruktioner av deltagarna i personlig träning. Den sekventiella analysen visar att koordineringen mellan verbala och fysiska handlingar är avgörande för tolkningen. Det är ofta centralt att motionären och tränaren ser varandra, eller att de har kontakt genom beröring. En annan viktig faktor är att tränarna väl- 
jer ut centrala element i situationen, nämligen en kroppsdel, en riktning eller det faktum att motionären ska utföra ett visst antal repetitioner. Ibland kombineras flera av dessa i samma instruktion. Därtill bidrar motionärernas förförståelse av situationen och deras förväntan på nästa steg i övningen till att yttrandena uppfattas som instruktioner. Deltagarnas institutionella roller kan heller inte överskattas, eftersom tränaren förväntas instruera och motionären följa instruktionerna. De frasformade instruktionerna fungerar även som verbalt material. Det vill säga de ger tränaren ljud att uttala som gör det möjligt att styra tempot och intensiteten i övningarna med rösten.

\subsection{Uppföljningar av den fysiska prestationen efter en frasformad instruktion}

I träningssessionerna bildar en frasformad instruktion, det fysiska utförandet av övningen och en eventuell uppföljning en IRU-sekvens. Som tidigare nämnts har vi använt motionärens fysiska responser för att se vilka av tränarens frasformade yttranden som tolkas som instruktioner. Tränarens uppföljningar efter den fysiska responsen visar i sin tur hur väl motionären förstått tränarens instruktion. Uppföljningar förekommer naturligtvis även efter instruktioner som inte är frasformade, men de faller utanför ramen för denna undersökning.

Efter vissa av de frasformade instruktionerna i materialet producerar tränaren uppföljningar efter motionärens fysiska prestation, men det förekommer även att dessa saknas. När uppföljningar saknas är det inte nödvändigtvis så att motionärens fysiska respons är inkorrekt. I stället visar tränaren genom att genast gå vidare i programmet att responsen var korrekt och tillräcklig.

De uppföljningar som till sin lexikala betydelse bekräftar att motionären utfört övningen korrekt har vi kallat bekräftande uppföljningar. Dessa utgörs exempelvis av så, yes eller dit ja (se ex. 5 r. 14). Andra uppföljande turer evaluerar motionärens prestation, och dessa evalueringar kan vara av lägre eller högre grad. Som evalueringar av lägre grad har vi definierat uppföljningar av typen bra (se ex. 6 r. 23), medan vi betraktar uppföljningar som uttrycker något utöver detta som evalueringar av högre grad, exempelvis ja: super (jfr Pomerantz 1984, Antaki m.fl. 2000, Lindström m.fl. 2019). Många av uppföljningarna är alltså frasformade. 
Uppföljningarna fungerar både som evalueringar av prestationen och som övergångssignaler före nästa moment $\mathrm{i}$ övningen eller nästa övning (jfr Norrby m.fl. 2018 och Lindström m.fl. 2019 för tredjedrag i servicesamtal). Speciellt används bekräftande uppföljningar och evalueringar av lägre positiv grad som övergångssignaler mellan övningar eller moment under träningssessionerna, men den lexikala utformningen anger inte nödvändigtvis om uppföljningen är mer en evaluering eller en övergångssignal. Funktionen av övergångssignal förstärks genom att tränarna ofta har blicken riktad bort från motionären och vänder sig mot platsen för nästa övning när de uttalar uppföljningen (jfr Goodwin \& Goodwin 1987, Rossano 2013). Somliga uppföljningar förekommer efter ett visst moment inne i en övning, medan andra förekommer efter ett övningsset. Ett påfallande drag är att många uppföljningar följs av en ny instruktion i samma tur. Vid ett tillfälle ger tränaren instruktionen två till och motionären utför rörelsen ytterligare två gånger, varefter tränaren säger yes vi tar vänster utan paus mellan uppföljning och instruktion. Många av de instruktioner som produceras direkt efter en uppföljning handlar om byte av sida eller att motionären får ta en liten paus: bra (.) vilar vi där.

Prosodiskt faller uppföljningarna i två grupper: en typ som uttalas mer framträdande än föregående frasformade instruktion, till exempel genom högre tonhöjd och långsammare talhastighet, och en typ som uttalas mycket snabbt och liksom i förbigående, vilket tonar ner uppföljningens aspekt av beröm. När tränarna producerar evalueringar av högre positiv grad använder de ofta klart större ljudstyrka och tonomfång och/eller högre tonhöjd samt förlänger något ljud, dvs. uppgraderad prosodi (jfr Curl 2002, Ogden 2006), men uppgraderad prosodi och lexikalt högre grad sammanfaller inte nödvändigtvis.

\subsection{En jämförelse mellan Finland och Sverige}

I detta avsnitt jämför vi inspelningarna från Finland och Sverige med varandra. När det gäller den institutionella kontexten finner vi inga uppenbara skillnader mellan länderna, vare sig när det gäller aktiviteter eller utformningen av den fysiska kontexten. I fråga om antalet och typen av frasformade instruktioner, liksom uppföljningar, finns det däremot vissa skillnader.

Av de 617 frasformade instruktionerna i vårt material förekommer 406 under de finlandssvenska träningspassen, medan drygt hälften så många, 211, förekommer under de sverigesvenska (se tabell 2). Att frasformade instruktioner är vanligare i Finland kunde peka på att finlandssvenska tränare är mer direkta 
i sin verbala utformning av instruktioner, vilket är en liknande tendens som Henricson \& Nelson (2017) fann i sin studie av råden i handledarsamtal. Eftersom vi inte räknat hur stor andel de frasformade instruktionerna utgör av alla instruktioner är det dock svårt att veta om skillnaden är utslag av individuella variationer eller kan kopplas till varieteterna. Typen av träning varierar något mellan de olika inspelningarna, t.ex. hur högt tempot är och hur mycket precision som krävs i rörelserna. Ju mer precisionskrävande rörelserna är, desto fler frasformade (och andra) instruktioner.

Tabell 2. Fördelningen av olika typer av referens till situerade element, antal och andel.

\begin{tabular}{|c|c|c|c|c|c|c|c|}
\hline & \multicolumn{2}{|c|}{ Räkning } & \multicolumn{2}{|c|}{ Kropp och/eller riktning } & \multicolumn{2}{|c|}{ Övriga } & \multirow[b]{2}{*}{ Totalt per land } \\
\hline & antal & andel & antal & andel & antal & andel & \\
\hline Finland & $134^{6}$ & $33 \%$ & 205 & $50 \%$ & 71 & $17 \%$ & 407 \\
\hline Sverige & 123 & $58 \%$ & 61 & $29 \%$ & 26 & $12 \%$ & 210 \\
\hline Totalt & 251 & $40 \%$ & 264 & $43 \%$ & 102 & $17 \%$ & 617 \\
\hline
\end{tabular}

Fördelningen mellan olika typer av referenser till situerade element skiljer sig något mellan Finland och Sverige. Medan omnämnande av kropp och/eller riktning är den vanligaste typen (50\%) i det finlandssvenska delmaterialet, är räkning den vanligaste typen i det sverigesvenska (58 \%). Skillnaderna beror troligen på att typen av övningar varierar mellan inspelningarna, exempelvis sådana övningar som kräver noggranna instruktioner och sådana som kräver mer generella.

Det finns mer markanta skillnader mellan Finland och Sverige när det gäller hur ofta och med vilken typ av yttrande tränarna följer upp motionärernas prestationer efter en instruktion. Uppföljningar är överlag mer frekventa i det sverigesvenska delmaterialet: 44 procent av prestationerna följs upp i Sverige, medan endast 25 procent följs upp i Finland (se tabell 3). Vidare utgörs största delen av uppföljningarna i Finland av bekräftande sådana, exempelvis $s a ̊$, medan evalueringar av lägre positiv grad, såsom bra, utgör den största gruppen i Sverige. Evalueringar av högre positiv grad, exempelvis snyggt gött, är därtill klart vanligare i Sverige än i Finland. Mönstret påminner om det som Lindström med flera (2019) fann i sin undersökning av värderingar i servicesamtal i Finland och Sverige, nämligen att värderingar tenderar vara mer uppgraderade i Sverige (jfr även Henricson \& Nelson 2017 om handledningssamtal). I

\footnotetext{
${ }^{6}$ Det finns tre fall i det finlandssvenska materialet där kropp och/eller riktning kombineras med räkning, vilket innebär att summan av de olika typerna överstiger det totala antalet frasformade instruktioner.
} 
båda delmaterialen är bra den vanligaste uppföljningen: 34 stycken i Sverige och 18 stycken i Finland.

Tabell 3. Uppföljning av den fysiska prestationen efter en frasformad instruktion. $^{7}$

\begin{tabular}{lcccr}
\hline & \multicolumn{2}{c}{ Finland $^{8}$} & \multicolumn{2}{c}{ Sverige $^{9}$} \\
& Antal & Andel & Antal & Andel \\
\hline Bekräftande uppföljningar & 55 & $54 \%$ & 18 & $19 \%$ \\
Evalueringar av lägre positiv grad & 36 & $35 \%$ & 47 & $51 \%$ \\
Evalueringar av högre positiv grad & 11 & $11 \%$ & 28 & $30 \%$ \\
Totalt & 102 & $100 \%$ & 93 & $100 \%$ \\
\hline
\end{tabular}

Det finns alltså vissa skillnader mellan de två delmaterialen. Det förekommer fler frasformade instruktioner i det finlandssvenska delmaterialet än i det sverigesvenska, och vilken typ av instruktioner som är vanligast skiljer sig också. Det förekommer däremot fler uppföljningar efter en fysisk prestation i det sverigesvenska delmaterialet, och uppföljningarna är oftare uppgraderade än i det finlandssvenska delmaterialet.

\section{Sammanfattning och avslutande diskussion}

I denna artikel har vi presenterat en undersökning av en typ av interaktion som är så gott som obeforskad inom det språkvetenskapliga fältet, nämligen personlig träning. I undersökningen fokuserar vi på korta yttranden som vi valt att kalla frasformade instruktioner, vilka tidigare inte belysts på svenska i denna typ av kontext. Som frasformade instruktioner har vi definierat yttranden som 1) saknar finit verb, 2) utgör självständiga syntaktiska, prosodiska och pragmatiska enheter och 3) uppmanar till en fysisk handling som följande drag. Vi har undersökt hur frasformade yttranden fungerar som instruktioner i personlig träning samt jämfört hur dessa yttranden används i ett finlandssvenskt och ett sverigesvenskt delmaterial.

Vår undersökning visar att betydelsen hos frasformade instruktioner i per-

\footnotetext{
${ }^{7}$ Vi har räknat en uppföljande tur som en uppföljning och klassificerat den enligt det element som har högst grad i turen, exempelvis där ja bra räknas som en evaluering av lägre positiv grad även om den också innehåller den bekräftande uppföljningen där ja.

${ }^{8}$ Två osäkra uppföljningar i det finlandssvenska materialet har ej räknats med: en otydlig och en svårklassificerad.

${ }^{9}$ I det sverigesvenska materialet ingår tre uppföljningar producerade av andra motionärer under gruppträningen.
} 
sonlig träning endast i en viss utsträckning bygger på deras verbala utformning. Därtill utnyttjar deltagarna alla tillgängliga semiotiska resurser för att förstå dem, nämligen den övergripande aktiviteten, de institutionella rollerna som tränare och motionär, kropparnas position och rörelser i rummet, tidigare interaktion samt icke-verbala drag hos instruktionerna (jfr Goodwin 2000).

Eftersom den övergripande aktiviteten utgörs av personlig träning har både tränare och motionärer förväntningar om att det deltagarna säger i första hand ska handla om de fysiska övningarna. Ofta produceras de frasformade instruktionerna när övningen redan introducerats, så att de är inbäddade $\mathrm{i}$ ett pågående projekt (jfr Lindström m.fl. 2017 om imperativer). De utgör ofta preciseringar eller korrigeringar av övningarna. De frasformade instruktionerna kan jämföras med kontrollinstruktioner som syftar till en omedelbar handling enligt De Stefanis \& Gazins (2014) indelning.

Vidare är de frasformade instruktionerna möjliga på grund av den självklara auktoritet som den personliga tränaren har under träningen (jfr Stevanovic \& Peräkylä 2012). Det finns en tydlig rollfördelning mellan vem som har rättighet att ge instruktioner och vem som drar nytta av att följa dem: tränaren förväntas ge instruktioner och motionären följa dem (jfr Curl \& Drew 2008, CouperKuhlen 2014, Lundin 2018). Att de frasformade yttrandena uppfattas som instruktioner beror alltså i hög grad på deltagarnas uppfattningar om sina egna och varandras förpliktelser i situationen.

Element i den fysiska miljön, såsom olika träningsredskap, styr kroppsrörelserna hos deltagarna (jfr Cekaite 2010). I vissa fall får det verbala innehållet stöd av kroppsliga element $\mathrm{i}$ instruktionen, det vill säga tränaren kombinerar den frasformade instruktionen med en visuell-kroppslig eller taktil-kroppslig demonstration. Ett frasformat yttrande kan emellertid fungera som instruktion också utan kroppsliga element, vilket är en skillnad mot de syntaktiskt-kroppsliga konstruktioner som Keevallik (2013) beskriver.

Resultatet påminner om ett antal undersökningar av frasformade yttranden och imperativer inom andra typer aktiviteter, såsom körlektioner på italienska respektive tyska (se De Stefani \& Gazin 2014, Deppermann 2018), aerobictimmar och ishockeyträningar på finska (se Torpo 1998, Rantala-Ekholm 1999) och servicesituationer på finska (se Sorjonen \& Raevaara 2014). Militära kommandon är ett område som Svenska Akademiens grammatik (1999, 4 s. 814) nämner. Gemensamma drag i dessa institutionella kontexter är att rollfördelningen är tydlig, att deltagarnas förståelse av verksamheten är stor, att den fysiska miljön begränsar handlingarna och att det är frågan om uppmaningar som skapar förväntningar på en fysisk respons. 
Vi fann inte någon speciell »uppmaningsprosodi» som skulle förtydliga de frasformade yttrandenas funktion som instruktioner (jfr SAG 1999, 4 s. 677, Gårding 1998 s. 121-122, Huhtamäki 2014). Stigande slutintonation förekommer visserligen hos vissa instruktioner, men även hos de uppföljande yttrandena. Den stigande intonation som används i de instruerande sekvenserna används sannolikt för att signalera att yttrandena utgör punkter på en lista och pekar således framåt i interaktionen (jfr Karlsson 2010, Huhtamäki 2015).

Frasformade instruktioner handlar alltså i många fall om detaljer i övningen, och de är bara i vissa fall nödvändiga för att övningen ska framskrida. I flera av de analyserade exemplen skulle motionären troligen ha utfört övningen på rätt sätt även utan tränarens instruktion. Det innebär att den instruerande dimensionen inte alltid är i förgrunden, utan det frasformade yttrandet används även för att uppmuntra motionären genom pågående interaktion. Detta gäller speciellt instruktionerna som inkluderar räkning, som ofta uttalas före den sista repetitionen av en viss rörelse.

Utifrån vår undersökning kan vi konstatera att frasformade yttranden inte bara är möjliga att förstå som instruktioner i personlig träning, utan de är också mycket väl anpassade till denna kontext. Tack vare att de är korta och komprimerade går det snabbt att uttala dem (jfr De Stefani \& Gazin 2014). På så sätt är de lätta att koordinera med den fysiska aktiviteten. En frasformad instruktion kan skjutas in strax före ett moment, och användas för att finjustera motionärens pågående prestation (jfr Deppermann 2018). Genom att instruktionerna är så korta är det också lätt för motionären att veta vilka aspekter tränaren fokuserar. De frasformade instruktionerna innehåller en begränsad mängd grammatisk information men refererar till situerade element i träningen vilket underlättar för motionären att förstå dem. De frasformade instruktionerna har också funktionen av verbalt material som tränaren kan uttala för att ange tempo och intensitet hos övningarna.

Frasformade instruktioner används nästan dubbelt så ofta i det finlandssvenska som i det sverigesvenska delmaterialet. Eftersom frasformade instruktioner kan sägas vara direkta och icke-modulerade kan detta resultat visa på en liknande tendens som hos råd i handledningssamtal i dessa länder (se Henricson \& Nelson 2017). I det sverigesvenska delmaterialet följs en större andel av de fysiska prestationerna upp. Därtill används evalueringar av lägre och högre positiv grad oftare i Sverige, medan allmänt bekräftande uppföljningar är vanligast i Finland. Resultatet pekar alltså i samma riktning som tidigare studier av skillnader mellan finlandssvensk och sverigesvensk interaktion, nämligen att uppbackningar och värderingar tenderar vara mer uppgraderade i Sverige (se 
Henricson \& Nelson 2017, Lindström m.fl. 2019). Dessa skillnader hör troligen samman med skillnader i de respektive kulturer där finlandssvenska och sverigesvenska talas.

\section{Transkriptionsnyckel}

(jfr Lindström 2008 s. 309, Hepburn \& Bolden 2013)

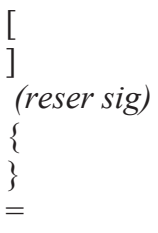

(.)

$\mathrm{mm}+\mathrm{m}$

sista:

foten

BRA

${ }^{\circ} \mathrm{bra}^{\circ}$

$>$ upp $<$

$<$ upp $>$

*ja tänkt*

.h

h.

.HH

$\mathrm{HH}$.

(ett)

(ohb)

?

hälen överlapp inleds

överlapp slutar

kommentar om en deltagares fysiska handling

samtidig fysisk handling inleds

samtidig fysisk handling avslutas

1) yttranden hakas på varandra utan paus

2) yttrandet fortsätter på annan rad

mikropaus (under 0,2 sekunder)

paus uttryck i sekunder

ljudet uttalas med brott inuti

förlängt ljud

starkt betonad stavelse

tal med högre ljudstyrka än omgivande tal

tal med lägre ljudstyrka än omgivande tal

tal som är snabbare än omgivande tal

tal som är långsammare än omgivande tal

tal med skratt i rösten

hörbar inandning

hörbar utandning

lång och ljudlig inandning

lång och ljudlig utandning

transkriptionen är osäker

ohörbart

fallande slutintonation

jämn slutintonation

stigande slutintonation

fetstil används för de frasformade instruktionerna

\section{Litteratur}

Antaki, Charles, Houtkoop Steenstra, Hanneke \& Rapley, Mark, 2000: "Brilliant. Next question." High-grade assessment sequences in the completion of interactional units. I: Research on language and social interaction 33. S. 235-262.

Blommaert, Jan \& Jie, Dong, 2010: Ethnographic fieldwork: a beginner's guide. Bristol: Multilingual matters. 
Bockgård, Gustav, 2007: Syntax och prosodi vid turbytesplatser. Till beskrivningen av svenskans turtagning. I: E. Engdahl \& A.-M. Londen (red.): Interaktion och kontext. Nio studier av svenska samtal. Lund: Studentlitteratur. S. 139-183.

Cekaite, Asta, 2010: Shepherding the child: embodied directive sequences in parentchild interactions. I: Text \& talk 30:1. S. 1-25.

Couper-Kuhlen, Elizabeth, 2014: What does grammar tell us about action? I: Pragmatics 24:3. S. 623-647.

Couper-Kuhlen, Elizabeth \& Selting, Margret, 2001: Introducing interactional linguistics. I: M. Selting \& E. Couper-Kuhlen (red.): Studies in interactional linguistics. Amsterdam/Philadelphia: John Benjamins publishing company. S. 1-22.

Couper-Kuhlen, Elizabeth \& Selting, Margret, 2018: Interactional linguistics: Studying language in social interaction. Cambridge: Cambridge University Press.

Curl, Traci S., 2002: The phonetics of sequence organization: an investigation of lexical repetition in other-initiated repair sequences in American English. Doctoral dissertation. Department of linguistics, University of Colorado.

Curl, Traci S. \& Drew, Paul, 2008: Contingency and action: a comparison of two forms of requesting. I: Research on language and social action 41:2. S.129-153.

De Stefani, Elwys \& Gazin, Anne-Danièle, 2014: Instructional sequences in driving lessons: Mobile participants and the temporal and sequential organization of actions. I: Journal of pragmatics 65. S. 63-79.

Deppermann, Arnulf, 2018: Instructing practices in German driving lessons: Differential uses of declaratives and imperatives. I: International journal of applied linguistics 28:2. S. 265-282.

Drew, Paul \& Heritage, John, 1992: Analyzing talk at work: an introduction. I: P. Drew \& J. Heritage (red.): Talk at work: interaction in institutional settings. Cambridge: Cambridge University press. S. 3-65.

Ford, Cecilia \& Thompson, Sandra, 1996: Interactional units in conversation: syntactic, intonational, and pragmatic resources for the management of turns. I: E. Ochs, E. Schegloff \& S. Thompson (red.): Interaction and grammar. (Studies in interactional sociolinguistics 13.) Cambridge: Cambridge University press. S. 134-184.

George, Molly, 2008: Interactions in expert service work. Demonstrating professionalism in personal training. I: Journal of contemporary ethnography 31:1. S. 108-131. https://doi.org/10.1177/0891241607309498.

Goffman, Ervin, 1981: Forms of talk. Oxford: Basil Blackwell.

Goodwin, Charles, 2000: Action and embodiment within situated human interaction. I: Journal of pragmatics 32. S. 1489-1522.

Goodwin, Charles \& Goodwin, Marjorie H., 1987: Concurrent operations on talk: notes on the interactive organization of assessments. I: IPrA Papers in Pragmatics 1:1. S. 1-55.

Grahn, Inga-Lill, 2017: Initierande tackhandlingar i sverigesvenska och finlandssvenska vårdsamtal - sekvensorganisering och funktion. I: Språk och interaktion 4: 4. S. 89-110. http://hdl.handle.net/10138/229739.

Grahn, Inga-Lill \& Huhtamäki, Martina, 2019: Frasformade instruktioner under fysisk aktivitet - form och funktion i interaktionell belysning. I: M. Bianchi, D. Håkansson, B. Melander, L. Pfister, M. Westman \& C. Östman (red.): Svenskans beskrivning 36. Förhandlingar vid trettiosjätte sammankomsten. Uppsala 25-27 oktober 2017. Uppsala: Institutionen för nordiska språk vid Uppsala universitet. S. 65-78. 
Henricson, Sofie \& Nelson, Marie, 2017: Giving and receiving advice in higher education. Comparing Sweden-Swedish and Finland-Swedish supervision meetings. I: Journal of pragmatics 109. S. 105-120. http://www.sciencedirect.com/science/journal/03782166.

Hepburn, Alexa \& Bolden, Galina B., 2013: The conversation analytic approach to transcription. I: J. Sidnell \& T. Stivers (red.): The handbook of conversation analysis. Chichester: Wiley-Blackwell. S. 57-76.

Heritage, John, 1997: Conversational analysis and institutional talk: analyzing data. I: D. Silverman (red.): Qualitative research: theory, method and practice. London: Sage Publications. S. 161-182.

Heritage, John \& Sorjonen, Marja-Leena, 1994: Constituting and maintaining activities across sequences: And-prefacing as a feature of question design. I: Language in society 23. S. 1-29.

Huhtamäki, Martina, 2012: Prosodiska drag i frågor. En undersökning av Helsingforssvenska samtal. I: Språk och stil NF 22:2. S. 153-184.

Huhtamäki, Martina, 2014: Intonation och funktion hos frågor med icke-interrogativ syntax. En undersökning av Helsingforssvenska flerpersonssamtal. Tal och språk 34:4. S. $147-173$.

Huhtamäki, Martina, 2015: Frågor med stigande och jämn slutintonation i Helsingforssvenska samtal. I: Folkmålsstudier 53: Meddelanden från Föreningen för nordisk filologi. S. 79-115.

af Hällström-Reijonen, Charlotta \& Reuter, Mikael, 2008: Finlandssvensk ordbok. Forskningscentralen för de inhemska språken. Helsingfors: Schildts förlags Ab. Tillgänglig på http://kaino.kotus.fi/fsob/?p=main.

Jefferson, Gail, 1990: List construction as a task and interactional resource. I: G. Psathas (red.): Interaction Competence. Washington D.C.: University Press of America. S. 63-92.

Karlsson, Susanna, 2010: Multimodalitet i listproduktion. I: Språk och interaktion 2. S. 141-170. http://hdl.handle.net/10138/28555.

Keevallik, Leelo, 2013: The interdependence of bodily demonstrations and clausal syntax. I: Research on language and social interaction 46:1. S. 1-21. https://doi.org/ 10.1080/08351813.2013.753710.

Lindström, Jan, 2008: Tur och ordning. Introduktion till svensk samtalsgrammatik. Stockholm: Norstedts akademiska förlag.

Lindström, Jan, Lindholm, Camilla, Grahn, Inga-Lill \& Huhtamäki, Martina, u.u.: Consecutive clause combinations in instructing activities: Directives and accounts in the context of physical training. I: Y. Maschler, S. Pekarek Doehler, J. Lindström \& L. Keevallik (red.): Emergent syntax for conversation: Clausal patterns and the organization of action. Amsterdam: John Benjamins publishing company.

Lindström, Jan, Lindholm, Camilla, Norrby, Catrin, Wide, Camilla \& Nilsson, Jenny, 2017: Imperatives in Swedish medical consultations. I: M.-L. Sorjonen, L. Raevaara $\&$ E. Couper-Kuhlen (red.): Imperative turns at talk: The design of directives in action. Amsterdam: John Benjamins publishing company. S. 299-324.

Lindström, Jan, Norrby, Catrin, Wide, Camilla \& Nilsson, Jenny, 2019: Task-completing assessments in service encounters. I: Research on language and social interaction 52:2. S. 85-103. doi: 10.1080/08351813. 2019. 1581468 
Lindwall, Oskar, Lymer, Gustav \& Greiffenhagen, Christian, 2015: The sequential analysis of instruction. I: N. Markee (red.): The handbook of classroom discourse and interaction. Maiden, MA: Wiley-Blackwell. S. 142-157.

Linell, Per, 2011: Samtalskulturer. Kommunikativa verksamhetstyper i samhället. (Studies in language and culture 18.) Linköping: Institutionen för kultur och kommunikation, Linköpings universitet.

Lundin, Katarina, 2018: Att instruera i idrottskontext. Educare 2018:1. S. 140-169.

Macbeth, Douglas, 2003: Hugh Mehan's "Learning Lessons" reconsidered: on the differences between the naturalistic and critical analysis of classroom discourse. I: American educational research journal 40:1. S. 239-280.

Martin, Cathrin, 2004: From other to self. Learning as interactional change. Doktorsavhandling. Uppsala: Pedagogiska institutionen, Uppsala universitet.

Martin, Cathrin \& Sahlström, Fritjof, 2010: Learning as longitudinal interactional change: From other-repair to self-repair in physiotherapy treatment. I: Discourse Processes 47:8. S. 668-697.

Mehan, Hugh, 1979: Learning lessons: Social organization in the classroom. Cambridge, MA: Harvard University press.

Mondada, Lorenza, 2011: Understanding as an embodied, situated and sequential achievement in interaction. I: Journal of pragmatics 43:2. S. 542-552.

Nilsson, Jenny, Norrthon, Stefan, Lindström, Jan \& Wide, Camilla, 2018: Greetings as social action in Finland Swedish and Sweden Swedish service encounters - a pluricentric perspective. I: Intercultural pragmatics 15:1. S. 57-88. doi:10.1515/ ip-2017-0030. https://helda.helsinki.fi/handle/10138/234613.

Nishizaka, Aug, 2016: Syntactical constructions and tactile orientations: procedural utterances and procedures in massage therapy. I: Journal of pragmatics 98. S. 18-35.

Norrby, Catrin, Lindström, Jan, Wide, Camilla \& Nilsson, Jenny, 2018: Kivasvenska och kanonsvenska. Sekvensavslutande värderingar i servicesamtal. I: B. Silén, A. Huhtala, H. Lehti-Eklund, J. Stenberg-Sirén, \& V. Syrjälä (red.): Svenskan i Finland 17. Helsingfors: Helsingfors universitet. S. 107-117.

Norrby, Catrin, Wide, Camilla, Lindström, Jan \& Nilsson, Jenny, 2012: Finland Swedish as a non-dominant variety of Swedish - extending the scope to pragmatic and interactional aspects. I: R. Muhr (red.): Non-dominant varieties of pluricentric languages: Getting the picture. In memory of Michael Clyne. Frankfurt am Main: Peter Lang. S. 49-62.

Norrby, Catrin, Wide, Camilla, Lindström, Jan \& Nilsson, Jenny, 2014: Finns det nationella svenska kommunikationsmönster? Tilltal i läkare-patientsamtal i Sverige och Finland. I: J. Lindström, S. Henricson, A. Huhtala, P. Kukkonen, H. Lehti-Eklund \& C. Lindholm (red.): Svenskans beskrivning 33. (Nordica Helsingiensia 37.) Helsingfors: Finska, finskugriska och nordiska institutionen, Helsingfors universitet. S. 343-352. http://hdl.handle.net/10138/144498.

Ogden, Richard, 2006: Phonetics and social action in agreements and disagreements. I: Journal of pragmatics 38:10. S. 1752-1775. https://doi.org/10.1016/j.pragma.2005.04.011.

Placencia, María Elena, 2008: Requests in corner shop transactions in Ecuadorian Andean and Coastal Spanish. I: K. P. Schneider \& A. Barron (red.): Variational pragmatics. A focus on regional varieties in pluricentric languages. Amsterdam: John Benjamins publishing company. S. 307-332. 
Pomerantz, Anita, 1984: Agreeing and disagreeing with assessments: Some features of preferred/dispreferred turn shapes. I: J. Heritage \& J. M. Atkinson (red.): Structures of social action: Studies in conversation analysis. Cambridge: Cambridge University Press. S. 57-101.

Rantala-Ekholm, Kati, 1999: Kiekko liikkuu, kiekko liikkuu: Jääkiekkovalmennuksen direktiiveistä [Om direktiv under ishockeyträningar]. Pro gradu-avhandling. Helsingfors: SKL, Helsingfors universitet.

Rossano, Federico, 2013: Gaze in conversation. I: J. Sidnell \& T. Stivers (red.): The handbook of conversation analysis. Chichester: Wiley-Blackwell. S. 308-329.

Sacks, Harvey \& Schegloff, Emanuel, 1973: Opening up closings. I: Semiotica VIII:4. S. 289-327.

Sacks, Harvey, Schegloff, Emanuel \& Jefferson, Gail, 1974: A simplest systematics for the organization of turn-taking for conversation. I: Language 50. S. 696-735.

SAG = Ulf Teleman, Staffan Hellberg \& Erik Andersson, 1999: Svenska Akademiens grammatik. Stockholm: Norstedts Ordbok.

Saville-Troike, Muriel, 2003: The ethnography of communication. An introduction. 3 upplagan. (Language in society 3.) Malden, MA: Blackwell publishing.

Schneider, Klaus P. \& Barron, Anne (red.), 2008: Variational pragmatics. A focus on regional varieties in pluricentric languages. Amsterdam: John Benjamins publishing company.

Sidnell, Jack, 2013: Basic conversation analytic methods. I: J. Sidnell \& T. Stivers (red.): The handbook of conversation analysis. Chichester: Wiley-Blackwell. S. 7799.

Sinclair, John \& Coulthard, Malcolm, 1975: Towards an analysis of discourse: The English used by teachers and pupils. London: Oxford University press.

Sorjonen, Marja-Leena \& Raevaara, Liisa, 2014: On the grammatical form of requests at the convenience store: Requesting as embodied action. I: P. Drew \& E. CouperKuhlen (red.): Requesting in social action. (Studies in language and social interaction 26.) Amsterdam: John Benjamins publishing company. S. 243-268.

Stevanovic, Melisa \& Peräkylä, Anssi, 2012: Deontic authority in interaction: the right to announce, propose, and decide. I: Research on language and social interaction 45: 3. S. 297-321. https://doi.org/10.1080/08351813.2012.699260.

Torpo, Lotta, 1998: Aerobic-tuntien direktiivit [Direktiv under aerobictimmar]. Pro gradu-avhandling. Helsingfors: SKL, Helsingfors universitet. 


\title{
Utvecklingen av interaktionell kompetens hos läkare som lär sig svenska
}

\author{
Mönster i frågesekvenser i rollspel med patienter
}

\author{
Av INGELA TYKESSON, LINDA KAHLIN \& MIHAELA \\ OANA ROMANITAN
}

\begin{abstract}
Tykesson, Ingela, ingela.tykesson@sh.se, Associate Professor, School of Culture and Education, Södertörn University; Kahlin, Linda, linda.kahlin@sh.se, Associate Professor, School of Culture and Education, Södertörn University; Romanitan, Mihaela Oana, mihaela.romanitan@ki.se, M.D., Ph.D., Department of Clinical Science and Education, Södersjukhuset (KI SÖS), S1: "The development of interactional competence of doctors learning Swedish. Patterns of question sequences in role-play with patients". Språk och stil NF 29, 2019, pp. 41-72.

County councils in Sweden annually engages foreign-educated doctors from other EU countries, to cover the shortage of doctors. This article examines a group of fourteen doctors that have been recruited from Eastern and Southern Europe to work in Sweden. It investigates the doctors' development of interactional competence during an intensive Swedish course conducted on a campus in Poland for 14 weeks. The investigation is conducted through role-plays in the form of medical consultations arranged on two occasions in the course, in the 6th and 12th weeks respectively. A total of 28 role-plays have been audio recorded and analysed using conversation analysis, CA. The main question is whether the participants' ability to respond to the patients' concerns advanced during the course.

The analysis shows that the doctors' ability to ask follow-up questions related to the patients' problem description improved on the second role-play occasion, as well as their ability to demonstrate their understanding of the patients' descriptions. There is also a tendency, the second time, for follow-up questions to lead to more fully developed responses from the patients. The result therefore indicates that the doctors' interactional competence increased during the course, despite the fact that the language teaching during the course is mainly based on written texts. In addition, a minor quantitative analysis indicates a faster talk rate, increased length of turns, and fewer hesitation marks during the second role-play.
\end{abstract}

Keywords: interactional competence, doctor-patient interaction, role-play, conversation analysis, second language learning, professional language, Swedish health care.

Det har länge varit brist på specialläkare i Sverige, och den fria rörligheten inom EU har ökat möjligheterna för landstingen att täcka denna brist genom att 
rekrytera utlandsutbildade läkare. ${ }^{1}$ Bristen på läkare inom många specialiteter verkar också komma att råda en lång tid framöver. Enligt en prognos fram till 2035 krävs en tillförsel av 500 utlandsutbildade läkare per år, om inte efterfrågan på läkare ska vara större än tillgången (Socialstyrelsen 2018a). ${ }^{2}$ Svensk sjukvård är således beroende av tillgången på utlandsutbildade läkare. Det handlar dels om svenskar som studerar till läkare utomlands, dels om läkare med ursprunglig hemvist i andra länder, framför allt inom EU. Någon offentlig statistik över hur många från respektive grupp som beviljas läkarlegitimation varje år finns inte. ${ }^{3}$

Inom ett samtalsinriktat forskningsprojekt har vi följt en grupp läkare från Öst- och Sydeuropa på deras väg mot att etablera sig som specialister i Sverige. ${ }^{4}$ De har fătt anställning via ett företag som på landstingens uppdrag rekryterar läkare från olika EU-länder och ansvarar för deras undervisning i svenska. Undervisningen bedrivs på ett internat i Polen under fjorton veckor. Enligt rekryteringsföretagets webbsidor erbjuds språkträning inriktad på professionellt, medicinskt språk och typiska situationer som läkarna kan ställas inför i den nya arbetsmiljön. Särskild tonvikt läggs vid att förbereda läkarna för god kommunikation med patienter och kollegor, uppger man. I denna artikel intresserar vi oss för hur en sådan typ av språkutbildning utanför målspråksmiljön förbereder deltagarna för yrkesrelaterat samtalande.

För att läkare från EU-länder ska få svensk läkarlegitimation krävs språkkunskaper i svenska, danska eller norska (Socialstyrelsen 2018b), men något sådant språkkrav var inte aktuellt för EU-läkare fram till 2015, då datainsamlingen gjordes. Emellertid krävde de flesta landsting att dessa läkare skulle ha klarat språktester för att få anställning. I överenskommelsen med rekryteringsföretaget garanterades att läkarna skulle ha uppnått B1-nivå efter intensivkursen i Polen och B2-nivå efter ca tre månaders vistelse i Sverige, med hjälp av individuell undervisning på distans. ${ }^{5}$

\footnotetext{
${ }^{1}$ Av de läkarlegitimationer som utfärdades i Sverige 2014 gick $52 \%$ till läkare som utbildats i ett annat EU-land och 7 \% till läkare från »tredje land» (Socialstyrelsen 2015).

${ }^{2}$ Sedan 2003 har Socialstyrelsen utfärdat fler läkarlegitimationer till personer som studerat utomlands än till personer som studerat i Sverige. Under 2016 utfärdades 2446 läkarlegitimationer och cirka $50 \%$ av dessa var till personer som utbildats i EU eller EES.

${ }^{3}$ Läsåret 2016/17 var det 2489 personer som studerade till läkare utomlands med studiemedel från Centrala studiestödsnämnden. Majoriteten av dessa studerade i Polen.

${ }^{4}$ Projektet, Utlandsrekryterade läkares inskolning $i$ sjukvårdssvenska $i$ Polen, är finansierat av Östersjöstiftelsen.

${ }^{5}$ Europarådets referensram (CEFR) beskriver språkkunskaper på sex nivåer: A1-C2. Gränsvärdena som anges i artikeln var aktuella 2015, då datainsamlingen gjordes. Därefter gäller C1-nivå (Socialstyrelsen 2018b).
} 
Analyserna som presenteras här är baserade på ett material som samlats in under en av svenskkurserna i Polen, där vi som forskare arrangerat läkarepatientsamtal i form av rollspel vid två tillfällen, i mitten och slutet av kursen. Vårt syfte är att ta reda på ifall läkarna utvecklat sin interaktionella kompetens, det vill säga förmåga att tolka och utföra språkhandlingar i socialt samspel, vilket vi gör genom att undersöka läkarnas sätt att ställa frågor och följa upp patienternas problembeskrivningar. Ett delsyfte är att undersöka hur deltagarnas allmänna språkfärdighet utvecklats.

Svenskkursen i Polen består mestadels av skriftspråksorienterad undervisning, utförd av polska lärare med utbildning i skandinavistik. Man följer i princip upplägget i Rivstart-serien (Levy Scherrer \& Lindemalm 2007, 2009), ett läroboksmaterial som ofta används i andraspråksundervisning i Sverige. Rollspelsövningar kan förekomma, men spontana dialoger är inte något frekvent inslag i undervisningen. Omkring femton procent av tiden ägnas åt medicinsk svenska. $^{6}$

\section{Interaktionell kompetens}

Begreppet interaktionell kompetens kan definieras som förmågan att samordna handlingar i interaktion relaterat till situationella förväntningar (Hall \& Pekarek Doehler 2011). Interaktionell kompetens innefattar ett flertal förmågor och kunskaper som en samtalsdeltagare behöver för att framgångsrikt kunna delta i social interaktion, bland annat förmåga att känna igen kontextspecifika samtalsmönster, konstruera turer så att de är igenkännbara för andra samt reparera problem och upprätthålla gemensam förståelse i samtal (Hall \& Pekarek Doehler 2011). ${ }^{7}$

Begreppet bygger enligt Young (2011) på tidigare teorier om kompetens, men till skillnad från kommunikativ kompetens, som räknas som en egenskap hos en individ, är interaktionell kompetens något som samkonstrueras av deltagarna i interaktionella praktiker. Interaktionell kompetens är, enligt Young, "not what a person knows, it is what a person does together with others» (2011 s. 430). Begreppet har sina rötter inom två olika forskningsdiscipliner, lingvistisk antropologi och conversation analysis (CA), där det började användas un-

${ }^{6}$ Muntlig uppgift under en intervju med kursens föreståndare, 9 juni 2015.

${ }^{7}$ För att understryka mångfalden använder vissa forskare termen i pluralform, interactional competencies (Kasper 2006 s. 86). 
gefär samtidigt (Hall 2018). Den lingvistiskt antropologiska traditionen, där till exempel Young ingår, fokuserar mer på hur individuell kunskap varierar i olika praktiker, medan CA-traditionen fokuserar mer på de universella strukturer för interaktion som samtalsdeltagare orienterar sig mot, oberoende av situation. Dessa två perspektiv har senare kombinerats (se vidare Hall 2018). För vår del ansluter vi oss närmast till den lingvistiskt antropologiska traditionen.

Interaktionell kompetens har fått ökad betydelse inom forskningen om andraspråksutveckling (Hall 2018), vilket innebär ett ökat fokus på meningsskapande i interaktion och de resurser som andraspråkstalare använder sig av för att göra sig förstådda och samspela med andra. Förmågan till interaktion i olika situationer är både kontextoberoende och kontextkänslig; i det senare ingår både att fortlöpande anpassa sig till vad som händer i samtalet och andra faktorer som har med den pågående aktiviteten att göra (Pekarek Doehler \& Petitjean 2017).

Forskningen om andraspråksutveckling har traditionellt varit inriktad på strukturella och kognitiva faktorer (Håkansson \& Norrby 2010). Under senare år har socialt förankrad forskning om de interaktionella resurser som används av andraspråkstalare vuxit sig starkare (Hall \& Pekarek Doehler 2011) och utmanat den tidigare etablerade uppfattningen där språkfärdighet ses som en separat komponent (jfr Bachman \& Palmer 1996). I stället betraktas språkfärdighet som en integrerad del (Markee 2008, Hall \& Pekarek Doehler 2011, Young 2011), eller som Markee (2008 s. 406) uttrycker det: »[d]eveloping interactional competence in a second language includes but goes beyond learning language as a formal system».

För vuxna andraspråksinlärare är interaktionell kompetens både en resurs och ett objekt för lärande (Kasper 2006). Rollspelen efterliknar det institutionella anamnessamtalet och läkarna förmodas här kunna dra nytta av sina tidigare erfarenheter av att genomföra denna typ av samtal på sitt modersmål. Vårt upplägg ger oss möjlighet att undersöka deltagarnas utveckling genom att studera hur de tar sig an samma uppgift vid två tillfällen. En svårighet är dock att urskilja vad som är ett resultat av utveckling och vad som beror på kontextuella skillnader (Sahlström 2011, Waring 2018). CA-forskning har traditionellt inte haft utveckling i fokus, och frågor som rör sambandet mellan lärande och interaktion återstår att reda ut (Hall \& Pekarek Doehler 2011). Allt fler forskare inom CA har dock intresserat sig för lärande som ett interaktionellt fenomen (se t.ex. Melander \& Sahlström 2011, Sahlström 2011, Nguyen 2012, Markee \& Kunitz 2013). 
Enligt Nguyen (2012) innebär interaktionell kompetens inom ramen för en institutionell diskursiv praktik bland annat förmåga att hantera sekventiellt organiserade handlingar i relation till det övergripande syftet och att hantera topiker som en del av samtalets sekventiella organisation. Dessa förmågor är specifika för varje diskursiv praktik. I vår studie har vi valt att operationalisera interaktionell kompetens på så vis att den handling vi fokuserar på är läkarnas sätt att ställa frågor i relation till frågemönster som påvisats i tidigare studier av läkare-patientsamtal, såsom Lindholm (2003), Boyd \& Heritage (2005), Heritage \& Maynard (2005) och Heritage (2010). Analysfokus ligger på hur läkarna ställer följdfrågor och på andra sätt följer upp patienternas problembeskrivningar.

\section{Tidigare forskning}

Forskningen om flerspråkigas utveckling av interaktionell kompetens på ett andraspråk har länge varit eftersatt. Att det tidigare fanns relativt få sådana studier konstateras exempelvis av Hall \& Pekarek Doehler (2011). De studier som gjorts har ofta gällt undervisningssammanhang, till exempel Cekaites studie (2007) av ett barns utveckling av interaktionell kompetens under sitt första år i en svensk skola och Young \& Miller (2004), som i en longitudinell studie visar att oerfarna talare av ett språk bara använder en mindre uppsättning interaktionella resurser. På senare år har allt fler forskare ägnat sig åt studier av utvecklingen av interaktionell kompetens utanför undervisningssituationer. Ett exempel är en studie av hur en au pair i Schweiz under en period av nio månader ökar sin förmåga att utnyttja resurser för att framföra vardagliga berättelser på ett andraspråk (Berger \& Pekarek Doehler 2018). Den och ett flertal andra studier inom samma område har samlats i en nyutgiven antologi av Pekarek Doehler m.fl. (2018). I antologin diskuteras också tidigare longitudinella studier i relation till klassisk CA-forskning (Wagner m.fl. 2018).

Många undersökningar har gjorts av rollspel som metod för språktestning, till exempel för utländska läkare i länder som Australien och Nya Zeeland, där man liksom i Sverige tar in många utlandsutbildade läkare (McNamara 1997, Wette 2011, Pill \& Mcnamara 2016, Woodward-Kron \& Elder 2016). Av forskning om rollspel som språkutvecklingsmetod i andraspråksundervisning har framgått att rollspel producerar alla typer av samtalsaspekter, enligt Kasper 
(2000), som lyfter fram metodens potential att synliggöra kulturbundna drag i interaktion.

Rollspel som pedagogisk metod förekommer allmänt i medicinska utbildningar, och metodens användbarhet har undersökts i en rad studier internationellt (t.ex. Joyner \& Young 2006, Nestel \& Tierney 2007, Luttenberger m.fl. 2014). Ett nordiskt exempel är Thomassen (2005), som analyserat rollspel mellan medicinstudenter och verkliga patienter i läkarutbildningar i Norge. Studien visar att det finns tvetydigheter på olika nivåer för deltagarna att hantera. En sådan är osäkerhet om vad det är för verksamhetstyp man deltar i, det vill säga om rollspelet ska uppfattas som en autentisk situation eller som en övningssituation. Linell \& Persson Thunqvist konstaterar också att rollspel innefattar »complexities and hybridities on several planes» (2003 s. 409), i en studie av arbetssökande. Studien pekar på problem med bibehållet fokus på rollspelandet och visar att deltagarnas uppfattning om verksamhetens inramning kan variera under samtalets gång. Rollspel kan således karakteriseras som en hybrid verksamhetstyp.

Med vår studie vill vi bidra med kunskap om utveckling av interaktionell kompetens hos vuxna språkinlärare, relaterat till yrkesanknutet samtalande i en ny institutionell språkmiljö. För att åstadkomma en longitudinell design använder vi oss av rollspel och hoppas därmed i någon mån även kunna bidra med didaktisk kunskap om rollspel som språkutvecklingsmetod.

\section{Material och metoder}

Den totala datainsamlingen i Polen gjordes vid tre tillfällen under sammanlagt tio dagar och genomfördes av Kahlin och Tykesson. Deltagare från två kurser under olika perioder ingick i studien. Under mötet med deltagare på den första kursen (16 personer) genomfördes intervjuer och observationer av undervisningen. Under mötena med deltagare på den andra kursen (14 personer) var vi huvudsakligen inriktade på att elicitera ett samtalsmaterial i form av rollspel, som vi designat för forskningsbruk. Rollspelen arrangerades av oss. De ägde rum under lektionstid, men ingick inte i den ordinarie undervisningen. Det hela presenterades för deltagarna som ett led i vår forskning och inte som ett undervisningspass. Deltagandet var frivilligt, men samtliga 14 kursdeltagare valde att vara med. 
Rollspelen genomfördes och spelades in vid två tidpunkter med samma deltagare, fördelade i halvgrupp. Rollspel 1 (RS1) gjordes under den 6:e kursveckan och rollspel 2 (RS2) under den 12:e kursveckan (se tabell 1).

Tabell 1. Rollspel: läkare-patientsamtal, audioinspelade.

\begin{tabular}{lllll}
\hline & Plats & Tid & Antal deltagare & Inspelningslängd \\
\hline RS1 & Polen & 6:e kursveckan & $14(2$ grupper $)$ & 2 tim 45 min \\
RS2 & Polen & 12:e kursveckan & 14 (2 grupper $)$ & 2 tim 19 min \\
\hline
\end{tabular}

Vid tidpunkten för RS2 hade deltagarna fătt undervisning i medicinsk svenska, vilket inte ingått före RS1, däribland en lektion i anamnessamtal. Som igångsättare för rollspelen visade vi sammanlagt fyra filmer med läkare-patientsamtal, två filmer före respektive tillfälle. Det är filmer som används i undervisningen av medicinstudenter i Sverige. I samband med filmvisningarna gavs utrymme för kommentarer och frågor. Vissa av kursens lärare deltog vid filmvisningarna, men under rollspelen var inga lärare närvarande.

En av projektdeltagarna, Mihaela Romanitan, som är läkare och neurologspecialist, har bidragit med att skapa realistiska sjukdomsfall att använda i rollspelen. Allt som allt hade vi förberett åtta fall. Varje läkare i respektive halvgrupp fick ett eget sjukdomsfall, samma fall och samma patient båda gångerna. Vi har alltså strävat efter att konstanthålla så många faktorer som möjligt, för att underlätta möjligheten att göra jämförelser. Alternativet att utsätta respektive läkare för en patient med en ny diagnos valde vi bort, eftersom vi bedömde att deltagarna ändå rätt snart skulle kunna lista ut vilken av våra åtta diagnoser som var aktuell, med tanke på att de suttit med som åhörare till varandras rollspel. Läkarna var inte informerade i förväg om att samma fall skulle återkomma vid det andra tillfället, vilket är viktigt att nämna.

I grupperna ingick yrkeserfarna läkare med specialistkunskaper inom olika discipliner och vissa, men inte alla, fick ett fall som var anpassat till deras specialisering. ${ }^{8}$ Kahlin och Tykesson turades om att agera patienter. För deltagarna markerade vi att vi ville ha en tydlig rollfördelning som innebar att en av oss enbart agerade patient, medan den andra, »bisittaren», var tillgänglig för stöttning, ifall läkaren själv uttryckte en önskan om språkhjälp. På så sätt ville vi sätta en tydlig ram för rollspelet och så långt som möjligt undvika att bryta il-

${ }^{8}$ Av forskningsetiska skäl går vi inte in på vilka medicinska och andra specialområden som fanns representerade. 
lusionen att läkaren befann sig inför en verklig patient. Bisittarens roll var främst att kunna gripa in ifall samtalet skulle stoppas upp alldeles, exempelvis av ordsökning (jfr Linell \& Persson Thunqvist 2003). Syftet var att försöka minimera hybriditetsproblemet.

Varje rollspel pågick i cirka sex minuter, med variationer både uppåt och nedåt $\mathrm{i}$ tid (det kortaste varade 3:44 minuter och det längsta 8:40 minuter). Vid inspelningarna användes endast audioinspelning. På grund av vårt beslut att inte filma rollspelen har vi inte tillgång till deltagarnas icke-verbala handlingar som underlag för våra analyser. Det är en svaghet med vår studie, men i valet mellan att rigga upp en filmkamera eller använda ett mer diskret inspelningssätt bestämde vi oss för det senare alternativet av det skälet att vi inte ville riskera att göra deltagarna onödigt spända i dessa tidiga faser av språkinlärning.

Samtliga 28 rollspel har transkriberats. I analyserna av rollspelen använder vi metodologiska verktyg från $\mathrm{CA}$, som utvecklats för att demonstrera empiriskt hur parter i naturligt förekommande samtal interagerar på tur för tur-basis (se t.ex. Heritage 1984, Sacks 1992). Trots att de samtal vi analyserar är arrangerade, utgår vi från principen om deltagarperspektiv, som är bärande inom CA (Schegloff 1996). Principen innebär att den som analyserar söker få grepp om hur deltagarna själva tolkar varandras samtalsbidrag. Det är tänkbart att vi i rollen som patienter anpassar våra yttranden efter våra antaganden om läkarnas språkliga nivå, vilket gör det extra viktigt att analysera interaktionen utifrån de tolkningar som görs i situationen, till exempel av läkarnas intonation. I rollen som patienter är vi hänvisade till de resurser som finns tillgängliga under det pågående samtalet, det vill säga samma resurser som används i naturliga samtal med andraspråkstalare för att avgöra om tillräcklig intersubjektivitet verkar vara uppnådd.

Analysdelen som följer inleds med en kort, kvantitativ analys av läkarnas språkproduktion vid vart och ett av rollspelstillfällena. Den är gjord i syfte att ge en översiktlig bild av läkarnas språkfärdighet, som i denna analysdel undersöks som en separat komponent. Efter det korta, inledande avsnittet ligger tonvikten på kvalitativ analys. Då analyseras för det första hur två av läkarna följer upp patienternas yttranden genom olika typer av följdfrågor i RS1 och RS2, för det andra läkarnas återbruk av centrala ord i patienternas yttranden och för det tredje en annan typ av verbalt återbruk, nämligen läkarnas användning av turinledande repetitioner som resurs i frågesekvenser. 


\section{Läkarnas ökade språkproduktion}

Innan vi går in på de kvalitativa analyserna av läkarnas utveckling av interaktionell kompetens vill vi som en bakgrund beskriva övergripande tendenser i hur läkarnas språkliga produktion på ord- och turnivå utvecklats mellan de två rollspelstillfällena. Denna första, kvantitativa analys gäller enbart läkarnas samtalsbidrag. Det innebär att vi temporärt lämnar vårt övergripande, dialogiska perspektiv för ett mer monologiskt perspektiv. Den kvantitativa analysen baseras på transkriptioner av läkarnas turer i samtliga rollspel. Eventuellt förekommande sekvenser av frågor till bisittaren har tagits bort.

Resultaten gällande samtalslängd, antal ord och antal turer i samtalet varierar avsevärt mellan individerna. Den stora variationen mellan individerna kan delvis förklaras av att de har fătt olika fall att ta sig an, och vissa är komplicerade och kräver mer interaktionellt arbete än andra.

Talhastighet är den komponent i språkproduktionen som visar på störst förändring. Hos samtliga läkare ökar antalet ord per minut i RS2 (läkarens ordproduktion är då uträknad i relation till den totala tid som samtalet pågår). För vissa är ökningen inte stor, för andra väsentligt större. Den genomsnittliga ökningen är 11 ord per minut. En annan komponent som pekar på att det skett en förändring är det totala antalet ord som läkarna producerar. I RS1 varierar ordmängden från 45 till 271 ord och i RS2 från 157 till 359 ord (ord som upprepas har då räknats varje gång det förekommer). Alla utom en läkare använder fler ord totalt vid det andra tillfället, och intressant nog gäller detta oavsett om den individuella läkarens rollspel då pågick längre eller kortare tid än vid det första tillfället.

Värt att notera är att den största ökningen av antalet ord finns hos de tre läkare som använder lägst antal ord i RS1. Av dessa är det två som använder cirka dubbelt så många ord i RS2 och en som använder fyra gånger så många ord i RS2. Så gott som samtliga (13 av 14 läkare) har också längre turer i genomsnitt i RS2. ${ }^{9}$ Det antal turer respektive läkare använder varierar från 11 till 50 turer i RS1 och från 18 till 42 turer i RS2. Även förekomsten av tvekljud (äh, öh, eh etc.) visar på individuell variation, men hos flertalet (9 av 14 läkare) minskar användningen av tvekljud i RS2.

Kvantitativa jämförelser som dessa kan vara missvisande, eftersom situationella faktorer varierar. Att göra sådana jämförelser innebär därför ett avsteg från samtalsanalytisk teori, som utgår från att ett samtal alltid är situerat

\footnotetext{
${ }^{9}$ Med tur avses en persons hela yttrande, som kan bestå av en eller flera turkonstruktionsenheter. En tur avgränsas i praktiken av talarbyte (Lindström 2008). Uppbackningar räknas inte som en tur.
} 
och specifikt (se t.ex. Sacks m.fl. 1974), ett argument som för övrigt kan riktas även mot longitudinella kvalitativa studier. Mångordighet behöver ju heller inte alltid vara ett uttryck för progression. En annan metodkritisk aspekt är att den ökade förmågan att genomföra patientsamtal i RS2 delvis också kan förklaras av att läkarna har fördel av att redan ha genomfört ett samtal om ifrågavarande åkomma, eftersom de fått samma fall två gånger. Dock hade det gått fem veckor mellan tillfällena, så all förändring kan inte förklaras av att läkarna kan ha reflekterat över sin första prestation och senare förmått anpassa sina frågeturer på grund av sin förkunskap om den aktuella diagnosen. Läkarna var heller inte informerade i förväg om att de skulle få samma fall andra gången. Situationell anpassning kan dessutom inte överföras från ett samtal till ett annat, beroende på det nyss nämnda förhållandet att två samtal aldrig är identiska.

Tendensen att kursdeltagarna förmår tala snabbare och med större flyt vid det andra rollspelstillfället är trots allt tydlig, och det ser vi som belägg för att deltagarna utvecklat sin språkfärdighet efter ytterligare fem veckors studier, vilket också är förväntat, med tanke på det intensiva undervisningstempot och läkarnas motivation och studievana.

\section{Analys av läkarnas frågemönster}

I denna första del av den kvalitativa analysen jämförs två av läkarna (läkare $\mathrm{E}$ och $\mathrm{G}$ ) och hur de följer upp patientens (P:s) initiala beskrivning av sina symtom genom olika typer av följdfrågor i RS1 respektive RS2. Dessa båda läkare har valts ut dels därför att de var och en på sitt sätt lyckas genomföra uppgiften förhållandevis väl redan i RS1, dels för att det hos båda finns relativt många uttryck för progression från det första till det andra rollspelstillfället. Det vi undersöker är hur läkarna samordnar sina interaktionella resurser under en första, inledande anamnesdel i samtalet. Liksom i andra typer av institutionella samtal ligger ansvaret för att interaktionen genomförs i enlighet med samtalets syfte på den professionella parten (Nguyen 2012). I likhet med studier av autentiska läkarsamtal urskiljer sig i rollspelen ett mönster i denna informationssökande del. Den inleds vanligen av en öppen, allmänt ställd fråga, vilken i regel följs upp av ett antal följdfrågor, för att framkalla en fylligare och mer precis beskrivning (Heritage 2010). Genom frågorna sätter läkarna agendan för olika delmoment av samtalet (Boyd \& Heritage 2005) och driver samtalet framåt ge- 
nom frågor i samklang med samtalets övergripande syfte. Med följdfråga avses här en fråga som innehållsligt knyter an till en föregående fråga, till exempel genom en begäran om precisering.

I utdrag (1) från RS1 använder läkaren (L) den inledande frågan »Hur kan jag hjälpa dig?». ${ }^{10}$ Öppna frågor inledda av ett frågeord används i regel för att efterfråga information av allmänt slag och uppmuntrar till responser som består av flera innehållselement (Lindholm 2003), precis som i responsen i (1), rad 2 3 , där $\mathrm{P}$ allmänt beskriver sina problem med huvudvärk. Uppmaningen på rad 11-12 uppmuntrar på ett liknande sätt till en utvecklad beskrivning. L ställer flera följdfrågor som introducerar nya deltopiker: på rad 5-6 och rad 8 efterfrågas information om var värken sitter. (Läkarnas frågor är fetmarkerade $\mathrm{i}$ transkriptionsutdragen 1-4.)

(1) RS1, läkare E (migrän)

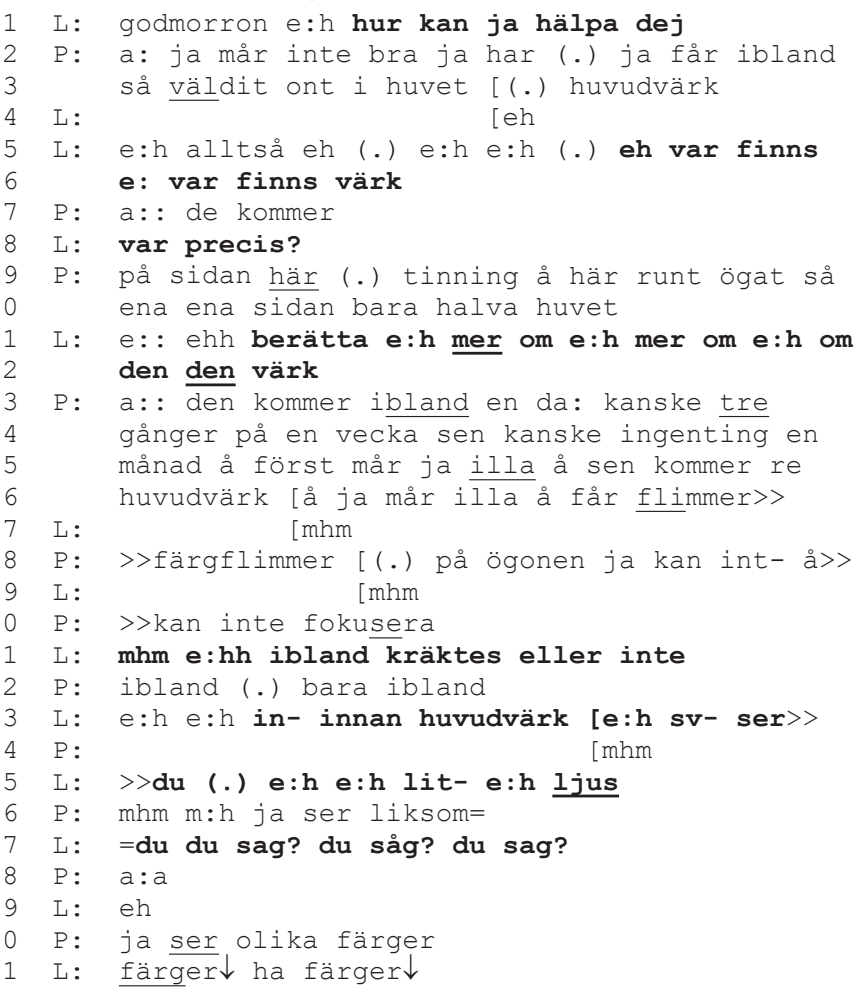

${ }^{10}$ Frågan förekommer i de filmer som visades före rollspelen och används i 22 av rollspelen, formulerad på samma eller liknande sätt. 


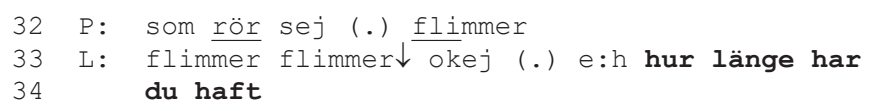

Denna inledande frågesekvens i (1) hålls samman av innehållsordet värk som L använder i två av frågorna ( $\operatorname{rad} 6,11-12$ och 23) och som återknyter till P:s inledande symtombeskrivning. På rad 23 och 25 ställer L en ledande fråga som är typisk för diagnostiserande frågor. Frågan är ja-optimerad, det vill säga innebär en grammatisk preferens för ett instämmande svar (Heritage 2010) och innehåller antaganden om symtom som skulle kunna höra samman med det problem som P beskriver. Således uppvisar detta samtal i RS1 redan drag som är typiska för ett läkare-patientsamtal. L har dock vissa svårigheter med att formulera sin fråga så att $\mathrm{P}$ beskriver de aktuella symtomen tillräckligt utförligt. Uppmaningen $e::$ ehh berätta e:h mer om e:h mer om e:h om den den värk på rad 11-12 ställs med flera tvekljud och omstarter. Dialogen är överlag utdragen, särskilt från rad 15 och framåt när $\mathrm{P}$ beskriver sina symtom innan värken kommer, bland annat genom att L upprepar vissa centrala ord (yttrandet analyseras vidare i utdrag 8). Samtalet präglas av tvekljud och andra typer av uppskjutande drag från L, vilket tyder på att L behöver tid för att hitta ord, till exempel L:s självinitierade självreparation $d u$ du sag? du såg? du sag? ( $\operatorname{rad} 27)$. Denna självreparation, liksom några repetitioner som flimmer flimmer $(\operatorname{rad} 33)$, kan också vara ett tecken på att L (här) ser rollspelet som en övningssituation, och kan alltså vara ett uttryck för rollspelets hybriditet. En svårighet med att bedöma detta är att självinitierade självreparationer generellt är vanligt förekommande i andraspråkssamtal (Markee 2000 s. 31).

I RS2 ställer samma läkare mer fokuserade följdfrågor och beskrivningen av symtomen görs på ett mer effektivt sätt.

(2) RS2, läkare E (migrän)

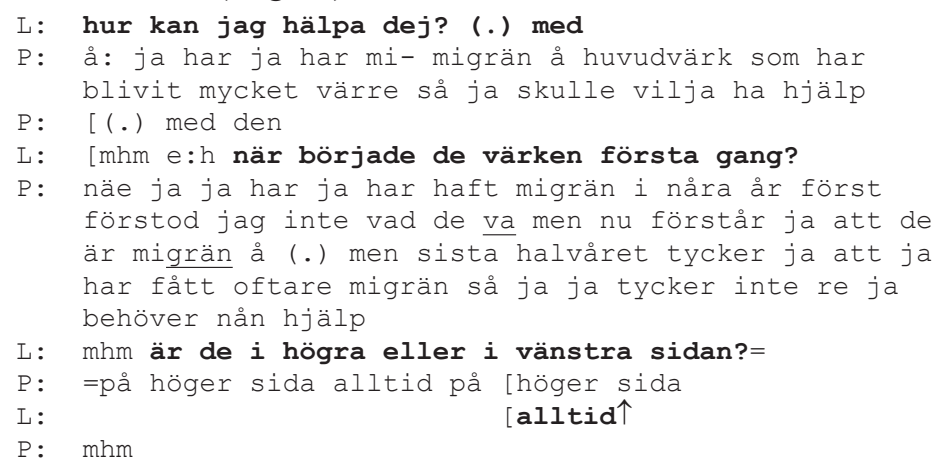




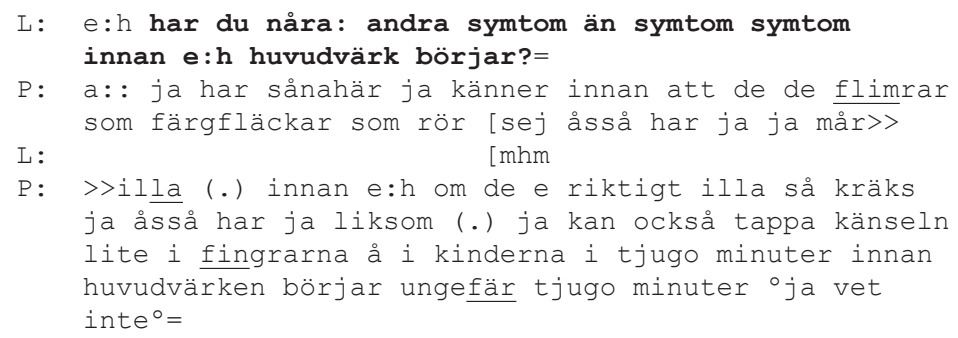

I (2) inleds samtalet med samma öppna fråga som i (1) och responsen består av en allmän beskrivning med flera innehållselement. Den skiljer sig från (1) genom att $P$ själv anger en diagnos. Därefter ställer $L$ en fokuserad följdfråga om när huvudvärken började ( $\operatorname{rad} 5)$. Genom den specifika frågan demonstrerar L tydligare än i RS1 att han förstått att P lider av återkommande problem och inte söker hjälp akut. Frågan resulterar i en utvecklad beskrivning av P:s besvär över tid. Därefter ställer L en preciserande följdfråga som presupponerar att P lider av ensidig huvudvärk. Frågan besvaras snabbt och följs upp av en fokuserad kontrollfråga: alltid $\uparrow(\operatorname{rad} 13)$. När L liksom i RS1 frågar om vilka symtom som föregår huvudvärken görs detta i form av en öppen fråga, som denna gång snävar in det delområde L vill ha information om ( $\operatorname{rad~15-16).~Det~leder~till~att~}$ $\mathrm{P}$ beskriver de symtom som föregår huvudvärken på ett sammanhängande och mer precist sätt än i RS1.

Rollspelen kännetecknas i likhet med verkliga läkare-patientsamtal av ett samspel mellan deltagarna. I både (1) och (2) leder samspelet mellan L och P till en sammanhängande symtombeskrivning från P. L uppvisar interaktionell kompetens även i RS1 genom att redan då förmå ställa följdfrågor som bidrar till att problemen beskrivs tämligen detaljerat. Dock ökar mängden information från P i RS2. L:s ökade interaktionella kompetens visar sig bland annat genom att följdfrågorna i RS2 knyter an till tidigare yttranden på ett tydligare sätt. Att de dessutom framförs med färre tvekljud och omstarter, vilket troligen är ett resultat av ökad språkfärdighet, bidrar till och ingår i en ökad interaktionell kompetens (jfr Markee 2008).

Den andra läkaren, G, ställer i (3), RS1, ungefär samma öppningsfråga som $\mathrm{E}$, och i sin respons beskriver P sina symtom med flera innehållselement. Det framgår att P:s arm har känts konstig sedan $i$ morse ( $\operatorname{rad} 2)$, alldeles som domnad ( $\mathrm{rad} 3)$. Beskrivningen följs endast upp av en uppbackning ( $\mathrm{rad} 4)$ från L, som därpå ställer en fråga som förekommer i nästan alla rollspelen: e: hur gammal är du? . Frågan och svaret om P:s ålder bildar en inskottssekvens ( $\operatorname{rad} 6-8)$ som bryter av flödet i utredningen av P:s besvär. L avviker därmed från mönst- 
ret som innebär att symtomen i P:s första allmänna respons följs upp med direkt relaterade följdfrågor.

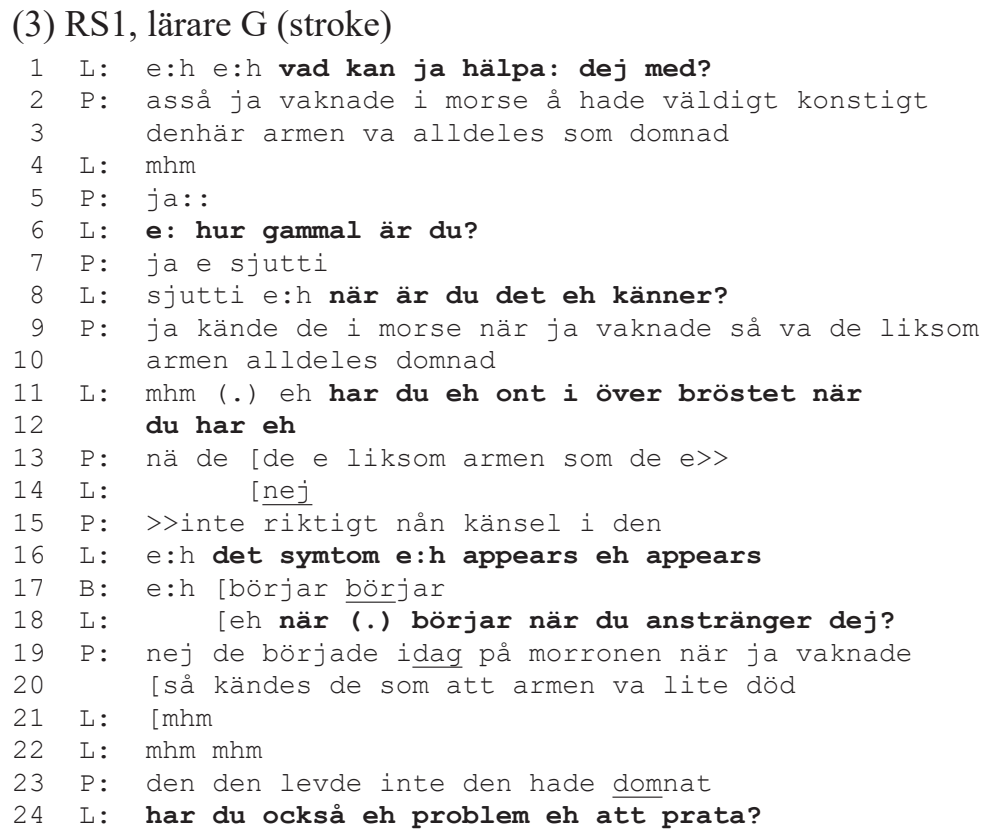

Först på rad 8 ställs en följdfråga (e:h när är du det eh känner?) som knyter an till patientens inledande problembeskrivning. P svarar: ja kände de i morse när ja vaknade och upprepar sedan informationen om att armen är domnad, vilket tyder på att $\mathrm{P}$ gör tolkningen att $\mathrm{L}$ inte uppfattat all information om problemet med armen. L fortsätter med en fokuserad fråga: e:h det symtom e:h appears eh appears (rad 16) men hittar inte rätt ord utan söker och făr viss hjälp av bisittaren ( $\operatorname{rad} 17)$. L börjar om med frågan eh när (.) börjar när du anstränger dej? ( rad 18), varpå P beskriver känslan i armen mer utvecklat, i flera svarsturer (från rad 19).

Även om utfrågningen löper lite osäkert och med många tvekljud, innehåller (3) för aktiviteten typiska följdfrågor. L ställer tre ledande följdfrågor ( $\operatorname{rad} 11$ $12,16,18$ och 24) som presupponerar symtom utifrån vad som troligen är L:s hypotes om P:s diagnos (stroke). Följdfrågorna är utformade som fokuserade frågeordsfrågor. Den typen av frågor används typiskt i läkare-patientsamtal för att begära specifik information eller en precisering, tills läkaren har fått tillräckligt med information (Lindholm 2003 s. 58 f.). 
I (4), med samma läkare i RS2, följs P:s första allmänna symtombeskrivning upp direkt av en öppen följdfråga: vad menar du? ( $\operatorname{rad} 3)$.

(4) RS2, läkare G (stroke)

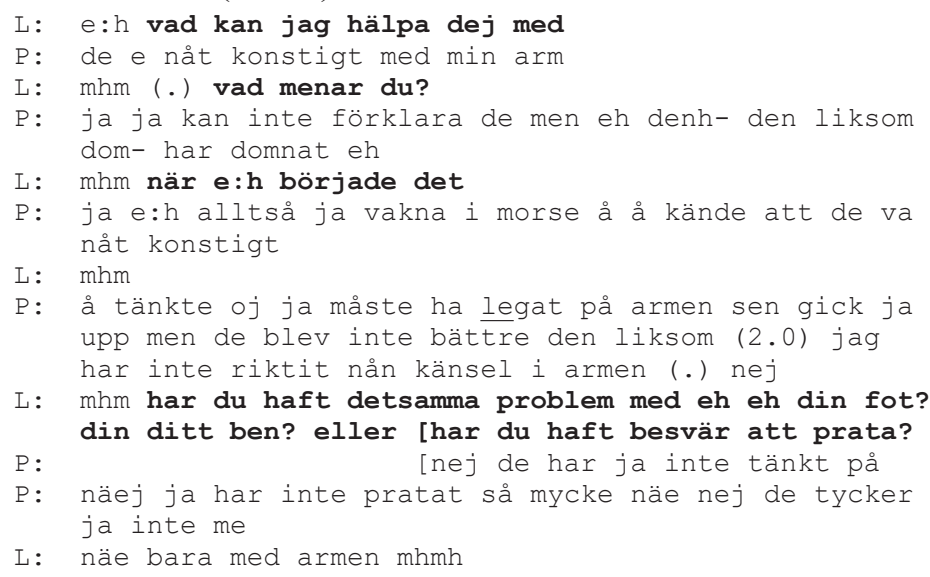

Följdfrågan vad menar du? ( rad 3) leder till att $\mathrm{P}$ fortsätter att beskriva sin känsla i armen. Därefter ställs en fokuserad följdfråga om när symtomen började ( $\operatorname{rad} 6)$. Det leder till en utvidgad tur där $\mathrm{P}$ först svarar på frågan och sedan utvecklar sin beskrivning. Därefter följer en flerledad fråga, tre ja/nej-frågor med presupponerade relaterade symtom ( $\operatorname{rad} 13-14)$. P besvarar dessa $\mathrm{i}$ två olika turkonstruktionsenheter, varpå L bekräftar sin förståelse av P:s huvudsakliga problem (näe bara med armen, rad 18). Den kommentaren återkopplar till P:s beskrivning och fungerar som en bekräftande avslutning på topiken. Genom den, liksom genom den flerledade frågan på rad 13-14 (har du haft detsamma problem med eh eh din fot? osv.), demonstrerar L även sin förståelse av P:s yttranden.

Läkare $\mathrm{G}$ följer det typiska samtalsmönstret för läkare-patientsamtal redan i RS1, men i RS2 leder läkare G:s sätt att ställa frågor till att P:s symtombeskrivning blir mer koherent och effektiv jämfört med RS1. Genom följdfrågor som knyter an innehållsligt möjliggörs en fylligare beskrivning kring huvudsymtomen innan obligatoriska delar (som ålder) betas av. Den flerledade frågan på rad 13-14 i (4) bidrar till att några av L:s antaganden om symtom enkelt kan dementeras. Läkare G uppvisar också en tydligare förståelse av vad P har sagt i RS2. Läkare E följer en liknande utveckling.

Av analyserna av dessa två läkare vill vi dra slutsatsen att det skett en utveckling av den interaktionella kompetensen. Liksom när det gäller vår slutsats i fö- 
regående avsnitt, att deltagarna utvecklat sin allmänna språkfärdighet, kan den invändningen göras att den ökade förmågan att genomföra patientsamtalet också kan förklaras av att läkarna fick samma fall att ta sig an i RS2. Något som talar emot den invändningen är att förmågan till situationell anpassning blir än viktigare när det gäller följdfrågor, eftersom sådana i hög grad måste anpassas till föregående yttrande.

\section{Verbalt återbruk}

I detta avsnitt analyseras ett sätt att knyta an till något som samtalspartnern sagt genom det Anward $(2000,2004)$ kallar för språklig återanvändning (se även t.ex. Tannen 1989, Landqvist 2010). Enligt Anwards återanvändningsteori lagras yttranden som fälls i ett samtal i minnet och används som byggstenar i nya yttranden. I rollspelen förekommer verbalt återbruk inbakat i läkarnas följdfrågor och kommentarer till patienternas beskrivningar av olika symtom. Det finns exempel i RS1, som i fallet med värk i (1), men annars förekommer det bara undantagsvis i RS1.

Ett exempel på verbalt återbruk i RS2 visas i (5), där P i sin beskrivning av ett symtom använder ordet onormalt ( $\operatorname{rad} 2)$, vilket plockas upp i L:s värderande kommentar de e inte normalt ( $\mathrm{rad} 5)$. Sådan användning av delar av en gammal tur kallar Anward (2004 s. 40) för »recycling with différance». (De återanvända orden är fetmarkerade i båda talarnas turer i transkriptionsutdragen 5-7 nedan.)

(5) RS2, läkare L (tarmproblem)

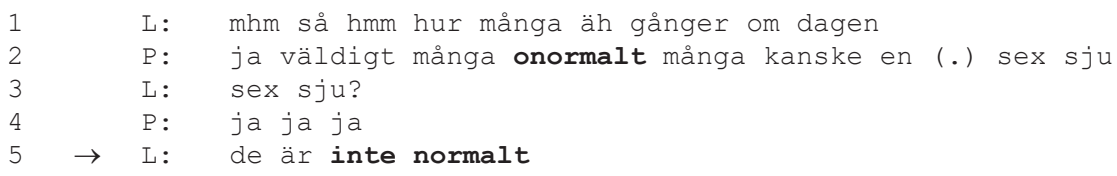

Samma fenomen finns i (6), där L i sin följdfråga äh när började ditt problem me äh äh sov? ( $\operatorname{rad} 4)$ knyter an till att $\mathrm{P}$ använt verbet sova i sin symtombeskrivning $(\operatorname{rad} 1)$.

(6) RS2, läkare J (sömnproblem)

$\begin{array}{lll}1 & \mathrm{P}: & \text { ja har jättesvårt å sova på nätterna } \\ 2 & \mathrm{~L}: & \text { jaha }\end{array}$ 


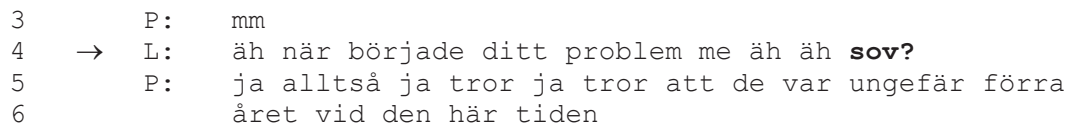

Frågan när började du att känna dej stressad? (rad 3) i (7) är ett annat exempel på en mer specifik följdfråga i RS2. För att få besked om hur länge P haft sina symtom, plockar L upp ordet stressad, som är ett av de olika symtom som $\mathrm{P}$ nämner i den föregående turen $(\operatorname{rad} 1-2)$.

(7) RS2, läkare B (panikångest)

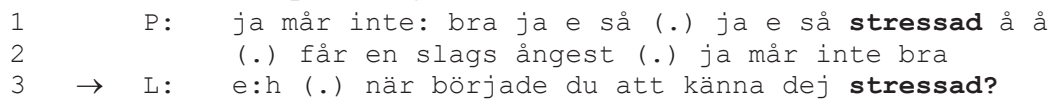

Att läkarna bygger vidare på den problembeskrivning som framkommit genom att upprepa ord eller delar av ord som P använt förekommer alltså i större utsträckning i RS2. Det visar på en skillnad jämfört med mönstret i RS1, som i stället består i att läkarna ställer mer allmänna följdfrågor som kan matcha varierande problembeskrivningar, såsom »Har du några andra symtom?»och »Hur länge har du haft det så?». ${ }^{11}$ Att anknyta mer specifikt till något symtom som patienten nämnt kan ha en förtroendeskapande effekt. Läkarnas sätt att följa upp patientens yttranden genom verbalt återbruk i RS2 visar på en ökad förmåga att demonstrera sin förståelse, vilket vi tolkar som en utveckling på gruppnivå av den interaktionella kompetensen.

\section{Repetition som resurs i frågesekvenser}

I denna avslutande del av analysen undersöks en annan typ av verbalt återbruk än i det föregående avsnittet, nämligen läkarnas bruk av turinledande repetitioner. Det är ett drag som förekommer så pass frekvent $\mathrm{i}$ läkarnas turer att vi ser det som ett mönster. Med repetition menas här identisk upprepning av ett eller flera ord i samtalspartnerns föregående tur. Baserat på en kartläggning av dessa lingvistiska element undersöker vi i det följande vilka sociala handlingar läkarna utför genom att upprepa något av det patienten just yttrat. Repetition är en mångfunktionell resurs som kan användas för att underlätta uppgiften att producera tal och för att göra samtalet mer koherent och tillgängligt, men också

${ }^{11}$ Den senare frågan förekommer i en av filmerna som visades före RS1. 
i strategier för att påverka lyssnaren, hävdar Norrick (1987), i en artikel där han ger en översikt av repetitioners funktion i samtal.

I vardagliga samtal förekommer repetitioner regelbundet i turinledningar (Schegloff 1987). Vår kartläggning av samtliga repetitioner visar att så är fallet också i läkarnas yttranden i rollspelen, men dessutom visar sig det dominerande mönstret vara att repetitionen i rollspelen ensam utgör en tur. Repetitioner förekommer i 20 av 28 rollspel och hos alla utom två av läkarna. Att repetitioner är potentiellt mångfunktionella gör avgränsningen mellan olika kategorier något diffus, »fuzzy», enligt Norrick (1987 s. 247), men vi har trots detta försökt oss på att kategorisera de förekomster vi kartlagt (se tabell 2). Det rör sig om totalt 45 förekomster, varav 28 i RS1 och 17 i RS2.

Tabell 2. Samtliga repetitioner, indelade $\mathrm{i}$ tre funktionskategorier. $\mathrm{F}=$ antal förekomster; $\mathrm{R}$ = antal rollspel där det finns förekomster. Rollspel per tillfälle: 14.

\begin{tabular}{lcccccccc}
\hline & 1. Ekorepetition & \multicolumn{2}{l}{$\begin{array}{l}\text { 2. Repetition } \\
\text { som bekräftelse }\end{array}$} & \multicolumn{2}{l}{$\begin{array}{l}\text { 3. Repetition } \\
\text { som begäran om } \\
\text { förtydligande }\end{array}$} & \multicolumn{2}{c}{ Totalt } \\
& F & R & F & R & F & R & F & $\mathrm{R}^{*}$ \\
\hline Rollspel 1 & 6 & 4 & 2 & 2 & 20 & 6 & $\mathbf{2 8}$ & $\mathbf{1 0}$ \\
Rollspel 2 & - & - & 10 & 5 & 7 & 5 & $\mathbf{1 7}$ & $\mathbf{1 0}$ \\
Totalt & $\mathbf{6}$ & & $\mathbf{1 2}$ & & $\mathbf{2 7}$ & & $\mathbf{4 5}$ & \\
\hline
\end{tabular}

* Respektive summa avser förekomst i antal olika rollspel, vilket inte kan utläsas av tabellen.

Tre huvudfunktioner har utkristalliserats i vår analys. Tolkningen av vilken huvudfunktion en repetition har är baserad på den reaktion som repetitionen leder till hos P. Kategori 1, ekorepetition, innefattar repetitioner som inte leder till någon hörbar respons hos samtalspartnern. Som framgår av tabell 2 finns det relativt få förekomster i den kategorin och enbart i RS1. I kategori 2, repetition som bekräftelse, finns de flesta förekomsterna däremot i RS2. Kategori 3 innefattar repetition som begäran om förtydligande. Andelen förekomster i denna kategori är störst i RS1. Det är också den största kategorin. (De repeterade orden är fetmarkerade i båda talarnas turer i transkriptionsutdragen 8-20 nedan.) 


\section{Ekorepetition (kategori 1)}

Norrick skiljer mellan repetitioner som utför vissa operationer, »significant repeats», och sådana som inte kräver någon särskild uppmärksamhet, »random repetition» (1987 s. 247). Repetitionerna i kategori 1, ekorepetition, påminner delvis om den senare, dock ser vi dem inte som slumpartade. Till kategorin ekorepetition hänför vi repetitioner som inte leder till någon hörbar reaktion hos samtalspartnern, utan att de för den skull avslutar ett lokalt projekt. Ett exempel är (8), där läkaren E i sina båda turer använder dubblerade repetitioner. ${ }^{12}$ Sådan egenupprepning av repetitioner förekommer inte i repetitioner inom de andra kategorierna.

(8) RS1, läkare E (migrän)

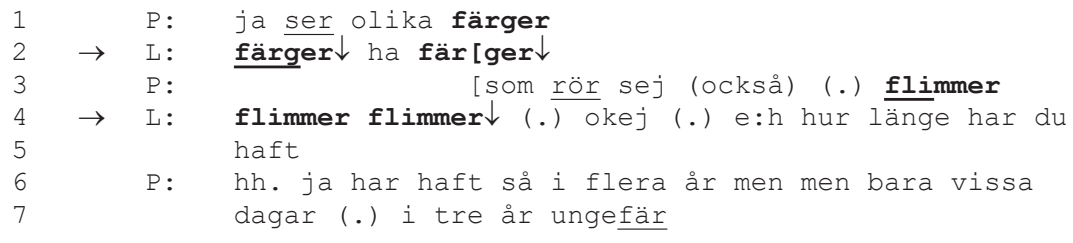

Den första av egenupprepningen i (8) (färger $\downarrow$ ha färger $\downarrow$ ) blir delvis överlappad av P:s nästa tur ( $\operatorname{rad} 3)$. Efter den påföljande egenupprepningen, flimmer flimmer $\downarrow$ (.) okej ( $\operatorname{rad} 4)$, finns en möjlig turbytesplats, men L ställer en ny fråga och behåller därmed turen. Att ingen av repetitionerna i (8) föranleder någon hörbar respons från $\mathrm{P}$ tyder på att dessa repetitioner är samtalsdrag som inte kräver samtalspartnerns uppmärksamhet. Eventuellt uttalar L i (8) de repeterade orden i första hand för att bekräfta dem inför sig själv, ett förfaringssätt som bara förekommer i RS1. En möjlig tolkning är att L processar flimmer flimmer såväl som färger ha färger, på liknande sätt som samma läkare gör i exemplet $d u$ du sag? du såg? du sag? i (1), rad 27. Att inramningen av den pågående verksamheten därigenom växlar om från läkare-patientsamtal till övningstillfälle kan i så fall ses som ett uttryck för rollspelets hybriditet.

Ett exempel av delvis annorlunda karaktär är (9), där P inte fäster något avseende vid L:s repetition på kvällen $\downarrow$ ( $\operatorname{rad} 5)$, ett tidsuttryck som P själv för övrigt upprepat internt i den föregående turen ( $\operatorname{rad} 3-4)$. Här kan den uteblivna reaktionen eventuellt bero på att $\mathrm{P}$ inte uppfattar L:s repetition, ef-

${ }^{12} \mathrm{E}$ är en av de två läkare som analyseras i avsnittet »Analys av läkarnas frågemönster», utdrag (1) och (2). 
tersom L:s repetition överlappar P:s tur på rad 4. P:s tur fortsätter också på $\operatorname{rad} 6$.

(9) RS1, läkare C (sömnproblem)

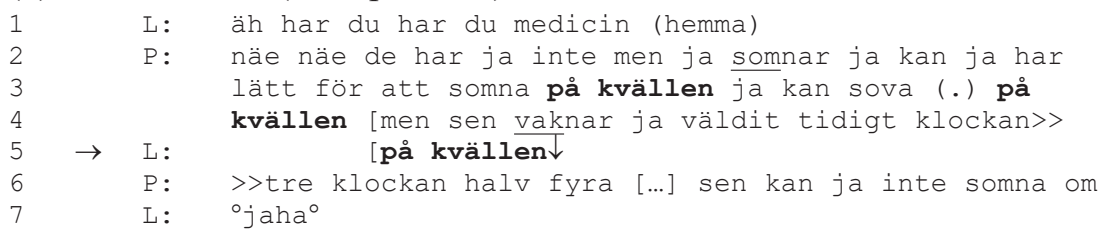

Repetitioner i kategorin ekorepetitioner förekommer i fyra av rollspelen i RS1, men förekomsterna är relativt få, totalt sex stycken. Ingen av läkarna använder ekorepetitioner i RS2. Att läkarna i RS2 låter bli att uttrycka sig på ett sätt som kan uppfattas som att de tänker högt och processar ett ord inför patienten ser vi som tecken på ökad interaktionell kompetens hos läkarna på gruppnivå. En alternativ tolkning är att deltagarna har ett ökat fokus på rollspelet som faktisk konsultation, snarare än en övningssituation.

\section{Repetition som bekräftelse (kategori 2)}

I frågesekvenser generellt kan repetitioner ha funktion som en signal om att svaret är noterat, enligt modellen fråga - svar - bekräftelse på svaret. Sådana kvittenser är vanliga när information ska föras in i ett formulär av något slag och används ofta för att avsluta en frågesekvens (Houtkoop-Steenstra 2000). Repetitioner som bekräftelse (kategori 2) har denna funktion. De avslutar ett lokalt projekt eller ingår i en turkonstruktionsenhet som avslutar ett sådant. I (10) kan även noteras att läkarnas användning av repetitioner som kvittenser på P:s svar ger läkarna en aning extra tid att planera nästa fråga i informationsinhämtandet.

(10) RS2 läkare M (panikångest)

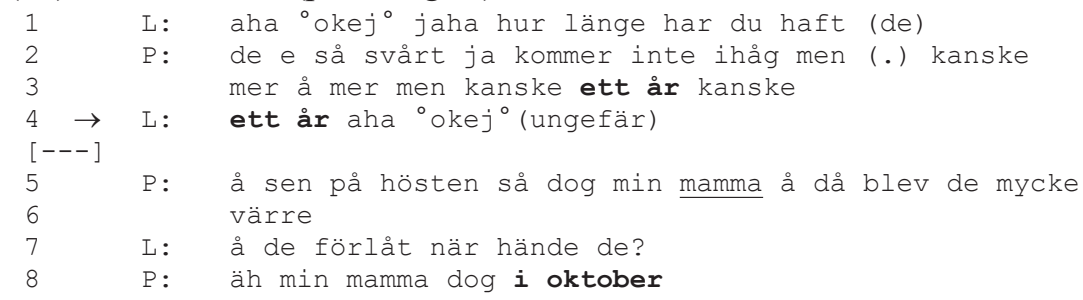




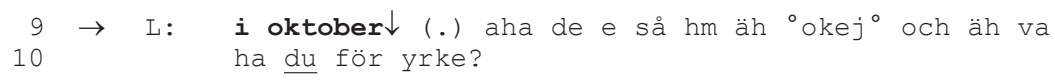

L i (10) vinner extra betänketid också genom att repetitionerna ett år respektive i oktober följs av småord som också fungerar bekräftande: aha okej (rad 4) och aha de e så, följt av tvekljuden $h m$ äh samt okej ( $\operatorname{rad} 9)$. I samma tur som repetitionen $i$ oktober $\downarrow$, i en ny turkonstruktionsenhet ( $\operatorname{rad} 9-10)$, ställer L en fråga: och äh va har du för yrke?. I (11) uttrycker sig L på ett liknande sätt i sina turer i de återgivna sekvenserna: tjutre $\downarrow$ öhm har du tagit ( $\operatorname{rad} 3-5)$, det vill säga kvittens plus tvekljud plus ny (avbruten) fråga, respektive datakunskap $\downarrow$ jaha det svårt ( rad 8-9), det vill säga kvittens plus värdering av svaret, följt av en ny fråga.

(11) RS2, läkare K (misstänkt ms)

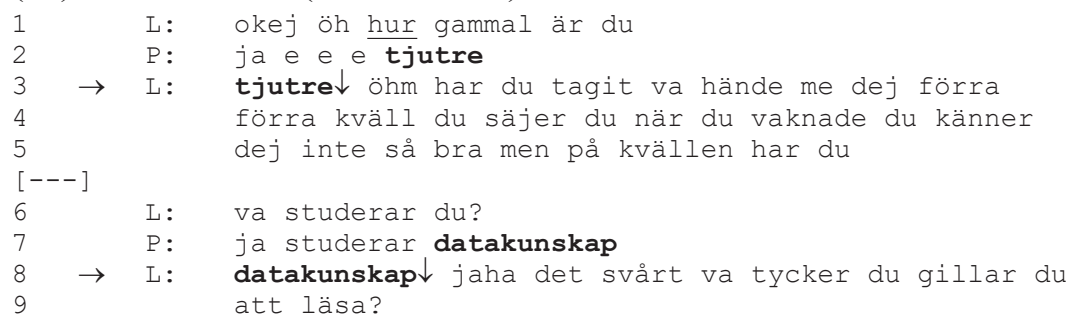

Att läkarna på detta sätt visar sin förståelse och därmed skapar trygghet hos patienten ser vi som ett uttryck för interaktionell kompetens. Repetitioner i funktionen bekräftelse förekommer oftare och hos fler av läkarna i RS2.

\section{Repetition som begäran om förtydligande (kategori 3)}

Prosodin spelar stor roll för hur repetitionerna tolkas, enligt Schegloff (1987). Här ska tilläggas att icke-verbala signaler, som vi inte haft möjlighet att dokumentera, sannolikt också spelar en viktig roll för patienternas tolkning i situationen, och det är ett viktigt skäl till att vi valt att basera vår kategorisering på patienternas reaktioner.

En repetition som sägs med frågetonfall kan tolkas som en implicit begäran om förtydligande (Andersson 2010). Det är en typ av reparation som till exempel Kitzinger (2014) kallar »repeat repair initiator». Ett sådant exempel är (12).

(12) RS1, läkare M (panikångest)

$\begin{array}{ll}1 & \text { P: ja känner att ja inte riktigt har kontroll på mej } \\ 2 & \text { själv som ja hade förut }\end{array}$ 


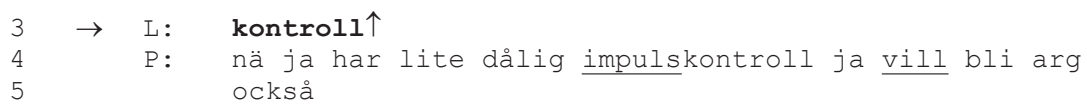

I (12) upprepar L kontroll $\uparrow$ med stigton ( $\operatorname{rad} 3)$ från P:s föregående tur. P ger ett förtydligande svar: nä ja har lite dålig impulskontroll och fortsätter turen med en utveckling av topiken: ja vill bli arg också. I de följande tre sekvenserna i (13) förstärks repetitionernas funktion som begäran om förtydligande av att L med sina repetitioner också ger uttryck för förvåning/misstro (jfr Norrick 1987).

(13) RS1, läkare L (tarmproblem)

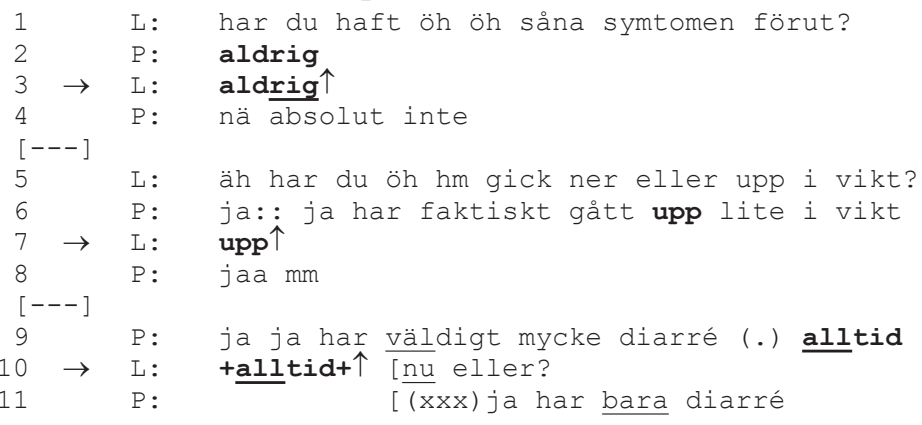

Repetitionerna, som uttalas med stigton i (13), fungerar som fokuserade kontrollfrågor (Lindholm 2003), exempelvis upp $\uparrow(\operatorname{rad} 7)$, som följer efter P:s svar på frågan om sin vikt, ja:: ja har faktiskt gått upp lite $i$ vikt ( $\operatorname{rad} 6)$ - ett svar som möjligen är anmärkningsvärt med tanke på P:s övriga symtom. Att repetitionerna kan tolkas som ett ifrågasättande av P:s svar gäller även L:s repetitioner av P:s extremfallsformuleringar ${ }^{13}$ aldrig $\uparrow(\operatorname{rad} 3)$ samt alltid $\uparrow(\operatorname{rad} 10)$, som uttalas med stark röstvolym. I samma tur begär L förtydligande också med den påföljande frågan $\underline{\text { nu eller? }}$.

En repetition med funktionen begäran om förtydligande kan också tolkas som ett metaspråkligt reparationsinitiativ, det vill säga signalera att den talande inte förstått innebörden i ett ord (jfr Wong 2000). Så är troligtvis fallet med do::mnat $\uparrow \mathrm{i}(14)$.

(14) RS2, läkare D (stroke)

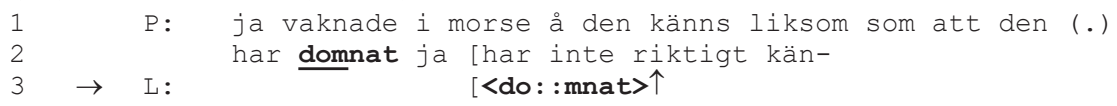

${ }^{13}$ Eng: extreme case formulations (Pomerantz 1986). 


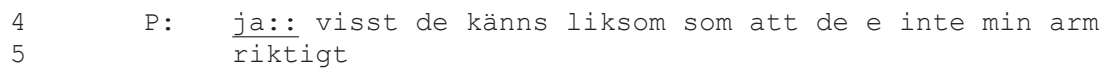

I (14), i RS2, uttalar L repetitionen do::mnat $\uparrow(\operatorname{rad} 3)$ på ett markerat sätt, långsamt med förlängt vokalljud på den första stavelsen och med stigton. I detta fall leder det till att $\mathrm{P}$ ger en utbyggd förklaring ( $\operatorname{rad} 4-5)$. Samma läkare (D) repeterar samma ord, domnat, i RS 1, och då framförs det på ett prosodiskt mindre markerat sätt.

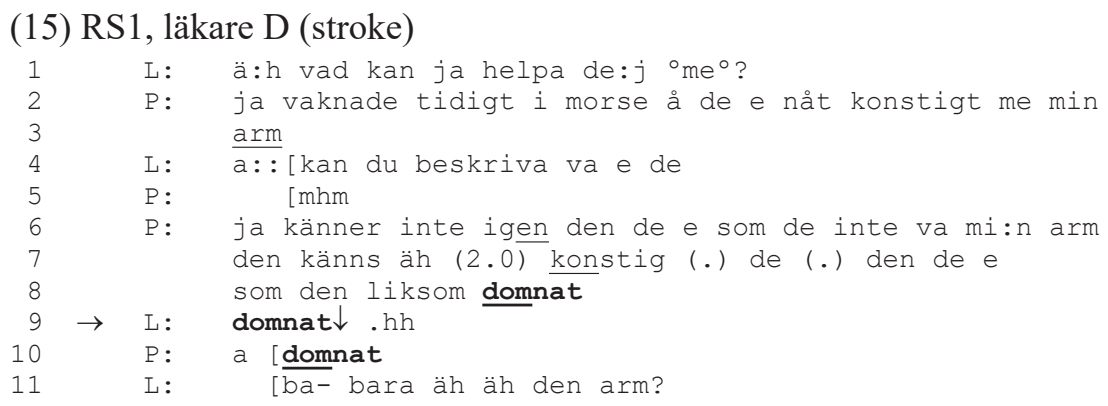

I det här fallet (15) upprepar L domnat med fallande ton, följt av en inandning. Här verkar L inte signalera att hen inte förstått ordet. P gör tolkningen att det är fråga om ett hörbarhetsproblem och ger respons bara i form av en bekräftelse: [j] a domnat ( $\operatorname{rad} 10)$, vilket tyder på att $\mathrm{P}: \mathrm{s}$ tolkning i situationen är att $\mathrm{L}$ är osäker på vad $\mathrm{P}$ har sagt, inte på ordets innebörd. L tar inte något nytt reparationsinitiativ utan fortsätter i nästa tur ( $\operatorname{rad} 11)$ med en ny fråga (bara äh äh den arm?) som delvis överlappar P:s svar på rad 10.

I (16), i RS2, indikerar L:s repetition dom vill? ( $\operatorname{rad} 5)$ att någonting är problematiskt i P:s föregående påstående dom vill åat mej på olika sätt ( $\operatorname{rad} 3-4)$.

(16) RS2, läkare I (paranoia)

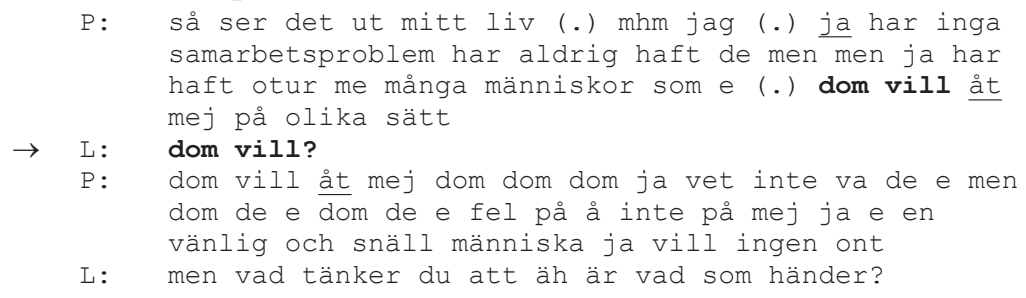

Repetitionen av den inledande delen av P:s yttrande (dom vill?) i (16) kan tolkas som en så kallad lucklämnande fråga, det vill säga »ofullbordade yttran- 
den [...] som kan uppfattas som avsiktligt avbrutna i syfte att vädja till motparten att fylla i ett eller flera ('förlösande') ord» (Linell \& Gustavsson 1987 s. 34). P uttrycker sig delvis osammanhängande i sin första tur, vilket gör att det är oklart om L:s repetition ska tolkas som metaspråkligt reparationsinitiativ (och i så fall skulle kunna signalera att partikelverbet vill åt är obekant för L). Repetitionen leder i alla fall till att $\mathrm{P}$ svarar med ett förtydligande (rad 6-8), ett utbyggt om än tämligen oklart sådant. L fortsätter med ett nytt initiativ ( $\mathrm{rad} 9$ ), en fokuserad frågeordsfråga (men vad tänker du att äh är vad som händer?).

Repetitioner som innebär en begäran om förtydligande kan ibland tolkas som en begäran om utveckling, alltså som en fortsättningssignal som uppmuntrar samtalspartnern att utveckla en topik eller en viss aspekt av det nyss sagda. En sådan kännetecknas (i engelskan) av fallande intonation och av att den inte är betonad, enligt Norrick (1987). Ett exempel med fallande intonation är repetitionen $\arg \downarrow(\operatorname{rad} 3)$, i (17) från RS1. Men repetitioner i rollspelen med denna funktion kan också uttalas med stigton, vilket visas i (19) nedan.

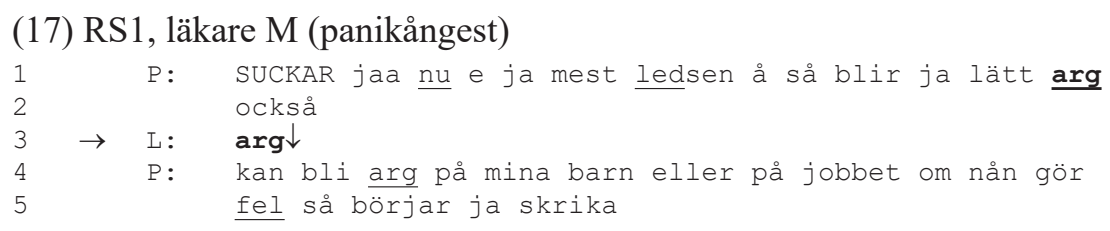

Exempel med fallande intonation finns även i (18) från RS2, där L:s repetition av lärare $\downarrow$ ( $\operatorname{rad} 3$ ) fungerar som en fortsättningssignal på samma sätt som i (17). Intrycket av att det är en fortsättningssignal förstärks av den lägre röstvolymen.

(18) RS2 läkare E (migrän)

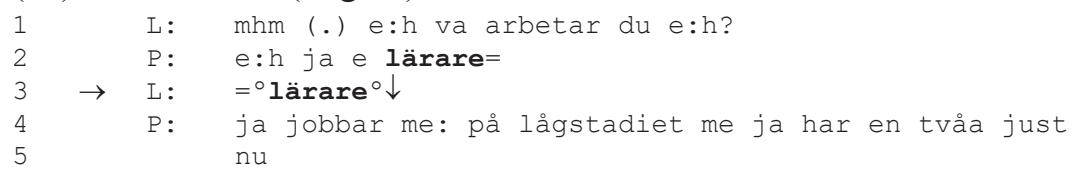

I (19), där L använder stigton, fungerar repetitionerna bakåtsyftande, det vill säga som ett sökande efter bekräftelse på att L hört rätt: P svarar bekräftande (ja::) i båda svarsturerna ( $\operatorname{rad} 5$ och 8). Men repetitionen fungerar också framåtsyftande, som en fortsättningssignal. På L:s upprepning tungt $\uparrow(\operatorname{rad} 4)$ ger P ett vagt svar (ja:: på nåt sätt) och fortsätter turen med en utveckling av topiken: 
åsså känner ja mej (.) väldit trött också ( $\operatorname{rad} 5$-6). På sin upprepning väldigt trött $\uparrow(\operatorname{rad} 7)$ får L ett preciserande svar: ja:: å sådär som om ja inte har sovit nånting $(\mathrm{rad} 8)$.

(19) RS1, läkare D (stroke)

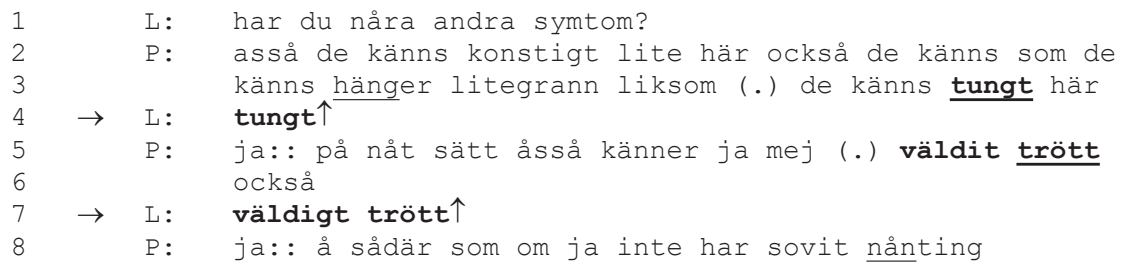

En annan läkare i RS1 (20) som repeterar ordet tung uttalar det svagt och utan stigton ( $\mathrm{rad} 4)$. P:s svar, ja åsså har ja ibland svårt å andas ( $\operatorname{rad} 5)$, visar att även en repetition som uttalas utan stigton kan fungera både bakåtsyftande och som en fortsättningssignal.

(20) RS1, läkare A (astma)

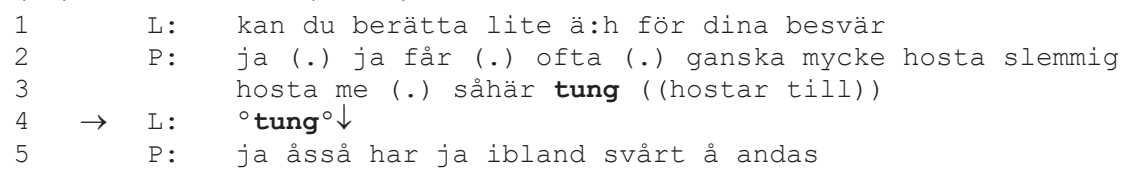

Utifrån rollspelsexemplen på repetitioner i kategori 3, begäran om förtydligande, kan vi inte påstå att intonationen är avgörande för hur repetitioner tolkas $\mathrm{i}$ interaktionen med dessa inlärare av svenska. En slutsats av hur repetitionerna bemöts av patienterna är att fallande intonation inte är nödvändig för att repetitionen ska tolkas som fortsättningssignal. Eventuellt bidrar uttalet med svag röst till att det uppfattas som fortsättningssignal, vilket (18) och (20) tyder på, men som nämndes inledningsvis i detta avsnitt spelar icke-verbala signaler sannolikt också en viktig roll för patienternas tolkning i situationen.

När det gäller kategori 3 är det svårare att peka på någon tydlig utvecklingstendens än vad som är fallet med de båda andra kategorierna. En viss tendens till en kvalitativ förändring är att läkarnas begäran om förtydligande oftare leder till mer utbyggda svar hos patienterna i RS2, möjligen beroende på att repetitionerna framförs med större säkerhet vid det andra rollspelstillfället. Exempel på detta finns i (14) och (16).

Begäran om förtydligande är den kategori som inrymmer flest förekomster. De allra flesta finns i RS1, och kanske är det en effekt av att läkarna har större 
behov av förtydliganden vid det första tillfället. Men i RS1 finns också exemplet med läkaren som tydligt ifrågasätter patientens extremfallsformuleringar (13), vilket inte tyder på osäkerhet hos läkaren utan tvärtom visar att läkaren besitter interaktionell kompetens redan vid denna tidpunkt. En övergripande slutsats om användningen av repetitioner i kategori 3 är ändå att det kan vara ett samtalsstrategiskt relativt enkelt (och för läkarna på förstaspråket möjligtvis väletablerat) sätt att föra läkare-patientsamtalet framåt.

\section{Sammanfattande diskussion}

På ett övergripande plan kan vi utifrån vår kvantitativa analys konstatera att läkarna vid det andra rollspelstillfället generellt har längre turer, talar mer och snabbare och använder färre tvekljud än vid det första tillfället. Det ser vi som tecken på utveckling av deltagarnas språkkunskaper och språkfärdigheter, även om det också måste tas med $\mathrm{i}$ beräkningen att det faktum att samma patient återkommer till en och samma läkare med samma symtom skapar en annan trygghet för läkaren den andra gången.

Den kvalitativa analysen pekar mot att även den interaktionella kompetensen hos läkarna har ökat. Samtalsmönstret för hur frågor och följdfrågor ställs redan i RS1 liknar det som påvisats i studier av autentiska läkare-patientsamtal, men läkarnas förmåga att ställa följdfrågor som mer direkt anknyter till patientens problembeskrivning ökar i RS2. Läkarna demonstrerar också sin förståelse för vad patienten har uppgett på ett tydligare sätt i RS2, till exempel genom att repetera centrala innehållsord från patientens problembeskrivningar i sina följdfrågor. Detta mer direkta sätt att följa upp patientens yttranden tolkar vi som ett uttryck för mer utvecklad interaktionell kompetens.

Bruket av repetitioner kan förenkla interaktionen för talaren genom att det ger lite extra betänketid - antalet förekomster är också flest i RS1 - men det står klart att läkarna använder repetitioner som en flerfunktionell resurs i rollspelen. Det står också klart att användningsmönstret förändras från RS1 till RS2. En skillnad visar sig i ekorepetitionerna, där talaren förefaller tänka högt eller processa något som nyss yttrats på liknande sätt som i en klassrumssituation. Sådana repetitioner förekommer bara i RS1. En annan skillnad är att repetition som begäran om förtydligande, det vill säga som ett reparationsinitiativ, tycks leda till mer utvecklade responser hos patienten i RS2. Detta ser vi som ett uttryck för ökad interaktionell kompetens, och detsamma gäller för re- 
petition som bekräftelse på ett centralt ord i patientens yttrande. Sådana förtroendeskapande kvittenser ges betydligt oftare och av fler läkare i RS2. Resultatet har beröringspunkter med Berbyuk Lindström (2008), som finner att icke-svenska läkare (»non-Swedes») använder repetitioner och omformuleringar som feedback mer intensivt än sina modersmålstalande kolleger. Dock visade Berbyuk Lindströms studie på en delvis motsatt tendens, nämligen att de som använde denna typ av feedback var de läkare som varit kortast tid i Sverige.

Den kvalitativa analysen visar hur samtalen byggs upp i relation till den pågående verksamheten. Sammantaget ger det en bild av att det skett en utveckling av läkarnas interaktionella kompetens vid det andra rollspelstillfället, men som Waring (2018) och andra påpekat måste slutsatser av det här slaget göras med viss försiktighet. Det longitudinella upplägget ger vissa möjligheter till jämförelser, men de kan aldrig bli helt rättvisande, på grund av svårigheten att urskilja vad som är ett resultat av utveckling och vad som beror på skillnader i den situationella kontexten. Idealt skulle vi därför ha arrangerat rollspel vid fler än två tillfällen (men det skulle ha krävt mer utrymme under kursens gång än dess föreståndare var intresserad av att ge oss). Här utgör emellertid deltagarperspektivet en viktig analytisk resurs. Samtalspartnerns reaktioner och responser är viktiga redskap för att avgöra vilka sociala handlingar som utförs och hur gemensam förståelse förhandlas fram. Genom de samtalandes tolkningar görs fortlöpande en värdering av den andra partens samtalsbidrag. Därmed sker »på plats» en indirekt värdering av andraspråkstalarens kompetens.

Som teoretiskt perspektiv bidrar begreppet interaktionell kompetens med värdefull kunskap om utvecklingen av ett andraspråk och i vår studie har detta perspektiv väckt intressanta frågor om hur förmågan att utföra sociala handlingar i interaktion utvecklas i relation till allmänna språkkunskaper och språkfärdigheter. Vi har kunnat se hur strukturellt enkla yttranden i form av repetitioner fyller viktiga funktioner i interaktionen. Att formulera sådana yttranden ställer relativt låga krav på språkkunskaper, däremot kräver det förmåga till situationell anpassning. Att läkarna klarar detta redan i RS1 kan förklaras av deras tidigare erfarenheter av anamnessamtal. Det kan också tyda på att förmågan att delta i och organisera sekventiella praktiker, såsom att hantera turtagning och reparationer, i viss mån är överförbart från förstaspråket (jfr Markee 2008).

Att demonstrera sin förståelse för vad samtalspartnern har sagt är en värdefull kompetens för andraspråkstalare (Markee 2000), inte minst som den professionella parten i institutionella samtal, där det kan finnas en oro hos lekmannen för att inte bli förstådd. Vi menar att det är en aspekt som är viktig att lyfta 
fram i språkutbildningar som syftar till att lära ut ett yrkesspråk (jfr Tykesson \& Kahlin 2014). Det finns en stor pedagogisk potential i att använda (inspelade) rollspel för reflektion och feedback till deltagarna om interaktionell kompetens. Rollspel är också, menar vi, en metod som stimulerar utvecklingen av interaktionell kompetens, då det är en interaktionsform där deltagarna behöver samordna olika språkliga resurser för att klara av att tala och lyssna simultant. Problemet med rollspelets hybriditet kvarstår dock.

I vårt upplägg prövade vi att minska hybriditeten genom att en av oss enbart agerade patient medan den andra var tillgänglig för språkstöd. Upplägget med denna tydligt markerade ram fungerade som vi avsett, genom att språkfrågor inte tog fokus från det fingerade patientmötet och läkarna generellt höll sig till sin professionella roll. Men det fanns vissa situationer när läkarna klev ur läkarrollen och därmed synliggjorde rollspelets hybriditet. Exempelvis är läkarens självreparation $d u$ du sag? du såg? du sag? i (1) ett tecken på att deltagarna kan uppfatta rollspelet som ett övningstillfälle i viss mån. Detsamma gäller som nämnts eventuellt också repetitioner i kategorin ekorepetitioner. Givet det faktum att rollspelen arrangerades i en lektionssal på en språkkurs kan vi inte heller utesluta att läkarna primärt kanske inte såg sig själva i sin professionella roll utan som elever.

Läkarnas dialoger med bisittaren kopplat till det fortsatta anamnessamtalet är intressanta att analysera ur ett pedagogiskt perspektiv, liksom för övrigt de kommentarer som rollspelarna och åhörarna gör efter rollspelen, vilket vi över huvud taget inte har gått in på. Vi har här valt att hålla fokus på läkarnas yrkesspråkande.

En kritik som kan anföras mot rollspel som metod för utveckling av interaktionell kompetens är att samtal med patienter i autentiska situationer har ett syfte som inte går återskapa i rollspel (jfr Nguyen 2012). I rollspel är det inte »skarpt läge» och läkarna har heller inte möjlighet att använda sina erfarenheter fullt ut. Bland annat kan de inte utnyttja multimodala resurser som fysisk undersökning av patienterna. Men trots den konstruerade situationen visade sig läkarna lägga ner kraft på att formulera frågor på sätt som var tillräckliga för att driva samtalen framåt. Läkarnas erfarenhet av verkliga anamnessamtal var troligen den främsta anledningen till att rollspelen gick att genomföra redan efter fem veckors svenskundervisning och med övningar i spontant samtalande bara i blygsam omfattning. 


\section{Litteratur}

Andersson, Helena, 2010: Interkulturell kommunikation på ett svenskt sjukhus. Fallstudier av andraspråkstalare i arbetslivet. Uppsala: Institutionen för nordiska språk, Uppsala universitet.

Anward, Jan, 2000: Allt du önskar kan du få? Om SAG och talspråket. I: Språk och stil NF 10. S. 197-220.

Anward, Jan, 2004: Lexeme recycled. How categories emerge from interaction. I: Logos and Language 5:2. S. 31-46.

Bachman, Lyle F. \& Palmer, Adrian S., 1996: Language testing in practice: Designing and developing useful language tests (vol. 1). Oxford: Oxford University Press.

Berbyuk Lindström, Nataliya, 2008: Intercultural communication in health care: non-Swedish physicians in Sweden. Göteborg: Göteborgs universitet.

Berger, Evelyne \& Pekarek Doehler, Simona, 2018: Tracking change over time in storytelling practices: A longitudinal study of second language talk-in-interaction. I: S. Pekarek Doehler, J. Wagner \& E. González-Martínez (red.): Longitudinal studies on the organization of social interaction. London: Palgrave Macmillan. S. 67-102.

Boyd, Elizabeth \& Heritage, John, 2005: Taking the history: questioning during comprehensive history-taking. I: J. Heritage \& D. W. Maynard (red.): Communication in medical care: interaction between primary care physicians and patients. Cambridge: Cambridge University Press. S. 151-184.

Cekaite, Asta, 2007: A child's development of interactional competence in a Swedish L2 classroom. I: The Modern Language Journal 91:1. S. 45-62.

Hall, Joan Kelly, 2018: From L2 interactional competence to L2 interactional repertoires: Reconceptualising the objects of L2 learning. I: Classroom Discourse 8:1. S. 25-39.

Hall, Joan Kelly \& Doehler, Simona Pekarek, 2011: L2 interactional competence and development. I: J. Kelly Hall, J. Hellermann \& S. Pekarek Doehler (red.): L2 interactional competence and development. Bristol: Multilingual Matters. S. 1-19.

Heritage, John, 1984: Garfinkel and ethnomethodology. Cambridge: Polity.

Heritage, John, 2010: Questioning in medicine. I: A. F. Freed \& S. Ehrlich (red.): "Why do you ask": The function of questions in institutional discourse. New York: Oxford University Press. S. 42-68.

Heritage, John \& Maynard, Douglas W. (red.), 2005: Communication in medical care: interaction between primary care physicians and patients. Cambridge: Cambridge University Press.

Houtkoop-Steenstra, Hanneke, 2000: Interaction and the standardized survey interview - the living questionnaire. Cambridge: Cambridge University Press.

Håkansson, Gisela \& Norrby, Catrin, 2010: Environmental influence on language acquisition. Comparing second and foreign language acquisition of Swedish. I: Language Learning 60:3. S. 628-650.

Joyner, Beres \& Young, Louise, 2006: Teaching medical students using role-play: Twelve tips for successful role-plays. I: Medical Teacher 28:3. S. 225-229. 
Kasper, Gabriele, 2000: Data collection in pragmatics research. I: H. Spencer-Oatey (red.): Culturally speaking: managing rapport in talk across cultures. London: Cassell. S. 316-341.

Kasper, Gabriele, 2006: Beyond repair: Conversation analysis as an approach to SLA. I: AILA Review 19. S. 83-99.

Kitzinger, Celia, 2014: Repair. I: J. Sidnell \& T. Stivers (red.): The handbook of conversation analysis. Oxford: Wiley-Blackwell. S. 229-256.

Landqvist, Mats, 2010: Samspel i rådgivningssamtal. I: A.-C. Edlund \& I. Mellenius (red.): Svenskans beskrivning 31. Umeå: Institutionen för språkstudier, Umeå universitet. S. 182-192.

Levy Scherrer, Paula \& Lindemalm, Karl, 2007: Rivstart: svenska som främmande språk. A1 + A2. Stockholm: Natur och kultur.

Levy Scherrer, Paula \& Lindemalm, Karl, 2009: Rivstart: svenska som främmande språk. B1 + B2. Stockholm: Natur \& kultur.

Lindholm, Camilla, 2003: Frågor i praktiken: flerledade frågeturer i läkare-patientsamtal. Helsingfors: Svenska litteratursällskapet i Finland.

Lindström, Jan, 2008: Tur och ordning: introduktion till svensk samtalsgrammatik. Stockholm: Norstedts akademiska förlag.

Linell, Per \& Gustavsson, Lennart, 1987: Initiativ och respons: om dialogens dynamik, dominans och koherens. Linköping: Linköpings universitet.

Linell, Per \& Persson Thunqvist, Daniel, 2003: Moving in and out of framings: activity contexts in talks with young unemployed people within a training project. I: Journal of Pragmatics 35:3. S. 409-434.

Luttenberger, Katharina, Grässel, Elmar, Simon, Cosima \& Donath, Carolin, 2014: From board to bedside - training the communication competences of medical students with role plays. I: Medical Education 14. S. 135-145.

Markee, Numa, 2000: Conversation analysis. Mahwah, N.J.: L. Erlbaum Associates.

Markee, Numa, 2008: Toward a learning behavior tracking methodology for CA-for-SLA. I: Applied Linguistics 29:3. S. 404-427.

Markee, Numa \& Kunitz, Silvia, 2013: Doing planning and task performance in second language acquisition: An ethnomethodological respecification. I: Language Learning 63:4. S. 629-664.

McNamara, Tim, 1997: 'Interaction' in second language performance assessment: Whose performance? I: Applied Linguistics 18. S. 446-466.

Melander, Helen \& Sahlström, Fritjof, 2011: Process eller produkt? Om samtalsanalysens möjligheter att studera lärande i interaktion. I: R. Säljö (red.): Lärande och minnande: som social praktik. Stockholm: Norstedts. S. 287-316.

Nestel, Debra \& Tierney, Tanya, 2007: Role-play for medical students learning about communication: Guidelines for maximising benefits. BMC Medical Education 2007, 7:3.

Nguyen, Hanh thi, 2012: Developing interactional competence: A conversation-analytic study of patient consultations in pharmacy. Houndmills, Basingstoke, Hampshire: Palgrave Macmillan.

Norrick, Neal, 1987: Functions of repetition in conversation. I: Text 7. S. 245-264.

Pekarek Doehler, Simona \& Petitjean, Cecile, 2017: Introduction: Interactional competences in institutional settings - Young people between school and work. I: S. Peka- 
rek Doehler, A. Bangerter, G. de Weck, L. Filliettaz, E. González-Martínez \& C. Petitjean (red.): Interactional competences in institutional settings: from school to the workplace. Cham: Palgrave Macmillan. S. 1-28.

Pekarek Doehler, Simona, Wagner, Johannes \& González-Martínez, Esther (red.), 2018: Longitudinal studies on the organization of social interaction. London: Palgrave Macmillan.

Pill, John \& McNamara, Tim, 2016: How much is enough? Involving occupational experts in setting standards on a specific-purpose language test for health professionals. I: Language Testing 33:2. S. 217-234.

Pomerantz, Anita, 1986: Extreme case formulations: a way of legitimizing claims. I: Human Studies 9. S. 219-229.

Sacks, Harvey, 1992: Lectures on conversation. Oxford: Blackwell Publishers.

Sacks, Harvey, Schegloff, Emanuel A. \& Jefferson, Gail A, 1974: A simplest systematics for the organization of turn-taking for conversation. I: Language 50. S. 696-735.

Sahlström, Fritjof, 2011: Learning as social action. I: J. Kelly Hall, J. Hellermann \& S. Pekarek Doehler (red.): L2 interactional competence and development. Bristol: Multilingual Matters. S. 45-66.

Schegloff, Emanuel A., 1987: Recycled turn beginnings: A precise mechanism in conversation's turn-taking organization. I: G. Button \& J. Lee (red.): Talk and social organization. Clevedon, England: Multilingual Matters. S. 70-100.

Schegloff, Emanuel A., 1996: Confirming allusions: Toward an empirical account of action. I: American Journal of Sociology 102:1. S. 161-216.

Socialstyrelsen, 2015: Nationella planeringsstödet 2015 - Tillgång och efterfrågan på vissa personalgrupper inom hälso- och sjukvård samt tandvård. Stockholm: Socialstyrelsen. http://www.shvab.se/Documents/Nationella\%20planeringsstödet.pdf

Socialstyrelsen, 2018a: Nationella planeringsstödet 2018. Bedömning av tillgång och efterfrågan på vissa personalgrupper inom hälso- och sjukvård samt tandvård. Stockholm: Socialstyrelsen. https://www.socialstyrelsen.se/globalassets/sharepointdokument/artikelkatalog/statistik/2018-2-23.pdf

Socialstyrelsen, 2018b: https://legitimation.socialstyrelsen.se/sv/utbildad-inom-eu-ellerees/lakare/ansok-om-legitimation.

Tannen, Deborah, 1989: Talking voices: repetition, dialogue, and imaginary in conversational discourse. Cambridge: Cambridge University Press.

Thomassen, Gøril, 2005: Den flerbunnete treningssamtalen: en studie av samtaler mellom pasient og student fra sykepleier- og medisinerutdanning. Trondheim: NTNU.

Tykesson, Ingela \& Kahlin, Linda, 2014: Att ge eller inte ge återkoppling: moldavisk callcenterpersonal i dialog med svenska uppringare. I: Nordand: nordisk tidsskrift for andrespråksforskning 9:1. S. 89-115.

Wagner, Johannes, Pekarek Doehler, Simona \& González-Martínez, Esther, 2018: Longitudinal research on the organization of social interaction: Current developments and methodological challenges. I: S. Pekarek Doehler, J. Wagner \& E. González-Martínez (red.): Longitudinal studies on the organization of social interaction. London: Palgrave Macmillan. S. 3-35.

Waring, Hansun Zhang, 2018: Teaching L2 interactional competence: problems and possibilities. I: Classroom Discourse 9:1. S. 57-67. 
Wette, Rosemary, 2011: English proficiency tests and communication skills training for overseas-qualified health professionals in Australia and New Zealand. I: Language Assessment Quarterly 8:2. S. 200-210.

Wong, Jean, 2000: Repetition in conversation: A look at "First and Second Sayings". I: Research on Language and Social Interaction 33:4. S. 407-424.

Woodward-Kron, Robyn \& Elder, Catherine, 2016: A comparative discourse study of simulated clinical roleplays in two assessment contexts: Validating a specific-purpose language test. I: Language Testing 33:2. S. 251-270.

Young, Richard F., 2011: Interactional competence in language learning, teaching, and testing. I: E. Hinkel (red.): Handbook of research in second language teaching and learning (vol. 2). New York: Routledge. S. 426-443.

Young, Richard F. \& Miller, Elizabeth R., 2004: Learning as changing participation: Discourse roles in ESL writing conferences. I: The Modern Language Journal 88:4. S. 519-535.

\section{Transkriptionsnyckel}

\begin{tabular}{|c|c|}
\hline$[---]$ & En eller flera rader utlämnade \\
\hline$\rightarrow$ & Markerar aktuell analysenhet, t.ex. initierad reparation \\
\hline (.) & Kort men märkbar paus, »mikropaus» \\
\hline (1.4) & Paus i tiondels sekunder \\
\hline 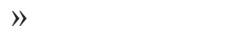 & Turen fortsätter på ny rad \\
\hline$=$ & Sammanhängande turer utan hörbart uppehåll \\
\hline hitt- & Avbrutet ord \\
\hline j: & Förlängning av vokal \\
\hline ja:: & Ytterligare förlängning av vokal \\
\hline övriga & Emfatiskt tryck \\
\hline${ }^{\circ} \mathrm{okej}^{\circ}$ & Sägs med svag röststyrka \\
\hline +aldrig + & Sägs med stark röststyrka \\
\hline & Ordet sägs med markant stigande intonation \\
\hline$\downarrow$ & Ordet sägs med fallande intonation \\
\hline jaså? & Yttrandet sägs med frågeintonation \\
\hline $\begin{array}{l}<\text { ord ord ord }> \\
((\text { hostar }))\end{array}$ & $\begin{array}{l}\text { Långsammare tal än det omgivande talet } \\
\text { Icke-verbala aspekter eller kommentarer till aktiviteter }\end{array}$ \\
\hline $\begin{array}{l}\text { P: på [höger sida } \\
\text { L: [alltid? }\end{array}$ & Överlappande tal \\
\hline (de där) & Möjlig tolkning av svårhörbart tal \\
\hline 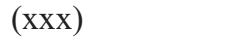 & Ohörbart (ett eller flera ord) \\
\hline & Inandning \\
\hline
\end{tabular}




\title{
Att koka ihop ett beslut \\ En multimodal interaktionsanalys av gemensamt besluts- fattande i vardagen
}

\author{
AV KLARA BERTILS \& SIMON MAGNUSSON
}

\begin{abstract}
Bertils, Klara, klara.bertils@lingfil.uu.se, Ph.D. student, Department of Linguistics and Philology, Uppsala University, Sweden. Magnusson, Simon, simon.magnusson@sh.se, Ph.D. student, School of Culture and Education, Södertörn University, Sweden: "Sharing decisions in the kitchen: A multimodal interaction analysis of joint decision-making in an everyday setting." Språk och stil NF 29, 2019, pp. 73-98.

This study explores the social organization and the necessary involvement in accomplishing sharedness in joint decision-making, by adopting a members' perspective on food preparation. Prior research on joint decision-making has mostly focused on verbal analysis of institutional interactions, e.g. medical encounters. In contrast, the current study carries out a multimodal interaction analysis of joint decision-making in everyday informal cooking among friends. The analysis demonstrates a crucial function of embodied actions, such as bodily stance, eye gaze and manipulation of objects, in organizing and coordinating decision-making sequences. Since the decisions in this particular setting often are based on a multisensory access to the objects of decision, establishing and displaying epistemic access comprise a constitutive part of joint decision-making. In line with this, we show that not allowing for an epistemically equal point of departure, the participants may be sanctioned when not accessing the empirical object of decision, e.g., not tasting the sauce. In addition to shedding light on the temporal organization of actions and the epistemic access central to organizing joint decision-making, the study offers an understanding of how participants as social actors constitute themselves as friends and family by means of making decisions shared in the midst of a mundane activity that constitutes daily life.
\end{abstract}

Keywords: decision-making, multimodality, participation, access, multisensoriality, conversation analysis, everyday interaction.

Varje dag fattar vi individuella och gemensamma, stora och små beslut. Vissa beslut fattas på rationella grunder, andra utifrån empiriska förnimmelser av världen. Ett sammanhang som innefattar många beslut av det senare slaget är

Vi vill tacka Clara Iversen, Marie Flinkfeldt och två anonyma granskare för insiktsfulla kommentarer på tidigare versioner av denna artikel. Vi vill också tacka alla deltagare som generöst och modigt välkomnat oss in i sina kök. 
matlagning. När man lagar mat tillsammans med familj och vänner behöver man enas om huruvida såsen är tillräckligt saltad och när klyftpotatisen börjar få fin färg och ska sättas på eftervärme. Dessutom behöver man finna lösningar på problem som uppstår under matlagningens gång, så att matlagningen inte stannar upp för att majonnäsen visar sig ha tagit slut. För att gemensamt gå från förslag till genomförande krävs kommunikativa praktiker, vilka vi i denna studie kommer att utforska med hjälp av multimodal interaktionsanalys.

Gemensamt beslutsfattande innebär dock inte bara att lösa problem och att effektivt uppnå resultat. Det handlar också om att i den sociala samvaron faktiskt göra besluten till gemensamt åstadkomna och således delade. Studier av beslutsfattande visar att människor tycks sträva mot att göra beslut just delade snarare än enskilt fattade (Stevanovic 2012, Koenig 2011, Landmark m.fl. 2015). För att fatta ett gemensamt beslut behöver deltagarna vara överens om både var i beslutsfattandesekvensen de befinner sig - om beslutet är fastställt eller fortfarande under förhandling - och beslutets innehåll - vad det är man faktiskt enas om (Stevanovic m.fl. 2017). Man behöver också visa varandra att man har den kunskap som krävs för att på goda grunder fatta beslut. Allt detta görs $\mathrm{i}$ interaktionen genom ständigt säkerställande och uppvisande av delad förståelse deltagarna emellan.

I föreliggande undersökning studerar vi gemensamt beslutsfattande i ett vardagligt sammanhang. Studien anlägger ett etnometodologiskt och samtalsanalytiskt perspektiv (se t.ex. Goodwin 2000, Schegloff 1996) och utgår från videoinspelningar av personer som lagar mat tillsammans i sina hem. Då tidigare samtalsanalytisk forskning har haft stark slagsida åt beslutsfattande i institutionella kontexter, särskilt läkare-patientsamtal (för en översikt, se t.ex. Landmark 2016), utgörs vårt bidrag särskilt av att vi studerar beslutsfattande i vardagen. Vi bidrar också med ett multimodalt perspektiv (Goodwin 2000, Mondada 2018a) på beslutsfattande, då vi studerar hur det koordineras i interaktion ansikte-mot-ansikte genom samordnandet av kroppar, objekt och verbala element. Studien ger dessutom en fördjupad förståelse för hur beslutsfattande görs till någonting gemensamt genom att närmare fokusera på hur deltagare förhåller sig till att skaffa och uppvisa tillgång till det som de ska fatta beslut om. I samband med detta diskuterar vi hur deltagarnas subjektiva upplevelser och erfarenheter av t.ex. smak behandlas som en förutsättning för att göra ett beslut till något som fattas gemensamt. 


\section{Gemensam matlagning som interaktion och kontext för beslutsfattande}

Matens och ätandets sociala betydelse märks i de många studier som har synliggjort social praktik genom att analysera situationer där mat har en central roll (se t.ex. Wiggins m.fl. 2001). Medan samtalsanalysen har en lång tradition av att studera samtal vid middagsbordet, har dock få studier fokuserat på den interaktion som sker medan maten tillreds. Några undantag utgör Stukenbrocks (2012) studie om interaktion mellan en tv-kock, en gäst och åskådare, Goldbergs (1975) studie med deltagare som följer ett recept och Conein (1997) om receptens roll för hur man dukar ett bord. Mondada (2014a) och Raevaara (2017) fokuserar båda på instruktioner i matlagningskurser. Mondada (2014a) undersöker hur råvaror manipuleras och transformeras till relevanta ingredienser i relation till kursledarens instruktioner, medan Raevaara (2017) studerar hur en ledare för en matlagningskurs för barn utformar sina anvisningar. Ursi (2016) undersöker hur oenigheter uppstår och utvecklas sekventiellt vid gemensam matlagning. Vad tidigare forskning visar är att köket är en viktig plats för social interaktion och att matlagning är en aktivitet som kräver noggrann koordinering mellan deltagare och med omgivande objekt. Allt detta gör matlagning till en kontext väl lämpad för att undersöka gemensamt handlande och beslutsfattande i ett vardagligt sammanhang.

Matlagning utmärker sig också genom att smakupplevelser och smakande är viktiga komponenter i aktiviteten. Att smak och smakande inte enbart ska ses som neurologiska och kognitiva processer, utan att de även kan betraktas utifrån sociala perspektiv, har lyfts i tidigare interaktionellt orienterad forskning (Wiggins \& Potter 2003; Mondada 2018b, 2018c, 2019, u.å.). Eftersom vi är intresserade av hur deltagare orienterar sig mot att skaffa sig tillgång till och kunskap om det som beslutet gäller, samt hur subjektiva upplevelser av olika objekt blir relevanta i beslutsfattandeprocessen, framstår matlagning som en intressant multisensorisk aktivitet.

\section{Beslutsfattande $\mathrm{i}$ interaktion}

Gemensamt beslutsfattande har inom samtalsanalytisk forskning främst studerats i medicinsk interaktion. ${ }^{1}$ Studier i denna kontext visar hur patienter

${ }^{1}$ I dessa sammanhang används i regel termen delat beslutsfattande (shared decision-making). Denna är etablerad i en vårdvetenskaplig kontext (se t.ex. Socialstyrelsen 2012), och framstår som en institutionell term snarare än grundad i detaljerad analys av interaktion. I samtalsanalytiska studier i andra kontexter än den medicinska används ibland termen gemensamt beslutsfattande (joint decision-making, se t.ex. Stevanovic 2012). I denna studie använder vi oss av den termen. 
kan delta i och bidra till beslut genom att verbalt och kroppsligt uppvisa instämmande eller motstånd mot läkarens behandlingsrekommendationer (se t.ex. Costello \& Roberts 2001; Stivers 2005a, 2005b, 2006; Koenig 2011; Hultberg \& Rudebeck 2017), samt hur läkare och patienter kan konstruera beslutsfattandesekvenser som mer eller mindre delade (Collins m.fl. 2005, Koenig 2011, Toerien m.fl. 2013, Landmark m.fl. 2015, Barnes 2017, Stivers m.fl. 2017). Utanför en medicinsk kontext har bl.a. Stevanovic och Peräkylä (2012) och Stevanovic (2012) undersökt gemensamt beslutsfattande i dyadiska arbetsplatsmöten. De menar att det i gemensamt beslutsfattande alltid ingår förhandling om deontiska rättigheter, d.v.s. deltagares auktoritet att fatta beslut. En deltagare som håller med om innehållet i ett beslut kan ändå göra motstånd mot dess deontiska aspekter genom att positionera sig som självständig. Beslutsfattande är dock inte begränsat till institutionellt präglade samtal, utan förekommer frekvent även i »vardagliga» aktiviteter. En beslutsfattandeprocess i institutionella samtal kan vara mer eller mindre formaliserad och behandlas som begränsad av sina deltagarramar (jfr Robinson 2003). Inte minst kan deltagares orientering mot asymmetriska institutionella roller (t.ex. läkare och patient) påverka hur beslutsfattandeprocessen går till. Vardaglig interaktion erbjuder delvis andra förutsättningar för lansering av förslag, för koordinering av hur beslutfattandet sker gemensamt och för att avgöra när en beslutsfattandesekvens är mogen för avslut.

Tidigare samtalsforskning har beskrivit beslutsfattandesekvensen som inledd av ett förslag som så småningom godtas (Houtkoop 1987, Stevanovic m.fl. 2017). Genom att lägga fram ett förslag öppnar talaren för att andra deltagare har rätten och skyldigheten att delta i beslutsfattandet (Charles m.fl. 1997, Stevanovic 2012, Stevanovic \& Peräkylä 2012). Talaren bjuder alltså in andra att delta i processen och indikerar att beslutet ska fattas gemensamt. Närhetsparet förslag-godtagande (Schegloff 2007) kan betraktas som kärnan i beslutsfattandesekvensen (Stevanovic m.fl. 2017) och kan ensamt utgöra sekvensen, såsom när en deltagare lägger fram ett förslag som omedelbart godtas av samtalspartnern (Stasser \& Stewart 1992). Det är dock inte ovanligt att sekvensen expanderas med ytterligare underordnade närhetspar, varför beslutsfattandesekvensen kan karaktäriseras som vad Schegloff (2007 s. 252) kallar »a sequence of sequences».

Ett gemensamt beslut kräver enligt Stevanovic (2012) att den som mottar ett förslag (proposal) 1) skaffar sig tillgång till förslagets innehåll (access), 2) instämmer i samtalspartnerns förslag (agreement) och 3) förbinder sig till den fö- 
reslagna framtida handlingen (commitment). Utifrån detta föreslås följande modell för uppkomsten av ett gemensamt beslut.

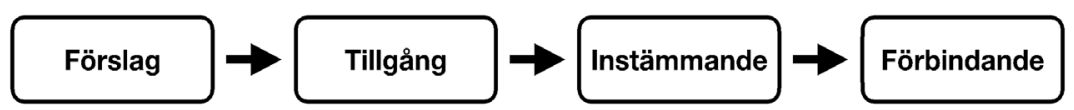

(Stevanovic 2012 s. 785, vår övers.)

Längs vägen kan förslaget avslås, vilket Stevanovic (2012) benämner som ett icke-beslut, eller konstrueras som ett unilateralt (icke-gemensamt) beslut. Detta sker genom att en deltagare undviker något av stegen: att skaffa tillgång, att instämma i förslaget eller att förbinda sig till handlingen. En deltagare kan också underminera och avstå sin rätt att delta i beslutsfattandet genom att hävda okunskap, d.v.s. avsaknad av epistemisk tillgång, eller avsaknad av deontisk auktoritet, d.v.s. rätten att fatta beslut (Landmark m.fl. 2015, Lindström \& Weatherall 2015).

Tidigare forskning har visat att beslutsfattandesekvenser kan inledas av bland annat frågor, påståenden och erbjudanden (se t.ex. Stivers m.fl. 2017). Dessutom framstår icke-verbala handlingar som högst centrala resurser för att initiera en förändring i gemensamt handlande (Stevanovic \& Monzoni 2016). Stevanovic m.fl. (2017) använder därför termen aktivitetshanterande drag (activity-management moves), definierat som en handling (verbal eller kroppslig) som påverkar ett gemensamt handlingsförlopp genom att föreslå inledning, förändring eller avslutande av en gemensam handling. Förslag, främst igenkännbara genom sin lingvistiska form (Stevanovic 2012 s. 782), framstår utifrån detta som en alltför begränsad term för ett förstadrag i en beslutsfattandesekvens. I föreliggande artikel tillämpar vi därför Stevanovic (2012) modell utifrån en breddad förståelse för vad som kan inleda en beslutsfattandesekvens. Alla former av förstadrag som kan initiera gemensam handling, $i$ vårt fall beslutsfattande, kallar vi handlingsinitiativ. Att en deltagare verbalt eller kroppsligt föreslår hur någonting kan utföras kallar vi, oberoende av sekventiell position och modalitet, för förslag.

Vi förstår det gemensamma i gemensamt beslutsfattande som deltagande $\mathrm{i}$ beslutsprocessen. Goodwin och Goodwin (2004) presenterar ett ramverk för deltagande där samtliga närvarande betraktas som aktiva deltagare i interaktionen. ${ }^{2}$ Oavhängigt deltagarnas verbala bidrag till interaktionen så är samtliga att

${ }^{2}$ Detta ramverk utgör delvis en kritik av Goffmans (1981) verbalfokuserade modell för deltagande som fokuserar den talande deltagaren. 
betrakta som aktörer som genom sin kroppsliga hållning, sitt blickspel och sin kropps förhållande till objekt i omgivningen visar upp sitt deltagande i pågående skeenden. I linje med detta utgår vi från Goodwin och Goodwins definition av deltagande som "actions demonstrating forms of involvement performed by parties within evolving structures of talk» (2004 s. 222).

En central resurs för att åstadkomma och visa upp engagemang i en gemensam handling är kroppens placering i rummet och gentemot andra kroppar och objekt. Positionering av den egna kroppen har beskrivits som synliga praktiker för att åstadkomma olika hållningar (eng. stances) inför en förelagd uppgift $\mathrm{i}$ den sociala interaktionen (Goodwin 2007). Att till exempel placera sin kropp så att man ser hur den andre hackar grönsaker åstadkommer en rad olika hållningar. Goodwin (2007) identifierar fem typer av hållningar med betydelse för deltagande. Man placerar sig själv gentemot objekt och andra människor i omgivningen i en instrumentell hållning så att man kan se, höra, förnimma så mycket som krävs för den relevanta aktiviteten. Positioneringen bidrar till en epistemisk hållning ${ }^{3}$ som demonstrerar att man har möjlighet att uppfatta och uppleva de betydelsefulla beståndsdelarna i den aktuella situationen. Därigenom visar deltagaren att man har inhämtat relevant information och därmed deltar på goda grunder i den gemensamma handlingen. Deltagarens kroppsliga position signalerar också huruvida man intar en samarbetande hållning (cooperative stance) inför aktiviteten och är del i dess genomförande. Utöver att uppvisa delaktighet, samarbetsvillighet och adekvat kunskapsinhämtning har kropparnas placering också moraliska och affektiva implikationer. En deltagare kan visa huruvida man litar på den andra personen och att den har de rätta förutsättningarna för att utföra sysslan genom att inta en moralisk hållning. Känsloyttringar kan markera affektiv hållning och sanktionera sådana handlingar som inte är i linje med det förväntade deltagandet. Vi återkommer i analyskapitlet till hur deltagare orienterar sig mot dessa kroppsliga hållningar som relevanta för adekvat deltagande i beslutsprocessen.

\section{Material och metod}

Föreliggande studie baseras på ca 150 beslutsfattandesekvenser ur ett videomaterial om 6,5 timmar, i vilka vänner och familjer lagar middag tillsammans.

\footnotetext{
${ }^{3}$ Goodwins användning av begreppet epistemic stance skiljer sig från användningen hos Heritage
} (2012), som främst utgår från den verbala turens grammatiska konstruktion. 
Deltagarna är i åldrarna 20-85 år och har varierande bakgrund, yrken och könsidentiteter. Datainsamlingen har skett i linje med Vetenskapsrådets forskningsetiska principer för humanistisk-samhällsvetenskaplig forskning (Vetenskapsrådet 2002). Deltagarna har muntligen och skriftligen informerats om studien och om sina rättigheter att dra tillbaka sin medverkan, samt gett sitt skriftliga samtycke till deltagande och till att författarna publicerar omaskerade bilder i vetenskapliga sammanhang. Materialet har transkriberats enligt Jeffersons (2004) principer för verbal transkription samt Mondadas (2014b) konventioner för multimodal transkription.

Inspelningarna analyseras genom etnometodologisk samtalsanalytisk metod (se t.ex. Schegloff 1996, Goodwin 2000). Det innebär att vi utifrån videoinspelningar av interaktion i detalj analyserar hur samtalsdeltagare gemensamt skapar och genomför sociala handlingar. Centralt är antagandet att handlingar skapas och tolkas sekventiellt, vilket innebär att betydelsen och utformningen av varje (verbal eller kroppslig) handling beror på vad som föregår den, samtidigt som varje handling förändrar kontexten och formar förutsättningarna för kommande handling. Därför kan handlingar inte analyseras isolerat utan måste förstås - av såväl samtalsdeltagare som forskare - utifrån i sin omedelbara kontext (Heritage 1984). I linje med Goodwin (2000) och Mondada (2018a) utgår vi från ett multimodalt perspektiv på språkande och social handling, där både verbala och kroppsliga handlingar samt interaktion med objekt ${ }^{4}$ i den omgivande miljön utgör semiotiska resurser för meningsskapande.

\section{Analys}

I det följande redovisar vi vår analys av beslutsfattandesekvenser i gemensam matlagning. I de tre första exemplen (1), (2) och (3) undersöks hur beslutsfattande initieras, koordineras och görs till en gemensam angelägenhet genom multimodala resurser. Det avslutande exemplet (4) fokuserar särskilt på det andra steget i Stevanovic (2012) modell för gemensamt beslutsfattande, nämligen tillgång till det som ska beslutas om. Vi resonerar här om hur deltagarna orienterar sig mot att skaffa och visa upp epistemisk tillgång som en förutsättning för deltagande och gemensamt beslutsfattande.

\footnotetext{
${ }^{4}$ Med objekt menas materiella ting som man kan se, höra eller röra (Nevile m.fl. 2014).
} 


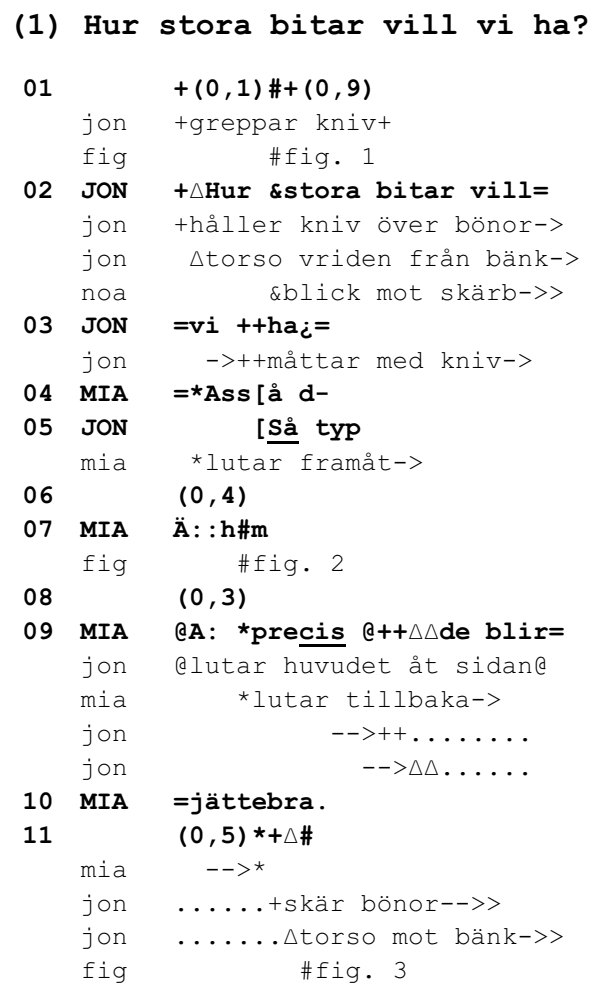

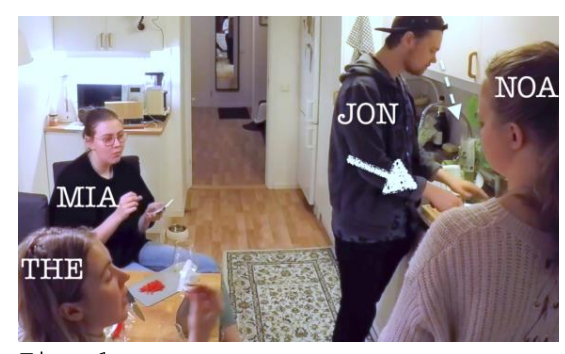
Fig. 1

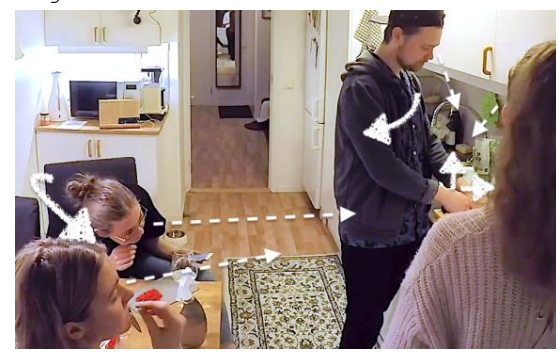

Fig. 2

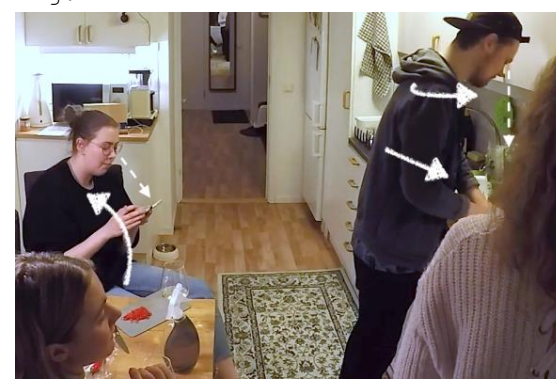

Fig. 3

Vårt första exempel (1) illustrerar hur deltagare multimodalt initierar och genomför ett gemensamt beslutsfattande i linje med Stevanovic (2012) modell. I exemplet lagar Mia, Noa, Jon och Therese mat tillsammans när Jon initierar ett gemensamt beslutsfattande angående hur bönorna ska skäras. ${ }^{5}$

Jon greppar kniven men börjar inte skära bönskidorna som ligger på skärbrädan utan stannar med kniven ovanför bönorna (fig. 1). Han ställer en fråga, formulerad med pronomenet vi, Hur stora bitar vill vi ha? ( $\operatorname{rad} 2-3)$. Jon framställer därmed bönskidornas storlek som ett beslut att fatta gemen-

${ }^{5}$ Transkriptionsnyckel baserad på Jefferson (2004) samt Mondada (2014b) finns bifogad. 
samt, grundat i deltagarnas vilja. Han vrider också överkroppen något mot Mia ( $\operatorname{rad} 2$; se position i fig. 2) i en s.k. body torque (jfr Schegloff 1998). Denna förändrade riktning av överkroppen signalerar en avvikelse från det pågående aktivitetsförloppet, som ska återtas när beslutsfattandesekvensen är avslutad. Hans fråga, tillsammans med hans förändrade kroppsposition, utgör ett handlingsinitiativ som inleder en beslutsfattandesekvens. Noa och Mia orienterar sig omedelbart mot skärbrädan: Noa genom att vända blicken däråt, och Mia genom att luta sig framåt mot Jon och skärbrädan (fig. 2). De skaffar sig därmed tillgång till det beslutet gäller: De kan se bönorna och skärbrädan. Genom denna position intar de en epistemisk hållning (Goodwin 2007) som demonstrerar att de inhämtar relevant kunskap och därmed kan delta adekvat i beslutsfattandet. Genom sina kroppspositioner visar deltagarna synbart sitt deltagande i beslutsfattandet. Jon föreslår därpå storlek genom att måtta med kniven över bönorna och säga $\underline{S a ̊ t t y p}(\operatorname{rad} 5)$. Mia sitter kvar i sin framåtlutade ställning med blicken mot skärbrädan och ser Jons förslag - hon möjliggör fortsatt tillgång till det som beslutet gäller och visar sig fortsatt involverad i beslutsfattandet. Därpå lutar hon sig tillbaka och instämmer verbalt i förslaget ( $r a d$ 9-10). Jon omsätter omedelbart förslaget i handling genom att skära bönorna enligt förslaget (fig. 3) och visar sig därmed beredvillig till det gemensamt fattade beslutet. Exemplet visar hur ett beslutsfattande lanseras som en gemensam uppgift varpå deltagarna skaffar sig tillgång till beslutets objekt (genom blickriktning, kroppspositioner och verbala uttryck) och därmed visar sitt engagemang. Först efter att den visuella tillgången är säkrad accepteras förslaget och genomförs.

Genom dessa steg i beslutsprocessen behöver deltagarna i ett gemensamt beslutsfattande vara överens om både var de befinner sig i beslutsprocessen och vad de beslutar om (jfr Stevanovic m.fl. 2017). I följande exempel (2) vill vi just visa hur deltagarna, med sina kroppar i interaktion i det materiella rummet, koordinerar beslutsfattandets steg när de förkastar och återupptar förslag på handling. Då förslagen gäller materiella objekt i deltagarnas omedelbara omgivning, blir det särskilt relevant att undersöka hur hantering av objekt blir en del av att orientera sig i sekvensen. I exemplet är vännerna Erik och Max i färd med att lösa ett problem som uppstått under matlagningen, nämligen att en ingrediens saknas. Max har gjort slut på majonnäsen, och de behöver nu hitta en ersättning när Erik ska laga coleslaw. Erik har föreslagit att ersätta majonnäsen med dijonsenap eller att göra egen majonnäs. Max har ställt sig avvaktande till förslagen, dock utan att explicit avvisa dem. När utdraget börjar står de båda och tittar in i kylskåpet efter 
(2) Den sista majonnäsen
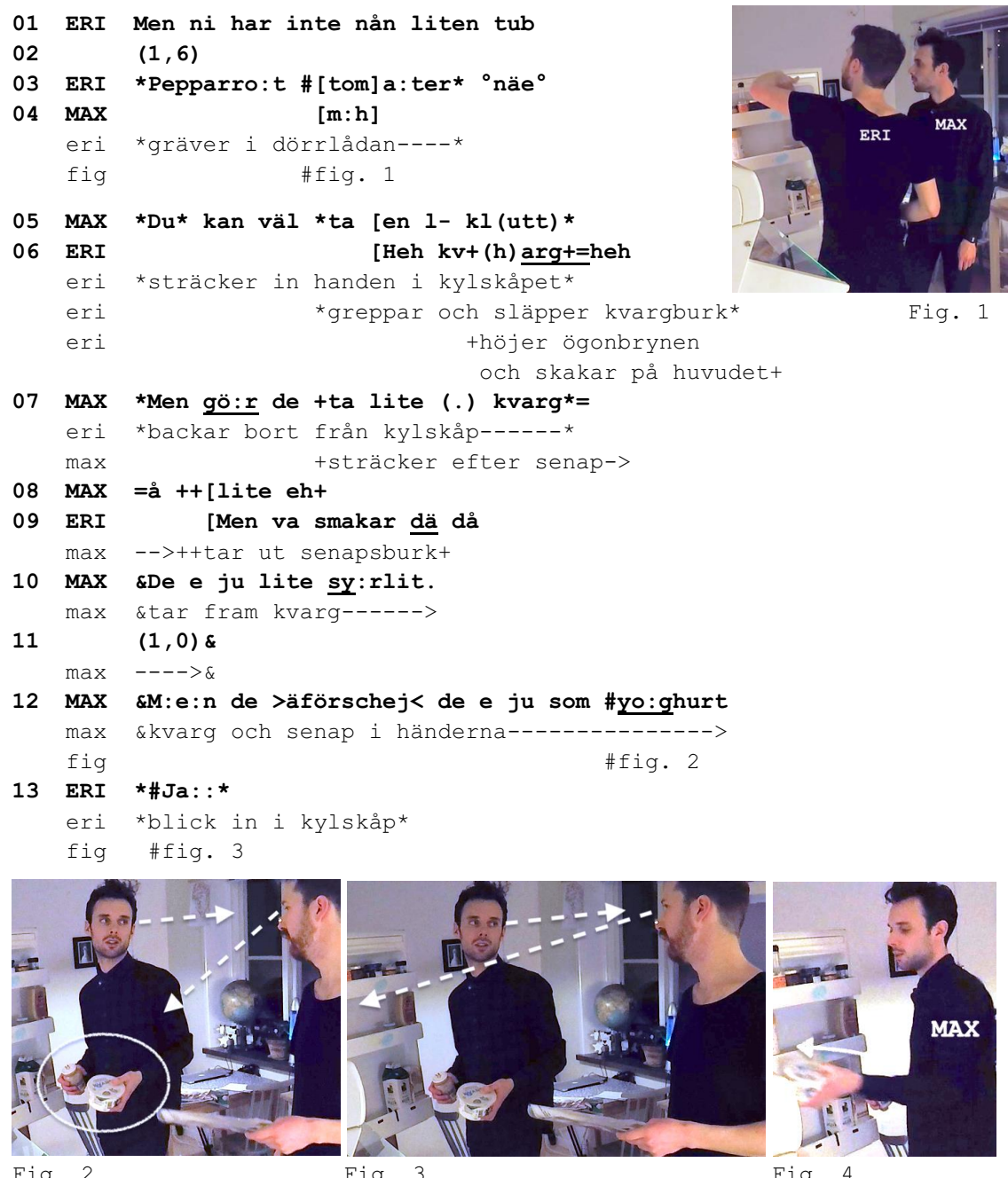

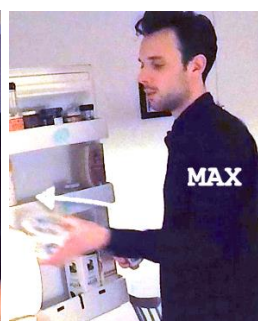

Fig. 4

$14 \quad(0,4)$

15 ERI \&\&Nä: \#de kanske inte gör\& från eller till

fig \#fig. 4

max $->\& \& s t a ̈ l l e r$ in kvarg i kylskåpet\&

16 MAX >Men \#d-< \#men du kan\#ske* kan ta dig en li:ten li:ten*= fig \#fig.5 \#fig.6 \#fig.7

eri

17 MAX =*\#skvätt* e: : h

eri *tar senap*

fig \#fig. 8 


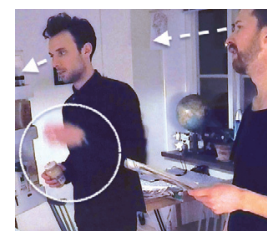

Fig. 5

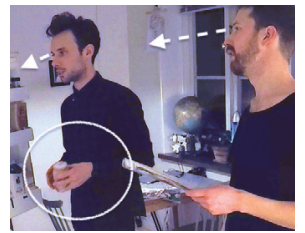

Fig. 6.

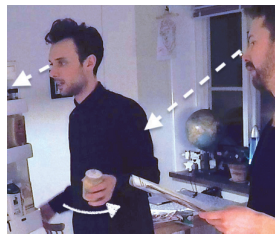

Fig. 7

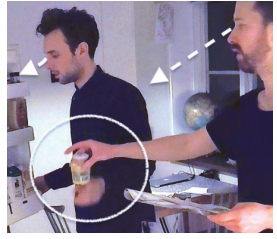

Fig. 8

18 ERI Å så säger vi att det är maxs fel att de ( )

19 MAX Mm,

någonting annat som kan ersätta majonnäsen. Vi fokuserar i denna analys på hur Max och Erik förkastar och återupptar förslag, och hur de koordinerar beslutsfattandesekvensen genom blickspel, kroppsposition och hantering av objekt.

Deltagarna inventerar kylskåpet $\mathrm{i}$ jakt på någonting som kan lösa det uppkomna problemet ( $\mathrm{rad} 1-4)$. Max påbörjar ett handlingsinitiativ i form av ett förslag ( $\operatorname{rad} 5)$, möjligen gällande den tidigare idén att använda dijonsenap. Samtidigt uppmärksammar och sträcker sig Erik efter en burk i kylskåpet, lyfter upp den och annonserar med skrattande röst och skämtsamt ansiktsuttryck dess innehåll kvarg ( $\operatorname{rad} 6)$. Därpå släpper han burken igen ( $\operatorname{rad} 6)$ och rör sig bort från kylskåpet ( $\operatorname{rad} 7)$, och förkastar därmed vad som kunde ha varit ett potentiellt förslag att använda kvarg. Max står dock kvar i samma position som tidigare, riktad mot kylskåpet. Samtidigt som Erik backar från kylskåpet uppmanar Max honom att faktiskt använda kvargen: Men gö:r de ta lite kvarg ( rad 7). Eriks omnämnande av sitt kylskåpsfynd kvarg ( $\operatorname{rad} 6)$ aktualiseras därmed som ett relevant förslag. Max explicitgör det som ett förslag genom imperativen gö: $r$ och $t a$. Erik frågar hur kvarg smakar ( $\operatorname{rad} 9)$. Genom sin fråga söker han adekvat epistemisk tillgång i form av kunskap om kvargens smakegenskaper. Därmed visar han sig involverad i beslutsfattandet, och behandlar kvargen som ett relevant förslag. Medan Max besvarar frågan (rad 10) tar han fram kvargen ur kylskåpet igen, tillsammans med den dijonsenap som tidigare föreslagits som potentiell kandidat. Genom att åter föra fram objektet från en sovande position (se Bergmann 1990) behandlar Max det som ett fortsatt aktuellt förslag. Därpå (rad 12) påpekar Max att kvarg kanske är att jämställa med ingrediensen yoghurt, som redan är nedblandad i coleslawen. Det inledande $M e:: n$ samt äförschej ('i och för sig') formulerar detta som en invändning, vilket projicerar ett avvisande av förslaget. Erik instämmer i invändningen (rad 13), vilket Max behandlar som ett förkastande av förslaget då han ställer tillbaka kvargen i kylskåpet ( $\operatorname{rad} 15)$. Förslaget att använda kvarg är nu slutgiltigt 
avvisat. Däremot behåller Max dijonsenapen i handen och modifierar därpå sitt tidigare förslag om att använda den till att Erik kanske kan ta dig en li:ten li:ten skvätt ( $\operatorname{rad} 16-17)$. Dijonsenapen har hållits kvar som fortsatt relevant under tiden de har diskuterat ett annat lösningsalternativ. Erik går med på förslaget att använda dijonsenap på villkoret att de inför matgästerna lägger ansvaret på Max ( $\operatorname{rad} 18)$.

Genom sin bibehållna kroppsposition riktad mot kylskåpet (fig. 1-8), till skillnad från Erik som med kropp och blick rör sig bort (rad 7), uppehåller sig Max vid Eriks förslag om kvarg som ännu aktuellt. Medan Erik behandlar beslutsfattandesekvensen som avslutad och förslaget som förkastat, håller Max sekvensen vid liv genom att behålla sin kroppsposition och genom att återuppväcka det objekt - kvargburken - som Erik ställt tillbaka när han avvisade sitt eget skämtsamt inramade förslag. Så länge förslaget är uppe på bordet som aktuell kandidat, hålls objektet också aktuellt i rummet (jfr Keisanen \& Rauniomaa 2012). När deltagarna sedan enas om att denna del av beslutsfattandesekvensen är avslutad och förslaget är förkastat, sätts kvargen tillbaka i kylskåpet och behandlas inte längre som ett relevant förslagsobjekt (jfr Rauniomaa \& Heinemann 2014, Day \& Wagner 2014).

Vi har i detta exempel sökt visa hur kroppsposition, blickar och hantering av objekt är centrala resurser för att koordinera beslutsfattande. Förslag framförs och hanteras genom att göra förslagsobjekten framskjutna i den kontextuella konfigurationen (Goodwin 2000). Genom att flytta förslagsobjektet fram och tillbaka, i det här fallet en burk kvarg, och genom att orientera sig mot den plats där objektet finns, i det här fallet kylskåpet, upprätthåller deltagarna en intersubjektiv uppfattning om huruvida beslutsfattandesekvensen är pågående eller avslutad samt huruvida objektet ännu är aktuellt som förslag (jfr Stevanovic m.fl. 2017). Genom att lyfta fram kvargen, titta på den och resonera om dess egenskaper, skaffar sig deltagarna också den kunskap som krävs för att fatta ett gemensamt beslut. De visar att de deltar i beslutsfattandet, och behandlar samtidigt kvargen som ett relevant och aktuellt förslag.

Betydelsen av kroppslig position, blickar och hantering av objekt för att koordinera beslutsfattande är särskilt framträdande i följande exempel (3). Här visar sig deltagarna angelägna om att grundligt bevittna och åskådliggöra varje steg i vad som visar sig bli en komplex beslutsfattandesekvens. I utdraget gör Max och Erik klyftpotatis i ugnen. Erik står och diskar med ryggen vänd mot spisen. Utdraget inleds med att Max böjer sig ner och tittar in i ugnen. ${ }^{6}$

\footnotetext{
${ }^{6}$ Den inledande turen är ett skämtsamt dialektalt uttalat 'Ge dig nu' som hör till föregående topik.
} 
(3) Sänka värmen på potatisen
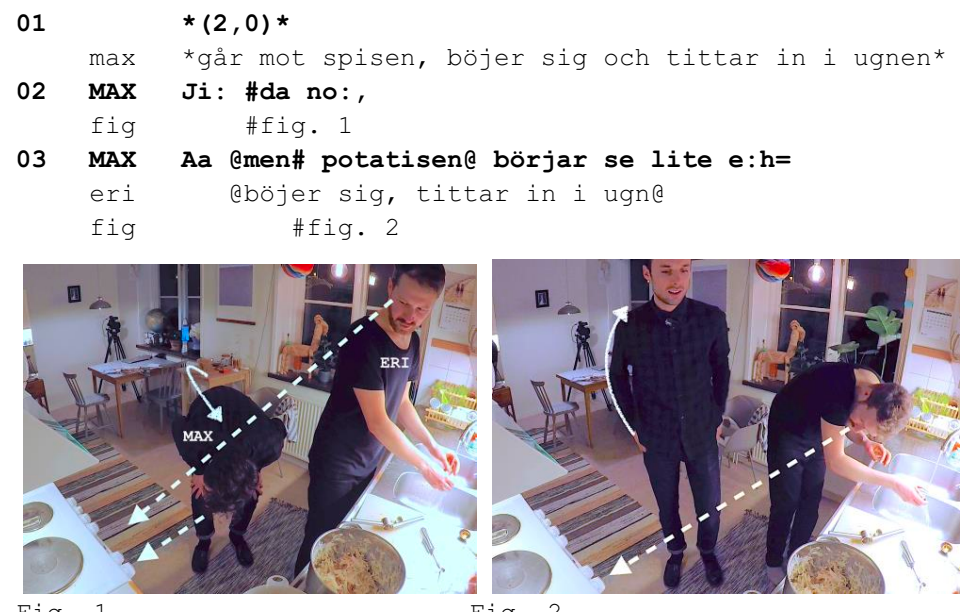

Fig. 1

Fig. 2
$04 \operatorname{MAX}=($.$) [härlig ut.$
05 ERI [Man kanske kan sä- man skulle kunna sä- för
06 den har ju \#redan fått $y:$ ta *man skulle ju så här $\max$ fig \#fig. 3

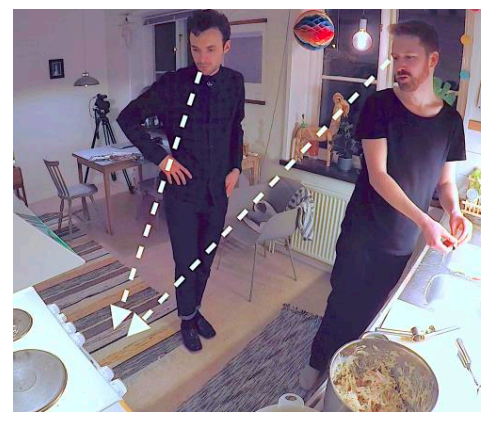

Fig. 3

07

08 MAX

$\max$

fig

09 MAX

fig

10 kunna* sänka *värmen \#om man inte [vill att de ska*
[Ja: :

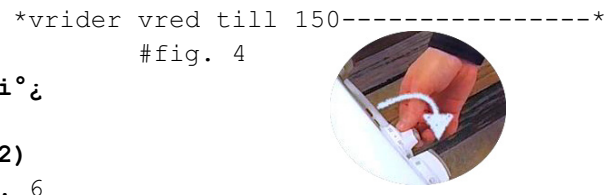


86 Klara Bertils \& Simon Magnusson
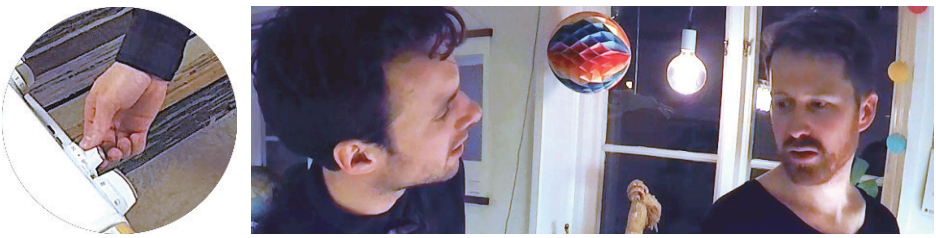

Fig. 5
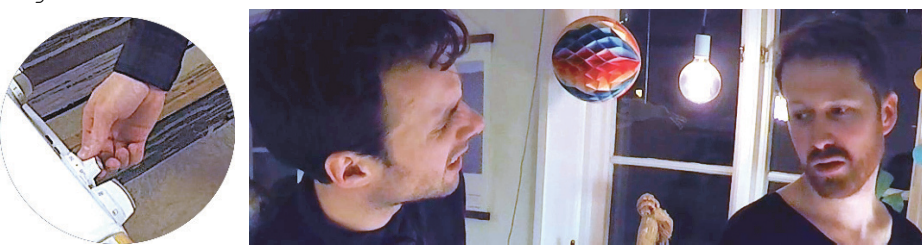

Fig. 6

11 ERI Aa eller tvåhu- *ja* eller hundra*sj*uttifem kanske? $\max \quad *$ vrider* ${ }^{*}$ vrider*

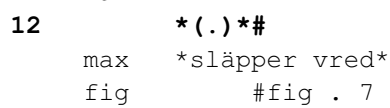
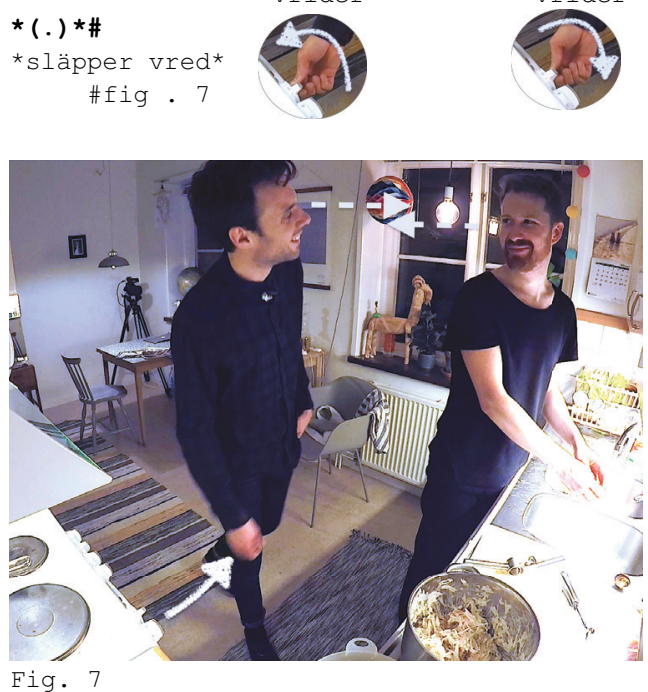

13 MAX he:h

14 ERI För det var ju tvåhundratjugi.

15 MAX Ja.

$16 \quad(2,0)$

17 ERI Då blir de så där perfekt ¿ (förställd röst))

18 MAX Ja-ö? ((förställd röst)) 
Max närmar sig spisen, böjer sig fram och tittar in i ugnen (fig. 1) varefter han rapporterar att potatisen börjar se lite härlig ut. Under Max' värdering böjer sig Erik och tittar även han in i ugnen och skaffar sig därmed tillgång till en egen uppfattning om potatisen (fig. 2). Han behandlar Max' värdering som ett handlingsinitiativ och visar att han deltar. Max och Erik ser till att båda inta samma epistemiska hållning, det vill säga ha och uppvisa möjlighet att förnimma potatisen och skapa sig en adekvat uppfattning om dess tillstånd (Goodwin 2000). Denna kunskap ligger till grund för ett informerat gemensamt beslut. Erik påbörjar, avbryter och omformulerar ett förslag, formulerade som möjliga handlingar med nedgraderad modalitet: man kanske kan sä- man skulle kunna sä( $\mathrm{rad} 5)$. I sin tredje omstart inleder han med motiveringen att potatisen redan har fått yta, och uttalar därpå ett förslag på handling. Redan efter motiveringen, innan förslaget har uttalats i sin helhet, närmar sig Max spisen och greppar ugnsvredet (fig. 4), och visar att han förbinder sig att agera i linje med förslaget. Han påbörjar omedelbart en sänkning till 150 grader, varpå han verbalt instämmer i förslaget ( $\operatorname{rad} 8)$.

Beslutet att sänka värmen behöver nu finkalibreras genom ett följande beslut om vilken den nya temperaturen ska vara. Max framför verbalt ett förslag om 150 grader ( $\operatorname{rad} 9$ ). Hans förslag är markerat som just ett initialt sådant genom både lingvistiska och kroppsliga resurser: Den uppåtgående intonationen med svagare volym mot slutet ger förslaget en frågande karaktär, samtidigt som han håller handen fortsatt på vredet och vänder huvudet mot Erik och möter hans blick. Max för också samman ögonbrynen och skapar en s.k. orosrynka i pannan, samtidigt som han spänner upp överläppen och visar övre tandraden (fig. 5, fig. 6), ett ansiktsuttryck som i tidigare forskning har beskrivits som tecken på epistemisk utmaning (jfr Kaukomaa m.fl. 2014). I detta exempel föreslår vi att Max' ansiktsuttryck fungerar som ett sätt att öppna upp för problematisering och modifikation av hans föregående handling att sänka värmen till 150 grader. Därmed visar Max att beslutsfattandesekvensen ännu inte är fullbordad trots att han faktiskt redan kan tyckas ha genomfört sitt förslag. Max genomförda justering av ugnsvredet kan utifrån detta förstås som att han har börjat genomföra förslaget att sänka värmen, snarare än att på eget bevåg besluta vilken den nya temperaturen ska vara. Han markerar att beslutsfattandesekvensen fortfarande pågår och att hans förslag ännu är uppe för förhandling.

Erik svarar med att vicka huvudet åt sidan samtidigt som han höjer ögonbrynen något (fig. 6). Därpå accepterar han initialt förslaget genom $A a$, följt av motförslaget eller tvåhu- varpå han reparerar med upprepad ja eller-inledd konstruktion ja eller hundrasjuttifem kanske? ( $\operatorname{rad} 11)$. Max vrider vredet till det föreslagna gradantalet i direkt anslutning till Eriks båda förslag, och Erik behåller blicken vid vre- 
det under hela samtalsturen. Max släpper vredet på 175 grader och skrattar (fig. 7), och Erik fortsätter med att motivera sitt förslag. Max instämmer och efter en två sekunders paus driver Erik sekvensen mot avslut genom att göra en värdering (Schegloff 2007 s. 123) med humoristiskt förställd röst Då blir de så där perfekt ${ }_{\dot{c}}$ ( $\operatorname{rad} 17)$. Den besvaras instämmande av Max ( $\operatorname{rad} 18)$ som även prosodiskt matchar Eriks röstläge och därmed uppvisar affiliering (Couper-Kuhlen 2012). Den gemensamma förställningen av rösten skulle kunna tolkas som att de uppmärksammar och ironiserar över noggrannheten i temperaturkompromissen.

Exemplet visar på flera aspekter av att göra beslut till gemensamt fattade. Både Max och Erik arrangerar sina kroppar så att de kan undersöka potatisens färg och skapa sig individuell empirisk grund för beslutsfattandet. Kropparnas placeringar utgör en hållning som visar att de är »appropriately cooperating in the joint accomplishment of the activity in progress» (Goodwin $2007 \mathrm{~s}$. 62) och gör sig till jämlikar i beslutsfattandet. Den triadiska uppställningen kropp-kropp-objekt skapar en gemensam fokuspunkt beskriven i tidigare forskning som central för mänsklig interaktion, språkande och intersubjektivitet (Tomasello 1999, Goodwin \& Duranti 1992). De intar båda en epistemisk hållning genom att skapa tillgång till det objekt som de ska besluta om. Genom att skaffa sig samma kunskap om objektet gör de sig epistemiskt likvärdiga i beslutet. Det påföljande utförandet av handlingen efter att de är överens om att värmen på potatisen ska sänkas görs även det gemensamt. Max' hand på vredet blir nytt fokus för den triadiska uppmärksamheten (se fig. 4) och efter en inledande förändring i gradantalet enligt Eriks förslag att sänka värmen vänder sig Max mot Erik för att förankra och modifiera det initiala förslaget att sänka till 150 grader. Genom ansiktsuttryck, prosodi och en bibehållen kroppsposition indikerar Max att sekvensen ännu inte är avslutad och håller öppet för fortsatt deltagande från Erik. Därigenom behandlas Erik som deltagande i beslutsprocessen även när det är Max som har handen på vredet och är den som instrumentellt genomför själva sänkningen. Intersubjektivitet upprätthålls både vad gäller beslutets innehåll - ugnstemperaturen - och vad gäller den sekventiella orienteringen i beslutsprocessen - att fastställa när beslutssekvensen avslutas (jfr Stevanovic m.fl. 2017).

I alla tre exempel som hittills har diskuterats skaffar alla deltagare synbart epistemisk tillgång till beslutsobjektet. I följande exempel (4) närstuderar vi just denna del i beslutsfattandet. Här presenteras ett avvikande exempel som synliggör vad som kan ske när en deltagare avstår från att skaffa sig adekvat kunskap om ett beslutsobjekt. Exemplet syftar till att stärka vår analys att deltagande och gemensamhet är tätt förknippade med att tillägna sig och uppvisa epistemisk tillgång, då den som inte skaffar sig sådan kan tillrättavisas och behandlas som inte tillräckligt deltagande. I följande exempel har Bea, Ida och ytterligare tre vänner en sås puttrande på spisen som nu ska smakas av. 


\section{(4) Smaka av såsen}
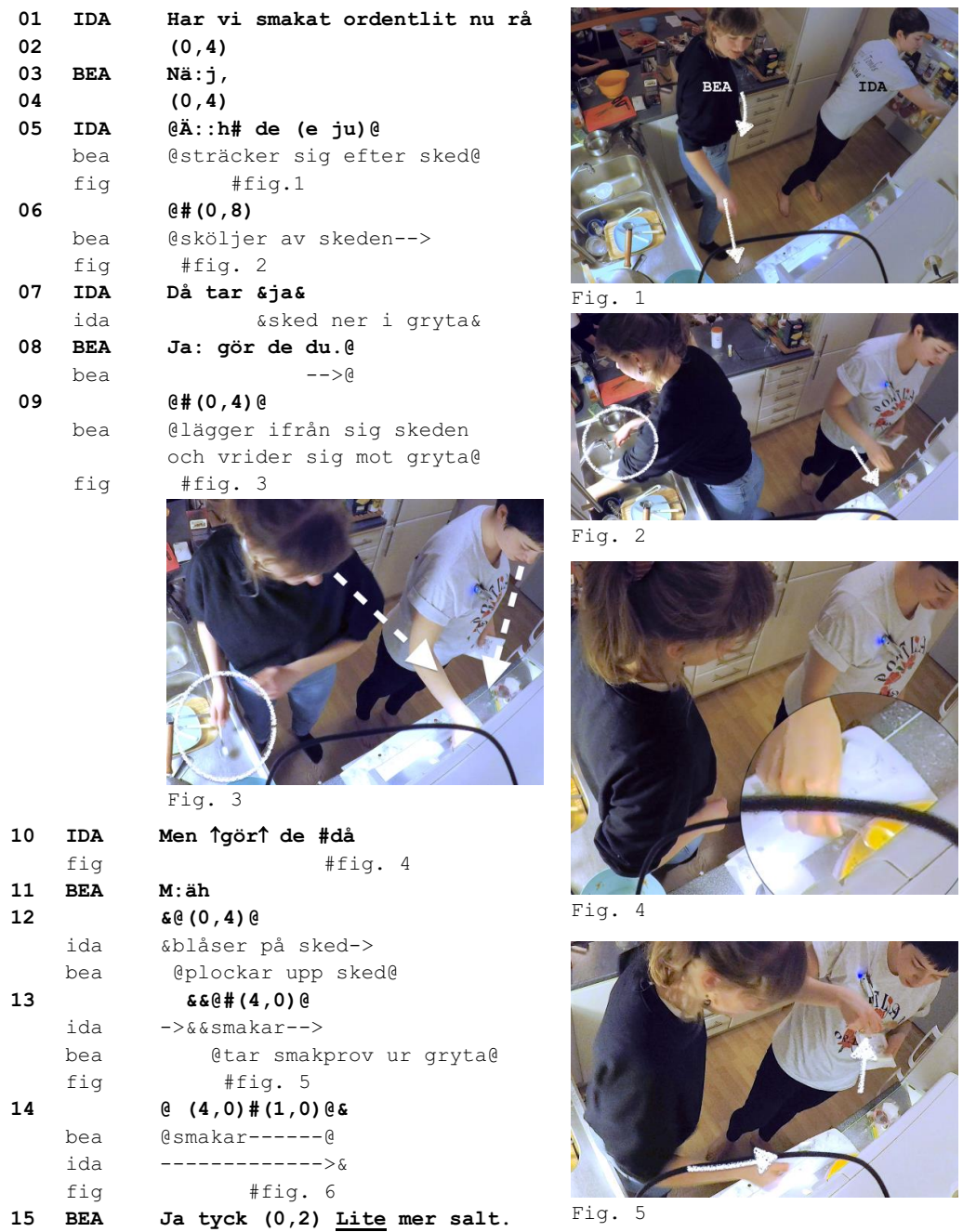

Fig. 2

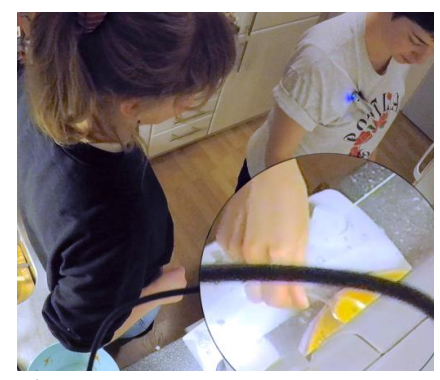

Fig. 4

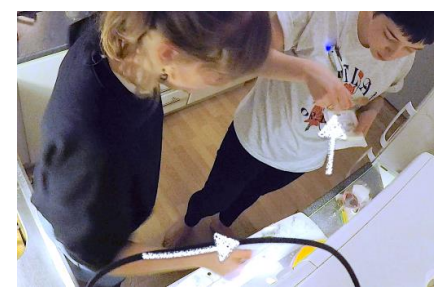

Fig. 5

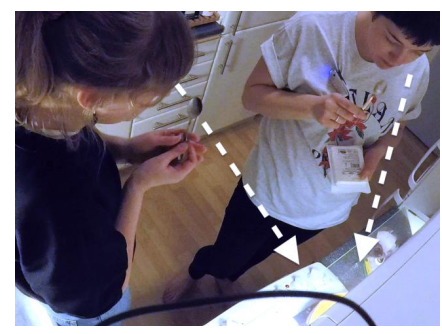

Fig. 6 
Ida frågar Har vi smakat ordentlit nu rå ( $\operatorname{rad} 1)$ och formulerar, genom pronomenet $v i$, smakandet som ett gemensamt ansvar. Bea svarar nekande på frågan ( $\operatorname{rad} 3)$ och behandlar den som ett handlingsinitiativ: Hon tar fram en tesked (fig. 1) som hon sköljer av i diskhon och förbereder sig således för att utföra den handling som saknas, dvs avsmakningen. Bea tar verbalt på sig uppdraget att smaka ( $\operatorname{rad} 7)$, samtidigt som hon tar fram en sked och därmed också kroppsligen visar att hon förbinder sig att utföra handlingen (fig. 2). Ida godtar Beas självrekrytering då hon explicit utnämner henne till den ansvariga att utföra smakandet Ja gör de $d u(\operatorname{rad} 8)$, samtidigt som hon själv lägger ifrån sig skeden och vänder sig mot Bea (fig. 3). Hon orienterar sig mot turen som ett förslag på arbetsfördelning och agerar som att hennes egen smakinsats nu skulle vara överflödig. Med Goodwins (2007) terminologi intar Ida en kooperativ hållning men inte instrumentell och epistemisk hållning. Genom att lägga ifrån sig skeden gör hon sig otillgänglig för att inhämta den kunskap som krävs för att bedöma såsen (instrumentell och epistemisk hållning), men genom sin kroppsliga orientering mot Bea (kooperativ hållning) deltar hon ändå i smakaktiviteten som icke-smakande åskådare. Bea uppmärksammar att Ida har förändrat sitt deltagande som nu består i att hon står lutad mot diskhon och iakttar Bea (fig. 4). Bea uppmanar henne med Men $\uparrow g \ddot{r} \uparrow$ det då ( $\mathrm{rad} 10)$, inledd av men som positionerar turen som en invändning mot Idas föregående handling att lägga ifrån sig skeden. Turen fungerar som ett tillrättavisande och indikerar att Idas deltagande som vittne till avsmakningen snarare än som medsmakare inte är tillräckligt. Bea intar en affektiv hållning och reagerar med invändning och uppmaning som om Ida inte deltar korrekt när hon står bredvid och bara bevittnar avsmakningen istället för att själv smaka (jfr Goodwin 2007 s. 71). Att turen kan analyseras som en tillrättavisning och inte endast en uppmaning stöds av att Ida bemöter den med ett mäh innan hon följer uppmaningen. Partikeln mäh är oss veterligen inte beskrivet interaktionellt men framstår här som ett andra led efter en uppmaning mot vilket talaren gör motstånd. Den är således både misaligning och disafilliative (Heritage 1984 s. 269).

Den affektiva turen i rad 10 indikerar också att Beas tillkännagivande att hon ska smaka på såsen ( $\operatorname{rad} 7)$ inte primärt gällde arbetsfördelning, i bemärkelsen att en av flera samarbetande parter åtar sig en uppgift. Snarare kan turen förstås som ett verbalt uppvisande av att Bea är i färd med att skaffa relevant epistemisk tillgång. Det är denna kunskap som kommer att ligga till grund för det efterföljande beslutet om hur såsen ska kryddas, och det är denna kunskap som Ida sanktioneras för att hon avstår från att inhämta. 
Efter Beas affektiva invändning etableras det för henne adekvata utförandet av en gemensam avsmakning. Ida plockar åter upp sin sked, rör runt i grytan och tar upp ett smakprov medan Bea kyler ner sitt smakprov på skeden genom att blåsa på den (fig. 5). De smakar sedan under fyra sekunder av såsen utan att titta på varandra (fig. 6). Att sensoriska upplevelser såsom avsmakning görs till något privat och individuellt genom tystnad och avsaknad av ögonkontakt har beskrivits för avsmakning i diverse kontexter (se t.ex. Mondada 2017). Tystnaden och det individuella fokuset fungerar också som uppvisande av epistemisk hållning. Genom noggrann avsmakning och påföljande eftertänksamhet skaffar de sig inte bara samma epistemiska grund att utgå från utan visar även upp för varandra att de nu har tillräcklig kunskap för att göra en kompetent bedömning. När båda deltagarna har inhämtat rätt kunskap kan de gemensamt fatta beslut utifrån de individuella smakupplevelserna. Ida inleder övergången från individuell smakning till att offentliggöra resultaten av sin smakupplevelse med ett förslag Ja tyck $(0,2)$ Lite mer salt $(\operatorname{rad} 15)$.

Detta exempel ger vid handen att det behandlas som otillräckligt deltagande att endast skaffa sig visuell tillgång i en beslutsfattandeprocess som beror av andra sinnen. Samtliga deltagare måste sensoriskt uppleva såsen för att gemensamt kunna fatta beslut om den. Att inte skaffa sig adekvat tillgång till beslutsobjektet och inta en epistemisk hållning kan behandlas som bristande deltagande. Det kan jämföras med exempel (3) ovan, där båda deltagarna vinnlägger sig om att med egna ögon se potatisens färg och yta och därefter fatta beslut om en lämplig åtgärd. Att man kan sanktioneras för att inte skaffa tillgång till det som är föremål för beslutet menar vi är ett argument för att uppvisande av epistemisk tillgång är en avgörande komponent för deltagande i gemensamt beslutsfattande.

\section{Sammanfattning och diskussion}

I den här studien intresserar vi oss för hur deltagare åstadkommer gemensamma beslut och förhåller sig till beslutsprocessen som gemensam. Vi söker grundläggande praktiker i en allmänmänsklig aktivitet, nämligen matlagning, och undersöker vad det är man delar i en gemensam beslutsfattandeprocess. Denna vardagliga aktivitet kräver kompetenta sociala aktörer som kan utföra och förstå sociala handlingar nödvändiga för att driva aktiviteten framåt. Vi kompletterar tidigare forskning som främst har behandlat beslutsfattande i s.k. 


\section{Klara Bertils \& Simon Magnusson}

institutionella miljöer, särskilt med fokus på läkare-patientsamtal. I dessa samtal kan möjligheterna för gemensamt beslutsfattande vara begränsade av kontextens institutionella ramar, såsom en asymmetri mellan deltagarna och en orientering mot olika institutionella roller med olika tillhörande förväntningar på kunskap och handlingsutrymme. I ett läkare-patientsamtal agerar deltagarna utifrån sina institutionella roller som läkare respektive patient, och ett beslut om behandling berör i slutändan främst patienten. I den här studien undersöker vi i stället en vardaglig kontext där deltagarna umgås vänner emellan. Även om det givetvis kan finnas asymmetrier mellan deltagarna även i denna kontext, rör de beslut som fattas av alla deltagare som har ett gemensamt intresse av slutresultatet - en god middag och en trevlig samvaro under matlagningen. Vi menar att studien genom sitt empiriska material av icke-institutionell karaktär fördjupar förståelsen av gemensamt beslutsfattande som socialt fenomen.

För att genomföra gemensamma handlingar tillsammans med andra människor krävs att deltagarna i detalj vet vad den andra gör, samt vilken slags kunskap den besitter och kan förväntas hållas ansvarig för (Goodwin 2013). Omvänt gäller att man för att delta i en aktivitet behöver visa att man deltar på rätt sätt genom att skaffa sig adekvat empiriskt underlag för beslutet. För att undersöka deltagande i beslutsfattandesekvenser har vi i denna undersökning, utifrån en modell för gemensamt beslutsfattande i interaktion (Stevanovic 2012), undersökt hur deltagare gör beslutsfattande till en gemensam angelägenhet. En central del i detta arbete är att skaffa och uppvisa tillgång till det empiriska underlag som beslutet gäller. Att visa varandra att man har tillgång till det som man ska fatta beslut om behandlas i våra exempel som en förutsättning för att delta i beslutsfattandet (jfr Goodwin \& Goodwin 2004). Genom att fokusera den kontextuella konfigurationen (Goodwin 2000) vid beslutsfattandesekvenser i ansikte-mot-ansikte-interaktion som rör den materiella världen kan vi visa hur gemensamhet utöver verbala resurser i hög grad åstadkoms genom deltagarnas kroppar, blickar och hantering av objekt under hela beslutsfattandesekvensen. Vi har visat hur deltagarna genom att inta kroppsliga hållningar kan godta eller avvisa samtalspartnerns förslag, visa att man inhämtar kunskap relevant för beslutet samt upprätthålla en intersubjektiv förståelse för huruvida beslutsfattandet är avslutat eller fortfarande pågår (jfr Stevanovic m.fl. 2017). Vidare menar vi att de sätt som deltagarna orienterar sig mot objekt i rummet är avgörande för att fokusera den gemensamma uppmärksamheten, och för att visa adekvat förståelse och gemensamhet i beslutsgången. Kroppsliga, materiella och sensoriska resurser framstår alltså i vårt material som högst centrala för 
att koordinera beslutsfattandet. Därför vill vi poängtera att ett multimodalt perspektiv är nödvändigt för att analysera och förstå gemensamt beslutsfattande så som det faktiskt utförs och hanteras av människor i interaktion ansikte mot ansikte. Det multimodala perspektivet är inte minst viktigt i en kontext där besluten handlar om att hantera och förändra objekt i den direkt omgivande materiella världen.

$\mathrm{Vi}$ argumenterar i linje med tidigare forskning att gemensamt beslutsfattande handlar om att visa upp sitt deltagande genom att inte bara skaffa lämplig kunskap utan också att signalera detta. Med hjälp av bland annat kroppspositionering visar man upp för motparten att man besitter kunskap relevant för den pågående aktiviteten. Genom detta arbete åstadkommer deltagarna uppvisbart välgrundade beslut som utgör byggstenar i den övergripande sociala samvaron.
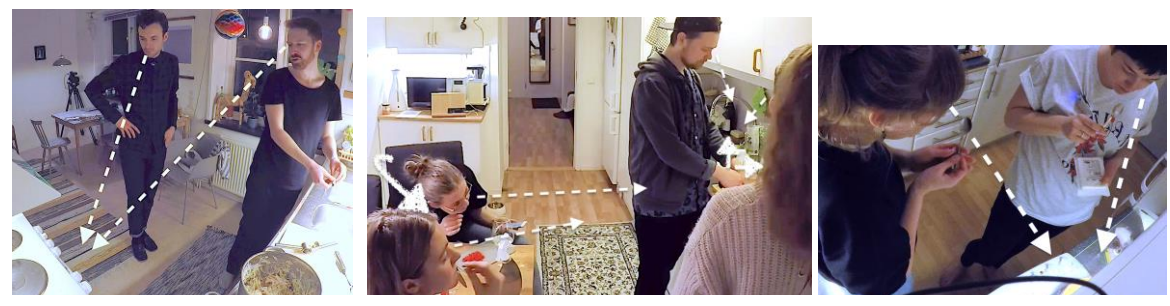

Fig 1-3. Åstadkommande och uppvisande av tillgång.

I vår analys kan vi visa att en deltagare som inte skaffar tillräcklig epistemisk tillgång, som då en deltagare inte smakar på såsen, sanktioneras genom affektiva reaktioner (exempel 4). Detta talar för analysen att uppvisande av tillgång till beslutsobjektet behandlas som en förutsättning för adekvat deltagande i beslutsfattandet. Det pekar också på att just tillgång till beslutsobjektet är någonting som kräver särskilda insatser för deltagande i beslutsfattande. Medan det räcker att en enskild deltagare föreslår en handling eller genomför den fastslagna handlingen, kräver anskaffande av tillgång alla deltagares individuella insats. För att besluta om potatisen är färdig att tas ut ur ugnen eller om såsen är bra kryddad måste bägge parter skaffa sig en enskild perceptuell uppfattning om matens tillstånd. Först därefter kan man diskutera handlingsalternativ och fatta ett underbyggt beslut. Deltagarna utgår från varandras individuella, specifika erfarenheter i bedömningen och gör ett arbete för att jämföra sina perceptioner och sträva mot en intersubjektiv uppfattning. Det räcker inte att en av deltagarna smakar och att vederbörandes bedömning kan gälla för samtliga, utan deltagarna orienterar sig mot varandras uppfattningar som unika och varje deltagares eget bidrag som nödvändigt. En viktig del i det gemensamma är så- 


\section{Klara Bertils \& Simon Magnusson}

ledes att dela och jämföra sina individuella uppfattningar, och gemensamhet och deltagande görs genom att införskaffa och beakta varje persons unika, specifika bidrag till den gemensamma processen. Det faktum att adekvat deltagande tycks innebära att införskaffa och uppvisa individuell kunskap gör besluten till verkligt delade, då varje deltagares unika uppfattning och insats möjliggör ett välgrundat gemensamt beslut. En central del i att göra någonting till gemensamt är att beakta och värdesätta det unika och subjektiva.

Stevanovic (2012) menar att deltagare genom att konstruera beslut som gemensamt fattade skapar samhörighet. Samhörighet tycks uppnås genom att man behandlar varandra som medansvariga deltagare i aktiviteten, och därigenom gör den till gemensam. I denna studie har vänner samlats för att umgås, laga mat och dricka vin tillsammans. Det delade beslutsfattandet förefaller här vara en viktig beståndsdel i aktiviteten, inte bara för att undvika att bli ensam ansvarig för hur maten smakar utan som en praktik för att göra gemenskap.

\section{Litteratur}

Barnes, Rebecca, 2017: Preliminaries to Treatment Recommendations in UK Primary Care: A Vehicle for Shared Decision Making? I: Health Communication 33(11). S. 1366-1376.

Bergmann, Jörg, 1990: On the local sensitivity of conversation. I: I. Markovà \& K. Foppa (red.): The Dynamics of Dialogue. Hertsfordshire: Harvester Wheatsheaf. S. 201-226.

Charles, Cathy, Gafni, Amiram \& Whelan, Tim, 1997: Shared decision-making in the medical encounter: what does it mean? (or it takes at least two to tango). I: Social Science \& Medicine 44(5). S. 681-692.

Collins, Sarah, Drew, Paul, Watt, Ian \& Entwistle, Vikki, 2005: 'Unilateral' and 'bilateral' practitioner approaches in decision-making about treatment. I: Social Science \& Medicine 61(12). S. 2611-2627.

Conein, Bernard, 1997: L'action avec les objets: Un autre visage de l'action située? I: Raisons pratiques 8. S. 25-45.

Costello, Brian \& Roberts, Felicia, 2001: Medical Recommendations as Joint Social Practice. I: Health Communication 13(3). S. 241-260.

Couper-Kuhlen, Elizabeth, 2012: Exploring Affiliation in the Reception of Conversational Complaint Stories. I: Emotion in Interaction. Oxford: Oxford University Press. S. 113-144.

Day, Dennis \& Wagner, Johannes, 2014: Objects as tools for talk. I: M. Nevile, P. Haddington, T. Heinemann \& M. Rauniomaa (red.): Interacting with Objects. Amsterdam: John Benjamins Publishing Company. S. 101-124. 
Goffman, Ervin, 1981: Footing. I: Forms of Talk. Oxford: Blackwell. S. 124-159.

Goldberg, Jo Ann, 1975: A system for the transfer of instructions in natural settings. I: Semiotica 14(3). S. 269-296.

Goodwin, Charles, 2000: Action and embodiment within situated human interaction. I: Journal of Pragmatics 32(10). S. 1489-1522.

Goodwin, Charles, 2007: Participation, stance and affect in the organization of activities. I: Discourse \& Society, 18(1). S. 53-73.

Goodwin, Charles, 2013: The co-operative, transformative organization of human action and knowledge. I: Journal of Pragmatics 46(1). S. 8-23.

Goodwin, Charles \& Duranti, Alessandro, 1992: Rethinking context: An introduction. I: C. Goodwin \& A. Duranti (red.): Rethinking context: Language as an interactive phenomenon. Cambridge: University Press. S. 1-42.

Goodwin, Charles \& Goodwin, Marjorie, 2004: Participation. I: A. Duranti (red.): A Companion to Linguistic Anthropology. Malden, MA: Blackwell Publications. S. 222-244.

Heritage, John. 1984: Garfinkel and ethnomethodology. Cambridge: Polity Press.

Heritage, John, 2012: Epistemics in Action: Action Formation and Territories of Knowledge. I: Research on Language and Social Interaction 45(1). S. 1-29.

Houtkoop, Hanneke, 1987: Establishing agreement: An analysis of proposal-acceptance sequences. Dordrecht: Foris Publications.

Hultberg, Josabeth \& Rudebeck, Carl Edvard, 2017: Patient participation in decisionmaking about cardiovascular preventive drugs: resistance as agency. I: Scandinavian Journal of Primary Health Care 35(3). S. 231-239.

Jefferson, Gail, 2004: Glossary of transcript symbols with an introduction. I: Conversation Analysis: Studies from the first generation. Amsterdam: John Benjamins. S. 1331.

Kaukomaa, Timo, Peräkylä, Anssi \& Ruusuvuori, Johanna, 2014: Foreshadowing a problem: Turn-opening frowns in conversation. I: Journal of Pragmatics 71. S. 132147.

Keisanen, Tiina \& Rauniomaa, Mirka, 2012: The Organization of Participation and Contingency in Prebeginnings of Request Sequences. I: Research on Language and Social Interaction 45(4). S. 323-351.

Koenig, Christopher, 2011: Patient resistance as agency in treatment decisions. I: Social Science \& Medicine 72(7). S. 1105-1114.

Landmark, Anne Marie Dalby, 2016: Negotiating patient involvement in treatment decision making: A conversation analytic study of Norwegian hospital encounters (Diss). Institutt for klinisk medisin, Universitetet i Oslo.

Landmark, Anne Marie Dalby, Gulbrandsen, Pål \& Svennevig, Jan, 2015: Whose decision? Negotiating epistemic and deontic rights in medical treatment decisions. I: Journal of Pragmatics 78. S. 54-69.

Lindström, Anna \& Weatherall, Ann, 2015: Orientations to epistemics and deontics in treatment discussions. I: Journal of Pragmatics 78. S. 39-53.

Mondada, Lorenza, 2014a: Cooking instructions and the shaping of things in the kitchen. I: M. Nevile, P. Haddington, T. Heinemann \& M. Rauniomaa (red.): Interacting with Objects. Amsterdam: John Benjamins Publishing Company. S. 199226. 
Mondada, Lorenza, 2014b: Conventions for multimodal transcription. https://franz.unibas.ch/fileadmin/franz/user_upload/redaktion/Mondada_conv_multimodality.pdf

Mondada, Lorenza, 2017: Tasting together: Multisensorial intersubjective experiences in interaction. Plenarföreläsning, 11 maj 2017 vid konferensen Intersubjectivity in interaction, Helsingfors universitet.

Mondada, Lorenza, 2018a: Multiple Temporalities of Language and Body in Interaction: Challenges for Transcribing Multimodality. I: Research on Language and Social Interaction 51(1). S. 85-106.

Mondada, Lorenza, 2018b: Visual practices: video studies, multimodality and multisensoriality. I: D. Favareau (red.): Co-operative Engagements in Intertwined Semiosis: Essays in Honour of Charles Goodwin. Tartu: University of Tartu Press. S. 304-325.

Mondada, Lorenza, 2018c: The multimodal interactional organization of tasting: Practices of tasting cheese in gourmet shops. I: Discourse Studies 20(6). S. 743-769.

Mondada, Lorenza, 2019: Rethinking bodies and objects in social interaction: A multimodal and multisensorial approach to tasting. I: U. Tikvah Kissmann \& J.van Loon (red.): Discussing New Materialism: Methodological Implications for the Study of Materialities. Berlin: Springer. S. 109-134.

Mondada, Lorenza, u.å: Taste and Connoisseurship in Social Interaction. Cambridge: Cambridge University Press.

Nevile, Maurice, Haddington, Pentti, Heinemann, Trine \& Rauniomaa, Mirka, 2014: On the interactional ecology of objects. I: M. Nevile, P. Haddington, T. Heinemann \& M. Rauniomaa (red.): Interacting with Objects. Amsterdam: John Benjamins Publishing Company. S. 3-26.

Raevaara, Liisa, 2017: Adjusting the design of directives to the activity environment. I: M.-L. Sorjonen, L. Raevaara \& E. Couper-Kuhlen (red.): Imperative Turns at Talk: The design of directives in action. Amsterdam: John Benjamins Publishing Company. S. 381-410.

Rauniomaa, Mirka \& Heinemann, Trine, 2014: Organising the soundscape. I: M. Nevile, P. Haddington, T. Heinemann \& M. Rauniomaa (red.): Interacting with Objects. Amsterdam: John Benjamins Publishing Company. S. 145-168.

Robinson, Jeffrey, 2003: An Interactional Structure of Medical Activities During Acute Visits and Its Implications for Patients' Participation. I: Health Communication 15(1). S. 27-59.

Schegloff, Emanuel, 1996: Confirming Allusions: Toward an Empirical Account of Action. I: American Journal of Sociology 102(1). S. 161-216.

Schegloff, Emanuel, 1998: Body Torque. I: Social Research 65(3). S. 535-596.

Schegloff, Emanuel, 2007: Sequence Organization in Interaction: A Primer in Conversation Analysis. Vol. 1. Cambridge: Cambridge University Press.

Socialstyrelsen, 2012: Shared decision making - en introduktion till delat beslutsfattande inom psykiatrisk vård. Stockholm: Socialstyrelsen.

Stasser, Garold \& Stewart, Dennis, 1992: Discovery of hidden profiles by decisionmaking groups: Solving a problem versus making a judgment. I: Journal of Personality and Social Psychology 63(3). S. 426-434.

Stevanovic, Melisa, 2012: Establishing joint decisions in a dyad. I: Discourse Studies 14(6). S. 779-803. 
Stevanovic, Melisa, Himberg, Tommi, Niinisalo, Maija, Kahri, Mikko, Peräkylä, Anssi, Sams, Mikko \& Hari, Riitta, 2017: Sequentiality, Mutual Visibility, and Behavioral Matching: Body Sway and Pitch Register During Joint Decision Making. I: Research on Language and Social Interaction 50(1). S. 33-53.

Stevanovic, Melisa \& Monzoni, Chiara, 2016: On the hierarchy of interactional resources: Embodied and verbal behavior in the management of joint activities with material objects. I: Journal of Pragmatics 103. S. 15-32.

Stevanovic, Melisa \& Peräkylä, Anssi, 2012: Deontic Authority in Interaction: The Right to Announce, Propose, and Decide. I: Research on Language and Social Interaction 45(3). S. 297-321.

Stivers, Tanya, 2005a: Non-antibiotic treatment recommendations: delivery formats and implications for parent resistance. I: Social Science \& Medicine 60(5). S. 949 964.

Stivers, Tanya, 2005b: Parent Resistance to Physicians' Treatment Recommendations: One Resource for Initiating a Negotiation of the Treatment Decision. I: Health Communication 18(1). S. 41-74.

Stivers, Tanya, 2006: Treatment decisions: Negotiations between doctors and parents in acute care encounters. I: J. Heritage \& D. Maynard (red.): Communication in Medical Care: Interaction Between Primary Care Physicians and Patients. (Studies in Interactional Sociolinguistics). Cambridge: Cambridge University. S. 279-312.

Stivers, Tanya, Heritage, John, Barnes, Rebecca K., McCabe, Rose, Thompson, Laura \& Toerien, Merran, 2017: Treatment Recommendations as Actions. I: Health Communication. 33(11). S. 1335-1344.

Stukenbrock, Anja, 2012: Empraxis und Displacement: Überblendete Räume in der Koch-Show-Interaktion. I: H. Hausendorf, L. Mondada \& R. Schmitt (red.): Raum als interaktive Ressource. Tübingen: Narr Verlag. S. 347-380.

Toerien, Merran, Shaw, Rebecca \& Reuber, Markus, 2013: Initiating decision-making in neurology consultations: 'recommending' versus 'option-listing' and the implications for medical authority. I: Sociology of Health \& Illness 35(6). S. 873-890.

Tomasello, Michael, 1999: The cultural origins of human cognition. Cambridge, Massachusetts: Harvard University Press.

Ursi, Biagio, 2016: «Et c'est qui le chef ? »: Négociations et manifestations du désaccord pendant la préparation de repas. Les cahiers de praxématique 67. http:// journals.openedition.org/praxematique/4448.

Vetenskapsrådet, 2002: Forskningsetiska principer inom humanistisk-samhällsvetenskaplig forskning. Stockholm: Vetenskapsrådet.

Wiggins, Sally \& Potter, Jonathan, 2003: Attitudes and evaluative practices: Category vs. item and subjective vs. objective constructions in everyday food assessments. I: British Journal of Social Psychology 42(4). S. 513-531.

Wiggins, Sally, Potter, Jonathan \& Wildsmith, Aimee, 2001: Eating Your Words: Discursive Psychology and the Reconstruction of Eating Practices. I: Journal of Health Psychology 6(1). S. 5-15. 


\section{Transkriptionsnyckel för verbal transkription (Jefferson 2004)}

\begin{tabular}{|c|c|}
\hline [ ] & Överlappande tal \\
\hline & Omedelbar övergång mellan två ord eller turer \\
\hline & $\begin{array}{l}\text { Mikropaus som understiger } 0,2 \text { sekunder } \\
\text { Pauser som överstiger } 0,2 \text { sekunder }\end{array}$ \\
\hline & Fallande intonation \\
\hline & $\begin{array}{l}\text { Viss stigande intonation som kan markera prosodiskt möjlig } \\
\text { turbytesplats }\end{array}$ \\
\hline & Mer stigande intonation vid turbytesplats \\
\hline & Starkt stigande intonation vid turbytesplats \\
\hline rd & $\begin{array}{l}\text { Betoning eller emfas, ju mer understruken desto starkare } \\
\text { betoning }\end{array}$ \\
\hline $\mathrm{RD}$ & $\begin{array}{l}\text { Versal skrift indikerar styrka och emfas, starkare än } \\
\text { understrykning }\end{array}$ \\
\hline$::$ rd & Kolon markerar förlängda ljud \\
\hline r- & Markerar att ordet avbryts \\
\hline$\uparrow$ & Uppåtstigande pilar indikerar förhöjt tonläge \\
\hline$\downarrow$ & Nedåtriktade pilar indikerar sänkt tonläge \\
\hline$<$ & Yttrandet som inramas sägs snabbare än omgivande tal \\
\hline$>$ & Yttrandet som inramas sägs långsammare än omgivande tal \\
\hline 0 & Yttrandet som inramas sägs tystare än omgivande tal \\
\hline$£$ & Yttrandet som inramas sägs med leende röst \\
\hline$(($ hostar $))$ & Dubbelparantes används vid metakommentarer \\
\hline$($ ) & Enkla parenteser används när transkriptionen är osäker \\
\hline & Inandning \\
\hline & Smackljud \\
\hline & det sägs \\
\hline
\end{tabular}

\section{Transkriptionsnyckel för multimodal transkription (Mondada 2014b)}

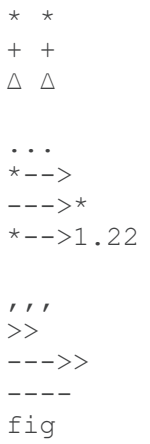

Multimodala handlingar avgränsas mellan två identiska symboler. Dessa avgränsningar placeras ut på den verbala raden som utgör tidslinje även för de kroppsliga handlingarna. Handlingen förbereds Handlingen fortsätter tills symboler dyker upp igen och markeras som avslutad i transkriptionen En handling som pågår länge kan också markeras med startoch slutrad Handlingen återgår Handlingen börjar innan transkriptionsexemplet Handlingen fortsätter efter transkriptionsexemplets slut Handlingen har nått sin apex

Exakt ögonblick markerad med \# i den verbala raden för när en skärmdump av videon tagits 


\title{
Att rädda planeten genom konsumtionsval Oatlys antagonistiska och lekfulla marknads- kommunikation
}

\author{
Av PER LEDIN \& DAVID MACHIN
}

\begin{abstract}
Ledin, Per, per.ledin@sh.se, Professor, School of Culture and Education, Södertörn University; Machin, David, david.machin@oru.se, Professor, School of Humanities, Education and Social Sciences, Örebro University: "Saving the planet through acts of consumption. Oatly's antagonistic and playful marketing communication”. Språk och stil NF 29, 2019, pp. 99-133.

There has been an increase in food products marketed through buzzwords like 'organic', 'local', 'recyclable', 'Fairtrade'. These have been described as part of a newer kind of ethical or emotional capitalism, where consumers can align with political issues through shopping. In this paper, we look at the brand Oatly, a Swedish milk alternative that has had global success. Oatly brands itself as sustainable and offers us the chance to save the planet by buying their oat milk. We carry out a critical multimodal discourse analysis of their value-based marketing communication. The results show that Oatly mixes the antagonistic and the playful and utilizes various semiotic materials in refined ways. We find signifiers of clear and direct political action from former times, for example in film clips and packaging design. The playful runs through many poster campaigns with posters that refer to each other, where we engage in a kind of hide and seek. The meta-communication that arises when Oatly says it is not advertising presents the company as an underdog going against the milk industry. Overall, this is a form of activism which is fun, chic and rather easy. Our critique of this kind of marketing communication is that acts of consumption shape what we know about, and how we act towards, actual socio-political matters. If global large companies are to control our money and feelings and decide how environmental problems are defined, we might not be able to save the planet.
\end{abstract}

Keywords: ethical food, Swedish marketing communication, multimodal critical discourse analysis, consumerism, politics, language play, meta-communication, packaging.

Vi lever i en tid där jorden är hotad och där ordet hållbarhet återkommer i alla möjliga sammanhang. Lindsey (2011) pekar till exempel på begrepp som »sustainable economic development», »sustainable knowledge», »sustainable businesses» och »sustainable democracy». På svensk botten kan vi notera att regeringen 2016 lanserade en strategi för hållbar konsumtion i ett miljömässigt, socialt och ekonomiskt perspektiv (Regeringskansliet 2016). Också som individer ska vi vara hållbara. En bok typisk för vår tid är Handbok för en hållbar människa: ta hand om dig och planeten samtidigt (Rolfsdotter-Jansson 2018). 
Det finns kritik av denna hållbarhetsdiskurs. Det har hävdats att hållbarhet $\mathrm{i}$ värsta fall används som en gröntvättning där företag och organisationer vill skapa lönsamma associationer till sitt varumärke snarare än ta sig an faktiska miljöproblem (Atkinson \& Kim 2015). Cook (2011) talar i detta sammanhang om »green capitalism» och ser en sådan kapitalism som en fiktion. Kapitalism innefattar ackumulering och expansion, att marknadsandelar ökar och vinster växer, vilket med nödvändighet är miljöbelastande. Ur ett marknadsföringsperspektiv är det ändå självklart att vara grön för att kunna bli framgångsrik. Till exempel Otman (2011) ställer upp 20 regler för grön marknadsföring. Dit hör att grönt i dag är självklart för de flesta, att det är coolt, att hållbarhet ska vara en del av själva produkten och att varumärken måste ta socialt ansvar.

Varumärken marknadsförs alltså i dag på gröna och etiska grunder, som något bra för vår hälsa, jord och miljö. Vi möter ord som organisk, ekologisk, närodlad, lokalproducerad, bra miljöval, GMO-fri, Fairtrade, som innebär rättvisemärkning, vilket inte är detsamma som KRAV-märkt eller Svanen-märkt osv. Vad orden mer exakt betecknar kan vara svårt att veta, som vad som gör det ekologiskt märkta kaffet, ofta importerat från Sydamerika, miljövänligt. Man inser därtill lätt att ett lokalproducerat vin inte behöver vara särskilt ekologiskt utan mycket väl kan framställas med hjälp av kemikalier och bekämpningsmedel. Ändå försöker många att handla på ett miljövänligt sätt och köpa det som framställs som hållbart. I det ligger att vår konsumtion, inte minst av mat, har blivit allt mer moralisk, så att vi genom matinköp kan ta ställning för det goda och rätta.

I den här artikeln tar vi oss an matvarumärket Oatly och deras havreprodukter. Vi gör en fallstudie av deras marknadskommunikation, som handlar om att rädda planeten. Oatly har framgångsrikt framställt sig som underdogen som går emot storföretagen och kämpar för jordens överlevnad. Som konsumenter bjuds vi in att ansluta oss till Oatlys kamp genom att köpa rätt och välja havredryck i stället för mjölk.

\section{Syfte}

Artikeln syftar till att kritiskt belysa Oatlys marknadskommunikation. Vi gör en socialsemiotisk analys och visar hur Oatly har skapat en antagonistisk retorik, där först mjölkindustrin och sedermera hela livsmedelsindustrin är fienden. Marknadskommunikationen innefattar ett särskilt tilltal, som är hu- 


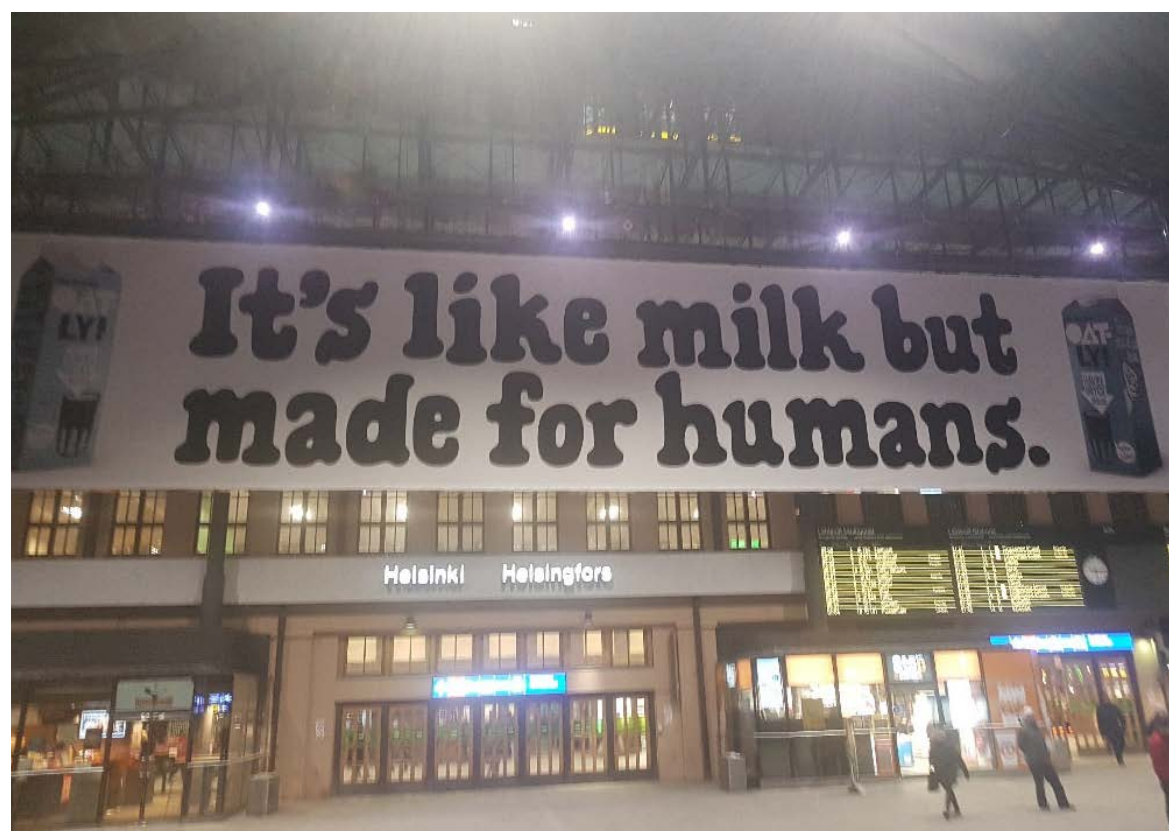

Figur 1. Oatly-banderoll från Helsingfors centralstation, mars 2019 (författarfoto).

moristiskt och lekfullt. Det offentliga rummet görs om till ett politiskt och varumärkt rum där du som konsument förväntas ta ställning för det goda. Denna kommunikation har gett Oatly globala marknadsframgångar under 2010-talet.

Figur 1 exemplifierar Oatlys antagonistiska och lekfulla retorik. Det vi ser är en banderoll med Oatlys taktfasta huvudslogan »It's like milk but made for humans». Den fanns uppsatt på Helsingfors centralstation i mars 2019, och med sin storlek dominerade den stationshallen. På en offentlig och välbesökt plats iscensätter den debatt och polemiserar mot mejerinäringen.

Vår kritiska ansats har ingenting att göra med alternativa mjölkprodukter i sig. Att människor föredrar drycker gjorda av havre, soja, kokos, mandel osv. har vi ingenting emot, lika lite som vi har något emot ekologisk mat i sig. Mjölk- och köttproduktion är en av många komplexa miljöfrågor att diskutera. Den sociala förändring vi vill diskutera rör att politik i dag är kopplat till globala företag och de produkter och värden som de marknadsför. Politik blir då en fråga om individuella konsumtionsval och inte, som förr, något som hör 
hemma i den liberala demokratin. Och politik bygger på kommunikation, vare sig den bedrivs av storföretag som Oatly eller av traditionella partier.

Vi ser Oatly som en del av vad som brukar kallas en nyliberal utveckling, där statens traditionella roll mer och mer tas över av marknaden (t.ex. Beck \& Beck-Gernsheim 2002). Det blir då individens uppgift att välja och köpa rätt och på så vis bli en hållbar människa som står för en hållbar planet. Detta kräver en konsument med ekonomiska resurser och stöder, menar vi, i grunden en kapitalistisk marknadslogik (jfr Banet Weiser \& Mukherjee 2012). Ytterst blir det globala storföretag som styr vilka miljömässiga utmaningar som hamnar på agendan.

Oatly ska ses som ett exempel på denna sociala förändring, som vi menar är värd att belysas kritiskt. Vår analys tar särskilt sikte på hur Oatly har utvecklat en marknadskommunikation som är helt värderingsbaserad, som säljer just värderingar, där vi som konsumenter förväntas göra moraliska investeringar. Den tar in det faktum att Oatly är ett globalt företag, vilket språkligt innebär att både svenska och engelska används, och berör kampanjer även utanför Sveriges gränser.

\section{Oatlys historia}

Varumärket Oatly erbjuder en mängd alternativ till mjölk. Huvudprodukten är havredryck med olika fetthalter och smaker, men det finns också glassar, crème fraiche, vaniljsås, energidrycker, latte och yoghurt (»Havregurt»). Det exakta utbudet varierar mellan olika marknader, också för att mjölkkonsumtionen är olika och inbjuder till skilda alternativ. Sverige har sedan knappt 100 år en hög konsumtion av mjölk och mejeriprodukter, inte minst på grund av det arbete föreningen Mjölkpropagandan inledde på 1920-talet, vilket bidrog till att gratis mjölk och lunch infördes i skolan 1946 (Jönsson 2006). Oatly är en del av den alternativa, växtbaserade mjölkindustrin, som blivit allt större och i dag är värd 16 miljarder dollar globalt (Franklin-Wallis 2019).

Oatly har sitt ursprung vid Lunds universitet på 1980-talet (Lagnevik m.fl. 2003 s. 122 ff.), där man experimenterade med mjölkalternativ. 1990 lyckades man, efter att ha attraherat riskkapital, framställa en havredryck där en patenterad enzymblandning tillåter havre och vatten att blandas. Med hjälp av olika tillsatser fick denna mjölk en lämplig smak, konsistens och textur, som också profilerade den mot den existerande sojamjölken. Det är ett ge- 
nomgående drag hos Oatly att både vara och inte vara som mjölk. Vatten med havre är ju något annat än mjölk, men Oatly såg till att produkten blev mjölklik.

Först såldes blandningen som bantningsmedel. 1994 bildades företaget Ceba Foods som en avknoppning från Lunds universitet, och havremjölken blev då ett alternativ för laktosintoleranta. 1996 lanserades den på ICA, liksom i Nordeuropa, där varumärket blev Mill Milk. Den svenska mjölkindustrin protesterade mot beteckningen havremjölk, som ändrades till havredryck (Oatly 2009). Ceba Foods lanserade 2001 varumärket Oatly, som i dag också är företagets namn, och breddade sortimentet. Den första egna fabriken byggdes 2006 utanför Landskrona med hjälp av nya investerare. 2009 designades förpackningarna om, och Oatly framställde sig nu som det hälsosamma alternativet, med en udd mot mjölkindustrin.

När Toni Petersson 2012 blev ny VD påbörjades ännu en omprofilering av varumärket, vilken sattes i verket 2014 och som vi återkommer till i analysen (Mccrow-Young 2016). Grundidén var att göra all kommunikation värderingsbaserad. Produkterna skulle inte marknadsföras, utan de värden som företaget stod för. Marknadsföringen, inklusive förpackningsdesignen, blev antagonistisk, med mjölkindustrin som fienden. Korna är de som förstör planeten, och att köpa komjölk framställdes som förkastligt. Oatly tog rollen som förkämpen för det goda, den som tog strid för den hållbara individen och planeten.

Till de slogans som användes hörde »It's like milk but made for humans» och »No milk. No soy. No badness». Mjölkindustrin, genom organisationen LRF Mjölk, stämde Oatly för vilseledande reklam i Marknadsdomstolen. Utslaget kom 2015 och innebar att Oatly förbjöds använda dessa slogans (i Sverige, utomlands används de fortfarande) - det kunde inte bevisas att mjölk var skadligt för människan (Wisterberg 2015). Domen blev en enorm succé för Oatly, som framstod som modiga och uppkäftiga i sin kamp mot etablissemanget, och den skaffade dem en ungdomlig supporterskara, inte minst via sociala medier.

Oatlys framgång bland unga bekräftades på musikfestivalen Way Out West 2016. Oatly trädde in som huvudsponsor och festivalen blev mjölkfri (Djerf 2015). I övrigt har marknadsföringen på senare år framgångsrikt inriktats på dels att stärka ställningen på de nordeuropeiska marknader där företaget sedan länge funnits, dels att ta sig in på den amerikanska och den kinesiska marknaden. 


\section{Etisk marknadskommunikation och matkonsumtion}

Att marknadskommunikation i dag ofta är etisk i meningen att den vill framställa produkter som ekologiska och naturliga har många uppmärksammat, inte minst socialsemiotiska forskare. Vi är vana vid att bilder av naturen används retoriskt i olika slags reklam för att signalera värden som ursprungligt, idylliskt, autentiskt m.m. (Hansen 2002). I dag kommuniceras sådana värden av många semiotiska resurser och material. Exempelvis visar Burrows (2013) hur »honest branding» tar sig uttryck i förpackningsdesignen av müsli från företaget Dorsey. Här används en dov, höstlik färgskala med jordnära toner. Alla förpackningar har en luftig layout, och på framsidan finns en enkel och stiliserad teckning av en växt, tillsammans med ett fönster som gör produkten synlig här finns inget att dölja. Som Ledin \& Machin (2018 kap. 5) säger är det i dag vanligt att förpackningar kommunicerar en produkt som kommer direkt från naturen till matbordet, och som, verkar det, inte har gått igenom någon industriell produktionsprocess.

För våra syften är det intressant att Andersson (2019) tar sig an Arlas marknadsföring $\mathrm{i}$ en socialsemiotisk analys av deras kosläpp vid bondgårdar. Det som möter är en välordnad och mycket svensk landsbygd. Det finns plakat där vi ser glada flickor dricka mjölk. Bondgårdarna, där en stor och uppblåsbar Arla-kossa står, är faluröda och ligger i ett öppet kulturlandskap. Borden där man kan sitta med gratis mjölk och bulle är enkla med rödvitrutiga dukar, och den svenska flaggan är hissad. Andersson argumenterar för att denna diskurs ideologiskt grundar sig på att Sverige är en modern och progressiv nation, där naturen är en demokratisk och öppen plats. Mjölk blir här något som skapar hälsa och bygger framgång (jfr Jönsson 2006).

Det kan noteras att Arla, som under 2010-talet sett mjölkförsäljningen gå ner samtidigt som Oatly vunnit marknadsandelar, i sin senaste reklamfilmskampanj använder orden »brölk», »prölk», »trölk» och »sölk», med en udd mot alternativa mjölkprodukter. I olika vardagssituationer, som till frukost och efter träning, väljer en karaktär bort dessa alternativ, och sloganen »Bara mjölk smakar mjölk» upprepas (Arla 2019). Oatlys svar på kampanjen blev att ta patent på Arlas påhittade mjölkord, något som fick Arla att anlita advokater i en process som i skrivande stund inte är avslutad (Törner 2019a).

Det autentiska tar sig också andra uttryck. När Starbucks i början av 2010talet designade om sina butiker var det för att framställa sig som en del av det traditionella lokalsamhället (Aiello \& Dickinson 2014). I de semiotiska materialen ingick exempelvis långbord $\mathrm{i}$ trä gjorda av gamla och patinerade plankor 
från närområdet, något som signalerar proveniens och blir ett sätt att symboliskt skapa en gemensam historia med rötter i ett 1900-tal (se Ledin \& Machin 2018 s. 115 ff. för liknande iakttagelser). Som Cavanaugh \& Shankar (2014) visar är detta att kommunicera autencitet något utmärkande för den globala kapitalismen. De tar upp språkliga distinktioner som på olika sätt suggererar autencitet på globala marknader och på så vis kan motivera ett högre pris. Bland annat undersöks charkmarknaden i Bergamo, där den lokala traditionen och hantverksskickligheten gärna betonas, trots att produktionen sedan länge är industrialiserad, med ord som till exempel terra, territorio och origini.

Denna strävan att gå tillbaka till ett förflutet kallar sociologen Bauman (2017) retrotopia. I en tid där jorden och mänskligheten står inför stora problem blickar vi inte längre framåt och organiserar oss kollektivt och politiskt för att påverka vår framtid, utan ser tillbaka. Vi idealiserar det som har varit och mytologiserar det som något stabilt, äkta och pålitligt, så att det förflutna blir en kur mot dagens problem och besvär. Clegg (2018) använder retrotopia för att förstå nutida organisationer och pekar på en etisk tomhet som bland annat hänger ihop med att sociala relationer och klyftor allt mer betingas av hur vi konsumerar på olika marknader (jfr Bauman 2007).

Den etiska marknadskommunikationen har bäring på konsumtionen, där vi kan investera i moraliska värden när vi köper mat. Vår tid genomsyras, säger sociologerna Johnston \& Cairns (2012), av »eating for change». Vi gör moraliska och politiska val, men inte kollektivt inom ramen för den liberala demokratin, utan som individer utifrån vilka värden globala matföretag säljer. Här finns ett »navigating guilt», alltså att lyckas konsumera utan att känna sig skyldig. I intervjuer framkommer hur konsumenter i USA utvecklar strategier för att navigera genom det komplexa matutbudet, där flertalet produkter säljs som etiska, hållbara, ekologiska osv. Som en informant säger: »I'd have to say I'm not ethical. [laughs] You know, a chicken's a chicken [laughs]» (a.a. s. 227). Banet Weiser \& Mukherjee (2012 s. 12) talar på ett liknande sätt om en »commodity activism», som innefattar en logik där »'doing good' and being a good consumer collapse into one and the same thing». Sådana etiska konsumtionspraktiker är »designed for the wealthy», vilket redan priset på produkterna visar. Exempelvis kostar Oatlys havredryck nästan dubbelt så mycket som vanlig mjölk.

Lagnevik m.fl. (2003), som är företagsekonomer och använder Oatly som ett exempel, noterar redan i början av 2000-talet att nya varumärken eftersträvar »high-value-added-products». Vi köper inte produkten i sig, inte heller bara en livsstil, utan vi köper värderingar som är politiskt laddade och internaliserar dem - vår konsumtion låter oss delta i kampen för jordens överlevnad i Oatlys fall. 


\section{Material}

Vi har använt fokuserad etnografi (Knoblauch 2005) för att samla in material, inklusive digital etnografi. Att utgå från fältarbete och observationer på plats har varit viktigt för att ringa in hur Oatly använder det fysiska rummet och skapar en platsbunden social interaktion. Vi har under 2018 och fram till sommaren 2019 bevakat vilka kampanjer Oatly drivit, strategiskt besökt olika urbana platser och även mataffärer. Det har gett ett rikt material som innefattar foton av bland annat affischer, banderoller och klistermärken i offentliga miljöer, inte minst tunnelbana och tåg, förpackningar i affärer och i olika hem och reklammaterial (foldrar, muggar) från events. Vi har också tagit fältanteckningar. Eftersom Oatly använder kampanjer i storstäder (men aldrig mindre orter) som ett sätt att ta plats i offentligheten, ingår sådana i materialet, mer exakt kampanjer i Stockholm 2018 och 2019, Berlin 2018 och Helsingfors 2019, vilket också är i linje med Oatlys nordeuropeiska marknadsbas. Materialet från Berlin, liksom en del foton i övrigt, är hämtade från nätet, vilket också gäller materialet från den svenska kampanjen Mjölken i skolan 2017, som vi avslutningsvis tar upp. Detta materialurval gör det möjligt att ge en fyllig bild av Oatlys kommunikation, där, menar vi, observationerna når en mättnad på så vis att ytterligare data och kampanjer inte i grunden skulle förändra den bild vi ger.

För att beskriva och problematisera kommunikationen utgår vi från tre semiotiska material som är viktiga för Oatly, närmare bestämt förpackningar, affischer och reklamfilm. Dessa relateras till de nämnda kampanjerna, där vi ibland också pekar på andra material. Det gör det möjligt för oss att visa på hur semiotiskt rik men ändå systematisk Oatlys marknadsföring är, med återkommande symboler och uttryck, anpassade till olika situationer och fysiska miljöer.

\section{Teoretiska och analytiska ingångar}

Vi utgår från socialsemiotisk teori, där Hodge \& Kress (1988) bok Social Semiotics utgör en viktig grund och där språkvetare utvecklat detaljerade analyser av olika semiotiska fenomen (t.ex. van Leeuwen 2005 och Ledin \& Machin 2018 är verk i samma tradition). Hodge \& Kress (1988 s. 12) menar att den traditionella semiotiken »likes to assume that the relevant meanings are frozen and fixed in the text itself», alltså att det finns en given kod, och att ett socialsemiotiskt perspektiv på betydelse i kontext innebär ett fokus på »the 
struggles and their uncertain outcomes that must be studied at the level of social action, and their effects in the production of meaning».

En viktig utgångspunkt är att semiotiska resurser är utvecklade i och bär spår av sociopolitiska kontexter, att de är knutna till intressen hos olika aktörer. Ytterligare en viktig utgångspunkt är att semiotiska resurser har materialitet. Denna tanke utvecklar Voloshinov (1973 s. 11) i sin marxistiska semiotik och säger »consciousness itself can arise and become a viable fact only in the material embodiment of signs». Vårt individuella och kulturella medvetande existerar alltså genom tecken, i social interaktion, och tecknet är för Voloshinov till sin natur ideologiskt. Semiotiska fenomen måste ses som situerade och materialiserade. En socialsemiotisk analys tar sig an hur semiotiska material och artefakter kommunicerar olika ideal och värden och, när den, som för oss, har en kritisk inriktning, hur dessa gynnar vissa men inte andra intressen.

Den sortens kommodifierade aktivism som Oatly driver, alltså att förändra världen genom konsumtion, bygger på en antagonistisk retorik som samtidigt är lekfull och ironisk på ett sätt som reklamspråk ofta är. Med andra ord använder Oatly uttryck som vi känner igen från traditionell reklam samtidigt som det antagonistiska, att ta strid för planeten och mot storföretagen, på olika sätt finns med. För att fånga detta har vi, med hjälp av tidigare forskning och preliminära analyser, ringat in tre betydelseskapande principer, som vi menar utmärker Oatlys marknadskommunikation. Principerna är att framkalla ett förflutet, att metakommunicera och att förkroppsliga rummet. Dessa principer ligger till grund för vår analys.

Att framkalla ett förflutet. Att reklam sedan länge och på olika sätt använder och iscensätter diskurser och röster från olika sociala sammanhang vet vi (t.ex. Cook 1992 kap. 9, Korpus 2008 kap. 7). Som vi visat i avsnitt 3 är etisk marknadskommunikation gärna baserad på att frammana ett naturligt och autentiskt ursprung för produkten (t.ex. Burrows 2013, Ledin \& Machin 2018 kap. 5). Oatly använder detta reklamgrepp för att iscensätta olika förflutna företeelser, inte minst politiska proteströrelser från det sena 1900-talet. Analytiskt använder vi »proveniens» för att fånga detta. Som Kress \& van Leeuwen (2001 s. 23) säger handlar detta om hur vi importerar tecken från andra kontexter. I praktiken känner vi igen ett visst material eller tecken från viss typ av tid och sammanhang, en social grupp eller subkultur - inte nödvändigtvis så att vi exakt kan placera tecknet, men så att, med Barthes (1977) ord, konnotationer uppstår. Exempelvis kan Oatlys val av typsnitt ibland föra tankarna till serie- och skämttidningar från det sena 1900-talet, vilket underbygger det lekfulla i kommunikationen. 
Att metakommunicera. Oatly tar gärna rollen som en uppkäftig outsider och gör det genom att på olika sätt metakommunicera, alltså genom kommunikation som riktar uppmärksamheten mot kommunikationen, inklusive språk som riktar uppmärksamheten mot språket. I vår analys fokuserar vi på tre sorters metakommunikation. Den första är språklekar, vanliga just i rubriker och slogans, och traditionellt viktiga i reklam för att skapa ett lekfullt och humoristiskt tilltal (t.ex. Myers 1994 kap. 5, Korpus 2008 kap. 6). Den andra kallar vi motstridiga förväntningar, och här riktar vi in oss på negationer och adversativa markörer, som båda är viktiga för att iscensätta motsättningar och även typiska för politisk debatt (jfr Ledin 1994). Negationer presupponerar att en motsatt eller åtminstone annorlunda värld existerar (jfr Fairclough 1992 s. 120 f.). I Oatlys slogan no badness gör negationen att en värld med badness förutsätts existera, och vi ska förstå att den har att göra med mejerinäringen. För adversativa markörer siktar vi in oss på konjunktionen men när den betyder att en förväntan motsägs och ett undantag pekas ut. I Lakoff (1971 s. 67) ges det klassiska exemplet John is a Republican but he is honest. Här finns en motstridig förväntan i det att sändaren implicerar att republikaner normalt är oärliga och John ett undantag. Att på detta vis aktualisera motstridiga förväntningar menar vi är grundläggande för Oatlys retorik. Den tredje sortens metakommunikation kallar vi paradoxer. Exempelvis säger Oatly ofta att deras reklam inte är reklam, vilket är en logisk motsägelse. Som Bateson (1972) förklarar tvingar paradoxer fram metakommunikativa inramningar. I det här fallet är, som vi ska visa, en rimlig inramning att Oatly gör parodi på traditionell reklam.

Att förkroppsliga rummet. Oatlys sätt att omforma platser och rum inbegriper att använda semiotiska material på sätt som direkt påverkar våra kroppar och därmed vår perception, något som sällan tas upp i den klassiska forskningen om reklamspråk, även om Jaworski \& Thurlow (2010) betonar att reklam bör förstås som en del av »semiotiska landskap». Scollon \& Scollon (2003 s. 205) kallar detta fokus på hur det fysiska rummet påverkar betydelseskapandet för »the principle of indexicality». De slår fast att alla semiotiska tecken »have as a significant part of their meaning how they are placed in the world» och att vi som sociala aktörer, situerade i tid och rum, blir en del av en platsbunden social interaktion. Detta ligger, menar vi, i linje med Spinozas (1994 s. 154) sätt att se på affekt som något som berör »affections of the body by which the body's power of acting is increased or diminished, aided or restrained, and at the same time, the ideas of these affections». Så vår perception och våra upplevelser av världen är beroende av vår kroppsliga hållning och rö- 
relse. Vi kommer i analysen att ta upp hur rumsliga relationer skapas och hur de gör att sociala aktörer binds till det fysiska och semiotiska rummet på olika sätt. Vi analyserar särskilt det tilltal som Oatly medvetet arbetar med och som berör kroppens relation till den omedelbara omgivningen. Rent språkligt är deixis, ofta kodat av pronomen och adverb, viktigt för att positionera kroppen och rikta uppmärksamheten. Liksom Scollon \& Scollon (2003 kap. 2) skiljer vi på tre typer av deixis, relaterade till rummet (den här), den sociala relationen (jag, $d u)$ och tiden $(d \stackrel{\circ}{a}, n u)$.

Vi berör som sagt olika semiotiska material och resurser. I detaljanalyserna använder vi oss av Ledin \& Machin (2018), där olika material analyseras, exempelvis förpackningar (kap. 5) och reklamfilm (kap. 7), och Ledin \& Machin (u.u. 2020), där betydelseskapande beskrivs utifrån semiotiska resurser, exempelvis färg (kap. 4) och typografi (kap. 5). Vad gäller språkliga iakttagelser analyserar vi svenskan, som Oatly använder i längre texter, utförligare än engelskan, som är språket i slogans och för roliga och coola formuleringar.

\section{Resultat}

I detta avsnitt presenterar vi våra resultat. Vi tar oss i tur och ordning an förpackningar, affischer och reklamfilm och relaterar dessa material till Oatlys kampanjer.

\subsection{Förpackningar och kampanjer}

I figur 2 ser vi Oatlys förpackningar efter omprofileringen 2014. För att skapa en sorts ursprung, en autencitet, är färgerna viktiga. De är gryniga, dämpade och ofta hybrida, i det här fallet blå-grå, annars orange-gul, och i övrigt används gärna grått och svart (se också figur 3 och 4), något som i sig kan föra tankarna till något naturligt och oprocessat (jfr Ledin \& Machin 2018 kap. 5, och Ledin \& Machin u.u. 2020 kap. 4). Det gryniga, ojämna intrycket förstärks av de barnsligt-naiva ikonerna (jfr Ledin \& Machin 2018 s. 106 ff. om ikonografi). Exempelvis ser dricksglaset på framsidan, med sina ojämna svarta toner, ut som om det vore handstencilerat, och det är inte olikt en barnboksillustration. Jämför vi med andra alternativa mjölkprodukter har de traditionellt klara färger, och framsidan innehåller ofta, som i Alpros fall - Oatlys amerikanska 
huvudkonkurrent - ett stiliserat foto av produkten (se kyldisken i figur 3), vilket var vad även Oatly använde före omprofileringen.

Om vi ser på typsnitt och slogans kan vi notera att varumärket skrivs med breda och ojämna blockbokstäver, återigen som något handgjort, och avslutas med ett utropstecken, vilket Oatly ofta använder: OATLY! Detta kontrasterar mot det traditionella typsnittet med tunna streck som hälsoprodukter brukar ha och Oatly förut hade. På sidan av förpackningen möter vi den återkommande sloganen »WOW! NO COW!» Här har vi ett rundat typsnitt. Den exakta proveniensen kan diskuteras, men att typsnittet användes på 1970-talet är säkert, till exempel i serietidningar. Det kunde också köpas på ark som s.k. gnuggisar. Sloganen är en språklek. Den är barnsligt enkel och rimmar (»wow-cow»). Den använder den för Oatly typiska negationen (»no»), som antyder en polemik mot mjölkindustrin. Det traditionella antagandet att mjölkprodukter kommer från kor gäller inte, utan här har vi alternativet, vilket emfatiskt understryks av de två utropstecknen.
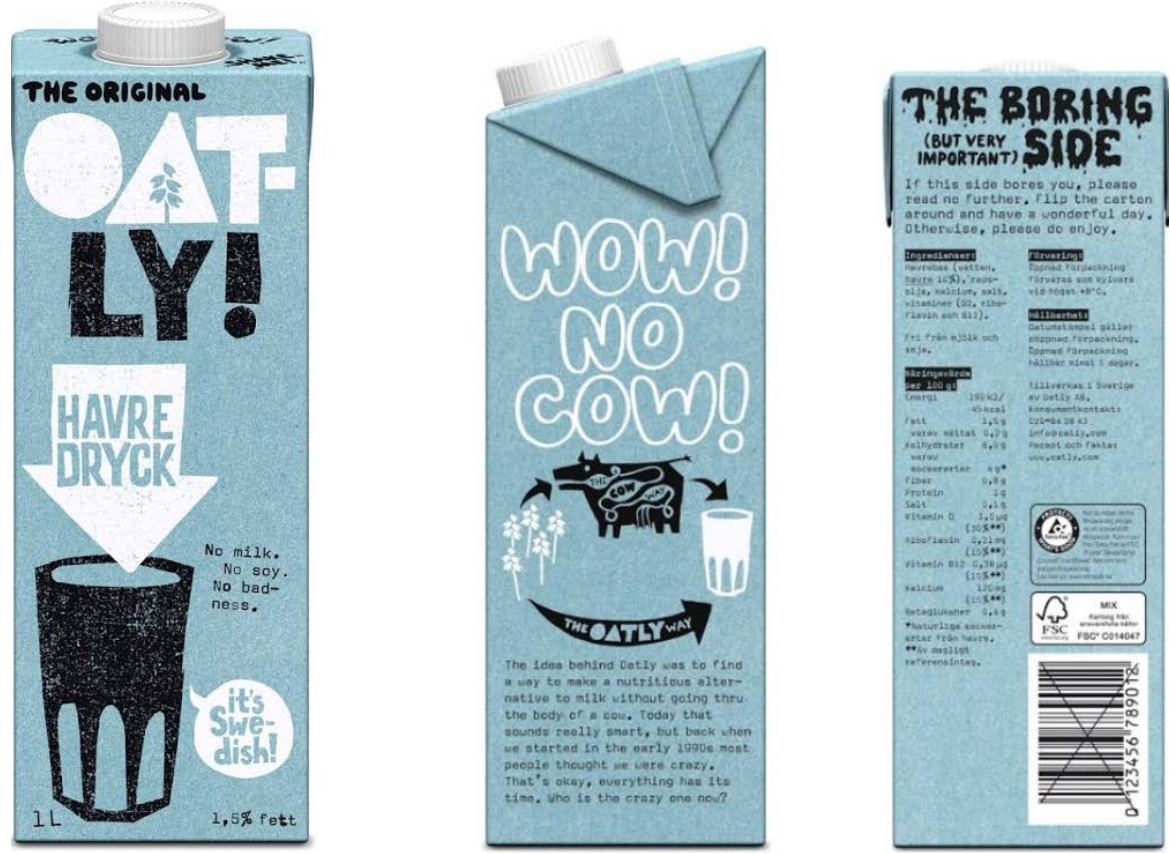

Figur 2. En Oatly-förpackning efter omprofileringen 2014. 
På samma sida finns ett diagram - som återkommer i olika reklammaterial som tydligt ger uttryck för Oatlys antagonistiska retorik, återigen med barnsligt-naiva ikoner (jfr Ledin \& Machin 2018 kap. 8 om diagram). Två processer kontrasteras, produktion av komjölk och havremjölk. Kon, som äter havre, tecknas detaljerat med sina inre organ, så att en komplicerad process blir tydlig. Oatlys produktion går från de vackert stiliserade havreaxen (som också återkommer i loggan) direkt till glaset. Detta ligger i linje med vad vi tidigare iakttagit om färger och ikonografi. Oatly, vars produktion förstås är högteknologisk, framställer det som att deras havredryck kommer direkt från naturen till glaset utan att ha gått igenom någon industriell eller miljöbelastande produktionsprocess.

Det naturliga ursprunget är alltså en viktig proveniens som Oatly kommunicerar. När det gäller att frammana och iscensätta ett förflutet är det också tydligt att det sena 1900-talet väcks till liv. Det finns en politiskt färgad proveniens, vilket vi anar av slogans med utropstecken, som i »no cow!». Ytterligare ett exempel är framsidans negerande slogan som förbjöds efter rättegången 2015: »No milk. No soy. No badness.» Negationerna presupponerar en värld som är fördärvad, med »badness», där mjölk och soja är matprodukterna som förstör. Typsnittet är det klassiska Courier, som väcker associationer till 1900talets skrivmaskiner, en tid, kan man tänka, där ord var ord och människor sa som det var. Det kan noteras att Oatly inte förklarar varför alternativ mjölk gjord på soja är dålig. Som vi förstår det är en anledning att sojaproduktion är omdiskuterad eftersom den sker storskaligt, också i regnskogsområden, och till
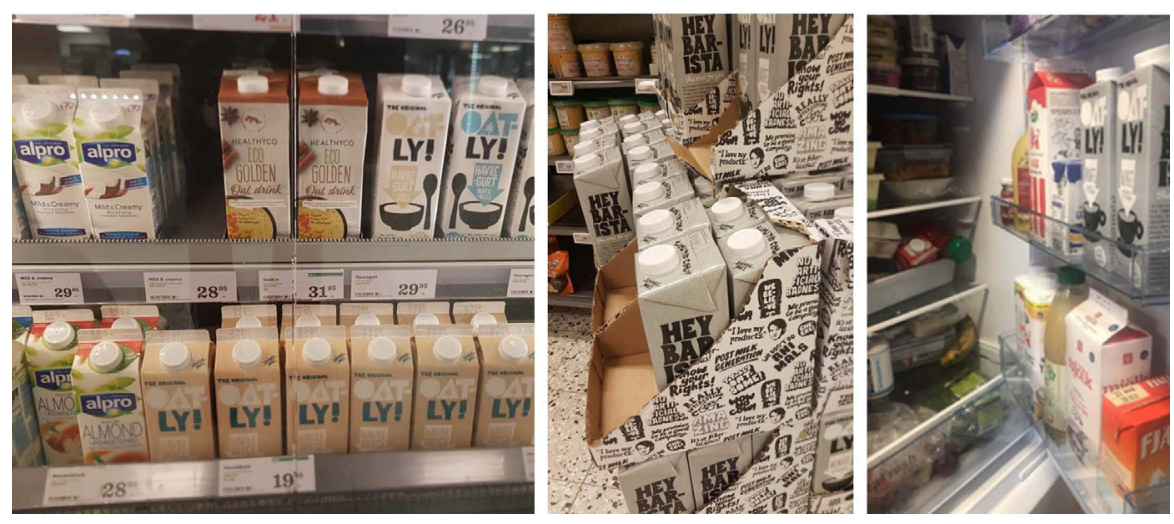

Figur 3. Oatlyförpackningar i kyldisken, på butiksgolvet och i kylskåpet (författarfoton). 
övervägande del blir till djurfoder. Ytterligare en anledning är att Oatlys huvudkonkurrenter, amerikanska Alpro och brittiska Silk, traditionellt har sojamjölk som hälsoalternativet.

En annan sorts dåtid iscensätts med populärkulturella referenser. Ser vi på baksidan av förpackningen i figur 2 så möter vi, vilket vi är vana vid och även är reglerat av lag, en ingredienslista, där andelen fett, protein, kolhydrater, vitamin D osv. listas på svenska. Men rubriken är ovanlig och lekfull och på engelska: »THE BORING SIDE», skrivet i ett till synes handmålat typsnitt med droppande färg. Vi kan tänka på den gamla skräckfilmsklichén med något skrivet med blod på en vägg, eller på en väggmålning med rinnande färg i en urban miljö.

Språket är ofta engelska och inte svenska, vilket ligger i linje med de populärkulturella och ofta anglo-amerikanska allusionerna. Man skulle kunna tänka att det vore naturligt att alludera på en oförstörd svensk landsbygd på just svenska för att kommunicera det autentiska och oprocessade. Som vi sett gör Arla det för att kommunicera att mjölk ger en naturlig hälsa (Andersson 2019). Oatly är däremot coola, uppkäftiga och urbana, allt annat än traditionell landsbygd. De har en svensk referens (skriven på engelska) på framsidan, en serietidningsaktig pratbubbla med utropet »it's Swedish!». På så vis vill de, liksom IKEA, anspela på Sveriges rykte om att vara modernt, jämställt och demokratiskt i den internationella marknadsföringen (jfr Kristoffersson 2015).

Som vi ser i figur 4 varierar Oatly systematiskt sidorna på förpackningarna, något som är typiskt för förpackningsdesign och som Oatly gör på sitt lekfulla sätt. En Oatly-konsument kan med nyfikenhet se fram emot vad nästa associationsrika, roliga och politiskt laddade budskap ska bli, vilket förutsätter att vi kroppsligt tar oss an förpackningen och vänder på den. På den högra förpackningen i figur 4 möter en typisk paradox: »IT TAKES BRAINS TO BE STUPID», där P:et är lekfullt vänt bak och fram (se också pallen med produkter i mitten av figur 3, som pryds av Oatlys många lekfulla typsnitt). Som Bateson (1972) förklarar är det sådana här (skenbara) paradoxer som kräver inramning, att vi förstår metakommunikationen, den position varifrån utsagan yttras. Här ska vi alltså förstå poängen med att på en och samma gång vara smart och korkad, och den făr vi om vi läser brödtexten: »We must look extremely dumb sometimes. Little Oatly in the south of Sweden thinking we can help the food industry become more accountable for their actions.» Den inramning som förklarar paradoxen handlar alltså om sanningssägaren, den som med oförstörd blick - vi anar det av det barnsligt-naiva typsnittet - ser på världen och vågar gå emot överheten. 
Figur 4. Sidan på svenska Oatlyförpackningar från 2019 (författarfoto).

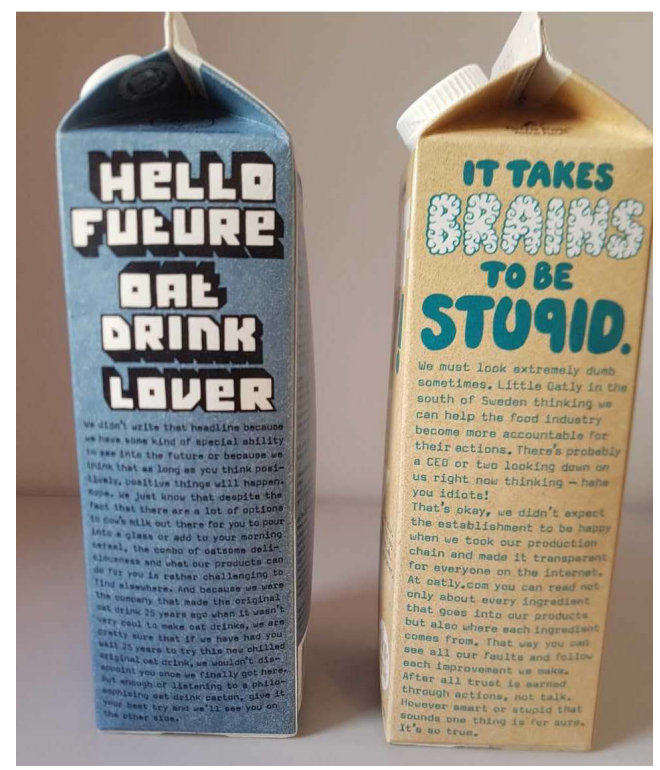

Den grafiska designen stöder denna tolkning, eftersom den frångår traditionella estetiska principer. Förpackningarnas brödtexter saknar marginaler, vilket bryter mot regler om läsbarhet (t.ex. Hellmark 1991). Typsnittet på den vänstra förpackningen i figur 4 tycks efterlikna de lågpixlade och ojämna bokstäver som fanns på tidiga datorskärmar eller datorspel, som Space Invaders på 1980-talet. Bokstäverna är skuggade, vilket ger en tredimensionell effekt, men skuggningen är ojämn och opolerad, som vore det en amatör som gjort den. Om vi studerar den första bokstaven i varje ord framstår skuggningen som slumpmässig, rentav ful. Så Oatly använder grafisk design för att signalera att de går sina egna vägar och struntar i konvenansen.

Som vi sagt är att förkroppsliga rummet typiskt för Oatlys kommunikation. Vi kan ana detta från de varierade förpackningssidorna med oväntade designlösningar. Än tydligare blir förkroppsligandet om vi ser på Oatlys stora affischer, där förpackningar återkommer. I figur 5 ser vi en jätteaffisch som i mars 2019 satt på det gamla posthuset i Helsingfors, mitt i centrum bredvid centralstation (jfr figur 1). De som passerade kunde ofta inte låta bli att vrida huvudet och blicka uppåt. På så vis påverkar den vår perception direkt. Vi möter Oatlys huvudslogan med sin monotona, trokéiska fyrtakt: »It's like milk but made for humans», i sig ett kroppsligt sätt att rytmisera språket, en sorts språklek. Här har vi också det men (»but») som kodar motstridiga förväntningar och polemik. 


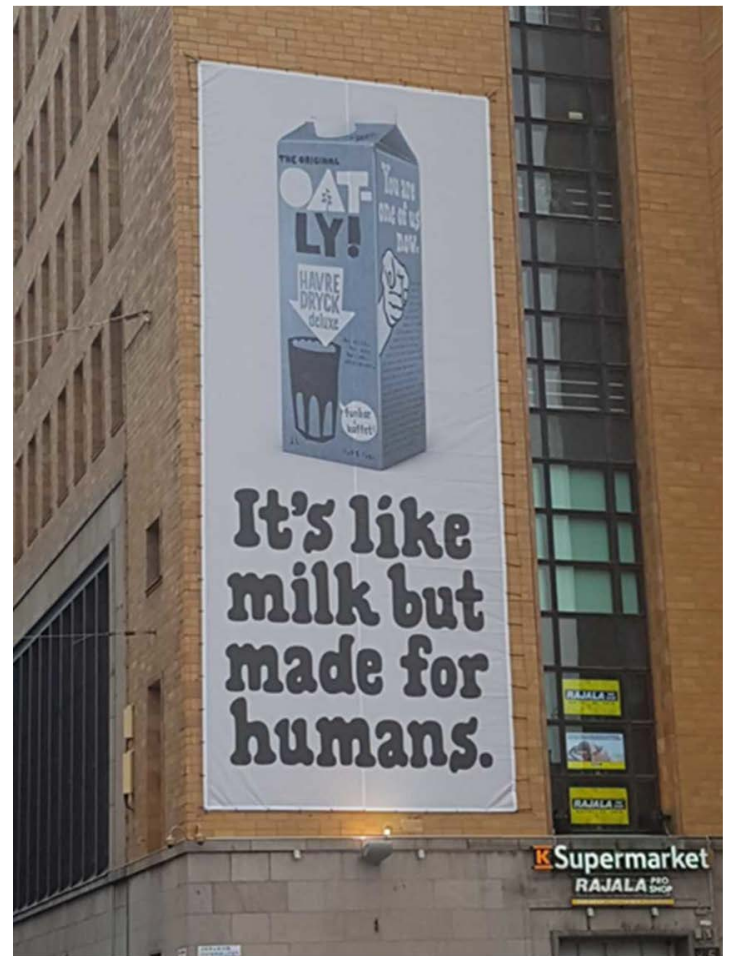

Figur 5. Affisch från Helsingfors, mars 2019 (författarfoto).

Traditionellt tänker vi att mjölk är en matprodukt för människor, men med detta men impliceras att det i själva verket är Oatlys havredryck som är människoföda.

Man kan hävda att själva storleken på affischen fungerar deiktiskt och i sig är ett förkroppsligat tilltal. Den påverkar vår blick och kroppshållning i det fysiska rummet. Till detta bidrar, vilket är typiskt för Oatly, sidan på den avbildade förpackningen. Som vanligt frammanas ett förflutet, här (en imitation av) en rekryteringsaffisch av en typ som känns igen från 1900-talet, där vi uppmanas ansluta till den politiska kampen. Vi möter en deiktisk gest, ett finger som pekar mot vårt ansikte, från en position långt ovanifrån, vilket kodar en uppfordrande social relation. I sloganen sägs » You are one of us now», där den sociala relationen blir att betraktaren fogas in i ett kollektiv, ett vi (»us») som med tidsdeixis (»now») infogas i den pågående och situerade läsakten. Naturligtvis har reklamspråk i allmänhet ett personligt tilltal (se t.ex. Pettersson 1974 om framväxten av du-tilltal i annonser på 1960-talet), men hos Oatly blir tilltalet något mycket mer kroppsligt. 


\subsection{Affischer och kampanjer}

En del av Oatlys marknadsföring är affischkampanjer, där olika offentliga platser omvandlas. Ofta används tåg- och tunnelbanestationer, liksom traditionella 1900-talsbyggnader (jfr figur 1 och 5 från Helsingfors). Affischerna, som innehåller en avbildad förpackning (jfr figur 5), är designade för att förkroppsliga rummet och skapar relationer mellan varandra och till förbipasserande. Ett återkommande grepp är att hänga affischer i långa rader, något vi ser i figur 6 från tunnelbanestationen Rozenthaler Platz i Berlin i september 2018 (se Fiedler 2018 om Berlinkampanjen).

Affischerna refererar till varandra och positionerar betraktarens kropp i det aktuella rummet. Det sker genom deiktiska uttryck för rumsrelationer, inte minst det demonstrativa pronomenet this och adverbet too. Den här affischraden börjar med »THIS POSTER» följt av ett »THIS» som pekar ut förpackningen och därmed drycken (längst upp till vänster i figur 6). Sen följer nio affischer i rad (varav vi ser fyra i figuren) som tillägg och backuper: »AND THIS ONE», »A BACKUP ONE TOO».
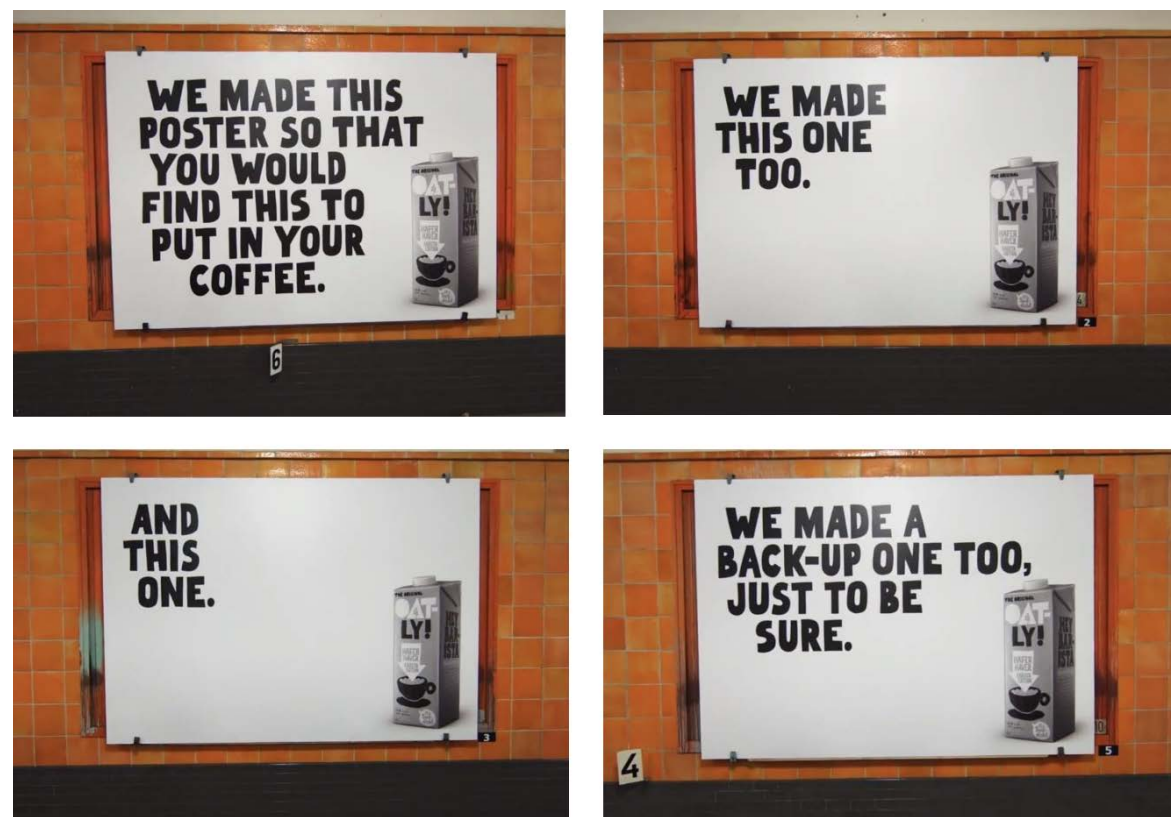

Figur 6. Affischkampanj på tunnelbanestationen Rosenthaler Platz i Berlin, september 2018 (fyra av totalt nio affischer i rad visas i figuren). 
Designen är enkel och avskalad. Vi ser de återkommande versala och ojämna blockbokstäverna på en vit bakgrund. Den grafiska utformningen skapar ett intryck av att ett budskap ropas ut med hög röst, samtidigt som ojämnheten visar på något opolerat eller handgjort. Vi kan notera att produktnamnet på förpackningsframsidan står på tyska »HAFER HAVER», följt av specifikationen »BARISTA EDITION», medan sidan, vilken som sagt är viktig på förpackningarna, är på engelska med rubriken och hälsningsfrasen »HEY BARISTA». Det är med andra ord produktnamnet på framsidan som språkanpassas - i Sverige heter det havredryck och i England oat-milk. Det är ingen slump att affischen tar upp barista-drycken, som i många länder lanseras som huvudprodukten och det rätta valet för den som vill njuta en latte (jfr Oatly 2019 om den amerikanska lanseringen och se mittenfotot i figur 3, där en pall med baristadryck, som inte är en kylvara, står på ett svenskt butiksgolv).

Tilltalet är förkroppsligat. De deiktiska uttrycken, i stora versala blockbokstäver, gör att uppmärksamheten flyttas från affisch till affisch, också beroende på kroppens position, om vi står på perrongen eller kommer in till stationen $\mathrm{i}$ ett inbromsande tåg. Vi får en känsla av detta i figur 7 där vi ser ett tåg passera och skymma sikten mot affischraden. Detta ligger i linje med vad Spinoza (1994) säger om affekt, hur kroppens rörelse och position i rummet påverkar perceptionen. Affischraden är ämnad att väcka nyfikenhet och bryta mot våra förväntningar på reklam. Metakommunikationen är besläktad med språklekar, bara att det nu är en fysisk lek, inte helt olik kurragömma på det sättet att affischer dyker upp och försvinner beroende på hur vi och andra rör oss. Raden med återkommande affischer ger en linjär och rumslig rytm att relatera till ut-

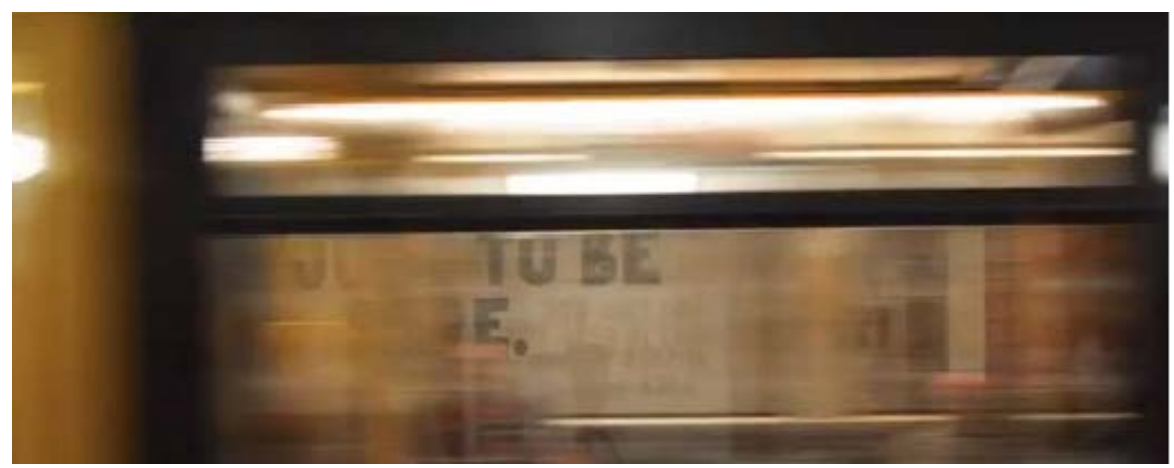

Figur 7. Ett tåg passerar Rosenthalzer Platz och skymmer sikten från perrongen. 
ifrån kroppens fysiska placering och rörelse. Detta är också beroende av det Lefebvre (2004) kallar stadens rytmer, alltså om vi är på väg till eller från jobbet, ska träffa en vän, om vi väntar eller sitter på tunnelbanan eller är på väg ut från stationen i lugn och ro eller i trängsel och rusningstrafik. Uppenbart är att Oatly har en känsla för storstadens rytm och puls i sitt sätt att kommunicera.

I figur 8 ser vi ytterligare en affischrad, nu från Stockholm i januari 2018 och placerad i gången ut från den nybyggda pendeltågsstationen vid Odenplan. Här fungerar nominalfrasen »17 POSTERS» deiktiskt. Den markerar hur affischerna sträcker ut sig och inviterar förbipasserande att utforska dem. Liksom i Berlin kodas den sociala relationen, här med »US» och »YOU». Det direkta tilltalet blir en del av affischernas deiktiska och självrefererande utformning och får sin betydelse i det fysiska rummet. Det är också tydligt att engelska används genomgående när Oatly vill framstå som coola och urbana.

Stockholmsaffischen är paradoxal i att den säger att den inte gör reklam, eller att den inte ger något skäl alls till varför läsaren ska köpa iMAT, som är Oatlys matlagningsgrädde. Som vanligt används en negation $\mathrm{i}$ »NO REASON» som gör att Oatly presupponerar en annan, traditionell värld där reklam ger köpskäl, en värld som Oatly säger sig inte vara en del av. Det finns inte heller mycket sakinformation, utan vi får mest veta att affischerna är affischer och hänger bredvid varandra. Paradoxer kräver som sagt inramningar, och den rim-

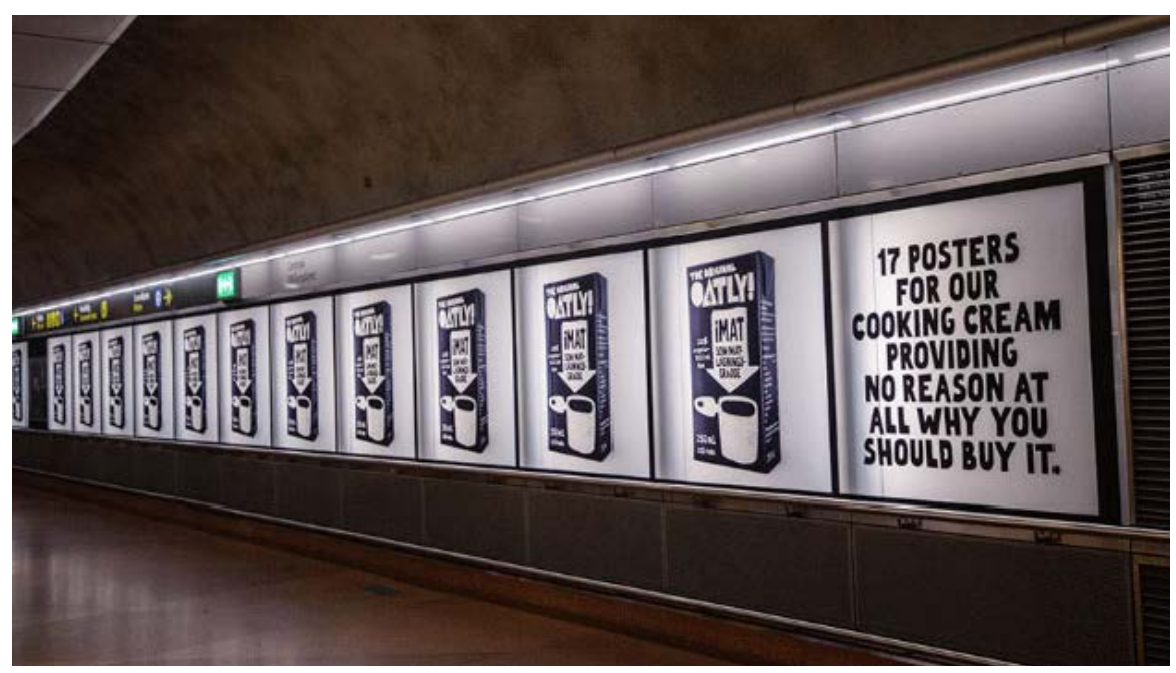

Figur 8. Affischrad från Stockholm, placerad i gången till den nybyggda pendeltågsstationen vid Odenplan, januari 2018. 
liga tolkningen är att Oatly gör narr av traditionell produktreklam (för mejerivaror). Det kan tilläggas att Oatlys egen kommunikationsbyrå, som nuförtiden finns in-house, har det självironiska namnet Oatly Department of Mind Control.

Det är inte alla kampanjer som renodlar den här typen av lekfull och självironisk ton. I maj 2019 genomfördes kampanjen »Hey food industry, show us your numbers» i Stockholm (se Törner 2019b). Här uppmuntrar Oatly livsmedelsindustrin att redovisa siffror för klimatpåverkan eller »carbon footprint» som det står på förpackningarna. Oatly har anlitat företaget CarbonCloud att räkna ut s.k. koldioxidekvivalenter. Vi ser sådana siffror på förpackningarna till höger i figur 9, och de är, från vänster till höger, från minst till mest fet havredryck, $0,33,0,35$ och 0,38 .

Typsnittet $\mathrm{i}$ kampanjsloganen, med åtskilda och kantiga ytor, framkallar som vanligt ett förflutet. Det har en proviens som för tankarna till tidiga digitala produkter, som 1980-talets tv-spel eller de första persondatorerna, eller en film som Matrix från slutet av 1990-talet. De små mellanrummen i typerna ger en likhet med blinkande tecken på en skärm (jfr typsnittet till vänster i figur 4). Det torde vara en association som ligger i linje med Oatlys ambition att utmana livsmedelsjättarna på sifferredovisning.

Återigen utnyttjas det fysiska rummet och offentliga platser strategiskt. Veporna i taket (till vänster) är från Stockholms centralstation, affischtavlan (i mitten) från förorten och Farsta centrum, och stickern (till höger) från bordet $i$ en tågkupé - jämför det gamla posthuset i Helsingfors i figur 5. När kampanjen tas upp i Resumé 2019 säger pr-chefen: »Vi vill gärna vara en del av det offentliga samtalet och då faller det sig naturligt att vara en del av det offentliga rum-
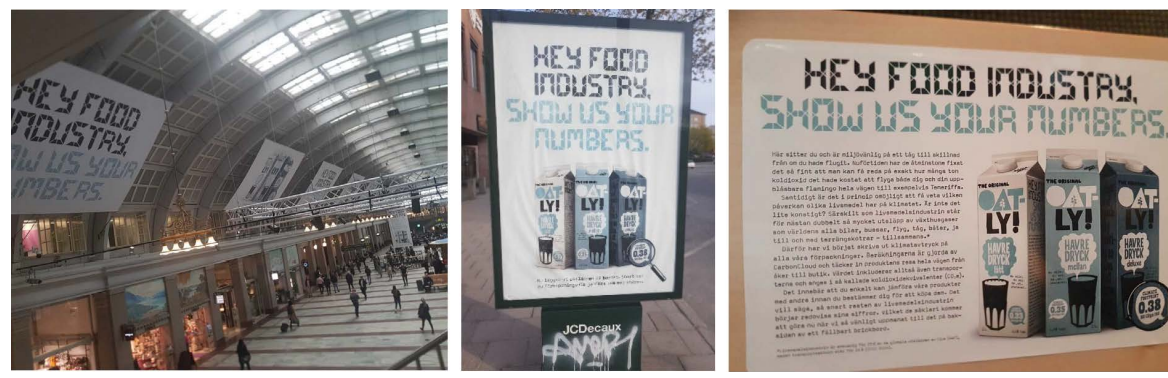

Figur 9. Tre semiotiska material från Stockholmskampanjen Hey food industry: vepor i taket på Stockholms centralstation, en affischtavla från Farsta centrum och en sticker på det utfällbara bordet vid ett tågsäte, maj 2019 (författarfoton). 
met. Därför gör vi ganska mycket reklam där folk rör sig, typ utomhus och på centralstationer.» (Törner 2019b).

Till skillnad från i de andra affischkampanjerna används svenska i denna kampanj, något som förekommer när Oatly lämnar sin lekfulla, uppkäftiga och ironiska stil och vill prata allvar. På affischtavlan från Farsta läser vi längst ner: »Nu lägger vi utsläppen på bordet. Snart kan du förhoppningsvis jämföra dem med andras.» Här har vi återigen det direkta tilltalet (»vi» och »du») tillsammans med tidsdeixis (»Nu» och »snart»), som pekar mot en bättre framtid där alla livsmedel har Oatlys klimatredovisning.

I stickern på det utfällbara brickbordet återfinns, strategiskt nog, en jämförelsevis lång text, som så ofta i 1900-talstypsnittet Courier. Tågpassagerare har mer tid för läsning än folk som skyndar genom stationer. Så här lyder den:

Här sitter du och är miljövänlig på ett tåg till skillnad från om du hade flugit. Nuförtiden har de åtminstone fixat det så fint att man kan få reda på exakt hur många ton koldioxid det kostat att flyga både dig och din uppblåsbara flamingo hela vägen till exempelvis Teneriffa.

Samtidigt är det i princip omöjligt att få veta vilken påverkan olika livsmedel har på klimatet. Är det inte lite konstigt? Särskilt som livsmedelsindustrin står för nästan dubbelt så mycket utsläpp av växthusgaser som världens alla bilar, bussar, flyg, tåg, båtar, ja till och med terrängskotrar - tillsammans.*

Därför har vi börjat skriva ut klimatavtryck på alla våra förpackningar. Beräkningarna är gjorda av CarbonCloud och täcker in produktens hela resa från åker till butik. Värdet inkluderar alltså även transporter och anges i så kallade koldioxidekvivalenter $\left(\mathrm{CO}_{2} \mathrm{e}\right)$.

Det innebär att du enkelt kan jämföra våra produkter med andra innan du bestämmer dig för att köpa dem. Det vill säga, så snart resten av livsmedelsindustrin börjar redovisa sina siffror. Vilket de såklart kommer att göra nu när vi så vänligt uppmanat dem på baksidan av ett fällbart brickbord.

* Livsmedelsindustrin är ansvarig för $25 \%$ av de globala utsläppen av $\mathrm{CO}_{2} \mathrm{e}$ (WWF) medan transportsektorn står för 14 \% (IPCC 2014).

Den första satsen iscensätter deiktiskt det förkroppsligade rummet och tilltalet. Vi har rumsdexis (»Här»), tidsdeixis, där presensformen »sitter» kodar en pågående läsakt i tågsätet, och ett direkt tilltal med »du». I övrigt sätter texten upp en polemik genom att jämföra och kontrastera. Tåg jämförs med flyg i det första stycket, och i det andra stycket pekas livsmedelsindustrin ut som en miljöbov, faktiskt den största, eftersom dess utsläpp sägs vida överstiga bil, flyg m.m. I avslutningen säger Oatly att de nu går i bräschen för klimatredovisning och uppmanar resten av livsmedelsindustrin att följa efter »på baksidan av ett fällbart brickbord» - allra sist kommer metakommunikation genom rumslig deixis tillbaka. 
Stilistiskt finns det inslag av ett specialiserat språk med ganska tunga sammansättningar: »livsmedelsindustrin», »växthusgaser», »klimatavtryck», »koldioxidekvivalenter» med facktermen » $\left(\mathrm{CO}_{2} \mathrm{e}\right) »$ tillagd, liksom en nominalisering som »beräkningarna». Asterisken sist i det andra stycket listas efter brödtexten med en hänvisning till rapporten »(IPCC 2014)», vilket signalerar formalitet och vetenskap och samtidigt är ett 1900-talssätt att referera till källor. Detta tekniska språk samsas med en enkel, personlig och stundtals retorisk-lekfull stil. Textens du påstås ta med »din uppblåsbara flamingo» på flygresan. Det ställs en vardaglig och direkt fråga, negerad och retorisk eftersom det givna svaret är ja: »Är det inte lite konstigt?» Den långa hopningen i det andra stycket avslutas med ett emfatiskt »ja»: »världens alla bilar, bussar, flyg, tåg, båtar, ja till och med terrängskotrar». Här är det oväntat och lite av en språklek att avsluta med »terrängskotrar», som knappast är ett fordon med samma spridning och klimatpåverkan som flyg eller bil. Att vi genom våra konsumtionsval kan och ska rädda planeten är tydligt. Läsaren uppmanas »jämföra våra produkter med andra innan du bestämmer dig för att köpa dem». Vad Oatlys siffror mer exakt står för och hur vi som konsumenter ska jämföra olika livsmedelsprodukter är inte självklart. Men Oatly erbjuder, här som annars, trevliga och enkla lösningar på komplexa miljöproblem - det går alltid att göra en insats genom att hälla havredryck i kaffet.

Oatly vore inte Oatly om inte det lekfulla också fick ta plats. I figur 10 ser vi en väggmålning från Södermannagatan i Stockholm. Väggmålningar är ytterligare ett återkommande semiotiskt material i Oatlys kampanjer, placerade strategiskt i kvarter med rötter i 1900-talets stadsliv, i det här fallet den forna och nu gentrifierade arbetarstadsdelen Södermalm. Vi kan jämföra med den väggmålning som Fielder (2018) kommenterar från Berlinkampanjen 2018. Den satt på ett numera övergivet hotell vid floden Spree och var gjord med droppande färg av det slag som typsnittet i figur 2 efterhärmar.

Återigen möter vi lite av en kurragömma-lek, eller ett ordpussel. Typsnittet härmar blinkande tecken på en datorskärm och fungerar perfekt för att blanda bokstäver och siffror så att de ser ganska lika ut. Rummet förkroppsligas på så vis att själva storleken på målningen med nödvändighet påverkar vår perception, vi kan knappast låta bli att titta på den, och vår uppmärksamhet dras då till myllret av tecken. Vi möter en sorts rebus som pockar på ett tolkningsarbete. Efter ett tag ser vi att det från rad 2 till 5 går att läsa ut: HEY FOOD INDUSTRY SHOW US OUR NUMBERS. Så lockas vi in i en språk- och sifferlek, samtidigt som det antagonistiska budskapet, där matindustrin utmanas, är tydligt. 
Figur 10. Väggmålning från Söder i Stockholm, maj 2019 (författarfoto).

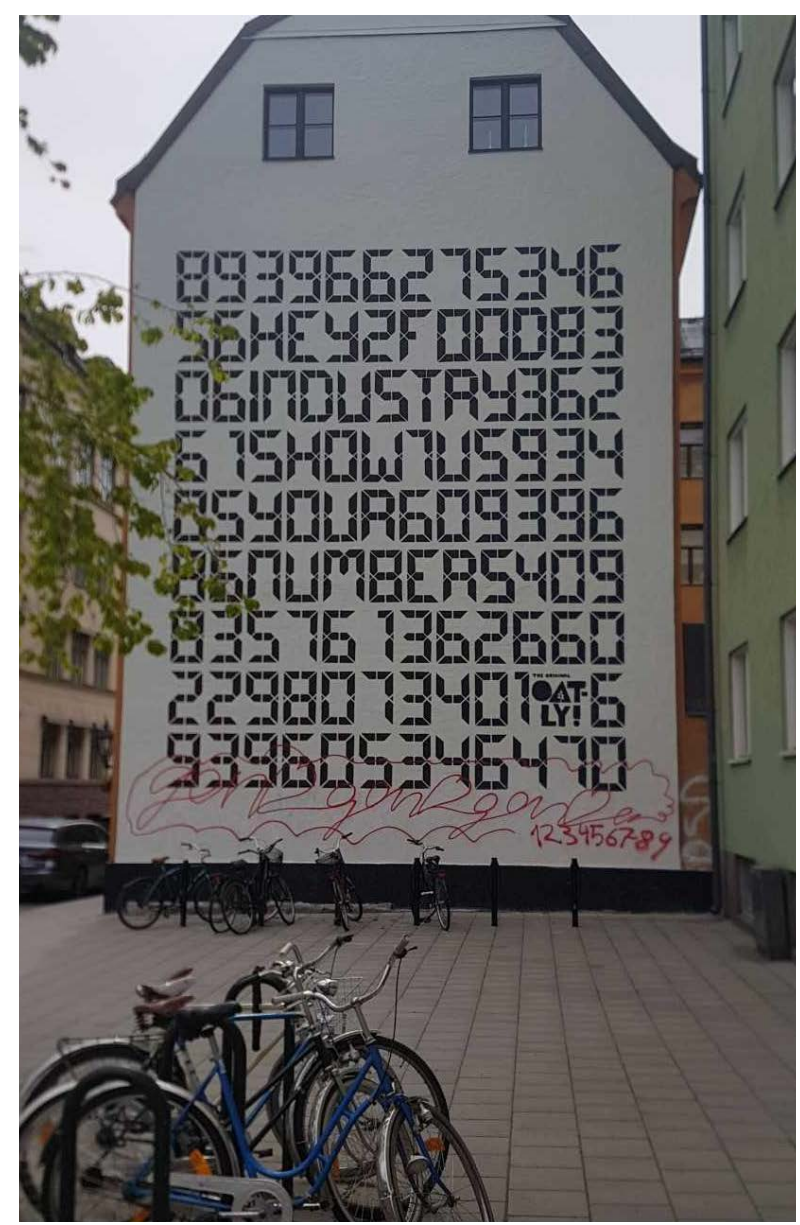

\subsection{Kampanjen Mjölken i skolan och reklamfilmen At school}

Under 2017 drev Oatly kampanjen Mjölken i skolan (se Rågsjö Thorell 2017). Som namnet antyder riktade den sig mot den fria skolmjölk som funnits sedan 1940-talet och särskilt mot det s.k. skolmjölksstödet, som innebär att EU subventionerar olika mjölkprodukter i svensk skola. Oatly ville gå emot mjölk som normen för lunchdryck, lansera havremjölk som alternativet och även påtala mjölkindustrins klimatpåverkan.

Vi ska snart detaljanalysera en reklamfilm men vill först påpeka att kampanjen som vanligt innefattade en rad kanaler och semiotiska material. Viktig och 
återkommande var den s.k. För- och motboken, ett häfte som kunde laddas ner från hemsidan, med undertiteln »Ett diskussionsinlägg om mjölk» - återigen är språket svenska och med inslag av formalitet i sammansättningen »diskussionsinlägg». I övrigt består häftet av 20 sidor där värderande påståenden från mjölkanhängare utgör rubrikerna på varje sida. Dessa går Oatly emot, ofta genom att hänvisa till mjölk- och köttindustrins växthusgasutsläpp. Ett exempel på ett sådant påstående, som Oatly i brödtexten problematiserar och polemiserar mot, är: »Jag har druckit mjölk i hela mitt liv och mår hur bra som helst.» Denna typ av dialogisk argumentation har en lång historia och användes till exempel av organisationen Nej till EU i kampanjen inför folkomröstningen 1994 (Ledin 1994), vilket återigen pekar på hur Oatly frammanar ett förflutet och återanvänder uttryck för politisk protest. Dessutom väcker motbok, som var ett sätt för staten att försöka minska alkoholmissbruket och som avskaffades 1955, 1900-talet till liv. Att kampanjen på så vis möjliggör associationer mellan mjölk och missbruk är förstås ett medvetet grepp av Oatly.

Reklamfilmer var viktiga i denna kampanj och utformades med VD:n Toni Petersson som protagonist och förkämpe för det goda. Den återkommande antagonisten kallas Kohuvudet och står för invanda föreställningar om mjölk och representerar ytterst mjölkindustrin. Miljöerna är enkla och vardagliga och innefattar till exempel ett besök på Oatlys fabrik i Landskrona och (med tydlig udd mot Arla) ett kosläpp. Av de fem klipp som släpptes väljer vi att detaljanalysera den 40 sekunder långa At school (som alltså har en engelsk titel men dialog på svenska), där miljön är en skolgård.

Vi gör en genreanalys och utgår från berättelsestrukturen, som i mycket liknar den enkla underhållande berättelse som ofta används i reklamfilmer (se Ledin \& Machin 2018 kap. 7). Vi har en utgångssituation och en komplikation, som blir det problem som driver handlingen. I den här filmen, och på grund av dess antagonistiska karaktär, får vi, som vi ska visa, ingen riktig upplösning så att världen bringas i ordning, utan ett resultat blir att den politiska kampen måste fortsätta. Vi kommenterar också, utifrån Young (1982), Oatlys sätt att metakommunicera med tittarna.

Vi disponerar analysen efter stegen i berättelsen, mer exakt utgångssituation, komplikation, resultat och koda. Vi använder skärmdumpar för att illustrera stegen. Bredvid skärmdumparna återfinns den transkriberade dialogen. För att visa att vi har att göra med talspråk använder vi gemener och typsnittet Courier. Huvudsatsavgränsning görs med / och avbrott markeras med -. Utrop och fråga återges skriftspråkslikt med ! och ?. 
Orientering (1-10 sekunder)

Toni kör på skolgården. Kohuvudet visar sig.

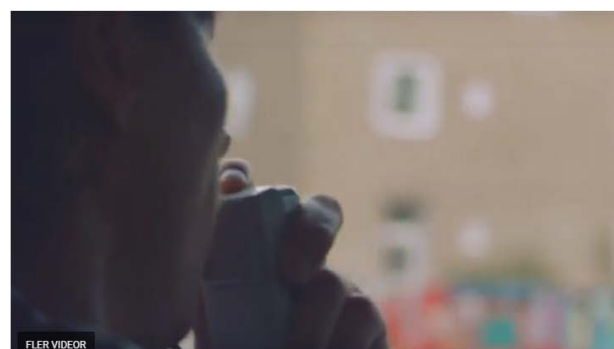

Toni: havre! havre! havredryck!

woah woah woah!

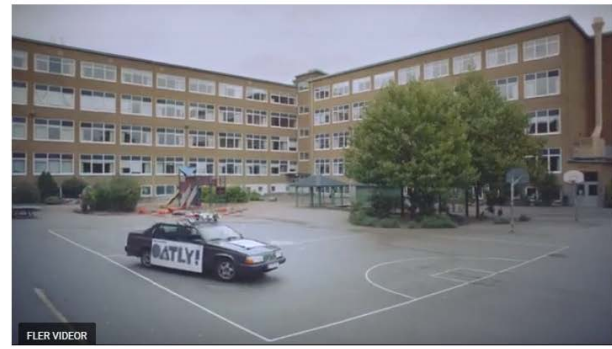

Toni: havre! havre! havredryck!

woah woah woah!

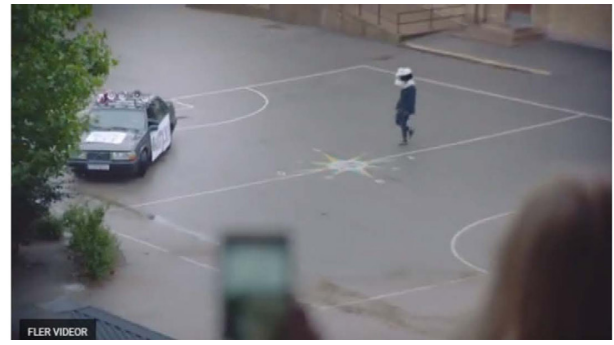

Kohuvudet: toni!

Toni fortsätter att skandera: havredryck! woah woah woah!

Kohuvudet: toni!

Toni fortsätter att skandera: havredryck!

woah woah woah!

Miljön är en funktionalistisk skola från 1960-talet med en asfalterad skolgård. Det finns en bollplan markerad men utan mål, och vi ser en rutschkana. Att ett alldagligt, sent 1900-tal framkallas är tydligt också av Tonis gamla Volvo, målad lite som dåtida polisbilar. Vi bjuds in att följa Tonis politiska kamp. Han åker runt och skanderar slagord med »havre» i en mikrofon med en uppsättning megafoner på biltaket. Kohuvudet går mot Toni och försöker påkalla hans uppmärksamhet, vilket Toni inte märker eller vill se. Kohuvudet bär en sorts mjuk maskeradkostym, lite som på ett barnkalas - figuren ser snarare söt än farlig ut. I den nedersta skärmdumpen står ett barn inne i skolan och tittar ner på det som utspelar sig. Som vi ska se är detta en del av en cirkelkomposition. 


\section{Per Ledin \& David Machin}

Komplikation (11-29 sekunder)

Kohuvudet försöker stoppa Toni från att sprida sitt budskap.

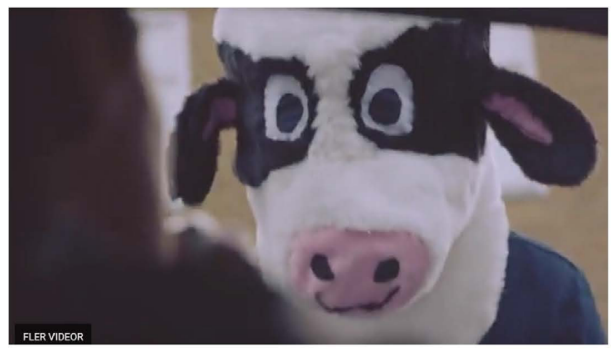

Kohuvudet: toni! stopp stopp!

Toni: vad är det?

Kohuvudet: du kan inte göra reklam pà skolan för din havredryck

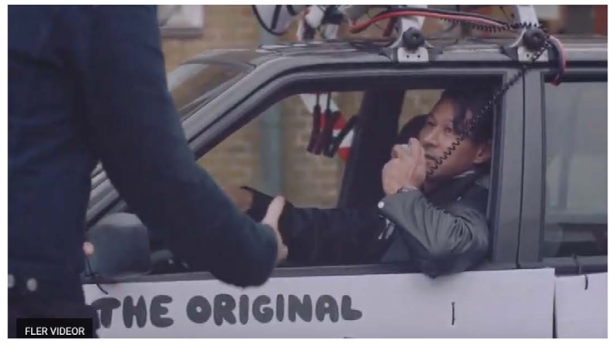

Toni: men EU sätter ju upp affischer för mjölkstödet-

Kohuvudet: -alltså barn dom behöver stöd / mjölk är bra / dom behöver näring

Toni: men kan man inte ge stöd åt vegetabiliska drycker också då och inte bara mjölk?

Kohuvudet: vad är det för fel med mjölk?

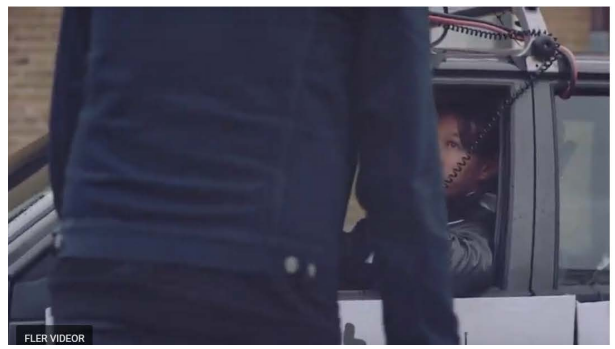

Toni: vad är det för fel med havredryck? det handlar om rättvisa åt barnen / dom ska få välja

Komplikationen inträder när Kohuvudet får kontakt med Toni med uppmaningen »stopp stopp!», följd av ett negerat påstående, modaliserat med hjälpverbet kan, som ger en anmodan: »du kan inte göra reklam på skolan för din havredryck». Toni håller förstås inte med. Det följer en dialogisk argumentation, där Kohuvudet representerar invanda men felaktiga uppfattningar. Barn behöver mjölk och näring, vad är fel på mjölk? Toni invänder hela tiden genom megafonen - med hjälp av men-inledda satser och säger, även om han en gång blir avbruten, att det handlar om EU:s stöd och att även vegetabiliska drycker ska serveras till skollunchen. Kohuvudet tar alltså 
rollen av en sorts ordningsvakt, medan Toni talar från ett retoriskt underläge, som en som vet men inte blir lyssnad på, och, anar vi, också på barnens vägnar.

Röstkvaliteterna och prosodin (som ju inte en transkription får fram) är viktiga för effekten. Kohuvudet talar släpigt och sävligt, och hans kroppshållning och rörelser är också släpiga och slängiga. Prosodin är inte typiskt svensk vad gäller exempelvis stavelselängderna, som framstår som ojämna eller godtyckligt utdragna. Kohuvudet, med sin maskeraddräkt, sin konstiga svenska och sitt försvar för mjölken, är därmed allt annat än genuin. Toni är däremot artikulerad och tydlig, och prosodiskt finns en västsvensk dialekt. Han är alltså ingen överlägsen 08, utan han har en klarsyn som, får vi tro, bottnar i en folklig förankring. Vi anar en man som sätter sig upp mot etablissemanget, mot ett sätt att leva och tänka som han menar är orättfärdigt.

Detta iscensätts med hjälp av fragment av och symboler för politisk kamp. Vi har mött banderoller, megafoner, slogans, typsnitt och ikonografi som för tanken till stenciler och skrivmaskiner och helt säkert till 1900-talets sista decennier. Miljöerna och materialen är genomgående lite slitna, eller ger sken av det. Det finns ett återkommande utanförperspektiv, som gör det möjligt att ta positionen som någon som har sett och förstått och som säger sanningen och utmanar makten. Vi som var unga på 1970-talet kan tänka på vänsterns politiska demonstrationer med megafoner, banderoller och taktfasta slogans.

Som politiska symboler fungerar de här artefakterna även för senare decennier och yngre målgrupper. Den som var aktiv i exempelvis DIY-rörelsen ( $d o$ it yourself) på 1990-talet känner lätt igen sig. I denna anarkistiska rörelse tog man avstånd från konsumtionssamhället och ordnade och skapade saker själv, utan inblandning av experter och storföretag. Musiken, som förstås låg utanför mainstream, var gärna punk och hardcore. Fanzines skrivna med Courier, liksom megafoner och banderoller, var återkommande artefakter. Vår poäng är att det politiska förflutna som framkallas inte är lokaliserat exakt i tiden och rummet, utan att Oatly medvetet skapar associationer som täcker in olika erfarenheter av politiskt engagemang.

Resultat (30-36 sekunder)

Resultatet blir att Toni fortsätter sitt kampanjande och att Oatly uppmanar till debatt. 

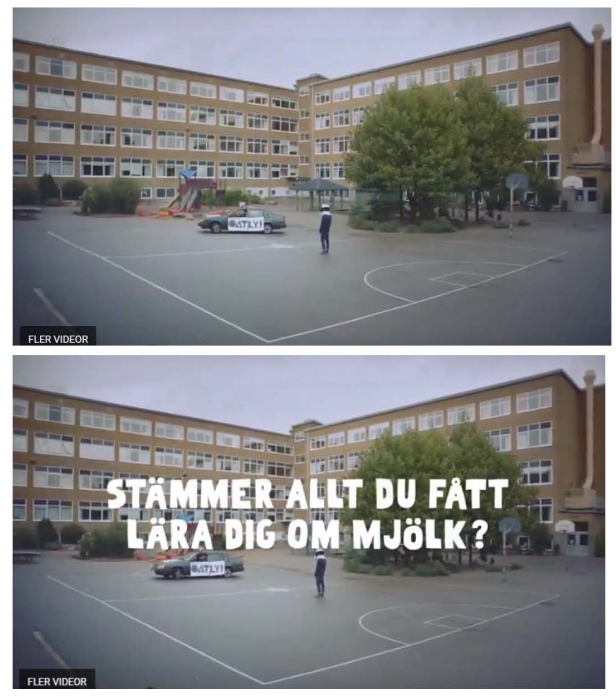

Toni: valfrihet àt barnen!

rättvisa åt alla! rättvisa!

rättvisa àt barnen!

Toni: rättvisa! rättvisa! rättvisa àt barnen!

Kohuvudet lyckas alltså inte stoppa Toni från att sprida sitt budskap, utan han fortsätter att åka runt och skandera slogans. Det kan noteras att rättvisa, ett begrepp som kan förknippas med vänstern och 1970-talet och andra begrepp som solidaritet, oproblematiskt samsas med det nyliberala begreppet valfrihet, som ju vann mark på 1980- och 1990-talet och hör ihop med kundtänk och privatiseringar: »valfrihet åt barnen! rättvisa åt alla!» En bildtext fälls in med den retoriska frågan: »STÄMMER ALLT DU FÅTT LÄRA DIG OM MJÖLK?». Att den står över skolan gör att det går att läsa in en kritik inte bara av mejerinäringen utan också av det traditionella utbildningssystemet. Kunskaper om mjölk får man inte av skolan, utan av Oatly.

Komplikationen leder därmed till två resultat, som hör hemma i två olika narrativa världar. Sett från karaktärernas värld, som Young (1982) kallar »taleworld», blir resultatet att Toni fortsätter att skandera. Det finns alltså ingen upplösning där allt ställs till rätta, utan kampen måste fortsätta. Det framgår också av att Tonis slogans hörs hela tiden genom resultat och koda. Sett från berättarens värld, som Young kallar »storyrealm» och innefattar den position från vilken karaktärsvärlden kommuniceras, blir resultatet att berättaren, som vi förstår driver Oatlys intressen, vill få till en politisk diskussion. Denna metakommunikation är viktig. Att låta karaktärsvärlden och berättarvärlden mötas på detta sätt gör att poängen med Tonis äventyr blir att bjuda in åskådaren att engagera sig i diskussionen om mjölk och jordens överlevnad (jfr den inbjudan som finns på affischen i figur 5). 
Koda (37-40 sekunder)

För- och motboken visas i bild tillsammans med Oatlys logga.

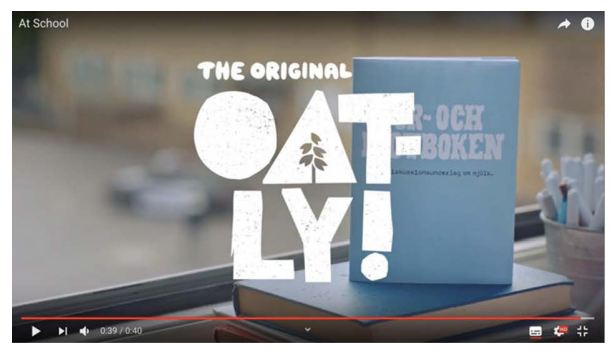

Toni (som fortfarande hörs genom

megafonen): havre! havre!

Kameran zoomar ut på samma sätt som den gjorde sist i utgångssituationen och vi ser ner på skolgården från det rum där vi vet att det står barn. Denna cirkelkomposition fungerar narrativt som en snygg avrundning och ideologiskt som ett sätt att ta barnens parti. Vi ser För- och motboken. Namnet är en uppenbar språklek, där »för» och »emot» signalerar politisk debatt. Att vi möter boken inne i ett klassrum gör att den får status av en lärobok av en typ som den traditionella skolan saknar.

När loggan »THE ORIGINAL OATLY!» fälls in avslutas filmen, och vi hamnar i det Young (1982) kallar »realm of conversion», alltså hos faktiska sociala aktörer. Det är återigen en kongenial metakommunikation. Berättelsen kopplas till den värld vi lever i, där vi tillsammans med Oatly ska rädda jorden.

\section{Diskussion}

Historien om Oatly är fascinerande. Den börjar med ett patent på ett enzym som låter vatten blandas med havre. Detta havrevatten görs mjölklikt och ska säljas. Det blir på 1990-talet till en bantningsdryck och sedan ett alternativ till mjölk för laktosintoleranta. Efter millenieskiftet blir det en allmän hälsodryck, också för den som vill ta avstånd från mjölk- och köttindustrin. På 2010-talet făr havrevattnet snart sagt magiska krafter. I alla fall blir det den dryck som räddar planeten. Förutsatt att vi köper den.

Vi har visat hur detta går till. Mer exakt har vi frilagt hur deras värderingsbaserade marknadskommunikation ser ut efter omprofileringen 2014, där för- 
packningarna var det semiotiska material som stod i centrum. Den blandar det antagonistiska och det lekfulla och utnyttjar olika semiotiska material på raffinerade sätt, och även det fysiska rummet, som blir ett politiskt och varumärkt rum, men också en plats för lek. Det antagonistiska och lekfulla kodas gärna samtidigt, som i sloganen »wow no cow», med en negation som ger en udd mot mjölkindustrin inbäddad i ett barnsligt rim. Ibland dominerar det lekfulla, som i kampanjer med affischer som refererar till varandra, där vi ska engagera oss $i$ en sorts kurragömmalek. Metakommunikationen som uppstår när Oatly säger sig inte göra reklam skapar samtidigt en antagonism, som går ut på att framställa företaget som underdogen som går emot mjölk- och i den senaste kampanjen hela livsmedelsindustrin. Att Oatly är ett globalt storföretag, där sedan ett par år den kinesiska staten är en av huvudägarna, är inget som kommer fram.

Ett utmärkande drag är att reklamen är språktät. Annars har utvecklingen gått mot att det visuella tar mer och mer utrymme på bekostnad av det verbala, så att en annons mycket väl kan sakna egentlig copy eller brödtext. Detta är tydligt i Korpus (2008) undersökning av språket, eller copyn, i Guldäggsvinnande annonser från 1976 till 2007, där skillnaden mellan start- och slutåret är mycket stor. På samma sätt kan nutida reklamfilm mycket väl sakna dialog (Ledin \& Machin 2018 kap. 7). För Oatly, som vunnit många Guldägg sedan omprofileringen 2014, är språket däremot viktigt för att mana till kamp på ett kul sätt. I slogans och självironiska stycken används engelska, vilket ger en cool och urban touch. När mejerinäringen ska utmanas i längre resonemang används svenska, som i kampanjen Mjölken i skolan.

Hela tiden framkallas ett förflutet, lokaliserat i 1900-talets senare decennier, gärna med hjälp av populärkulturella (serie- och skämttidningar, tidiga datorer osv.) eller politiska (taktfasta slogans, megafoner osv.) allusioner. Proveniensen är bred eller vag i den meningen att den inte går tillbaka på en exakt kontext. Den som varit engagerad i en politisk grupp som går emot etablissemanget känner igen sig, vare sig det var på 1970-, 1980- eller 1990talet. Till saken hör också att Oatlys kampanjer äger rum i storstäder och drar nytta av traditionella offentliga platser: det forna posthuset eller centralstationen i Helsingfors och Stockholm, en tunnelbanestation eller väggen på ett nedlagt hotell i Berlin, en gentrifierad före detta arbetarstadsdel eller ett förortscentrum i Stockholm. Allt detta är traditionella 1900-talsplatser, olika knutpunkter där landet administrerades eller där vanliga människor bodde och arbetade. Viktigt för Oatly är att det rör sig om platser med puls och folk i rörelse. Platserna utnyttjas skickligt för att gå den urbana målgruppen in på livet. 
Så ett bidrag som denna artikel ger är att visa hur Oatlys multimodala kommunikation faktiskt är utformad. Att reklamspråk traditionellt är lekfullt och kan vara ironiskt och framkalla ett förflutet, och att det finns ett direkt tilltal, det vet vi (t.ex. Myers 1994). Men Oatlys sätt att göra detta och samtidigt vara antagonistiska och förkroppsliga det fysiska rummet så att vi binds till de semiotiska materialen menar vi, tillsammans med språktätheten, är det retoriskt utmärkande.

Den sortens kommodifierade aktivism som Oatly står för behöver diskuteras och kritiskt belysas. Den innebär att miljömässiga utmaningar tas om hand av globala storföretag och att politiskt engagemang inte blir att engagera sig i den liberala demokratin utan att köpa rätt värderingar - för det är som sagt värderingar som Oatly säljer. Banet Weiser (2012) uttrycker det som att aktivisten i det nyliberala samhället kan vara vem som helst, så länge som varumärkets värderingar stöder konsumtionsvalen. Och valen får oundvikligen en moralisk halt: »participating in brand cultures feels like participating in an ethical or moral frame» (s. 219). Bauman (2007 s. 11) uttrycker något liknande när han säger att denna konsumtion av värderingar omvandlar traditionella sociala relationer »through the annexation and colonization by consumer markets of the space stretching between human individuals». Vår mellanmänskliga samvaro, hur vi relaterar till varandra, betingas alltså av att du som människa blir vad du köper, så att valet mellan att köpa havredryck eller mjölk blir en fråga om vem som tar strid för det rätta.

Matkonsumtion handlar alltså till stor del om »navigating guilt» (Johnston \& Cairns 2012), att hantera skuldkänslor som följer av att känna en oro och en press att göra det goda och rätta. Att köpa och internalisera ett varumärkes värderingar kan vara en lättnad, säger Banet Weiser (2012 s. 219), ett sätt att känna ett lugn i en värld där klyftorna ökar och jordens framtid är i fara. Här menar vi att Oatly är skickliga på att skapa känslomässiga band till varumärket, att förkroppsliga moraliska värderingar och hållningar i sin kommunikation. Att de lyckats samla aktivister beror nog också på att de får konsumenter att känna sig införstådda, att deras språklekar och självironi får målgruppen att känna sig lite smart när den hänger med.

Det hör till saken att den här typen av »high-value-added-products» (Lagnevik m.fl. 2003) köps av en välbärgad medelklass (Banet Weiser \& Mukherjee 2012), av den rikaste procenten av jordens befolkning. För att ingå i den procenten krävs det i dagsläget en årsinkomst på bortåt 29000 euro, något som en heltidsanställd svensk förskollärare eller lagerarbetare har (Kurt 2019). I många av jordens länder, exempelvis Indien, Bangladesh och Malaysia, har yt- 
terst få det. Det är denna rikaste procent som har resurserna att köpa etisk mat och moral - den största delen av jordens befolkning har fullt upp med att överhuvudtaget skaffa sig en inkomst.

Att jorden är hotad är uppenbart, och vi är, liksom många andra föräldrar, oroliga för våra barns framtid. Unga veganer, och många andra grupper, är också oroliga och rädda för om jorden ska finnas kvar. Att välja att köpa havredryck, som en del av jordens rikaste gör, är i det sammanhanget förståeligt, trots att det knappast löser de globala och miljömässiga utmaningar vi står inför. Oatly gör det möjligt för individer att ta ställning för en hållbar planet, att i alla fall göra något.

Det är något annat som för oss skaver med den kommodiferade aktivism som Oatly exemplifierar. Det har att göra med hur vi känslomässigt som individer binds till varumärkeskulturer i vilka vi investerar pengar för att känna oss trygga (Banet Weiser 2012). Vi lever i dag, säger Illouz (2007), i den emotionella kapitalismens tidevarv. Traditionellt är vi vana att skilja mellan sak och person, förnuft och känsla, privat och offentligt, vare sig det gäller att delta i demokratiska val eller köpa något vi behöver. Men i dag är det ekonomiska, inklusive vår matkonsumtion, och det emotionella, inklusive våra privata och intima band till varandra, sammanflätade. Det är också så Banet Weiser (2012 s. 219) beskriver varumärkeskulturer och de »affective connections» de har: »Brand cultures exceed the products they represent and, through this excess, offer community to individuals that assures affective connection with others as well as with themselves.» Här finns, menar vi, en fara. Om globala storföretag ska styra våra pengar och känslor och bestämma vad som är ett miljöproblem, finns det en risk att vi inte klarar att rädda planeten.

\section{Litteratur}

Aiello, Giorgia \& Dickinson, Greg, 2014: Beyond authenticity: A visual-material analysis of locality in the global redesign of Starbucks Stores. I: Visual Communication 13:3. S. 303-321.

Andersson, Helen, 2019: Recontextualizing Swedish nationalism for commercial purposes: A multimodal analysis of a milk marketing event. I: Critical Discourse Studies 16:5. S. 583-603.

Arla, 2019: Brölk? Trölk? Pjölk? Sölk? Nääe. Bara mjölk smakar mjölk. Tillgänglig på: https://www.arla.se/produkter/mjolk/bara-mjolk-smakar-mjolk/ [hämtad 3.5.2019]. Atkinson, Lucy \& Kim, Yoojung, 2015: "I drink it anyway and I know I shouldn't": Understanding green consumers' positive evaluations of norm-violating non-green pro- 
ducts and misleading green advertising. I: Environmental Communication 9:1. S. $37-57$.

Banet Weiser, Sarah, 2012: Authentic TMs: The politics of ambivalence in brand culture. New York \& London: New York University Press.

Banet Weiser, Sarah \& Mukherjee, Roopali, 2012: Introduction: Commodity activism in neoliberal times. I: S. Banet Weiser \& R. Mukherjee (red.): Commodity Activism: Cultural resistance in neoliberal times. New York \& London: New York University Press. S. 1-24.

Barthes, Roland, 1977: Image, music, text. London: Fontana.

Bateson, Gregory, 1972: A theory of play and fantasy. I: Steps to an ecology of mind. New York: Ballantine. S. 67-73.

Bauman, Zygmunt, 2007: Consuming Life. Cambridge: Polity Press.

Bauman, Zygmunt, 2017: Retrotopia. Malden, MA: Polity Press.

Beck, Ulrich \& Beck-Gernsheim, Elisabeth, 2002: Individualization: Institutionalized individualism and its social and political consequences. London: Sage.

Burrows, Jessica, 2013: Visually communicating 'honesty': A semiotic analysis of Dorset Cereals' packaging. University of Leeds. Magisteruppsats. Tillgänglig på: http://media.leeds.ac.uk/files/2013/07/Jessica-Burrows-BACS-2013.pdf [hämtad 23.2.2017].

Cavanaugh, Jillian R. \& Shankar, Shalini, 2014: Producing authenticity in global capitalism: Language, materiality, and value. I: American Anthropologist 116:1. S. 51-64.

Clegg, Stewart R., 2018: Reading Bauman and Retropia. I: Scandinavian Journal of Management 43. S. 354-363.

Cook, Guy, 1992: The discourse of advertising. London \& New York: Routledge.

Cook, Jacklyn, 2011: 'Green capitalism' or environmental justice? A critique of the sustainability discourse. I: Focus 63 . S. 45-51.

Djerf, Kristin, 2015: Oatly ny huvudsponsor - nu blir Way Out West mjölkfritt. I: Dagens Media 2.6.2015. Tillgänglig på: https://www.dagensmedia.se/medier/eventsponsring/oatly-ny-huvudsponsor-nu-blir-way-out-west-mjolkfritt-6088243 [häm$\operatorname{tad}$ 5.5.2019].

Fairclough, Norman, 1992: Discourse and social change. Cambridge: Polity Press.

Fiedler, Pascal, 2018: Oatly's marketing strategy-Unveiling the hype! This brand was sold out in New York. Now, it is coming to Berlin. I: Mission.org 12.9.2018. Tillgänglig på: https://medium.com/the-mission/oatlymarketingadcampaigneeae9250c018 [hämtad 9.5.2019].

Franklin-Wallis, Oliver, 2019: White gold - the unstoppable rise of alternative milks. How wellness upstarts spoiled milk's healthy reputation - and built a billion-dollar industry from juicing oats and nuts. I: The Guardian 29.1.2019. Tillgänglig på https: //www.theguardian.com/news/2019/jan/29/white-gold-the-unstoppable-rise-of-alternative-milks-oat-soy-rice-coconut-plant [hämtad 13.3.2019].

Hansen, Anders, 2002: Discourses of nature in advertising. I: Communications 27. S. 499-511.

Hellmark, Christer, 1991: Typografisk handbok. Stockholm: Ordfront.

Hodge, Bob \& Kress, Gunther, 1988: Social Semiotics. Cambridge: Polity Press.

Illouz, Eva, 2007: Cold intimacies: the making of emotional capitalism. Cambridge: Polity Press. 
Jaworski, Adam \& Thurlow, Crispin, 2010: Semiotic Landscapes. London: Continuum. Johnston, Josée \& Cairns, Kate, 2012: Eating for change. I: S. Banet Weiser \& R. Mukherjee (red.): Commodity activism: Cultural resistance in neoliberal times. New York \& London: New York University Press. S. 219-239.

Jönsson, Håkan, 2006: Den svenska mjölkpropagandan. I: Forskning \& Framsteg 3. Tillgänglig på: https://fof.se/tidning/2006/3/den-svenska-mjolkpropagandan [hämtad 9.5.2019].

Knoblauch, Hubert, 2005: Focused ethnography. I: Forum Qualitative Sozialforschung/ Forum Qualitative Social Research 6:3. Art. 44.

Korpus, Einar, 2008: Reklamiska: Guldäggsannonser 1975-2009. Diss. Örebro universitet.

Kress, Gunther \& van Leeuwen, Theo, 2001: Multimodal discourse: The modes and media of contemporary communication. London: Arnold.

Kristoffersson, Sara, 2015: IKEA. En kulturhistoria. Stockholm: Atlantis.

Kurt, Daniel, 2019: Are you in the top one percent of the world? I: Investopedia 9.5.2019 (uppdaterad version av artikeln). Tillgänglig på:

https://www.investopedia.com/articles/personal-finance/050615/are-you-top-onepercent-world.asp [hämtad 9.5.2019].

Lagnevik, Magnus, Sjöholm, Ingegerd, Lareke, Anders \& Östberg, Jacob, 2003: The dynamics of innovation clusters. A study of the food industry. Cheltenham, UK \& Northampton, MA, USA: Edward Elgar.

Lakoff, Robin, 1971: The role of deduction in grammar. I: C. J. Fillmore \& D. T. Langendoen (red.): Studies in linguistic semantics. New York: Hole, Rinehart and Winston. S. 63-70.

Ledin, Per 1994: Språk och makt i EU-debatten. I: Språk och stil NF 4. S. 19-63.

Ledin, Per \& Machin, David, 2018: Doing Visual Analysis. London: Sage.

Ledin, Per \& Machin, David, u.u. 2020: Introduction to Multimodal Analysis. Andra upplagan. London: Bloomsbury.

Lefebvre, Henri, 2004: Rhythmanalysis: Space, time and everyday life. London: Continuum.

Lindsey, Timothy C., 2011: Sustainable principles: Common values for achieving sustainability. I: Journal of Cleaner Production 19. S. 561-565.

Mccrow-Young, Alexandra, 2016: Changing the world through consumption: The contradictions of political engagement in the case of Oatly. Magisteruppsats. Lunds universitet. Tillgänglig på: https://lup.lub.lu.se/student-papers/search/publication/ 8872536 [hämtad 22.2.2017].

Myers, Greg, 1994: Words in ads. London: Arnold.

Oatly, 2009: Nyhetsbrevet Historien om Oatly. Tillgänglig på: http://mb.cision.com/ Public/MigratedWpy/90618/684324/935b9189c4338638.pdf [hämtad 23.3.2019].

Oatly 2019: Barista Edition Oatmilk. Tillgänglig på: https://us.oatly.com/products/ barista-edition-oatmilk [hämtad 4.5.2019].

Otman, Jacquelyn A., 2011: The new rules of green marketing. San Francisco, CA: Berrett-Koehler Pub.

Pettersson, Gertrud, 1974: Reklamsvenska: Studier över varumärkesannonser från 1950- och 1960-talen. Diss. Lunds universitet.

Regeringskansliet, 2016: Strategi för hållbar konsumtion. Tillgänglig på: 
https://www.regeringen.se/artiklar/2016/10/strategi-for-hallbar-konsumtion/ [häm$\operatorname{tad}$ 3.3.2019].

Rolfsdotter-Jansson, Catarina, 2018: Handbok för en hållbar människa: Ta hand om dig själv och planeten samtidigt. Malmö: Roos Tegnér.

Rågsjö Thorell, Andreas, 2017: Oatly tar strid mot skolmjölken. Resumé 5.10.2017. Tillgänglig på: https://www.resume.se/nyheter/artiklar/2017/10/05/oatly-tar-stridmot-skolmjolken2/ [hämtad 13.1.2019].

Scollon, Ron \& Scollon, Suzie Wong, 2003: Discourses in place: Language in the material world. London: Routledge.

Spinoza, Benedict de, 1994: A Spinoza Reader: The Ethics and Other Works, översatt av Edwin M. Curley. Princeton \& Chichester: Princeton University Press.

Törner, Amanda, 2019a: Oatlys nya drag - varumärkeskyddar Arlas »brölk». I: Resumé 18.9.2019. Tillgänglig på: https://www.resume.se/nyheter/artiklar/2019/09/18/oatlys-nya-drag--vill-varumarkeskydda-arlas-brolk/ [hämtad 20.9.2019].

Törner, Amanda, 2019b: Oatly om den hyllade utomhuskampanjen: »Fler förstår att vi inte bara snackar». I: Resumé 29.4.2019. Tillgänglig på: https://www.resume.se/nyheter/artiklar/2019/04/29/oatly-visar-upp-vad-deras-produkter-gor-for-avtryck-paklimatet/ [hämtad 3.5.2019].

van Leeuwen, Theo, 2005: Introduction to social semiotics. London: Routledge.

Voloshinov, Valentin N., 1973: Marxism and the philosophy of language. New York: Seminar Press.

Wisterberg, Erik, 2015: Oatly förlorar mot Svensk Mjölk - tvingas ändra marknadsföringen. I: Dagens Media 19.11.2015. Tillgänglig på: https://www.dagensmedia.se/ marknadsforing/kampanjer/oatly-forlorar-mot-svensk-mjolk-tvingas-andra-marknadsforingen-6234999 [hämtad 8.5.2019].

Young, Katherine, 1982: Edgework: Frame and boundary in the phenomenology of narrative communication. I: Semiotica 21. S. 292-310. 


\title{
Gällande gällande och andra avseendemarkörer
}

\author{
Av ULLA STROH-WOLLIN
}

\begin{abstract}
Stroh-Wollin, Ulla, ulla.stroh-wollin@nordiska.uu.se, Professor. Department of Scandinavian Languages, Uppsala University: "Concerning gällande and other "in-what-respect markers" ". Språk och stil NF 29, 2019, pp. 134-167.

This article deals with the development of the kind of lexical items in Swedish that correspond to English regarding, concerning, as regards, with reference to, etc., i.e. lexical items that head phrases specifying in what respect a certain constituent of the clause (or the entire proposition) pertains. A quantitative analysis, based on large newspaper corpora, reveals a most dynamic situation: "in-what-respect markers" come and go. Two newcomers have appeared recently, gällande (from the participle of gälla 'concern') and när det kommer till (borrowed, word for word, from English when it comes to), while others, e.g. beträffande ('concerning') and i fråga om (lit.: in question about) are rapidly losing ground. However, the decline of the latter started before the former were beginning to gain ground. Instead, it seems as när det gäller (lit. when it concerns), the - beyond comparison - most frequent in-what-respect marker in present-day Swedish, and the related vad gäller (lit. [in] what concerns) have ousted - from a very modest position before 1950 - earlier more frequent variants. The hypothesis that a competitive in-what-respect marker should be syntactically versatile is tested and strengthened, but it does not fully explain the complex dynamics of the field. Nevertheless, the author dares to predict some further success of both gällande and när det kommer till.
\end{abstract}

Keywords: participial prepositions, complex prepositions, Swedish, angående, beträffande, gällande, rörande, vad gäller, när det gäller, när det kommer till.

\section{Inledning}

Den undersökning som presenteras i det följande startade för några år sedan med iakttagelsen att ordet gällande, tycktes det mig, hade fått fotfäste som preposition och användes ungefär på samma sätt som beträffande eller angående. Ett autentiskt exempel återges i (1). ${ }^{1}$ Kursiven i exemplet avser den fras som utgörs av gällande + dess komplement. Samma princip används genomgående i artikeln.

${ }^{1}$ Ett exempel från min handledarvardag som återges med författarens tillstånd. 
(1) Även gällande $O V$-ordföljd finns det en stor variation mellan texterna.

När jag först lade märke till detta prepositionella bruk av gällande kändes det främmande. Själv hade jag i en mening som den i (1) i stället valt till exempel beträffande eller ett flerordsuttryck som när det gäller eller vad gäller, möjligen $i$ fråga om.

En kontroll i några ordböcker gav mig stöd, såtillvida att de inte presenterade gällande som en preposition. Fortfarande i 14:e upplagan av Svenska Akademiens ordlista (SAOL) från 2015, liksom i Svensk ordbok från 2009, är ordet enbart ett oböjligt adjektiv. Som adjektiv används det bland annat i uttryck som göra gällande, göra sig gällande och gällande lag. I Svenska Akademiens grammatik (från 1999), hädanefter SAG, exemplifieras prepositioner som bildats genom »lexikalisering» av presensparticip med beträffande, rörande och angående (SAG del 2 s. 716). Gällande som preposition nämns inte i detta sammanhang eller annorstädes i verket. Såväl beträffande som rörande och angående noteras som prepositioner även i SAOL och Svensk ordbok. Däremot tar inget av de nämnda verken upp avseende som preposition, fastän ordet används (ehuru ganska sällan) i denna funktion.

Efter en inledande sondering i Språkbankens korpusar stod det klart att gällande verkligen var en preposition på frammarsch. Det framkom också att beträffande och vad beträffar är på snabb reträtt. Det framstod alltså som om det sker en sorts ommöblering bland den här sortens uttryck, som jag i det följande kommer att omtala som avseendemarkörer och se som konkurrenter inom funktionsdomänen (eller fältet) »markera avseende» (se vidare nedan). En intressant omständighet är att denna ommöblering tycks ske ganska obemärkt, trots att förändringarna är klart mätbara på bara några decennier.

Det övergripande syftet med föreliggande studie har varit att försöka förstå hur de olika avseendemarkörerna förhåller sig till varandra och hur fältet »markera avseende» förändrats under modern tid. Den empiriska undersökningen bygger på excerpering av olika presskorpusar som är tillgängliga i Språkbanken. Dessa har använts för att kartlägga de olika avseendemarkörernas frekvens, inbördes fördelning och vissa grammatiska egenskaper vid olika tidpunkter. Mina exempel i det följande är hämtade ur detta material när inget annat anges. Jag markerar i dessa fall efter varje exempel från vilken specifik korpus det är taget. 


\subsection{Termen avseendemarkör}

De ord och uttryck som behandlas nedan har det gemensamt att de inleder fraser som på något vis inskränker ett satsleds eller hela propositionens giltighet $\mathrm{i}$ ett visst avseende. Trots att de kan skifta i form är de ofta utbytbara mot varandra. Som framgått ovan vore såväl beträffande som vad gäller och $i$ fråga om möjliga alternativ till gällande i exemplet i (1). Termen avseendemarkör är ett sätt att fånga dem alla i ett enda begrepp utifrån den gemensamma funktionen att markera avseende.

I SAG (del 3 s. 552) identifieras en särskild typ av adverbial som uttrycker just avseende. (Se också Holm 1991.) Dessa »avseendeadverbial» är, enligt beskrivningen, ofta uppbyggda kring ett semantiskt tungt adjektiv (t.ex. formellt eller spelmässigt sett), men, avslutar man, »[h]it hör också adverbial inledda med prepositioner med betydelse av 'avseende' som i fråga om, vad gäller, beträffande». Typen illustreras i SAG med exemplen i $(2 \mathrm{a}-\mathrm{c})$.

(2) a. Också Engqvist har fel i fråga om pappret.

b. I Stockholm har vi kommit jämförelsevis långt vad gäller utbyggnaden av barnomsorgen.

c. Jakob instämde med mig beträffande mötesförberedelserna.

Något som inte framgår i SAG är att fraser som inleds med $i$ fråga om, vad gäller, beträffande etc. inte nödvändigtvis fungerar som adverbial. De kan även vara attribut i nominalfraser, se exemplen i $(3 a-c)$.

(3) a. Den största stegringen i fråga om tonnage avser de egentliga motorfartygen ... (ORDAT)

b. Debatten om kvoter vad gäller inhemsk produktion och köp utifrån pågår ständigt. (GP 1994)

c. Kraven på lagändringar beträffande innehav av illegala vapen är välbefogade ... (GP 2013)

I SAG beskrivs avseendemarkörerna genomgående som prepositioner; $i$ fråga om och vad gäller ses som komplexa prepositioner (SAG del 2 s. 719). Jag har dock tvekat inför den beteckningen för de uttryck som innehåller finita verb, bland annat för att ett par av dem tillåter tempusväxling; exempelvis förekommer när det gällde vid sidan av det vanligare när det gäller. För enkelhetens skull har jag därför valt den gemensamma beteckningen avseende-markör.

För säkerhets skull bör det också påpekas att även vanliga enkla prepositioner, kanske särskilt om, ibland kan ersätta ovan nämnda uttryck. Begreppet avseendemarkör omfattar dock endast sådana uttryck vars primära uppgift är att markera just avseende. 


\subsection{Svenskans avseendemarkörer}

Arbetsnamnet på min undersökning har hela tiden varit »Gällande gällande» kort och gott, eftersom det var nykomlingen gällande som först väckte mitt intresse. Relativt snart stod det emellertid klart att det var lämpligt att försöka inventera förrådet av avseendemarkörer för att få en överblick över hela avseende-fältet. Ambitionen har varit att hitta alla avseendemarkörer som används i modern svenska. ${ }^{2}$ Till dessa hör ytterligare en nykomling vid sidan om gällande, nämligen när det kommer till. Till en början uppfattade jag när det kommer till som en rent tillfällig anglicism, men också detta uttryck har helt klart fått fotfäste i svenskan.

Formmässigt kan avseendemarkörerna indelas i tre huvudsakliga typer: sådana som har sitt ursprung i presensparticip, sådana som har sitt ursprung i finita bisatsmatriser, en del inledda med $v a d$, andra med när, samt komplexa prepositioner uppbyggda enligt mönstret preposition + substantiv + preposition. Jag räknar med följande varianter av de olika typerna:

- participformade prep.:

$$
\begin{aligned}
& \text { angående } \\
& \text { avseende } \\
& \text { beträffande } \\
& \text { gällande } \\
& \text { rörande }
\end{aligned}
$$

- finita matriser: vad $(\mathrm{x})$ angår/vad angår $(\mathrm{x})$
vad avser
vad $(\mathrm{x})$ beträffar/vad (det) beträffar $(\mathrm{x})$
vad (det) gäller/gällde
när/då det gäller/gällde
när det kommer till

- prep. + subst. + prep.:

i fråga om med avseende på

I den andra gruppen ovan, där uttrycken uppvisar viss formmässig variation, får fortsättningsvis följande beteckningar representera alla varianter av respektive uttryck: vad (...) angår, vad (...) beträffar, vad (det) gäller, när det gäller.

Att verben angåa, avse, beträffa och gälla återkommer i mer än en avseendemarkör hänger rimligtvis samman med att de gärna används med en uttunnad

${ }^{2}$ Jag har däremot inte beaktat äldre varianter som anbelangande( $s$ ) eller vidkommande, som knappast är i bruk idag, och inte heller vad (...) anbelangar, som möjligen förekommer, men är tämligen ovanligt. 
avseendebetydelse, även om de i andra sammanhang kan ha en mer pregnant innebörd, som t.ex. då avse står för 'ha för avsikt' eller gälla för 'vara giltig'. Det är väl också sannolikt att en konstruktion banat vägen för en annan med samma verb.

\subsection{Forskningsbakgrund}

Just avseendemarkörer som kategori har inte tilldragit sig särskilt stor uppmärksamhet i forskningen. (Däremot har lexikografer förstås haft anledning att beakta enskilda uttryck, se vidare avsnitt 1.5.) Att det finns vissa adverbial som kan betecknas som avseendeadverbial uppmärksammades, såvitt jag kunnat utröna, för första gången av Lisa Holm (1991) i en uppsats som senare kom att ligga till grund för den paragraf i SAG (del 3, adverbial, § 115) där typen behandlas. Holms uppsats handlar emellertid inte om fraser som inleds med de uttryck som behandlas här, utan om fraser som formellt sett, spelmässigt etc. I SAG:s behandling (ibid.) nämns, som framgått, även fraser med beträffande, vad gäller, i fråga om etc. men inte att sådana fraser också kan fungera attributivt (jfr avsn. 1.1).

Det finns emellertid en relativt färsk artikel som verkligen behandlar några svenska avseendemarkörer, Anton Granvik \& Susanna Taimitarha (2014): »Topic marking prepositions in Swedish: A corpus-based analysis of adpositional synonymy», som tar upp angående, gällande, beträffande och rörande, dvs. fyra av de fem participformade uttrycken jag identifierat ovan, men inte avseende. Som framgår av uppsatsens titel betecknar författarna dessa ord som topikmarkörer, vilket skulle kunna tolkas som en snävare funktionell avgränsning än den jag gör med termen avseendemarkör, men så är inte fallet. Som jag återkommer till nedan används avseendemarkörer bara ibland, och inte primärt, som inledare av fraser som uttrycker topik i en mer etablerad bemärkelse, men Granvik \& Taimitarhas term inskränker sig alltså inte endast till detta bruk, utan avser ordens användning i stort. ${ }^{3}$

Granvik \& Taimitarhas artikel handlar om hur man ska kunna identifiera semantiska, grammatiska och kontextuella skillnader mellan de fyra prepositionerna för att definiera dem i relation till varandra. Utgångshypotesen var att to-

\footnotetext{
${ }^{3}$ König \& Kortmann (1991 s. 120) identifierar tre huvudsakliga domäner för engelska verbavledda prepositioner, varav en är »topic/perspective». Här finner man bland annat prepositioner som concerning och regarding, dvs. motsvarigheter till svenskans beträffande, angående etc. Beskrivningen »perspective» ligger, som jag ser det, närmare betydelsen 'avseende' än 'topik', men jag menar att det svenska begreppet faktiskt bäst fångar vad det är fråga om.
} 
tal synonymi inte existerar: »one form - one meaning». Undersökningen är baserad på excerpering av samtliga förekomster av de respektive prepositionerna i PAROLE-korpusen, vilka sedan blir föremål för en sofistikerad statistisk analys. PAROLE-korpusen inbegriper blandade genrer - romaner, tidningar, tidskrifter och webb-texter - från 1990-talet. Den omfattar drygt 24 miljoner tokens och finns tillgänglig för sökning på Språkbanken.

De genomförda analyserna visade att beträffande var den klart mest frekventa av de fyra prepositionerna (466 belägg) och den som framstod som förstahandsalternativet i många fall. Den föredras vid självständigt adverbiellt bruk, typiskt i initial position. Den näst vanligaste prepositionen var rörande (199 belägg); den används nästan uteslutande attributivt och framstår mest som ett stilistiskt alternativ tillsammans med någon av de övriga. Nästan lika vanlig som rörande är angående (187 belägg) som särskilt används som komplement vid ord för kommunikation. Den minst frekventa prepositionen är gällande (77 belägg) som, liksom rörande, används företrädesvis attributivt.

Trots att man således kan identifiera vissa skillnader mellan de fyra studerade prepositionerna är Granvik \& Taimitarhas slutsats att dessa skillnader är subtila och att deras analys snarast understryker hur lika orden är. Detta var inte författarnas förväntade (eller önskade) resultat. Som läsare kan man emellertid tycka att det »negativa» resultatet är väl så intressant. Uppenbarligen råder en stor semantisk och funktionell överlappning mellan de olika participformade avseendemarkörerna.

\subsection{Teoretiska utgångspunkter och preciserade frågeställningar}

Den undersökning jag redogör för i det följande utgår delvis ifrån samma frågor som Granvik \& Taimitarha (2014) ställde sig, men den skiljer sig från deras studie på ett par viktiga punkter. Dels anlägger jag ett diakront perspektiv, dels ser jag på hela funktionsdomänen »markera avseende» och beaktar alla de olika typerna av avseendemarkörer, dvs. inte enbart de participformade.

Inom semantiken talar man ibland om samlingar av betydelsebesläktade ord som semantiska fält eller semantiska domäner. När jag talar om funktionsdomänen, eller fältet, "markera avseende» använder jag samma sorts rumsliga metaforik om den samling av ord och uttryck med funktionen att markera avseende som är undersökningsobjektet i denna studie.

Just en funktionsdomän som »markera avseende» låter sig relativt lätt avgränsas; antalet ord och uttryck som kan räknas in är måttligt, vilket är natur- 
ligt med tanke på att den funktion de fyller inte är särskilt komplex. Intressant nog är de ändå fler än några enstaka. Dessutom visar det sig att avseendemarkörer, kanske i högre grad än man spontant föreställer sig, kommer och går. Denna dynamik motiverar i hög grad ett diakront studium. Och det faktum att det råder en påfallande stor utbytbarhet mellan uttrycken inom domänen, också mellan sådana av olika strukturell typ, motiverar att man tar dem alla i beaktande.

Trots att den semantiska och funktionella överlappningen mellan de olika avseendemarkörerna är avsevärd, tror jag att det ligger något i devisen »one form - one meaning» som är värd att ta till vara, även i detta sammanhang. Om språket, som devisen implicerar, gör motstånd mot en hög grad av synonymi, så ligger det också i sakens natur att likvärdiga ord och uttryck konkurrerar med varandra och att vissa försvinner.

Min utgångpunkt i det följande är att fältet »markera avseende» kan, mutatis mutandis, jämföras med ett biologiskt ekosystem. I ekosystemet kan inte alltför lika arter samexistera; var och en måste ha sin egen (som ekologerna kallar det) nisch. Konkurrens mellan arter som är väldigt lika leder till att en av dem tar över helt eller till att flera blir kvar genom att specialisera sig inom olika, men smalare nischer. ${ }^{4} \mathrm{Nu}$ behöver man inte dra parallellen så långt att vi ska förvänta oss att bara en enda av avseendemarkörerna skulle kunna överleva. Men om man utgår ifrån att behovet av avseendemarkörer i princip borde vara mättat i ett språksamhälle med en väl utvecklad skriftspråkskultur och ett antal etablerade texttyper av resonerande karaktär, så är det inte orimligt att tänka sig att en markör som av någon anledning växer sig allt starkare gör det på andras bekostnad.

En hypotes som undersöks i det följande är att förmåga att uppträda i olika syntaktiska kontexter är en konkurrensfördel, så att en avseendemarkör som har eller utvecklar en större funktionell bredd än andra brer ut sig mer än vad som står i direkt proportion till antalet användningsområden. För avseendemarkörernas del tänker jag att det finns två grammatiska egenskaper som därvid är basala. Den ena är förmågan att ta komplement av olika form. Ett komplement till en avseendemarkör är alltid ett nominalt led. Oftast är komplementet en vanlig nominalfras med ett substantiviskt huvudord, men också nominala bisatser, dvs. att-satser och interrogativa bisatser, samt infinitivfraser förekommer. Den andra basala egenskapen handlar om i vilka syntaktiska positioner som av-

${ }^{4}$ Termen nisch etablerades under det tidiga 1900-talet, men ansluter förstås till darwinistiska föreställningar om konkurrensen mellan arter. Se vidare Pocheville 2015 för en genomgång av nisch-begreppet och dess utveckling. 
seendefrasen, dvs. avseendemarkören + komplementet, kan förekomma. Används dessa fraser t.ex. lika gärna i attributiv som i adverbiell funktion?

Uppenbarligen uppstår nya avseendemarkörer ibland, vilket rimligen bidrar till dynamiken inom fältet. Hur kommer detta sig? I sin uppsats »On the reanalysis of verbs as prepositions», som bland annat handlar om prepositioner som concerning och regarding, skriver König \& Kortman (1991 s. 121) att »deverbal prepositions tend to develop where primary prepositions are not available». Avseendemarkörer fyller alltså en funktion där "vanliga» prepositioner inte räcker till. Men detta förklarar inte att nya avseendemarkörer uppstår i ett läge där man kan tycka att språket redan förfogar över ett tillräckligt antal olika varianter.

Jag utgår i detta sammanhang ifrån att avseendemarkörer inte bara uppkommer för att de behövs; de är även resultat av spontana språkliga processer, inte sällan grammatikaliseringsprocesser. Som grammatikaliserade avseendemarkörer tänker jag mig främst dem som utvecklats ur verbala uttryck. De skulle då vara exempel på det första steget i den utveckling som återges i (4), hämtad ur Hopper \& Traugott 2003 (s. 7), och som illustrerar hur ett »icke-grammatiskt» uttryck kan övergå i ett formord och senare i ett bundet grammatiskt morfem. Exempelvis kan avseendemarkören gällande förstås som en omtolkning av ett verbalt presensparticip (ett innehållsord) som preposition (ett formord).

(4) content item $>$ grammatical word $>$ clitic $>$ inflectional affix

Det finns mycket inom grammatikaliseringsforskningen som är omdebatterat, t.ex. huruvida det finns anledning att tala om en grammatikaliseringsteori eller om grammatikalisering »bara» är ett fenomen med vissa typiska drag. Olika forskare har också helt olika syn på vad det är som driver grammatikaliseringsprocesser, t.ex. vilken roll man ska tilldela semantisk blekning respektive syntaktisk förenkling (se t.ex. Rosenkvist 2006 för en diskussion).

Här använder jag termen grammatikalisering enbart som beteckning på en process - en process där ett innehållsord, eller ett flerordsuttryck, genomgår en grammatisk omtolkning och antar karaktär av formord. En sådan omtolkning blir tydlig då ordet/uttrycket uppvisar förändrade grammatiska egenskaper. Detta konkretiseras kort nedan, med gällande som exempel, för att underlätta den fortsatta läsningen. I övrigt finner jag ingen anledning att inta den ena eller andra teoretiska positionen i detta sammanhang, eftersom min empiriska undersökning inte avser hur enskilda avseendemarkörer uppkommer (även om jag något återkommer till den aspekten i diskussionen i avsnitt 4).

Det är, som nämndes ovan, i första hand de olika verbala uttryckens utveck- 
ling till avseendemarkörer som jag betraktar som grammatikaliseringsprocesser. Jag utgår i dessa fall ifrån att de olika verbens mera pregnanta betydelser, som t.ex. 'giltig' för gällande, inte har aktualiserats i de kontexter där en grammatisk omtolkning skett, vilket inte utesluter att subtila betydelseskillnader mellan uttrycken kan kvarstå. Vidare utgår jag ifrån att de participformade prepositionerna har startat som verbala particip i efterställda attributiva fraser (jämförbara med relativsatser), medan fraser som inleds med uttryck som när det gäller och när det kommer till kan antas ha haft uteslutande adverbiell funktion i början. Men med fortgående grammatikalisering börjar båda typerna av fraser alltmer anta karaktär av prepositionsfraser, vilket borde möjliggöra såväl adverbiell som attributiv användning. Därmed kan man förvänta sig att participfraserna också dyker upp som adverbial och de när-inledda finita uttrycken också som attribut.

En kontroll bland gällande-fraserna i det undersökta pressmaterialet stöder antagandet om utvecklingsgången. I de äldsta korpusarna inleder gällande alltid attributiva fraser, som i (5a), men senare under 1900-talet förekommer de även $\mathrm{i}$ adverbiella fraser, alldeles entydigt så i t.ex. (5b).

(5) a. Slutligen överlämnades även den mindre medaljen [...] för ett banbrytande tekniskt forskningsarbete gällande utvecklingen av indirekt kokning vid tillverkning av sulfat- och sulfitcellulosa. (ORDAT: 1933)

b. Däremot är han upprörd över att vi tycker att Olof Johansson agerade senfärdigt gällande Skagerrak när han ännu var miljöminister. (GP 1994)

En adverbiell fras kan förstås även uppträda i fundamentsposition. I de flesta fall är detta endast ett alternativ till en senare placering, så t.ex. i (6a), där en final placering av gällande läget $i$ truppen skulle vara lika grammatisk. Men ibland får avseendefrasen en mer självständig karaktär av topiksättare och kan inte lika lätt flyttas; detta gäller t.ex. (6b). Ibland kan den även stå som ett fritt topikled före en sats eller en replik, som (6c).

(6) a. Gällande läget i truppen är han dock positiv. (GP 2013)

b. Gällande själva fartygsolyckan anser hon att Estonia ska bärgas. (GP 1994)

c. Slutligen gällande frånvaron av innehållsdeklaration ställd av museet: Crispin, visst är det skönt att slippa den här typen av trygghetsförsäkringar ... (GP 1994)

Alla avseendemarkörer förekommer till någon del i både $\mathrm{i}$ attributiva och adverbiella fraser. Däremot är det inte självklart att de gör det i samma utsträckning. Enligt min hypotes bör en framgångsrik avseendemarkör visa stor varia- 
tion härvidlag. Om den dessutom gärna inleder topikfraser, satsintegrerade och kanske till och med fristående sådana, så är det ytterligare tecken på dess breda användbarhet.

Sammanfattningsvis ser jag alltså funktionsdomänen »markera avseende» som ett fält där det råder konkurrens om utrymmet. Systemet är inte statiskt, bland annat eftersom det inte är slutet, utan öppet och släpper in nya avseendemarkörer efter hand. Undersökningen går ut dels på att beskriva själva dynamiken inom denna domän, dels på att testa hypotesen att syntaktisk allsidighet är en konkurrensfördel. Därmed kan följande konkreta frågor formuleras för undersökningen:

- Hur vanliga är olika avseendemarkörer vid olika tidpunkter? Hur förändras deras inbördes styrkeförhållanden över tiden?

- Vilka komplement tar de olika avseendemarkörerna och kan man se någon utveckling i detta avseende?

- I vilka syntaktiska positioner uppträder fraser som inleds med de olika avseendemarkörerna och kan man se någon utveckling i detta avseende?

Undersökningen berör inte eventuella semantiska skillnader mellan olika uttryck, även om sådana skulle kunna spela en viss roll för utvecklingen, egentligen både för de framgångsrika uttryckens förmåga att breda ut sig på andras bekostnad och för kvantitativt marginella att behålla en plats i systemet. Upplägget ger emellertid inte utrymme för analyser av detta slag.

\subsection{Avseendemarkörerna i Svenska Akademiens ordbok}

Innan vi går vidare finns det anledning att också kort summera vad som framkommer om de olika avseendemarkörerna i Svenska Akademiens Ordbok (SAOB), eftersom detta kan bidra till det diakrona perspektivet.

Artiklarna angå, angående, afse, afseende (samtliga från 1898), beträffa, beträffande (båda från 1908), gälla (1929), rörande (1962) samt fråga (1926) visar att en del av avseendemarkörerna är välbelagda tidigt, medan andra inte nämns. Den utslätade betydelsen hos angå, avse, beträffa, gälla och röra, ${ }^{5}$ som går igen i dessa verb och i de relaterade participen i avseendemarkörerna, föreligger emellertid i samtliga fall senast på 1700-talet.

Av de participformade uttrycken beskrivs angående, beträffande och rörande som sedan länge etablerade prepositioner. Också uttrycken vad (...) angår och vad (...) beträffar är tidiga. Liksom verben angå och beträffa i sig har

${ }^{5}$ Dessa verb återkommer själva i varandras betydelsebeskrivningar. 
den prepositionella användningen av participen och uttrycken vad (...) angår och vad (...) beträffar tyska förebilder (och föreligger även i danskan och holländskan $\left.{ }^{6}\right)$.

Till skillnad från de just nämnda uttrycken presenteras varken gällande, när det gäller eller vad (det) gäller som avseendemarkörer i SAOB - trots att verbet gälla i sig redan på 1500-talet uppvisar en allmän betydelse av 'vara fråga om, röra sig om, avse'. Att gällande saknas förvånar förstås inte, men däremot möjligen att varken när det gäller eller vad (det) gäller tas upp.

Liksom i de moderna ordböckerna beskrivs inte participet avseende som preposition i SAOB. Inte heller nämner man förbindelsen vad avser. Däremot framgår att verbalsubstantivet avseende i förbindelsen med (alt. $i$ ) avseende på använts åtminstone sedan 1700-talet. Det senare gäller även förbindelsen $i$ fråga om.

Av artiklarna om angående och beträffande framgår explicit att fraser som inleds med dessa ord kan fungera både attributivt (»efter subst.») och adverbiellt (»vid verb 1. adj.»), men även utgöra »en fristående förbindelse utan syntaktisk anslutning till ngt ord 1. uttryck i satsen» (identiskt formulerat i båda artiklarna). Det senare innebär i regel att uttrycket står vänsterdislokerat, dvs. före fundamentet i den följande satsen. Det framgår genom en hänvisning i artikeln beträffande till artikeln beträffa att denna möjlighet föreligger även för hvad beträffar.

I övriga fall är den syntaktiska beskrivningen inte lika explicit. Av de givna exemplen framgår dock att fraser med andra etablerade avseendemarkörer än de ovan nämnda som inledare kan uppträda med både attributiv och adverbiell funktion. Däremot ges i dessa artiklar inga ytterligare exempel på vänsterdislokerade topikfraser. Detta kan bero på att sådana saknas, men det behöver ju inte nödvändigtvis vara så.

\section{Material och metod}

Som framgått ovan bygger föreliggande studie på belägg som hämtats från Språkbankens pressmaterial. I avsnitt 2.1 diskuterar jag valet av korpusar, i avsnitt 2.2 redogör jag för excerperingsförfarandet och i avsnitt 2.3 för beräkningarna. Undersökningens akribi kommenteras kort i avsnitt 2.4.

${ }^{6}$ SAOB:s benämning; väl sannolikt liktydigt med nederländskan. 


\subsection{Korpusval}

Materialet till studien har primärt hämtats från 22 olika korpusar med blandat pressmaterial från början av 1900-talet och fram till 2013. Från de senaste decennierna har det varit möjligt att gruppera materialet $\mathrm{i}$ tre femårsperioder (1994-98, 2001-05, 2006-10) och en treårsperiod (2011-13), vilket ger sammantagna korpusar om 54-103 miljoner tokens för dessa perioder. Tidigare decennier är mera glest representerade. Dessa korpusar är också mycket mindre, från drygt en miljon tokens (Press 65) till drygt fem miljoner tokens (DN 1978). Detta har vissa konsekvenser för analysen, som jag återkommer till. Materialläget kan sammanfattas enligt följande:

- ORDAT: SvD:s årsbok 1923-45, 1948, 1958

- Press 65

- Press 76

- DN 1987

- GP 1994 + Press 95-98

- GP 2001-2005

- GP 2006-2010

- GP 2011-2013

1,53 miljoner tokens

1,12 miljoner tokens

1,35 miljoner tokens

5,12 miljoner tokens

60 miljoner tokens

103 miljoner tokens

93 miljoner tokens

54 miljoner tokens

Utöver detta material har jag för en kompletterande undersökning gjort sökningar i Aftonbladet från 1830-tal till 1860-tal, som finns tillgängliga i samlingen Kubhist bland Språkbankens historiska material (se vidare om detta i avsnitt 3).

Valet av pressmaterial faller sig naturligt av olika skäl. Tidningsprosa kan förväntas innehålla ett för resonerande skriftspråk representativt urval av olika avseendemarkörer. De texter som förekommer i dagstidningar är naturligtvis resonerande i olika hög grad, men blandningen av journalistiska genrer kan snarast anses främja just ett representativt urval. Det är också en fördel att det rör sig om texter skrivna av ett större antal författare, vilket innebär att man normalt inte behöver befara att t.ex. specifika skribenters stil får ett omotiverat genomslag. Naturligtvis kan man inte helt bortse ifrån att journalistiska stilideal eller det relativa utrymme som ägnas nyheter, kultur, sport etc. kan förändras över tiden och att det i någon mån kan påverka utfallet.

När det gäller korpusarna från 1965 och framåt är jämförbarheten i nämnda avseenden sannolikt så god man kan begära. Svenska Dagbladets årsbok ger ett mera formellt intryck, men har ändå bedömts som tjänlig för att förlänga perspektivet bakåt till förra halvan av 1900-talet. ${ }^{7}$

${ }^{7}$ Det kan också påpekas att jag helt och hållet har utgått ifrån sverigesvenskt textmaterial. Jag har, mot bakgrund av att Granvik \& Taimitarha (2014), som är finländare, utan kommentar inbegrep gällande i sin undersökning, i efterhand gjort kontrollsökningar på gällande i några av Språkbankens korpusar med finlandssvenska dagstidningar. Utan att gå in på detaljer tyder resultatet av dessa sökningar på att gällande som preposition faktiskt etablerades något tidigare i finlandssvenskan än i sverigesvenskan. 
En stor fördel med presskorpusarna från de senare decennierna är storleken. De olika avseendemarkörernas relativa frekvens varierar stort, dels sinsemellan, dels i enskilda fall över tiden. Också av denna anledning är det inte överdrivet att räkna frekvenser utifrån en samlad textmängd på 50 till 100 miljoner ord. Frågan är hur man ska förhålla sig till de tidigare, i detta sammanhang, små korpusarna.

Det finns två principiella problem när det gäller korpusarnas storlek. Det ena är förstås att felmarginalen för frekvensuppgifter ökar ju mindre korpusen är och kan vara än mer besvärande om de ord och uttryck man undersöker är lågfrekventa. Det andra problemet är mindre uppmärksammat, nämligen att det kan det vara komplicerat att jämföra relativa ordfrekvenser i material av mycket olika storlek. I takt med att en korpus utökas tillkommer hela tiden nya ord, vilket innebär att den relativa frekvensen, t.ex. räknad som förekomst per tusen eller en miljon ord, förändras för alla belagda ord. Dessutom förändras den på olika sätt för ord som är olika vanliga. Med ökande korpusstorlek planar skillnaden ut. Har man väl kommit upp i en viss korpusstorlek blir alltså utfallet någorlunda tillförlitligt och jämförbart. Men utfallet av en sökning i en korpus som befinner sig en bit under denna storlek kan vara svårt att jämföra med motsvarande sökning i en större korpus. ${ }^{8}$

Hur stor måste då korpusen vara för att frekvensen ska ha uppnått en någorlunda stabil nivå? Detta problem har jag för denna studies vidkommande försökt bestämma på ett förhållandevis praktiskt sätt. Utifrån de frekvenser jag räknat fram för olika avseendemarkörer förefaller det som om korpusen DN 87 med sina drygt fem miljoner tokens ger ett utfall som förfaller logiskt i jämförelse med de senare, mycket större korpusarna. I de mindre korpusarna, som täcker mellan en och en och en halv miljon tokens, uppträder många av avseendemarkörerna däremot med en misstänkt hög frekvens. När det gäller ORDAT-materialet kan detta delvis hänga samman med texternas formella karaktär, men också Press 65 och Press 76 visar höga frekvenser jämfört med de senare korpusarna.

För att ytterligare skaffa mig en uppfattning om korpusstorlekens betydelse för frekvensen har jag undersökt utfallet i korpusar av olika storlekar för fyra ord där man inte förväntar sig större tidsmässiga fluktuationer. Jag valde med

${ }^{8}$ Tack till Lars Borin, Språkbanken, som orienterat mig om detta och tipsat mig om Baayen: Word frequency distributions (2001). Denna bok har om inte annat gjort det klart för mig att analys av ordfrekvens är ett mycket komplicerat område. Efter samtal med statistiker har jag förstått att en mera sofistikerad statistisk analys av det material jag behandlar i denna studie skulle kräva betydligt större insats än den eventuella vinsten vore värd. Jag nöjer mig således här med både en förenklad beskrivning och ett förenklat analysförfarande. 
hjälp av Nusvensk frekvensordbok (del 1: Allén 1970) ut fyra ord som ligger på lite olika plats inom ett för denna studie relevant frekvensspann, nämligen fanns, helst, sida och stigit. Den relativa frekvensen (belägg per en miljon tokens) beräknades på följande material (i storleksordning): Press 65 (1,12 miljoner tokens), Press 76 (1,35 miljoner tokens), DN 87 (5,12 miljoner tokens), Press 96 (6,52 miljoner tokens), Press 95 (7,68 miljoner tokens), Press 98 (10,7 miljoner tokens), Press 97 (13,7 miljoner tokens), GP 1994 (21,3 miljoner tokens), GP 2011-13 (54 miljoner tokens), GP 2006-10 (93 miljoner tokens) och GP 2001-05 (103 miljoner tokens). Utfallet ses i figur 1.

Av figuren framgår att frekvensen i Press 65 är jämförelsevis mycket hög i tre av de fyra beräkningarna. I Press 76 är den lika hög för sida och klart förhöjd även för stigit. DN 87 däremot visar genomgående värden som ligger ganska nära dem som gäller i de stora korpusarna. Och även om man kan se fluktuationer i frekvens när det gäller det lägre korpusspannet, menar jag ändå att kontrollen visar att DN 87 går att jämföra med de större korpusarna när det gäller frekvensberäkningar.

Däremot bedömer jag att det finns anledning att inte ta med de tre äldsta korpusarna, dvs. ORDAT, Press 65 och Press 76, vid jämförelser mellan olika avseendemarkörers relativa frekvens. Det äldsta materialet kommer emellertid att

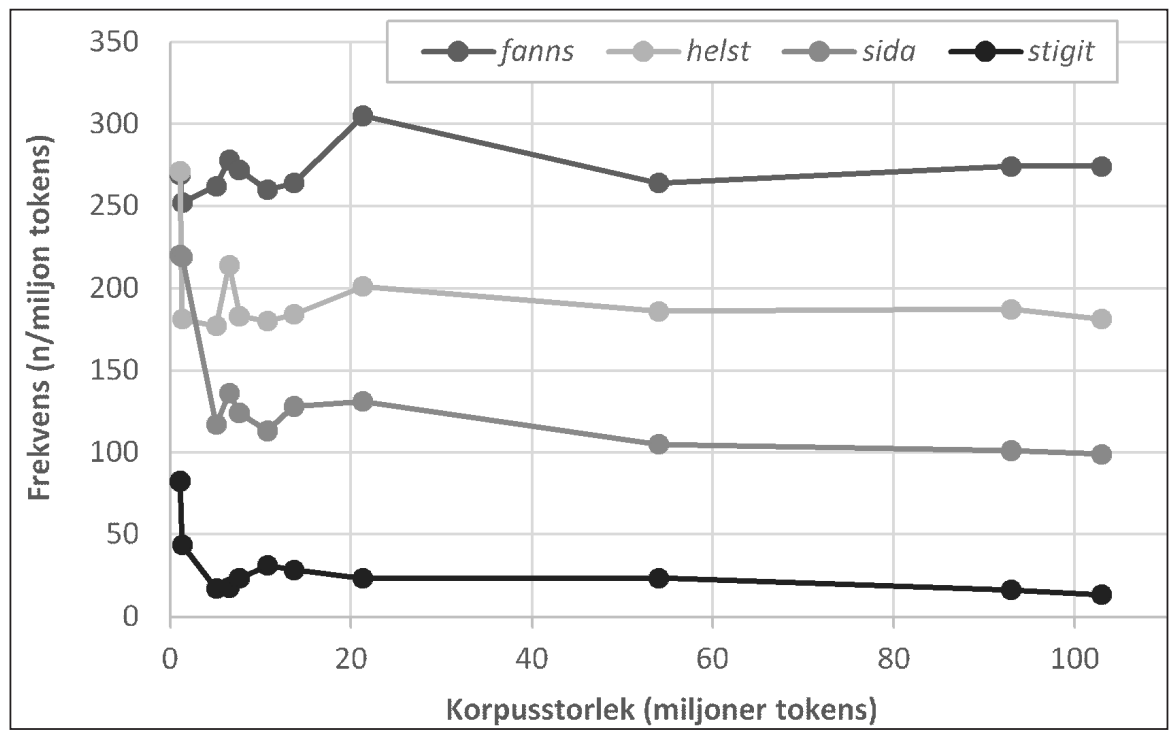

Figur 1. Den relativa frekvensen för orden fanns, helst, sida och stigit i korpusar av olika storlek. 
beaktas vid jämförelser av den procentuella fördelningen mellan olika avseendemarkörer inom de enskilda korpusarna. Också denna fördelning är mindre tillförlitlig i de mindre korpusarna än i de större, men om man vill studera huvudtendenserna fyller de en funktion.

\subsection{Excerpering och sortering av belägg}

Excerperingen av belägg har primärt gjorts med hjälp av sökverktyget Korp. Dessa sökningar har inte i något fall utnyttjat Språkbankens ordklasstaggning, som bedömts som alltför otillförlitlig för mina syften i detta sammanhang. Därmed har naturligtvis ett antal sökningar gett en rad träffar som inte är belägg på de eftersökta avseendemarkörerna, vilka då har måst sorteras ut manuellt $\mathrm{i}$ de filer där sökträffarna sparats. I de fall antalet belägg är mycket stort har utsorteringen gjorts med hjälp av sökning på utslagsgivande söksträngar och viss efterkontroll.

Följande gäller för utsorteringen av irrelevanta sökträffar:

- angående

- avseende

- beträffande

- gällande

- rörande

- $\operatorname{vad}(\ldots)$ angår

- vad avser
- Ingen manuell utsortering har gjorts.

- Träffar på avseende som substantiv har sorterats ut manuellt.

- Ingen manuell utsortering har gjorts.

- Träffar på gällande har sorterats ut manuellt när ordet fungerar som pre-nominalt attribut (som i gällande lag) och predikativ ( $x$ är gällande) samt i uttrycken göra gällande (att ...) och göra sig gällande, därutöver som efterställt attribut i betydelsen 'giltig' (ex.: en ny tidtabell, gällande från 15 januari).

- Träffar på rörande som adjektiv i betydelsen 'gripande' i attributiv, predikativ och adverbiell funktion (ex.: en rörande historia) samt som verbalt eller substantiverat particip med bibehållen konkret grundbetydelse (ex.: två timmars rörande i grytorna) har sorterats ut manuellt.

- Träffar på vad angår har sorterats ut i de fall vad har interrogativ betydelse (ex.: Vad angår det här mig?).

- Träffar på vad avser har sorterats ut i de fall vad har interrogativ betydelse (ex.: Vad avser du att göra härnäst?). 
- $\operatorname{vad}(\ldots)$ beträffar $\quad-$ Ingen manuell utsortering har gjorts.

- vad (det) gäller _ - Träffar på vad gäller har sorterats ut i de fall vad har interrogativ betydelse (ex.: Vad gäller saken?), primärt genom sökning på frågetecken.

Träffar på vad det gäller utan nominalt komplement har sorterats ut manuellt. I dessa fall har verbet sin absoluta betydelse (ex.: vad det gäller är ...; man måste veta vad det gäller).

- när det gäller

- Träffar på när det gäller utan komplement har sorterats ut, primärt genom sökning på gäller + komma/ punkt/frågetecken/utropstecken/citattecken/tankstreck samt på bäst/sämst när det gäller och när det gäller som.

- när det kommer till - Träffar på metaforen när det kommer till kritan har sorterats ut manuellt, liksom de belägg där det är referentiellt subjekt samt de belägg där det är expletivt subjekt som företrädare för postponerad att-sats (ex. när det kommer till min kännedom att ...).

- i fråga om

- Ingen manuell utsortering har gjorts.

- med avseende på

- Ingen manuell utsortering har gjorts.

Som förklaras nedan har en del beräkningar måst baseras på resultatet av denna första utsortering, vilken endast avser utrensning av irrelevanta sökträffar. Andra beräkningar utgår ifrån att också belägg som uppträder i identisk form två eller flera gånger i samma text uteslutits (se vidare nedan). Rent praktiskt har denna utrensning startat med att beläggen i varje text först sorteras i alfabetisk ordning, så att dubbletter uppträder i direkt följd och därmed relativt lätt kan upptäckas.

\subsection{Beräkningar}

Den kvantitativa analysen som behandlas i avsnitt 3 bygger på beräkningar av

- de olika avseendemarkörernas relativa frekvens (antal förekomster per en miljon tokens)

- fördelningen mellan olika avseendemarkörer inom enskilda korpusar

- fördelningen mellan olika avseendemarkörers olika komplement inom enskilda korpusar

- fördelningen mellan olika avseendemarkörer på fraser i olika syntaktiska positioner inom enskilda korpusar. 
När det gäller de relativa frekvenserna beräknas de, som framgått ovan, endast på materialet från DN 1987 och senare. Det är dessa beräkningar som baseras på antalet belägg inklusive dubbletter. I framför allt de senare korpusarna förekommer ganska många dubbletter (eller tripletter etc.). Detta hänger samman med att samma text kan förekomma i flera redigeringsversioner. Eftersom antalet tokens i materialet som helhet också inbegriper dessa olika textversioner, måste frekvensberäkningen utföras på alla relevanta förekomster inklusive dubbletterna.

I de övriga beräkningarna, som handlar om fördelningar inom enskilda korpusar, spelar korpusens totala antal tokens ingen roll. Dessa beräkningar utgår därför ifrån antalet belägg exklusive dubbletter.

\subsection{Akribi}

Det material som hanteras i undersökningen består av över 72000 belägg inklusive dubbletter och över 69000 belägg exklusive dubbletter. Med ett så stort material är det omöjligt att inom rimlig tid uppnå hundraprocentig korrekthet i alla beräkningar. Och även om den grammatiska taggningen bara har gjorts på ett delmaterial måste man även där räkna med en viss felmarginal, dels därför att också detta material trots allt är ganska stort och taggningen delvis måste göras via söktekniska knep, dels därför att det är svårt att alltid vara helt konsekvent $\mathrm{i}$ bedömningen av enskilda belägg.

Detta innebär emellertid inte något egentligt problem i sammanhanget; resterande fel och inkonsekvenser i sortering och taggning bör påverka resultaten av beräkningarna rätt marginellt (ofta endast på promille-nivå).

\section{Resultat}

I detta avsnitt presenteras resultatet av de beräkningar som beskrivs ovan. I avsnitt 3.1 redogörs för utvecklingen i stort; vinnare och förlorare i ett ganska kort och ett lite längre perspektiv identifieras. Avsnitt 3.2 handlar om de olika avseendemarkörernas grammatiska egenskaper och vad som utmärker en vinnare. 


\subsection{Vinnare och förlorare}

\subsubsection{Det korta perspektivet}

Redan i det korta perspektiv som korpusarna från 1987 till 2013 representerar kan man se några tydliga tendenser. Det finns, som nämnts, två nykomlingar: gällande och när det kommer till. Som framgår av figur 2 ligger gällande ett litet steg före i processen; när det kommer till är belagt en enda gång i DN 87.

Samtidigt som gällande och när det kommer till är på väg upp finns det några avseendemarkörer som tydligt är på väg ner, främst beträffande, i fråga om och vad (...) beträffar, se figur 3 .

Den verklighet som återspeglas i figurerna 2 och 3 visar emellertid bara ett mikroperspektiv. Om man tar alla avseendemarkörer i beaktande måste man konstatera att det är två varianter som är överlägset mycket vanligare än de övriga, nämligen när det gäller och vad (det) gäller. Som framgår av tabell 1 varierar den relativa frekvensen stort mellan olika avseendemarkörer. När det gäller är faktiskt vanligare än samtliga de övriga tillsammans. Det näst vanligaste uttrycket, vad (det) gäller, uppvisar en frekvens som är ungefär en fjärdedel av den för när det gäller, men samtidigt betydligt högre än övriga uttrycks frekvenser. Det står också klart att vissa avseendemarkörer är tämligen blygsamt belagda i materialet.

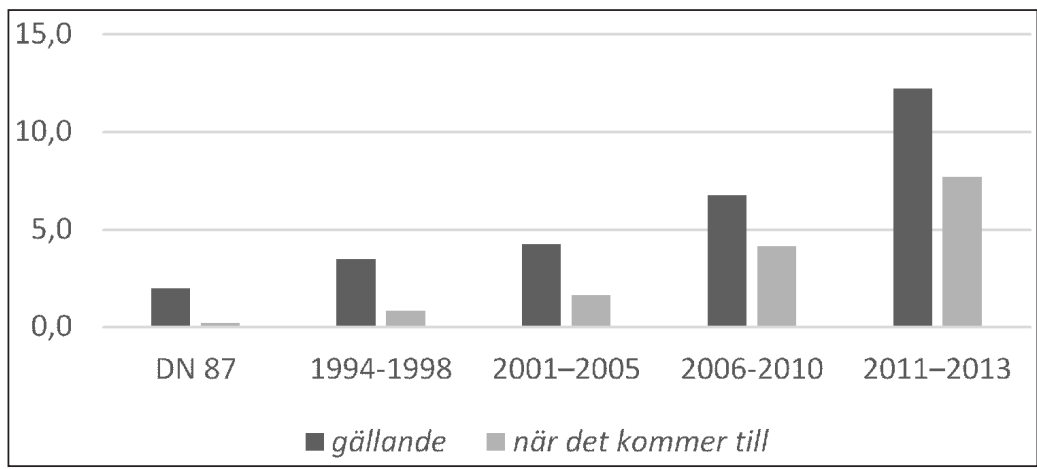

Figur 2. Den relativa frekvensen för gällande och när det kommer till 19872013. Antal belägg per en miljon tokens. 


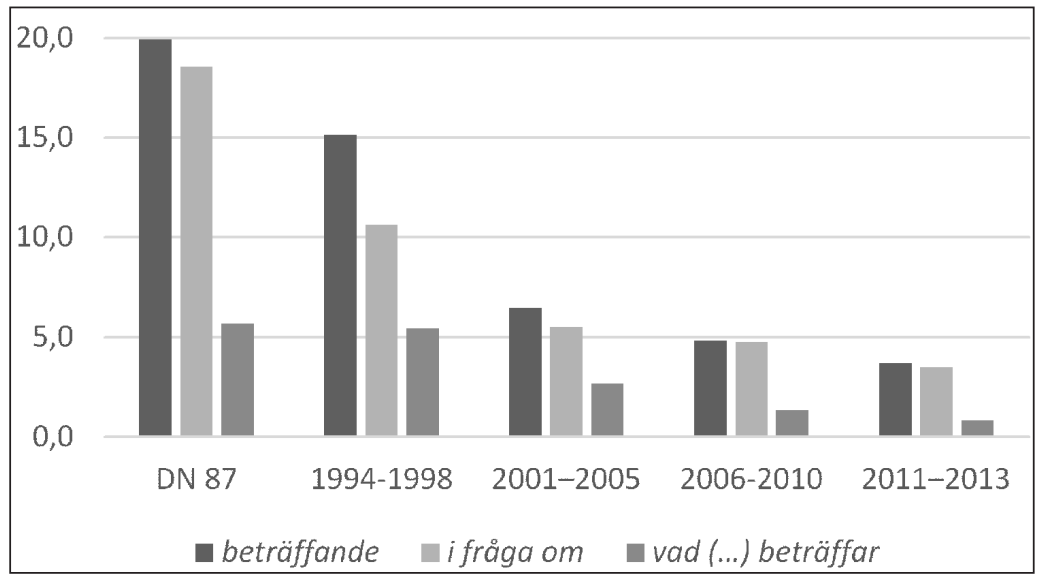

Figur 3. Den relativa frekvensen för beträffande, i fråga om och vad (...) beträffar 1987-2013. Antal belägg per en miljon tokens.

Tabell 1. Den relativa frekvensen för samtliga avseendemarkörer. Antal belägg per en miljon tokens.

\begin{tabular}{lrrrrr}
\hline & & $1994-$ & $2001-$ & $2006-$ & $2011-$ \\
& DN 87 & 1998 & 2005 & 2010 & 2013 \\
\hline angående & 8,4 & 10,9 & 10,9 & 10,8 & 14,1 \\
avseende & 0,6 & 3,0 & 3,2 & 3,0 & 3,1 \\
beträffande & 19,9 & 15,2 & 6,5 & 4,8 & 3,7 \\
gällande & 2,0 & 3,5 & 4,2 & 6,7 & 12,2 \\
rörande & 5,5 & 7,2 & 5,5 & 5,4 & 5,9 \\
vad (..) angår & 0,2 & 0,2 & $<0,1$ & 0,0 & 0,0 \\
vad avser & 1,2 & 1,0 & 0,6 & 0,4 & 0,6 \\
vad (..) beträffar & 5,7 & 5,4 & 2,7 & 1,3 & 0,8 \\
vad (det) gäller & 36,1 & 44,1 & 38,1 & 34,0 & 31,7 \\
när det gäller & 134,8 & 146,9 & 137,0 & 139,4 & 127,6 \\
när det kommer till & 0,2 & 0,8 & 1,6 & 4,1 & 7,7 \\
i fråga om & 18,6 & 10,6 & 5,5 & 4,8 & 3,5 \\
med avseende på & 0,4 & 1,1 & 1,2 & 0,9 & 0,6 \\
\hline
\end{tabular}

\subsubsection{Ett lite längre perspektiv}

Eftersom korpusarna före 1987 inte är tillräckligt stora för att beräkna relativa frekvenser som är jämförbara med de senare korpusarnas är tidsperspektivet i föregående avsnitt mycket kort. En viss uppfattning om utvecklingen på lite längre horisont kan man däremot få genom att jämföra de olika avseendemarkörernas andelar inom respektive korpus. Dessa presenteras i tabell 2 . 
Tabell 2. Den procentuella fördelningen mellan de olika avseendemarkörerna i de olika korpusmaterialen. I de fall en avseendemarkör är belagd men andelen understiger $1 \%$ markeras det med $<1$. En nolla innebär att belägg helt saknas.

\begin{tabular}{lrrrrrrrr}
\hline & $\begin{array}{c}\text { ORDAT } \\
(\%)\end{array}$ & $\begin{array}{r}\text { P 65 } \\
(\%)\end{array}$ & $\begin{array}{r}\text { P76 } \\
(\%)\end{array}$ & $\begin{array}{r}\text { DN 87 } \\
(\%)\end{array}$ & $\begin{array}{c}94-98 \\
(\%)\end{array}$ & $\begin{array}{c}01-05 \\
(\%)\end{array}$ & $\begin{array}{c}06-10 \\
(\%)\end{array}$ & $\begin{array}{c}11-13 \\
(\%)\end{array}$ \\
\hline angående & 6 & 4 & 5 & 4 & 4 & 5 & 5 & 7 \\
avseende & 2 & $<1$ & $<1$ & $<1$ & 1 & 1 & 1 & 1 \\
beträffande & 28 & 16 & 12 & 8 & 6 & 3 & 2 & 2 \\
gällande & $<1$ & 1 & 1 & $<1$ & 1 & 2 & 3 & 6 \\
rörande & 20 & 5 & 4 & 2 & 3 & 3 & 2 & 3 \\
vad $(\ldots)$ angår & 3 & 2 & $<1$ & $<1$ & $<1$ & $<1$ & 0 & 0 \\
vad avser & 0 & $<1$ & $<1$ & $<1$ & $<1$ & $<1$ & $<1$ & $<1$ \\
vad $(\ldots)$ beträffar & 12 & 9 & 5 & 2 & 2 & 1 & $<1$ & $<1$ \\
vad (det) gäller & $<1$ & 4 & 9 & 15 & 18 & 18 & 16 & 15 \\
när det gäller & 3 & 40 & 53 & 58 & 59 & 63 & 65 & 60 \\
när det kommer till & 0 & 0 & 0 & $<1$ & $<1$ & $<1$ & 2 & 4 \\
ifråga om & 22 & 19 & 9 & 8 & 4 & 3 & 2 & 2 \\
med avseende på & 3 & 1 & $<1$ & $<1$ & $<1$ & $<1$ & $<1$ & $<1$ \\
\hline
\end{tabular}

När man förlänger perspektivet på detta sätt får man en bild av det tidiga 1900-talet som kan förvåna. I ORDAT-korpusen är det inte alls när det gäller och vad (det) gäller som dominerar. Dessa uttryck är där tvärtom rätt ovanliga. I stället är det beträffande som är den vanligaste avseendemarkören med en andel av $28 \%$, tätt följd av i fråga om på $22 \%$ och rörande på $20 \%$. Samtliga dessa sjunker därefter gradvis till dagens låga andelar mellan 2 och $3 \%$. Uttrycket vad (...) beträffar, som nu i stort sett är helt försvunnet, är också förhållandevis vanligt i ORDAT med en andel på $12 \%$. När det gäller och vad (det) gäller gör den motsatta karriären, framför allt det förra uttrycket närmast exploderar under andra halvan av förra seklet och tycks ha landat någonstans runt $60 \%$.

Med tanke på att texterna i ORDAT-korpusen ger ett betydligt formellare intryck än texterna i de senare korpusarna kan man förstås fråga sig om utfallet för denna korpus snarast är en fråga om stil. De delvis dramatiska skillnaderna talar dock emot den hypotesen; stilskillnader kan spela in, men inom vissa gränser. För övrigt faller siffrorna för Press 65 och Press 76 väl in mellan dem för ORDAT och DN 87, vilket styrker den allmänna bild som tabell 2 antyder.

För en modern språkbrukare kan det emellertid förefalla anmärkningsvärt att de nu i särklass vanligaste avseendemarkörerna spelade en så blygsam roll för bara sjuttio år sedan. För att ytterligare undersöka rimligheten i detta har jag sökt efter när det gäller och hvad (det) gäller i några av Språkbankens tidnings- 
korpusar från 1800-talet, nämligen Aftonbladet från 1830-tal till 1860-tal. ${ }^{9}$ Sammantaget består de fyra korpusarna av ca 200 miljoner tokens, och totalt uppvisar dessa 290 belägg på avseendemarkören när det gäller, vilket innebär en relativ frekvens om 1,45 per miljon tokens. En så låg förekomst tyder på att när det gäller var en novation ungefär vid sekelskiftet 1800. Sökningen på hvad (det) gäller resulterade inte i några belägg alls, vilket talar för att denna avseendemarkör kanske uppstått runt nästa sekelskifte, dvs. omkring 1900.

\subsubsection{Vinnare och förlorare - en summering}

Genomgången ovan visar vinnare och förlorare bland avseendemarkörerna i ett kort och ett halvlångt perspektiv. Man kan se att gällande och när det kommer till går stadigt framåt i det korta perspektivet. Men dessa uttryck har ännu inte hunnit så långt i sin karriär.

I ett lite längre perspektiv kan man se att flera tidigare dominerande uttryck - beträffande, rörande, vad (...) beträffar och i fråga om - är på reträtt, delvis nästan borta. I gengäld har när det gäller och vad (det) gäller kommit på bred front.

Vissa uttryck, nämligen avseende, vad avser, vad (...) angår och med avseende $p a ̊$, har under hela den period som undersökningen täcker spelat en marginell roll. (Intressant nog gäller det alltså alla de uttryck som utgår ifrån verbet avse.) Dessa uttryck kan ha varit vanligare tidigare, men det behöver förstås inte vara så.

\subsection{Vad utmärker en vinnare?}

\subsubsection{Avseendemarkörernas komplement}

Avseendemarkörer kan i varierande omfattning ta som komplement vanliga nominalfraser, nominala bisatser och att-inledda infinitivfraser, se de respektive fetstilta leden i $(7 \mathrm{a}-\mathrm{c})$.

(7) a. Vad utlandsresandet angår, står man inför en revolution av de franska levnadsvanorna. (Press 65)

b. Det finns inga föreskrifter angående hur höga strålvärden de får ha. (GP 2002)

c. Danskarna ligger långt före svenskarna när det kommer till att skriva manus. (GP 2005)

\footnotetext{
${ }^{9}$ Språkbankens presskorpusar från 1800-talet är maskininlästa men (i skrivande stund) inte vidare bearbetade. Detta innebär vissa problem som har förhindrat mig att generellt utsträcka denna undersökning till 1800-talet.
} 
I tabell 3 redovisas för de i modern svenska nio vanligaste avseendemarkörerna andelen nominalfraskomplement (NF), bisatskomplement (BS) och infinitivkomplement (IF) i materialets tre sista korpusar, dvs. GP 2011-2013. De uttryck som redovisas är i detta material representerade med ett antal belägg från 137 (avseende) till 5300 (när det gäller). De uttryck som inte redovisas uppvisar som mest endast 44 belägg i de tre korpusarna tillsammans. Beräkningarna för när det gäller avser här endast denna exakta fras, dvs. inbegriper inte de varianter som inleds med $d a ̊$ eller som har verbet i preteritum. På motsvarande sätt avser beräkningarna för vad gäller inte varianter med expletivt det och/eller preteritum.

Tabell 3. Procentandelen nominalfras-, bisats- och infinitivfras-komplement i GP 2011-2013 för de nio vanligaste avseendemarkörerna.

\begin{tabular}{lccc}
\hline $\begin{array}{l}\text { Avseendemarkör } \\
(\mathrm{n})=\text { beräkningsunderlag }\end{array}$ & $\begin{array}{c}\mathrm{NF} \\
(\%)\end{array}$ & $\begin{array}{c}\mathrm{BS} \\
(\%)\end{array}$ & $\begin{array}{c}\mathrm{IF} \\
(\%)\end{array}$ \\
\hline angående (615) & 93 & 6,5 & 0,3 \\
avseende $(137)$ & 99 & 1,5 & 0,0 \\
beträffande $(180)$ & 97 & 2,8 & 0,0 \\
gällande (528) & 97 & 2,7 & 0,6 \\
rörande (255) & 98 & 2,0 & 0,0 \\
vad gäller (1 274) & 97 & 0,7 & 1,9 \\
när det gäller $(5$ 300) & 88 & 2,3 & 9,2 \\
när det kommer till (351) & 88 & 1,4 & 11,1 \\
i fråga om $(164)$ & 94 & 2,4 & 3,7 \\
\hline
\end{tabular}

Som framgår av tabell 3 är det ovanligt att särskilt de participformade avseendemarkörerna tar infinitivkomplement. Bland participen utmärker sig däremot angående genom en förhållandevis hög andel (6,5 \%) bisatskomplement. Generellt sett är bisatskomplement annars inte så vanliga. Ett bidrag till den möjligen förvånansvärt höga andelen angående med bisatskomplement kan vara en förkärlek för denna preposition när man refererar hur någon kommenterar ett förhållande, en händelse eller en diskussionspunkt som måste återges med en hel sats, se t.ex. (8a). Ibland förkommer angående även i icke-satsformade meningar som den i (8b), som man kan misstänka är en förklaring efter ett återgivet citat.

(8) a. "Nu gäller det att stå på egna ben», säger han angående att föreningen inte längre får EU-bidrag till sin verksamhet. (GP 2013)

b. Restaurang Sjömagasinets ägare angående att man återerövrat sin prestigefulla stjärna i Guide Michelin. (GP 2013) 
Det kanske intressantaste resultatet i tabell 3 är emellertid att både när det gäller och när det kommer till har en i sammanhanget hög andel infinitivkomplement, 9,2\% respektive $11,1 \%$. Går man hela vägen tillbaka till 1800-talsmaterialet visar det sig dessutom att andelen för när det gäller i själva verket har varit mycket högre. I 1800-talsmaterialet ligger den på $40 \%$ för att sedan sjunka successivt till dagens nivå, se figur 4 . Man kan därmed tänka sig att just benägenheten att ta infinitivkomplement kan ha varit en viktig egenskap för att bana väg för detta uttrycks inträde bland avseendemarkörerna. I figur 4 redovisas även utvecklingen för när det kommer till från perioden 1994-98 och framåt. Denna avseendemarkör ser inte ut att ha startat på samma sätt som när det gäller. Bara 2 av de 50 första beläggen t.o.m. 1998 (ett vardera i Press 96 och Press 97) har infinitivkomplement.

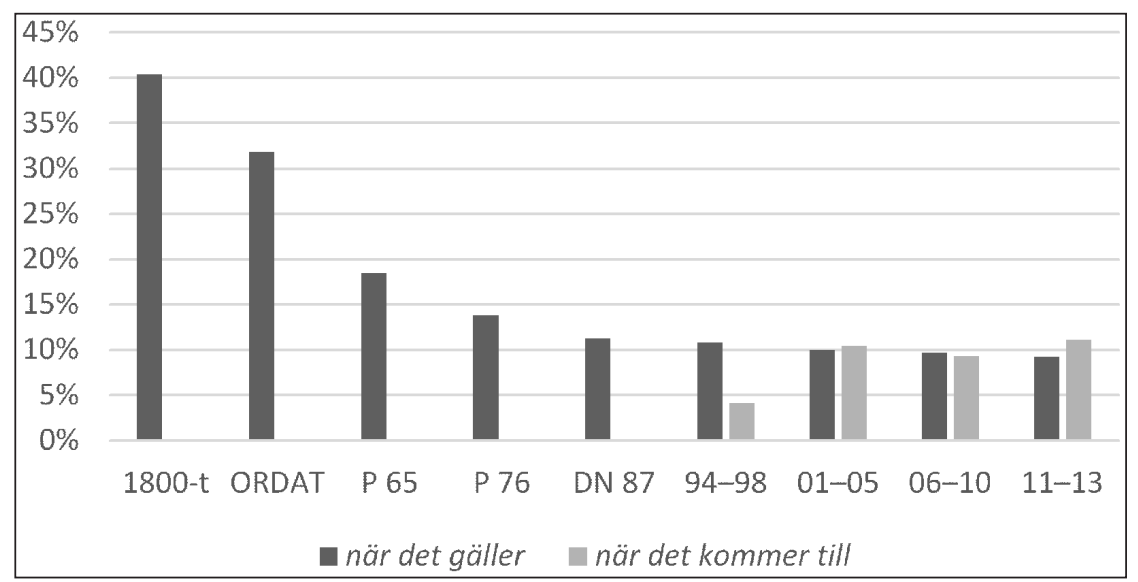

Figur 4. Andelen infinitivkomplement för när det gäller och när det kommer till i de olika korpussamlingarna.

Att både när det gäller och när det kommer till tycks ha landat på en nivå av ungefär $10 \%$ infinitivkomplement kan tyda på att det är en naturlig andel för en avseendemarkör som utan problem kan ta alla typer av komplement.

\subsubsection{Avseendefrasernas syntaktiska funktioner}

Som framhållits ovan kan de fraser som inleds av avseendemarkörer fungera både som attribut och adverbial. Det är emellertid inte alltid så enkelt att avgöra när man ska räkna med det ena eller det andra. I (9a) återges ett belägg från materialet, där frasen $i$ fråga om tolerans är tvetydig i detta avseende. Man kan 
t.ex. spela med ledföljden och placera den nämnda frasen ensam i fundamentet som i (9b); i så fall skulle den klassas som adverbial. Men det går lika bra att som i (9c) sätta den längre sekvensen några föredömen i fråga om tolerans $\mathrm{i}$ fundamentet; i det fallet skulle avseendefrasen betraktas som ett attribut till $f \ddot{o}$ redömen.

(9) a. Dessa immigranter var dock knappast [...] några föredömen i fråga om tolerans. (Press 65)

b. I fråga om tolerans var dessa immigranter dock knappast några föredömen.

c. Några föredömen $i$ fråga om tolerans var dessa immigranter dock knappast.

Den mycket stora andelen tvetydiga belägg gör det mer eller mindre omöjligt att med hjälp av en regelrätt syntaktisk analys utröna hur olika avseendefraser fördelar sig på olika funktioner. Samtidigt är det förstås intressant att få någon uppfattning om hur fraserna förhåller sig till varandra härvidlag, utifrån hypotesen att en vinnande avseendemarkör bör ha en allsidig användning. För detta ändamål har därför en förenklad analys gjorts, som i stort utgår ifrån en mekanisk sortering av avseendefrasernas placering i satsen.

För att få ett övergripande mått på avseendefrasers tendens att fungera attributivt har sådana avseendefraser som står efter substantiv (exklusive egennamn) och i direkt anslutning till dessa kategoriserats som »Post-N». Undantag har dock gjorts för fraser efter substantiv som ingår i vissa konventionaliserade uttryck, t.ex. ligga i framkant(en)/täten/toppen/botten, lägga åt sidan, se genom fingrarna, sätta ner foten, byta fot, spela en (...) roll, ord står mot ord, till exempel, $i$ alla fall. Avseendefraserna är i dessa fall knappast attribut till det föregående substantivet och undantas eftersom de inte så sällan ansluter just till uttryck av den nämnda typen. I övrigt är sorteringen helt mekanisk. Långt ifrån alla fraser som klassats som post-N är attribut, vilket i någon mån uppvägs av att det å andra sidan också finns attributiva fraser som inte fångas genom metoden. Men osäkerheten är hög, och poängen är helt enkelt endast att stora skillnader i andelen Post-N-fraser inledda med olika avseendemarkörer trots allt bör avspegla skillnader i deras benägenhet att fungera attributivt.

Vid sidan om kategoriseringen som Post-N noteras för de olika avseendefraserna hur stor andel som är adverbial i fundamentspositionen, som i (10a), samt hur stor andel som används som fria topikfraser, dvs. dislokerade till vänster om fundamentet, som i (10b). Förekomst i dessa positioner säger naturligtvis en del om vilka av uttrycken som gärna används som »topikmarkörer», men samtidigt är det ett tecken på frasernas adverbiella karaktär. Fraser som inte fal- 
ler inom någon av de tre nämnda kategorierna klassas som »övriga»; dessa kan vara såväl adverbiella som attributiva.

(10) a. När det gäller bostadsrätter är det föreningen som bestämmer. (GP 2013)

b. Angående fransmännen; vem har sagt att de är så kloka? (GP 2002)

I tabell 4 redovisas hur fraser som inleds med de i dagens svenska nio vanligaste avseendemarkörerna fördelas på de olika syntaktiska positionerna i GP 2011-13. Som i föregående avsnitt har de mindre vanliga varianterna till vad gäller och när det gäller utelämnats ur undersökningen.

Tabell 4. Procentuell fördelning på syntaktiska positioner i GP 2011-13 för fraser inledda med de nio vanligaste avseendemarkörerna. Post-N = ställning i direkt anslutning till ett substantiv, $\mathrm{Fu}=$ fundamentsplacerat adverbial, Fri topik $=$ vänsterdislokerat fritt topikled.

\begin{tabular}{lcccc}
\hline $\begin{array}{l}\text { Inledande avseendemarkör }(\mathrm{n})= \\
\text { beräkningsunderlag }\end{array}$ & $\begin{array}{c}\text { Post-N } \\
(\%)\end{array}$ & $\begin{array}{c}\text { Fu } \\
(\%)\end{array}$ & $\begin{array}{c}\text { Fri topik } \\
(\%)\end{array}$ & $\begin{array}{c}\text { Övriga } \\
(\%)\end{array}$ \\
\hline angående (615) & 52 & 7 & 8 & 33 \\
avseende $(137)$ & 73 & 2 & 0 & 25 \\
beträffande $(180)$ & 39 & 28 & 4 & 28 \\
gällande $(528)$ & 68 & 5 & 1 & 26 \\
rörande (255) & 79 & 1 & 0 & 20 \\
vad gäller $(1274)$ & 36 & 20 & 0 & 44 \\
när det gäller (5 300) & 31 & 30 & 0 & 39 \\
när det kommer till (351) & 30 & 27 & 0 & 43 \\
i fråga om $(164)$ & 35 & 11 & 0 & 54 \\
\hline
\end{tabular}

Som framgår av tabellen står fraser som inleds med de participformade avseendemarkörerna oftare i Post-N-positionen än övriga uttryck, vilket är logiskt om man utgår ifrån att de har sitt ursprung i efterställda attributiva particip och fortsatt prioriterar den attributiva funktionen. Fraser som inleds med beträffande avviker dock från de övriga genom en mera varierad fördelning. Uppenbarligen används dessa gärna även som adverbial. Detta kan ha underlättats av att verbet beträffa egentligen endast överlevt i uttrycken beträffande och vad (...) beträffar, vilka därigenom möjligen fått »leva sitt eget liv». De är dock svårt att visa om så verkligen är fallet. Oavsett orsaken till beträffande-frasernas varierade användning, så ligger det nära till hands att se den som en förutsättning för den dominerande ställning bland avseendemarkörerna som beträffande tidigare haft.

Några av participuttrycken utmärker sig också genom att förekomma i fria topikfraser, vilket andra typer av avseendemarkörer sällan gör. (Belägg på 
detta saknas helt i materialet från 2011-13.) Inte minst gäller det angående som fătt en särskild roll i ärenderubriceringar; i pressmaterialet dyker uttrycket upp t.ex. som rubrik till insändare. Förklaringen påminner en del om den som ovan getts till fenomenet att samma preposition jämförelsevis ofta tar bisatskomplement.

I övrigt är det beträffande och, i någon mån, gällande som förekommer i fria topikled. Med tanke på att prepositionen gällande är relativt ny kan man tänka sig att den är stadd i utveckling och att gällande-fraser rör sig mot en syntaktisk fördelning som liknar den beträffande-inledda fraser har idag (och som de mer eller mindre tycks ha haft under hela undersökningsperioden).

Fraser som inleds med de fyra icke-participformade avseendemarkörerna uppträder både som attribut och som adverbial. Intressant nog gäller detta även fraser som inleds med den tämligen nya avseendemarkören när det kommer till, för vilka det är lätt att tänka sig en rent adverbiell start och där man därför kanske hade förväntat sig en lägre andel post-N. En närmare titt på när det kommer till-fraser i post-N-position i hela materialet visar emellertid att andelen stadigt ökar från 12 \% i korpusarna från 1994-98 till de 30 \% som redovisas för 201113 i tabell 4. Det tyder på en utomordentligt stark och snabb etablering av uttrycket som avseendemarkör.

Siffrorna för tiden före 2011-13 bekräftar också att när det kommer till-fraser verkligen startat som adverbial, dessutom som adverbial i fundamentet.

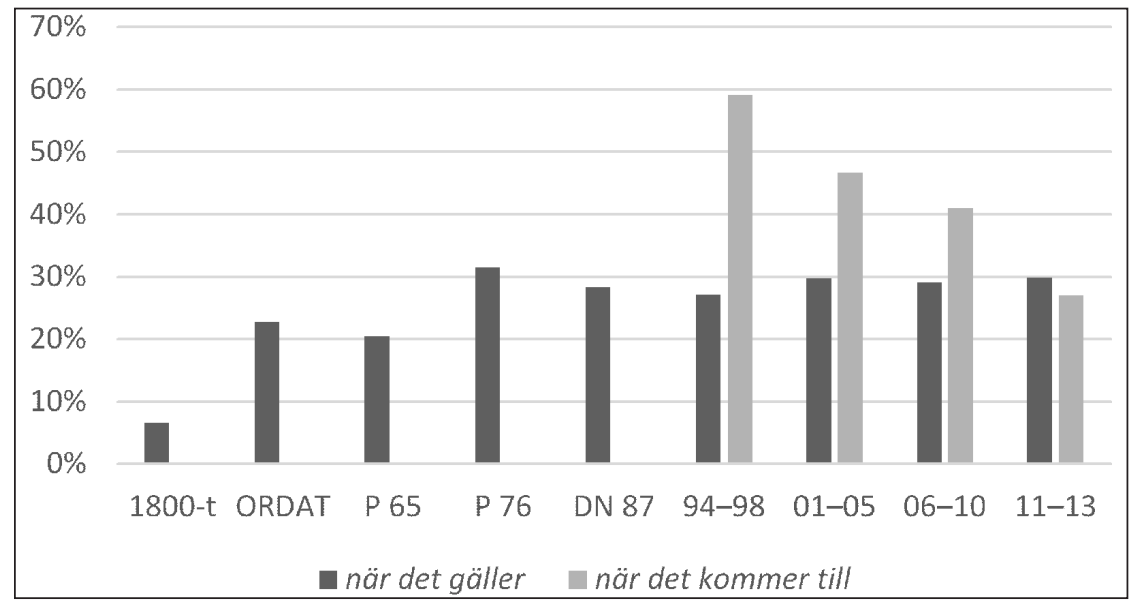

Figur 5. Andelen fundamentsplacerade adverbial för fraser som inleds med när det gäller och när det kommer till i de olika korpussamlingarna. 
Man kan i detta avseende jämföra utvecklingen med fraser inledda med när det gäller, se figur 5 där andelen fundamentsplacerade adverbial för fraser inledda med när det gäller respektive när det kommer till redovisas. Här framgår att när det gäller-fraserna inledningsvis inte så ofta förekom som fundament, medan när det kommer till-fraserna företrädesvis hade just denna position när de först dök upp. Skärskådar man beläggen ytterligare visar det sig att det enda belägget i DN 87 och samtliga nio i GP 1994 var av detta slag.

Som framgår av figur 5 tycks när det gäller-fraserna ha landat på en andel mellan 25 och $30 \%$ adverbialsfundament. Samma andel gäller för när det kommer till-fraserna i de senaste av de undersökta korpusarna - och även för beträffande-fraser (jfr tabell 4). Det finns därmed kanske anledning att tro att denna nivå är den naturliga för en avseendemarkör som lika gärna inleder attributiva som adverbiella fraser och att den nedåtgående trenden för när det kommer till nu kommer att plana ut.

\subsubsection{Vad utmärker en vinnare? - en summering}

Den dominerande avseendemarkören i modern svenska, när det gäller, utmärker sig dels genom att gärna ta infinitivfraser som komplement, dels genom att fraser inledda med detta uttryck fungerar väl i olika syntaktiska positioner och också relativt ofta används som topikaliserat adverbial. Infinitivkomplement förekommer numera utan problem även med när det kommer till, men är i övrigt ovanliga, i synnerhet efter de participformade avseendemarkörerna. Det senare uttrycket liknar det förra även genom en liknande spridning på syntaktiska positioner.

De båda nämnda uttrycken är alltså formellt ganska lika, men tycks ha startat på olika sätt: när det gäller kan en gång ha tagit sig in på arenan just genom att ta infinitivkomplement, medan när det kommer till ursprungligen i huvudsak förekom i topikfraser. Man får av figurerna 4 och 5 intrycket att när det gäller landat i andelar som står i direkt proportion till uttrycksbehoven beträffande infinitivkomplement och som inledare av topikfraser under senare delen av 1900-talet, medan när det kommer till raskt närmat sig samma nivåer under den korta tid uttrycket varit aktuellt som avseendemarkör i svenskan.

Bland de participformade prepositionerna utmärker sig den tidigare så dominerande beträffande som mindre bunden till attributiva fraser än de övriga. Dess andel som inledare av topikaliserade adverbial är i paritet med andelen för när det gäller och när det kommer till. 
En egenskap som talar till de participiella uttryckens fördel är att de, åtminstone ett par av dem, lättare än de övriga avseendemarkörerna tycks fungera bra som inledare av fria topikfraser. I första hand beträffande och - i särskilt hög grad - angående används så. Även gällande förekommer i dessa fraser, men (så långt materialet sträcker sig) i mera begränsad omfattning.

\section{Slutsatser och kommentarer}

\subsection{Ett dynamiskt fält med många spelare}

Resultaten av undersökningen visar tydligt att avseendemarkörer kommer och går. Det gör de till och med i så hög grad att det inte är oproblematiskt att studera fältet »markera avseende» utan att anlägga ett diakront perspektiv. Mina siffror för angående, beträffande, gällande och rörande för perioden 1994-98 visar ungefär samma inbördes fördelning som Granvik \& Taimitarha (2014) fann för samma ord i PAROLE-korpusen, även om beträffande i mitt material inte är fullt så dominerande som i PAROLE och angående något vanligare än rörande (i PAROLE är de ungefär lika vanliga); gällande svarar för en relativt blygsam andel i båda materialen. Men ett decennium senare ser det helt annorlunda ut. Redan i början av 00-talet har beträffande tappat stort. Och perioden 2011-13 visar det omvända styrkeförhållandet mellan beträffande och gällande jämfört med 1994-98.

Samtidigt består vissa skillnader mellan orden. Granvik \& Taimitarha (2014 s. 284) finner att angående i högre grad än övriga används vid ord för kommunikation, vilket rimmar väl med min iakttagelse att denna prepositions höga andel bisatskomplement kan hänga samman med att den gärna används när någon kommenterar en omständighet som refereras med en hel bisats (jfr avsnitt 3.2.1 och exempel (8a)). Sådana subtila drag hos enskilda uttryck kan innebära att de intar en egen liten nisch i systemet och kvarstår utan att i så hög grad breda ut sig på andras bekostnad.

Granvik \& Taimitarha (2014 s. 283 f.) konstaterar också att gällande används ungefär som beträffande, fastän mycket mer sällan - och företrädesvis som attribut, medan beträffande är vanligt även i adverbiell ställning. Ett skäl till den låga andelen gällande skulle kunna vara, resonerar författarna, att detta ord (olikt beträffande) inte bara är en preposition, utan också används som adjektiv och verbalt particip. Den senare utvecklingen visar emellertid att den förklaringen knappast håller; numera föredras gällande i många fall. 
Intressant nog visar emellertid beträffande fortsatt en större benägenhet än gällande att inleda adverbial, gärna i fundamentet. Detta behöver nu inte vara bestående, men det aktualiserar en annan sida av avseendemarkörernas utbytbarhet. Det stora fallet för beträffande startade sannolikt i mitten av det förra seklet; andelen i 90-talstexterna är bara en bråkdel av den man finner i ORDAT-korpusen med texter från förra halvan av 1900-talet. Men detta fall beror inte på att beträffande ersatts med en annan participformad preposition, utan på att (främst) när det gäller, som ofta inleder adverbiella fraser och gärna står i satsinitial position, kommit på bred front. I ORDAT-korpusen svarar beträffande tillsammans med rörande, i fråga om och vad (...) beträffar för $82 \%$ av alla belägg på avseendefraser, medan när det gäller tillsammans med vad (det) gäller används i 75 \% av fallen i GP 2011-13 (jfr tabell 2).

En så dramatisk ommöblering bland spelarna på fältet »markera avseende» hade knappast varit möjlig om uttrycken inte kunde tillmätas en mycket stor semantisk och funktionell överlappning. Deras formella uppbyggnad - om det rör sig om ett före detta particip, en finit bisatsinledning eller en komplex preposition (enligt mönstret preposition + substantiv + preposition) - tycks inte vara ett hinder för att utveckla en bred användningspotential. I många fall kan uttryck av olika form utan vidare ersätta varandra.

\subsection{Hur uppstår och utvecklas en avseendemarkör?}

Det framhölls inledningsvis att grammatikalisering spelade en stor roll vid uppkomsten av olika avseendemarkörer. Men grammatikalisering är inte den enda möjliga förklaringen.

För komplexa prepositioner som bygger på mönstret preposition + substantiv + preposition kanske man helt enkelt kan nöja sig med att tala om uttrycken som lexikaliserade. I SAG (del 2 s. 716, 718 f.) används termen lexikalisering även om avseendemarkörer av de andra typerna, vilket väl kan försvaras om man endast ser på lexikalisering som uppkomsten av nya lexikonenheter (jfr Svanlund 2002 s. 41), men jag ser en viss skillnad i hur detta gått till. Uttryck som i fråga om och med avseende på kan ses som produktivt bildade fraser som stelnat och egentligen inte så mycket mer, till skillnad från exempelvis rörande och gällande, för vilka man måste räkna med en omtolkning från verbalt particip till preposition (dvs. en grammatikalisering).

En annan möjlighet är att helt enkelt importera avseendemarkörer eller åtminstone bilda dem på utländsk förebild. Det tyska inflytandet gör sig gällande i både angående och beträffande och motsvarande finita uttryck vad (...) angår 
och vad (...) beträffar. Att komplementet i de senare uttrycken kan stå före verbet kan också hänga samman med det tyska ursprunget, men skulle också kunna förklaras som en så kallad kilkonstruktion.

Ett intressant drag beträffande de finita vad-inledda uttrycken är att man egentligen rent formellt skulle förvänta sig en preposition före $v a d$, företrädesvis $i$. - Utan preposition är dessa uttryck, strukturellt sett, så kallade fria relativsatser. En preposition skulle göra dem till prepositionsfraser, vilket skulle stå i bättre samklang med hur de används. - Men det är mycket ovanligt att vad föregås av en preposition och förekommer i mitt material aldrig vid verben angå och beträffa. Däremot finns det nio belägg på motsvarande uttryck med gälla, t.ex. det i (11a), och ett belägg på $i$ vad avser, i ett pastischartat citat ur Grönköpings Veckoblad, se (11b).

(11) a. Stora teatern hade återigen försprång $i$ vad det gäller aktualiteter: [...] (ORDAT: 1930)

b. [...] och finnes för dagen egentl. föga övrigt att tillönska sig, åtm. $i \mathrm{vad}$ avser en lika färgrik som vidsträckt flora [...] (Press 98)

Den regelmässiga avsaknaden av preposition i de finita avseendemarkörerna som inleds med vad talar för att mönstret som sådant är fast förankrat i vår språkliga repertoar. Möjligen är det importerat från början, men det fungerar även i senare novationer som vad avser och vad (det) gäller.

En avseendemarkör där man med stor säkerhet kan se en direkt utländsk förebild är förstås när det kommer till, som utan tvivel måste antas vara en direkt överföring från engelskans when it comes to. Det spännande med detta uttryck är att det tycks ha tagit sig in i svenskan som renodlad topikmarkör, men anpassat sig oerhört snabbt och nu uppvisar samma distribution som när det gäller både vad avser komplementtyper och vilka syntaktiska positioner de fraser de inleder kan inta.

Andra avseendemarkörer förefaller emellertid ha utvecklats på rent svensk botten. Av dessa tar SAOB upp endast rörande; deras förstabelägg på detta ord som preposition är från 1759. Verbet avse i den allmänna betydelse som går igen i vad avser och prepositionen avseende, tycks, enligt SAOB, ha en märklig etymologi och antas ha bildats sekundärt (och ganska sent) till substantivet $a v$ seende. (I en anmärkning framhålls särskilt om verbet avse i dess moderna betydelser att de »hafva ingen motsvarighet i danskan och kunna på det hela ej omedelbart återföras till tyska förebilder».) Det förefaller sannolikt att de participformade prepositionerna rörande och avseende genomgått grammatikaliseringsprocesser som liknar den för gällande, och vad avser ansluter, som sagt, till mönstret för vad angår och vad beträffar. 
Särskilt intressanta är de avseendemarkörer som utgår ifrån verbet gälla, dvs. när det gäller, vad (det) gäller och gällande. Som nämnts tas ingen av dessa upp i artikeln gälla från 1929 i SAOB. Och undersökningen bekräftar att de alla är ovanliga i svenskan under förra halvan av 1900-talet. Som framgått av avsnitt 3.1.2 är när det gäller belagt redan på 1800-talet, men uttrycket svarar endast för $3 \%$ av avseendemarkörerna i ORDAT-korpusen. Redan i Press 65 är andelen uppe i $40 \%$, så man kan verkligen tala om en kometkarriär. Som även nämnts är hvad (det) gäller inte belagt i de 1800-talskorpusar jag undersökt och kommer senare och långsammare än när det gäller. Med all sannolikhet är alltså vad (det) gäller sekundärt i förhållande till när det gäller.

Vad är det då som gör att när det gäller utvecklas till avseendemarkör? Man kan ju notera att uttrycket har en avvikande form jämfört med tidigare finita uttryck som blivit avseendemarkörer; det inleds med när, inte $v a d$, och dessutom följs den temporala inledaren av ett expletivt det. En annan omständighet som är intressant $\mathrm{i}$ sammanhanget är att andelen infinitivkomplement är anmärkningsvärt hög i det äldsta materialet.

Artikeln gälla (v. 4) i SAOB tar upp 6 huvudbetydelser, varav tre kan anses fullt levande. Den utslätade betydelse som verbet har i avseendemarkören när det gäller tas upp som 5: "vara fråga om, röra sig om, avse, [...] angå, (be)röra». Denna betydelse föregås av den betydlig äldre 'vara giltig', som behandlas under punkt 2, och bruket av gälla i uttryck som avser att något står på spel etc., som behandlas under punkt 4.

Som moment a) under punkt 5 behandlas den opersonliga konstruktionen. Här påpekas att den särskilt används med åtföljande infinitiv eller verbalabstrakt och att uttrycket »i dessa fall icke alltid [är] klart skilt från $4 d »$. Moment 4d) förtecknar fall där det gäller betyder 'det är nödvändigt' eller 'det är viktigt', och då ofta åtföljs av en infinitiv eller att-sats. Äldsta anförda belägg är hämtat från Dalins Argus (1734): »Då gäller det at försöka.» Man kan alltså tänka sig att verbet i den opersonliga konstruktionen det gäller med infinitiv från början haft en mer pregnant betydelse, men att kontexten ofta tillåtit en tolkning där den aktion som infinitiven betecknar inte framstår som särskilt viktig, utan bara vad det handlar om. Särskilt nära till hands är den tolkningen vid ett bisatsinledande när/då det gäller/gällde, vilket talar för att avseendemarkören uppkommit just så. Detta skulle även förklara dess starka benägenhet att konstrueras med infinitiver.

Verbet i när det gäller-fraser har numera i allmänhet en utslätad avseende-betydelse. Den mer specifika betydelsen att något står på spel eller liknande finns dock kvar i de fall komplement saknas, som t.ex. i som bäst när det 
verkligen gäller eller när det gäller som mest (fall som alltså inte ingår i undersökningen, se avsnitt 2.2).

Eftersom när det gäller-konstruktioner rent formellt ser ut som vilka temporala bisatser som helst kan man förstås fråga sig om vi egentligen i det här fallet har att göra med något mer än en sorts konventionalisering av den inledande kollokationen. Men då är det viktigt att notera att avseendemarkören när det gäller också kan inleda attribut, inte bara adverbiella led. En sådan funktionell expansion förutsätter en grammatisk omtolkning av uttrycket. Allt tyder också på att den utvidgningen i användningen ägt rum på ett tidigt stadium; i meningen i (12), från en av Aftonbladet-korpusarna, är det t.ex. svårt att uppfatta när det gäller-frasen som något annat än ett attribut till det föregående substantivet.

(12) Vi anföra här i förbigående ett kostligt exempel på Allehandas otroliga förplumpningsförmåga när det gäller att motsäga sig sjelf. (Aftonbladet, 1840-tal)

Hur ska vi nu, slutligen, se på betydelsen av när det gäller för uppkomsten av uttrycket vad (det) gäller, och senare dessa båda för uppkomsten av prepositionen gällande? Hade de senare uttrycken kunnat uppstå av sig själva? Ja, är nog svaret på den frågan, fast med det tillägget att vad (det) gäller-varianten säkert har anslutit sig till det etablerade mönster som redan förelåg i vad angår och vad beträffar; i övrigt är sannolikt den allmänna betydelsen 'angå, avse, röra' hos ett verb (som här gälla) tillräcklig för att olika avseendemarkörer ska kunna uppstå. Men det hindrar ju inte att ett uttryck ändå kan bana vägen för ett annat som bygger på samma verb.

\subsection{Vem vinner, vem förlorar?}

Resultaten av undersökningen styrker hypotesen att allsidig användbarhet är en konkurrensfördel för en avseendemarkör. Den nu utan jämförelse mest populära varianten, när det gäller, inleder både adverbiella och attributiva fraser, och gärna topikaliserade adverbial. Den kan även ta olika typer av komplement och utmärker sig särskilt genom en hög andel infinitivkomplement. I en ställning tycks dock participformade avseendemarkörer föredras framför när det gäller (och andra icke-participformade uttryck), nämligen som inledare av vänsterdislokerade fria topikfraser.

Av de participformade prepositionerna är beträffande den variant som förefaller mest allsidig. Som andra participbaserade avseendemarkörer tar den 
ogärna infinitivkomplement, men den inleder både attributiva och adverbiella fraser och den förekommer, till skillnad från när det gäller, även i fria topikfraser. Denna allsidighet bör ses i ljuset av ordets tidigare dominans; i ORDAT-korpusen är beträffande den vanligaste avseendemarkören av alla.

Samtidigt är allsidigheten uppenbarligen inte det enda som avgör utsikterna för en avseendemarkör. Det är ju bland annat påfallande att just det allsidiga beträffande nu tycks vara på väg ut ur svenskan. Tittar man lite bakåt visar det sig också att t.ex. rörande, som inte alls är en särskild allsidig avseendemarkör utan i hög grad håller sig till attributiva fraser, också var ganska vanlig under det tidiga 1900-talet. Det enskilda ordets egenskaper är alltså inte helt utslagsgivande; man måste också se till vilka medspelare det har. Utan när det gäller, och för all del vad (det) gäller, på banan tycks flera uttryck ha haft chansen.

Man kan ändå fråga sig varför beträffande i snabb takt tappar mark, liksom vad (...) beträffar. Kanske är »felet» bara att verbet beträffa i övrigt inte har någon plats i den moderna svenskan och att dessa uttryck därmed framstår som mer formella och utdaterade än de övriga, att de stilistiskt är på väg till samma avdelning som prepositionen anbelangande(s) eller subjunktionerna änskönt och alldenstund. Men också ett lexikalt okomplicerat och rimligt allsidigt uttryck som i fråga om, tidigare rätt vanligt, minskar också i snabb takt. Det är inte uppenbart varför.

Trots att avseendemarkörernas 1900-talshistoria till stor del tycks ha handlat om att i första hand när det gäller och i andra hand vad (det) gäller lagt beslag på en stor del av fältet »markera avseende», så ser man ändå just nu två uttryck som vinner mark, låt vara ännu på en låg nivå: gällande och när det kommer till. Hur kommer det att gå för dem?

Prepositionen gällande startade först och leder kvantitativt. Ännu i det senaste materialet ser den ut att uppträda företrädesvis i attributiva fraser, men den är långt ifrån begränsad till sådana. Mitt inledande exempel (1) visar ju gällande i en topikaliserad adverbiell fras, och den förekommer även i fria topikfraser. På så sätt ligger vägen öppen för gällande att bli det nya beträffande.

Anglicismen när det kommer till intar fortfarande en kvantitativt underordnad position. Men dess formella utveckling är imponerande snabb. Från att synbarligen ha startat som en ren topikmarkör används när det kommer till nu ungefär på samma sätt (om än inte i samma omfattning) som när det gäller, och båda uttrycken visar samma höga andel infinitivkomplement. Mycket talar alltså för att när det kommer till kan bli en allvarlig konkurrent till när det gäller. 


\section{Material}

Språkbanken: https://spraakbanken.gu.se/

\section{Litteratur}

Allén, Sture, 1970: Nusvensk frekvensordbok baserad på tidningstext. Del 1. Graford. Homografkomponenter. Stockholm: Almqvist \& Wiksell international (distr.).

Baayen, R. Harald, 2001: Word Frequency Distributions. Dordrecht: Kluwer Academic Publishers.

Granvik, Anton \& Taimitarha, Susanna, 2014: Topic-marking prepositions in Swedish. A corpus-based analysis of adpositional synonymy. I: Nordic Journal of Linguistics 37(2). S. 257-296.

Holm, Lisa, 1991: Satsadverbial eller sättsadverbial. I: M. Thelander (red.): Svenskans beskrivning 18: Förhandlingar vid Artonde sammankomsten för svenskans beskrivning, Uppsala den 25-26 oktober 1990. Lund: Lund University Press. S. 172-180.

Hopper, Paul \& Traugott, Elizabeth Closs, 2003: Grammaticalization. $2^{\text {nd }}$ ed. Cambridge: Cambridge University Press.

König, Ekkehard \& Kortmann, Bernd, 1991: On the reanalysis of verbs as prepositions. I: G. Rauh (red.): Approaches to Prepositions. (Tübinger Beiträge zur Linguistik 358.) Tübingen: Gunter Narr Verlag. S. 109-125.

Pocheville, Arnaud, 2015: The ecological niche: History and recent controversies. I: T. Heams, P. Huneman, G. Lecointre \& M. Silberstein (red.): Handbook of evolutionary thinking in sciences. Dordrecht: Springer. S. 547-586.

Rosenkvist, Henrik, 2006: Fyra vyer av begreppet grammatikalisering. I: V. Molnár, G. Paulsson \& G. Andersson (red.): Vetenskapssocieteten i Lund: Årsbok. S. 57-73.

SAG = Teleman, Ulf, Hellberg, Staffan \& Andersson, Erik, 1999: Svenska Akademiens grammatik. Stockholm: Norstedts Ordbok.

SAOB = Ordbok över svenska språket utgiven av Svenska Akademien. 1.-. 1893-. Lund.

SAOL = Ordlista över svenska språket utgiven av Svenska Akademien. 14 uppl., 2015. Stockholm: Norstedts.

Svanlund, Jan, 2002: Lexikalisering. I: Språk och stil NF 12. S. 7-45.

Svensk ordbok, 2009. Utgiven av Svenska Akademien. Stockholm: Norstedts. 


\title{
Frekvens som mått på produktivitet
}

\section{En konstruktionsgrammatisk undersökning av förflytt- ningskonstruktioner i svenskan}

\author{
Av JOEL OLOFSSON
}

\begin{abstract}
Olofsson, Joel, joel.olofsson@hv.se, Ph.D., Division of Educational Science and Languages, University West: "Frequency as a measure of productivity - a construction grammar study of motion constructions in Swedish". Språk och stil NF 29, 2019, pp. 168-202.

The productivity of syntactic constructions is often measured by the number of different verbs used in the verb slot, i.e. the type frequency of the construction.

This article investigates 17 double-adverbial motion constructions and their occurrence in a large corpus of blogs.

The study shows that there is a difference between the constructions in both token and type frequency, as well as with regard to the number of rare and non-motion types used in the constructions. For instance, a construction such as the [VERB-runt-i] 'verb-about-in' occurs with 225 different verbs even though the overall token frequency of the construction is intermediate, while the [VERB-ner-till] 'verb-down-to' construction only occurs with 107 verbs, even though the construction itself is more common. This indicates that the former construction appears to be more productive than the latter.

The study also shows that the productivity of Swedish motion constructions shows up even more clearly if we apply more refined frequency measurements than only raw type frequency, such as the number of types without a conventionalized motion meaning, as well as the number of construction-unique types, i.e. types occurring in only one of the constructions investigated. For instance, non-motion verbs like skoja 'joke', and spexa 'clown about' are exclusively found in the [VERB-runt-på] construction, while animal verbs like snigla 'snail' and älga 'moose' are mainly found in the [VERB-iväg-till].
\end{abstract}

Keywords: motion verbs, construction grammar, frequency, productivity.

\section{Inledning}

Denna artikel är en konstruktionsgrammatisk studie av produktiviteten hos vad jag kallar förflyttningskonstruktioner i svenskan. Jag fokuserar på sådana för-

Tack till Benjamin Lyngfelt, Åsa Wengelin och två anonyma granskare för värdefulla synpunkter på en tidigare version av artikeln. 
flyttningskonstruktioner som bygger på ett verb, ett riktningsadverb och en prepositionsfras.

Förflyttning kan beskrivas som en scen där någon eller något förflyttas (av egen eller yttre kraft) från en punkt till en annan (jfr Talmy 2000b). Låt oss titta på följande exempel med svenska förflyttningsuttryck: ${ }^{1}$

(1) a. Siri springer iväg till bussen.

b. Siri kvistar iväg till bussen.

Verbfraserna i satserna i (1) kan i konstruktionsgrammatiska termer beskrivas som en förflyttningskonstruktion med strukturen [VERB-iväg-till-NP], där ett rörelseverb följs av riktningsadverbet $i v a ̈ g$ och en prepositionsfras med prepositionen till, som betecknar förflyttningens slutmål. Verbet springa i (1a) är ett relativt vanligt rörelseverb. Verbet kvista i (1b) är också ett känt rörelseverb, men inte lika frekvent. I enlighet med t.ex. Bybee (2010 s. 34, 2013 s. 54) kan därför springa, främst av frekvensmässiga skäl, ses som starkare knutet till konstruktionen än kvista (jfr Olofsson 2017).

Ytterligare exempel på förflyttning hittar vi i (2).

(2) a. Arne krockade in i staketet.

b. ?Arne krockade iväg till affären.

c. ?Arne krockade omkring på stranden.

Här används samma verb men olika kombinationer av riktningsadverb och prepositioner. I (2a) används verbet krocka i konstruktionen [VERB-in-i], i (2b) i konstruktionen [VERB-iväg-till] och i (2c) i konstruktionen [VERB-omkring-på]. Vi kan se att utan vidare kontext fungerar inte verbet krocka lika bra i $(2 \mathrm{~b}-\mathrm{c})$ som i (2a), vilket markerats med frågetecken. Det är dock inte helt omöjligt att tänka sig kontexter där $(2 \mathrm{~b}-\mathrm{c})$ hade varit acceptabla meningar (jfr Olofsson 2016). ${ }^{2}$ Det innebär att begränsningen inte tycks ligga på det grammatiska planet, utan istället verkar det handla om i vilken grad verbet och konstruktionen typiskt associeras till varandra.

Att ett visst ord, t.ex. ett rörelseverb, fungerar mer eller mindre bra i en viss konstruktion behöver inte nödvändigtvis bero på att det föreligger några absoluta syntaktiska eller semantiska restriktioner, vare sig hos konstruktionen eller

\footnotetext{
${ }^{1}$ Språkexemplen i den här artikeln bygger på autentiskt språkbruk, även om de i många fall är redigerade för att förenkla presentationen.

${ }^{2}$ En möjlig kontext till (2b) skulle kunna vara att Arne är en mycket dålig bilförare och därför brukar krocka inte bara med en utan flera bilar på sin väg till affären. För (2c) skulle det kunna vara en lek som går ut på att man ska krocka med de andra deltagarna och att denna lek sker på stranden.
} 
hos verbet, utan det kan också handla om i vilken grad bruket är konventionaliserat (Olofsson 2017, jfr Bybee 2010).

Konstruktioner är olika produktiva, dvs. de uppvisar olika benägenhet att användas med många och nya lexikala enheter. Ett sätt att mäta konstruktioners produktivitet är att undersöka deras s.k. typfrekvens, dvs. det antal olika lexikala enheter (t.ex. verb) som förekommer i en konstruktion (Goldberg 2006, Barðdal 2008, Bybee 2010, 2013). I föreliggande studie, där jag undersöker 17 förflyttningskonstruktioner testar jag även andra frekvensvarianter som mått på produktivitet. Hur vanligt är det, i en given korpus, att ett verb bara förekommer en gång i en viss konstruktion eller rent av endast en gång i en enda av ett antal konstruktioner med gemensamma drag? Och hur vanligt är det med verb som saknar inherent rörelsebetydelse?

I Olofsson 2017 jämfördes två konstruktioner, en med verb, adverbet $i v a ̈ g$ och prepositionsfras med till [VERB-iväg-till] och en med verb och enbart prepositionsfras med till [VERB-till]. Syftet med den studien var att undersöka i vilken utsträckning användning av både mer konventionella och mindre konventionella verb påverkas i en struktur med riktningsadverb jämfört med en struktur utan. Studien visade att konstruktionen med riktningsadverb används produktivt i större utsträckning än konstruktionen med enbart en prepositionsfras.

För att dels kunna jämföra konstruktioner med mer likartade strukturella egenskaper, dels kunna jämföra ett större omfång av konstruktioner, undersöker jag i den här artikeln olika typer av frekvens för 17 olika förflyttningskonstruktioner (av typen i 1-2, med både adverb och preposition) i en korpus. En frekvensbaserad undersökning kan i många fall ge viktig information om konstruktionernas specifika egenskaper och deras relation med olika typer av verb, som inte lika enkelt kan fångas med fokus på grammatikalitet. De frågeställningar som jag ämnar besvara är följande:

a) Hur skiljer sig typfrekvensen mellan olika förflyttningskonstruktioner, och vad kan vi lära oss av detta?

b) Hur ser förhållandet ut mellan olika sorters frekvens dels för respektive konstruktion, dels för konstruktionerna generellt?

c) I vilken utsträckning förekommer konstruktionerna med unika typer, dvs. typer som enbart förekommer i en konstruktion och inte i de andra?

Frågeställning (a) undersöks främst för att komma åt konstruktionernas olika grad av produktivitet. Frågeställning (b) handlar om att ställa olika mått på typfrekvens i relation till tokenfrekvens, dvs. hur vanliga konstruktionerna är i en korpus, vilket kan visa om produktivitet även hänger ihop med hur förhållandet mellan typ- och tokenfrekvens ser ut hos de undersökta konstruktionerna. Den 
sista frågeställningen (c) undersöks för att fånga relationen mellan specifika verb och verbgruppers relation till specifika konstruktioner, vilket kan ge en bild av hur vissa konstruktioner attraherar vissa typer av verb.

Artikeln är indelad i sex avsnitt. I avsnitt 2 presenteras bakgrund och tidigare forskning om rörelseverb och förflyttning. Avsnitt 3 handlar om konstruktionsgrammatik, som är den teoretiska ramen för artikeln. I avsnitt 4 redogörs för undersökningens material och metod. Resultatet från undersökningen presenteras i avsnitt 5, dels med fokus på konstruktionerna, dels med fokus på grupper av verb som i olika utsträckning förekommer med de undersökta konstruktionerna. Avslutningsvis summeras och diskuteras resultaten i avsnitt 6 .

\section{Förflyttning och spatiala typer}

Svensk forskning om rörelseverb och förflyttning (t.ex. Zlatev \& Yangklang 2004, Viberg 2013, Blomberg 2014) tar, liksom den internationella forskningen om förflyttning i övrigt (t.ex. Slobin 2004, 2008) ofta sin utgångspunkt i Talmys typologiska arbeten (Talmy 1985, 2000b). Talmy (2000b) beskriver en rörelsehändelse (eng. motion event) på följande vis: »The basic Motion event consists of one object (the Figure) moving or located with respect to another object (the reference object or Ground)» (s. 25). En sådan ganska allmän beskrivning kan referera till olika typer av förflyttning. Till exempel kan man skilja mellan egenförflyttning (3a), där den som förflyttas utgör subjektsreferent, och objektsförflyttning (3b), där den/det som förflyttas typiskt fungerar som objektsreferent (se Viberg 1981 s. 52-53). I (3a) är det Maja som förflyttas och i (3b) är Maja den som orsakar att glassen förflyttas.

(3) a. Maja sprang till kiosken.

b. Maja kastade glassen mot kiosken.

I föreliggande studie fokuserar jag på förflyttningskonstruktioner som beskriver egenförflyttning.

Man kan också skilja mellan olika spatiala typer, beroende på vilket förhållande som finns mellan den/det som förflyttar sig och den lokativa referenspunkten. I SAG (del $3 \mathrm{s.} 467$ ff.) redovisas de spatiala typer som återges i tabell 1 . 
Tabell 1. Spatiala typer i SAG.

\begin{tabular}{|c|c|c|}
\hline Typ & Definition & Exempel \\
\hline MÅL & rörelse i förhållande till målet & $\begin{array}{l}\text { När Eino var } 10 \text { år flyttade } \\
\text { han till Sverige. }\end{array}$ \\
\hline RIKTMÄRKE & rörelse i förhållande till det tilltänkta målet & $\begin{array}{l}\text { Maria sprang mot ett } \\
\text { hyreshus. }\end{array}$ \\
\hline UTGÅNGSPUNKT & rörelse i förhållande till utgångspunkten & $\begin{array}{l}\text { Statsministern kommer } \\
\text { direkt från Paris. }\end{array}$ \\
\hline VÄG & en rörelses bana & $\begin{array}{l}\text { Lotta gick uppför fjället. } \\
\text { Vi passerade Motala. }\end{array}$ \\
\hline BEFINTLIGHET & $\begin{array}{l}\text { "anger subjektreferentens plats i vila (eller i } \\
\text { rörelse som inte påverkar befintligheten)» } \\
\text { (SAG del } 3 \mathrm{~s} .468)\end{array}$ & $\begin{array}{l}\text { Det står en kaffebryggare } \\
\text { på diskbänken. }\end{array}$ \\
\hline
\end{tabular}

I tabellen visas den spatiala typen i vänsterkolumnen, följt av en definition i mittenkolumnen och en exempelmening i högerkolumnen som illustrerar hur den spatiala typen ska förstås. Typen BEFINTLIGHET kräver kanske en kommentar, då den rent intuitivt förknippas med motsatsen till förflyttning. Typen kan användas för att beskriva en typ av förflyttning som sker inom ett begränsat område, exempelvis Lotta rusade omkring i parken. Detta kallas i denna artikel befintlighetsförflyttning (BEFINTLIGHET ${ }_{\text {FÖRF }}$ ). ${ }^{3}$

I artikeln undersöker jag 17 olika förflyttningskonstruktioner där samtliga typer utom VÄG finns representerade. ${ }^{4}$ Några exempel på dessa konstruktioner visas i (4):

(4) a. Vi gick in i butiken.

b. Jag sprang iväg mot huset.

b. Hon rusade omkring på stan.

(RIKTMÄRKE)

c. Han kilade ut från affären.

(BEFINTLIGHET FÖRFL $_{\text {F̆ }}$ )

(UTGÅNGSPUNKT)

I alla fyra exemplen används konstruktioner som består av ett verb, ett riktningsadverb och en prepositionsfras.

Riktnings- och befintlighetsadverb kan ofta kombineras med en prepositionsfras. Detta kallar SAG dubbeladverbial, vilket är en kombination av två (eller fler) adverbial som tillsammans utgör ett primärt satsled (SAG del 3 s. 441).

\footnotetext{
${ }^{3}$ Etiketten befintlighetsförflyttning är vald för att ligga så nära SAG som möjligt.

${ }^{4}$ De undersökta konstruktionerna innehåller dubbeladverbial, närmare bestämt riktningsadverb och prepositionsfras (se nedan). VäG uttrycks oftast med en konstruktion som innehåller enbart prepositionsfras, så som Vi gick förbi kyrkan, vilket på syntaktiska grunder faller utanför fokus i den här artikeln.
} 
(5) a. Vi åkte ut till landet (MÅL)

b. Vi åkte iväg till byn (MÅL)

Trots ett utgångspunktsbetecknande adverb, som ut i (5a) och iväg i (5b), ger helheten av de båda exemplen en måltolkning, och en relativt undanskymd roll för själva utgångspunkten. Men så måste inte fallet alltid vara:

(6) Vi åkte in från Motala

I (6) sticker det målbetecknande adverbet in ut mer än adverben i (5). Enligt SAG är inte ordningen mellan två delar i ett dubbeladverbial grammatiskt reglerad utan beror på stilistiska eller pragmatiska faktorer. Men när riktningsadverbial av olika betydelsekategorier kombineras till dubbeladverbial finns det en tendens att ordna adverbial i tidsföljd, så att t.ex. utgångspunkten kommer före målet, som i $(7 \mathrm{a})$ :

(7) a. Vi flög från Gambia till Tanzania

b. Vi flög till Tanzania från Gambia

Men precis som i (6) ovan fungerar ordningen i (7b), med målmarkören först och utgångspunkten efter. Skillnaden mellan (7a) och (7b) handlar främst om informationsstruktur. Det bör påpekas att den här ordningen främst gäller konstruktioner med två prepositionsfraser, som i (7). Ordningen i de konstruktioner, med en adverbfras och en prepositionsfras, som undersöks i den här artikeln verkar mindre flexibla (jämför Vi springer iväg till affären med ?Vi springer till affären iväg).

\section{Konstruktionsgrammatik}

I den här artikeln analyserar jag förflyttningsuttryck med hjälp av konstruktionsgrammatik. Det är ett teoretiskt perspektiv där generaliseringar över språkliga strukturer beskrivs i termer av konstruktioner, vilka är konventionaliserade kluster av särdrag (lexikala, syntaktiska, prosodiska, pragmatiska, semantiska osv.) som binder samman form och betydelse (Fillmore m.fl. 1988, Goldberg 1995, 2006).

Inom konstruktionsgrammatik gör man ingen skarp uppdelning mellan grammatik (baserad på generella regler) och lexikon (baserat på det speci- 
fika, t.ex. ord och idiom). Detta antagande bygger bl.a. på det faktum att ett språk omfattar ett stort antal uttryckssätt som är för generella för att placeras i lexikon och samtidigt för specifika för att kunna beskrivas genom allmänna grammatiska regler. Istället utgår man inom konstruktionsgrammatiken från att ett språks grammatik består av en uppsättning mer eller mindre komplexa konstruktioner som i ett schematicitetskontinuum sträcker sig från generella konstruktioner till mer specifika sådana (se Fried 2015). Det kan handla om allt från lexikalt fyllda uttryck (gött mos), via mönster som består av både lexikalt fyllda, fixerade led och öppna luckor, så som prepositionsfrasen $[i$ ADJaste laget] där ett adjektiv i superlativ är det som kan varieras medan $i$ och laget är fixerade (jfr den kakan var i sötaste laget och den bilen var i dyraste laget), till öppna, fullt schematiska konstruktioner så som [PÅSTÅENDESATS]. Tidiga konstruktionsgrammatiska undersökningar fokuserar i stor utsträckning på delvis fyllda mönster och produktiva idiom (Fillmore m.fl. 1988). Goldberg (1995) argumenterar för att även abstrakta, syntaktiska konstruktioner bidrar med betydelse. Ett klassiskt exempel är He sneezed the napkin off the table, ${ }^{5}$ där verbet sneeze i sig inte innehåller någon förflyttningskomponent. Istället menar Goldberg att betydelsen 'att flytta på något genom att nysa' kommer från konstruktionen [V-NP-(ADV)-PP], som hon kallar causedmotion (jfr objektsförflyttning hos Viberg 1981). Den här typen av konstruktioner, som kallas argumentstrukturkonstruktioner, återfinns relativt högt upp på schematicitetsskalan.

Det är dock viktigt att poängtera att graden av schematicitet inte enbart är något som skiljer olika typer av konstruktioner från varandra, utan även antas finnas inom en och samma (typ av) konstruktion. Exempelvis kan en förflyttningskonstruktion beskrivas på olika nivåer, vilket illustreras i (8): ${ }^{6}$

(8) a. [V-ADVL]

b. [V-ADV-PP]

c. $[\mathrm{V}-i v a ̈ g-\mathrm{PP}]$

d. [V-iväg-till $N P]$

e. springa iväg till bussen

\footnotetext{
${ }^{5}$ För svenska motsvarigheter, så som Kim nös bort dammet från bordet/Kim nös bort inbrottstjuvarna, se Sjögreen 2015 s. 17.

${ }^{6}$ Diessel (2015) beskriver fyra typer av nätverkslänkar mellan konstruktioner (taxonomiska, horisontella, syntaktiska och lexikala länkar). (8) är ett exempel på taxonomiska länkar. Jämför även med Sjögreens (2015 s. 87) beskrivning av olika abstraktionsnivåer för kausativa bort-konstruktioner.
} 
Här är (8a) den mest generella nivån med öppna luckor för varje led, medan (8b) är specificerad till dubbeladverbial med adverb och PP. (8c) är mer speci-

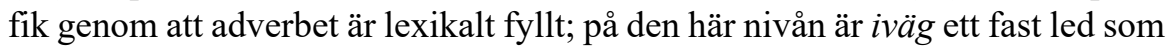
inte byts ut medan verb och preposition är öppna. I (8d) är även prepositionen ifylld och i (8e) är samtliga led lexikalt fyllda (och motsvarar närmast en fast fras).

I linje med detta resonemang har vissa forskare (t.ex. Boas 2008) ifrågasatt Goldbergs abstrakta konstruktioner då de tenderar att övergenerera, dvs. de är inte tillräckligt precisa med avseende på vilka verb som kan och inte kan användas med dem. Ta exempelvis följande exempel från Boas (2008 s. 120121):

(9) a. Miriam talked herself blue in the face.

b. *Miriam spoke herself blue in the face.

Enligt Boas fungerar verbet talk i (9a) bra i en resultativ konstruktion, vilket inte gäller verbet speak i (9b). ${ }^{7}$ Detta visar att semantiskt lika verb inte alltid kan förekomma i samma konstruktioner, vilket måste vara en del av engelska språkbrukares språkliga kompetens. Enligt Boas visar detta att en abstrakt argumentkonstruktion inte ger tillräckligt med information för att kunna generera (9a) och samtidigt förhindra (9b). Med andra ord blir det svårt att med en »independent meaningful construction» avgöra vilka verb konstruktionen ska kombineras med (Boas 2008 s. 123).

Istället föreslår bl.a. Croft (2003) och Boas (2008) att konstruktioner kan beskrivas på en mer specifik nivå. Croft talar om verbspecifika och verbklassspecifika konstruktioner, och Boas talar om minikonstruktioner för att beskriva ungefär samma sak, nämligen konventionaliserade mönster knutna till vissa verb eller särskilda grupper av verb (se även Sjögreen 2015 s. 73).

Tre saker är viktiga att påpeka i det här sammanhanget. För det första, det är inte en fråga om en lexikalistisk språksyn, utan det är fortfarande centralt att hantera språkliga uttryck som konstruktioner. Till exempel kan man fortfarande anta att betydelsen hos verbet i stor utsträckning beror på konstruktionen (se Goldberg 1995).

För det andra, det finns en metodologisk fördel med en mer specifik analys eftersom den är närmare konkret språkbruk, något som Croft (2003)

\footnotetext{
${ }^{7}$ Resonemanget kanske är överrestriktivt. Söker man på Google kan man exempelvis hitta uttryck som speak herself hoarse, även om talk förstås är frekventare i konstruktionen.
} 
uttrycker på följande vis: „Verb-specific and verb-class-specific constructions $[\ldots]$ are much closer to what a speaker actually hears and uses.» (s. 64) $)^{8}$

För det tredje, fokus på konstruktioner på en mer specifik nivå innebär inte nödvändigtvis att man förkastar idén med abstrakta konstruktioner helt och hållet. Detta uttrycker Boas (2013 s. 239) på följande vis: »This means that while very broad generalizations are captured by Goldberg-type abstract meaningful constructions, more limited conventionalized patterns are captured by more concrete constructions at various midpoints of the hierarchical network.»

\subsection{Frekvenseffekter och produktivitet}

I och med att konstruktioner är konventionaliserade antas frekvens spela en central roll för hur språkets struktur formas och för hur det förändras (Barðdal 2008, Bybee 2010, 2013). Exempelvis menar Dąbrowska (2004 s. 25) att »[f]luent language users are remarkably sensitive to the statistical properties of their language».

Man brukar skilja mellan två huvudtyper av frekvens som har olika effekter på språket: tokenfrekvens och typfrekvens.

Tokenfrekvens refererar till det antal gånger som en språklig enhet förekommer i en text eller korpus. Om förflyttningskonstruktionen [VERB-omkring-på] förekommer med verbet springa tio gånger i en korpus är tokenfrekvensen för [springa-omkring-på]10. Genom upprepad användning av ett ord eller uttryck, dvs. ökad tokenfrekvens, blir det starkare befäst i språkbrukarnas minne (jfr entrenchment i Langacker 2009 s. 638 eller strength i Bybee 2010 s. 18). ${ }^{9}$ En konsekvens av detta antas vara att högfrekventa flerordsuttryck analyseras av språkbrukare som en enhet snarare än som flera kompositionellt hopsatta delar. Hög tokenfrekvens antas också ha reducerande och konserverande effekter (t.ex. att be going to blir gonna respektive bevarandet av äldre böjningsmönster hos frekventa verb).

\footnotetext{
${ }^{8}$ Det traditionella idealet för grammatiska analyser är att sträva efter maximal generalitet. Men utifrån ett perspektiv där grammatisk struktur beskrivs som ett kontinuum från det mest generella till det mest specifika är strävan efter maximal generalitet mindre problematisk och utesluter alltså inte en analys där specifika tokens instansierar både specifika och generella konstruktioner, dvs. analysen kan sträva efter maximal generalitet och ett språkbruksnära perspektiv samtidigt.

${ }^{9}$ Det finns även mer avancerade statistiska metoder att beräkna befästning på än med ren tokenfrekvens (se t.ex. Stefanowitsch 2013, Olofsson 2017).
} 
Typfrekvens är det antal olika typer av enheter som förekommer i en konstruktion, t.ex. olika verb i en förflyttningskonstruktion. Det betyder att uttryck som springer runt $i$ och smyger runt $i$ representerar olika typer i konstruktionen [VERB-runt-i] oavsett hur många gånger de förekommer i en korpus. Så om [VERB-runt-i] endast förekommer med de två verben, är konstruktionens typfrekvens två. Det finns flera studier (t.ex. Goldberg 1995 s. 137, Barðdal 2008, Dąbrowska 2008) som argumenterar för att hög typfrekvens korrelerar med hög produktivitet, dvs. möjligheten att använda en konstruktion med nya och okonventionella enheter.

Ett mått som kombinerar token- och typfrekvens är s.k. type/token-ratio (förkortas ibland TTR), ett mått på hur många typer en konstruktion har i förhållande till dess antal tokens. Vanligtvis används det för att mäta lexikal variation i en text, men det kan också användas för att ange en konstruktions grad av produktivitet (jfr Colleman 2015).

Ett annat mått på produktivitet är s.k. hapaxer (eller hapax legomena), som är ord och uttryck som endast förekommer en gång i en stor korpus (Baayen \& Lieber 1991, Baayen 1993). I den här artikeln räknas ett verb som enbart förekommer en gång i en specifik konstruktion som en hapax, även om verbet i sig förekommer flera gånger i andra konstruktioner (jfr Olofsson 2017). Hapaxer antas vara centrala för produktiviteten eftersom det är bland dessa man hittar merparten av ord och uttryck som är nya och inte redan kända för en stor grupp av språkbrukare. ${ }^{10}$ Dock hittar man även exempel på lågfrekventa ord och uttryck som inte är nya, utan välkända för de flesta språkbrukare och inte sällan upptagna i en ordbok.

I den här artikeln skiljer jag därför mellan hapaxer generellt och s.k. icke-lexikaliserade hapaxer (jfr rare items hos Zeldes 2012), ${ }^{11}$ dvs. verb som endast förekommer en gång $i$ en konstruktion och som saknar en lexikaliserad förflyttningsbetydelse. Dessutom urskiljer jag något som jag kallar konstruktionsunika typer, vilka är verb som uteslutande förekommer med en av de undersökta konstruktionerna och inte i andra.

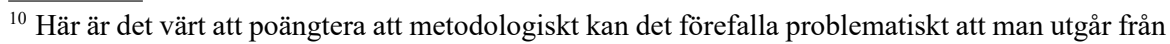
en kategorisk skillnad mellan hapaxer $(n=1)$ och lågfrekventa typer (t.ex. $n<5)$. Hapaxer är bra korpusindikatorer för produktivitet, men det gäller även andra lågfrekventa element.

${ }^{11}$ Lexikaliserad är en term som använts på flera olika sätt inom språkvetenskapen. I den här artikeln används termen icke-lexikaliserad för verb som saknar rörelsebetydelse. Många av dessa verb kan givetvis vara lexikaliserade med andra betydelser.
} 


\section{Metod och material}

Materialet för undersökningen är hämtat från Språkbankens korpusar Bloggmix 2012 och 2013, vilka tillsammans består av 133859971 tokens.

Syftet med korpusundersökningarna är att få fram konstruktionernas token- och typfrekevens samt den semantiska variationen mellan de förekommande verben. Token- och typfrekvenserna ligger till grund för de olika frekvensbaserade jämförelser mellan konstruktionerna som presenteras i avsnitt 5.1. Totalt används sju frekvensmått, varav ett är tokenfrekvens och sex är varianter av typfrekvens (se avsnitt 5.1). Tokenfrekvensen visar hur ofta konstruktionerna förekommer i korpusarna oavsett vilket verb som förekommer i dem.

Dessutom har jag systematiskt gått igenom alla typer för att se vilka verb och grupper av verb som förekommer med vilka konstruktioner. Detta redovisas i avsnitt 5.2.

Som jag nämnde i avsnitt 3.1 undersöker jag hur många av de verb som förekommer i korpusundersökningen som är s.k. icke-lexikaliserade typer, dvs. inte har någon inherent rörelsebetydelse i sin typiska betydelse. Här har jag klassat ett verb som icke-lexikaliserat rörelseverb (IL) om det inte finns upptaget i SO med en rörelsebetydelse. Detta är dock något problematiskt, då det medför att en liten andel verb som faktiskt är rörelseverb hamnar i denna kategori. Till exempel finns självfallet verbet åka med i ordboken och klassas därför inte som en IL. Men sammansättningen akutåka, som har åka som efterled, finns inte angiven i ordboken och har därför klassats som IL, trots att man intuitivt kan förstå det som ett rörelseverb. Det finns också exempel med verb som jag som enskild språkbrukare vet har en rörelsebetydelse, t.ex. kubba, men som inte nödvändigtvis är ett känt verb för en större språkgemenskap. Givetvis kan inte en ordbok ta med alla ord i ett språk, men vi kan åtminstone utgå från att de mest kända rörelseverben finns beskrivna där. Det blir ett sätt att förhålla sig objektivt till klassificeringen av verb.

\subsection{Urval}

Jag har utgått från 17 förflyttningskonstruktioner (tabell 2), som valts för att de representerar de spatiala typerna MÅL, RIKTMÄRKE, UTGÅNGSPUNKT Och BEFINT-

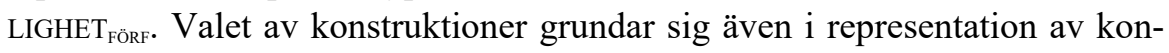


struktioner av varierande frekvens, dvs. både konstruktioner som är vanliga och konstruktioner som är mindre vanliga. ${ }^{12}$

Tabell 2. Förflyttningskonstruktioner och spatiala typer.

\begin{tabular}{|c|c|c|}
\hline Konstruktion & Spatial typ & Exempel \\
\hline [VERB-iväg-till-NP] & MÅL & Hon gick iväg till skolan. \\
\hline [VERB-in-i-NP] & MÅL & Hon gick in i parken. \\
\hline [VERB-in-till-NP] & MÅL & Hon gick in till stan. \\
\hline [VERB-fram-till-NP] & MÅL & Hon gick fram till bordet. \\
\hline [VERB-bort-till-NP] & MÅL & Hon gick bort till bordet. \\
\hline [VERB-ner-till-NP] & MÅL & Hon gick ner till city. \\
\hline [VERB-upp-till-NP] & MÅL & Hon gick upp till övervåningen. \\
\hline [VERB-fram-mot-NP] & RIKTMÄRKE & Hon gick fram mot bordet. \\
\hline [VERB-bort-mot-NP] & RIKTMÄRKE & Hon gick bort mot bordet. \\
\hline [VERB-ut-från-NP] & UTGÅNGSPUNKT & Hon gick ut från parken. \\
\hline [VERB-ut-ur-NP] & UTGÅNGSPUNKT & Hon gick ut ur parken. \\
\hline [VERB-ner-från-NP] & UTGÅNGSPUNKT & Hon gick ner från övervåningen. \\
\hline [VERB-upp-från-NP] & UTGÅNGSPUNKT & Hon gick upp från källaren. \\
\hline [VERB-omkring-på-NP] & BEFINTLIGHET $_{\text {FÖRF }}$ & Han gick omkring på stan. \\
\hline [VERB-omkring- $i$-NP] & BEFINTLIGHET FöRF $_{\text {FÖ. }}$ & Hon gick omkring i parken. \\
\hline [VERB-runt-på-NP] & BEFINTLIGHET $_{\text {FÖRF }}$ & Hon gick runt på torget. \\
\hline [VERB-runt- $i$-NP] & BEFINTLIGHET FößR $_{\text {F }}$ & Hon gick runt i parken. \\
\hline
\end{tabular}

Mittenkolumnen visar den spatiala typen för konstruktionen som helhet. Denna styrs i regel av prepositionsfrasens semantik. Det betyder att konstruktionen kan innehålla adverb som har en annan inherent betydelse. I Strzelecka 2003 (s. 104) anges exempelvis iväg och bort som adverb som implicerar en utgångspunkt, men i tabell 2 ser vi att båda dessa adverb kan ingå i konstruktioner som på grund av den följande prepositionen är målorienterade.

Konstruktionerna har samma övergripande struktur i det att de innehåller ett verb, ett adverb och en prepositionsfras. I konstruktionsgrammatiska termer kan man säga att de instansierar en mer generell struktur [VERB-ADV-PP], något jag återkommer till i avsnitt 5.

Anledningen till att jag valt konstruktioner med samma struktur är att de ska kunna vara så jämförbara som möjligt. I Olofsson 2017 jämförs konstruktionerna [VERB-iväg-till-NP] och [VERB-till-NP]. Den jämförelsen visar att skillnader i distribution och verbfördelning inte enbart behöver vara en fråga om frekvens eller semantic fit, utan de kan också bero på att det ingår mer semantisk förflyttningsinformation i den förra konstruktionen än i den senare, vilket kan förklara varför nya/ovanliga verb oftare förekommer i konstruktionen med

${ }^{12}$ Urvalet baseras till viss del på en preliminär analys av korpusen. 
riktningsadverb än i den utan. I den här undersökningen bistår de olika konstruktionerna med lika mycket information om rörelse, riktning, utgångspunkt, slutpunkt och förhållningspunkt.

Samtliga konstruktioner utom en i tabell 2 förekommer i par med en annan konstruktion som innehåller samma riktningsadverb. Exempelvis ser vi att omkring förekommer med både $i$ och på och att fram förekommer med till och mot. I det senare fallet motsvarar de två konstruktionerna två olika spatiala typer. Men även vid de två konstruktionerna med omkring, som båda har samma spatiala typ, kan det finnas skillnader dem emellan, inte minst i fråga om frekvens och vilka typer av verb de associeras med.

Den konstruktion som inte ingår i en parrelation är [VERB-iväg-till-NP]. Denna konstruktion har tidigare blivit utförligt beskriven i Olofsson 2014 och till viss del i Olofsson 2016, 2017. Den konstruktionen kartläggs även i den här artikeln - framför allt för att den föreliggande undersökningen enklare ska kunna jämföras med tidigare undersökningar - men nu med ett delvis annat material.

\subsection{Korpusundersökning}

Vid excerperingen ur de båda korpusarna har jag använt söksträngar som motsvarar var och en av de 17 undersökta konstruktionerna. Exempelvis användes söksträngen [pos = "VB"] [word = "iväg"] [word = "till"] för konstruktionen [VERB-iväg-till]. Med söksträngar av detta slag făr man även träffar som är exempel på annat än de avsedda konstruktionerna (se exempel 10 längre ner), vilka måste sorteras bort manuellt. Dessutom fångar inte söksträngarna exempel med omvänd ordföljd, vilket dock inte bör påverka resultatet nämnvärt. Det finns inget som talar för att någon av konstruktionerna skulle användas med omvänd ordföljd i större utsträckning än de andra.

I tabell 3 visas dels antalet träffar för varje söksträng, dels antalet faktiska belägg på motsvarande konstruktioner, sorterade utifrån konstruktionernas frekvens. ${ }^{13}$

Sammanlagt gav sökningarna över 74000 träffar. Efter att ha rensat bort dubbletter och felträffar, återstod totalt 32526 belägg på de eftersökta konstruktionerna.

Låt oss ta konstruktionerna [VERB-omkring-på] och [VERB-omkring-i] som

\footnotetext{
${ }^{13}$ Av utrymmesskäl anges inte prepositionsfrasens NP-rektion i konstruktionsbeskrivningarna. Detta gäller även i följande tabeller.
} 
Tabell 3. Frekvenser för söksträngar och relevanta konstruktioner i Bloggmix 2012 och Bloggmix 2013.

\begin{tabular}{|c|c|c|c|}
\hline Söksträng & Frekvens (n) & Konstruktion & Frekvens (n) \\
\hline $\mathrm{VB}+i n+i$ & 23373 & [VERB-in-i] & 8321 \\
\hline $\mathrm{VB}+i n+$ till & 7626 & [VERB-in-till] & 5392 \\
\hline $\mathrm{VB}+i v \ddot{a} g+t i l l$ & 4431 & [VERB-iväg-till] & 3873 \\
\hline $\mathrm{VB}+n e r+t i l l$ & 4984 & [VERB-ner-till] & 3560 \\
\hline $\mathrm{VB}+$ runt $+i$ & 5715 & [VERB-runt-i] & 2556 \\
\hline $\mathrm{VB}+u p p+t i l l$ & 8421 & [VERB-upp-till] & 2380 \\
\hline $\mathrm{VB}+$ runt $+p a ̊$ & 3949 & [VERB-runt-på] & 1648 \\
\hline $\mathrm{VB}+u t+$ från & 1796 & [VERB-ut-frän] & 979 \\
\hline $\mathrm{VB}+$ bort + till & 1164 & [VERB-bort-till] & 802 \\
\hline $\mathrm{VB}+$ fram + till & 7816 & [VERB-fram-till] & 786 \\
\hline $\mathrm{VB}+u t+u r$ & 1646 & [VERB-ut-ur] & 742 \\
\hline $\mathrm{VB}+$ omkring $+i$ & 1127 & [VERB-omkring-i] & 456 \\
\hline $\mathrm{VB}+$ omkring $+p a ̊$ & 683 & [VERB-omkring-på] & 382 \\
\hline $\mathrm{VB}+$ ner + från & 623 & [VERB-ner-från] & 307 \\
\hline $\mathrm{VB}+u p p+$ från & 694 & [VERB-upp-från] & 244 \\
\hline $\mathrm{VB}+b o r t+m o t$ & 101 & [VERB-bort-mot] & 63 \\
\hline $\mathrm{VB}+$ fram + mot & 290 & [VERB-fram-mot $]$ & 35 \\
\hline Alla & 74439 & Alla & 32526 \\
\hline
\end{tabular}

exempel på hur sökträffarna har hanterats. I dessa konstruktioner anges riktning med adverbet omkring, och prepositionsfrasen med prepositionen på respektive $i$ betecknar den semantiska rollen PLATS. I korpusundersökningen har jag därför tagit bort träffar där prepositionsfrasen betecknar en annan semantisk roll, exempelvis de i (10):

(10) a. Vi ska driva omkring i jättemånga dagar.

b. Han balanserar omkring på bakbenen.

c. Vi cyklade omkring i shorts.

d. Signe har burit omkring på dockan.

I (10a) betecknar prepositionsfrasen $i$ jättemånga dagar en tidsangivelse. I (10b) betecknar prepositionsfrasen det SÄTT aktiviteten balansera sker på. Man kan också tänka sig bakbenen som INSTRUMENT då frasen liknar andra sådana uttryck, så som på hästen eller på cykeln. (10c) innebär att förflytta sig iförd någon form av klädesplagg, i det här fallet ett par shorts. I (10d) är verbet bära transitivt. I fall som det i (10d) spelar möjligtvis prepositionsfrasens rektion en viss roll för hur uttrycket ska tolkas, då docka inte är något typiskt rumsadverbial med rollen PLATS utan oftast uppfattas som ett objektsliknande adverbial med rollen TEMA.

Ett exempel där prepositionsfrasens rektion är det enda som skiljer två yttranden åt visas i (11): 


\section{Joel Olofsson}

(11) a. Jag drar omkring på stan.

b. Jag drar omkring på vagn och barn.

I (11) används samma lexikala enheter, bortsett från prepositionsfrasens rektion. Rektionen i (11a) är stan, som är en lokativ enhet, på så vis att det är en plats där man kan befinna sig, medan vagn och barn i (11b) typiskt är något som subjektet flyttar på. Med Vibergs (1981) termer kan man här skilja mellan egenförflyttning och objektsförflyttning. Skillnaden mellan (11a) och (11b) beror i stor utsträckning på vår encyklopediska kunskap. Exempel av typen (11b) har plockats bort från undersökningen, då det är egenförflyttning som undersöks i den här artikeln.

Som vi såg i tabell 3 har träffar tagits bort även för de andra undersökta konstruktionerna. Inte sällan handlar det om olika tidsuttryck. I (12) ges några få sådana exempel.

(12) a. Se fram mot nästa helg.

b. Nu går vi in i vecka 30 .

c. Vi kämpade in i det sista.

I (12a) handlar det om konstruktionen [se-fram-mot DATUM/TID], i (12b) om [in-i-DATUM/TID] och i (12c) om [in-i-det sistallängsta].

\section{Resultat}

I det här avsnittet redovisas först resultatet med fokus på konstruktionerna som helhet i 5.1. Här visas olika typer av frekvensuppgifter för respektive konstruktion. Därefter redovisas resultatet med fokus på verben i 5.2. Här presenteras olika grupper av verb och i vilken utsträckning de förekommer med de olika konstruktionerna.

\subsection{Konstruktioner}

Uppgifter om konstruktionernas frekvens visas i tabell 4. Här ser vi de undersökta konstruktionerna i vänsterkolumnen, följt av konstruktionens tokenfrekvens, typfrekvens, antal hapaxträffar, antal icke-lexikaliserade typer, icke-lexikaliserade hapaxer, konstruktionsunika verb samt icke-lexikaliserade hapaxer som också är unika typer för respektive konstruktion. Respektive mått förklaras i den följande diskussionen. 
Tabell 4. Frekvensinformation för de undersökta konstruktionerna. $\mathrm{Hx}=$ antal hapaxträffar, IL = antal icke-lexikaliserade typer, ILH = icke-lexikaliserade hapaxer, UV = konstruktionsunika verb, ILHU = icke-lexikaliserade hapaxer som är unika för respektive konstruktion.

\begin{tabular}{lccrrrrr}
\hline Konstruktion & Tokens & Typer & Hx & IL & ILH & UV & ILHU \\
\hline [VERB-in-i] & 8321 & 160 & 51 & 42 & 23 & 38 & 12 \\
[VERB-in-till] & 5390 & 108 & 37 & 27 & 11 & 10 & 4 \\
[VERB-iväg-till] & 3873 & 149 & 67 & 46 & 26 & 27 & 20 \\
[VERB-ner-till] & 3560 & 107 & 44 & 27 & 17 & 10 & 6 \\
[VERB-runt-i] & 2553 & 225 & 83 & 90 & 53 & 55 & 38 \\
[VERB-upp-till] & 2380 & 87 & 31 & 21 & 15 & 3 & 2 \\
[VERB-runt-på] & 1643 & 176 & 78 & 66 & 41 & 28 & 19 \\
[VERB-ut-från] & 979 & 70 & 30 & 11 & 6 & 5 & 2 \\
[VERB-bort-till] & 802 & 60 & 23 & 9 & 5 & 1 & 1 \\
[VERB-fram-till] & 785 & 65 & 33 & 9 & 5 & 6 & 3 \\
[VERB-ut-ur] & 742 & 59 & 21 & 7 & 2 & 2 & 0 \\
[VERB-omkring-i] & 456 & 96 & 41 & 21 & 18 & 5 & 3 \\
[VERB-omkring-på] & 382 & 83 & 43 & 12 & 11 & 3 & 2 \\
[VERB-ner-från] & 307 & 39 & 18 & 2 & 2 & 1 & 1 \\
[VERB-upp-från] & 244 & 28 & 9 & 1 & 0 & 1 & 0 \\
[VERB-bort-mot] & 63 & 17 & 13 & 1 & 1 & 1 & 1 \\
[VERB-fram-mot] & 35 & 17 & 12 & 1 & 1 & 2 & 1 \\
\hline
\end{tabular}

I tabellen kan vi se en stor variation i hur ofta konstruktionerna förekommer i korpusen, dvs. konstruktionernas tokenfrekvens. Överst $\mathrm{i}$ tabellen visas [VERB-in-i] som är den vanligaste konstruktionen (8 321 tokens) och längst ner visas de lågfrekventa konstruktionerna [VERB-fram-mot] (35 tokens) och [VERB-bort-mot] (63 tokens).

I kolumnen för antal typer visas en relativt stor variation mellan de olika konstruktionerna. [VERB-runt-i] är den konstruktion som har högst typfrekvens (225) medan [VERB-bort-mot] och [VERB-fram-mot] endast förekommer med 17 typer vardera. Förhållandet mellan konstruktionernas typ- och tokenfrekvens illustreras av figur 1 .

Tokenfrekvensen visas längs $\mathrm{x}$-axeln och typfrekvens längs y-axeln. De olika punkterna som linjen sträcker sig mellan är de 17 undersökta konstruktionerna, med den minst frekventa konstruktionen [VERB-fram-mot] längst till vänster och den mest frekventa konstruktionen [VERB-in-i] längst till höger. I figuren löper dessutom en rät linje, vilken visar den genomsnittliga relationen mellan typer och tokens. ${ }^{14}$

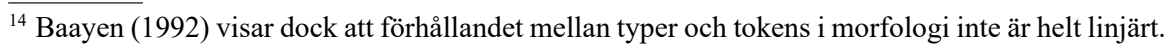


184 Joel Olofsson

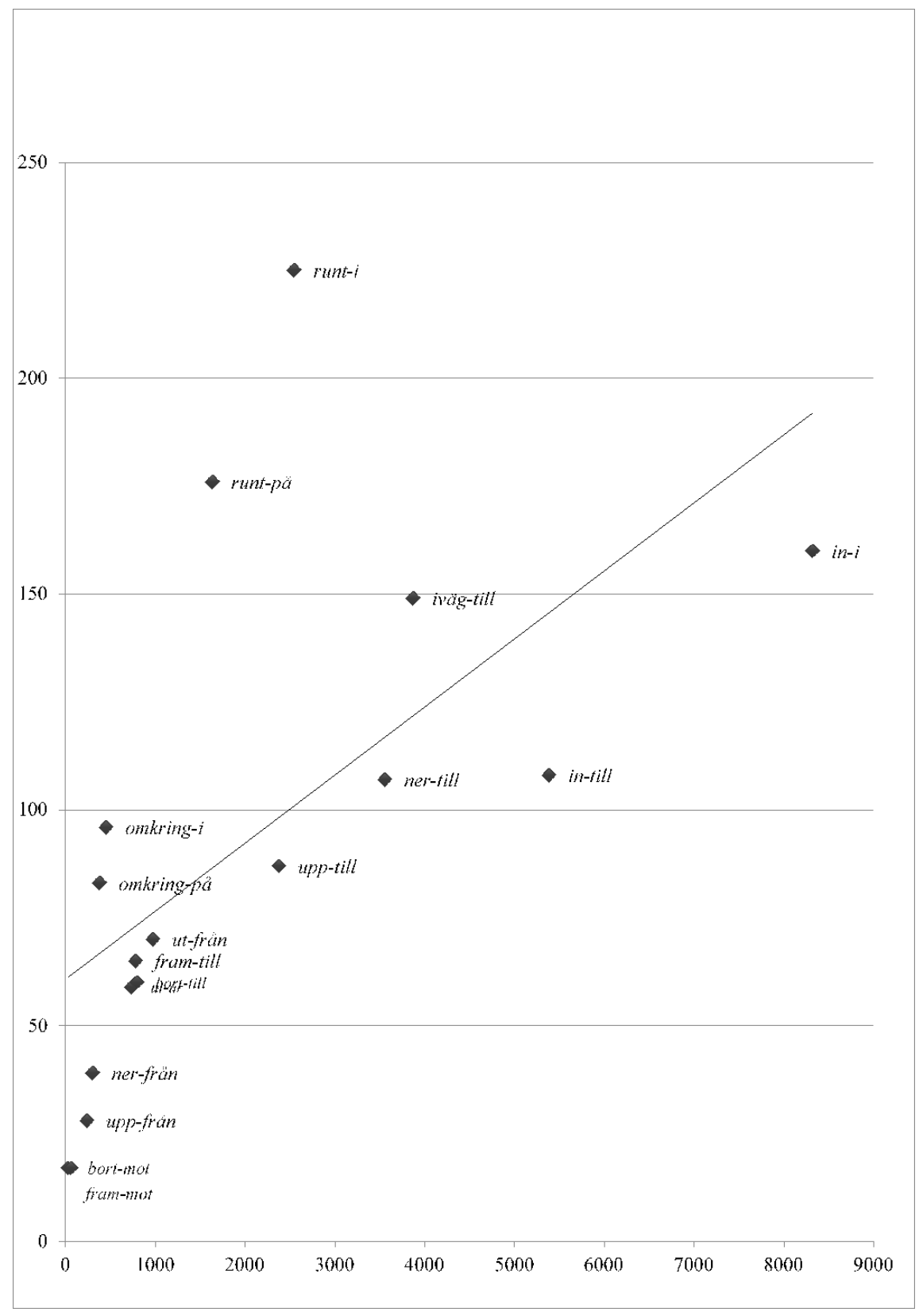

Figur 1. Förhållandet mellan konstruktionernas typ- (y-axeln) och tokenfrekvens (x-axeln). 
Som framgår av figur 1 verkar det inte finnas någon enkel relation mellan typ- och tokenfrekvens. Det föreligger en viss statistisk sannolikhet för att många tokens innebär fler typer, men avvikelserna i de enskilda fallen är påfallande. Det är till exempel två konstruktioner med förhållandevis få tokens, [VERB-runt-i] och [VERB-runt-på], som har högre typfrekvens än [VERB-in-i] trots att den senare har den högsta tokenfrekvensen (jfr tabell 4). Som också framgår av tabell 4 förekommer den relativt lågfrekventa konstruktionen [VERB-omkring-i] med fler typer än fem mer frekventa konstruktioner, nämligen [VERB-upp-till], [VERB-ut-från], [VERB-bort-till], [VERB-fram-till] och [VERB-ut-ur].

Vidare i tabell 4 visas olika varianter av typfrekvens. I den fjärde kolumnen visas antalet hapaxer som konstruktionerna förekommer med, dvs. instanser av konstruktionen som enbart förekommer en gång $\mathrm{i}$ korpusen. Precis som för typfrekvens är det [VERB-runt-i] som hamnar i topp.

I den femte kolumnen visas antalet icke-lexikaliserade typer. Som jag nämnde tidigare bygger den indelningen på huruvida verben finns upptagna $\mathrm{i}$ SO med en förflyttningsbetydelse eller inte. Även i denna kolumn har [VERBrunt-i] högst siffra.

Den sjätte kolumnen i tabell 4 visar träffar som är hapaxer och samtidigt icke-lexikaliserade. Den här sortens typfrekvens utesluter de fall där en hapax bara är en redan känd men lågfrekvent variant, och är på så vis ett mått som tydligare visar hur ofta en konstruktion förekommer med nya verb.

I den sjunde kolumnen visas det antal verb som är unika för respektive konstruktion. De konstruktionsunika verben kan ge ytterligare information angående konstruktionens produktivitet. Exempelvis kan man anta att det finns en uppsättning relativt grundläggande rörelseverb, som används mer eller mindre frekvent i alla konstruktioner. Studerar vi en konstruktion som [VERB-omkring-på] är den relativt produktiv om man enbart utgår från ren typfrekvens. Men tittar vi på antalet konstruktionsunika typer istället ser vi att endast tre av de typerna är unika för just den konstruktionen. Jämför vi med [VERB-runt-i], så förekommer den konstruktionen med ett stort antal unika typer, samtidigt som den har hög typfrekvens.

I den sista kolumnen visas icke-lexikaliserade hapaxer som uteslutande förekommer i en av de undersökta konstruktionerna (ILHU).

I figur 2 illustreras förhållandet mellan konstruktionernas tokenfrekvens och den sistnämnda typen av frekvens, dvs. ILHU. 


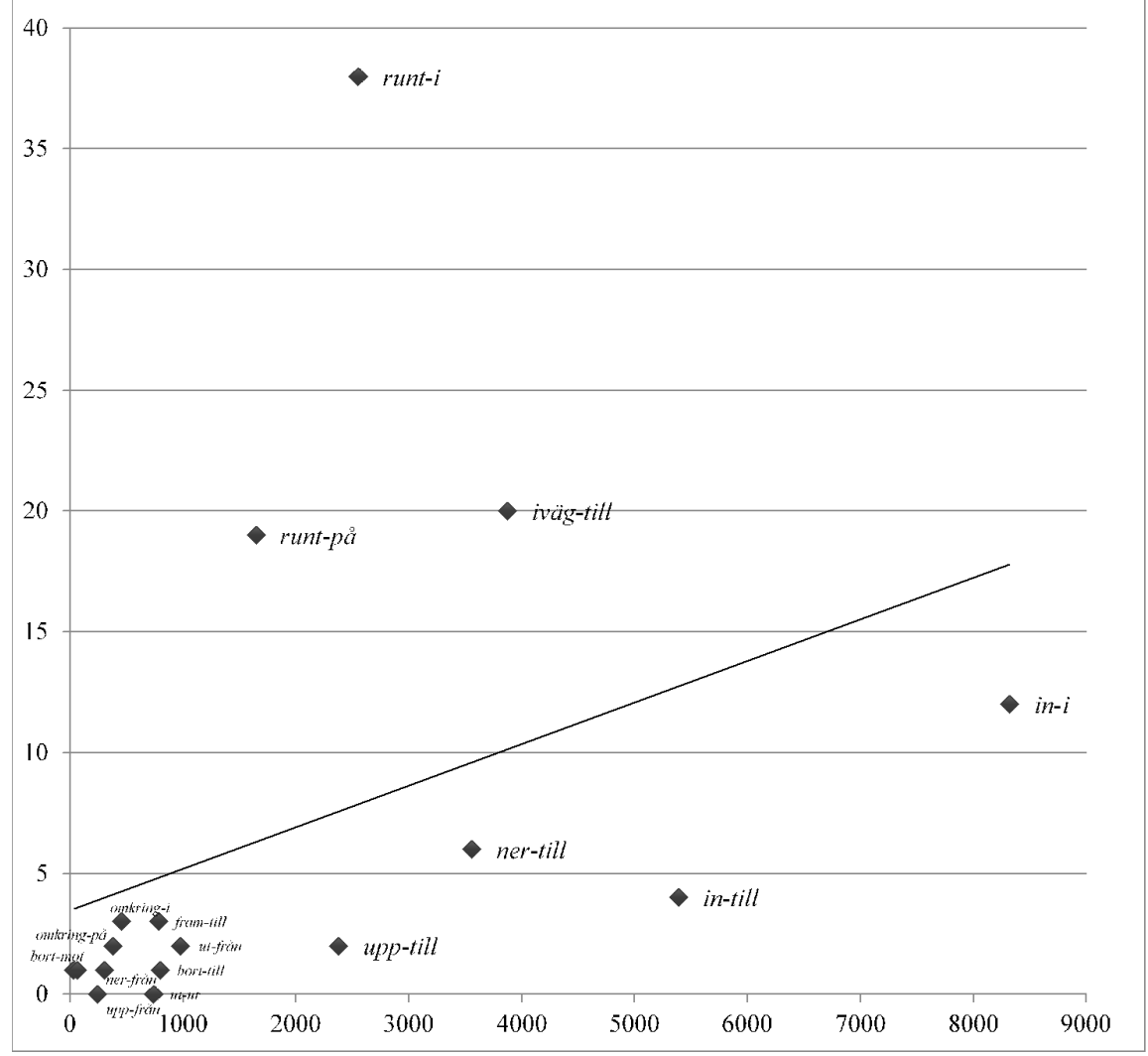

Figur 2. Förhållandet mellan antalet icke-lexikaliserade konstruktionsunika hapaxer (y-axeln) och tokenfrekvens (x-axeln).

I figur 2 är typfrekvensen (y-axeln) baserad på konstruktionsunika verb med icke-lexikaliserad rörelsebetydelse som endast förekommer en gång. Detta mer snäva mått än vanlig hapax är kanske det som tydligast pekar ut vilka av de undersökta konstruktionerna som i störst utsträckning används produktivt. Här är det framför allt [VERB-runt-i], [VERB-runt-på] och [VERB-iväg-till] som sticker ut. Vi kan också se att en konstruktion som [VERB-in-i] med relativt hög typfrekvens (se tabell 4 och figur 1) med detta mått hamnar betydligt lägre än [VERB-iväg-till], trots att den senare har lägre typfrekvens. 


\subsection{Verb}

I det här avsnittet redovisas resultat med verb som utgångpunkt istället för konstruktioner. Först presenteras de vanligaste verben i undersökningen, dels i fråga om antal tokens, dels i fråga om antalet konstruktioner som de förekommer i. Därefter gör jag nedslag i några grupper av verb som utmärker sig i undersökningen. Detta är en indelning som på många sätt påminner om den i Levin 1993, där författaren visar hur olika grupper eller klasser av verb kan förekomma i liknande syntaktiska strukturer. Skillnaden mellan min redovisning i det här avsnittet och Levins är främst att hon utgår från ett lexikaliskt perspektiv med huvudfokus på verbens egenskaper, medan jag utgår från konstruktionernas egenskaper. Det är viktigt att redan här påpeka att indelningarna ibland bygger på gemensam funktion och ibland på betydelse. Redogörelsen görs inte nödvändigtvis på samma nivå hela tiden. Fokus ligger på att redovisa hur verb med olika grad av konventionalitet används i de undersökta konstruktionerna. Syftet är alltså inte enbart att redovisa lexikala verbklasser.

Totalt förekommer 450 olika verb i undersökningen. Av utrymmesmässiga skäl redovisas inte alla verb och verbgrupper. Jag har istället valt ut ett antal grupper av verb som illustrerar dels hur förflyttningskonstruktioner kan användas med verb som normalt inte förknippas med förflyttning, dels hur vissa verb och grupper av verb associeras med en eller ett fătal förflyttningskonstruktioner medan andra används i flera konstruktioner (jfr Olofsson 2017).

Den vanligaste typen i undersökningen är verb som har en inherent rörelsebetydelse som refererar till rörelsesätt (manner of motion, Slobin 2004). Exempel på sådana verb är:

- vattenrelaterade rörelseverb (t.ex. kråla, paddla, segla, simma, snorkla, surfa, vada)

- fordonsrelaterade rörelseverb (t.ex. bila, bussa, cykla, hoja, moppa, sparkcykla, velocipeda)

- planlös förflyttning (t.ex. driva, drälla, flanera, hatta, irra, loda, luffa, skrota, skräpa, spankulera, strosa)

- verb som har en inbakad riktning (t.ex. komma, passera, retirera, tvärkomma, återvända)

- djurverb med rörelsebetydelse (t.ex. orma och snigla, åla, älga)

Andra grupper med verb som inte lika tydligt har (eller helt saknar) förflyttning i sin betydelse är t.ex.: 
- verb som innebär särskilda kroppsrörelser som inte nödvändigtvis har med själva förflyttningssättet att göra (t.ex. bocka, fladdra, flaxa, fläkta, fäkta, gunga, guppa, jazza, skaka, sprattla, studsa, vagga, vibrera, vingla)

- verb som innebär att skynda eller stressa (t.ex. hasta, hetsa, jäkta, lunch-hasta, skynda, stressa, tokstressa)

- verb som uttrycker livsstil (t.ex. leva, lyxa, njuta)

- verb som innebär att man grejar eller att något krånglar (böka, glatta, greja, joxa, knöla, krångla, pyssla, rådda, trassla)

- verb som har en predikativ funktion (t.ex. flumma, glassa, muppa, schteka ${ }^{15}$, sega, slöa)

- verb som anger ansträngning (baxa, gröta, harva, härja, nöta, orka, pressa, pumpa, röja, streta, traggla, tränga)

I det följande granskar jag närmare några ytterligare grupper av verb som är extra intressanta, antingen för att de kan användas med flera av de undersökta konstruktionerna eller för att de är begränsade till endast en eller ett fătal konstruktioner.

\subsubsection{Vanliga verb}

Med vanliga verb kan man mena åtminstone två olika saker. I det ena fallet handlar det om de verb som har högst tokenfrekvens jämfört med de andra verben i undersökningen. Jag avser då hopslagen frekvens oberoende av vilka konstruktioner de förekommer i. I det andra fallet handlar det om de verb som förekommer med olika konstruktioner. De båda dragen behöver inte sammanfalla med varandra, utan ett verb med hög tokenfrekvens kan mycket väl förekomma i en eller ett fåtal konstruktioner, medan ett lågfrekvent verb kan förekomma i flertalet eller samtliga konstruktioner.

Låt oss börja med att titta på det förstnämnda. I tabell 5 visas de tio mest frekventa verben i korpusundersökningen. Här är verbens förekomst i samtliga av de undersökta konstruktionerna inkluderad.

I mittenkolumnen visas antalet tokens för respektive verb i undersökningen, dvs. i samtliga undersökta konstruktioner, medan det i den högra kolumnen visas hur många procent av undersökningens totala antal tokens (32 524) det utgör. Exempelvis utgör verbet gå $18 \%$ av undersökningens träffar. Därefter föl-

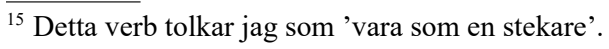


Tabell 5. De tio mest frekventa verben i korpusen.

\begin{tabular}{lcc}
\hline Verb & Antal tokens & $\%$ av undersökningens totala tokens (32 524) \\
\hline gå & 5823 & 18 \\
åka & 4861 & 15 \\
komma & 3675 & 11 \\
hoppa & 2312 & 7 \\
skola & 1542 & 5 \\
springa & 1479 & 5 \\
flytta & 1175 & 4 \\
dra & 985 & 3 \\
vara & 568 & 2 \\
kliva & 558 & 2 \\
Totalt & 22978 & 71 \\
\hline
\end{tabular}

jer åka och komma med $15 \%$ respektive $11 \%$ av träffarna. På nedersta raden visas att den sammanlagda tokenfrekvensen för de tio mest frekventa verben utgör $71 \%$. Förutom skola och vara (som behandlas i 5.2.3) är dessa typiska rörelseverb. De resterande 440 verben i undersökningen representerar således mindre än $30 \%$ av de totala beläggen.

Om vi istället granskar vanliga verb utifrån förekomst i flest konstruktioner får vi en delvis annan bild än den i tabell 5. Detta visas i tabell 6.

Tabell 6. De tio verb som förekommer i flest konstruktioner.

\begin{tabular}{|c|c|c|c|c|c|c|c|c|c|c|}
\hline $\begin{array}{l}\text { Verb } \\
\text { (tokens) }\end{array}$ & iväg & $\begin{array}{l}\text { om- } \\
\text { kring }\end{array}$ & runt & ut & in & fram & bort & ner & upp & $\begin{array}{l}\text { Antal } \\
\text { kstr }\end{array}$ \\
\hline $\begin{array}{l}\text { gå } \\
(5 \text { 823) }\end{array}$ & till & i, på & i, på & ur, från & i, till & till, mot & till, mot & till, från & till, från & 17 \\
\hline $\begin{array}{l}\text { springa } \\
(1479)\end{array}$ & till & $\mathrm{i}, \mathrm{på}$ & i, på & ur, från & i, till & till, mot & till, mot & till, från & till, från & 17 \\
\hline $\begin{array}{l}\text { (4 861) } \\
\text { (aka }\end{array}$ & till & $\mathrm{i}, \mathrm{på}$ & i, på & ur, från & i, till & till & till, mot & till, från & till, från & 16 \\
\hline $\begin{array}{l}\text { krypa } \\
(286)\end{array}$ & till & $\mathrm{i}$, på & i, på & ur, från & i, till & till, mot & till & till, från & till, från & 16 \\
\hline $\begin{array}{l}\text { rulla } \\
(227)\end{array}$ & till & $\mathrm{i}, \mathrm{på}$ & i, på & ur, från & i, till & till, mot & till, mot & till, från & till & 16 \\
\hline $\begin{array}{l}\text { smyga } \\
(128)\end{array}$ & till & i, på & i, på & ur, från & i, till & till, mot & till & till, från & till, från & 16 \\
\hline $\begin{array}{l}\text { rida } \\
(128)\end{array}$ & till & i, på & i, på & ur, från & $\mathrm{i}$, till & till, mot & till, mot & till & till, från & 16 \\
\hline $\begin{array}{l}\text { komma } \\
(3675)\end{array}$ & till & & i, på & ur, från & i, till & till, mot & till, mot & till, från & till, från & 15 \\
\hline $\begin{array}{l}\text { köra } \\
(528)\end{array}$ & till & i, på & i, på & ur, från & i, till & till & till & till, från & till, från & 15 \\
\hline $\begin{array}{l}\text { promenera } \\
(346)\end{array}$ & & i, på & i, på & ur, från & i, till & till & till, mot & till, från & till & 15 \\
\hline
\end{tabular}


I tabellen ser vi de tio verb som förekommer i flest av de undersökta konstruktionerna (kstr). Liksom i föregående tabell hittar vi verbet gå högst upp. Men sedan hamnar både åka och komma lite längre ner i denna tabell jämfört med tabell 5. Av totalt 450 verb är det endast två verb, gå och springa, som förekommer i alla de 17 undersökta konstruktionerna.

Vi ser att verb som hoppa, skola, flytta och dra, som fanns med i tabell 5, inte finns med i tabell 6 . Här hittar vi istället exempel på relativt lågfrekventa verb så som krypa, rulla, smyga och rida, som endast förekommer mellan 100 och 300 gånger totalt i korpusundersökningen. Det finns med andra ord inte något linjärt samband mellan ett verbs tokenfrekvens och antalet konstruktioner det förekommer i.

Låt oss också titta på de vanligaste verben för respektive konstruktion. För att det inte ska ta för mycket plats $i$ artikeln har jag begränsat det till de fem vanligaste verben per konstruktion. Detta visas i tabell 7.

Tabell 7. De fem vanligaste verben för var och en av de undersökta konstruktionerna.

\begin{tabular}{|c|c|c|c|}
\hline Konstruktion & Tokens & Typer & de fem vanligaste verben (tokens) \\
\hline [VERB-in-i] & 8321 & 160 & $\begin{array}{l}\text { hoppa (2 109), gå (1 817), komma (1 215), flytta (740), } \\
\text { kliva (392) }\end{array}$ \\
\hline [VERB-in-till] & 5390 & 108 & åka (2 128), komma (733), gå (509), skola (454), dra (301) \\
\hline [VERB-iväg-till] & 3873 & 149 & $\begin{array}{l}\text { åka (773), skola (446), dra (414), komma (298), sticka } \\
\text { (264) }\end{array}$ \\
\hline [VERB-ner-till] & 3560 & 107 & $\begin{array}{l}\text { gå (884), åka (875), komma (279), skola (243), springa } \\
(165)\end{array}$ \\
\hline [VERB-runt-i] & 2553 & 225 & gå (446), springa (241), strosa (167), åka (109), resa (99) \\
\hline [VERB-upp-till] & 2380 & 87 & åka (665), gå (450), komma (314), skola (186), flytta (79) \\
\hline [VERB-runt-på] & 1643 & 176 & gå (270), springa (244), strosa (148), åka (73), glida (53) \\
\hline [VERB-ut-från] & 979 & 70 & $\begin{array}{l}\text { komma (389), gå (189), checka (67), flytta (44), springa/ } \\
\text { kliva (27) }\end{array}$ \\
\hline [VERB-bort-till] & 802 & 60 & $\begin{array}{l}\text { gå (229), åka (97), promenera (66), springa (61), komma } \\
(40)\end{array}$ \\
\hline [VERB-fram-till] & 785 & 65 & gå (467), springa (73), hinna (30), hitta (20), rida (17) \\
\hline [VERB-ut-ur] & 742 & 59 & komma (253), gå (155), kliva (61), hoppa (29), springa (18) \\
\hline [VERB-omkring-i] & 456 & 96 & gå (83), springa (47), strosa (21), vandra (18), flyta (18) \\
\hline [VERB-omkring-på] & 382 & 83 & springa (62), gå (50), krypa (28), strosa (23), vandra (18) \\
\hline [VERB-ner-från] & 307 & 39 & ramla (68), komma (44), trilla (36), hoppa (27), gå (20) \\
\hline [VERB-upp-från] & 244 & 28 & komma (93), dyka (29), kliva (26), gå (23), hoppa (14) \\
\hline [VERB-bort-mot] & 63 & 17 & gå (14), traska (12), promenera (7), rulla (5), åka (4) \\
\hline [VERB-fram-mot] & 35 & 17 & gå (9), springa (5), rusa (5), komma (3), [resten (1)] \\
\hline
\end{tabular}


Precis som i tabell 5 där de mest frekventa verben utgör en majoritet av undersökningens totala tokens, ser vi att det mest frekventa verbet i respektive konstruktion utgör en stor andel av konstruktionens totala tokenfrekvens, t.ex. verbet gå (467 tokens) i konstruktionen [VERB-fram-till] (785 tokens).

I nästa avsnitt presenteras grupper av verb som har en intressant semantik och/eller som endast förekommer med en eller ett fåtal av de undersökta konstruktionerna, eller på ett annat sätt är intressanta, exempelvis genom att de blivit diskuterade i tidigare forskning.

\subsubsection{Oavsiktlig rörelse}

Denna grupp av verb tar typiskt ett subjekt som inte har rollen AGENT, dvs. de betecknar en aktivitet som inte är avsiktlig från subjektreferentens sida.

I tabell 8 visas de olika verben i den vänstra kolumnen. I kolumnerna därefter följer de undersökta konstruktionerna. Av utrymmesskäl visas konstruktionens riktningsadverb i översta raden, medan prepositionen används för att markera vilken av konstruktionerna det handlar om. I kolumnen längst till höger visas antalet konstruktioner som varje enskilt verb används i.

Tabell 8. Verb som uttrycker oavsiktlig rörelse.

\begin{tabular}{|c|c|c|c|c|c|c|c|c|c|c|}
\hline $\mathrm{V}$ & iväg & omkring & runt & ut & in & fram & bort & ner & upp & $\begin{array}{l}\text { antal } \\
\text { kstr }\end{array}$ \\
\hline ramla & till & i/på & $\mathrm{i}$ & ur/från & $\mathrm{i} /$ till & & & till/från & & 10 \\
\hline halka & till & i/på & i/på & & $\mathrm{i}$ & & till & till & & 8 \\
\hline snubbla & & & i/på & ur/från & $\mathrm{i}$ & & & & till & 6 \\
\hline trilla & & & på & ur/från & $\mathrm{i}$ & & & från & & 5 \\
\hline störta & & & & ur & $\mathrm{i}$ & till & & från & & 4 \\
\hline rasa & & & i/på & & & & & från & & 3 \\
\hline dimpa & & & & & $\mathrm{i}$ & & & från & & 2 \\
\hline falla & & & & från & & & & från & & 2 \\
\hline fumla & & på & $\mathrm{i}$ & & & & & & & 2 \\
\hline famla & & & $\mathrm{i}$ & & & & & & & 1 \\
\hline stupa & & & & & $\mathrm{i}$ & & & & & 1 \\
\hline tumla & & & $\mathrm{i}$ & & & & & & & 1 \\
\hline
\end{tabular}

Tabellen visar att de oavsiktliga verben framför allt förekommer med de källorienterade konstruktionerna [VERB-ut-ur/från] och [VERB-ner-från], liksom de befintlighetsorienterade [VERB-omkring-i/på] och [VERB-runt-i/på]. De målorienterade konstruktionerna är i mindre utsträckning representerade. Verben 
ramla och halka är de verb i gruppen som används i flest konstruktioner, tio respektive åtta.

I många av de undersökta konstruktionerna, t.ex. [VERB-ut-ur], [VERB-utfrån], [VERB-in-i] och [VERB-ner-från], behåller subjektet rimligtvis sin ickeagentiva karaktär, så som i Han ramlar ner från taket eller Hon snubblade in $i$ brevlådan. Men i följande exempel framstår subjektsreferenten mer som en agentiv egenförflyttare:

(13) Nu ska jag halka iväg till bokhandeln (för att köpa en bok).

Exempel (13) är inte en beskrivning av någon som halkar på sin väg till bokhandeln, utan någon som rör sig på ett halkande sätt, möjligtvis förflyttar sig på ett halt underlag. Den här användningen är intressant i och med att verbets typiska semantik och förflyttningens semantik på sätt och vis uttrycker motsatta semantiska komponenter. Trots detta uppstår ingen semantisk krock.

\subsubsection{Hjälpverb}

Ibland kan en förflyttningsscen beskrivas med ett hjälpverb utan något huvudverb som i sig uttrycker förflyttning. Nikanne \& Östman (2006 s. 67) ger följande exempel:

(14) Peter måste/skall/borde till Åbo/badrummet/sängs/vessan.

SAG beskriver detta på följande vis: »Vissa hjälpverb konstrueras direkt med adverbial för mål eller i någon mån med adverbial för utgångspunkt. Ett rörelseverb kan då ses som underförstått efter hjälpverbet.» (SAG del $3 \mathrm{s.} \mathrm{470).}{ }^{16} \mathrm{Ni}$ kanne \& Östman (2006 s. 68) ger dock följande exempel på hjälpverb som fungerar sämre än de i (14): ${ }^{17}$

(15) a. *Han får till Åbo.

b. *Han kan till Åbo.

c. *Han lär till Åbo.

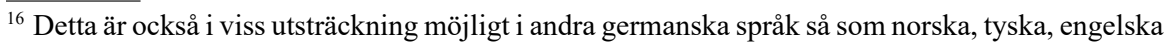
(Kjellmer 2002) och danska (Vikner 1988 s. 17).

${ }^{17}$ Det är viktigt att poängtera att Nikanne \& Östmans (2006) utgångspunkt är konstruktioner med verb och prepositionsfras. De behandlar inte konstruktioner med verb, adverb och prepositionsfras. Det som gäller för enkeladverbialkonstruktioner behöver inte gälla för dubbeladverbialkonstruktioner.
} 
Detta ska enligt Nikanne \& Östman bero på att förflyttningskonstruktion med hjälpverb används för att uttrycka framtid.

Korpusundersökningen i denna artikel ger en mer systematisk genomgång av vilka hjälpverb som används, och i vilka konstruktioner de används. Detta visas i tabell 9.

Tabell 9. Hjälpverb som förekommer i de undersökta konstruktionerna.

\begin{tabular}{|c|c|c|c|c|c|c|c|c|c|c|}
\hline$\overline{\mathrm{V}}$ & iväg & omkring & runt & ut & in & fram & bort & ner & upp & antal kstr \\
\hline ska & till & & $\mathrm{i}$ & ur/från & i/till & till & till & till/från & till/från & 12 \\
\hline hinna & till & & & ur/från & $\mathrm{i} / \mathrm{till}$ & till & till & till/från & till & 10 \\
\hline vilja & till & & & ur/från & i/till & till & & till & till & 8 \\
\hline måste & till & & & ur/från & $\mathrm{i} / \mathrm{till}$ & & & till & till & 7 \\
\hline behöva & & & & & & & till & till & & 2 \\
\hline få & till & & & & & & & & till & 2 \\
\hline måste-måste & till & & & & & & & & & 1 \\
\hline
\end{tabular}

Flera av hjälpverben i tabell 9 förekommer i flera konstruktioner. ${ }^{18}$ Till exempel används ska i 12 av de 17 undersökta konstruktionerna och hinna används i tio. Det som sticker ut är att befintlighetskonstruktionerna [VERB-omkring-i/ på] och [VERB-runt-i/på], som generellt förekommer med ett stort antal typer, inte förekommer med några hjälpverb, bortsett från ett belägg på ska i konstruktionen [VERB-runt-i].

\subsubsection{Perceptionsverb}

Vanligtvis när perceptionsverb används i förflyttningskonstruktioner brukar man göra en tolkning som kallas fiktiv rörelse, vilket är när en riktning beskrivs utan att det finns någon faktisk rörelse (Talmy 2000a, Olofsson 2011). Detta illustreras i (16).

(16) Hon kikade in i kuvertet.

I (16) undergår inte subjektet någon förflyttning, utan exemplet kan snarare beskrivas som att 'någon riktar uppmärksamhet mot ett mål'. Slobin (2008 s. 2) gör i dessa sammanhang en skillnad mellan visual path och physical motion.

\footnotetext{
${ }^{18}$ Två exempel är behöver bort till vårdcentralen och fick iväg till toan. Det bör påpekas att det senare mycket väl kan vara ett felstavat gick. Dock har jag noterat bruket av fick iväg i talspråk, även om det är ovanligt.
} 
Fiktiv rörelse i svenskan har tidigare uppmärksammats av Lundbladh (1991). Han ger även exempel med andra verb än perceptionsverb, så som dem i (17).

(17) a. På östsidan stupar vägen ner i dalen.

b. Vägen skär ner i kullen.

c. Skogen klättrar upp för berget.

Exemplen i (17) skiljer sig något från (16) då subjekten här avser inanimata företeelser, och uttrycken beskriver ett statiskt förhållande snarare än en förflyttning.

De belagda perceptionsverben i min undersökning är kika, kolla, nosa, sniffa, spana och titta. Undersökningen visar att verben framför allt används i konstruktionerna [VERB-runt-i/på] och [VERB-in-i/till]. Konstruktionerna [VERBomkring-i] och [VERB-ner-till] används med endast ett verb vardera, medan fyra konstruktioner inte används alls, däribland konstruktionen [VERB-iväg-till], som används med flertalet av de verbgrupper som presenteras i den här artikeln. Verben titta och kika används i sex respektive fem av de 17 konstruktionerna medan nosa och sniffa endast används med [VERB-runt-i] och [VERBrunt-på].

Detta visar att perceptionsverben även kan användas i samband med konkret förflyttning. En viktig skillnad här är att riktningsadverbet måste ha partikelbetoning (jfr Strzelecka 2003, SAG del 3 s. 413).

(18) a. Hon kollade runt på stan

b. Hon kollade runt på stan

Med betoning på verbet, som i (18a), görs i större utsträckning en fiktiv tolkning, medan förflyttningstolkningen görs då adverbet är betonat, som i (18b) (jfr liknande observation i Strzelecka 2003 s. 124).

\subsubsection{Ljudverb}

Nästa grupp består av ljudhärmande verb (jfr Olofsson 2014, Viberg 2015). Ralph (1991) gör en skillnad mellan verb som betecknar ljudets egenskap (t.ex. braka, döna, skramla) och verb som betecknar frambringande av ljud/läte (t.ex. brumma, bröla, skrika). Det första fallet handlar om ett resultat av själva förflyttningen, medan det i det senare fallet är den/det som förflyttar sig som samtidigt frambringar ljudet (jfr Causal Relation Hypothesis i Goldberg 1995 s. 62). 
De verb som betecknar ljudets egenskap i korpusen är braka, dundra, fräsa, klafsa, knattra, panga, plaska, ploppa, plumsa, poppa, puttra, pysa, rassla, skramla, skvalpa, smacka, smasha, smälla, susa, svischa, tuta och vina.

Undersökningen visar att denna typ av ljudverb förekommer mer eller mindre i alla typer av konstruktioner, även om [VERB-iväg-till], [VERB-in-i] och [VERB-runt-i] är de konstruktioner som förekommer med flest verb. Beträffande de två senare konstruktionerna kan man notera att verben som används med [VERB-in-i] sällan också förekommer med [VERB-runt-i] och vice versa.

Susa är det verb som förekommer med flest konstruktioner. Hela tolv verb förekommer endast med en enda konstruktion.

Andra verb som braka, panga, smasha, smälla används i stort sett bara med [VERB-in-i] med denna tolkning. På så vis skiljer sig dessa verb från verb som susa, svischa och vina som också är ett resultat av själva förflyttningen, men inte på grund av kontakt med målet.

De verb i undersökningen som istället betecknar frambringande av ljud eller läte är brumma, grymta, huttra, lalla, pipa, smattra, surra, tissla, tralla och tuffa.

Undersökningen visar att även denna typ av ljudverb främst används i [VERB-iväg-till] och [VERB-runt-i], liksom [VERB-runt-på], men i mindre utsträckning i [VERB-in-i] än för verben som betecknar ljudets egenskap.

Tralla är det verb, tätt följt av pipa, som förekommer med flest konstruktioner. Här handlar det om en aktivitet som sker samtidigt som själva förflyttningen (jfr Talmy 2000b, 2017), inte ett sätt att förflytta sig på.

Andersson (1997) menar att »[1]judangivelser som hosta, hicka, snörvla, väsa är redan en aning marginella som rörelseverb, och andra ljudangivelser som sjunga, prata är i det närmaste omöjliga» (s. 42). Min undersökning visar att det visst är möjligt att använda den här typen av ljudverb i förflyttningskonstruktioner, men kanske inte i vilka konstruktioner som helst.

\subsubsection{Kollisionsverb}

Nästa grupp av verb har det gemensamt att de används i en förflyttningskonstruktion för att beteckna en scen där den som förflyttar sig på ett plötsligt och kraftfullt sätt kommer i kontakt med ett MÅL. Kollisionsverben i undersökningen (bumpa, dunka, krascha, kraschlanda, krocka, kvadda, stöta och törna) är således en typ av kontaktverb (jfr Viberg 1983). Korpusundersökningen visar att de här verben uteslutande används med konstruktionen [VERB-in-i], precis som de närbesläktade ljudverben (t.ex. panga och smälla) i förra avsnittet. I (19) visas två exempel på kollisionsverb i konstruktionen [VERB-in-i]. 
(19) a. Han kraschade in i staketet

b. Hon kraschade in i rummet

I (19a) är staketet det mål som subjektet kolliderar med. I (19b) är det inte lika uppenbart vad det är subjektet kolliderar med, men det framgår ändå att en kollision uppstår i samband med dess förflyttning. Det är värt att notera att själva kollisionstolkningen kan uppstå även med vanliga rörelseverb, så som i Han springer in i staketet.

\subsubsection{Skojverb}

Följande grupp av verb förmedlar mer ett sätt att vara än något man gör. Att fjanta innebär att man är fjantig, tramsa att man är tramsig, vela att man är velig. Några av verben har normalt ett föremål för aktiviteten. Till exempel busar eller skojar man ofta med någon, även om denna roll inte realiseras i de aktuella konstruktionerna. Denna grupp av verb (busa, fjanta, lattja, leka, showa, skoja, spexa, spralla, stoja, stöka, tramsa, vela och vimsa) väljer jag att kalla skojverb. Undersökningen visar att verben används i ett begränsat antal konstruktioner. Bortsett från en användning av skoja i [VERB-in-i] och tre belägg (busa, lattja och stöka) i konstruktionerna [VERB-omkring-på] och [VERB-omkring-i], är det uteslutande i konstruktionerna [VERB-runt-i] och [VERB-runt-på] som de här verben används.

\section{Avslutande diskussion}

I den här artikeln har jag undersökt skillnader i frekvens hos 17 förflyttningskonstruktioner. Undersökningen visar en stor variation mellan konstruktionerna avseende olika frekvenser. Man kan fråga sig varför frekvens är centralt för att undersöka relationen mellan verb och förflyttningskonstruktioner. För det första antas det, bl.a. inom bruksbaserad konstruktionsgrammatik, att frekvens spelar en stor roll för språkets struktur och förändring (Bybee 2010). Till exempel ses typfrekvens ofta som ett mått på hur produktiv en konstruktion är (t.ex. Goldberg 2006, Barðdal 2008, Bybee 2010). För det andra kan man se fokus på frekvens som en metodologisk fördel, nämligen att man kan fånga tendenser i språkbrukarnas användning av förflyttningskonstruktioner, som inte nödvändigtvis kan härledas till syntaktiska eller semantiska restriktioner hos verben eller konstruktionerna. 
I inledningen ställde jag tre frågor. Den första handlade om skillnader i typfrekvens mellan de olika konstruktionerna. Artikeln visar en stor variation mellan konstruktionerna, där några få ([VERB-runt-i], [VERB-runt-på], [VERB-in-i] och [VERB-iväg-till]) uppvisar en hög typfrekvens, medan andra (t.ex. [VERBner-från], [VERB-upp-från], [VERB-bort-mot] och [VERB-fram-mot]) förekommer med färre typer. Låg typfrekvens verkar, till viss del, sammanfalla med att konstruktionen som helhet har låg tokenfrekvens. Det är givetvis logiskt på så vis att det krävs ett stort antal tokens för att flera typer ska representeras, närmare bestämt minst en token för varje typ. Det innebär att en konstruktion med låg tokenfrekvens per automatik har låg typfrekvens. Men det betyder inte att konstruktioner med hög tokenfrekvens per automatik har hög typfrekvens. Exempelvis har konstruktionerna [VERB-runt-i] och [VERB-runt-på] högre typfrekvens än [VERB-in-i] trots att den senare är mer än tre gånger så vanlig mätt $\mathrm{i}$ antal tokens.

Förhållandet mellan typ- och tokenfrekvens knyter också an till den andra frågeställningen, som handlade om förhållandet mellan olika sorters frekvens för respektive konstruktion å ena sidan och för konstruktionerna generellt å den andra. Bland annat visar denna artikel att förhållandet mellan typ- och tokenfrekvens är komplext. Konstruktionerna [VERB-runt-i] och [VERB-upp-till] är ungefär lika vanliga i korpusen (2 553 respektive 2380 ), men den förstnämnda förekommer med mer än dubbelt så många typer (225 respektive 87 ). Utgår man från ett annat mått på typfrekvens, antalet icke-lexikaliserade typer, visar undersökningen att [VERB-runt-i] har mer än fyra gånger så många verb som saknar rörelsebetydelse än [VERB-upp-till]. I och med att konstruktionerna har ungefär lika hög tokenfrekvens, betyder det att den ena oftare används med en stor variation av verb, varav många är lågfrekventa i konstruktionen, medan den andra har fler verb som förekommer med hög tokenfrekvens i konstruktionen (jfr liknande observation i Olofsson 2017 s. 101 f.). Exakt vilken funktion tokenfrekvensen har när det kommer till produktivitet är fortfarande en öppen fråga. Bybee (2010) menar att hög tokenfrekvens har negativ inverkan på produktiviteten då högfrekventa instanser av en konstruktion ger intrycket av att konstruktionen främst associeras med dessa och därmed uppfattas som mindre öppen för andra (nya) typer. Man kan hur som helst inte helt utesluta att hög tokenfrekvens främjar produktiviteten.

Den tredje frågeställningen, som också fokuserar på frekvens, handlar om i vilken utsträckning konstruktionerna uppträder med verb som enbart förekommer i en konstruktion och inte i de andra. Undersökningen visar att det finns verb och grupper av verb som är starkt förknippade med en viss konstruktion. 
Exempelvis förekommer konstruktionerna [VERB-runt-i] och [VERB-in-i] med en relativt stor andel unika typer. Förekomst av unika typer kan bero på både frekvens och olika strukturella restriktioner. Det kanske tydligaste exemplet på det senare är att kollisionsverben uteslutande används med konstruktionen [VERB-in-i]. Ett annat liknande exempel på när en grupp av verb förknippas med uteslutande en konstruktion är användningen av skojverb i [VERB-runt-i] och [VERB-runt-på]. Men här är det inte uppenbart fråga om en semantisk restriktion, utan verkar istället handla om en konventionell användning: en frekvensmässig relation mellan den typen av verb och konstruktionerna i fråga (jfr Olofsson 2017).

Konstruktionernas olika egenskaper och frekvensmässiga förutsättningar är kunskap som språkbrukare antas ha (jfr Malmgren 2001 s. 3). Man kan alltså tänka sig att språkbrukare har kunskap om sådant som att verb som betecknar ett ljuds egenskap används i de flesta förflyttningskonstruktioner, så som braka in i rummet eller braka omkring i rummet, medan de som betecknar ett frambringande av ett ljud eller läte (t.ex. tralla) främst används med [VERB-ivägtill], [VERB-runt-i] och [VERB-runt-på], och att djurverb främst används med [VERB-iväg-till].

Detta resonemang knyter an till Crofts (2003) och Boas (2008) idé om att analysera konstruktioner på en mer specifik nivå. Det innebär inte att man för den sakens skull helt kan förkasta den mer abstrakta analysnivå som Goldberg (1995) föreslår - det finns flera anledningar att anta att en sådan nivå existerar, inte minst antagandet att generalisering över konkreta instanser leder till abstraktion (se t.ex. Ross \& Makin 1999, Langacker 2000). Dessutom medger Boas (2008) att även om Goldbergs abstrakta konstruktionsnivå inte är tillräcklig för att förutsäga idiomatisk produktion av specifika instanser, kan den abstrakta nivån spela en viktig roll vid förståelse, tolkning och viss produktion av helt nya instanser (dvs. produktivitet): »While argument structure constructions seem to be of great importance for the understanding of novel utterances, they are not sufficient for the production of all novel utterances.» (s. 128)

I den här artikeln förs även en diskussion om produktivitet utifrån typfrekvens och hapaxer, med utgångspunkten att en hög typfrekvens och ett stort antal hapaxer korrelerar med en hög grad av produktivitet. Framför allt problematiseras begreppet hapax, vilket brukar definieras som ord, fraser och instanser av en konstruktion som endast förekommer en gång $i$ en korpus. Jag presenterar en snävare definition, som fokuserar på sådana verb som endast förekommer en gång, saknar rörelsebetydelse och som förekommer uteslutande i en av de undersökta konstruktionerna. Detta är ett mått som troligtvis tydligare visar 
konstruktionernas olika grad av produktivitet. Här tyder resultatet på att det endast är [VERB-runt-i], [VERB-runt-på], [VERB-iväg-till] och [VERB-in-i] som i någon större utsträckning används produktivt. Men kanske är detta mått lite för snävt. Istället för att fokusera på instanser av konstruktioner som endast förekommer en gång, skulle man lika gärna kunnat fokusera på instanser som förekommer få (t.ex. en till fem) gånger. Det finns inget självändamål med att enbart fånga de allra mest lågfrekventa instanserna. Huvudpoängen med hapaxer är att hitta nya och relativt okända uttryck, och det finns därför ingen egentlig anledning att utesluta en ny okonventionell instans bara för att den förekommer två eller fler gånger. Med ett sådant bredare mått skulle man kunna finna fler intressanta nyanser i frågan om förflyttningskonstruktioners olika grad av produktivitet.

Avslutningsvis visar den här artikeln att olika förflyttningskonstruktioner är produktiva i olika grad, dvs. har olika stor potential att användas med nya verb eller redan kända verb med ny funktion. I artikeln argumenterar jag för att konstruktionernas produktivitet främst beror på frekvens, men även konstruktionernas strukturella egenskaper kan spela roll. Det verkar finnas ett intressant samspel mellan dessa båda faktorer som är värt att reda ut, vilket motiverar fler studier av konstruktioner och produktivitet.

\section{Litteratur}

Andersson, Erik, 1997: Svenska rörelseverb och måladverbial. I: S. Haapamäki (red.): Svenskan i Finland 4. (Skrifter från svenska institutionen vid Åbo Akademi 3.) Åbo: Åbo Akademi. S. 35-50.

Baayen, Harald, 1992: Quantitative aspects of morphological productivity. I: G. Booij \& J. van Marle (red.): Yearbook of Morphology 1991. Dordrecht: Springer. S. 109-149.

Baayen, Harald, 1993: On frequency, transparency and productivity. I: G. Booij \& J. van Marle (red.): Yearbook of Morphology 1992. Dordrecht: Kluwer. S. 181-208.

Baayen, Harald \& Lieber, Rochelle, 1991: Productivity and English derivation: A corpus-based study. I: Linguistics 29. S. 801-844.

Barðdal, Jóhanna, 2008: Productivity. Evidence from case and argument structure in Icelandic. Amsterdam: John Benjamins.

Blomberg, Johan, 2014: Motion in language and experience. Actual and non-actual motion in Swedish, French and Thai. (Travaux de l'institut de linguistique de Lund 53.) Lund: Lunds universitet.

Boas, Hans, 2008: Determining the structure of lexical entries and grammatical constructions in Construction Grammar. I: Annual Review of Cognitive Linguistics 6. S. 113-144. 
Boas, Hans, 2013: Cognitive Construction Grammar. I: T. Hoffman \& G. Trousdale (red.): The Oxford Handbook of Construction Grammar. Oxford: Oxford University Press. S. 233-254.

Bybee, Joan, 2010: Language, usage and cognition. Cambridge: Cambridge University Press.

Bybee, Joan, 2013: Usage-based theory and exemplar representation. I: T. Hoffman \& G. Trousdale (red.): The Oxford Handbook of Construction Grammar. Oxford: Oxford University Press. S. 49-69.

Bybee, Joan \& Thompson, Sandra A., 2007: Three frequency effects in syntax. I: J. Bybee (red.): Frequency of use and the organization of language. Oxford \& New York: Oxford University Press. S. 269-278.

Colleman, Timothy, 2015: Constructionalization and post-constructionalization: The constructional semantics of the Dutch krijgen-passive in a diachronic perspective. I: J. Barðdal, E. Smirnova, L. Sommerer \& S. Gildea (red.): Diachronic Construction Grammar. Amsterdam \& Philadelphia: John Benjamins. S. 213-255.

Croft, William, 2003: Lexical rules vs. constructions: a false dichotomy. I: H. Cuyckens, T. Berg, R. Dirven \& K.-U. Panther (red.): Motivation in Language: Studies in honour of Günter Radden. Amsterdam \& Philadelphia: John Benjamins. S. 4968.

Dąbrowska, Ewa, 2004: Language, mind and brain: some psychological and neurological contraints on theories of grammar. Edinburgh: Edinburgh University Press.

Dąbrowska, Ewa, 2008: The effects of frequency and neighbourhood density on adult speakers' productivity with Polish case inflections. An empirical test of usage-based approaches to morphology. I: Journal of Memory and Language 58. S. 931-951.

Diessel, Holger, 2015. Usage-based construction grammar. I: E. Dąbrowska \& D. Divjak (red.): Handbook of Cognitive Linguistics. Berlin: Mouton de Gruyter. S. 295321.

Fillmore, Charles J., Kay, Paul \& O’Connor, Mary Catherine, 1988: Regularity and idiomaticity in grammatical constructions. The case of Let alone. I: Language 64(3). S. 501-538.

Fried, Mirjam, 2015: Construction Grammar. I: A. Alexiadou \& T. Kiss (red.): Syntax - Theory and Analysis. Berlin: de Gruyter. S. 974-1003.

Goldberg, Adele, 1995: Constructions. A Construction Grammar Approach to Argument Structure. Chicago \& London: University of Chicago Press.

Goldberg, Adele, 2006: Constructions at Work. The Nature of Generalization in Language. Oxford \& New York: Oxford University Press.

Kjellmer, Göran, 2002: Must down. On non-occurring verbs of motion in Modern English. I: Nordic Journal of English Studies 1(2). S. 339-353.

Langacker, Ronald, 2000: A dynamic usage-based model. I: M. Barlow \& S. Kemmer (red.): Usage-Based Models of Language. Stanford: CSLI Publications. S. $1-63$.

Langacker, Ronald, 2009: A dynamic view of usage and language acquisition. I: Cognitive linguistics 20(3). S. 627-640.

Levin, Beth, 1993: English Verb Classes and Alternations. A Preliminary Investigation. Chicago \& London: University of Chicago Press. 
Lundbladh, Carl-Erik, 1991: Processverb med tillståndsbetydelse. I: M. Thelander, B.-L. Gunnarsson, O. Hammermo, O. Josephson, C. Liberg, B. Nordberg \& C. Östman (red.): Svenskans beskrivning 18. Lund: Lund University Press. S. 248260.

Malmgren, Sven-Göran, 2001: Förnybart, reliabelt och tvåsamt föräldraskap. Om subjektiv och objektiv produktivitet hos några suffix. I: S. Allén (red.): Gäller stam, suffix och ord. Festskrift till Martin Gellerstam den 15 oktober 2001. Göteborg: Meijerbergs institut för svensk etymologisk forskning. S. 302-311.

Nikanne, Urpo \& Östman, Jan-Ola, 2006: Finland-Swedish directionality in conceptual semantics and in construction grammar: A methodological dialogue. I: M. Suominen \& A. Arppe (red.): A man of measure. Festschrift in honour of Fred Karlsson on his 60th birthday. Turku: SKY Journal of Linguistics. Volume 19. S. 66-86.

Olofsson, Joel, 2011: Det känns lite som att googla in i en frysbox. Om rörelsekonstruktioner och produktivitet. I: A.-C. Edlund \& I.-M. Mellenius (red.): Svenskans beskrivning 31. Umeå: Institutionen för språkstudier, Umeå universitet. S. 294303.

Olofsson, Joel, 2014: Argument structure constructions and syntactic productivity. The case of Swedish motion constructions. I: Constructions 1-7/2014. S. 1-17.

Olofsson, Joel, 2016: Kontextuell påverkan på produktivitet. I: A. W. Gustafsson, L. Holm, K. Lundin, H. Rahm \& M. Tronnier (red.): Svenskans beskrivning 34. Lund: Lunds universitet. S. 371-384.

Olofsson, Joel, 2017: Förhållandet mellan rörelseverb och förflyttningskonstruktioner. Lexikogrammatisk associationskraft och produktivitet. I: Norsk lingvistisk tidsskrift 35. S. 87-107.

Ralph, Bo, 1991: Strömningar inom ordforskningen. I: M. Thelander, B.-L. Gunnarsson, O. Hammermo, O. Josephson, C. Liberg, B. Nordberg \& C. Östman (red.): Svenskans beskrivning 18. Lund: Lund University Press. S. 9-28.

Ross, Brian. H. \& Makin, Valerie S., 1999: Prototype versus exemplar models. I: R. Sternberg (red.): The Nature of Cognition. Cambridge, MA: MIT Press. S. 205-241.

SAG $=$ Teleman, Ulf, Hellberg, Staffan \& Andersson, Erik, 1999: Svenska Akademiens grammatik. Stockholm: Norstedts ordbok.

Sjögreen, Christian, 2015: Kasta bort bollen och äta bort sin huvudvärk. En studie av argumentstrukturen i kausativa bort-konstruktioner. (Skrifter utgivna av Institutionen för nordiska språk vid Uppsala universitet 94.) Uppsala.

Slobin, Dan, 2004: The many ways to search for a frog. Linguistic typology and the expression of motion events. I: S. Strömqvist \& L. Verhoeven (red.): Relating Events in Narrative Vol. 2: Typological and Contextual Perspectives. Mahwah, NJ: Lawrence Erlbaum Associates. S. 219-257.

Slobin, Dan, 2008: Relations between Paths of Motion and Paths of Vision: A crosslinguistic and developmental exploration. I: V. Mueller-Gathercole (red.): Routes to Language. Studies in Honor of Melissa Bowerman. Mahwah, NJ: Lawrence Erlbaum Associates. S. 197-221.

$\mathrm{SO}=$ Svensk ordbok, utgiven av Svenska Akademien 2009. Stockholm: Norstedts.

Stefanowitsch, Anatol, 2013: Collostructional analysis. I: T. Hoffman \& G. Trousdale (red.): The Oxford Handbook of Construction Grammar. Oxford: Oxford University Press. S. 290-306. 
Strzelecka, Elżbieta, 2003: Svenska partikelverb med in, ut, upp och ner. En semantisk studie ur kognitivt perspektiv. (Skrifter utgivna av Institutionen för nordiska språk vid Uppsala universitet 62.) Uppsala.

Talmy, Leonard, 1985: Lexicalization patterns: semantic structure in lexical forms. I: T. Shopen (red.): Language typology and syntactic description, vol. III: Grammatical categories and the lexicon. Cambridge: Cambridge University Press. S. 57149.

Talmy, Leonard, 2000a: Toward a cognitive semantics. Vol. 1: Concept structuring systems. Cambridge, Mass.: MIT Press.

Talmy, Leonard, 2000b: Toward a Cognitive Semantics. Vol.2: Typology and Process in Concept Structuring. Cambridge, Mass.: MIT Press.

Talmy, Leonard, 2017: Foreword. Past, present, and future of motion research. I: I. Ibarretxe-Antuqano (red.): Motion and space across languages and applications. Amsterdam: John Benjamins. S. 1-12.

Viberg, Åke, 1981: Svenska som främmande språk för vuxna. I: K. Hyltenstam (red.): Språkmöte. Svenska som främmande språk, hemspråk, tolkning. Lund: Liber läromedel. S. 21-65.

Viberg, Åke, 1983: Fysiska kontaktverb i svenskan. En skiss. I: Svenskans beskrivning 14. Lund: Institutionen för nordiska språk. S. 174-185.

Viberg, Åke, 2013: Seeing the lexical profile of Swedish through multilingual corpora. The case of Swedish åka and other vehicle verbs. I: K. Aijmer \& B. Altenberg (red.): Advances in corpus-based contrastive linguistics. Studies in honour of Stig Johansson. Amsterdam: John Benjamins. S. 25-56.

Viberg, Åke, 2015: Sensation, perception and cognition Swedish in a typological-contrastive perspective. I: Functions of language 22(1). S. 96-131.

Vikner, Sten, 1988: Modals in Danish and event expressions. I: Working Papers in Scandinavian Syntax 39. S. 1-33.

Zeldes, Amir, 2012: Productivity and Argument Selection. From Morphology to Syntax. Berlin: De Gruyter.

Zlatev, Jordan \& Yangklang, Peerapat, 2004: A third way to travel: the place of Thai in the motion event typology. I: S. Strömqvist \& L. Verhoeven (red.): Relating Events in Narrative Vol. 2: Typological and Contextual Perspectives. Mahwah, NJ: Lawrence Erlbaum Associates. S. 159-190.

\section{Källor}

Korp, Bloggmix < spraakbanken.gu.se/korp/ > (tillgänglig 151105)

Google, $<$ www.google.se $>$ (tillgänglig 151105) 


\title{
Dialekter, platser och identiteter
}

\section{Språk- och kulturvetenskapliga förklaringar till språklig förändring och stabilitet i Torsby och Edsbyn}

\author{
Av JENNY NILSSON \& SUSANNE NYLUND SKOG
}

\begin{abstract}
Nilsson, Jenny, jenny.nilsson@sprakochfolkminnen.se, Associate Professor, Institute for Language and Folklore; Nylund Skog, Susanne, susanne.nylund.skog@sprakochfolkminnen.se, Associate Professor, Institute for Language and Folklore: "Dialects, places and identities. Sociolinguistic and culture analytical explanations of dialect change and stability in Torsby and Edsbyn in rural Sweden". Språk och stil NF 29, 2019, pp. 203-232.

This study investigates processes for dialect change in two seemingly similar rural villages (Torsby and Edsbyn) in two separate dialect areas in Sweden. The aim is to describe dialect change since the 1940s, and to explain the reasons for the different processes by using sociolinguistic and culture analytical methods. In both Edsbyn and Torsby the dialects are levelling towards the standard, but with different momentum. In Edsbyn, the dialect is much more standardized than in the significantly more stable Torsby. In a Swedish context, the linguistic stability in Torsby is striking. The culture analysis reveals that part of the explanation for the difference between Edsbyn and Torsby is the way the citizens perform belongingness. The Edsbyn informants consider themselves as part of a larger north Swedish area, whereas the Torsby informants primarily display a very local belongingness. In other words, there seems to be a connection between how large a region a person considers him- or herself to be part of, or feels belongingness to, and how important the dialect is. In this case, the smaller the region, the more important the dialect. In the article, we suggest that the reason for the separate processes of dialect change in Edsbyn and Torsby is the informants' orientations to place and dialect.
\end{abstract}

Keywords: dialect change, dialect stability, place, identity, belongingness, cultural analysis, rural Sweden.

Dialekter är i ständig förändring, och urbanisering jämte ökad mobilitet och språkkontakt har medfört att förändringen har gått extra snabbt de senaste 50 åren. Det gäller inte minst i Sverige, där flera studier visat att dialekter i allmänhet utjämnas mot standardsvenska (se t.ex. Thelander 1979, Sundgren 2002, Svahn \& Nilsson 2014). Det betyder inte att det måste gå till på samma sätt överallt, och i denna artikel visar vi hur processer för språkförändring kan se olika ut på två, till det yttre, mycket lika orter i två olika dialektområden:

Tack till Fredrik Skott för hjälp med den historiska beskrivningen av Edsbyn och Torsby, samt till två anonyma granskare för konstruktiva kommentarer på en tidigare version. 
Torsby i norra Värmland och Edsbyn i sydvästra Hälsingland. Syftet är dels att beskriva hur dialekten på dessa två orter har förändrats på 70 år, dels att utifrån sociolingvistiska och kulturanalytiska perspektiv göra försök att förklara vad de skilda förändringsmönstren beror på. Vi, en sociolingvist och en etnolog, vill också visa hur en tvärvetenskaplig ansats av den typ vi gör här erbjuder flera nya viktiga pusselbitar till svaret på vad som orsakar språklig förändring.

Artikeln är upplagd enligt följande: I avsnitt 1 redogör vi för olika processer för dialektförändring. I avsnitt 2 beskrivs några av de modeller som kan hjälpa till att förklara drivkraften bakom språkförändring, ur både individuellt och kulturellt perspektiv. I avsnitt 3 presenteras studiens material och de undersökta orterna introduceras, vilket följs av en beskrivning av hur analyserna genomförts i avsnitt 4. I avsnitt 5 redogör vi för studiens resultat, både den språkliga analysen och kulturanalysen, och dessa sammanfattas och diskuteras i avsnitt 6 där möjliga förklaringar till likheter och skillnader mellan dialektförändringsprocesserna i Torsby och Edsbyn lyfts fram.

\section{Dialektförändringsprocesser}

Flera tidigare studier har kunnat konstatera att språkkontakt är en förutsättning för språkförändring. Utgångspunkten för den här studien är att det förhåller sig så, och att språkbrukare anpassar sig till sina samtalspartner (se t.ex. Trudgill 1986, Giles m.fl. 1991, Hinskens 1998). Sociolingvisterna Peter Auer och Frans Hinskens $(1996,2004)$ har föreslagit en trestegsmodell för hur språkförändring går till. I det första steget samtalar talare av två varieter (se även Giles 1973, Coupland 1980, 1984, Trudgill 1986). I ett sådant samtal är det enligt Auer och Hinskens mest sannolikt att den mer dialektala talaren anpassar sig till den mer standardspråkliga (Auer \& Hinskens 1996, 2004). Nilsson (2015b) har dock konstaterat att det inte nödvändigtvis måste vara så, utan att en mer standardspråklig person också av olika skäl kan anpassa sig till en dialektal samtalspartner.

I Auer och Hinskens nästa steg tar den dialektala talaren med sig den nya språkformen in i nästa samtal, och börjar använda den i interaktion med individer som inte själva använder det nya draget. Att det här steget ska äga rum är mer sannolikt om en talare utsätts för det nya språkdraget ofta. För att det tredje steget ska uppnås, det som innebär språkförändring på längre sikt och i större omfattning, krävs det att ett stort antal invånare i ett språksamhälle anammar 
den nya språkformen och införlivar den i sin varietet. Den här modellen tar emellertid individens anammande av nya språkdrag som given och fångar inte den individuella motivationen till att språk förändras. I den här studien vill vi visa hur enskilda individer också förhåller sig till dialekt å den ena sidan och platsen där dialekten talas å den andra.

Själva förändringen kan resultera i en rad olika språkliga scenarier. Ett av de vanligaste, och mest beskrivna åtminstone för europeiska förhållanden, är utjämning mot en nationell eller regional standardvarietet. Ett par stora forskningsprojekt har behandlat standardisering i Europa (se till exempel studierna i Kristiansen \& Coupland 2011, samt Kristiansen \& Grondelaers 2013) och utjämning har också rapporterats från bland annat Danmark (Pedersen 2005, Gregersen \& Kristiansen 2015), Norge (Sandøy 2015a), Nederländerna, Tyskland, Spanien, Polen, England, Grekland och Ryssland (Auer 2005). Även svenska studier har kunnat konstatera sådan utjämning (se t.ex. Thelander 1979, Sundgren 2002, Nilsson 2009, 2017, Svahn \& Nilsson 2014).

Samtidigt rapporterar en rad forskare att vissa områden är betydligt mer stabila (se t.ex. Sundgren 2002, Ivars 2003, Sandøy 2004, 2015b, Friðriksson 2008, liksom Nilsson 2015a som behandlar just stabilitet i Torsby). Anledningen till att en del dialekter är mer resistenta än andra mot standardpåverkan kan vara språkpolitisk, men en starkt bidragande orsak till detta förhållande torde vara vilken uppfattning talarna av en dialekt har om den egna varieteten, om platsen där den talas, liksom hur lokalförankrade olika individer är (se t.ex. Røyneland 2005 och Friðriksson 2008). I denna studie belyser vi dessa aspekter ytterligare.

Sociolingvisten Barbara Johnstone har också visat att bruket av dialekt indexerar lokalidentitet och plats (se t.ex. Johnstone m.fl. 2006, Johnstone \& Kielsing 2008, Johnstone 2009, 2014). Försöket att förklara stabilitet och förändring kan alltså få god hjälp av kulturanalytiska modeller om hur lokalidentitet skapas och upprätthålls i relation till plats. Några för oss centrala studier inom dessa områden beskrivs i följande avsnitt.

\section{Identitet och plats}

Inom forskning som berör plats och identitet brukar det antas att det finns ett samband mellan platser och de människor som befolkar dessa platser. Sociologen Stephanie Taylor (2012 s.13) framhåller att »where someone is born has a 
special importance for identity» - till exempel registreras och noteras födelseort i arkiv och passhandlingar. Det i sin tur skulle kunna innebära att personers identitet tillskrivs dem av deras födelseort, vilket i förlängningen ger dem rätten att göra anspråk på den platsen som »hemma» (s. 51, se även Löfgren 1996).

Etnologen Owe Ronström (2016 s. 22) påpekar att utgångspunkten för »den moderna epokens mystiska geografi» är att speciella platser skapar speciella människor med en viss slags livsform. Med andra ord är identitet och plats nära sammanlänkade. Ett sätt att uttrycka en sådan koppling är genom att tala dialekt, och vi kommer att diskutera grad av dialektalitet med utgångspunkten att identitet och plats står i ständig växelverkan.

Ett begrepp som är viktigt för oss i våra försök att förklara skillnader i dialektförändringsprocesser som sammanfattar länken mellan plats och identitet är belongingness, som vi här har översatt med tillhörandehet. Begreppet kommer ursprungligen från psykologin (Baumeister \& Leary 1995) och innebär det tillstånd eller den känsla där en individ är en betydande del av något. Individen upplever alltså stark tillhörighet och identifierar sig med en viss socialgrupp, familj, förfäder eller en speciell region (Prins 2006 s. 288), eller med andra ord känner sig som en del av in-gruppen (Tajfel \& Turner 1979). Att tala dialekt skapar en länk mellan människor och platser - eller som Taylor (2012 s. 22) uttrycker det »a sense of belonging and an identity as a person of that place». Dialekten kan alltså skapa, upprätthålla och visa upp tillhörandehet (s. 117).

Platser i sig får bland annat sin identitet av de personer som befolkar dem, men också från vad människor tycker om platsen. Det gäller både personer som bor på platsen och de som inte gör det (Taylor 2012 s. 64, se även Prins 2006). Attityden till den egna hemorten, och andra orter runt omkring, är alltså en central del i förståelsen av hur dialekttalare konstruerar sin lokalidentitet (Taylor 2012 s. 25).

När vi i den här artikeln talar om identitet menar vi, i enlighet med Törrönen (2013), att identitet, eller identiteter, är föränderliga konstruktioner som får tillfällig stabilitet och betydelse i konkreta situationer (s. 80, se även Nylund Skog 2012, 2018a). Vi vill här rikta uppmärksamheten mot sådana situationer och mot hur individens identiteter uppstår i en dialektisk växelverkan med andras och egna uppfattningar (Brubacker \& Cooper 2000 s. 15-16). I den här artikeln har vi valt att inte ytterligare resonera och problematisera de båda begreppen plats och identitet (men se Nylund Skog 2012). Istället tar vi fasta på den process som länkar de båda, nämligen det vi valt att kalla tillhörandehet. 
Här undersöker vi således hur informanterna konstruerar sig som lokala eller regionala genom hur de talar om och förhåller sig till den egna orten, den egna dialekten och andras dialekter, liksom deras flyttbenägenhet och deras inställning till dialektförändring. Vi kopplar också detta till dialektbruket och dialektförändringen i Torsby och Edsbyn.

\section{Platserna och informanterna}

Materialet för denna studie har samlats in inom projektet Svenska dialekter i förändring. ${ }^{1}$ Projektets huvudsyfte var att jämföra dialektförändringsprocesser på två orter som demografiskt är mycket lika varandra: Torsby i norra Värmland och Edsbyn i sydvästra Hälsningsland. Både Torsby och Edsbyn har ungefär 4000 invånare och ligger en bit från större orter. Från Torsby är det ungefär tio mil till Karlstad och från Edsbyn är det tre och en halv mil till Bollnäs och ca sju mil till Söderhamn. En del pendlar dagligen från Sunne till Torsby, och viss utpendling sker till Karlstad. Något fler pendlar från Edsbyn än till, framförallt till och från Bollnäs. I både Torsby och Edsbyn är det möjligt att leva ett helt liv utan att resa till andra orter speciellt ofta - det finns skolor, arbetstillfällen, sjukvård och dagligvaruaffärer.

Vad beträffar skillnader och likheter mellan Edsbyn och Torsby idag utmärker sig Edsbyn bl.a. genom att många invånare tillhör något kyrkligt samfund och deltar i ett livaktigt föreningsliv (Götlind m.fl. 2003). Detta har troligtvis medfört många kontakter mellan Edsbybor och personer från andra delar av Sverige. Vi återkommer i slutdiskussionen till vad det kan innebära för dialektsituationen.

Vår studie baseras dels på nya inspelningar, dels på äldre inspelningar. De nya inspelningarna gjordes i Torsby 2011 och i Edsbyn 2013. Allt material insamlades $\mathrm{i}$ ett sociolingvistiskt syfte, och intervjuerna gjordes med utgångspunkten att få informanterna att tala så avslappnat och mycket som möjligt, och därmed styrdes inte samtalen enligt en förutbestämd agenda. Istället var målet för intervjuaren att vara lyhörd för vad informanterna ville berätta och uppmuntra samtalen i den riktningen. Det innebär för den här studiens del att en del frågor som varit kulturanalytiskt relevanta aldrig ställdes, och kulturanalysen baseras alltså på vad informanterna valde att berätta. Ut-

\footnotetext{
${ }^{1}$ Projektet pågick mellan 2011 och 2016 och finansierades av Svenska Akademien med stöd av Knut och Alice Wallenbergs stiftelse (KAW 2009.0296) samt Vetenskapsrådet.
} 
över intervjuerna fyllde också informanterna i en omfattande enkät som efterfrågade deras sociala bakgrund, mobilitet, livsstilsval och attityder till den egna och andras dialekter.

I denna studie undersöker vi samtal mellan en intervjuare och en till tre informanter. Sammanlagt har vi analyserat sex ungdomar, tre respektive fyra unga vuxna, fyra äldre vuxna och fyra extra dialektala vuxna från båda orter. Inom ramen för projektet spelades många fler informanter än så in, och här får dessa utvalda informanter representera hur det kan låta i dagens Edsbyn och Torsby i den meningen att såväl de minst dialektala som de mest dialektala är inkluderade i urvalet.

De nyinspelade informanternas tal har jämförts med inspelningar från 1940-talet. Från Edsbyn har tre informanter inspelade 1941 analyserats, och från Torsby tre informanter inspelade 1946. Samtliga är födda mellan 1872 och 1889. Informanter inspelade vid den här tiden var i allmänhet rekryterade på basis av bofasthet och grad av dialektalitet; önskemålet var helt enkelt att dokumentera ett äldre språksystem, och därför söktes ofta isolerade och mycket dialektala personer upp (Bockgård \& Nilsson 2011). Eftersom projektet ville jämföra hur dialekten på 2010-talet låter jämfört med den som talades på respektive ort på 1940-talet, inkluderades alltså informanter utvalda på samma sätt som de informanter som rekryterades för 70 år sedan. En översikt av studiens informanter redovisas i tabell 1.

Tabell 1. Studiens informanter.

\begin{tabular}{lcc}
\hline Informantgrupp & Edsbyn & Torsby \\
\hline Ungdomar (grupp 1) & 6 & 6 \\
Yngre vuxna (grupp 2) & 3 & 4 \\
Äldre vuxna (grupp 3) & 4 & 4 \\
Dialektala informanter 2010-tal (grupp 4) & 4 & 4 \\
Dialektala informanter 1940-tal (grupp 0) & 3 & 3 \\
TOTALT & 20 & 21 \\
\hline
\end{tabular}

Dialekterna i både Edsby- och Torsbyområdet är mycket välbeskrivna (se t.ex. Noreen 1877, 1878, Kallstenius 1927, Broberg 1973 och Lindén 1977). Många dialektbeskrivningar framhåller just den aktuella dialekten som extra intressant och speciell, och särskilt har det värmländska dialektområdet ofta beskrivits som komplext, inte minst på grund av närheten till Norge. Det område (Fryksdalen) Torsby ligger i är emellertid ansett som relativt homogent på grund av naturliga och topografiska hinder (Broberg 1973).

I denna studie talar vi oftast om Torsbydialekt och Edsbydialekt. Dessa benämningar använder vi som samlingstermer för de olika traditionella dialekter 
som talas i och runt respektive ort - i Torsbyområdet omtalas av informanterna exempelvis fryksdalska, övre fryksdalsmål, metbäcksmål och östmarksdialekt och i Edsbyområdet ovanåkersmål och alftamål. Traditionellt har det säkert funnits flera skillnader mellan de olika lokala varieteterna, inte minst på lexikal nivå, men i det nyinspelande materialet är sådana skillnader mycket små.

\section{Genomförande av språklig analys och kulturanalys}

I avsnitt 4.1 beskriver vi hur vi har genomfört den språkliga analysen och i avsnitt 4.2 beskriver vi kulturanalysen.

\subsection{Språklig analys}

I denna artikel diskuterar vi två distinkta uppsättningar av språkliga variabler: för det första dialektvariabler (vilka kan realiseras som en dialektvariant eller en standardvariant) och för det andra nya variabler (vilka kan realiseras som en ny variant eller en standardvariant). Dialektvariablerna realiseras inte med en ny variant eller vice versa i vårt material.

Här är det på sin plats att påpeka att standard är ett problematiskt koncept som snarast är en abstrakt tanke, eller ett ideal, som knappast förekommer i verklig interaktion mer än möjligen i vissa mediala sammanhang (Thelander 1996, Teleman 2003, Magnusson Petzell \& Nilsson 2015). Standardsvenska kan beskrivas som motsatsen till dialekter och sociolekter och avslöjar alltså inte en talares geografiska eller sociala bakgrund (Teleman 2003, Josephson 2004). När vi här talar om standardvarianter menar vi alltså språkdrag som inte är geografiskt utmärkande och som inte heller kan räknas som nya varianter.

Även konceptet dialekt är problematiskt (se t.ex. Svahn 2003 och även Svahn \& Nilsson 2014 för mer ingående diskussioner av detta), och olika forskare inkluderar språkdrag på olika nivåer i begreppet. Här avser vi med dialektvarianter språkdrag som är geografiskt avgränsade, men som också kan förekomma i en större region (se även Auer 2005). Vi inkluderar emellertid inte urbana drag (jfr Auer 2005 s. 7) i de dialektvarianter vi undersöker här, eftersom det för oss är viktigt att särskilja urbana och andra nya språkdrag från dialektala drag. Därför talar vi om dem som nya varianter, dvs. språkdrag som inte 
tidigare dokumenterats i de aktuella dialektområdena och inte heller förekommer i inspelningarna från mitten av 1900-talet. Sådana nya varianter kan vara drag som signalerar urbanitet och modernitet, i det här fallet ett frikativt $i$-uttal av /ej/ (ungefär [i:j], så att ord som hej och säger uttalas hij och sijer) samt fri$\mathrm{kativt} / \mathrm{r} /$, liksom i Torsby potentiellt frikativt långt $/ \mathrm{i} / \mathrm{och} / \mathrm{y} /$ (se även Svahn \& Nilsson 2014). ${ }^{2}$ Det kan också vara förändringar i uttal som tycks vara en del av en pågående förändring i svenskans vokalsystem, så att $\ddot{a}$ och $\ddot{o}$ får ett öppnare uttal (motsvarande [æ:] och [œ:]) och kort $\ddot{o}$ uttalas [ө] (Leinonen 2010a, 2010b, Wenner 2010).

Givetvis har både dialekter och standardvarieteter världen över ständigt stått i förändring, med stor inter- och intraindividuell variation som följd (se t.ex. Coupland 2009, Pedersen 2009 liksom Kristiansen \& Coupland 2011 och bidragen däri). I den här studien låter vi den varietet som talas av informanterna inspelade under mitten av 1900-talet representera den lokala varieteten vid det tillfället, och de nyinspelade informanternas tal får representera hur det kan låta på 2010-talet. Vi försöker förklara varför förändring gått till på olika sätt, snarare än att i detalj redovisa varje informants språkbruk.

Valet av dialektvariabler har genererats utifrån materialet, och samtliga studerade variabler förekommer i inspelningarna. De nya variablerna valdes utifrån tidigare studier om förändringar och novationer i svenskan (se t.ex. Bruce 2010, Leinonen 2010a, 2010b, Wenner 2010, Svahn \& Nilsson 2014, Öqvist under arbete). De flesta variabler är fonologiska eller morfologiska, men några syntaktiska och lexikala variabler, liksom en prosodisk variabel, analyserades också, vilket framgår av tabell 2 .

Tabell 2. De undersökta dialektvariablerna.

\begin{tabular}{lcc}
\hline Variabler & Edsbyn & Torsby \\
\hline Fonologiska & 26 & 22 \\
Morfologiska & 14 & 23 \\
Syntaktiska & 6 & 2 \\
Lexikala & 1 & 7 \\
Prosodiska & 1 & 0 \\
\hline TOTALT & 48 & 54 \\
\hline
\end{tabular}

Som framgår av tabell 2 har alltså 48 dialektvariabler undersökts i Edsbyn och 54 i Torsby. Därtill har sju nya variabler undersökts i Torsby, och fem i Edsbyn. Genom att analysera en så stor mängd variabler går det att överblicka hur

\footnotetext{
${ }^{2}$ I Edsbyn är situationen mer komplex eftersom dessa varianter också ingått i den traditionella dialekten. Detta behandlas i Nilsson, Leinonen \& Wenner u.u.
} 
dialektsystemet förändrats under 70 år: Vad finns kvar, vad försvinner och vad ersätts den traditionella dialekten med?

De studerade variablerna har excerperats ur samtliga informanters tal. Därefter har det noterats hur dessa variabler realiserats. På så vis får man en bild av varje informants individuella språkliga repertoar (som den realiseras vid inspelningstillfället; den kan givetvis skifta beroende på kontext och samtalspartner). De här individuella språkliga repertoarerna får representera ett utsnitt ur dialekten som den talades på 1940-talet respektive på 2010-talet, och här visar vi hur dialekten, liksom bruket av nya varianter, varierar mellan olika åldersgrupper liksom mellan olika tidpunkter. Vi fokuserar inte på intra-individuell variation i denna studie, men kan konstatera att det finns en direkt korrelation mellan att realisera ett stort antal dialektvariabler som dialektvarianten och frekvens, med andra ord så är de talare som använder en stor del av det traditionella dialektsystemet också mer konsekventa $\mathrm{i}$ att realisera dessa som dialektvarianten.

\subsection{Kulturanalys}

Som vi framhöll inledningsvis är plats och identitet sammanbundna. Vi påpekade också att det råder ett dialektiskt förhållande mellan plats och identitet såtillvida att vi människor kan skapa identitet med utgångspunkt i platser, samtidigt som platser också får identitet genom de människor som befolkar dem. Vi framhöll också att ett utbrett antagande handlar om att vi naturligt hör hemma på en plats genom att vara födda på den. I denna artikel är det dock en viktigare utgångspunkt att vi människor aktivt kan sträva efter en viss identitet kopplad till en plats. Likaså kan vi vilja ta avstånd ifrån identiteter. Båda dessa aktiviteter kan bland annat ske med hjälp av klädstil, yrkesval, rörelsemönster och tal, med andra ord genom kulturella praktiker (Nylund Skog 2018b). I artikeln tar vi fasta på några aspekter av sådana praktiker och gör en kulturanalys av dessa.

I svenska sammanhang är det framförallt etnologerna Billy Ehn och Orvar Löfgren som förknippas med kulturanalysen (se 1982, 2001 och 2007). Boken Kulturanalys har sedan den första gången trycktes 1982 reviderats och uppdaterats i flera omgångar. I den reviderade utgåvan med titeln Kulturanalyser från 2001 skriver författarna att kulturanalysen inriktas på känsla och handling, likaväl som språk och tänkande. Avsikten är att undersöka ett fenomen ur olika perspektiv, att söka sammanhang och nyckelsymboler samt att fästa blicken på 


\section{Jenny Nilsson \& Susanne Nylund Skog}

det som tas för givet och inte ifrågasätts (s. 14). Kulturanalysen inbegriper med Ehn \& Löfgrens terminologi bland annat perspektivering och kontrastering. Perspektivering handlar om att skapa distans för att få fatt på det invanda och självklara, att göra jämförelser eller att tänka i liknelser, medan kontrastering handlar om att ta fasta på motsatspar (s. 155 ff.). Inspirerade av dessa analytiska sätt att nalkas ett fält har vi med utgångspunkt i informanternas utsagor bland annat frågat oss vem som kvalificerar sig som Torsby- respektive Edsbybo och vem som inte gör det, vad som utgör motsatsen till dialekt, samt vilka teman, symboler, ord och ordkombinationer som är återkommande. Vi har inriktat kulturanalysen på fyra huvudfrågor: beskrivningen av dialekten som regional eller lokal, attityden till den egna dialekten och andras dialekter, attityden till dialektförändring samt informanternas flyttbenägenhet.

\section{Analys och resultat}

I det här avsnittet presenteras våra analyser och resultat. I 5.1 redovisar vi den språkliga analysen och resultaten och i 5.2 kulturanalysen.

\subsection{Dialekt och novation i Torsby och Edsbyn}

I figur 1 och 2 redovisas Edsby- respektive Torsbyinformanternas realisering av de undersökta dialektvariablerna på respektive ort. ${ }^{3}$ Varje stapel representerar en enskild informants språkbruk, och under stapeln anges vilken grupp informanten tillhör liksom ett särskiljande nummer inom gruppen (så t.ex. informant 3:2 tillhör grupp 3, äldre vuxna, och har fått det individuella numret $2 \mathrm{i}$ den gruppen). Den del av stapeln som markeras som dialektvariant (D) innebär att informanten realiserar så många dialektvariabler som dialektvarianten vid något tillfälle $\mathrm{i}$ inspelningen (men i allmänhet också någon gång som standardvarianten). Den del av stapeln som markerats som standardvariant (S) innebär att informanten realiserar så många dialektvariabler enbart som standardvarianten i inspelningen. En del informanter saknar belägg på några variabler, vilket i förekommande fall markeras överst på stapeln.

\footnotetext{
3 På Institutet för språk och folkminnens hemsida finns ljudexempel från representanter för de olika grupperna i Edsbyn och Torsby.
} 


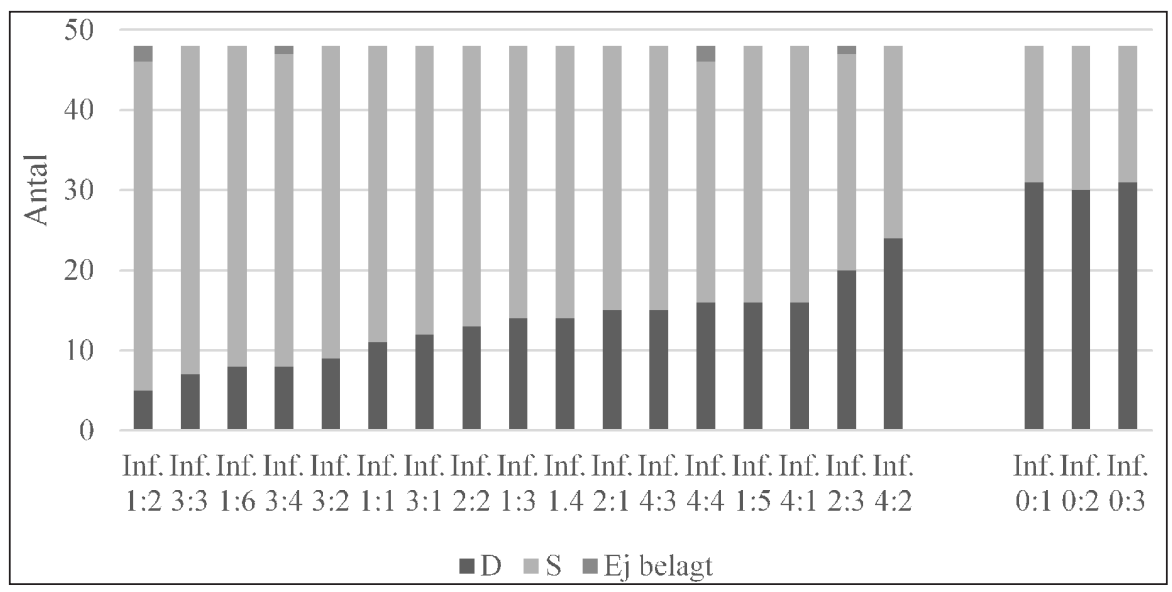

Figur 1. Edsbyinformanternas realisering av dialektvariabler som dialektvariant (D) eller standardvariant (S).

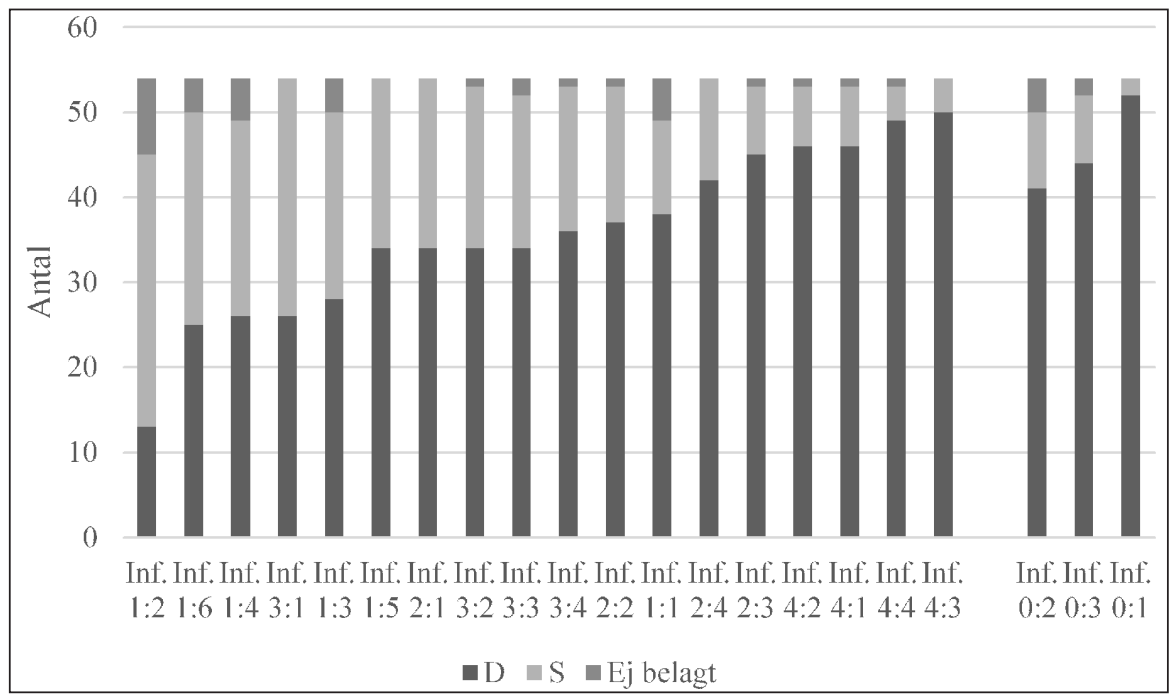

Figur 2. Torsbyinformanternas realisering av dialektvariabler som dialektvariant (D) eller standardvariant (S).

Av diagrammen i figur 1 och 2 kan flera resultat utläsas. I Edsbyn realiserar samtliga nyinspelade informanter dialektvariablerna som standardvarianten $\mathrm{i}$ större utsträckning än dialektvarianten. I Torsby är situationen omvänd merparten av informanterna realiserar de flesta dialektvariablerna som dialekt- 


\section{Jenny Nilsson \& Susanne Nylund Skog}

varianten, åtminstone någon gång i inspelningen. Edsbyinformanterna är alltså betydligt mer utjämnade mot standard än vad Torsbyinformanterna är. Utjämningsprocessen verkar dessutom ha startat tidigare i Edsbyn än i Torsby; till höger i respektive diagram redovisas 1940-talsinformanternas språkbruk. Här framkommer alltså att de informanter som spelades in i Torsby på 1940-talet är betydligt mer dialektala än de som spelades in i Edsbyn vid samma tid om man kvantitativt ser till realiseringen av dialektvariabler som dialekt- eller standardvariant.

I tabell 3 jämför vi spannet av antalet använda dialektdrag i de olika grupperna. Notera att antalet undersökta dialektvariabler är något fler i Torsby, varför också procent anges för att underlätta jämförelsen mellan de två orterna.

Tabell 3. Spannet av antalet dialektdrag i respektive grupp i Edsbyn och Torsby.

\begin{tabular}{lcc}
\hline \multirow{2}{*}{ Informantgrupp } & \multicolumn{2}{c}{ Antal drag } \\
\cline { 2 - 3 } & Edsbyn (totalt 48) & Torsby (totalt 54) \\
\hline Ungdomar (grupp 1) & $5-16(10-33 \%)$ & $13-38(24-70 \%)$ \\
Yngre vuxna (grupp 2) & $13-20(27-41 \%)$ & $34-45(63-83 \%)$ \\
Äldre vuxna (grupp 3) & $7-12(14-25 \%)$ & $26-36(48-66 \%)$ \\
Dialektala informanter 2010-tal (grupp 4) & $15-24(31-50 \%)$ & $46-50(85-92 \%)$ \\
Dialektala informanter 1940-tal (grupp 0) & $30-31(62-64 \%)$ & $41-52(76-96 \%)$ \\
\hline
\end{tabular}

Som framkommer av tabellen (liksom i figur 1 ovan) är de informanter som är inspelade på 1940-talet de mest dialektala i Edsbyn, de realiserar mellan 30 och 31 av 48 dialektvariabler som dialektvarianten, vilket kan jämföras med grupp 4 som valdes enligt samma principer om än 70 år senare. De dialektala informanterna inspelade i Edsbyn 2013 använder mellan 15 och 24 dialektdrag och är alltså inte lika dialektala som informanterna inspelade på 1940-talet, även om den mest dialektala 2011 inte har så mycket färre drag än den minst dialektala 1941. I Torsby ser det annorlunda ut - trots att de informanter som spelades in 1946 är så pass dialektala är motsvarande grupp inspelade 2011 lika dialektala. I Torsby är dessutom samtliga grupper dialektala, vilket framgår inte minst i jämförelsen med Edsbyinformanterna. I Edsbyn realiserar ungdomarna $10-44 \%$ av dialektvariablerna någon gång som dialektvarianten, medan så många som mellan 24 och 70 \% gör det i Torsby. På båda orter är gruppen yngre vuxna betydligt mer dialektal än äldre vuxna: I Edsbyn använder de yngre vuxna mellan 27 och $41 \%$ av de undersökta dialektdragen medan de äldre endast använder mellan 14 och $25 \%$. I det betydligt mer dialektala 
Torsby använder de yngre vuxna hela $63-83 \%$ av de studerade dialektdragen, och de äldre vuxna använder något mindre: $48-66 \%$.

I tabell 4 redovisas även hur stor del av antalet undersökta dialektdrag som används av någon informant i respektive grupp - det vill säga hur stor del av dialektsystemet som används av varje grupp. Som framgår av tabellen använder 1940-talsinformanterna inte samtliga undersökta dialektdrag. En orsak kan vara att dessa inspelningar är kortare än de som är gjorda i nutid, och att de inte har belägg på vissa drag kan bero på att belägg på variabeln saknas, eller att just dessa informanter inte använde dragen. De »saknade» dragen finns emellertid beskrivna i äldre litteratur, så resultatet ska inte förstås som att ett dialektdrag tillkommit till exempel i Torsby där 1940-talsinformanterna använder 53 av 54 och de dialektala 2010-talsinformanterna samtliga 54.

Tabell 4. Antalet undersökta dialektdrag som återfinns i varje grupp i Edsbyn och Torsby.

\begin{tabular}{lccccc}
\hline \multirow{2}{*}{ Informantgrupp } & \multicolumn{4}{c}{ Antal drag } \\
\cline { 2 - 3 } \cline { 5 - 6 } & \multicolumn{2}{c}{ Edsbyn (totalt 48) } & & \multicolumn{2}{c}{ Torsby (totalt 54) } \\
\cline { 2 - 3 } \cline { 5 - 6 } & Antal & Antal & \% \\
\hline Ungdomar (grupp 1) & 23 & 48 & & 45 & 83 \\
Yngre vuxna (grupp 2) & 25 & 52 & & 52 & 96 \\
Äldre vuxna (grupp 3) & 19 & 39 & & 45 & 83 \\
Dialektala informanter 2010-tal (grupp 4) & 32 & 66 & & 54 & 100 \\
Dialektala informanter 1940-tal (grupp 0) & 45 & 94 & & 53 & 98 \\
\hline
\end{tabular}

Som framkommer av tabell 4 användes i början av 2010-talet en betydligt större del av det traditionella dialektsystemet i Torsby än i Edsbyn. I Torsby återfinns $83 \%$ av de studerade dialektdragen hos ungdomar och äldre vuxna: $96 \%$ hos unga vuxna och hela $100 \%$ hos de dialektala informanterna. Alla informanter i Torsby använder en rad götamålsdrag liksom apokopering av verb i preteritum och infinitiv (t.ex. kall för 'kallade/kalla'), substantiv (gubb 'gubbe' och vid trestaviga substantiv ändelseförsvagning som i lärer 'lärare'), och en del adjektiv och adverb (myck 'mycket', ill 'illa' och bar 'bara'). Det som förekommer mer sällan i inspelningarna från 2011 är sådana drag som används sporadiskt också i inspelningarna från 1946. Dessutom tycks de användas mindre och mindre av varje generation. Ett exempel på det är bruket av uvulart $r([\mathrm{R}])$ som används i samtliga för götamålet typiska po-

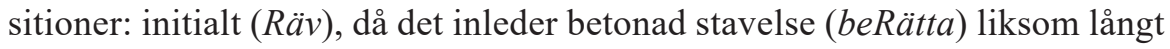
efter betonad vokal (väRRe) av de dialektala informanterna både 1941 och 2011. De vuxna informanterna inspelade 2011 använder endast uvulart $r$ ini- 


\section{Jenny Nilsson \& Susanne Nylund Skog}

tialt och då det inleder betonad stavelse, men långt $r$ efter betonad vokal uttalas aldrig uvulart. Ungdomarna, trots att de är anmärkningsvärt dialektala, använder inte uvulart $r$ överhuvudtaget (se även Nilsson 2015a). Trots det måste Torsbydialekten betraktas som stabil, även om inte alla informanter använder samtliga studerade dialektdrag.

I Edsbyn har däremot en stor förändring skett. I inspelningarna från 1941 återfanns 45 av $48(94 \%)$ av de undersökta dialektdragen, medan det i 2010-talsmaterialet från Edsbyn som helhet endast finns 35 (73 \%) av dessa drag belagda. Den grupp som på egen hand använder flest av dialektdragen är som förväntat de dialektala informanterna, och de andra grupperna gör alltså inte bruk av mellan 48 och $61 \%$ av de traditionella dialektvarianterna. De flesta informanterna använder regionala norrländska drag (jfr Thelander 1979) som finns i många dialekter, t.ex. så kallat tjockt $l$ ([r], i fortsättningen betecknat med $L$ ), avsaknad av kongruens (dom är fin), $t$-bortfall i substantiv och verb i preteritum (huse respektive kasta), /s1/ uttalas [ $\mathrm{r}$ ] (så att sluta uttalas schLuta), bortfall av vokal i obetonad stavelse (litn) samt $e$-ändelse i substantiv och verb (t.ex. häster och kaster). Därtill använder flera informanter ett frikativt, uvulart $r$-ljud som påminner om ett amerikanskt $r$-ljud ([ь]). Men en stor del av systemet tycks alltså ha om inte försvunnit så användas mycket marginellt. I inspelningarna från 2013 finns inte belägg på en rad av de dialektdrag som var vanliga 1941, till exempel så kallad norrländsk förmjukning där $g$ och $k$ framför främre vokaler uttalas med $j$ eller $t j$ (väjen 'vägen' respektive styttjen 'stycken'), avsaknad av stämton i konsonantförbindelserna $r t$, $r k$ och $r p$ som traditionellt uttalats med sje-ljud (mösjt 'mört', masjnad 'marknad'), $t$-förslag (tschött 'kött'), frikativt kort $i$ och $y$, långt $a$ uttalat som $\ddot{a}$ eller hårt $g$ i konsonantförbindelserna $\lg$ och $r g$ (älg uttals med $g$ som i god). Dialektsystemet har alltså krympt i Edsbyn, och ersatts av standarddrag. Därtill tillkommer några nya drag i Edsbyn, som inte tidigare funnits beskrivna där. Ungdomarna i Edsbyn öppnar de långa vokalerna $\ddot{o}$ (så att föl har samma $\ddot{o}$-kvalitet som standardsvenskans för, dvs. [œ:]) och, i synnerhet, $\ddot{a}$ (så att häl har samma $\ddot{a}$-kvalitet som i standardsvenskans här, dvs. [æ:]). Dessutom uttalas /ej/ som [i:j]. I Edsbyn har för övrigt frikativt /i/ och /y/ varit traditionella dialektdrag, men de tycks vara i en process där de möjligen kan komma att omtolkas som urbana drag (Nilsson, Leinonen \& Wenner u. u.). I Edsbymaterialet har enbart ungdomar belägg på dessa drag, liksom 1940-talsinformanterna som har både långa och korta frikativor i sitt tal.

I Torsby förekommer inga av dessa nya drag i någon av informantgrupperna. Tidigare forskning har visat att individer som använder nya drag också är rela- 
tivt utjämnade, till exempel ungdomar i Västergötland (Svahn \& Nilsson 2014). Torsbydialekten har ännu inte urbaniserats eller standardiserats i samma utsträckning som Edsbydialekten. Men det som är anmärkningsvärt är inte att Edsbydialekten utjämnats så pass mycket; det är snarast förväntat med tanke på vad andra studier av dialektförändring i Sverige kommit fram till. Snarare är det det dialektalt stabila Torsby som utmärker sig. I det följande försöker vi förklara vad det beror på att dialekten förändrats med så olika hastighet i Edsbyn och Torsby, trots att orterna har så många yttre likheter. Vi fokuserar särskilt på att förklara hur det kan komma sig att Torsbydialekten är så stabil.

\subsection{Förhållningssätt till dialekten och platsen}

För att försöka förstå varför dialektförändringsprocesserna ser så olika ut i Edsbyn och Torsby har vi undersökt intervjuerna och de skriftliga enkäterna med hjälp av kulturanalytiska redskap och med utgångspunkt i fyra teman: flyttbenägenhet och band till platsen (5.2.1), attityden till dialektförändring (5.2.2), attityden till den egna dialekten och andras dialekt (5.2.3), liksom informanternas beskrivning av dialekten som regional eller lokal (5.2.4).

\subsubsection{Flyttbenägenhet och band till platsen}

I enkäterna har informanterna fått uppge var de helst skulle vilja bo: på en mindre ort, på en större ort eller om de helst bor kvar där de bor. I både Edsbyn och Torsby vill de allra flesta bo kvar och de är också positiva till den lokala dialekten. De tre yngre informanter som vill flytta från Edsbyn tycker också de om den lokala dialekten, eller är åtminstone neutrala till den. I Torsby, däremot, är de tre unga informanter som uppger att de vill flytta därifrån dels negativa till den lokala dialekten, dels är deras dialekt tydligt utjämnad mot standardsvenska. Liknande mönster som det i Torsby fann också sociolingvisten Malene Monka (2015) i en studie av dialektförändring i Danmark. Det tycks med andra ord som om avlägsnandet från platsen är förknippat med en distansering från dialekten i Torsby, vilket alltså inte är fallet i Edsbyn. Som vi kommer att se i det följande verkar det också som om dialekt i Torsby är associerat med att stanna och vara förankrad i och rotad på en dialektal plats.

Informanterna är alltså i de flesta fall positiva till att bo kvar i Edsbyn respektive Torsby, men orsakerna till detta verkar skilja sig något åt. I Edsbyn 


\section{Jenny Nilsson \& Susanne Nylund Skog}

framhåller till exempel Sara (34 år) naturen och den höga levnadsstandarden som skäl att bo där. Hon påpekar också att ett hus som motsvarar det hon har i Edsbyn skulle kosta många miljoner i Stockholm.

\section{Exempel 1. Att bo i Edsbyn.}

S: nä men jag har jag har alltid trivts i (.) jag skulle inte vilja bo i stör- större (.) jag tycker liksom att det är (.) sen tycker jag det är skönt att komma ja men på en (...) ut liksom så tycker jag det är kul att ha den där pulsen men jag tycker liksom (.) nära naturen det är lugnt det är liksom man kan bo (.) vid sidan av och ha ett hus som skulle ha kostat (.) många miljoner i stockholm med ett läge som skulle ha varit mycket sämre i stockholm *skrattar*

$I: m$

S: så det är väl liksom såna grejer

$I: m$

S: och sen sen har det väl lite med att göra att jag träffade karln ganska tidigt som också (.) är här så annars (.) vem vet jag hade kanske sökt jobb nån annanstans och hamnat nån annanstans och trivts jättebra där

Sara tecknar i exemplet Edsbyn som en av flera möjliga och bra platser att leva på. Det gör även yngre informanter från Edsbyn, till exempel säger en 18-årig kvinna: »ja på gården trivs jag, det är jättefint vi har jättelång utsikt, vi ser ju över hela liksom hela sjölandskapet». Här poängteras utsikten som gör att Edsbyn framstår som en större och mer utbredd ort än vad den egentligen är. Platsen Edsbyns utseende står i fokus och dialekten eller människorna som bor på platsen nämns inte. En äldre man talar också om fördelarna med Edsbyns utbredning, men inte om den jättelånga utsikten utan om att det är som ett »enda stort kontaktnät allting». Då knyter han alltså Edsbyn till människor som bor på andra platser »över hela Sverige».

I Torsby verkar dialekten ha en mer framskjuten position i lokalkänslan. I följande exempel från Torsby diskuterar Lisa och Erik (17 år) Värmland, värmlänningar och värmländskan:

Exempel 2. Värmland.

L: värmland alltså värmland ska vara värmland (.) värmland är liksom något speciellt med dialekten och

$I: j a$

L: det är mysigt och alla liksom är (.) alltså det kan (.) alltså alla är nästan liksom som att värmlänningar är ett eget så här folkslag

E: ja (.) vad var det det var ju en (.) han skrev en dikt eller 


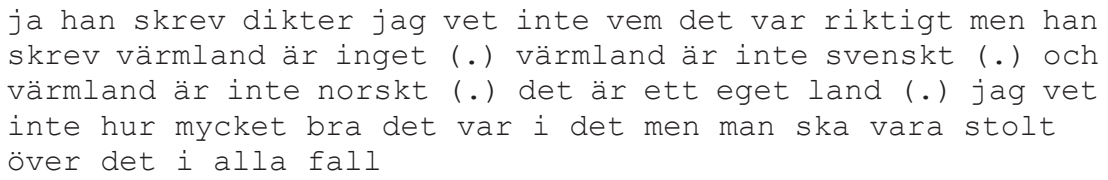

I utdragets första rader beskriver Lisa Värmland som »något speciellt med dialekten», det finns alltså enligt henne en direkt koppling mellan dialekten och platsen. Hon säger dessutom att värmlänningar är som ett eget folkslag, och Erik utvecklar detta med att Värmland är som ett eget land att vara stolt över. Här finns paralleller till historikern Benedict Andersons (2006) diskussion om hur nationer skapas och hålls samman av föreställda gemenskaper om att ett visst folk hör hemma på en viss plats.

Andra ungdomar från Torsby med omnejd framhåller också dialekten som det bästa med att bo där de bor, samt att platsen har en rad andra fördelar. En ung man säger exempelvis att han tycker att det »är så himla fint där jag bor», och en annan ung man påpekar att han tycker att »det är väldigt mycket trevligt folk» i Torsby.

I det sista citatet ser vi ett tydligt exempel på att en plats får sin karaktär (och i det här fallet attraktionskraft) genom de människor som bor där. Sammantaget ger också citaten från de unga informanterna från Torsby en bild av orten som en »himla fin» plats med ett eget mycket trevligt folk. På så vis gestaltas Torsby som en speciell plats medan Edsbyn beskrivs som en av flera fina platser. Som vi kommer att se förstärks denna bild av informanternas attityder till dialektförändring.

\subsubsection{Attityder till dialektförändring}

Av enkäterna framstår attityden till dialektförändring som relativt lika i Edsbyn och Torsby. På båda orter har ungefär hälften uppgett att det inte spelar någon roll, och andra hälften att det är synd. Vilka som uppgett vad skiljer sig emellertid åt. I Torsby är den halva informanter som är mest dialektal negativ till dialektförändring och det är endast yngre, mindre dialektala, personer som inte tycker att det spelar någon roll. I Edsbyn däremot finns inget samband mellan vare sig ålder eller grad av dialektalitet och inställningen till dialektförändring.

I Edsbyn tycks dialekten av många vara något som tillhör det förflutna, vilket får illustreras av följande exempel där två kvinnor, Majken och Alice, födda på 1920-talet i Alfta utanför Edsbyn samtalar med intervjuaren. 
Exempel 3. Tala eller inte tala Alftamål.

A: han (.) stod lik här uppe då för alltid var det det troliga var där att det var alltid nåt (.) barn (.) här uppe då som var döda (.) för mer (.) var (.) alla barnen på tjugoåtta år

M: alle barena alla barnen

$I: m$

M: du prata inte [nåt alftamål

A: $\quad$ [barena

A: nä *skrattar*

M: du ska göra det nu du ser du

A: det har man ju (.) försökt lagt ifrån sig *skattar*

$\mathrm{M}:$ *skrattar*

I: ja har ni försökt lägga ifrån er det

A: ja

$I: j a$

A: alftamålet ja (.) ja för att man (.) mina (.) skolkompisar och så (.) ee åtminstone flickor de åkte ju till stockholm de och (.) fick jobb där och inte kunde de då prata alftamål

Exemplet inleds med att Alice berättar om barnadödlighet förr i tiden, och hon använder då den standardspråkliga formen alla barnen. Majken korrigerar Alice med den dialektala formen alle barena och påpekar också att Alice inte talar Alftamål. Majken tycks alltså ha förväntningar om att Alice ska tala Alftamål, eftersom hon bjudit in Alice till sitt hem för att intervjuaren ska få dokumentera den äldre dialekten. Alice besvarar detta med »det har man ju (.) försökt lagt ifrån sig», och positionerar alltså sig själv som modern i förhållande till den äldre dialekten. Hon förklarar också att hennes vänner (men inte hon själv tycks det som) flyttade till Stockholm och arbetade där, och att dialekten i dessa urbana sammanhang inte fungerade som uttrycksmedel, vilket också tycks ha påverkat hennes eget förhållningssätt till den traditionella dialekten.

Även andra informanter i Edsbyn ger exempel på situationer då de eller andra »försöker skärpa sig å prata fint» (kvinna, 49 år). En viktig skillnad som vi tolkar det gentemot situationen i Torsby är att det inte verkar vara speciellt markerat att välja att tala fint $i$ Edsbyn, men att det i Torsby är något av nöd för att göra sig förstådd. En kvinna i 50-årsåldern påpekar att hon automatiskt förändrar sin dialekt när hon talar med personer som inte kommer från Torsby »för en tror ju inte att de ska förstå». Detsamma poängterar en jämnårig man som berättar att när han är ledare för jaktlaget så »förfinar» han sig automatiskt av »säkerhetsskäl» eftersom det inte är självklart att alla begriper.

Att låta bli att förfina sig kan också vara en strategi för att skapa tillhörandehet och gruppidentitet. Johanna, en kvinna i 60-årsåldern, berättar om pojkar som »springer på Torsby» och pratar dialekt »så det jämt dryper om det». Hon 
tror att de tycker att det är »häftigt» och »roligt när inte alla förstår vad de säger»».

I Torsby talar också en rad informanter om dialektförändringen som en förlust. Detta exemplifieras nedan, där den mycket dialektala Lars-Erik, som är född 1960 utanför Torsby, beklagar dialektförändringen.

Exempel 4. Tvätta ur dialekten.

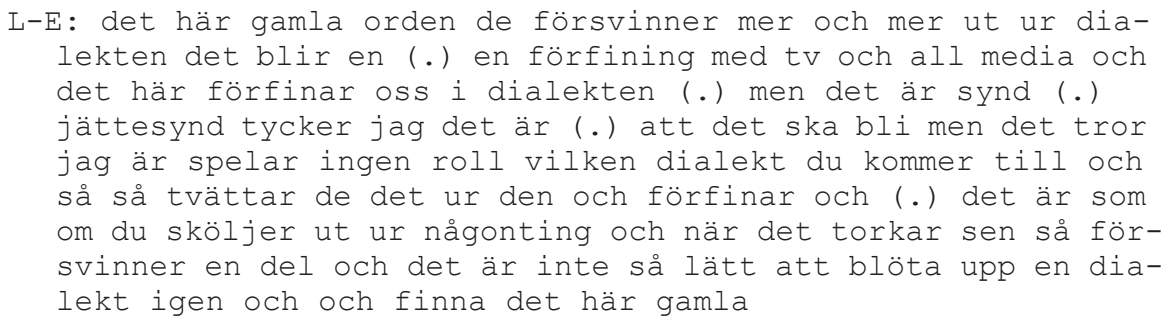

För Torsbyborna är med andra ord dialekten ingenting de kan lägga ifrån sig eller ta av sig som ett plagg. I citatet från Lars-Erik framstår istället dialekten som en viktig del av identiteten, som när den nöts bort och tvättas ur också är borta för alltid och omöjlig att plocka upp igen. Det blir svårt att finna den gamla när den en gång tvättats ur, säger Lars-Erik. Samtidigt som han alltså påpekar att dialekten i Torsby är gammal, har den ur ett kulturanalytiskt perspektiv aktualitet och ett identitetsskapande värde i nuet.

När det gäller informanterna från Torsby är inställningen till dialekten alltså annorlunda än för Edsbyborna. Visserligen betraktar även Edsbyborna dialekten som någonting gammalt, men som Alice gav uttryck för har man lagt dialekten bakom sig. Den tycks också möjlig att plocka upp och använda om man så skulle önska. Med andra ord tycks inte dialekten i Edsbyn ha samma genomgripande betydelse för identiteten som den verkar ha för Torsbyborna. Detta förstärks av informanternas attityder till den egna och andras dialekter som vi ska diskutera i följande avsnitt.

\subsubsection{Den egna dialekten och andras dialekter}

De flesta informanter på båda orter uppger att de är positivt inställda till den egna dialekten som svar på en direkt fråga. Torsbyborna uttrycker att de är stolta över sin dialekt och beskriver den ofta som grov (vilket inte nödvändigtvis verkar vara något negativt), och säger också att det låter "gött» (kvinna, 16 år). I exemplet nedan har ett medelålders par, Åke och Johanna, intervjuats och 
sitter och fyller i den skriftliga enkäten tillsammans, vilket alltså också spelas in.

Exempel 5. Favoritdialekten.

$\AA$ : ja vilken av sveriges dialekter är din favorit (.) ((läser högt från enkätformuläret))

$\mathrm{J}:$ mmmmmm

$\AA$ A: men nok e de gött å kom hem och hör värmländska när en varit bort och åkt

$\mathrm{J}: \mathrm{ja}$

$\AA$ : det tror ja allt

Här ser vi att dialekten förknippas med tillhörandehet och hemkänsla. I Torsby är det fler informanter än i Edsbyn som gör självskattningen att de talar mycket dialekt. Vi tolkar det som att de genom sin dialekt och kunskap om dialekten signalerar att de hör hemma i Torsby. I Torsby talar också flera informanter om den lokala dialekten i relation till »svenska», dvs. att den mer eller mindre utgör ett eget språk, eller i alla fall en varietet som avsevärt skiljer sig från standardsvenskan. Detta exemplifieras av utdraget nedan, där Anders som är 55 år berättar om sitt språkbruk och hur det skiftar både över tid och mellan olika situationer.

Exempel 6. Fryksdalska och svenska.

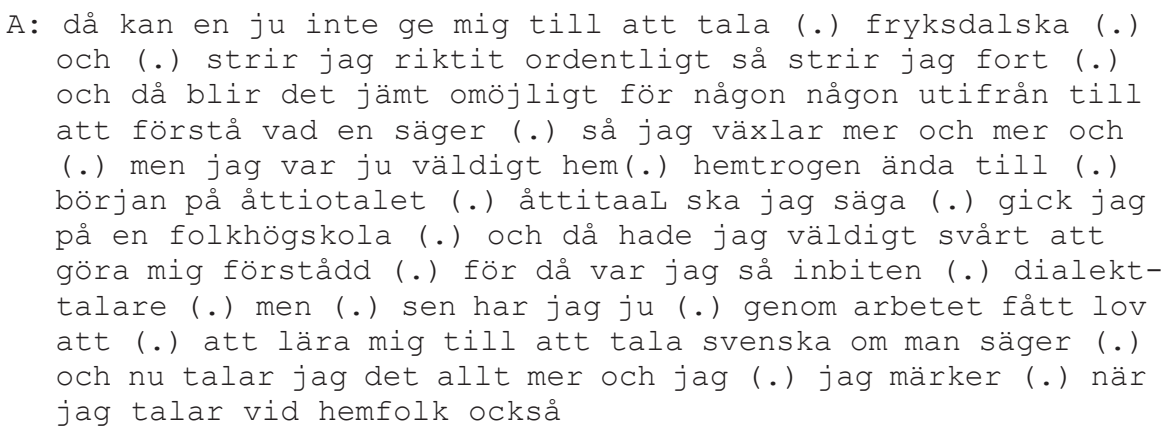

Som framkommer av utdraget är Anders mån om att tala den lokala dialekten på inspelningen så att den dokumenteras. Han gör en självreparation och växlar från det standardspråkliga åttiotalet till det dialektala åttitaaL. Dialekten och »svenskan» praktiseras parallellt och utgör två aspekter av hans identitet i nuet. Under intervjun påpekar Anders vid återkommande tillfällen att han råkar tala för fint, och korrigerar sig till att tala dialekt. Han vill alltså presen- 
tera den dialektala Anders under intervjun, den person som hör hemma i Torsby. Inspelningstillfället erbjuder alltså, precis som vi såg i exemplet ovan, en möjlighet att visa upp dialekten och iscensätta den lokala identiteten. Notera också att Anders i citatet beskriver sig som hemtrogen och att det i Torsby finns ett hemfolk, alltså personer som genom sin dialekt naturligt hör hemma i Torsby.

Även Edsbyborna använder termen hem när de ska beskriva sin dialekt, men i deras fall länkas hem till trevlig och dialekten beskrivs som hemtrevlig, mysig, nyanserad och charmig. Det finns drag av infantilisering av dialekten i dessa beskrivningar och då är den inte heller att förstå som ett kulturellt kapital. Snarare tycks dialekten här fungera som en lugn norrländsk kontrast till den rörliga och globaliserade omvärlden, representerad av söder. Edsbyborna menar att nordliga dialekter är tryggare och pålitligare, och till exempel beskrivs skånskan av dem som dryg och norrländskan som trygg. Edsbyborna som grupp föredrar alltså norrländska men inte skånska och rikssvenska. Inte heller Torsbyborna tycker om skånska, men som svar på vilken deras favoritdialekt är får värmländskan och den lokala dialekten flest röster.

De flesta informanterna i Edsbyn bedömer att de själva talar en del dialekt. En man i 70-årsåldern, Harry, säger under intervjun: »vi pratar väl ganska mycket dialekt här uppe tycker jag». Harry talar emellertid själv inte speciellt mycket dialekt under intervjun; faktum är att han är en av de mest utjämnade informanter som projektet spelat in. Det kan mycket väl hända att han talar mer dialekt $i$ andra situationer, men han gör det alltså inte alltid med en person som talar en mer standardnära varietet (i det här fallet intervjuaren). Det ger även exemplet nedan uttryck för. I exemplet påtalar Majken för sin make Eje att han inte talar den lokala dialekten fast det är det som ur hennes perspektiv är meningen med inspelningen.

Exempel 7. Alftamål.

M: ni pratar inte nåt alftamål här fast vi ska göra det nu

$E:$ jo men hon får hon

M: han pratar det annars men inte nu

$\mathrm{E}$ : hon verkar så belåten ändå

Majken vänder sig därefter till intervjuaren och påpekar att Eje brukar tala Alftamål. Eje svarar Majken med att intervjuaren inte tycks ha några invändningar. Det kan vara värt att påpeka att intervjuaren inte hörde traditionellt Ovanåkersmål eller Alftamål en enda gång under fältarbetet, till skillnad från i Torsby där traditionell dialekt talades överallt och av många. 
Här framgår alltså att Torsbyborna ger sin dialekt en större betydelse när det gäller frågor om tillhörandehet och hemkänsla än Edsbyborna. De är också kunnigare om sin och andra dialekter och betraktar dialekten som en betydelsefull del av att vara Torsbybo. I Edsbyn tycks dialekten vara av mindre betydelse. Den betraktas som ett av flera och valbara möjliga sätt att signalera tillhörandehet. Dessa tolkningar bekräftas när vi i det följande kommer att diskutera hur informanterna beskriver de platser där de lever.

\subsubsection{Regional eller lokal}

När Edsbyborna talar om sig själva, platsen de bor på och sin dialekt är det ofta i termer av större områden än Edsbyområdet. De refererar exempelvis till Hälsingland, norra Sverige och till Norrland. Samtidigt kan de använda mindre enheter för att skapa förankring och tillhörandehet. I exemplet nedan berättar ett äldre par, Britta och Olle, för intervjuaren att deras dotter inte bytt namn då hon gift sig, utan behållit familjens gårdsnamn.

\section{Exempel 8. Gårdsnamn.}

B: GÅRDSNAMN då så våran dotter hon hon bytte aldrig efternamn

I: är det vanligt att man att man byter namn

$O:$ nä men att man tar gårdsnamn

$I: \quad[j \mathrm{ja} j \mathrm{a}$

B: [ [att man tar gårdens namn är väldigt vanligt

$I: j a$

B: både i hälsingland och i dalarna

I utdraget beskriver Britta hur dottern valde att inte byta bort gårdsnamnet när hon gifte sig. Vi har i vår undersökning inte uppgifter om huruvida dottern talar mycket dialekt eller ej, men troligt är att hon inte behöver göra det för att höra hemma i Edsbyn. Gårdsnamnet fungerar nämligen identitetsskapande och markerar tillhörandehet. Å andra sidan framgår i utdraget att praktiken att ta namn efter en gård är utbredd i både Hälsingland och närliggande Dalarna. Det här innebär att Brittas dotter av utomstående inte automatiskt kopplas till Edsbyn utan snarare till ett löst avgränsat område i norra Sverige. Med hjälp av gårdsnamnet kan alltså Brittas dotter framhålla olika nivåer av tillhörandehet i olika sammanhang och kanske även kontrollera hur hennes tillhörandehet beskrivs och vad den signalerar. Hur en dialekt uppfattas och tas emot av andra går däremot inte att kontrollera på samma sätt. Den kanske inte ens fungerar att göra sig begriplig med, vilket framkommer i citatet ovan där Johanna i Torsby påpekar att unga Torsbybor talar utpräglad dialekt i av- 
sikt att vara »häftiga» och obegripliga. Ur ett kulturanalytiskt perspektiv är detta ett sätt för de unga männen att markera tillhörandehet och den egna gruppens gränser.

Även Torsbybor kan ge svepande beskrivningar av de områden eller platser de anser sig tillhöra. I ett tidigare exempel minns vi till exempel två ungdomar som reflekterade över Värmland och värmländska. Överlag beskriver dock Torsbyborna sin dialekt som något mycket lokalt, och specificerar och beskriver den i relation till andra lokala dialekter, snarare än i svepande uppdelningar i norr och söder. I exemplet nedan iscensätter Anders, som bor i Utterbyn strax utanför Torsby, på eget initiativ för intervjuaren hur olika lokalbefolkningen kan låta, trots att de bara bor några kilometer från varandra.

Exempel 9. Östmarking.

A: och (.) en östmarking det kan en allt höra än idag när det kommer en östmarking han talar ungefär såhär (.) och kommer en från metbäcken en by som ligger i östmarks socken då är det (.) då är det riktigt att de drar så

I intervjumaterialet från Torsby pratar informanterna ofta om sin egen och andras dialekt, och berättar för intervjuaren om olika ord och uttryck. Torsbyborna förhåller sig alltså till intervjusituationen som en möjlighet eller uppmaning att berätta om dialekten. Det förekommer inte mer än undantagsvis i materialet från Edsbyn, trots att ett par av de som intervjuats varit aktiva i studiecirklar om den lokala dialekten och också deltagit i att författa beskrivningar av dialekten. Eftersom samtliga informanter på båda orter på förhand hade fått information om att inspelningen gjordes i syfte att samla in och beforska den lokala dialekten och samma forskare genomförde samtliga intervjuer, torde inspelningssituationen och förutsättningarna vara relativt lika.

Sammanfattningsvis kan vi alltså konstatera att Torsbyborna kopplar samman sin dialekt med ett mindre geografiskt område än vad Edsbyborna gör. Som vi skrev tidigare och som framkommer i exemplet ovan har också Torsbyborna en klar uppfattning om sin dialekt och närliggande dialekter, något som Edsbyborna inte har i samma utsträckning. Som vi tolkar det är alltså att tala och behärska sin dialekt viktigare för Torsbyborna än för Edsbyborna. Att vara en »äkta» Torsbybo är att tala dialekt, för att kvalificera sig som Edsbybo tycks inte det krävas. 


\section{Att förklara språklig förändring och stabilitet}

Vi har alltså kunnat konstatera att dialekten förändras i olika takt i Edsbyn och Torsby. I Edsbyn har utjämningen mot standard kommit mycket längre än i det språkligt betydligt mer stabila Torsby. I Edsbyn förekommer också nya drag, både ett sådant som kan klassas som urbant (/ej/ uttalat som frikativt /i/) och sådana som kan antas vara en del av pågående förändringar i svenskans vokalsystem (öppet uttal av långt $\ddot{a}$ och $\ddot{o}$ ) men som troligen också sprids från urbana miljöer. Vi har också sett att Torsby- respektive Edsbyborna konstruerar sig olika i intervjuer och enkäter. Kulturanalysen ger vid handen att sätten som Edsbyborna och Torsbyborna visar tillhörandehet på skiljer sig åt: Edsbyborna framhåller naturen och det materiella kulturarvet som faktorer som gör deras plats speciell. Torsbyborna lyfter återkommande fram dialekten som en markör för tillhörandehet. Vår tolkning är att medan Edsbyborna ser dialekten som ett kulturarv och ett möjligt val i en större språklig repertoar, ser Torsbyborna dialekten som en del av den samtida kulturen.

I det här avsnittet knyter vi ihop de språkliga och kulturanalytiska resultaten och försöker förklara varför de olika processerna för språkförändring ser så olika ut i Edsbyn och Torsby. Enligt Auer och Hinskens $(1996,2004)$ modell för språkförändring, som vi beskrev inledningsvis, påverkar en standardtalare en dialekttalare, och dialekttalaren tar sedan med sig den nya formen och påverkar andra dialekttalare, eftersom talare tar efter varandra (se även Trudgill 1986, Giles m.fl. 1991, Hinskens 1998). Så torde det också ha gått till i Edsbyn och Torsby, eftersom den trend vi ser är utjämning mot standardsvenska. Alla informanter har givetvis kontakt med talare av andra varieteter i större eller mindre utsträckning. Däremot är det inte säkert att Torsbyborna utsätts för nya språkdrag lika frekvent som Edsbyborna eller är lika mottagliga.

Ur ett historiskt perspektiv har Edsbyn präglats av starka sociala nätverk, frireligiösa samfund och ett aktivt föreningsliv (Götlind m.fl. 2003). Detta har lett till att Edsbyns invånare tidigt haft täta kontakter med personer från andra dialektområden och mer standardnära talare, vilket kan förklara varför utjämningsprocessen mot standard startat så tidigt i Edsbyn jämfört med Torsby och också kommit mycket längre.

Som framkom i avsnitt 5.1 är det emellertid inte Edsbyn som utmärker sig språkligt i ett större perspektiv; svenska dialekter har på många håll utjämnats mot standardsvenska i samma omfattning som i Edsbyn, eller till och med mer (se t.ex. Thelander 1979, Sundgren 2002, Nilsson 2009, 2017, Svahn \& Nilsson 2014). Istället är det den dialektala stabiliteten i Torsby som är anmärknings- 
värd, och det är således Torsby som behöver förklaras för att förstå skillnaden mellan Edsbyn och Torsby.

Torsbyborna, menar vi, förhåller sig också på ett annat sätt än Edsbyborna både till den egna orten och till dialekten. Av våra resultat framkom att Edsbyborna ser sig som en del av ett större norrländskt område, medan Torsbyborna främst ser sig som tillhöriga mycket lokalt. Det tycks alltså som om det finns ett samband mellan hur stor region man ser sig själv som en del av, eller med andra ord känner tillhörandehet med, och hur viktig dialekten är. I fallet Edsbyn och Torsby råder relationen att ju mindre region, desto viktigare är dialekten. Huruvida detta är ett mönster som stämmer även på andra språksamhällen får framtida forskning utvisa.

Taylor (2012 s. 22) påpekar att handlingen att tala dialekt skapar ett band mellan individen och platsen, och medför en känsla av tillhörandehet och lokalidentitet. Dialekten, menar hon, skapar, upprätthåller och utför tillhörandehet (s. 117). För att kunna upprätthålla tillhörandehet i Torsby verkar det utifrån våra resultat krävas just en viss grad av dialektalitet, och dialekten blir således ett sätt att uttrycka lokalidentitet (se även Nilsson \& Wenner 2017).

Som vi skrev inledningsvis tänker vi oss att det inte bara är platsen som formar dialekten, det är också dialekten, och talet om dialekten, som formar en plats. Om en plats, som i det här fallet Torsby, återkommande omtalas som ett ställe där en viss dialekt talas kommer den orten kanske att konstrueras som dialektal. Ur ett sådant perspektiv har tillhörandehet egentligen inte med den fysiska platsen att göra, utan det handlar snarare om vad platsen symboliserar. Samma geografiska plats representerar på så vis olika historier och mening (Farahani 2007 s. 38, jfr Hall 2002 s. 242). För oss framstår därför också undersökningar av hur identitet och plats sammankopplas som centrala för att förstå varför dialekter förändras eller inte förändras.

Sammanfattningsvis menar vi att det krävs att individer känner tillhörandehet med den grupp eller identitet som förknippas med nya språkdrag för att en språklig varietet ska förändras (se t.ex. Niedzielski \& Giles 1996). Vi menar också att individers och gruppers uttryck för tillhörandehet med platsen där den aktuella dialekten talas är en viktig pusselbit $i$ att förstå både dialektförändring och dialektal stabilitet. Sammantaget är alltså Edsbybornas och Torsbybornas förhållningssätt till dialekten och till platsen där den talas avgörande faktorer för att dialektförändringen har gått så olika snabbt i Edsbyn och Torsby. 


\section{Litteratur}

Anderson, Benedict, 2006 [1983]: Imagined Communities: Reflections on the origin and spread of nationalism. London: Verso.

Auer, Peter, 2005: Europe's sociolinguistic unity, or: A typology of European dialect/ standard constellations. I: N. Delbecque, J. van der Auwera \& D. Geeraerts (red.): Perspectives on Variation: Sociolinguistic, Historical, Comparative. (Trends in Linguistics. Studies and Monographs 163.) Berlin: Walter de Gruyter. S. 7-42.

Auer, Peter \& Hinskens, Frans, 1996: The convergence and divergence of dialects in Europe. New and not so new developments in an old area. I: Sociolinguistica 10. S. 1-30.

Auer, Peter \& Hinskens, Frans, 2004: The role of interpersonal accommodation in a theory of language change. I: P. Auer, F. Hinskens \& P. Kerswill (red.): Dialect change: Convergence and divergence in European languages. Cambridge: Cambridge University Press. S. 335-357.

Baumeister, Roy F. \& Leary, Mark R., 1995: The need to belong: desire for interpersonal attachments as a fundamental human motivation. I: Psychological bulletin 117(3). S. 497-529.

Bockgård, Gustav \& Nilsson, Jenny, 2011: Dialektologi möter interaktionsforskning. En introduktion till interaktionell dialektologi. I: G. Bockgård \& J. Nilsson (red.): Interaktionell dialektologi. Uppsala: Institutet för språk och folkminnen. S. 7-50.

Broberg, Richard, 1973: Språk- och kulturgränser i Värmland. En översikt och några synpunkter. Svenska landsmål och svenskt folkliv B:67. (Också utgiven under egen titel i Uppsala 2001.)

Brubacker, Rogers \& Cooper, Frederick, 2000: Beyond "Identity". I: Theory \& Society 29. S. $1-47$.

Bruce, Gösta, 2010: Vår fonetiska geografi. Lund: Studentlitteratur.

Coupland, Nikolas, 1980: Style-shifting in a Cardiff work-setting. I: Language in Society $9(1)$. S. 1-12.

Coupland, Nikolas, 1984: Accommodation at work: Some phonological data and their implications. I: International Journal of the Sociology of Language 46. S. 49-70.

Coupland, Nikolas, 2009: Dialects, standard and social change. I: M. Maegaard, F. Gregersen, P. Quist \& J. Normann Jørgensen (red.): Language attitudes, standardization and language change. Oslo: Novus. S. 27-49.

Ehn, Billy \& Löfgren, Orvar, 1982: Kulturanalys: Ett etnologiskt perspektiv. Stockholm: Liber förlag.

Ehn, Billy \& Löfgren, Orvar, 2001: Kulturanalyser. Lund: Gleerups.

Ehn, Billy \& Löfgren, Orvar, 2007: När ingenting särskilt händer: Nya kulturanalyser. Eslöv: Brutus Östling bokförlag Symposion.

Friðriksson, Finnur, 2008: Language change vs. stability in conservative language communities: A case study of Icelandic. Göteborg: Institutionen för lingvistik. 
Giles, Howard, 1973: Accent mobility: A model and some data. I: Anthropological linguistics 15(2). S. 87-105.

Giles, Howard, Coupland, Nikolas \& Coupland, Justine, 1991: Accommodation theory: Communication, context, and consequence. I: H. Giles, J. Coupland \& N. Coupland (red.): Contexts of Accommodation. Cambridge: Cambridge University Press. S. 168.

Gregersen, Frans \& Kristiansen, Tore, 2015: Inledning. Sprogforandring i virkelig tid. I: F. Gregersen \& T. Kristiansen (red.): Hvad ved vi nu? Efter ti års forskning i dansk talesprog. Köpenhamn: Sprogforandringscentret. S. 9-44.

Götlind, Anna, Bergström, Eva \& Haraldsson, Kjell, 2003: Eldsjälar, nätverk och lokal gemenskap: studier kring föreningsliv och företagande i Mora, Leksand, Edsbyn och Östervåla. Falun: Dalarnas forskningsråd.

Hall, Stuart, 2002: Kulturell identitet och diaspora. I: C. Eriksson, M. Baaz \& H. Thörn (red.): Globaliseringens kulturer: Den postkoloniala paradoxen, rasismen och det mångkulturella samhället. Nora: Nya Doxa. S. 231-244.

Hinskens, Frans, 1998: Dialect levelling: a two-dimensional process. I: Folia linguistica 32(1-2). S. 35-52.

Ivars, Ann-Marie, 2003: Lokalt och regionalt i svenskan i Finland. Tendenser i språkutvecklingen i norr och söder. I: G. Akselberg, A. Marit Bødal \& H. Sandøy (red.): Nordisk dialektologi. Oslo: Novus. S. 51-81.

Johnstone, Barbara, 2009: Pittsburghese shirts: commodification and the enregisterment of an urban dialect. I: American Speech 84(2). S. 157-175.

Johnstone, Barbara, 2014: "100\% Authentic Pittsburgh": Sociolinguistic authenticity and the linguistics of particularity. I: V. Lacoste, J. Leimgruber \& T. Breyer (red.): Indexing Authenticity: Sociolinguistic Perspectives. (Linguae \& litterae 39.) Berlin, München, Boston: DeGruyter. S. 97-112.

Johnstone, Barbara, Andrus, Jennifer \& Danielson, Andrew E., 2006: Mobility, Indexicality, and the Enregisterment of 'Pittsburghese'. I: Journal of English Linguistics 34(2). S. 77-104.

Johnstone, Barbara \& Kiesling, Scott F., 2008: Indexicality and experience: Exploring the meanings of /aw/-monophthongization in Pittsburgh. I: Journal of Sociolinguistics 12(1). S. 5-33.

Josephson, Olle, 2004: Ju. Ifrågasatta självklarheter om svenskan, engelskan och andra språk i Sverige. Stockholm: Norstedts akademiska förlag.

Kallstenius, Gottfrid, 1927: Översikt av Värmlands svenska dialekter. Svenska landsmål och svenskt folkliv 21(2).

Kristiansen, Tore \& Coupland, Nikolas (red.), 2011: Standard languages and language standards in a changing Europe. Oslo: Novus.

Kristiansen, Tore \& Grondelaers, Stefan A. (red.), 2013: Language (De)standardisation in Late Modern Europe: Experimental Studies. Oslo: Novus.

Leinonen, Therese, 2010a: An Acoustic Analysis of Vowel Pronunciation in Swedish Dialects. (GRODIL 83.) Groningen: Rijksuniversiteit.

Leinonen, Therese, 2010b: Vokaluttal i svenska dialekter. I: Språkbruk 2010(3). S. 1015.

Lindén, Petrus, 1977: Ord och uttryck i ovanåkersmålet. Ovanåker. 
Löfgren, Orvar, 1996: Att höra hemma: Identiteter och territorier i historiskt perspektiv. Kungliga Vitterhets Historie och Antikvitetsakademiens årsbok. Stockholm: Almqvist \& Wiksell. S. 64-78.

Magnusson Petzell, Erik \& Nilsson, Jenny, 2015: Svenskt talspråk efter 1800 - huvudlinjer i utvecklingen. I: H. Sandøy (red.): Talemål etter 1800. Norsk i jamføring med andre nordiske språk. Oslo: Novus. S. 355-380.

Monka, Malene, 2015: Mobilitet, sted og sprogforandring I: F. Gregersen \& T. Kristiansen (red.): Hvad ved vi nu?: Efter ti års forskning i dansk talesprog. Köpenhamn: Sprogforandringscentret S. 83-90.

Niedzielski, Nancy \& Giles, Howard, 1996: Linguistic accommodation. I: H. Goebl, P. H. Nelde, Z. Starý \& W. Wölck (red.): Contact Linguistics: An International Handbook of Contemporary Research. Berlin: Mouton de Gruyter. S. 332-342.

Nilsson, Jenny, 2009: Dialect change? I: Nordic Journal of Linguistics 32(2). S. $207-$ 220.

Nilsson, Jenny, 2015a: Stabilitet och förändring i norra Värmland - Dialekten i Torsbyområdet 1940-tal och 2010-tal. I: Folkmålsstudier 53. S. 167-98.

Nilsson, Jenny, 2015b: Dialect accommodation in interaction: Explaining dialect change and stability. I: Language \& Communication 41. S. 6-16.

Nilsson, Jenny, 2017: Something old, something new: Some processes for dialect change in Sweden. I: Nordic Journal of Linguistics 40(3). S. 351-371.

Nilsson, Jenny, Leinonen, Therese \& Wenner, Lena, u. u.: Tracking change in social meaning: the indexicality of damped /i/ in rural Sweden. I: J.-A. Villena Ponsoda, F. Díaz-Montesinos, A.-M. Ávila-Muñoz \& M. Vida-Castro (red.): Language Variation - European Perspectives VII. Selected papers from the Ninth International Conference on Language Variation in Europe (ICLaVE 9), Malaga, June 2017.

Nilsson, Jenny \& Wenner, Lena, 2017: The unruly dialect variant [a]: The case of the opening of $(\varepsilon)$ in the traditional Torsby dialect. I: I. Buchstaller \& B. Siebenhaar (red.): Language Variation - European Perspectives VI: Selected Papers from the Eighth International Conference on Language Variation in Europe (ICLaVE 8), Leipzig, May 2015. Amsterdam/Philadelphia: John Benjamins Publishing Company. S. 99-111.

Noreen, Adolf, 1877: Fryksdalsmålets ljudlära. Uppsala.

Noreen, Adolf, 1878: Ordbok öfver Fryksdalsmålet samt en ordlista från Värmlands älfdal. Uppsala.

Nylund Skog, Susanne, 2012: Livets vägar: Svenska judinnors berättelser om förskingring, förintelse, förtryck och frihet. Uppsala: Institutet för språk och folkminnen.

Nylund Skog, Susanne, 2018a: The German Language, Preiselbeeren and Orange Juice. Processes of Identification in a Swedish-Jewish Woman's Everyday Storytelling. I: Ethnologia Scandinavica 48. S. 26-37.

Nylund Skog, Susanne, 2018b: Samlare, jägare och andra fågelskådare. Stockholm: Carlsson Bokförlag. 
Pedersen, Inge Lise, 2005: Processes of standardisation in Scandinavia. I: P. Auer, F. Hinskens \& P. Kerswill (red.): Dialect change. Convergence and Divergence in European Languages. Cambridge: Cambridge University Press. S. 171-195.

Pedersen, Inge Lise, 2009: The social embedding of standard ideology through four hundred years of standardization. I: M. Maegaard, F. Gregersen, P. Quist \& J. Normann Jørgensen (red.): Language attitudes, standardization and language change. Oslo: Novus. S. 51-68.

Prins, Buakje, 2006: Narrative Accounts of Origins. A Blind Spot in the Intersectional Approach? I: European Journal of Women's Studies 13(3). S. 277-290.

Ronström, Owe, 2016: Öar och öighet. Introduktion till östudier. Stockholm: Carlssons.

Røyneland, Unn, 2005: Dialektnivellering, ungdom och identitet. Ein komparativ studie av sprakleg variasjon og endring $i$ to tilgrensande dialektområden, Røros og Tynset. (Acta Humaniora 231.) Oslo: Universitetet i Oslo.

Sandøy, Helge, 2004: Types of society and language change in the Nordic countries. I: B.-L. Gunnarsson m.fl. (red.): Language Variation in Europe. Papers from the Second Interantional Conference on Language Variation in Europe, ICLaVE 2, Uppsala University, Sweden, June 12-14, 2003. Uppsala: Uppsala universitet. S. 53-76.

Sandøy, Helge (red.), 2015a: Talemål etter 1800. Norsk i jamføring med andre nordiske språk. Oslo: Novus.

Sandøy, Helge, 2015b: Austlandsk etter 1800. I: H. Sandøy (red.): Talemål etter 1800. Norsk i jamføring med andre nordiske språk. Oslo: Novus. S. 159-179.

Sundgren, Eva, 2002: Återbesök i Eskilstuna. En undersökning av morfologisk variation och förändring i nutida talspråk. (Skrifter utgivna av Institutionen för nordiska språk vid Uppsala universitet 56.) Uppsala: Uppsala universitet.

Svahn, Margareta, 2003: Dialektbegreppet - ett diskussionsinlägg. I: G. Akselberg, A. M. Bødal \& H. Sandøy (red.): Nordisk dialektologi. Oslo: Novus. S. 503-513.

Svahn, Margareta \& Nilsson, Jenny, 2014: Dialektutjämning i Västsverige. Uppsala: Institutet för språk och folkminnen.

Teleman, Ulf, 2003: Tradis och funkis. Svensk språkvård och språkpolitik efter 1800. Stockholm: Norstedts ordbok.

Tajfel, Henri \& Turner, John C., 1979: An integrative theory of intergroup conflict. I: W. G. Austin \& S. Worchel (red.): The social psychology of intergroup relations. Monterey, CA: Brooks/Cole. S. 33-37.

Taylor, Stephanie, 2012 [2010]: Narrative of Identity and Place. London: Routledge. Thelander, Mats, 1979: Språkliga variationsmodeller tillämpade på nutida Burträsktal. (Studia Philologiae Scandinavicae Upsaliensia 14:1-2.) Uppsala: Acta Universitatis Upsaliensis.

Thelander, Mats, 1996: Från dialekt till sociolekt. I: L. Moberg \& M. Westman (red.): Svenskan i tusen år. Glimtar ur svenska språkets utveckling. Stockholm: Norstedts. S. 163-181.

Trudgill, Peter, 1986: Dialects in Contact. (Language in society 10.) Oxford: Basil Blackwell Ltd. 


\section{Jenny Nilsson \& Susanne Nylund Skog}

Törrönen, Jukka, 2013: Situational, Cultural and Societal Identities. Analysing subject positions as classifications, participant roles, viewpoints and interactive positions. I: Journal for the Theory of Social Behaviour 44(1). S. 80-98.

Wenner, Lena, 2010: När lögnare blir lugnare. En sociofonetisk studie av sammanfallet mellan kort ö och kort u i uppländskan. (Skrifter utgivna av Institutionen för nordiska språk vid Uppsala universitet 80.) Uppsala: Uppsala universitet.

Öqvist, Jenny, under arbete: Perspektiv på Stockholmska. 


\title{
Perspektiv på paradigm
}

\section{Kuhns paradigmbegrepp och språkvetenskapen}

\author{
Av PER KLANG
}

\begin{abstract}
Klang, Per, per.klang@nordiska.uu.se, Ph.D. student, Department of Scandinavian Languages, Uppsala University: "Perspectives on Paradigms. Kuhn's Concepts of Paradigm in Linguistics". Språk och stil NF 29, 2019, pp. 233-260.

The subject matter of this paper is Thomas S. Kuhn's term paradigm and its role in linguistics. The term marks the key concepts for distinguishing mature sciences from immature ones. According to Kuhn, natural science is mature, since it is driven by a paradigm, but whether there are paradigms in linguistics is still a matter of debate. This paper argues that the disagreement is rooted in the ambiguity of the term paradigm. Later, Kuhn abandoned it in favor of transparent replacement terms, i.e. disciplinary matrix and exemplar. This became known by Kuhn's contemporary philosophers of science, but arguably less so in other disciplines. By the time Kuhn had elucidated his concepts, various interpretations of paradigm had already taken hold in other fields, including linguistics. This paper makes two observations in the literature on linguistic paradigms. First, the ambiguity has led some researchers to assume a global perspective on paradigms, where others assume a local perspective. However, excluding one view for another defeats their combined purpose. This paper opts for a holistic interpretation. Second, the linguistics paradigms described in this paper do not meet the definitions of Kuhn's replacement terms. It is suggested that this discord can be understood by considering differences in the training and practice of linguists and natural scientists. On the whole, the education of the former is less permeated by symbol manipulation in formal systems than that of the latter.
\end{abstract}

Keywords: paradigm, disciplinary matrix, exemplar, philosophy of science, formal system.

1962 publicerades Thomas S. Kuhns The Structure of Scientific Revolutions (i fortsättningen SSR), en beskrivning av naturvetenskapen som gick stick i stäv med den rådande synen på den vetenskapliga verksamheten och kunskapstillväxten. Kuhn ifrågasatte den dåvarande bilden av vetenskapen som en följd av extraordinära forskningsinsatser med en stadig kumulativ kunskapstillväxt. Han argumenterade för att en sådan bild inte stämde överens med den dagliga

Under arbetet med paradigmens roll i språkvetenskapen har jag fått möjlighet att diskutera mina utkast och tankar med olika personer. Jag vill här särskilt tacka David Håkansson, Malin Klang, Björn Melander, Ulla Stroh-Wollin, deltagarna vid Svenskans beskrivning 37 i Åbo (i synnerhet Saara Haapamäki) samt mina doktorandkollegor i kursen Att doktorera i nordiska språk. Jag tackar även två anonyma granskare för värdefulla synpunkter på en tidigare version av denna artikel. 


\section{Per Klang}

verksamheten som snarare utmärktes av längre perioder av matematisk pussellösning. Genom att se bortom enskilda banbrytande forskningsinsatser och fokusera på det vanliga arbetet, kunde han urskilja återkommande växlingar mellan normalvetenskapliga perioder och extraordinära perioder. Det förklarande fenomen som höll samman dessa kallade Kuhn för paradigm, ett begrepp vars betydelse diskuteras än i dag och vars koppling till språkvetenskapen utgör huvudämnet för den här artikeln.

Huruvida det existerar språkvetenskapliga paradigm är en öppen fråga och den har diskuterats av många. En del hävdar att språkvetenskapliga paradigm existerar, t.ex. Smith (2011), och en del hävdar motsatsen, t.ex. Percival (1976), som menar att språkvetenskapliga forskningsgemenskaper inte möter Kuhns definition av paradigm. Andra kan tyckas förhålla sig mer ambivalenta i frågan, t.ex. Koerner (1977 s. 168) som menar att begreppet behöver omdefinieras för att passa språkvetenskapen. Håkansson (2017 s. 50) förhåller sig skeptisk till att begreppet paradigm kan användas på språkvetenskapen och menar att det inte är självklart att Kuhns resonemang utan vidare kan överföras på humanistiska vetenskaper eftersom dessa kännetecknas av många olika intresseområden; se Kjørup (1999) och Svensson (2017) för exempel på denna bredd.

I ovan nämnda debatt om de språkvetenskapliga paradigmens existens kan man urskilja en önskan om en väldefinierad kuhneansk begreppsapparat. För att arbeta fram en sådan behöver man strikt följa Kuhns paradigmdefinition och samtidigt ta hänsyn till språkvetenskapens bredd och historia. Ett sådant företag kan mycket väl vara genomförbart, men det är nog lättare sagt än gjort att tillfredsställa både kritiker och förespråkare. Syftet med den här texten är därför inte att använda Kuhns paradigmbegrepp för att förstå språkvetenskapen och dess historia; detta har redan gjorts i flera arbeten. Tanken är i stället att undersöka språkvetenskapliga arbeten som använder sig av Kuhns paradigmbegrepp, i syfte att ta reda på om det finns några problem med hur paradigmbegreppet har använts. För att uppnå syftet följs följande steg: (i) redovisa nödvändig bakgrund till paradigmbegreppet, (ii) redovisa Kuhns definition av paradigm, (iii) redovisa hur paradigmbegreppet har använts för att studera språkvetenskapen, (iv) undersöka om resultatet av steg iii stämmer överens med definitionerna från steg ii, (v) problematisera resultatet av steg iii och iv. Utifrån dessa fem steg identifieras två problem i hur paradigmbegreppet har använts i tidigare beskrivningar av språkvetenskaplig verksamhet.

Det första problemet är att man i språkvetenskapen tenderar att prata förbi varandra när man använder Kuhns centrala begrepp paradigm. Faktum är att 
det har använts på olika sätt och med olika betydelser. Detta är delvis en följd av att paradigmbegreppet i den första utgåvan av SSR (Kuhn 1962) inte var väldefinierat, utan flertydigt. Forskare började då arbeta utifrån olika perspektiv på paradigm. När Kuhn åtta år senare förtydligade sig i ett postskript till den andra upplagan av SSR (Kuhn 1970a), ${ }^{1}$ hade ett flertal tolkningar redan etablerat sig. Kuhn hade förlorat kontrollen över begreppet, och de olika perspektiven på paradigm lever kvar än i dag.

Det andra problemet är att språkvetenskaplig verksamhet inte riktigt kan kopplas till det som Kuhn avsåg med paradigmbegreppet. Kuhn menade att naturvetenskaplig verksamhet genomsyrades av ett logiskt matematiskt formellt system från grundutbildning till specialistnivå. De verksamheter som inte gjorde det såg han som något annat. Då formella system utgör en hörnsten $\mathrm{i}$ Kuhns paradigmbegrepp blir det - som vi ska se - något svårt att argumentera för språkvetenskapliga paradigm.

I avsnitt 1 härnäst, redovisas i tur och ordning: (i) en beskrivning av några vetenskapsfilosofiska föregångare till Kuhn, (ii) huvuddragen i Kuhns beskrivning av naturvetenskapen och annan vetenskap, (iii) den kritik som beskrivningen möttes av från vetenskapsfilosofiskt håll och (iv) Kuhns förtydligande av paradigmbegreppet vilket var en av kritikens konsekvenser. Avsnitt 2 behandlar mottagandet och användningen av Kuhns paradigmbegrepp inom språkvetenskapen samt de olika perspektiv på paradigm som presenterats där. I samma avsnitt illustreras även de problem som uppstår när man kopplar Kuhns begrepp till språkvetenskapen. Avsnitt 3 innehåller en avslutande diskussion om textens huvudsakliga poänger.

\section{SSR och paradigmbegreppet}

I detta avsnitt ger jag en ganska omfattande beskrivning av SSR och paradigmbegreppet, i syfte att ge en överskådlig bild av SSR och de begrepp som ingår i den. I översikten av SSR och paradigmbegreppet tar jag upp följande aspekter: (i) hur forskare inom det vetenskapsfilosofiska etablissemanget såg på vetenskap innan SSR publicerades, (ii) vad det huvudsakliga innehållet i SSR är, (iii) hur SSR togs emot av det vetenskapsfilosofiska etablissemanget samt (iv)

${ }^{1}$ Innehållet i Kuhn 1962 och Kuhn 1970a är i stort sett samma bortsett från postskriptet och ett antal smärre justeringar. I den här texten används beteckningen SSR när distinktionen mellan upplagorna inte är av större betydelse. I sammanhang där distinktionen är av vikt används referenserna Kuhn 1962 och Kuhn 1970a. 
vilka förtydliganden Kuhn valde att göra utifrån etablissemangets kritik. Dessa punkter beskrivs i underavsnitten 1.1-1.4 nedan.

Om ämnet är paradigm och inte SSR kan man dock fråga sig varför jag inte utgår ifrån den »rätta» definitionen. En anledning är att man i språkvetenskapen inte är överens om vilken definition man vill arbeta utifrån. Den tolkning av paradigm som förespråkas i den här texten stämmer inte heller överens med de tidigare tolkningarna av begreppet inom språkvetenskapen, åtminstone inte vad gäller de tolkningar som diskuteras här. Därför kan det vara bra att känna till den syn på SSR och dess kontext som den här texten vilar på, dvs. dess föregångare, dess innehåll, dess mottagande samt de förtydliganden som följde på dess mottagande.

\subsection{Vetenskapssynen före SSR}

En av de centrala frågorna för vetenskapsfilosofin är demarkationsproblemet, dvs.: Vad räknas som vetenskap? SSR publicerades i en tid då vissa antaganden inom den logiska positivismen - den då rådande vetenskapsfilosofin - var ifrågasatta. Ett av dessa antaganden var verifikationsprincipen, vilken har förekommit i flera formuleringar (Uebel 2019 § 3.1). Förenklat kan den formuleras som följer: en meningsfull sats måste vara empiriskt avgörbar, dvs. det måste gå att ge sinnesbaserat stöd för satsen eller dess negation. Om en utsaga kan verifieras eller falsifieras är den kognitivt meningsfull, annars inte.

Karl Popper godtog inte verifierbarhet som demarkationskriterium, och menade bland annat att det finns utsagor som aldrig slutgiltigt kan verifieras på grund av induktionsproblemet (Popper 1959). ${ }^{2}$ Ett annat av Poppers argument mot verifikationismen är de teorier för vilka man kan tänkas finna stöd, men inte slutgiltiga motbevis. ${ }^{3}$ Det måste vara möjligt för ett empiriskt system att kunna motsägas av observationer, dvs. det måste vara falsifierbart. Är det inte falsifierbart, är det inte vetenskap. Utsagan behöver för den delen inte vara kognitivt meningslös, utan snarare i behov av precisering och omformulering innan den kan uppställas i falsifierbar form. Poppers resonemang innebär alltså

${ }^{2}$ Induktionsproblemet bygger på frågan om huruvida det är rimligt att tro att en viss kedja av händelser som har hänt kommer att fortsätta att hända i framtiden, t.ex. att solen alltid kommer att gå upp. Popper menar, likt David Hume, att det är logiskt omöjligt att empiriskt fastslå en universell utsaga om världen via observationer som man inte har gjort än (Thornton 2018). Däremot skulle en utebliven soluppgång slutgiltigt motbevisa generaliseringen. Falsifierbarhet kan då till skillnad från verifierbarhet sägas vara ett bättre kriterium för vetenskapligheten i studiet av allutsagor.

${ }^{3}$ Ett känt exempel är astrologi (men alla är inte eniga). Se Hansson 2017 för fler exempel. 
att en teori kan vara vetenskaplig utan övrigt empiriskt stöd om den har visat sig falsifierbar, och att en teori med stort empiriskt stöd kan tas för pseudovetenskap om den inte har visat sig falsifierbar.

Popper blev senare kritiserad för att vara alltför preskriptiv gällande falsifierbarhet och vetenskapens metoder (se t.ex. Thornton $2018 \S 1$ ). Kuhn var en av hans opponenter, och kritiken föll som hårdast i SSR, vilket beskrivs i nästa avsnitt.

\subsection{Innehållet i SSR}

Genom att urskilja ett antal vetenskapliga utvecklingsfaser i naturvetenskapens historia visar Kuhn (1962) bl.a. att en allmän acceptans av ett paradigm är ett tecken på vetenskaplig mognad. Mognaden följer av att forskare enas om grundläggande antaganden, vilket strömlinjeformar och påskyndar den naturvetenskapliga kunskapstillväxten. Konsensus underlättar kommunikationen mellan olika gemenskaper inom naturvetenskapen som helhet och effektiviserar således arbetet. Preparadigmatiska skolor saknar paradigm, och postparadigmatiska verksamheter, som naturvetenskapen, arbetar utifrån paradigm.

Innan ett fält har nått vetenskaplig mognad menar Kuhn (1962) att den föregås av en preparadigmatisk period utan paradigm (fas 1), som leds in i en postparadigmatisk period av normalvetenskap (fas 2) genom ett enhälligt accepterande av ett paradigm. Normalvetenskapen kännetecknas av arbete där forskarna inte strävar efter originalitet, utan efter att försöka lösa pusselliknande problem inom paradigmet. Detta gör det paradigmstyrda fältet effektivt, eftersom man i tider av normalvetenskap inte behöver ödsla tid på att väga ett paradigm mot ett konkurrerande. Under denna period tillkommer dock fler och fler anomalier som inte kan lösas inom paradigmet och verksamheten bromsas upp när problemen blir svårare och svårare att lösa. Problemen blir till slut så svårhanterliga att en kris uppstår (fas 3), vilken följs av en revolution (fas 4) där ett nytt paradigm föreslås som ett resultat av en exceptionell forskningsinsats (fas 5). Sedan upprepas fas 2-5 om och om igen. En sådan vetenskapsstruktur hade enligt Kuhn åtminstone två konsekvenser för den då rådande vetenskapssynen. Dessa beskrivs nedan.

Den första konsekvensen av normalvetenskap är att forskare på olika sätt kringgår motstridiga resultat i stället för att angripa antagandena i paradigmet. Detta beteende går emot Poppers idealiserade bild av den extraordinära falsifierande forskningen. Något tillspetsat kan man säga att det normala för Popper 
är en forskare som i första hand ifrågasätter paradigmet, i andra hand sig själv, och det normala för Kuhn är en forskare som i första hand ifrågasätter sig själv, $\mathrm{i}$ andra hand paradigmet.

Den andra konsekvensen av Kuhns beskrivning av vetenskapen är att den vetenskapliga kunskapsutvecklingen inte kan betraktas som kumulativ. Det rör sig alltså inte om ett stadigt tillägg av nya sanningar till gamla sanningar, eller om en stabil rörelse mot en absolut sanning. (Se Bird 2018 § 2 för en utförlig redogörelse för Kuhns bidrag.) Den stadiga tillväxten sker visserligen i perioder av normalvetenskap, men påverkas i tider av kris, och återgår till det normala efter ett paradigmskifte. Skiftet leder till en revidering av de gamla bedrifterna och i en sådan revidering sker ibland det som i dag kallas för Kuhn-bortfall, dvs. att vissa resultat från det tidigare paradigmet inte hanteras i det nya paradigmet. Detta har lett till att fenomen som tidigare kunde förklaras, inte längre kan det (Kuhn 1970a s. 99-100). Detta är delvis ett resultat av vad Kuhn (1962) och Feyerabend (1970) kallar för inkommensurabilitet. Begreppets uppkomst tillskrivs både Kuhn och Feyerabend. Dess betydelse är omtvistad, men innebörden är ungefär att idéer och antaganden inom ett paradigm inte är strikt jämförbara med vad som gäller inom ett senare paradigm. ${ }^{4}$

\subsection{Mottagandet av SSR}

SSR hyllades av många, men kritiserades även kraftigt. En av dess tidiga kritiker var Shapere (1966) som menade att SSR föreskrev en subjektiv och irrationell forskningspraktik, bland annat på grund av konsekvenserna av Kuhn-bortfall. På liknande sätt blev SSR hårt ansatt i konferensvolymen Criticism and the growth of knowledge från 1970, vilken innehåller bidrag av ett antal namnkunniga vetenskapsfilosofer som kritiserar Kuhns beskrivning ur ett popperianskt eller post-popperianskt perspektiv. Nedan beskrivs den huvudsakliga kritiken i dessa bidrag.

Toulmin (1970) menar att distinktionen mellan den normala och den revolutionära fasen av vetenskap inte håller. Han saknar bland annat ett svar på hur pass inkommensurabla koncept mellan två forskningsgenerationer måste vara för att de ska kunna betraktas som en revolution. Williams (1970) anser dock

${ }^{4}$ Enligt Bird (2018 § 4) går det att urskilja tre typer av inkommensurabilitet: (i) den metodiska, dvs. det saknas ett gemensamt mått då metoderna för jämförelse och utvärdering har förändrats, (ii) den perceptuella, dvs. teorin påverkar hur observationer tolkas, (iii) den språkliga, dvs. översättningsproblem av termer utgör ett hinder för jämförelser av paradigm. 
att både Poppers och Kuhns bidrag är av stor vikt för förståelsen av vetenskapen, men att de båda saknar tillräckligt med data för att kunna övertyga honom om att deras uppfattningar verkligen stämmer.

Watkins (1970) främsta kritik illustreras i följande citat av Kuhn (1970 s. 6): »In a sense, to turn Sir Karl's [dvs. Poppers] view on its head, it is precisely the abandonment of critical discourse that marks the transition to a science.» Watkins frågar sig varför Kuhn inte fokuserar på vetenskap när den är som bäst, och varför han fokuserar på »hack science», fritt översatt: 'dålig vetenskap'. Hur kan bristen på ett kritiskt förhållningssätt vara definierande för vetenskapen? Watkins menar att Kuhn har fel och att det vetenskapliga samfundets främsta karakteristik inte är övergivandet av kritisk diskussion.

Popper (1970) var skeptisk till normalvetenskap. Trots att Kuhn (1970b) menade att deras vetenskapssyner inte var så olika som man ville hävda, vek sig Popper inte. Dock erkänner Popper att han faktiskt inte har tänkt så mycket på distinktionen mellan normalvetenskap och extraordinär vetenskap, men han är tydlig med vad han tycker om den.

I shall therefore state again that what Kuhn has described does exist, and that it must be taken into account by historians of science. That it is a phenomenon which I dislike (because I regard it as a danger to science) while he apparently does not dislike it (because he regards it as 'normal') is another question; admittedly, a very important one. (Popper 1970 s. 52)

Även Feyerabend (1970) och Lakatos (1970) kritiserar Kuhn för att föreskriva normalvetenskap. Men innan jag går in på deras kritik kan det här vara värt att nämna att den vetenskapsfilosofiska diskursen under den här tiden var ganska underfundig, hård och tillspetsad. Detta märks inte minst i texterna från den tiden, men det har även påpekats av deltagare i Poppers ökända tisdagsseminarium. ${ }^{5}$ En sådan diskurs skulle i dag kunna uppfattas som opassande i vissa akademiska sammanhang.

Feyerabend (1970 s. 200) menar att Kuhns begrepp normalvetenskap är för generellt och att det som gäller för Kuhns normalvetenskap även kan sägas gälla för en mängd andra verksamheter. Han liknar bland annat normalvetenskap med organiserad brottslighet och tar en kassaskåpssprängare som exempel. Han menar att man kan byta ut Albert Einstein mot John Dillinger (en amerikansk gangster) som också introducerade nya och revolutionerande idéer, som också hanterade perioder av ordinära inbrott och extraordinära genombrott, som (kanske) också ifrågasatte sin egen insats i stället för verkty-

${ }^{5}$ Se Watkins 1997 för en redogörelse. 
gen och metodiken, och så vidare. För dagens läsare kan Feyerabends metaforik tyckas laddad, på gränsen till brottslig, men det är så hans argument ser ut.

Feyerabends vetenskapssyn skiljer sig från Kuhns, då han i stället för normalvetenskap förespråkar metodologisk anarki, under parollen »anything goes». Han ser detta som ett utmärkande drag för vetenskap, en tanke som han senare utvecklar i Against method (Feyerabend 2010 [1975]). Enligt Feyerabend ska dock inte "vad som helst fungerar» tolkas som en preskriptiv regel; det ska snarare kopplas till skriet från en vettskrämd rationalist som har tagit en närmare titt på vetenskapens historia (s. xvii).

Lakatos (1970) försöker förena fördelarna med Poppers falsifikationism med fördelarna med Kuhns beskrivning i ett ramverk som han kallar methodology of scientific research programmes (i fortsättningen kallat forskningsprogram). Ett forskningsprogram är uppbyggt av en kärna av grundantaganden med ett antal omkringliggande hjälphypoteser. När ett resultat strider mot ett grundantagande, lägger forskaren inte skulden på kärnan, utan på någon av hjälphypoteserna. På så vis kan en svagare variant av Poppers falsifikationism och Kuhns idé om paradigmets styrka rymmas tillsammans. Hjälphypoteserna revideras då successivt eller byts ut så att resultaten stämmer överens med grundantagandena.

Forskningsprogram kan vara mer eller mindre progressiva eller degenererande. Ett progressivt forskningsprogram kännetecknas av att det både producerar originella teorier och bekräftade förutsägelser; ett degenererande program gör inte det (Lakatos 1970 s. 33-34).

Lakatos (1970) menar att man inte kan belasta nystartade forskningsprogram med Poppers hårda krav på falsifikation; de behöver tid att etablera sig. Inte heller kan man betrakta vetenskapliga revolutioner som plötsliga irrationella förändringar i synsätt. Historien säger emot både Kuhn och Popper på dessa punkter. Det som sker är att ett progressivt program ersätter ett degenererande program.

Ett bidrag återstår att nämna, och det är Masterman (1970). Mastermans kritik gäller främst paradigmbegreppets flertydighet, och hon listar 21 olika betydelser av paradigm komplett med citat och sidhänvisning (s. 61-65). Masterman menar att om normalvetenskap faktiskt finns och går emot delar av den rådande vetenskapssynen, så är det oerhört viktigt att försöka ta reda på vad ett kuhneanskt paradigm faktiskt är (s. 60). Även om Mastermans text också har andra förtjänster, påverkade just denna iakttagelse Kuhns framtida arbete, vilket vi återkommer till i nästa avsnitt. 
Kuhn fick tillfälle att bemöta sina kritiker i ett avslutande bidrag till konferensvolymen. Han såg tre huvudfåror i kritiken: (i) valet av sociologisk metod, (ii) konceptet normalvetenskap, och (iii) en irrationell vetenskapssyn. Vad gäller metoden menar Kuhn att även hans kritiker, t.ex. Lakatos, använder sig av sociala förklaringar till att forskare gör sina val. Beträffande konceptet normalvetenskap menar Kuhn att det ordinära är en förutsättning för det extraordinära. För att kunna revoltera måste det finnas en norm att revoltera mot. Avseende den irrationella vetenskapssynen anser inte Kuhn att hans modell är mer irrationell än Lakatos, och efterfrågar ett kriterium som skiljer ett progressivt forskningsprogram från ett degenererande (1970c s. 239).

Sammanfattningsvis har här några synpunkter från Kuhns kritiker lyfts fram. Det är dock längesedan SSR publicerades och mycket har hänt sedan dess. Hacking (2012 s. xxxvii) menar att SSR kan vara, men inte nödvändigtvis är, mer relevant för en tidigare epok i vetenskapshistorien än för hur vetenskaper praktiseras i dag. Han understryker dock att SSR för alltid har förändrat vår vetenskapssyn. ${ }^{6}$

\subsection{Förtydligandet av paradigmbegreppet}

SSR blev kritiserad på flera punkter, men kritiken mot flertydigheten i begreppet paradigm tycks ha påverkat Kuhn mest, i synnerhet Mastermans (1970) kritik. Han förtydligade sig därför, dels i artikeln Second thoughts on paradigms (Kuhn 1974), dels i ett postskript till den andra utgåvan av SSR (Kuhn 1970a). Kuhn introducerade då två nya begrepp vilka han önskade att man använde $\mathrm{i}$ stället för paradigm (s. 175):

disciplinary matrix: $»$ the entire constellation of beliefs, values, techniques, and so on shared by the members of a given community»

\footnotetext{
${ }^{6}$ De logiska positivisterna ifrågasatte den skarpa uppdelningen mellan natur- och humanvetenskapen. Visst såg de olikheter, men ansåg inte att det fanns en kategorisk skillnad mellan generella metodologier och mål (Uebel 2019 § 2.3). Påverkade av den språkliga vändningen inom västerländsk filosofi verkade de bland annat för ett empiriskt observationsspråk som skulle ena vetenskaperna. Detta mål gick ofta under rubriken unified science. Intressant nog publicerades Kuhns SSR först i positivisternas The International Encyclopedia of Unified Science, en serie med syftet att ena vetenskaperna. Detta är anmärkningsvärt, då Kuhn, en av ledarfigurerna i den historiska vändningen, i SSR delar upp vetenskap i två delar: mogen naturvetenskap och annan vetenskap. Enligt Hacking (2012 s. xxxiii) har många därför menat att Kuhn omkullkastade wienkretsen och lade grunden för post-positivismen. Detta var förmodligen omedvetet. Kuhn arbetade senare vidare med positivisternas överbryggande observationsspråk i syfte att skingra kommunikativa sammanbrott och att ena vetenskaperna.
} 
exemplar: »one sort of element in that constellation, the concrete puzzle-solutions which, employed as models or examples, can replace explicit rules as a basis for the solution of the remaining puzzles of normal science».

Den disciplinära matrisen kan betraktas som en mängd antaganden som en gemenskap delar, och elementet exemplar ovan är ett av dessa. Den disciplinära matrisens element kan variera i antal och typ, men Kuhn lyfter särskilt fram ytterligare tre element för naturvetenskapen: symboliska generaliseringar, förklarande modeller och värderingar (1970a s. 182-186). Det är alltså enighet om den disciplinära matrisen som förklarar hur man inom och mellan forskningsgemenskaper effektivt kan kommunicera och arbeta med varandra.

Det andra elementet, symboliska generaliseringar, är uttryck som kan ställas upp i logisk form, $A \rightarrow B$, som kan läsas: ' $A$ implicerar $B$, eller $B$ följer av $A$ ', eller som matematiska formler, $f=m a$, dvs. Newtons andra rörelselag vilken kan läsas: 'den resulterande kraften är densamma som massan gånger accelerationen'. Vore det inte för ett generellt accepterande av formaliserade uttryck som dessa och de system de tillhör, skulle inte forskare kunna använda de kraftfulla matematiskt-logiska tekniker som kännetecknar normalvetenskap och inte heller kunna kommunicera effektivt med varandra mellan olika forskningsgemenskaper.

Det tredje elementet är förklarande modeller, t.ex. analogin att gasmolekyler beter sig som små elastiska biljardbollar i slumpmässig rörelse (Kuhn 1970a s. 184). En sådan modell kan gälla allt från metafysik till konkret taxonomi. Modeller tillhandahåller bland annat metaforik och analogier, vilket till exempel kan skönjas i grammatikens trädmetaforik. Modellerna hjälper till att sätta ramar för vad som räknas som rimliga förklaringar och lösningar.

Det fjärde elementet är värderingar, t.ex. kriterier för att jämföra teorier, identifiera svårlösliga problem och motivera metodval. Kuhn menar att vid en bedömning av en teori måste den t.ex. kunna tillåta normalvetenskaplig pusselverksamhet (1970a s. 184). Den måste kunna ställas upp i symbolisk form. Men även mer övergripande värderingar förekommer, t.ex. huruvida resultatet av vetenskapen måste (eller inte måste) vara användbart för samhället.

Elementet exemplar syftar på de konkreta problem och lösningar som studenten får som typexempel (Kuhn 1970a s. 186). Exemplaren ersätter explicita regler och utgör en bas för kvarvarande lösningar i normalvetenskapen, och förtjänar en lite längre utläggning då det är det koncept som Kuhn anser har blivit mest missförstått. För att förstå vad Kuhn menar med exemplar behöver vi titta närmare på hans bild av den naturvetenskapliga utbildningens struktur. 
Kuhn kopplar de tre elementen symboliska generaliseringar, förklarande modeller och värderingar till en global nivå i naturvetenskapen. Elementet exemplar fungerar som en länk mellan globala och lokala nivåer (Kuhn 1974). Som nybliven student i naturvetenskap börjar man enligt Kuhn studera grunderna i matematik, fysik, kemi, biologi osv. Genom studiet av dessa tillägnar man sig de tre globala elementen i den disciplinära matrisen. Elementens giltighet följer med utbildningspaketet som tyst kunskap, och är inte något som ifrågasätts. Oavsett om man fortsätter som fysiker, kemist eller biolog, får naturvetare på global nivå en ganska homogen skolning. Alla lär sig t.ex. Newtons andra rörelselag, $f=m a$, och en mängd andra grundläggande antaganden. Inte bara rörelselagarna, utan formler i allmänhet specialiseras sedan mer och mer ju längre man kommer i sin utbildningsbana. De symboliska generaliseringarna och deras specifika instanser agerar där som ett gemensamt metaspråk i ett formellt system vilket genom härledningar underlättar och effektiviserar kommunikationen mellan olika naturvetenskapliga forskningsgemenskaper. Detta djup är något som Kuhn anser att många har missförstått. Han menar att en sociolog eller lingvist som noterar att $f=m a$ utan större problem kan yttras och tolkas av det naturvetenskapliga samfundet inte nödvändigtvis har förstått betydelsen av den lyckade kommunikationen (Kuhn 1970a s. 188). Den ytliga tolkningen leder till att de missar de djupgående exemplar som präglar utbildningen.

Efter att studenterna har lärt sig grunderna kan de välja olika inriktningar. En student som väljer någon inriktning inom fysiken, säg fysik $2 \mathrm{~A}$ i stället för $2 \mathrm{~B}$, $2 \mathrm{C}$, eller 2D, kommer då kanske att få lära sig mer specifika instanser av Newtons andra lag kopplade till inriktning A. Kuhn skriver:

All physicists, for example, begin by learning the same exemplars: problems such as the inclined plane, the conical pendulum and Keplerian orbits; instruments such as the Vernier, the calorimeter, and the Wheatstone bridge. As their training develops, however, the symbolic generalizations they share are increasingly illustrated by different exemplars. Though both solid-state and field-theoretic physicists share the Schrödinger equation, only its more elementary applications are common to both groups. (Kuhn 1970a s. 186)

Det finns en kedja av exemplar, mer specialiserade instanser som förbinder de lokala nivåerna med de globala. Ju mer specialiserade studenterna blir, från grundutbildning till forskarutbildning till självständiga forskare, desto mer specialiserade blir problemen och de symboliska generaliseringarna. Det förekommer då t.ex. en global formel $f=m a$, som alla känner till, och mer specialiserade och lokala instanser av $f=m a$ som en viss gemenskap känner 


\section{Per Klang}

till, och så vidare. Poängen är att oavsett specialiseringsgrad så kan naturvetare från olika lokala specialiseringar i princip presentera sina resultat på en global nivå. Trädet i figur 1 nedan illustrerar en modell av Kuhns beskrivning.

I figuren presenteras varje lokalt steg i utbildningen till vänster och exemplar för fysik till höger. (Det är inte formlerna i sig som är intressanta utan de vertikala och horisontella förbindelser som de formar mellan olika gemenskaper. Därför presenteras de i generaliserad form.) Figuren illustrerar även två av fyra element i Kuhns disciplinära matris, dvs. symboliska generaliseringar och exemplar. I det här fallet rör det sig om Newtons andra rörelselag, vilken introduceras globalt för att sedan ytterligare specialiseras genom exemplar under utbildningens gång. De andra elementen, värderingar och modeller, specialiseras också genom exemplar under utbildningens gång, men utelämnas ur figuren för läsbarhetens skull.

Den disciplinära matrisens fyra element är således något som delas globalt $\mathrm{i}$ naturvetenskapen. Det tysta antagandet om vetenskaplighet i termer av symboliska generaliseringar, vissa värderingar, och förklarande modeller är något som genomsyrar alla steg i utbildningen för att sedan specialiseras i mer lokala former av exemplar.

Man kan då notera att det är flertydigt när Kuhn i SSR 1962 skriver om paradigm. Paradigm kan betyda både disciplinär matris och exemplar. Det kan alltså samförekomma flera olika paradigm (dvs. exemplar) på lokal nivå inom
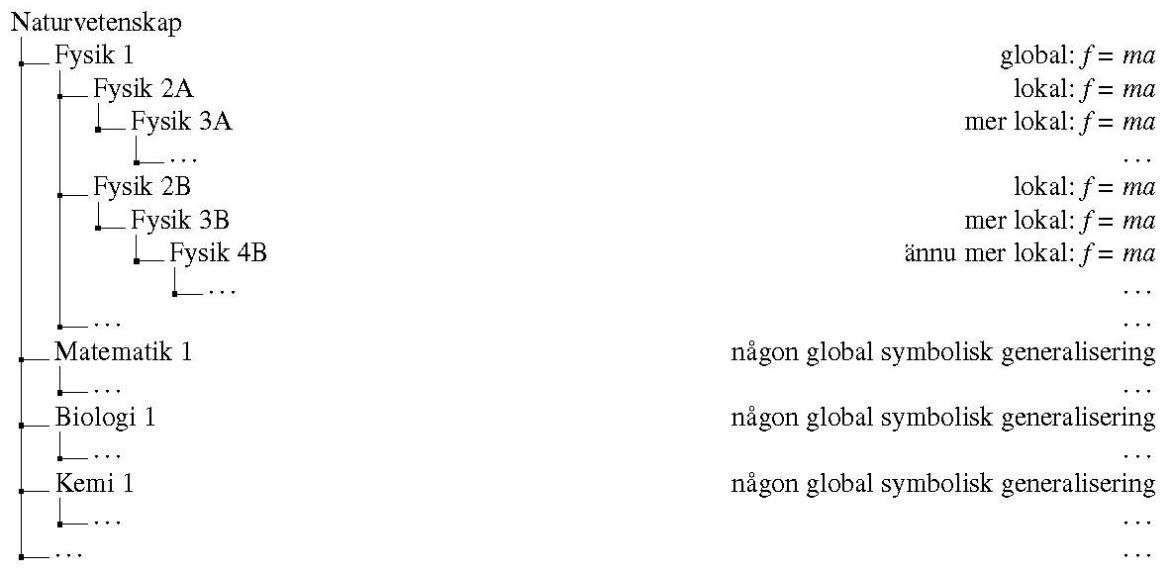

Figur 1. Arvshierarkisk modell av Kuhns (1970a) globala och lokala beskrivning av naturvetenskapen. 
ett paradigm (dvs. disciplinär matris), men inte samförekomster av disciplinära matriser på global nivå. Givet de tolkningsproblem som uppstår vid en bristande definition av paradigmbegreppet, är det inte svårt att inbilla sig att två samexisterande symboliska generaliseringar, där t.ex. massa eller längd hade olika definitioner, skulle försvåra kommunikationen och det vetenskapliga arbetet avsevärt.

Att som i Kuhn 1962 använda paradigmbegreppet för både mängden och ett av dess element är inte helt lyckat, därav förtydligandet i andra utgåvan av SSR. Å ena sidan kan en uttolkare av Kuhn som fokuserar på en ytlig exemplarbeskrivning på en lokal nivå se en stor pluralitet av forskningsgemenskaper i naturvetenskapen och därför kanske missa länken till det första exemplaret som håller dem samman på en global nivå. Å andra sidan kan en läsare som fokuserar på en ytlig exemplarbeskrivning på global nivå tillskriva den en alltför stor homogenitet, och därför kanske missa länkarna till exemplaren på de lägsta lokala nivåerna som utgör den bredd i specialisering som förekommer. Det är bl.a. därför som paradigmbegreppet bör undvikas.

Den disciplinära matrisen som tidigare kallades paradigm utmärker alltså vad Kuhn kallar mogen vetenskap. I en sådan matris kan det finnas flera olika varianter av symboliska generaliseringar, modeller, värderingar och exemplar än de som tas upp här. För att tydliggöra detta ställs dessa element upp i en attribut-värde-matris i figur 2.

Den disciplinära matrisen i figur 2 består av attribut till vänster och värden inom hakparenteser till höger om attributet. Dessa kan även betraktas som mängder och element, om det faller sig mer naturligt. På första raden finns attributet DISCIPLINÄR MATRIS (längst till vänster) vars värde är element [1, 2, 3, 4] (längst till höger). Dessa element representeras som attribut-värde-par på var sin rad. På den andra raden ges attributet [1] SYMBOLISKA GENERALISERINGAR vars värden är Newtons rörelselagar t.ex. [ $f=m a]$. På den tredje raden ges attributet [2] FÖRKLARANDE MODELLER vars värden är förklaringar t.ex. ['gas är som ...']. På den fjärde raden ges attributet [3] VÄRDERINGAR vars värden är en uppsättning normer, t.ex. [Ockhams rakkniv]. Attribut 1-3 är således enbart specifikationer utan något djup. Det intressanta sker på rad fem där värdena till [4] EXEMPLAR är instanser av den disciplinära matrisens tre första element [1-3] som har ordnats hierarkiskt utifrån dess specialiseringsgrad. Denna över- och underordning representeras av klammerparenteser; ju mer inbäddat $i$ parenteser ett exemplar är, desto mer lokalt är exemplaret, och ju mindre inbäddat i parenteser ett exemplar är, desto mer globalt är det. Lägg där särskilt märke till hur graden av specialisering i figur 2 förhåller sig till graden av lo- 


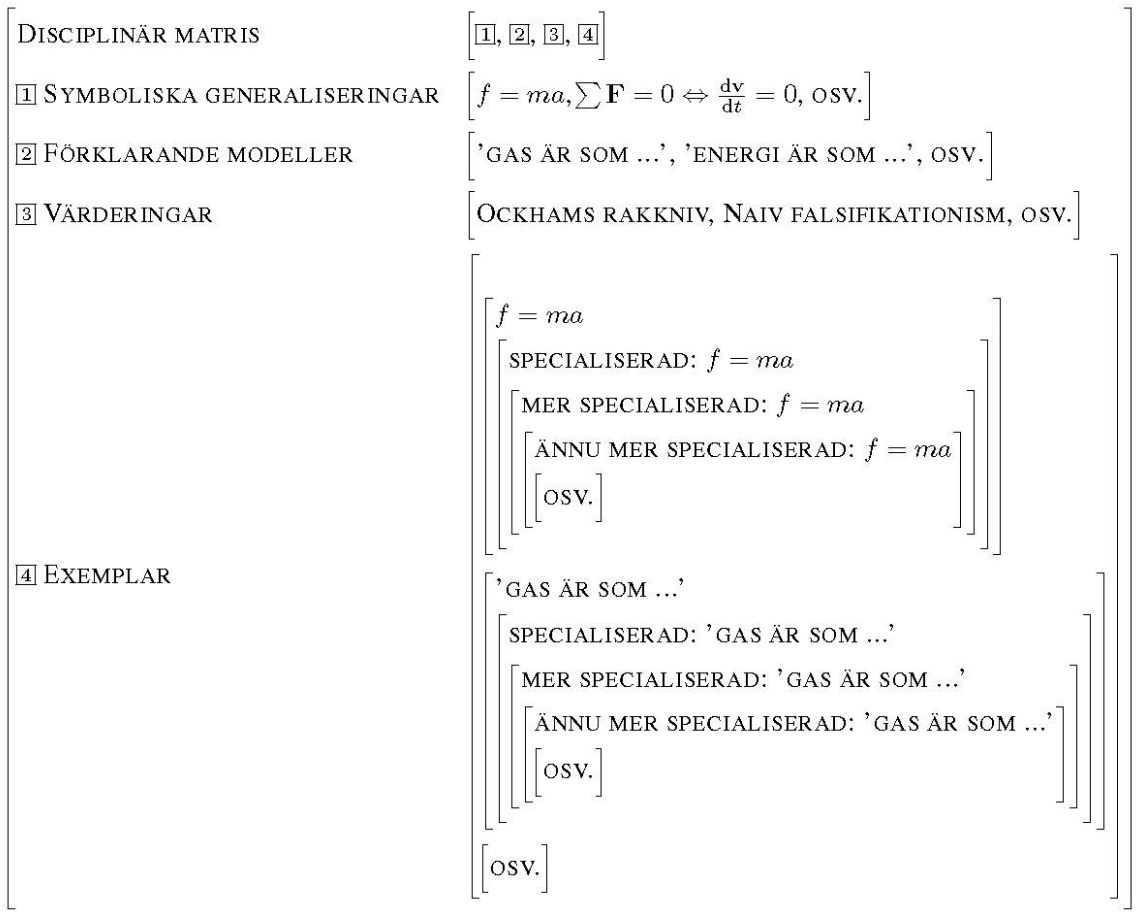

Figur 2. Kuhns exempel på den disciplinära matrisens element uppställd som attribut-värdematris.

kalitet i figur 1. Lokala exemplar (tidigare kallade för paradigm) länkas till ett globalt exemplar (tidigare kallat för paradigm) vilka samtliga är en del av den disciplinära matrisen (tidigare kallad för paradigm).

Det finns alltså ett djup i Kuhns paradigmbegrepp som inte blir synligt förrän det ges en hierarkisk framställning mot vilken den ytnära betydelsen kan kontrasteras. Med risk för upprepning: man kan inte endast ta hänsyn till en ytlig beskrivning av en disciplinär matris för en forskningsgemenskap - oavsett om man lägger den på global eller lokal nivå. Man måste även beakta den djupgående kedja av specialiserade gruppantaganden i form av exemplar som länkar den globala nivån med lokala nivåer. Man kan inte heller endast ta hänsyn till den globala nivån, för då missar man det sammanhängande djup som naturvetenskapen är uppbyggd av och de kommunikativa fördelar som det innebär. Vertikal konsensus effektiviserar; horisontella skiften i konsensus revolutionerar. 
Sammanfattningsvis kan man säga att Kuhns beskrivning av naturvetenskapen som definierad och driven av konsensus kring den disciplinära matrisen fick stort genomslag, detta i en tid då den logiska positivismen var starkt ifrågasatt. Kuhns sociologiska historieskrivning visar att Poppers demarkationskriterium inte håller; forskare betraktar ganska ofta motsägelser som anomalier vilka de kringgår på olika sätt. Han visar även att kunskapstillväxten endast är stadig i tider av normalvetenskap för att sedan successivt stanna av i takt med att antalet anomalier växer. Vid skiften av disciplinära matriser faller till och med vissa förklaringar bort. Observationen av ett sådant bortfall stred mot den rådande synen på vetenskaplig rationalitet utifrån vilken man endast bytte disciplinär matris om den nya konkurrerande disciplinära matrisen kunde lösa dels nya problem, dels allt som den tidigare kunde. På historisk grund visar Kuhn att forskare kan anta en ny disciplinär matris trots att vissa resultat som kunde hanteras i den tidigare disciplinära matrisen inte kunde förklaras av den nya. Detta kallas som sagt Kuhn-bortfall och förklaras som ett resultat av inkommensurabilitet. Ett nytt demarkationskriterium med det centrala begreppet paradigm hade presenterats. Den vetenskapsfilosofiska eliten kritiserade Kuhn för att föreskriva en irrationell och omoralisk vetenskapssyn och Kuhn försvarade sig. Flera av vetenskapsfilosoferna formulerade egna vetenskapssyner i relation till Kuhns som också är värda att ta på allvar. Men det var Mastermans kritik av flertydigheten i begreppet paradigm som påverkade Kuhn till den grad att han senare förtydligade sig med termerna disciplinär matris och exemplar.

I bemötandet av kritiken i Criticism and the growth of knowledge insåg Kuhn (1970c s. 272) att han hade förlorat kontrollen över paradigmbegreppet, och ska senare ha övergett det (Hacking 2012 s. xviii). Detta har dock inte hindrat andra från att fortsätta använda det, och tolkningarna är mångskiftande.

\section{Globala och lokala perspektiv på paradigm i språk- vetenskapen}

Kuhns beskrivning väckte intresse även utanför naturvetenskapen. Detta kan delvis bero på 60-talets intellektuella trend där man försökte förstå sitt forskningsfält genom att upprätta domänspecifika historiografier; en del språkvetare hakade på trenden, och beskrev språkvetenskapens historia med Kuhns begreppsapparat (Greene 1974 s. 489). 
De arbeten som tas upp här är blott nedslag, och redogörelsen kan inte betraktas som uttömmande. Dess syfte är snarare att peka ut ett gemensamt drag för flera språkvetenskapliga arbeten där Kuhns paradigmbegrepp används. Det som förenar dessa är vad som kan kallas för en ytnära analys, dvs. att man endast fokuserar på en nivå i en forskningsgemenskaps hierarki av specialiseringar. ${ }^{7}$ I språkvetares bruk av paradigm anläggs antingen ett ytnära lokalt perspektiv eller ett ytnära globalt perspektiv. Utifrån det förstnämnda pekar man på lokal nivå ut språkvetenskapliga forskningsgemenskaper i vilka det förekommer symboliska generaliseringar, värderingar, modeller och skolboksexempel. Utifrån det sistnämnda argumenterar man för att det saknas instanser av dessa fyra element som delas av samtliga inom språkvetenskapen. Mot bakgrund av dessa perspektiv och Kuhns förtydligande av paradigmbegreppet, kan vi förhoppningsvis bättre förstå de problem som kan tyckas uppstå i och med språkvetares användning av paradigm samt den önskan som tycks finnas om en väldefinierad kuhneansk begreppsapparat för språkvetenskapliga ändamål.

Efter att den första upplagan av SSR (Kuhn 1962) hade givits ut, tog många betydelsen av paradigm för given. En del tog kanske även för givet att deras uppfattning av paradigm var densamma som alla andras. Detta gäller t.ex. Chafes (1968) artikel »Idiomaticity as an anomaly in the Chomskyan paradigm», vilken inleds: »Those who have read Thomas Kuhn's book, The Structure of Scientific Revolutions, will understand my title without further explanation.» I ljuset av föregående avsnitt om SSR är detta osannolikt, eftersom paradigmbegreppet inte var särskilt väldefinierat 1968. Den typen av retorik förekommer likväl ibland i språkvetenskaplig verksamhet.

SSR blev så pass uppmärksammad av språkvetare att det 1964 och 1968 anordnades ett symposium respektive en konferens med fokus på SSR och paradigmbegreppets relevans för lingvistikens historia. Bidragen, skrivna av namnkunniga lingvister, samlades i konferensvolymen Studies in the History of Linguistics, Traditions and Paradigms som kom ut 1974, fyra år efter att Kuhn hade förtydligat sig i den andra utgåvan av SSR. Åtta av tjugotvå artiklar i volymen refererar till Kuhn och förhåller sig till paradigmbegreppet.

Bortsett från Hymes (1974), hänvisar samtliga författare i volymen till den första utgåvan av SSR (Kuhn 1962). Författarna verkar också omedvetna om den vetenskapsfilosofiska debatten samt de begreppsliga förtydliganden som följde på den, bl.a. i andra utgåvan av SSR (Kuhn 1970a). Några författare ur-

${ }^{7}$ Med ytnära åsyftas inte att författarnas analyser bör tas för ytliga i nedsättande mening. 
skiljer vad de betraktar som språkvetenskapliga paradigm (Diederichsen 1974, Kiparsky 1974, Verburg 1974), en del har andra infallsvinklar på språkvetenskap och paradigm (Stocking 1974, Wolff \& Thorne 1974). Samtliga av dessa applicerar dock begreppet på språkvetenskapen relativt förbehållslöst, likt Chafe (1968). Ett undantag är Diederichsen som menar att språkvetenskapliga forskningsgemenskaper inte tycks möta vissa av Kuhns kriterier. Diederichsen, som urskiljer ett komparativt paradigm, skriver:

I am not sure if we are quite justified in calling these patterns »paradigms» in Kuhn's special sense (1962:10). For one thing, they do not »include law, theory and instrumentation together». But as they have "prepared the student for membership in the particular scientific community with which he will later practice» and have »seldom evoked overt disagreement over fundamentals», I think it will be justifiable to call them so, at least in quotation marks. (Diederichsen $1974 \mathrm{~s}$. 277)

Diederichsen anlägger då ett lokalt ytnära perspektiv på paradigm. Han fokuserar på de verksamhetsdrag som han tycker stämmer överens med beskrivningarna i SSR, men kopplar dem inte övertygande till den globala aspekten. Så tolkas här även Kiparsky (1974) och Verburg (1974). Diederichsens paradigmförslag kritiseras av Greene som skriver från ett globalt perspektiv:

What has taken place is not a revolution within the framework of historically oriented comparative philology but rather a dramatic shift of interest and attention from diachronic to synchronic studies [...]. The complaint of contemporary comparative philologists is not that their field has been revolutionized but rather that it has been abandoned or sadly neglected. (Greene 1974 s. 498)

Med andra ord, hur kan det finnas ett paradigm om inte samtliga språkvetare har antagit det nya paradigmet? Även Metcalf (1974 s. 253) anlägger ett ytnära globalt perspektiv: »[T]here has not yet emerged a 'paradigm' (in the Kuhnian sense) all-embracing enough to encompass the whole field of the 'Study of Language'.» Detta gör även Hymes (1974 s. 10): „Each new 'paradigm' simply has not succeeded in establishing complete authority.» Enligt det ytliga globala perspektivet ska samtliga utövare inom lingvistik styras av ett auktoritärt paradigm.

Hymes (1974 s. 18) är även orolig för att paradigmbegreppet skall användas för politiska syften där ledarfigurer för en inriktning med hjälp av historieskrivning kan stärka sin position. Han tar bland annat upp Chomskys historieskrivning i Cartesian Linguistics (1966), vilken har kritiserats för just detta, bland annat av Koerner (1978). En aspekt av den debatten gäller huruvida det har förekommit språkvetenskapliga revolutioner eller ej, vilken enligt Haapamäki 
(2002) har diskuterats betydligt oftare än paradigmbegreppet. Av praktiska skäl diskuteras inte revolutioner ingående här.

Det finns även språkvetare som starkt ifrågasatt paradigmbegreppets kompatibilitet med språkvetenskapen, t.ex. Grotsch (1982), Arens (1987), Newmeyer (1996) och Percival (1976) vars kritik beskrivs mer ingående nedan. ${ }^{8}$ Detta till trots, finns det senare ansatser där språkvetare identifierar språkvetenskapliga paradigm, t.ex. Smith (2012) i sin avhandling om inkommensurabiliteten mellan två språkvetenskapliga paradigm (sociolingvistik och transformationsgrammatik) och Allan (2003) i en diskussion om vad han kallar för makroparadigm. Såväl Smith som Allan anlägger ett ytnära lokalt perspektiv i och med att de t.ex. antar ett chomskyanskt paradigm som de inte kopplar samman med exemplar upp till en globalt delad nivå i en disciplinär matris för språkvetenskapen.

Det förekommer även identifikation av paradigm i mer specifika forskningsgemenskaper. Randquist (1984) utgår ifrån den första utgåvan av SSR och anlägger ett ytnära lokalt perspektiv på nordistikens forskningsideologi och forskningspraktik. Hon delar upp nordistiken i två generella paradigm: det diakronisk-komparativa och det synkronisk-strukturalistiska (s. 205). Komparativisterna höll sig främst till datadrivna metoder, och strukturalisterna till teoridrivna.

Paradigmbegreppet figurerar även i större historiografiska arbeten. Det diskuteras i The History of Linguistics in the Nordic Countries (Hovdhaugen m.fl. 2000 s. 7-8). Där urskiljs bland annat ett paradigm för (i) komparativisterna (s. 97), (ii) junggrammatikerna (s. 95), (iii) allmän lingvistik (s. 230), (iv) strukturalismen (s. 250) och (v) generativismen (s. 315). Det förekommer flera ytnära lokala beskrivningar, men det är svårt att urskilja en koppling mellan lokala exemplar och globala exemplar. Även det mycket omfångsrika verket Western linguistics. An historical introduction refererar till Kuhns paradigmbegrepp i första utgåvan (Seuren 1998); det tycks dock inte finnas någon definition av eller längre diskussion om paradigmbegreppet.

Koerner har vid ett flertal tillfällen tagit upp Kuhns paradigmbegrepp i sitt arbete för att stärka historiografins ställning i lingvistiken (t.ex. i Koerner 1972, 1976, 1977, 1978). Han menar att det inte går att anta Kuhns idéer rakt av, men att de kan modifieras så att de passar lingvistiken (1977 s. 168). Han skriver dock att han aldrig riktigt har förstått distinktionen mellan de två betydelserna av paradigm som de presenteras i Kuhns postskript (1970a):

${ }^{8}$ Grotsch 1982 och Arens 1987 är skrivna på tyska, och jag utgår därför från Haapamäki (2002 s. 329) som menar att dessa forskare ifrågasätter kompatibiliteten. 
Unfortunately, Kuhn used the term in many different senses [...], and I fail to understand even the difference between the two kinds of 'paradigm' on which Kuhn insisted in his reply to earlier criticism [...]. (Koerner 1972 s. 258)

I stället för att försöka förstå Kuhns begreppsliga förtydligande, antar Koerner en annan betydelse som han kopplar till formen paradigm. Utifrån den betydelsen identifierar han tre språkvetenskapliga "paradigm» utifrån ett ytnära lokalt perspektiv. Detta kan anses olyckligt eftersom Koerners paradigmbegrepp då inte har så mycket med Kuhns paradigmbegrepp att göra annat än till form och källhänvisning. Det hade då kanske varit bättre att använda en annan term.

I språkvetenskapen kan man alltså urskilja ett globalt och ett lokalt perspektiv. Vi har sett att dessa perspektiv leder till oenigheter, som i fallet med Hymes konferensvolym från 1974. Ett senare exempel på argument från dessa olika ståndpunkter kan urskiljas i Percival 1976 och Haapamäki 2002, vilket beskrivs mer ingående nedan.

Percival (1976 s. 285) ställer två frågor: (i) har man tolkat lingvistikens historia med Kuhns teori på korrekt sätt, och (ii) kan Kuhns teori förklara lingvistikens historia? Nej, svarar Percival på dessa frågor (s. 288). Som stöd för sina ståndpunkter lutar han sig bland annat mot generativismens skilsmässa från strukturalismen genom Chomsky $(1957,1965)$.

Percival menar att antaganden måste ha fullt stöd i det språkvetenskapliga samfundet för att kunna räknas som paradigm. Han tar här visserligen hänsyn till Kuhns begrepp disciplinär matris men tycks ha förbisett exemplar i den tvådelade begreppsuppdelningen, dvs. djupet i den lokala-globala länken. I stället för det djupgående exemplaret talar Percival ytligt om skolboksexempel. Detta påverkar således hans analys av generativismen.

Enligt Percivals tolkning av Kuhn uppvisar generativismen samtliga element i den disciplinära matrisen: (i) symboliska generaliseringar i form av omskrivningsregler, dvs. härledningsregler $(A \rightarrow a)$, (ii) en ontologisk modell av genererade meningar, (iii) värderingar i form av enkla och generella förklaringar (Ockhams rakniv) samt (iv) skolboksexempel, i det här fallet en lärobok av Langacker (1972). Men Percival menar att detta inte räcker på grund av bristande konsensus inom språkvetenskapen. Han skriver:

There are two main problems in this regard. On one hand, many linguists continue to subscribe to theories other than generative grammar, e.g. stratificational grammar, systemic grammar, string analysis, various brands of European structuralism etc. [...]. On the other hand, the adherents of generative grammar themselves have split into a number of competing schools of thought over the past decade. (Percival 1976 s. 289) 


\section{Per Klang}

Percival har visserligen antagit den disciplinära matrisen men inte exemplaret som förbinder de globala nivåerna i utbildningens struktur med de lokala, specialiserade nivåerna. Att det finns skolboksexempel är inte tillräckligt enligt Kuhns beskrivning, om de endast är exempel inom den generativa skolan; för att räknas som språkvetenskapliga exemplar måste de introduceras i grundutbildningen för att sedan successivt specialiseras. Utifrån Percivals ytliga globala kriterium för paradigm kan man då förledas att tro att generativismen skulle kunna fångas upp av Kuhns paradigmkonception. Att så inte är fallet blir tydligt om man jämför Percivals ytliga beskrivning av skolboksexemplen, illustrerad i figur 3 nedan, med Kuhns djupgående beskrivning av naturvetenskapen, illustrerad i figur $2 \mathrm{i}$ avsnitt 1.

För säkerhets skull bör här nämnas att det finns flera specialiserade instanser av $A \rightarrow a$. Läroboken Syntax (Carnie 2002) illustrerar en sådan specialiseringsprogression tydligt, men faktum kvarstår att denna specialiseringskedja inte är förankrad i språkvetenskaplig utbildning i allmänhet. Om du frågar en slumpmässigt utvald språkvetare om det generativa axiomet och den generella omskrivningsregeln för en kontextfri grammatik typ 2 i Chomsky-Schützenberger-hierarkin, så kommer hen förmodligen inte att kunna ge dig ett svar. Det samma kan förmodligen tänkas gälla för grammatiker. Få svarar nog: Absolut! Du syftar på $\mathrm{S}$ och på att en icke-terminal nod skrivs om till en eller flera icke-terminala och/eller terminala noder.

Det ligger något i Percivals slutsats att den generativa grammatiken inte utgör ett språkvetenskapligt paradigm, men argumenten som leder honom till den slutsatsen håller inte för närmare granskning. De premisser som Percival utgår ifrån överlappar endast delvis med Kuhns definitioner och paradigmkonceptioner, eftersom Percival inte tar skillnaderna mellan naturvetenskaplig och språkvetenskaplig utbildning i beaktande. Om Percival hade visat att det inte är fallet att språkvetenskaplig utbildning från grundutbildning till specialisering generellt genomsyras av fler och fler specialiserade exemplar av omskrivningsregler, hade hans slutsats kanske stått sig. Men då han inte antar den andra betydelsen av paradigm kan han inte redogöra för varför olika paradigm i betydelsen exemplar kan samförekomma. Detta gör hans argumentation öppen för angrepp från dem som har ett ytnära lokalt perspektiv på Kuhns paradigmbegrepp. Låt oss därför titta närmare på Haapamäki (2002) som vänder sig mot Percivals slutsats utifrån ett sådant perspektiv.

Haapamäki utgår ifrån följande definition av paradigm:

Paradigmen är enligt Kuhn vetenskapliga landvinningar som uppfyller två krav: de skall vara originella och de skall vara öppna. En forskargemenskap som arbe- 


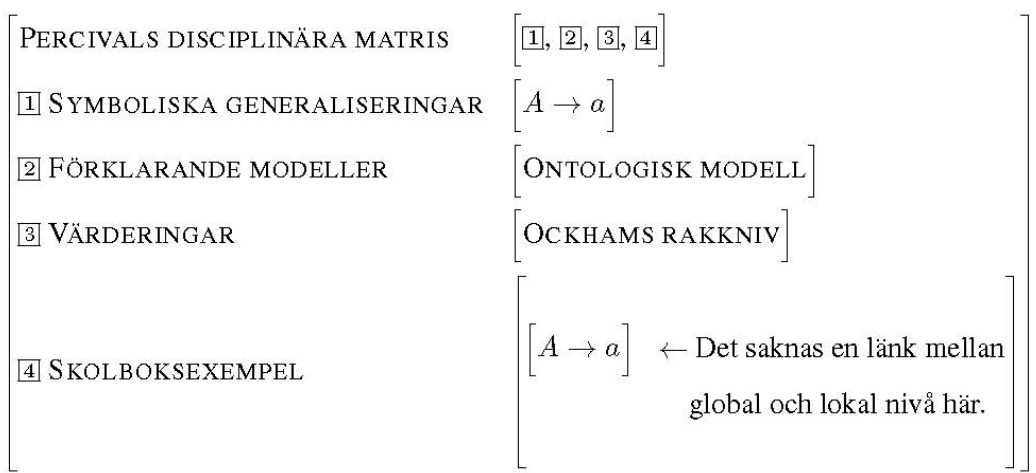

Figur 3. Percivals (1976) ytnära globala disciplinära matris.

tar inom ett paradigm delar en uppsättning grundantaganden och överenskommelser, det vill säga har gemensamma uppfattningar om centrala metoder, begrepp, problem och problemlösningar. Dessa presenteras i regel i läroböcker, vilkas betydelse Kuhn mycket starkt betonar för den paradigmstyrda forskningen. (Haapamäki 2002 s. 326)

Utifrån definitionen ovan tycks Haapamäkis förståelse av Kuhns paradigmbegrepp stämma ganska bra överens med Percivals (1976) och andra språkvetares definitioner. Men där Percival har ett ytnära globalt perspektiv har Haapamäki ett ytnära lokalt perspektiv, och hon har därför anledning att argumentera emot hans slutsats. Haapamäkis lokala perspektiv är synligt i hennes tolkning av Kuhns beskrivning av mer specialiserade naturvetenskapliga undergrupper i vilka man kan »urskilja olika mindre samfund. Som Kuhn vidare påpekar kan paradigmen hänföra sig till just sådana, mycket små samfund.» (Haapamäki 2002 s. 334-335)

Det Haapamäki skriver i föregående stycke stämmer, men det hon talar om är endast en del av Kuhns paradigmkonception, dvs. exemplar, och en disciplinär matris kan innehålla flera exemplar på olika nivåer; se figur 1-2 i avsnitt 1. Isolerade konkurrerar dessa dock inte med varandra. De utgör bara ytterligare specialiserade instanser av samma sak. Hon drar därför slutsatsen att det kan förekomma flera paradigm samtidigt, vilket stämmer när det gäller exemplar, men inte när det gäller disciplinära matriser. Haapamäkis ytnära lokala perspektiv motsäger egentligen inte Percivals ytnära globala perspektiv; de kompletterar snarare varandra. Det är först när exemplaret förstås som en djupgående del i den disciplinära matrisen som bilden av Kuhns paradigmbegrepp blir fullständig. 


\section{Per Klang}

Sammanfattningsvis: Under den historiska vändningen sökte forskare förklaringar till den gemenskap man var en del av, bland annat i dess historia. Språkvetenskapen var inget undantag, och Kuhns paradigmbegrepp har där använts av flera. En del av de forskare som här har diskuterats antar paradigmbegreppet utan vidare specificering, och diskuterar inte den problematik som förknippas med det. Dessutom tycks en del forskare som har tagit hänsyn till problematiken vilja använda paradigmbegreppet trots att Kuhn explicit avråder från detta och av förklarliga skäl i stället förordar termerna disciplinär matris och exemplar. På ett övergripande plan kan man urskilja två grupper av forskare: de med ett ytnära globalt perspektiv på språkvetenskapliga forskningsgemenskaper, och de med ett ytnära lokalt perspektiv på språkvetenskapliga forskningsgemenskaper. Dessa perspektiv är inte förenliga tagna var för sig, men kan begripligt förenas när man tar hänsyn till djupet, dvs. till utbildningen som helhet och de exemplar som förbinder mer specialiserade lokala nivåer med mindre specialiserade nivåer. Inget av de refererade arbetena i detta avsnitt antar ett holistiskt perspektiv på begreppet paradigm som motsvarar Kuhns definition av den disciplinära matrisen.

\section{Avslutande diskussion}

Den här texten erbjuder inte en utförlig beskrivning av språkvetenskapens struktur eller olika skolbildningars kamp. Däremot beskriver den hur det tvetydiga begreppet paradigm har använts inom och på språkvetenskapen, samt hur man antingen genom ett globalt eller lokalt perspektiv har antagit endera av de två fenomenen som paradigm åsyftade. En ytlig analys från det ena perspektivet ger lika mycket rätt som en ytlig analys från det andra perspektivet. Antas den ena betydelsen utan den andra, blir dock bilden inte fullständig. Om man däremot tolkar Kuhn så att paradigm syftar på både den disciplinära matrisen och de exemplar som förekommer på olika nivåer i verksamhetens utbildning och forskning, klarnar bilden något. Utifrån den tolkning jag framfört i den här artikeln är det rimligt att anlägga ett holistiskt perspektiv på paradigmbegreppet. Dock borde det tydligt framgå att om man använder begreppet paradigm på språkvetenskapen eller någon annan verksamhet försvåras kommunikationen med andra forskare, eftersom begreppet kan betyda flera saker. 
Det finns även två andra saker som jag strävat efter att lyfta fram i artikeln. Den första är att de generella betydelserna av Kuhns begrepp paradigm ingår i termerna disciplinär matris och exemplar. Begreppet paradigm är alltså semantiskt överflödigt. Det andra är att språkvetenskapen tycks sakna en beskrivning av en disciplinär matris som stämmer överens med definitionen av begreppet i Kuhn 1970 och 1974. Detta beror på att matematik och logik inte utgör fundamenten i språkvetenskaplig utbildning; de är inte de språk genom vilka vi främst kommunicerar våra resultat med varandra. Det verkar inte heller gå att urskilja ett formellt system som förenar dialektologer, namnforskare, textforskare, grammatiker, lexikografer osv. Där skiljer sig språkvetenskapen från Kuhns beskrivning av naturvetenskap. Språkvetenskaplig utbildning och forskning genomsyras inte av fler och fler specialiserade fall av symboliska generaliseringar, och ännu tycks ingen ha observerat en genomgående värdering eller förklaringsmodell som utgör de andra elementen i den disciplinära matrisen. Visst förekommer liknande saker på olika nivåer och inriktningar i språkvetenskaplig utbildning, men det finns inte något språkvetenskapligt axiom som samtliga språkvetare får lära sig och som deras forskning mekaniskt kan härledas tillbaka till.

I Kuhns uppdelning får språkvetenskapen - som så många andra vetenskaper - därmed kategoriseras som preparadigmatisk utan disciplinär matris, till skillnad från den postparadigmatiska naturvetenskapen med disciplinär matris. En sådan uppdelning är dock för grov för att kunna säga något intressant om preparadigmatiska verksamheter, menar Kuhn (1970a s. xliii); det kan stämma. Det känns inte helt rättvisande att karaktärisera språkvetenskapens verksamhet som en omogen motpol till den mogna naturkunskapen. Språkvetenskap är ju så mycket mer än ett brustet kriterium. ${ }^{9}$ Med det sagt ligger det ändå något $\mathrm{i}$ Kuhns idé om att den disciplinära matrisen effektiviserar kommunikationen, och kanske kan språkvetenskapen en dag komma att formalisera sina grundantaganden.

Måste all verksamhet vara effektiv? Nej, det anser jag inte. Till de vetenskaper som stänger till, snävar av och skyndar på, kan det behövas en balanserande verksamhet som öppnar upp, breder ut och saktar ned. På ett övergripande plan kan kanske humaniora ses som en sådan verksamhet.

Men om språkvetenskapen inte hålls samman av ett formellt system, vad är det då som förenar språkvetare bortsett från det gemensamma studieobjektet språk? Saknar språkvetenskapen exemplar? Det är något oklart. I beskriv-

${ }^{9}$ Se Kuhn 2000 för mer om hans syn på skillnader mellan natur- och humanvetenskap. 
ningen som givits i det här arbetet saknas det exempel på exemplar som genomsyrar språkvetenskaplig utbildning. Och visst saknar vi symboliska generaliseringar som karakteriserar Kuhns disciplinära matris, eftersom matematik och logik inte är generellt integrerade i språkvetenskaplig utbildning. Men detta utesluter inte att det finns något annat som binder språkvetenskaplig verksamhet samman.

För Kuhn kännetecknas naturvetenskapens verksamhet av längre normalvetenskapliga perioder med mekanisk pussellösning inom formella system, och kortare avbrott av extraordinärt revolutionerande arbete där det formella systemets grundläggande beståndsdelar, såsom axiom, omskrivningsregler och symbolspråk ifrågasätts. Min bild av språkvetenskap är snarast den motsatta till naturvetenskap. Språkvetenskapen kännetecknas av långa perioder där det vanliga arbetet innefattar ifrågasättandet och utvecklandet av grundläggande begrepp, metoder och regler, samt av ovanligare avbrott med pusselliknande arbete inom formella system. Från ett sådant perspektiv kan man se att det som utmärker extraordinärt revolutionerande arbete i naturvetenskap, dvs. omprövningar av begrepp och grundantaganden, utmärks som ordinärt i språkvetenskap. Som exempel kan man tänka sig alla de parallellt gångbara definitioner av språk, tempus, subjekt, makt, evidentialitet som används inom språkvetenskapen. Från ett annat perspektiv kan man se att det som utmärker ordinärt arbete i naturvetenskapens historia utmärks som extraordinärt och revolutionerande i språkvetenskapens historia, t.ex. bruket av Chomskys (1957) formalisering av omedelbar konstituentanalys (Bloomfield 1933). Låt oss utveckla detta resonemang.

Där naturvetenskapens normala verksamhet är bunden av operationaliseringar inom ett formellt system, är en del språkvetares normala verksamhet något friare. Man skulle kunna säga att språkvetare vanligtvis arbetar inom ett informellt system, bortom axiom och teorem. Exakt vad detta informella system består av och var dess gränser ska dras är något oklart, och av praktiska skäl förhåller jag mig lite svävande kring detta. Inom detta system är det dock möjligt att göra saker som man inte kan i ett formellt system. Det är möjligt att tolka om grundläggande antaganden, begrepp eller händelser och få dem att betyda något nytt från ett nytt perspektiv, och låta denna nytolkning stå parallellt med ett annat perspektiv på samma fenomen. Detta kan inte göras lika lätt inom ett formellt system med storheter som massa och längd, eller tid. Om det fanns flera konkurrerande definitioner av dessa så skulle det formella systemet falla, eftersom det kräver entydighet för att kunna användas mekaniskt och effektivt. 
Inom delar av humaniora och språkvetenskap kan vi även vanligtvis fråga oss om någonting är bra eller dåligt för människor. ${ }^{10}$ Frågor om moraliska eller psykologiska konsekvenser av ett fenomen kan diskuteras utanför ett formellt system. Sådana frågor blir t.ex. synliga i klarspråksarbete, diskursanalys och språkdidaktik. Men det är förmodligen ovanligt att söka efter motbevis eller fråga sig om Newtons andra rörelselag är generellt bra eller dålig för någon eller något inom ett formellt system i en period av normalvetenskap.

Jag påstår inte att anarki råder inom det informella systemet. En språkvetare kan t.ex. inte utan vidare fråga sig varför försäljningen av en produkt avtog mellan oktober och november 1996. Om det däremot finns ett språkligt skäl till den minskade försäljningen, kan det ändå finnas anledning att undersöka fenomenet, t.ex. i form av en misslyckad kränkande formulering i reklam för produkten. Likt alla andra måste språkvetaren koppla sin forskning till tidigare relevanta arbeten och motivera sitt val av ämne.

Nackdelen med att agera inom ett informellt system är påfallande i det arbete som ligger bakom denna artikel; jag har här sållat i ett stort material och det finns inget pålitligt och snabbt sätt att ta reda på vad olika forskare menar, och vad de tror att andra menar, med paradigm. Varje enskild text måste läsas i sin helhet, och jag behöver ta ställning till på vilket sätt deras tolkning förhåller sig till SSR. Det finns inga formella kriterier för vad som är relevanta arbeten för de som arbetar inom informella system. Det går alltså inte att ta en av de texter som citerats och via dess form mekaniskt bedöma den: Irrelevant, den följer ej av humanioras tredje axiom, eller Relevant! Den följer av relevansaxiomet.

Fördelen med att agera inom ett formellt system är att härledningarnas sanningsvärde garanteras av axiomen samt härledningsreglerna. När saker följer förlitar man sig på systemet och dess regler. Nackdelen (om man är naiv falsifikationist) eller fördelen (om man är kuhnian) med det formella systemet är att naturvetaren endast i tider av kris kan lyckas med att ifrågasätta axiomen till den grad att de får omdefinieras. Då kan det bli läge för en ny ekvation som hanterar massa, längd och tid. När ett grundläggande antagande byts ut garanteras inte längre sanningsvärdet i de satser som följer av det. Det har skett en revolution och exemplaren måste ses över. När delar av det formella systemet raseras, får det konsekvenser i utbildningens samtliga steg från det allra finkornigaste specialiserade exemplar i spetsforskningen till den allra grovkornigaste generaliseringen i grundutbildningen.

${ }^{10}$ Alla språkvetare eller humanister kan dock inte dras över en kam. Logik faller t.ex. inom humaniora trots att många av dess frågor är begränsade till formella system. Utöver detta suddas gränser ut genom tvärvetenskapliga samarbeten. 
De huvudsakliga syftena med det formella och informella systemet är olika. Det som kan göras i det ena kan inte göras lika lätt i det andra. Båda systemen behövs, tills ett bättre alternativ presenterar sig. Möjligheten att kunna ställa en fråga utanför ett formellt system är således inte att ringakta. En uppenbar nackdel är förstås den något vaga och därför mindre effektiva kommunikationen som det tycks leda till, men mot denna nackdel går det att ge flera exempel på frågeställare vars arbete har lett till klarheter inom ineffektiva informella system. Låt här nämnas forskare som: Margaret Masterman, Thomas Kuhn, Virginia Woolf, Charles Fillmore, Noam Chomsky, John L. Austin, Elisabet Engdahl och Douglas Hofstadter. Flera av dessa är kända för arbeten inom formella system. Men möjligen är det ändå i första hand för deras prestationer inom det informella systemet som en del av oss är som mest tacksamma, och då inte bara vad gäller författarnas prestationer, utan även för de möjligheter som det informella systemet tillhandahåller.

\section{Litteratur}

Allan, Keith, 2003: Linguistic metatheory. I: Language sciences 25(6) S. 533-560.

Bird, Alexander, [vinter] 2018: Thomas Kuhn. I: E. N. Zalta (red.): The Stanford encyclopedia of philosophy. Metaphysics Research Lab, Stanford University. https:// plato.stanford.edu/archives/win2018/entries/thomas-kuhn.

Bloomfield, Leonard, 1933: Language. Chicago: The University of Chicago Press.

Carnie, Andrew, 2002: Syntax. A generative introduction. Oxford: Blackwell Publishing. Chomsky, Noam, 1957: Syntactic structures. Haag: Mouton.

Chomsky, Noam, 1965: Aspects of the theory of syntax. (Special technical report / Massachusetts institute of technology. Research laboratory of electronics 11.) Cambridge, Massachusetts: MIT press.

Chomsky, Noam, 1966: Cartesian linguistics. A chapter in the history of rationalist thought. New York: Harper \& Row.

Diderichsen, Paul, 1974: The foundation of comparative linguistics. Revolution or continuation? I: D. Hymes (red.): Studies in the history of linguistics. Traditions and paradigms. Bloomington/London: Indiana University Press. S. 277-306.

Feyerabend, Paul K., 1970: Consolations for the specialist. I: I. Lakatos \& A. Musgrave (red.): Criticism and the Growth of Knowledge. Cambridge: Cambridge University Press. S. 197-230.

Feyerabend, Paul K., 2010 [1975]: Against method. 4:e upplagan. London: Verso.

Greene, John C., 1974: The history of science and the history of linguistics. I: D. Hymes (red.): Studies in the history of linguistics. Traditions and paradigms. Bloomington/ London: Indiana University Press. S. 487-501.

Haapamäki, Saara, 2002: Studier i svensk grammatikhistoria. Åbo: Åbo akademi.

Hacking, Ian, 2012: Introductory essay. I: Thomas S. Kuhn: The structure of scientific revolutions. Chicago: University of Chicago press. S. vii-xxxvii.

Hansson, Sven Ove, 2017: Science and pseudo-science. I: E. N. Zalta (red.): The Stanford encyclopedia of philosophy. Metaphysics Research Lab, Stanford University. https://plato.stanford.edu/entries/pseudo-science/. 
Hovdhaugen, Even, Karlsson, Fred, Henriksen, Carol \& Sigurd, Bengt, 2000: The history of linguistics in the Nordic countries. Helsingfors: Societas Scientiarum Fennica.

Hymes, Dell, 1974: Introduction. Traditions and paradigms. I: D. Hymes (red.): Studies in the history of linguistics. Traditions and paradigms. Bloomington/London: Indiana University Press. S. 1-38.

Håkansson, David, 2017: Språkvetenskapen och teorierna. I: D. Håkansson \& A.-M. Karlsson (red.): Varför språkvetenskap? Kunskapsintressen, studieobjekt och drivkrafter. Lund: Studentlitteratur. S. 39-55.

Kiparsky, Paul, 1974: From paleogrammarians to neogrammarians. I: D. Hymes (red.): Studies in the history of linguistics. Traditions and paradigms. Bloomington/London: Indiana University Press. S. 277-306.

Koerner, E. F. K., 1972: Towards a historiography of linguistics. $19^{\text {th }}$ and $20^{\text {th }}$ century paradigms. I: Anthropological Linguistics 14(7). S. 255-280.

Koerner, E. F. K., 1976: The importance of linguistic historiography and the place of history in linguistic science. I: Foundations of language 14(4). S. 541-547.

Koerner, E. F. K., 1977: On the non-applicability of Kuhn's paradigms to the history of linguistics. I: J. Kegl, D. Nash \& A. Zaenen (red.): Proceedings of the seventh annual meeting of the north eastern linguistic society. Cambridge, Massachusetts: Department of Linguistics \& Philosophy, MIT. S. 165-174.

Koerner, E. F. K., 1978: Toward a historiography of linguistics. $19^{\text {th }}$ and $20^{\text {th }}$ century paradigms. (Amsterdam studies in the theory and history of linguistic science 3. Studies in the history of linguistics 19.) Amsterdam: John Benjamins.

Kuhn, Thomas S., 1962: The structure of scientific revolutions. (International encyclopedia of unified science 2:2.) Chicago: University of Chicago Press.

Kuhn, Thomas S., 1970a: The structure of scientific revolutions. 2:a omarbetade upplagan. (International encyclopedia of unified science 2:2.) Chicago: University of Chicago Press.

Kuhn, Thomas S., 1970b: Logic of discovery or psychology of research. I: I. Lakatos \& A. Musgrave (red.): Criticism and the Growth of Knowledge. Cambridge: Cambridge University Press. S. 1-23.

Kuhn, Thomas S., 1970c: Reflections on my critics. I: I. Lakatos \& A. Musgrave (red.): Criticism and the Growth of Knowledge. Cambridge: Cambridge University Press. S. 231-278.

Kuhn, Thomas S., 1974: Second thoughts on paradigms. I: F. Suppe (red.): The structure of scientific theories. Urbana: University of Illinois Press. S. 459-482.

Kuhn, Thomas S., 2000: The natural and the human sciences. I: J. Conant \& J. Haugeland (red.): The Road since Structure. Chicago: The University of Chicago Press. S. 216-223.

Lakatos, Imre, 1970: Falsification and the methodology of scientific research programmes. I: I. Lakatos \& A. Musgrave (red.): Criticism and the Growth of Knowledge. Cambridge: Cambridge University Press. S. 91-196.

Langacker, Ronald W., 1972: Fundamentals of linguistic analysis. New York: Harcourt Brace Jovanovich.

Masterman, Margaret, 1970: The nature of a paradigm. I: I. Lakatos \& A. Musgrave (red.): Criticism and the Growth of Knowledge. Cambridge: Cambridge University Press. S. 59-90.

Metcalf, George J., 1974: The Indo-European hypothesis in the sixteenth century linguistics. The discovery of Finno-Ugrian. I: D. Hymes (red.): Studies in the history 
of linguistics. Traditions and paradigms. Bloomington/London: Indiana University Press. S. 233-257.

Newmeyer, Frederick. J., 1996: Generative linguistics. A historical perspective. (Routledge history of linguistic thought series 2.) London: Routledge.

Percival, W. Keith, 1976: The applicability of Kuhn's paradigms to the history of linguistics. I: Language 52(2). S. 285-294.

Popper, Karl R., 1970: Normal science and its dangers. I: I. Lakatos \& A. Musgrave (red.): Criticism and the Growth of Knowledge. Cambridge: Cambridge University Press. S. 51-58.

Popper, Karl R., 1959 [1934]: The logic of scientific discovery. London: Hutchinson \& Co.

Randquist, Madeleine, 1984: Att tala nordistiskt. Några karakteristiska drag hos svensk nordistik och dess texter. I: Svenskans beskrivning 14. Lund: Lunds universitet. S. 205-213.

Seuren, Pieter A. M., 1998: Western linguistics. An historical introduction. Oxford: Blackwell.

Shapere, Dudley, 1966: Meaning and scientific change. I: R. Garland Colodny (red.): Mind and cosmos. Essays in contemporary science and philosophy. Pittsburgh: The University of Pittsburgh. S. 41-85.

Smith, P., 2011: Kuhnian incommensurability between two paradigms of contemporary linguistics. Sheffield: The University of Sheffield.

Stocking, Jr., George W., 1974: Some comments on history as a moral discipline. “Transcending 'Textbook' Chronicles and Apologetics". I: D. Hymes (red.): Studies in the history of linguistics. Traditions and paradigms. Bloomington/London: Indiana University Press. S. 511-519.

Thornton, Stephen, [hösten] 2018: Karl Popper. I: E. N. Zalta (red.): The Stanford encyclopedia of philosophy. Metaphysics Research Lab, Stanford University.

Toulmin, Stephen. E., 1970: Does the distinction between normal and revolutionary science hold water? I: I. Lakatos \& A. Musgrave (red.): Criticism and the Growth of Knowledge. Cambridge: Cambridge University Press. S. 39-48.

Uebel, Thomas, [våren] 2019: Vienna Circle. I: E. N. Zalta (red.): The Stanford encyclopedia of philosophy. Metaphysics Research Lab, Stanford University.

Verburg, Pieter A., 1974: Vicissitudes of paradigms. I: D. Hymes (red.): Studies in the history of linguistics. Traditions and paradigms. Bloomington/London: Indiana University Press. S. 191-230.

Watkins, John, 1970: Against 'Normal Science'. I: I. Lakatos \& A. Musgrave (red.): Criticism and the Growth of Knowledge. Cambridge: Cambridge University Press. S. 25-38.

Watkins, John. 1997: Karl Popper. A Memoir. I: The American Scholar 66(2). S. 205-219.

Williams, L. Pearce, 1970: Normal science, scientific revolutions, and the history of science. I: I. Lakatos \& A. Musgrave (red.): Criticism and the Growth of Knowledge. Cambridge: Cambridge University Press. S. 49-50.

Wolff, Kurt H. \& Thorne, Barry, 1974: Notes on the sociology of knowledge and linguistics. I: D. Hymes (red.): Studies in the history of linguistics. Traditions and paradigms. Bloomington/London: Indiana University Press. S. 502-510. 


\section{Smärre bidrag}

\section{Legend och legendar - reflektioner kring en lexikal konkurrens i svenskan}

Ingen som regelbundet läser svensk dagspress torde ha kunnat undgå att konstatera att användningen av ordet legendar under de senaste decennierna har ökat lavinartat i frekvens, inte minst inom sportjournalistiken, där ordet också har sitt ursprung, vilket inte daterar sig längre tillbaka i tiden än 1963 (Nyord 1986 s. 140). Det rör sig således om en lexikal innovation som på förhållandevis kort tid rönt formidabla framgångar, detta på bekostnad av ordet legend, som i sin utvidgade betydelse 'framstående person som är föremål för mytbildning' (SO bd 1 s. 1754, NEO bd 2 s. 274) inte heller tycks vara av gammalt datum i svenskan. Så finns denna betydelse inte upptagen i SAOB:s artikel om ordet från 1939 (bd 15 sp. 465) och den förekommer heller inte i fjärde bandet av Olof Östergrens Nusvensk ordbok från 1934 (1981 bd 2 sp. 1551-1552). Betydelsen i fråga är förmodligen resultatet av en konkretisering av den betydelse som ordet har i uttrycket levande legend. Detta uttryck har enligt Bo Bergman (2007 s. 195) "sin förebild i engelskans living legend från början av 1900-talet», då det användes av Lytten Strachey i hans Eminent Victorians (1918) och i svenskan skulle uttrycket levande legend enligt samme författare »vara känt åtminstone sedan 1980-talet». Användningen av det enkla ordet legend med personbetydelse - som Bergman överhuvudtaget inte nämner - skulle alltså kunna vara ett nyare fenomen i svenskan än till och med legendar.

I ett uttryck som levande legend är emellertid enligt min mening ordet legend inte ursprungligen personbetecknande i egentlig mening. Det rör sig snarare om ett slags personifiering av dess abstrakta betydelse 'sägen, myt'. Det är på detta sätt som ordet används i följande citat från del 2 av Selma Lagerlöfs Troll och människor (1921 s. 280), där Sankta Lucia inte bara personifierar »ljuset» och »hjärtevärmen», utan också så att säga »legenden» om sig själv. Det är följaktligen tveksamt att, i likhet med Ylva Byrman i radioprogrammet Språket den 18 mars 2014, anföra denna förekomst av ordet legend som ett bevis på att det så tidigt som 1921 kunde användas med personbetecknande betydelse:

Aldrig såg jag på den tiden en härligare syn, än när dörren upplåts och hon [Sankta Lucia] trädde in i kammarens mörker. Och jag ville väl önska, att hon aldrig måtte upphöra att visa sig på de värmländska gårdarna. Ty hon är ljuset, som betvingar mörkret, hon är legenden, som övervinner glömskan, hon är hjärtevärmen, som gör frusna nejder tilldragande och soliga mitt i vintern. (Mina kursiveringar; likaså i övriga exempel i artikeln.) 
Mot en sådan analys talar också det faktum att satsens predikativ inte som i normalfallet står i obestämd (Björn Borg är en legend inom tennisen) utan i bestämd form (legenden) och att dess subjekt inte namnger den historiska personen i fråga utan betecknar den tradition som hon givit upphov till specifikt i Sverige (»Luciafirandet»). Den analys som i uttrycket levande legend ser ordet legend som personifierande men inte personbetecknande har även stöd i det faktum att ordet legendarisk i SAOB (1939 bd 15 sp. 466) bland annat sägs kunna användas om en person »som blivit till en legend», dvs. en person som har kommit att identifieras med sin egen legend, samtidigt som man under uppslagsordet legend inte finner detta ord upptaget i dess strikt personbetecknande betydelse, utan endast i betydelserna 'helgonlegend' eller 'otrolig eller osannolik historia, berättelse'.

Om alltså ordet legend $\mathrm{i}$ uttrycket levande legend bevarar sin abstrakta betydelse, förefaller det rimligt att anta att bestämningen levande också den här skall uppfattas personifierande och tilldelas betydelsen 'i gestalt av människa' snarare än 'nu levande'. Levande legend är alltså beteckningen på en person som så intimt förknippas med den mytbildning som denna person är föremål för att personen identifieras med myten: 'en myt i mänsklig skepnad'. Men så tolkas knappast uttrycket i modern tid, då bestämningen helt klart har fått betydelsen 'nu levande', en betydelse som befäster huvudordet i dess konkreta betydelse 'mytomspunnen person'. Denna betydelse påverkades inte av om uttrycket då reducerades till sitt huvudord. Ett och samma ord kom på så sätt att beteckna såväl myten som dess mytiska huvudperson. I en senare utveckling har ordet frikopplats från mytbegreppet och kommit att användas för att beteckna en för en stor allmänhet känd person, en »kändis» eller berömdhet. Denna semantiska utvidgning är ett faktum i dag men var det förvisso inte på Selma Lagerlöfs tid.

Hur skall man då förklara dagens situation, där två ord - legend och legendar - konkurrerar med varandra i betydelsen 'berömd person'? Det rör sig till yttermera visso om en konkurrens där det enligt samstämmiga uppgifter (se t.ex. Strömberg 1998 och Oreström 2013) råder synonymi och i vilken det senare ordet är »nykomlingen» medan det förra, enligt Språkrådet (»Språklådan», april 2018), fortfarande är »vanligare i bruket» än sin konkurrent på grund av det mer begränsade användningsområdet hos ordet legendar, med dess, som nämnt, huvudsakliga hemvist inom sportjournalistiken.

En tänkbar förklaring till uppkomsten av ordet legendar står tveklöst att finna i den osäkerhetskänsla som fortfarande vidlåder ordet legend med avseende på möjligheten att låta det beteckna personer. Denna osäkerhetskänsla och tendensen att som en följd av den ta sin tillflykt till ordet legendar för att beteckna en berömd person belyses av följande citat:

En annan ständigt återkommande läsarfråga är skillnaden mellan legend och legendar. Många irriterar sig nämligen över att vi ibland omskriver somliga berömdheter som just legender. Jag har själv länge trott att en legend enbart är en mytisk berättelse och alltså inte kan vara en person. En person kring vilken det förekommer legender blir i stället en legendar. Dock visar ett studium av Nationalencyklopedin att en person visst kan vara en legend. En nyans av begreppet är nämligen, enligt NE: »om framstående person som är föremål för mytbildning: han är en levande legend». (Göteborgs-Postens »Läsardialog» 6.3.2006) 
Språkrådet tar i sin »Frågelåda» (april 2018) inte ställning till frågan om orsakerna till uppkomsten av ordet legendar, utan konstaterar endast ett det idag är »helt etablerat $\mathrm{i}$ svenskan» och att det i förhållande till legend, som sägs kunna vara »tvetydigt», erbjuder en »fördel» därför att »det klargör att det är en människa som avses». Denna »fördel» anges inte av Språkrådet explicit som en möjlig orsak till uppkomsten av ordet legendar men en sådan slutsats kan nog sägas ligga latent i det resonemang som förs. »Osäkerhet» eller »tvetydighet» såsom begränsande faktorer i bruket av ordet legend utgör dock inte ensamma ett tillräckligt kriterium när det gäller att förklara ordet legendar, detta beroende på de svårigheter som är förknippade med att fastställa en något så när exakt tidpunkt för den semantiska utvecklingen hos ordet legend från 'myt' och 'personifierad myt' till 'mytomspunnen person' och därifrån till 'berömd person' i allmänhet. Det går alltså inte att på grundval av enbart detta kriterium med någon säkerhet avgöra att ordet legend över huvud taget har med uppkomsten av ordet legendar att göra.

Kriteriet i fråga blir emellertid starkare när det kombineras med ett annat, nämligen det som kan formuleras utifrån följande antagande: Den regelbundenhet med vilken ordet legend i dagens svenska åtföljs av epitetet levande i detta senare ords omtolkade betydelse av 'nu levande', 'som lever nu' har hos språkbrukarna skapat uppfattningen att det enkla ordet legend endast kan referera till personer som inte är i livet vid tidpunkten för ordets användning i tal eller skrift. Det kan därför sägas ha uppstått en semantisk lucka som man genom att bilda ordet legendar har velat fylla i en situation där man upplevde att endast kollokationen levande legend fanns att tillgå för att beteckna en berömd person som är i livet. Betydelsen 'berömd person' har alltså delats upp på två ordformer beroende på om personen i fråga lever eller ej. Att denna uppdelning är en realitet i det aktuella språkbruket framgår av att man tycks dra sig för att tala om en person som levande legendar eftersom kombinationen av dessa ord ger intryck av pleonasm. Uppdelningens realitet framgår också av att ett epitet som blivande förefaller väl förenligt med huvudordet legendar för att karakterisera en ung person som senare i livet kan förmodas uppnå så stor berömmelse att vederbörande då kan omtalas, inte som en legend, men just som en legendar eller en levande legend. Följande citat belyser detta förhållande:

Från en legend till en blivande legendar. När Alicia Vikander fick ta emot en Oscar för bästa kvinnliga biroll var det första gången på 41 år som en svensk fick Hollywoods finaste pris för en skådespelarinsats. (Aftonbladet 29.2.2016)

Legenden i fråga är Ingrid Bergman, som 1974 belönades med en Oscar för sin biroll i filmen Orientexpressen. Ingrid Bergman avled 1982 och betecknas därför inte som en legendar. Omvänt gäller för Alicia Vikander att hon redan under sin livstid kan förväntas uppnå en så hög grad av berömmelse att hon gör sig förtjänt av epitetet legendar. Men frågan är om hon redan då kan komma att omtalas som en »legend inom svensk film»?

Obenägenheten att använda legend på bekostnad av legendar blir än tydligare om möjligheterna för den omtalade personen att senare i sitt liv uppnå status av legendar framställs som osäkra genom modaliserande uttryck som väl kanske (1) eller ett verb som tro (2): 
(1) Men Michel är väl kanske en blivande legendar (Språkbankens »Twittermix» i Korp 2008)

(2) Green som blivit min stora favorit och som jag tror kommer att växa till en legendar (Ibid.) [= 'som jag tror är en blivande legendar']

Det som sagts ovan betyder dock inte att ordet legendar skulle vara oförenligt med karakteristiken av en vid tiden för denna karakteristik avliden person. Förutsättningen för detta är att skribenten i sin karakteristik anlägger ett samtidsperspektiv snarare än efter eftertidsperspektiv. Både »Svarte Filip» Johansson (3) och Erik Lemming (4) är med detta senare perspektiv legender inom svensk idrott (fotboll respektive friidrott), men de var redan i sin samtid berömda i sina respektive idrotter, en berömmelse som med den moderna termen legendar väl fångar den hjältegloria som redan under deras livstid omgav dem. I exempel (4) möter vi till och med Erik Lemming redan i början av hans karriär, långt innan hans insatser hade gjort honom aktuell för att beskrivas som legendar. Man skulle kunna säga att skribenten här genom ordet blivande anlägger ett förtidsperspektiv medan perspektivförskjutningen i (3) ligger i kopulaverbets tempus: 'var en legendar' > 'är en legend':

(3) En annan legendar var »Svarte Filip» Johansson (Göteborgs-Posten 23.4.1994)

(4) År 1899 uppenbarade sig Erik Lemming (blivande legendar i Öis), som ensam försvarade kretsens anseende vid allmänna tävlingen i Eskilstuna. (Ibid. 26.12.2004)

Tillkomsten av den lexikala nybildningen legendar har således förvisso semantiska orsaker, men den har inte desto mindre underlättats av en rent språklig omständighet, nämligen existensen av adjektivet legendarisk, utifrån vilket ordet legendar uppenbarligen har bildats genom retrograd avledning med samtidig substantivering av suffixet -ari(us), som egentligen är adjektiviskt och som återfinns som sådant i de engelska (legendary), franska (légendaire) och tyska (legendär) ord som motsvarar svenskans legendarisk. Detta ord är belagt i svenskan endast sedan 1898 och intressant att konstatera är att adjektivet dessförinnan hade formen legendär (SAOB bd $15 \mathrm{sp} .465$ ), vilken i svenskan sedan länge är utkonkurrerad av formen legendarisk. Intressant är också att konstatera att utvecklingen i tyskan är den motsatta: adjektivet legendär har där under påverkan av franskans légendaire mer eller mindre slagit ut det äldre och idag ovanliga legendarisch (Etymologisches Wörterbuch des Deutschen 1993 s. 780).

Det som är speciellt för utvecklingen legendarisk > legendar i svenskan med avseende på »retrograderingens» (Johannisson 1964 s. 15) art är att denna så att säga endast är partiell: I ordet legendarisk identifieras två suffix, det latinska -ari(us), men också det inhemska -isk (tyskans -isch), som i svenskan (liksom -isch i tyskan) normalt ersätter det grekiska $-i k$ i adjektiv, detta eftersom i svenskan -ik blivit ett substantiviskt suffix (politik, musik osv.). »Retrograderingen» påverkar emellertid endast isk-suffixet och kvar blir det ofullständiga ari-suffixet i form av -ar, vilket alltså tolkas som ett substantiviskt suffix. Vi får således i svenskan två former, det enkla legend och det avledda legendar, som konkurrerar om det betydelseinnehåll som i t.ex. engelska ryms i det enda ordet legend. 
Det är ofrånkomligt att en lexikal konkurrens som den mellan legend och legendar ger upphov till allmänhetens kommentarer och omdömen, i form av t.ex. diskussionsinlägg $\mathrm{i}$ sociala medier på internet, insändare $\mathrm{i}$ dagspressen eller frågor i tidningarnas språkspalter. I fallet legend vs legendar har reaktionerna varit osedvanligt många och övervägande negativt hållna. Man ifrågasätter framför allt behovet av »nykomlingen» legendar vid sidan av det etablerade och som en synonym betraktade legend, och man lägger skulden för denna »onödiga» innovation på sportjournalistiken. Man hänvisar också till andra språk som »klarar sig» utan den svenska distinktionen. Följande citat är representativt för hur det låter i många debattinlägg:

Det sistnämnda ordet legendar är tänkvärt nog inte lånat från andra språk utan fritt uppfunnet av sportjournalister. Tyskan har Legende, engelskan har legend, franskan har legend men de talar inte om legendarer. Det gör bara svenskar med överhettat sportintresse. (Göteborgs-Posten 29.8.2012)

Men frågan är om man trots allt inte ska betrakta ordet legendar som en lexikal tillgång för svenskan. Det tillåter detta språk att i ett enda ord uttrycka det som i engelskan kräver två ord, living legend. Svenskans fördel i förhållande till franskan och tyskan är till och med ännu större. Det stämmer nämligen inte att, som det sägs i citatet, franskan skulle ha ett personbetecknande ord *legend (vilket i så fall skulle ha varit *légend). Detta språk har helt enkelt inte någon direkt motsvarighet varken till legendar eller till legend (om person), utan endast det abstrakta légende med betydelsen 'myt, sägen'. Franskan måste därför ta sin tillflykt till adjektivet légendaire som bestämning till ett substantiv för att kunna tala om legendarer och legender. Tyskan har inte heller någon direkt motsvarighet $\left({ }^{*}\right.$ Legend) till svenskans legendar och legend, men kan, till skillnad från franskan, använda det abstrakta Legende personifierande, speciellt i kombination med adjektivet lebend: »In Hollywood zählt Marlon Brando [1978] zu den lebenden Legenden der Filmwelt. » (Duden 1999 bd 5 s. 2386)

Det förhållandevis nyskapade ordet legendar försvarar därmed, enligt min mening, sin närvaro i det svenska språkets lexikon. En helt annan sak är att det lätt kan gå inflation i ordet, om det rentav inte redan har gjort det: »Häromdagen gick denne legendarernas legendar runt på 65 slag.» (Svenska Dagbladet 6.2.1995)

\section{Litteratur}

Bergman, Bo, 2007: Ordens ursprung. Stockholm: Wahlström \& Widstrand.

Duden. Das große Wörterbuch der deutschen Sprache, Band 5. Mannheim-LeipzigWien-Zürich: Dudenverlag 1999.

Etymologisches Wörterbuch des Deutschen. 2. Auflage. Berlin: Akademie Verlag 1993 [1989].

Johannisson, Ture, 1964: Tendenser i nutida svensk ordbildning. I: Nutidssvenska. Uppsatser i grammatik. Stockholm-Göteborg-Uppsala: Almqvist \& Wiksell. S. $7-$ 22.

$\mathrm{NEO}=$ Nationalencyklopedins ordbok, andra bandet. Höganäs: Bokförlaget Bra Böcker 1996. 
Nyord i svenskan från 40-tal till 80-tal. Stockholm: Esselte Studium 1986.

Oreström, Bengt, 2013: Svenska ordboken. 6:e uppl. Lund: Studentlitteratur.

$\mathrm{SAOB}=$ Ordbok över svenska språket utgiven av Svenska Akademien, femtonde bandet. Lund: P.H. Lindstedts Univ.-Bokhandel 1939.

$\mathrm{SO}=$ Svensk ordbok, första bandet. Stockholm: Norstedts 2009.

Strömberg, Alva, 1998: Stora synonymordboken. 2:a uppl. Stockholm: Strömbergs.

Östergren, Olof, 1981 [1934]: Nusvensk ordbok. Andra bandet. Stockholm: Wahlström \& Widstrand. 


\section{Recensioner}

Fremer, Maria: Tilltal i reklamfilm. Du-reformen i ett historiskt perspektiv. (Nordica Helsingiensia 55.) Diss. 264 s. Helsingfors universitet 2018. ISSN 1795-4428, ISBN 978-951-4628-1.

Maria Fremers avhandling behandlar den så kallade du-reformen i Sverige, alltså den förändring av tilltalsskicket som skedde från 1950-talet och framåt. Denna beskrivs ofta ha skett snabbt, men som visas i avhandlingen är det en bild som behöver nyanseras. Det gäller då både tidsperspektivet (processen var utsträckt över flera decennier) och situationen före förändringen beträffande bruket av $d u / n i /$ titulering. I avhandlingen visas också att användningen av $d u$ som diskursmarkör ökar i samband med du-reformen.

I ett kort inledande kapitel ges en introduktion till ämnet och den övergripande samhälleliga kontexten skissas också, varefter syftet beskrivs. Detta är att »bidra till förståelsen av du-reformen genom en sociolingvistisk studie av tilltalsformer i bruk» (s. 18), något som motiveras av att en »detaljerad uppföljning av hur språkbruket ser ut kring den brytningstid som utgörs av du-reformen saknas» (s. 18). Närmare bestämt är det tre övergripande frågor som Maria Fremer vill besvara:

1. Stämmer det att det nästan alltid var olämpligt att tilltala obekanta personer med $n i$ eller $d u$ ?

2. Skedde förändringen faktiskt nästan över en natt, eller var den i själva verket långsammare? När och var började den och hur spred den sig? När var den helt genomförd?

3. Vilka var de omständigheter som ledde till att en sådan omvälvning kunde ske? (S. 18)

Materialet för undersökningen är reklamfilmer producerade i Sverige. Det är därmed »det sverigesvenska offentliga språket och den urbana medelklassens språk» (s. 18-19) som belyses.

Kapitel 2 ger en teoretisk inramning. Sociolingvistikens framväxt och utveckling beskrivs kort och därefter ges en översikt över internationella studier av tilltal. I två delkapitel görs sedan begreppsutredningar rörande mer detaljerade frågor anknutna till just avhandlingens material: dels tittartilltal, dels fristående $d u$. I det därpå följande kapitlet redovisas forskning om svenskt tilltal, både diakront och synkront. Slutsatserna är att vi vet mer om bruket i skrift än i tal och att själva övergångsprocessen är mindre välstuderad. Dessutom förefaller tilltal med $d u$ före du-reformen åtminstone i skrift förekomma i situationer där man enligt gängse beskrivningar hade förväntat sig titulering. Tilltal med $n i$ är heller inte helt ovanligt, trots att detta ofta beskrivits som ohövligt. Titeltilltal var »i allmänhet att föredra» (s. 39) till personer utanför den närmaste umgängeskretsen, 
men var också komplicerat och inte sällan omständligt och krångligt. Fjärde kapitlet beskriver materialet, vilket delas upp kortare och längre filmer, och en översiktlig beskrivning av innehållet i dessa båda typer av filmer ges. Därefter redogörs för en del metodiska frågor, speciellt vissa gränsdragningar som behöver göras vid excerperingen av relevanta belägg.

De därpå följande sex kapitlen utgör avhandlingens empiriska del. I kapitel 5 redovisas en kvantitativ undersökning av bruket av $d u / n i$ som tittartilltal. Det framkommer bl.a. att både $d u$ och $n i$ har kunnat användas ända sedan 1920-talet, vilket visar att den bild av situationen före du-reformen som ofta ges bör modifieras. Särskilt intressant i förhållande till tidigare forskning är att det här är ett muntligt material som undersöks, och en jämförelse med tryckta reklamannonser indikerar en tydlig skillnad mellan utvecklingen i tal och skrift. Likaså visar det sig att du-reformen pågår över längre tid, från andra hälften av 50-talet till första hälften av 70-talet. De undersökta längre husmorsfilmerna har också en mer konservativ hållning och ni förekommer i dessa så sent som 1973, vilket kan ses i ljuset av en (inom urban medelklass) traditionell kvinnoroll med krav på formell artighet och belevenhet.

Det visar sig alltså att $d u$ tidigt används trots att det enligt vanlig uppfattning skulle anses höra hemma i familjära sammanhang under denna period. Likaså förekommer $n i$, fastän detta tilltal har beskrivits som ohövligt. Hur kan detta komma sig, och i vilka sammanhang uppträdde $d u$ respektive $n i$ ? I kapitel 6, där $d u$ till tittaren studeras, och 7, som ägnas åt $n i$, belyses detta genom ett kvalitativt studium av belägg på de skilda tilltalen. Enkelt uttryckt kan sägas att $d u$ före du-reformen förefaller vara kopplat till känslomässig argumentation, medan $n i$ snarare hänger samman med förnuftsargument. De negativa attityderna till $n i$ tycks inte vara generella, utan snarast kopplade till situationer där mottagaren förväntat sig titulering. Efter du-reformen används $d u$ även i neutrala och sakliga sammanhang, men utvecklingen går långsammare i husmorsfilmerna. För ni:s del uppstår en möjlighet att använda detta parodiskt eller som markör för gammalmodighet efter du-reformen. Den allmänna samhällsutvecklingen mot informalisering och intimisering framkommer också tydligt i de analyserade exemplen.

Det för våra dagar främmande titulerandet är ovanligt som tittartilltal, vilket är naturligt eftersom titeltilltal alltid är exkluderande medan tittartilltalet bör vara generellt. Några få exempel finns emellertid och dessa studeras i kapitel 8. Huvuddelen av det kapitlet ägnas dock åt dialogtilltal mellan olika rollfigurer i filmerna. Konklusionen av genomgången är att titulerandet framstår som markerat och i viss mån besvärligt, och resultaten styrker alltså bilden av titelbruket som i flera avseenden problematiskt.

Kapitel 9 redovisar en lite separat undersökning av bruket av $d u$ som diskursmarkör. En kvantitativ studie visar att detta i reklamfilmerna blivit markant vanligare från mitten av 60-talet, vilket antagligen avspeglar dels att $d u$ kommit att bli mer allmänt använt, dels en informalisering av reklamfilmsgenren i linje med den allmänna samhällstrenden under perioden. Med en interaktionell infallsvinkel studeras sedan olika exempel på diskursmarkören $d u$ och vilka funktioner denna har i samtalsanalytiskt perspektiv. Ytterligare en något separat undersökning redogörs för i kapitel 10, där ett mindre material reklamfilmer från perioden 1980-2013 studeras. Resultaten tyder - föga oväntat - på att $n i$ och titeltilltal blivit ovanligt och mycket markerat, samt att $d u$ som diskursmarkör fortsatt att öka i frekvens. 
Kapitel 11 sätter in resultaten i en större samhällelig kontext och relaterar dem även till de mer generella språkförändringar som skedde under den aktuella perioden. I ett avslutande 12 kapitel sammanfattas arbetet och vissa förslag till fördjupning och vidare forskning ges också.

Som framgår är det en mångsidig bild som ges av de studerade filmerna, vilket naturligtvis på många sätt är positivt. Dock kan man fundera på om avhandlingen inte hade vunnit på att stramas upp lite. Undersökningen av materialet från perioden 1980-2013 kan ju inte säga mycket om du-reformen som då låg rätt långt bakåt $i$ tiden. Och det som framkommer är som berörts tämligen förväntat: att använda $n i$ eller titulering på 2000-talet hade ju varit högst påfallande.

Likaså kan man fundera över den i kapitel 9 redovisade undersökningen av $d u$ som diskursmarkör. Den är tveklöst intressant och mycket väl genomförd. Men den bildar ändå något av ett sidospår i avhandlingen - på vilket vis bidrar den till att besvara de frågor som ställs i kapitel 1 ?

Avhandlingen hade också vunnit på en mer ingående diskussion av hur de studerade reklamfilmerna förhåller sig till naturligt förekommande interaktion och vilka slutsatser om den allmänna språkutvecklingen de därigenom tillåter. Författaren framhåller själv att »materialet till stora delar är fiktivt, regisserat och redigerat» (s. 52). Detta förhållande hade kunnat dryftas utförligare. Situationen är ju komplex: i vissa fall är det helt uppenbart tittaren som tilltalas, och i andra är det lika klart att det rör sig om en dialog mellan rollfigurer i filmen. Men det finns också exempel på hur personer i filmerna tilltalas av en anonym speakerröst och i andra fall kan rollrelationerna vara mer otydliga med t.ex. olika former av inre monolog. Till det kommer att det finns rikliga inslag av sådant som sånger, reklamfraser och verser med rytm- och rimkrav som kan påverka valet av tilltalsord.

Frågan om vad filmerna kan säga om tilltalsskicket gäller också deras relation till dimensionen skriftligt och muntligt. Uppenbarligen har det funnits skillnader rörande attityden till niande i tal och skrift. I språkhandledningar från den aktuella perioden (t.ex. Erik Wellanders Riktig svenska) framhålls att $n i$ kan användas som singulart tilltal i skriftliga sammanhang. Talet i filmerna är förstås förberett och planerat, inte sällan med skriftlig förlaga. Ofta är säkert ambitionen att ge ett intryck av naturligt och ledigt talspråk, men det finns också sådant som tydligt har drag av uppläsningsspråk. Ett klart exempel är utdrag 43 Wettergren - Eves vårkappor från 1933 (s. 131-132) där bl.a. plurala verbformer används. Dessa verbformer var ju helt främmande för talspråket och delvis också stigmatiserade som stel och onaturlig »boksvenska». Man kan därför fråga sig i vad mån det är talspråkets eller skriftspråkets tilltalsskick som blir belyst här. Samtidigt bör det framhållas att det finns goda skäl att anta att materialet i huvudsak avspeglar muntliga förhållanden. Som berörts ovan visar en jämförelse med tryckta annonser på en tydlig skillnad mellan filmerna och det tryckta materialet, vilket ju indikerar att det inte är skriftspråksbruket vi främst möter i reklamfilmerna. Men frågan om muntlighet och skriftlighet hade förtjänat att utredas närmare.

Dessutom är det ju så att valet av tilltal kan vara en del av en medveten strävan efter att skapa ett visst intryck. I utdrag 14 (s. 104), Wettergrens sportkläder - Jawes kläder (1933), används $d u$ genomgående, vilket uppenbarligen är ett led i ambitionen att framställa kläderna som moderna, sportiga och ungdomliga. Detta handlar alltså snarast om vilken stilprägel reklamfilmen har och vilken effekt man är ute efter. En lite utförligare 
diskussion av materialets representativitet hade därför även hjälpt till att klargöra i vad mån ett av syftena med avhandlingen också är att beskriva den svenska reklamfilmens historia i sin samhälleliga kontext (vilket självfallet är ett högst intressant ämne); nu känns det som att det ges en hel del av sådant utan att det riktigt framhålls i syftesbeskrivningen.

Vad gäller materialet måste slutligen sägas att de kvantitativa resultat som presenteras i kapitel 5 inte sällan bygger på relativt fă belägg. Att räkna procent på små siffror är alltid något av ett vågspel. Men tack vare en välvald beräkningsmodell med glidande medelvärden lyckas Maria Fremer ändå få fram tydliga och övertygande resultat. Man kan faktiskt säga att hennes undersökning är ett bra exempel på hur kvantitativa metoder kan göra det möjligt att se tendenser som inte är helt lätta att urskilja med blotta ögat. Det är elegant gjort!

Som redan berörts avkastar undersökningen en rad intressanta resultat, och Maria Fremer resonerar nyanserat och klokt om det som framkommit. Tack vare denna avhandling har vi fătt en väsentligt fördjupad bild av en av de största omvandlingarna inom svenskan under 1900-talet. Det är signifikativt, och visar också på ämnets samhällsrelevans, att de pensionerade affärsbiträden som Tykesson-Bergman (2006) intervjuat anger just du-reformen som »den mest genomgripande förändring de varit med om under sin yrkesverksamma tid» (s. 196).

Ämnet öppnar också upp för större perspektiv på språkliga aspekter av den radikala förvandling som Sverige genomgick från andra hälften av 1800-talet. I väsentliga delar kan denna sägas innebära att språket hos de nya grupper som tog steget ut på den offentliga arenan (t.ex. tack vare den allt starkare arbetarrörelsen) var det som kom att bli mönster för det mer formella språket. Det var ju inte det som Adolf Noreen (1903 s. 28 f.) benämner mellanstil, det bildade samtalsspråket som användes $i$ »finare» privat umgänge, som blev norm, utan Chronschougharnas - av de bildade illa sedda - boksvenska som vann mark.

För det är ju tydligt att $n i$ inte av alla sågs som omöjligt att använda. I så fall hade det ju inte kunnat användas i reklamfilmer på det som det gjordes. Det fanns uppenbarligen grupper som accepterade att nias och sådana som fann detta förolämpande. Att de förra i större utsträckning utgjordes av de mer välsituerade grupper som inte riskerade att bli niade asymmetriskt och nedlåtande är knappast ägnat att förvåna. Det är likaså klart att de som förespråkade $n i$ gjorde anspråk på att stå för den goda smaken: »Vad som står hindrande i vägen för ett sådant språkbruk [ni som artigt tilltal] är uteslutande missförstånd och fördomar [...] den [uppfattningen att $n i$ skulle vara oartigt] saknar numera varje stöd i förebildligt språkbruk» hävdade t.ex. Erik Wellander (1939 s. 225) och redan 1886 skrev Nils Linder (s. 116): »Åtminstone så långt är det nu kommet, att ingen verkligt bildad man eller qvinna känner sig förnärmad öfver att, af bekanta eller obekanta, tilltalas med $N i, I$ eller $D e$. » Men det var inte alltså inte företrädarna för denna hållning som genom du-reformen drog det längsta strået; i stället fick de anpassa sig till språkbruket hos åtminstone delar av arbetarrörelsen.

Som framgått innehåller Maria Fremers avhandling många tankeväckande resultat om tilltalsskickets förändring och den samhälleliga inramningen av denna utveckling. Det bör också framhållas att avhandlingen är påfallande välskriven. Texten flyter fint och det är lätt att följa med resonemangen. Detta är så mycket mer välkommet som avhandlingen behandlar något som alla som använder svenskan har en relation till: det 
är nog få som aldrig har behövt fundera över tilltalsfrågor vid ett eller annat tillfälle. I avhandlingens slutackord framhåller Maria Fremer att hon gjort sin undersökning "med den bredare allmänheten i åtanke» (s. 221) och framför förhoppningen att avhandlingen ska vara av intresse också för den publiken. Jag är övertygad om att så är fallet.

\section{Litteratur}

Linder, Nils, 1886: Regler och råd angående svenska språkets behandling i tal och skrift. Stockholm: P. A. Norstedt \& Söners förlag.

Noreen, Adolf, 1903: Vårt språk. Nysvensk grammatik i utförlig framställning. Första bandet. Lund: C.W.K. Gleerups Förlag.

Tykesson-Bergman, Ingela, 2006: Samtal i butik. Språklig interaktion mellan biträden och kunder. (Stockholm studies in Scandinavian philology 41.) Stockholm: Stockholms universitet.

Wellander, Erik, 1939: Riktigt svenska. En handledning i svenska språkets vård. Stockholm: Svenska Bokförlaget P.A. Norstedt \& Söner.

Björn Melander

Loenheim, Lisa: Att tolka det sammansatta. Befästning och mönster i förstaoch andraspråkstalares tolkning av sammansättningar. (Meijerbergs arkiv för svensk ordforskning 43.) Diss. 274 s. Göteborgs universitet 2019. ISSN 0348-7741, ISBN 978-91-87850-02-8.

Lisa Loenheim undersöker i sin avhandling hur första- och andraspråkstalare av svenska tolkar sammansatta ord, närmare bestämt nominala och adjektiviska sammansättningar. Avhandlingen baseras på en enkätstudie men tar sin utgångspunkt i en teoretisk diskussion inom ramen för bruksbaserad kognitiv lingvistik (t.ex. Langacker 2008, Bybee 2010). Den tar även upp ett lexikalt-semantiskt perspektiv samt flerspråkighets- och språkinlärningsaspekter. De centrala frågorna utifrån det bruksbaserade perspektivet kretsar kring förhållandet mellan lexikala enheter och schematiska mönster när det gäller tolkningen av sammansatta ord: Sammansättningar kan å ena sidan inläras, lagras, processas och tolkas som helheter, dvs. på samma sätt som icke-sammansatta ord; å andra sidan kan schematiska enheter påverka hur talarna tolkar sammansättningar. Det är ett vanligt antagande inom kognitiv lingvistik att den viktigaste faktorn i detta sammanhang är ordens frekvens: Frekventa element, dvs. element som förekommer ofta i talarnas språkliga input, lagras som helheter i det mentala lexikonet, medan sällsyntare element processas genom schematiska mönster och generella kognitiva principer. Därmed spelar även faktorn exponeringstid en roll: Ju längre tid en talare har utsatts för språklig input, desto högre blir graden av befästning av frekventa element. Eftersom det är exponeringstiden som främst skiljer L1- från L2-talare är termen främst känd från andraspråksforskningen. Loenheims fokus på skillnaden mellan dessa två grupper är 
dock inte bara aktuell med tanke på andraspråksperspektivet men också relevant ur ett mer generellt kognitivt perspektiv.

Avhandlingen omfattar nio kapitel som följs av en sammanfattning på engelska. De första tre kapitlen innehåller den inledande diskussionen. Kapitel 1 presenterar avhandlingens upplägg och syfte samt ger en översikt över avhandlingens struktur. Kapitel 2 sammanfattar tidigare forskning om sammansättningar på svenska och andra språk. Diskussionen tar upp de semantiska relationerna mellan sammansättningarnas led (som t.ex. JÄMFÖRELSE eller SYFTE) som har undersökts inom ramen för olika s.k. relationstypologier. Fokus ligger dock på empirisk forskning kring hur sammansatta ord tolkas. Den visar att det är rimligt att urskilja vissa tolkningsstrategier snarare än en statisk uppsättning semantiska relationer, framför allt med hänsyn till tolkningen av okända sammansättningar. Två strategier framstår som särskilt relevanta: »egenskapsprojicering» och »relationslänkning». Tolkas t.ex. ordet apörn som 'örn som på något sätt liknar en apa' (egenskapsprojicering) eller som 'örn som har en tematisk relation till (t.ex. jagar) apor' (relationslänkning)? Dessa två konkurrerande strategier är även viktiga element i den empiriska undersökningen eftersom informanterna kan förväntas använda dem i sina försök att tolka experimentella, nybildade sammansättningar. En annan central fråga är hur talare identifierar sammansättningars semantiska huvudled: Är en apörn en örn eller en apa? Medan det för svenskans del anses vara klart att det finns en prefererad sammansättningsstruktur där huvudledet placeras till höger och modifierande element till vänster, saknas det större empiriska undersökningar om huruvida denna preferens påverkar själva tolkingsprocessen. Loenheim refererar dock studier som visar att olika preferenser i talares L1 och L2 kan påverka hur sammansatta ord tolkas i de respektive språken. Detta kan också ligga bakom en del av de problem som L2-talare har med segmenteringen av svenska sammansättningar, enligt tidigare studier som Loenheim avslutningsvis diskuterar.

I kapitel 3 presenteras det teoretiska ramverket för den empiriska undersökningen, som utgörs av centrala begrepp, dels från bruksbaserad kognitiv lingvistik, där avhandlingen är starkast förankrad, dels från lexikal semantik. Loenheim behandlar de viktigaste begreppen inom bruksbaserad lingvistik som är relevanta för hennes undersökning, med särskilt fokus på förhållandet mellan lexikala och schematiska enheter. I bruksbaserad lingvistik framstår språkförmågan som en integrerad del av människans generella kognitiva förmågor, vilket bl.a. innebär att icke-språkspecifika faktorer som frekvens och saliens spelar en avgörande roll för hur enheter i individens språkliga input kategoriseras och representeras mentalt. Detta är inte begränsat till fyllda enheter (t.ex. ordet zebrafisk) utan gäller även schematiska enheter (t.ex. abstrakta sammansättningsmönster på olika schematiska nivåer som $[\mathrm{NN}],\left[\mathrm{N}_{\mathrm{djur}} \mathrm{A}-\mathrm{N}_{\mathrm{djur}}\right.$ в] eller [zebra-N]). Schemabegreppet är centralt inom kognitiv grammatik och relaterade ramverk som konstruktionsgrammatik, där scheman ibland beskrivs i form av »exemplar» (t.ex. Bybee 2013), dvs. abstraktioner över enskilda förekomster av språkliga enheter i input. Medan exemplarbegreppet åsyftar den kognitiva sidan, är konventionaliseringen av lexikala eller schematiska enheter ett resultat av sociala mekanismer i språkgemenskapen (jfr Schmids (2015) »Entrenchment-and-Conventionalization Model»). Att ett ord är lexikaliserat (dvs. konventionaliserat) innebär alltså inte automatiskt att det uppvisar en hög grad av kognitiv befästning hos individuella 
talare. Diskussionen av relevanta perspektiv från den lexikala semantiken fokuserar på termerna kompositionalitet, genomskinlighet och meningspotential (som hos Svanlund 2009 och Allwood 2003), och dessa termer kopplas även till (delvis) motsvarande kognitiva begrepp. Medan sammansättningar kan vara genomskinliga i den meningen att de är analyserbara enligt kända språkliga mönster, är detta inte detsamma som kompositionalitet i betydelsen förutsägbarhet. I en sammansättnings meningspotential ingår däremot även kontextens betydelse för hur ordet tolkas, beroende på talarnas samlade språkliga erfarenheter. Detta är särskilt relevant vad gäller skillnaden mellan L1- och L2-talares tolkning av sammansatta ord eftersom meningspotentialerna kan vara olika för båda grupperna.

I kapitel 4-6 presenteras själva den empiriska undersökningen. I kapitel 4 redovisas metoden och materialet för enkätstudien. Här ingår även diskussionen av hypoteserna och de undersökta strukturerna samt presentationen av informanterna. Informantgruppen består av 190 ungdomar som studerar på olika studieförberedande gymnasieprogram (på sex svenska gymnasieskolor under 2015), därav 124 som har svenska som förstaspråk och 66 med svenska som andraspråk. Det är påfallande konsekvent, ur ett bruksbaserat perspektiv, att Loenheim inte bara skiljer mellan L1- och L2-talare (för det mesta baserat på självrapportering), utan indelar grupperna ytterligare i undergrupper utifrån kategorierna YTTERLIGARE L1 och EXPONERINGSTID (via variabeln STARTÅLDER). Det är sannolikt att informanterna i de olika undergrupperna inte har haft samma mängd svenskspråkig input, vilket har implikationer bl.a. för hur de hanterar frekventa sammansättningar kognitivt. I själva enkäten anger informanterna hur de tolkar presenterade sammansättningar (inom mer eller mindre kontextualiserande exempelmeningar). Enkäten består av två delar, en flervalsdel, där informanterna väljer mellan olika svarsalternativ, och en fritextdel, där de själva förklarar sin tolkning. På ett övergripande plan syftar hypoteserna på sammansättningarnas struktur och semantik utifrån ett kognitivt perspektiv. De kan sammanfattas enligt följande:

a. Huvudledets placering till höger är starkt etablerad i nominala sammansättningar; informanterna identifierar det sista ledet som huvudledet.

b. I adjektiviska sammansättningar är denna preferens mindre etablerad.

c. Frekventa sammansättningar har en starkt konventionaliserad betydelse och tolkas mer samstämmigt än mindre frekventa och tillfälliga bildningar.

Ytterligare hypoteser avser skillnader mellan L1- och L2-talarna som relateras till variabeln exponeringstid, t.ex. hypotesen att L1-talarnas tolkningar av nominala sammansättningar i högre grad än L2-talarnas speglar den vanliga strukturen med huvudledet till höger eftersom schemat inte har uppnått samma grad av kognitiv befästning hos L2talarna. Av samma anledning ställer Loenheim t.ex. upp hypotesen att samstämmigheten i L1-talarnas tolkningar vid etablerade och frekventa sammansättningar är högre än i L2-talarnas.

De undersökta strukturerna omfattar olika typer av nominala och adjektiviska sammansättningar som har testats på dels frekventa, dels mindre frekventa eller tillfälliga sammansättningar (se tablå 1). Undersökningarna går ut på att identifiera vilka tolkningsmönster informanterna prefererar. Detta gäller bl.a. huvudledets placering och föroch efterledets semantiska relationer, däribland kontrasten mellan jämförande egenskapsprojicering och tematisk relationslänkning. 
Tablå 1. Undersökta strukturer i urval.

\begin{tabular}{|c|c|c|c|}
\hline & struktur & mönster & exempel \\
\hline \multirow{3}{*}{. } & huvudledets placering & {$\left[\mathrm{NN}_{\text {huvud }}\right]$ vs $\left[\mathrm{N}_{\text {huvud }} \mathrm{N}\right]$} & spelkort, vagnbarn \\
\hline & $\begin{array}{l}\text { jämförande egenskapsprojicering } \\
\text { vs tematisk relationslänkning }\end{array}$ & {$\left[\mathrm{N}_{\text {egenskap }} \mathrm{N}\right]$ vs $\left[\mathrm{N}_{\text {tematisk roll }} \mathrm{N}\right]$} & $\begin{array}{l}\text { apörn, skräpkruka, } \\
\text { kvinnopräst, } \\
\text { mansläkare }\end{array}$ \\
\hline & $\begin{array}{l}\text { AGENT VS PATIENT vid verbavled- } \\
\text { ning }\end{array}$ & {$\left[\mathrm{N}_{\mathrm{AGENT}} \mathrm{N}\right] \mathrm{vs}\left[\mathrm{N}_{\mathrm{PATIENT}} \mathrm{N}\right]$} & $\begin{array}{l}\text { polismisshandel, } \\
\text { studentförakt }\end{array}$ \\
\hline 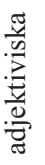 & $\begin{array}{l}\text { huvudledets placering } \\
\text { egenskap vs orsak }\end{array}$ & $\begin{array}{l}{\left[\mathrm{AA}_{\text {huvud }}\right] \text { vs }\left[\mathrm{A}_{\text {huvud }} \mathrm{A}\right] \text { vs }[\mathrm{AA}]} \\
{\left[\mathrm{N}_{\text {egenskap }} \mathrm{A}\right] \text { vs }\left[\mathrm{N}_{\text {orsak }} \mathrm{A}\right]}\end{array}$ & $\begin{array}{l}\text { blågul, sötsur } \\
\text { iskall, kryddstark }\end{array}$ \\
\hline
\end{tabular}

Resultaten från enkätens flervalsdel utreds i kapitel $5 \mathrm{i}$ form av detaljerade kvantitativa analyser som typiskt innehåller mycket noggranna deskriptiva analyser av tolkningspreferenserna och variationen i tolkningsmönstren samt statistiska analyser som påvisar vilka signifikanta skillnader som finns mellan de olika informantgrupperna. I kapitel 6 diskuteras resultaten från enkätens fritextdel i form av en detaljerad kvalitativ analys som även påvisar vissa kvantitativa tendenser.

I kapitel 7 och 8 sammanfattas och diskuteras analyserna. Loenheim påpekar att resultaten i stort sett bekräftar hypoteserna men också ger anledning till att (ur en kognitiv synvinkel) modifiera vissa antaganden om svenska sammansättningars struktur. Eftersom det är omöjligt att här gå in på detaljerna nämner jag istället vad som kan uppfattas som övergripande tendenser. I [NN]-sammansättningar tolkar informanterna vanligtvis efterledet som huvudled. Detta tyder på att schemat som placerar huvudledet till höger är starkt etablerat. I mindre frekventa (dvs. mindre befästa) sammansättningar förekommer dock även avvikande tolkningar med förledet som huvudled. Det schematiska mönstret förefaller alltså mindre befäst än de enskilda sammansättningarna. Däremot hanteras [AA]-sammansättningarna inte på samma sätt som de nominala bildningarna. När informanterna tolkar tillfälligt bildade adjektiviska sammansättningar determinativt (dvs. när de identifierar ett semantiskt huvudled), prefererar informanterna istället snarare tolkningar med huvudledet till vänster. Vad gäller den semantiska relationen mellan för- och efterled väljer informanterna jämförande egenskapsprojicering framför relationslänkning i sina tolkningar. Detta kan primärt förklaras genom etablerade mönster på en delvis schematisk nivå (t.ex. [DJUR-N] som betecknar något som har vissa likheter med det nämnda djuret snarare än någon tematisk relation). På ett generellt plan kan man konstatera att långt ifrån alla informanter tolkar sammansatta ord på samma sätt eller enligt samma scheman. Ändå visar resultaten att L1-talarna är mer samstämmiga och konventionella i sina tolkningar än L2-talarna, både när det gäller etablerade och frekventa sammansättningar och när det gäller sammansättningsmönster på olika schematiska nivåer som t.ex. [ $\mathrm{NN}_{\text {huvud }}$, $\left[\mathrm{N}_{\text {PATIENT }} \mathrm{N}\right]$ eller [zebra-N]. L2-talarnas avvikande tolkningar kan förklaras dels genom att det kan finnas divergerande mönster i deras respektive L1 som aktiveras under tolkningsprocessen, dels genom att de har haft mindre svenskspråkig input. I brist på strukturella ledtrådar, dvs. kognitivt befästa enheter eller 
mönster, använder informanterna sig av allmänkognitiva principer eller kontextuell information i sina tolkningar.

Sammantaget utgör Loenheims avhandling ett viktigt bidrag till forskningen om svenska sammansättningar, i synnerhet genom att konsekvent fokusera på tolkningsperspektivet. Samtidigt kan den även läsas som ett bidrag till den bruksbaserade lingvistiken i allmänhet där just förhållandet mellan fyllda och schematiska enheter är ett mycket aktuellt och fortfarande kontroversiellt ämne. Således poängterar Loenheim (i avslutningskapitlet 9) att vidare empirisk forskning behövs för att kunna slå fast om mycket abstrakta scheman som $\left[\mathrm{XX}_{\text {huvud }}\right]$ är kognitivt realistiska, dvs. om talare verkligen prefererar tolkningar med efterledet som semantiskt huvudled oberoende av ordklass. Detta är en mycket större teoretisk fråga som Loenheim naturligtvis inte kan svara på, utan bara anknyta till.

\section{Litteratur}

Allwood, Jens, 2003: Meaning potentials and context. Some consequences for the analysis of variation in meaning. I: H. Cuyckens, R. Dirven \& J. R. Taylor (red.): Cognitive approaches to lexical semantics. (Cognitive Linguistics Research 23.) Berlin/New York: Mouton de Gruyter. S. 29-65.

Bybee, Joan, 2010: Language, usage and cognition. Cambridge: Cambridge University Press.

Bybee, Joan L., 2013: Usage-based theory and exemplar representations. I: T. Hoffmann \& G. Trousdale (red.): The Oxford handbook of construction grammar. Oxford: Oxford University Press. S. 49-69.

Langacker, Ronald W., 2008: Cognitive Grammar. A basic introduction. Oxford: Oxford University Press.

Schmid, Hans-Jörg, 2015: A blueprint of the Entrenchment-and-Conventionalization Model. I: Yearbook of the German Cognitive Linguistics Association 3. S. 3-25.

Svanlund, Jan, 2009: Lexikal etablering. En korpusundersökning av hur nya sammansättningar konventionaliseras och får sin betydelse. (Stockholm Studies in Scandinavian Philology N.S. 52.) Stockholm: Acta Universitatis Stockholmiensis.

Steffen Höder

Lundin, Katarina: Att utbildas till svensklärare i teori och praktik. (Lundastudier i nordisk språkvetenskap A 78.) 162 s. Lunds universitet 2018. ISSN 0347-8971, ISBN 978-91-88473-87-5.

Det är lätt att känna sig missmodig över den svenska skolans nutid och framtid när man följer debatten i nyhetsmedier och på sociala medier. Något av det missmodet griper mig också när jag först tittar på Katarina Lundins bok Att utbildas till svensklärare i teori och praktik. Är det verkligen någon som fortfarande utbildas till svensklärare, tänker 
jag svartsynt, är det inte snarare så att dagens lärarstudenter tänker att de ska bli lärare, i första hand, medan ämnesinnehållet skjuts alltmer i bakgrunden? Så ser väl min egen erfarenhet ut, av lärarstudenter och lärarutbildningsdiskussioner. Men när jag lägger igen boken känner jag mig faktiskt fylld av en märkvärdig optimism. Framför allt kanske för att de fyra lärarstuderande som här kommer till tals förmedlar en både reflekterande och seriös hållning till sitt framtida yrke. Och i deras reflektioner är det ämnesspecifika ingalunda skjutet i bakgrunden.

Men låt oss ta det från början. Katarina Lundin har under fem års tid följt fyra studenter under deras utbildning till svensklärare. Studien inleds år 2013 då de fyra studenterna är mellan 21 och 32 år gamla. De ska alla bli - eller är väl nu - ämneslärare med svenska som ett av sina ämnen. Som andra ämne i sin examen har de historia, samhällskunskap eller teater. Det är spännande att få följa de här studenterna, som man som läsare tycker sig komma ganska nära, under de nio terminer som utbildningen varar. Under studiens och utbildningens gång samlas de fyra studenterna till elva gruppintervjuer kring olika teman. Varje intervju är ungefär 45 minuter lång och beskrivs av Lundin som halvstrukturerad. Gruppintervjuerna bildar stommen i boken och långa citat från samtalen visar hur diskussionerna har gått. Vid några tillfällen har Lundin använt en variant av intervjumetoden stimulated recall, så att hon själv som samtalsledare gett en återkopplande introduktion eller visat ett utdrag ur transkriptioner av tidigare gruppintervjuer. På så sätt har deltagarna fått tillfälle att reflektera över hur de själva tänkte över ett visst tema tidigare under utbildningen och studenternas utveckling hamnar i fokus.

De teman som valts ut för gruppintervjuerna anknyter alla till »ämneskunskaper, språkvård och lärarprofession» (s. 9) och har viss slagsida åt den språkliga delen av svenskämnet - till skillnad alltså från den litterära delen. Tonvikten ligger mycket tydligt på den kommande professionsrollen, som exempelvis »Kopplingen mellan ämneskunskaper och pedagogiska kunskaper/teori och praktik» eller »Läsning av elevskrivna texter för bedömning eller läsning för språkutveckling». Det senare temat utvecklas tydligare än de övriga eftersom bokens fjärde kapitel, som beskrivs som ett specifikt perspektiv på studenternas självbild och utveckling, helt ägnas åt de fyra lärarstudenternas förhållningssätt till språkvård, språknormer, språkutveckling och bedömning i skolans kontext. Det blir där uppenbart att hanteringen av elevskrivna texter är en arena för konflikt mellan ideologi och praktik, och i synnerhet efter att lärarstudenterna haft sin första VFU (verksamhetsförlagd utbildning) drabbas de av insikten att det är svårt - eller kanske omöjligt - att hantera elevers skriftliga prestationer i enlighet med de ideal som de själva omfattar. Så här säger studenten Maria (s. 74), i ett av gruppsamtalen:

ja och sedan sitta uppe till halv två bara för att man vill ge en bra bedömning på ett brev som en elev har skrivit... och det tror jag också såhär, hur i svenskämnet ska man utforma, hur ska man göra uppgifter för att utveckla eleverna utan att jag ska sitta med hundratjugo brev som jag ska gå igenom?

I mötet med VFU-skolornas praktik kommer de fyra studenterna till insikt om att arbetsbördan och tidsbristen är reella problem i det yrke de valt. De kämpar alla fyra, om än på olika sätt, för att hålla fast vid sin ambition att ge alla elever konstruktiv och individuell återkoppling på skrivna texter utan att tvingas hamna i ett mera instrumentellt förhållningssätt till elevernas skrivande. Häri ligger något av det hoppingivande som boken förmedlar: studenterna vill räcka till i sin lärarroll. 
Lundin resonerar, utifrån studenternas förhållningssätt till de framtida elevernas skrivande, om det komplexa förhållandet att språknormer i undervisningen måste kontextualiseras på två olika sätt, dels i förhållande till elevens nivå, dels i förhållande till språkutvecklingen och den därmed sammanhängande normförändringen. Det går idag knappast att tala om att en skriftspråksnorm är förhärskande i svenskan. Studenternas resonemang om språknormer beskrivs med utgångspunkt i Telemans (1979) tre olika typer av förhållningssätt till språknormering: kommunikationsteknisk ändamålsenlighet, socio-politisk inställning och laissez-faire. Lundin konstaterar att studenterna av skolverkligheten tvingas in $\mathrm{i}$ en fjärde hållning som kan beskrivas som praktikorienterad. Den tvingar studenterna att, av tidsmässiga och praktiska skäl, hantera elevernas texter på ett sätt som inte är förenligt med deras egen grundsyn, där de vill förbättra möjligheterna för varje elev att kunna kommunicera sitt budskap med utgångspunkt i god kunskap om språkvård och språknormer.

Utöver de gruppintervjuer som utgör bokens stomme har de utvalda studenterna också fått genomföra tre skrivuppgifter, där de skrivit relativt korta texter kring tre skilda ämnen. Temat för en av dessa uppgifter är läraren som språkvårdare, och där har avsikten varit att belysa rollen som språkvårdare och språkutvecklare i det andra ämne de har i sin utbildning vid sidan av svenska. På så sätt får diskussionen om hur studenterna som lärare vill och kan förhålla sig till språknormer i elevernas skrivande ytterligare en dimension.

Syftet med projektet Att utbildas till lärare i teori och praktik har varit att undersöka och problematisera de lärarstuderandes utveckling »som människor, som studenter, som blivande lärare och som språkbrukare» (s. 9). Studenternas eget språkbruk behandlas i bokens femte kapitel, där fyra av intervjuerna beskrivs utifrån kvantitativa och kvalitativa analyser. Lundins intryck, skriver hon, är att studenterna uttrycker sig annorlunda i de senare intervjuerna än i de tidigare, och de språkliga analyserna är ett sätt att försöka belägga detta intryck. Mycket riktigt visar det sig att både ordlängden och nominalkvoten (mätt som enkel nominalkvot) har ökat i studenternas tal mellan de första intervjutillfällena och de sista. Från det resultatet går Lundin vidare i en analys av tre utvalda språkdrag, och resonerar med SFL-terminologi om hur studenternas sätt att utvidga sina yttranden går från utveckling mot högre grad av specificeringar och tillägg. Draget att utveckla yttranden med alltså-konstruktion, här exemplifierat med Jasmins utsaga från intervju nummer 2: »men jag tänker det är ju en sak, alltså har eleven förstått det den läser, alltså jag tror att skriver den av exakt eller ...», avtar under utbildningstiden. I de senare intervjuerna har användningen av sambandsorden men och för ökat och studenterna verkar alltså ha förvärvat en bättre förmåga att mera specifikt ge uttryck för komplexa samband. Tyvärr har avsnittet om studenternas språkliga utveckling flera illustrerande citat från de tidigare intervjuerna, men vad jag kan se inga exempel från de senare. Jag har all tillit till analysen, men flera citat från intervju 10 och 11 hade berikat framställningen.

Slutligen bidrar studenternas egna texter, som de skrivit med mycket öppna anvisningar om sin egen utveckling under utbildningstiden, till bokens rika helhet av perspektiv på en framtida svensklärarverksamhet. Inför skrivuppgiften har de fătt ta del av de transkriberade utskrifterna av intervjumaterialet och sedan inbjudits att skriva en personlig reflektion utifrån ett självvalt perspektiv. Studenttexterna presenteras i sin helhet och med studenternas namn som författarnamn i bokens sjätte kapitel. Ett begrepp som 
återkommer vid flera tillfällen i boken, nämligen skolans kompensatoriska uppdrag, formuleras här på olika sätt, och det står klart att de fyra studenterna har en stark övertygelse om att skolan har till uppgift att hjälpa alla elever att erövra vad man kan kalla det offentliga språket. Utifrån sina skilda erfarenheter sliter de på olika sätt med denna uppgift. Någon beskriver sin syn på skolans kunskapsuppdrag och demokratiuppdrag, som han inledningsvis sett som skilda från varandra, men genom utbildningens och den egna utvecklingens roll kommit att uppfatta som delar av ett och detsamma. Att göra studenterna till medförfattare är ett ovanligt grepp men ger här tydligt uttryck för studenternas utveckling från nybörjarstudenter till snart färdiga lärare och medforskare. Här lyfts såväl djupa ämneskunskaper som skolans demokratiuppdrag och skolans vardag fram som styrande för arbetet.

Lundins bok Att utbildas till svensklärare i teori och praktik bygger på studier av bara fyra studenter. De framstår i sina skrivuppgifter som välformulerade och tydliga i sina ställningstaganden. Det ligger nära till hands att fundera över om inte studien i sig gett just de här fyra studenterna bättre verktyg att reflektera över sina studier och sin framtid så att de kanske också utvecklats till ännu bättre studenter - och lärare. Men man kan naturligtvis också fundera över den valda metoden. De deltagande studenterna valdes ut på så sätt att de tillfrågades om deltagande utifrån sitt engagemang under föreläsningar i svenska språkets struktur, som Lundin själv höll. Ursprungligen deltog åtta studenter, i två olika grupper, men den ena gruppen upplöstes av olika skäl efter ett år. Ytterligare en studentgrupp hade krävt en lite annan redovisning, tror jag, men hade givetvis bidragit med ytterligare fyllighet. Nu är detta en fallstudie, och representativitet är därmed underordnat. De fyra studenter som läsaren får möta här är just fyra studenter. De här individerna, engagerade och reflekterande, finns inom dagens lärarutbildning, och studien bidrar med ett värdefullt perspektiv på skolans vardag och uppdrag, så som dessa kan uppfattas av morgondagens lärare.

Boken väcker många frågor, mot bakgrund av dagens lärarbrist. Hur ska vi klara att få nyblivna lärare att både stanna kvar i yrket och behålla sina höga ideal? Och är det egentligen alls möjligt för en svensklärare i dagens skola att ge eleverna verktyg för att hantera till exempel de, dem och dom, för att nu dyka ned i en aktuell språkfråga. Är det ens möjligt att vara språkvårdare på allvar i en tidspressad lärarroll? De här diskussionerna tar sig Lundin inte an, i denna bok, men de ligger implicit $i$ texten och inbjuder till vidare diskussion. Många lärarutbildare och lärarstuderande borde vara intresserade av att läsa boken. Den är inte bara lättläst och erbjuder ingångar till spännande diskussioner; den ger också uppslag till fortsatta studier av hur lärarstuderandes kunskapsutveckling och språkutveckling hänger ihop.

\section{Litteratur}

Teleman, Ulf, 1979: Språkrätt. Om skolans normer och samhällets. Malmö: Gleerups. 
McCulloch, Gretchen: Because Internet. Understanding the New Rules of Language. 326 s. Riverhead Books. New York 2017. ISBN 987-0-73521093-6.

För en tid sen var jag på resande fot och skrev följande statusuppdatering på Facebook: »Kom just på mig själv med att skriva att jag sitter på en 'irriterande dålig uppkoppling'. Men herregud. Jag har väl inte 'kopplat upp mig' sen tidigt 00-tal (bi-bi-BI-bi-BI-bi-bi). Däremot är det ett rätt svagt wi-fi på det här tåget.» Jag hade haft lite svårt att komma igång med den här recensionen och visste inte riktigt hur jag skulle börja för att göra boken rättvisa. Men plötsligt landade inledningen rakt i knäet på mig. Because Internet av Gretchen McCulloch förklarar nämligen på ett utmärkt sätt precis vad det var som hände där på tåget och varför jag plötsligt fick syn på mitt eget språkbruk.

Because Internet är en populärvetenskaplig bok som på 326 sidor introducerar läsaren till språket på internet och vad internet gör (och inte gör) med vårt språk. McCulloch är en kanadensisk språkvetare som för en del säkert är bekant genom podcasten Lingthusiasm. I podcasten diskuterar och populariserar McCulloch ihop med den australiska kollegan Lauren Gawne så vitt skilda teman som fältarbete, språkdokumentation och pragmatik. Och, förstås, språket på internet.

Språket på internet får mycket kritik. Det vet alla som har lyssnat på Språket i P1 de senaste åren, eller som själv i någon kapacitet svarat på allmänhetens undringar om språk. Med jämna mellanrum kan man läsa journalistiska spekulationer rörande om emojier kommer att ersätta det skrivna språket, om emojier kanske kan fungera som ett universellt språk eller om det möjligen inte är så att nya teknologier som sms, chatt eller mejl kommer att bli språkets undergång. De flesta som läser recensioner i Språk och stil är troligen benägna att svara att varken pennan eller tryckpressen lyckades ta kål på språket, så antagligen kommer inte de här teknologierna att göra det heller. Men vi kan alla observera att det finns saker vi inte gjorde med språket innan kommunikationssätt som förknippas med internet uppstod. Till exempel har det aldrig tidigare varit möjligt för så stora delar av världens befolkning att göra sin röst hörd i offentligheten. De nya möjligheterna leder till förändringar och nya beteendemönster. Och det är de här mönstren, i stort och smått, som McCulloch avser att beskriva. Och inte bara det, utan hon vill också ge verktyg så att läsaren själv ska kunna betrakta innovativt språkbruk och börja analysera det med en språkvetares sätt att tänka (s. 7).

Boken består av åtta kapitel, som behandlar olika aspekter av vår textburna internettillvaro. I de sju första går författaren igenom stora mängder forskning, kopplar samman den och sätter den i kontext. Ibland har det funnits luckor då tillgänglig forskning inte har besvarat de frågor som hon har velat ställa. Då har hon kompletterat med egna undersökningar. I det avslutande kapitlet filosoferar hon kring internet som metafor för språket, till skillnad från boken eller ordboken som metafor.

I kapitel 1 positioneras skrivandet på internet på spektrumen formellt/informellt och talat/skrivet. Där utreds förutsättningarna för text som är avsedd att läsas av få nära i tiden, respektive text som är avsedd att läsas av många när som helst. Skrivandets materiella förutsättningar präglar kapitlet, särskilt i fråga om vikten av förkortningar när man har ont om utrymme. Förkortningar som har uppstått och spridits på internet, som $L O L$ och $W T F$, kopplas samman med långt äldre skriftpraktiker som förkortningar på ro- 
merska mynt och i telegram. Det andra kapitlet har ett variationslingvistiskt anslag och ger exempel på hur forskning om geografisk och social variation kan gå till med hjälp av tjänster som Twitter.

I det tredje kapitlet kopplas gruppspråk och teorier om språk och migration till generationer av internetanvändare. Vad avslöjar det om mig att jag säger att jag »kopplar upp mig» snarare än »har wi-fi», och att jag känner till och kan härma hur modemet lät på den tiden då man just kopplade upp sig för att kunna surfa? Jo, det visar något om min ålder och vilken sorts användare jag är och har varit. Lägg till informationen att jag har vänner som jag pratar om genom att använda deras »nick» från olika diskussionsforum från tiden kring millennieskiftet snarare än deras folkbokförda namn. Och att jag aldrig skulle skriva meddelanden med bara versaler. Det ska enligt McCulloch räcka för att på ett ungefär kunna identifiera när jag började använda internet för sociala ändamål (före Facebook, som kräver att man använder »riktiga» namn, men jag har aldrig kodat $\mathrm{i}$ Unix, så jag uppfattar versaler som högljutt). Mina barn, båda födda på 2010-talet, kan på samma sätt lätt kategoriseras som det som McCulloch kallar »post-internet people»: de som inte ens kan föreställa sig en värld utan internet och som inte säger googla utan söka. Vi har olika sätt att använda internet, vilket tar sig uttryck inte bara i vanor och användarmönster, utan också genom hur vi uttrycker oss om och på internet.

I bokens fjärde kapitel går McCulloch in på ämnen som nog vanligen är det som avses när oron över att internet förstör språket kommer på tal. Här behandlar hon typografisk ton och hur typografisk frihet och innovation kommer till uttryck i sociala medier. Hon återkommer därvid till förkortningar som fenomen för att kunna diskutera hur internetspråket faktiskt påverkar språket i övrigt. När förkortningar lexikaliseras, förses med grammatik och flyttar in i det talade språket, som $L O L$, som har kommit att utveckla tempusböjning och överföras till nya språkliga kontexter, synliggörs vår förmåga till grammatisk analys och reanalys. Här drar hon paralleller mellan dagens expressiva stavning (trååååååakigt) och stavningen före införandet av en standardiserad stavningsnorm. Perspektivet är engelska språkets, men en svensk läsare ser lätt likheter med den svenska standardiseringshistorien (Teleman 2003, Josephson 2016).

Kapitlet därefter tar sig an en annan utmaning för den som bekymrar sig för språkets förfall under inflytande av internet, nämligen emojier. McCulloch redogör bland annat för en studie som hon genomfört tillsammans med podcast-partnern Gawne. De analyserar emojier som internetspråkets gester, och diskuterar dem övertygande utifrån etablerad gestteori. Hon tar också upp emojiers syntax. Med jämna mellanrum får verk som »Bibeln i emojier» och liknande spridning på internet. Den som försökt läsa ett sådant verk har troligen märkt att läsbarheten hänger ganska mycket samman med hur väl man redan känner till vad det borde stå. I själva verket, menar McCulloch, är emojier inte någon särskilt övertygande grund för ett universellt symbolspråk, utan hon menar att vi använder emojier på ett helt annat sätt. Hon angriper emojianvändning som en fältlingvist och skaffar sig listor över vilka emojier som tenderar att förekomma tillsammans med högst frekvens. Resultatet är inte något som kan ligga till grund för en analys av semantiska roller eller av om emojispråket har SVO- eller SOV-ordföljd. I stället finner hon att det vanligaste är att en emoji förekommer med en likadan av samma sort. Reduplikation är alltså det dominerande mönstret för emojier. Utifrån det kan man resonera kring vad vi använder emojier till. Det verkar, utifrån McCullochs analys, inte vara för att ge uttryck för narrativ. Snarare tycks det handla om metakommentarer och intensitet. 
Det sjätte kapitlet tar upp utvecklingen av skriftlig kommunikation från brev till Facebook via 1990-talets chattrum. Teknik och lokala konventioner påverkar hur vi uttrycker oss och hur vi kan uttrycka oss. Metoder för sortering av data i sociala medier och diskussionsforum gör också att vi har lättare att finna våra likar idag; vi är inte begränsade av geografi eller tidszoner för att hitta personer med likartade intressen. Kapitlet därefter behandlar meme. Även här tas vi med på en teknikhistorisk odyssé genom skämt som faxats mellan kontor och länkar och bilder som mejlats runt på mejllistor. Men läsaren tas också igenom syntaktisk analys av meme-språket »lolcat» (som åtföljer kattbilder i form av repliker som »I can haz cheeseburger?») och av meme-hunden Doges språk.

Because Internet är en rik källa för forskningsuppslag. En stor del av de studier som refereras saknar motsvarigheter inom det svenska och nordiska språkområdet. Inom ett B- eller C-uppsatsseminarium skulle det kunna uppstå en stor mängd intressanta och helt genomförbara uppsatsämnen. Det är också en bok som mycket väl kan användas som kurslitteratur eller inspirationslitteratur på grundkurser i svenska, nordiska språk och lingvistik. Parallellt med att McCullochs bok har växt fram har hon och Gawne i olika poddavsnitt diskuterat förutsättningarna för analys av språk på internet. Det finns därmed ett bra bredvidlyssningsmaterial som både breddar och belyser bokens innehåll. Även som fortbildningslitteratur för den som vill få en läsvärd men på inget vis förenklad införing i forskningsläget för språket $\mathrm{i}$ bruk på internet är detta ett bra val.

Den som läser den här boken med kritiska forskare som Blommaert (2013) i bakhuvudet kan sakna resonemang om vem som har tillgång till vilken sorts skriftmaterialitet, alltså de socioekonomiska förutsättningarna för att alls kunna vara en internetspråkbrukare förr och nu. För att delta i och vara en fullvärdig medlem i gruppen som behärskar internetspråket krävs tillgång till just internet. Någon form av uppkoppling är nödvändig, liksom något i stil med en dator, läsplatta eller smart telefon. Detta kräver en del resurser, vilket McCulloch inte riktigt befattar sig med. Det är tråkigt; den aspekten hade kunnat nyansera bilden av internetanvändaren ytterligare. Bristen, om man tycker att det är en sådan, kan förklaras med att det hon är ute efter att säga något om det språk som finns på internet, inte det som inte finns där.

En oro jag hade inför min läsning var att boken och den refererade forskningen skulle präglas av ett enspråkigt anglosaxiskt perspektiv. Till min glädje och förvåning kom den misstanken på skam. Den som letar efter svenska eller nordiska exempel får visserligen leta länge, men även om de flesta språkproven är engelska finns bland annat såväl arabiska som franska och portugisiska exempel med.

Styrkan hos Because Internet ligger inte i att den ger en tämligen heltäckande överblick över vad som pågår med språket på internet. Snarare ligger den i att varje kapitel också, liksom i förbifarten, förmedlar de grundläggande språkvetenskapliga begrepp och förhållningssätt som läsaren behöver för att förstå vad som pågår. Så innehåller exempelvis kapitel 2 en grundläggande introduktion till sociolingvistik, komplett med geografisk och social variation, nätverksteori och attitydforskning, alla knutna till fenomen som är specifika för internetspråket. Genom att samtidigt ge en introduktion till olika språkvetenskapliga forskningsfälts uppkomst och utveckling visar McCulloch även läsaren hur internet och digitalisering förändrar (och ofta förenklar) språkforskarens arbetsvardag. Det är dessutom en väldigt rolig bok. Den som kommenterar sin läsning med LOL kan faktiskt mycket väl ha skrattat högt på riktigt. 


\section{Litteratur}

Blommaert, Jan, 2013: Writing as a sociolinguistic object. I: Journal of Sociolinguistics 17(4). S. 440-459.

Josephson, Olle, 2018: Språkpolitik. Stockholm: Morfem.

Teleman, Ulf, 2003: Tradis och funkis. Stockholm: Norstedts Ordbok.

Susanna Karlsson

Norrby, Catrin \& Håkansson, Gisela: Samtal om svenska. Förhandling, positionering och känslosvall. 216 s. Morfem. Stockholm 2018. ISBN 978-9188419-05-7.

I Samtal om svenska har författarna med två olika metoder låtit ett antal lärare och elever värdera och diskutera fjorton skriftliga exempelmeningar - dels genom en enkätstudie, dels genom en fokusgruppsundersökning. Studiernas syfte, metod och resultat redovisas $i$ en inledning som följs av tolv tematiska kapitel plus slutord, en referenslista samt bilagor, där bland annat själva enkätformuläret återfinns. Vart och ett av bokens kapitel avslutas med en sammanfattning och tips på vidare läsning. Som regel avslutas bokens kapitel med ett avsnitt med rubriken »Utblick». Dessa avsnitt innehåller förslag till lärare på hur de kan omsätta bokens teman till diskussionsuppgifter i klassrummet. Dessutom finns ett antal textrutor som redogör för tidigare forskning, kompletterande information om undersökningen eller vetenskapliga begrepp som språkideologi.

Enkäten i studien utgår alltså från fjorton språkbruksexempel, som varje deltagare har fått poängsätta på en skala från mycket dåligt till mycket bra. Meningarna har valts för att locka till diskussion, och de flesta av dem representerar sådant som uppfattats som avvikelser från standardskriftnormen - grammatiskt eller stilistiskt. Klassiska språkriktighetsfrågor (Han är mycket äldre än mig) och inlärartypiska varianter som utebliven inversion (Efter tre dagar biljetterna kom med posten) ingår men också talspråkliga meningar (De e ju sjukt mycket större) och dialektala (Hon såg han väldigt tydligt), liksom två helt normenliga meningar från formella genrer (Den förnybara energin $i$ Sverige har stor potential att byggas ut under lång tid framöver).

Enkätsvaren har i huvudsak samlats in via kontaktpersoner på olika skolor. Sammanlagt har nästan 100 gymnasielärare och över 1000 gymnasieelever från arton skolor fördelade på femton orter över hela Sverige deltagit. Dessutom har enkäter genomförts på skolor i Brysselområdet och i Spanien bland elever som läser svenska som gymnasieämne. Lärarna är i åldrarna 25-65 år, något fler kvinnor än män, nästan hälften svensklärare. De övriga undervisar i andra ämnen. Eleverna går i gymnasiet och uppgav till $90 \%$ att de har svenska som förstaspråk. Cirka 60 \% går ett studieförberedande gymnasieprogram och cirka $40 \%$ ett yrkesförberedande.

Fokusgruppsstudien bygger på fjorton samtal där deltagarna diskuterat i grupper om fyra till fem personer med minst en av författarna som samtalsledare. Det är tre lärargrupper från Sverige och elva elevgrupper, varav sju från Sverige och fyra från skolorna 
i utlandet. Deltagarna i Sverige hör hemma på tre olika skolor vilkas fingerade beteckningar pekar på deras geografiska hemvist: Sydskolan, Västskolan och Centrumskolan. Inga fokusgrupper har genomförts på skolor i norra Sverige.

De samlade enkätresultaten redovisas kortfattat i kapitel 2, och författarna återknyter sedan till flera av dem i de tematiska kapitlen. Generellt pekar resultaten på en i hög grad samstämmig bild om skriftspråkliga normer över Sverige som geografiskt område. Inte ens det exempel som brukar beskrivas som dialektalt, Hon såg han väldigt tydligt, gav några substantiella geografiska skillnader i enkäten, vilket förvånar författarna som hade förväntat sig större regionala skillnader. Även för oss framstår resultatet som intressant. Vi tolkar det dessutom som ett positivt resultat att de geografiska skillnaderna är så små, eftersom det kan uppfattas som ett tecken på att förmedlingen av den gemensamma skriftspråksnormen verkar fungera likvärdigt över hela landet.

Andra resultat från enkätundersökningen som - trots att de inte är oväntade - fångar vårt intresse, är att lärarna generellt bedömer normavvikelser hårdare än eleverna och att eleverna på studieförberedande program i sin tur generellt bedömer dem hårdare än eleverna på yrkesförberedande program. Författarnas tolkningsförslag är att eleverna på studieförberedande program »orienterar sig mer mot skriftspråket som ett ideal» (s. 34).

Ett annat intressant resultat är att även om elever och lärare tyckte ganska olika om de flesta av exemplen, var de helt överens om en sak: Till de allra sämsta hörde de två exempel som signalerar inlärarsvenska (Efter tre dagar biljetterna kom med posten och Det var ett helt år, som jag kunde inte gå över huvud taget). Vår reflektion är att det resultatet indikerar att inlärarvariation ligger långt från skriftspråksnormen. Det speglar också hur språkvården har resonerat kring bra och dåligt, rätt och fel. Som exempel på direkta felaktigheter eller »det som inte är svenska» brukar just inlärarspråk anföras, medan dialektal variation brukar beskrivas som svenska, om än ej tillhörande standardskriften (Westman 1989 s. 5, Språkriktighetsboken 2005 s. 20).

Enkätresultaten ger alltså mycket att fundera på för den som är intresserad av standardskrift och variation i svenskan, men de diskuteras inte så ingående ur det perspektivet, eftersom författarnas intresse främst riktas mot hur elever och lärare diskuterar dessa språkfrågor. Bokens resterande kapitel ägnas åt fokusgruppsdiskussionerna. Resultaten från dem beskrivs tematiskt och spänner över såväl samtalsanalys som folklingvistik och språkvårdsargument.

Kapitel 3 är det mest samtalsanalytiskt inriktade. Det handlar om hur man språkligt positionerar sig i samtal och förhandlar ståndpunkter i gruppdiskussionerna, det vill säga hur det generellt går till att diskutera i fokusgrupper. Det huvudsakliga resultatet är att deltagarna i studien i högre grad uttrycker enighet än oenighet om språkexemplen.

Kapitel 4 handlar om vilka känslor som uttrycks inför de olika exempelmeningarna, samt hur det görs. Författarna konstaterar att de känslor som väcks mestadels är negativa, och att vissa uttryckssätt ger upphov till stark irritation, primärt hos lärarna, som också uttrycker sig mer tvärsäkert om dem. Det gäller framför allt exemplen på språkriktighetsklassiker som de, dem och dom, samt hans/hennes eller sin. Eleverna uttrycker sig mindre irriterat än lärarna.

Därefter följer fyra kapitel (kapitel 5-9) som behandlar vilka typer av förklaringar deltagarna anför i sina diskussioner. Vi finner här många ledtrådar till hur skriftspråk värderas. I kapitel 5 visas framför allt att språkliga auktoriteters råd ges stor tyngd. Ele- 
verna åberopar svensklärare som normauktoriteter, medan lärarna åberopar personer som Lars-Gunnar Andersson, Fredrik Lindström och publikationer som Språktidningen och Språkriktighetsboken. De redogör då sällan för argumentationen bakom ett råd, utan konstaterar helt enkelt att detta är rätt eftersom NN har sagt det. Som språkvårdare kan vi lite sorgset notera att det alltså inte verkar vara språkvårdens argumentation som åberopas, utan själva expertauktoriteten.

I diskussionerna som refereras i kapitel 6 tillskrivs engelskan stor påverkan på svenskan. Framför allt lärarna jämför svenska konstruktioner med engelska och utgår ofta från att engelskan orsakar förändringar i svenskan och funderar bland annat på om engelskan kan ha »rört till» användningen av sina respektive deras? Författarna menar att engelskan ges ett förklaringsvärde som den inte nödvändigtvis har och att den fungerar som det första stället att leta på när man söker svar på frågan om varför språket förändras.

Att språket förändras visar deltagarna stor medvetenhet om, vilket framgår i kapitel 7. Språkförändring används också för att förklara flera klassiska språkriktighetsfrågor, som kommer utan att och större än mig/jag. Tidsperspektivet hos deltagarna är då kort, och de uttrycker det i stil med »har kommit på senaste tiden». Här skiljer sig lärare och elever åt på så sätt att lärarna oftast förespråkar de äldre formerna, medan eleverna förhåller sig mer neutrala.

Fler förklaringar diskuteras i anslutning till exemplen på ordföljdsvariation i kapitel 8 (Efter tre dagar biljetterna kom med posten och Det var ett helt år, som jag kunde inte gå över huvud taget). De beskrivs av deltagarna som fel som »invandrare kan göra», och de diskuteras inte i samband med språkförändring utan i samband med språkinlärning. Här menar författarna att ordföljdsmönster kan signalera modersmålstalare respektive inlärare av svenska och att ordföljd också används som ett kriterium för bra och dålig svenska (s. 119). Ordföljdens signalvärde och den kontext deltagarna uppfinner till de kontextlösa exemplen har betydelse för hur ordföljdsmönstret bedöms. Detta tydliggörs bland annat när en grupp prövar exemplet Efter tre dagar biljetterna kom med posten. De menar att det skulle kunna fungera om det ingick i en dikt. Implikationen är då att poetisk frihet skulle kunna förklara ordföljden, och inte nödvändigtvis inlärarfaktorn.

Vi tycker också att kapitel 7 och 8 tydliggör hur olika saker man kan reagera på i ett exempel, delvis beroende på vilken kontext man föreställer sig. Trots att deltagarna i diskussionerna har fătt kontextlösa exempel väger de inte sällan in tänkbara kontexter och försöker bedöma exemplen i relation till dem. Lärarna och eleverna fokuserar ofta på skilda saker, och föga förvånande tenderar lärarna att diskutera det som författarna tänkt sig att meningen ska exemplifiera, eftersom lärarna har större erfarenhet av vad man ska vara uppmärksam på i standardnormens utkanter. Eleverna kan i högre grad reagera på annat, och sätter exemplen delvis i andra (ofta skolrelaterade) kontexter. Det visar hur kontextberoende språkriktighetsbedömningar kan vara.

Kapitel 9 handlar om de uteblivna regionala skillnaderna. Författarna hade förväntat sig diskussioner om exemplet Hon såg han väldigt tydligt, men kontentan av kapitlet blir snarast att regional variation - till skillnad från inflytande från engelskan - är en förklaring som deltagarna knappast använder alls.

Kapitel 10 och 11 avviker från de övriga genom att ta upp fenomen som författarna inte hade förväntat sig men som blev framträdande i materialet. Kapitel 10 handlar om 
$j u$, som deltagarna uppfattar som ett onödigt utfyllnadsord som framförallt används av yngre. Kapitel 11 framhäver lekfullheten i de språkliga diskussionerna. Både lärarna och eleverna härmar t.ex. regionala drag (tjockt $l$ och stockholmskt rom för dom) och stereotypt ungdomsspråk.

I kapitel 12 återkommer enkätresultaten. Kapitlet beskriver hur deltagarna bedömt om de tror att exemplen kommer från tal eller skrift och visar återigen på kontextens relevans för språkriktighetsbedömningen. I stort visar resultaten från såväl enkäten som fokusgrupperna att eleverna har en god intuition för vad som hör hemma i tal och i skrift, liksom en god medvetenhet om olika genrekrav.

Kapitel 13 handlar om språkriktighetsargument och vilka som förekommer i gruppdiskussionerna. Eleverna använder ofta funktionsargumentet att ett uttryck fungerar för att överföra information. Andra argument förekommer också, men vi lägger särskilt märke till att det etymologiska argumentet som varit så vanligt tidigare i språkvårdshistorien, inte alls används i dessa diskussioner.

I slutordet $\mathrm{i}$ kapitel 14 fångas några av de tidigare temana upp och resultaten diskuteras. Ett sådant tema är att lärarna och eleverna positionerar sig på delvis olika, delvis liknande sätt. Medan lärarna framställer sig just som gruppen lärare behöver eleverna i samtalen konstruera en egen gruppidentitet. Men båda grupperna kan använda det exemplen aktualiserar på ett lekfullt sätt och på så vis skapa en gruppidentitet. Avslutningsvis framhåller författarna att det är för tidigt att veta om de olikheter i uppfattningar som framkommit mellan elever och lärare är tecken på språkförändringar eller om de unga så småningom kommer att anamamma vuxenvärldens uppfattningar.

Läst ur ett språkvårdsperspektiv ger boken mycket intressant information om hur standardskriftsvenskans normer uppfattas. Både resultaten av enkäten och diskussionerna är givande ur den synvinkeln. Att varken elevers eller lärares bedömningar av exemplen skiljer sig nämnvärt över landet tyder på att skriftspråksnormen på något sätt överförs likvärdigt, så att standardskriftsvenskan verkligen fungerar som hela Sveriges skriftspråk, trots att det ligger olika långt från talspråket i skilda delar av landet. Hur mycket av detta som kan tillskrivas skolans undervisning och hur mycket som kan tillskrivas andra skriftspråksaktiviteter säger denna undersökning ingenting om, men det är uppenbart något som verkar fungera väl i det svenska språksamhället.

Ett tydligt resultat av studien är att det nästan enbart är lärarna som irriterar sig på exempelmeningarna, medan eleverna förhåller sig mer känslomässigt neutrala. Att diskutera och hantera känslor kring språklig variation framstår alltså inte som direkt akut för just eleverna. Lärarna däremot har ett ansvar att stötta elevernas tillägnande av standardnormen. Eftersom vi själva som universitetslärare har gett respons på språkriktighetsfrågor i många texter kan vi mycket väl föreställa oss att lärarnas »känslosvall» har ett samband med den arbetsuppgiften. Att man, efter att ha kommenterat några hundra uteblivna att efter kommer, känner något på skalan mellan irritation och raseri, måste väl betraktas som en allmänmänsklig reaktion? Och just det som ligger på gränsen till acceptans i standard är ju också vanligast förekommande, svårast att hantera och leder till mest frustration. Denna insikt leder oss vidare till slutsatsen att bokens övningar i språklig självreflexion (utblickarna) hellre borde utföras i lärarrummet än i klassrummet. Om några är i skriande behov av att diskutera och 
hantera sina känslor inför språklig variation är det väl snarast vi lärare? Det vore ju mycket vunnet om vi på såväl universitet som skola kunde förmedla standardskriftens normer med ett minimum av aggressioner.

Sammanfattningsvis ger boken många insikter i hur lärare och elever diskuterar språkfrågor. Det är svårt att föreställa sig någon språkintresserad som inte skulle ha nytta av boken och målgruppen för boken sägs vara alla som har språket som sitt arbetsfält. Utblickarnas förslag till diskussioner med elever i klassrummet ger dock intrycket att bokens primära målgrupp är blivande eller yrkesverksamma svensklärare. Ibland nämns också målen i styrdokumenten för svenskämnet explicit. Samtal om svenska gör på intet sätt anspråk på att vara en lärobok för lärarutbildningen, men den skulle ändå kunna bidra med infallsvinklar och kunskap på kurser i språksociologi eller språkvård och språkriktighet. För yrkesverksamma lärare, som kanske är bokens allra mest naturliga målgrupp, finns förstås också mycket att hämta.

\section{Litteratur}

Språkriktighetsboken. Utgiven av Svenska språknämnden. Stockholm: Norstedts akademiska förlag 2005.

Westman, Margareta, 1989. Åsikter om svenskt språkbruk. I: Språkvård 3. S. 5-16. 


\section{Bengt Nordberg 1936-2019}

Professor emeritus Bengt Nordberg har avlidit 83 år gammal. Han var professor i sociolingvistik och verksam vid Institutionen för nordiska språk i Uppsala. I Språk och stil har han medverkat såväl med artiklar om egen forskning som med recensioner av böcker och avhandlingar.

Bengt Nordberg växte upp i Eskilstuna och kom i mitten av 1950-talet till Uppsala för att utbilda sig till svensklärare. Han tog sin fil.mag. 1961 och undervisade en tid på olika skolstadier i och omkring Uppsala. 1967 återupptog han studierna i nordiska språk vid Uppsala universitet och blev fil.lic. 1972. Han hade då redan varit med om att inrätta FUMS, en forskningsavdelning med inriktning mot modern svenska, och blev tidigt också dess föreståndare.

Bengt Nordberg var under en period universitetslektor i Umeå och anställd vid Svenska språknämnden i Stockholm. Han återkom 1976 till FUMS och Institutionen för nordiska språk i Uppsala. Fyra år senare tillträdde han en HSFR-professur i sociolingvistik. Rådsprofessuren överfördes 1994 till Uppsala universitet. Där blev han kvar till sin pensionering 2001.

Bengt Nordbergs forskningsintressen var mångskiftande och i ständig utveckling. Han inledde med stilistik och språkvård. Han blev sedan en av Sveriges främsta företrädare för den nya disciplinen sociolingvistik. Med stöd av dåvarande HSFR och andra fonder kom han under en lång följd av år att initiera och driva en rad uppmärksammade forskningsprojekt, som kom att göra FUMS till ett centrum för sociolingvistisk forskning i Norden.

Eskilstunaspråkets sociala variation var ett återkommande tema i Bengt Nordbergs forskarliv. Det första stora talspråksprojekt som bedrevs vid FUMS gällde språket i Eskilstuna. Syftet med studien var att mot en social bakgrund beskriva ett mellansvenskt stadsspråk. Informella intervjuer spelades in, vilka omfattade uppåt en halv miljon ord. I det lediga och vardagliga talspråket gjorde han studier av morfologiska variationsmönster, av vokalsystemets utveckling liksom av olika sätt att uttrycka modalitet. Till Eskilstunaundersökningen återknöts också 29 år senare, då en uppföljningsstudie gjordes, vilket innebar att man kunde se hur talspråket förändrats mellan 1967 och 1996. En sådan jämförelse av förändringar i verklig tid är på många sätt unik och naturligtvis av stort forskningsintresse också i ett internationellt perspektiv.

Bengt Nordberg skrev många artiklar, rapporter och böcker om sociolingvistik och sociolingvistiska metoder. I boken Det mångskiftande språket (1985) gav han en värdefull översikt över de första tio åren av sociolingvistisk 
forskning vid FUMS. I andra publikationer visade han hur språket inte bara är ett sätt att överföra ett kognitivt innehåll från människa till människa utan hur själva språkformen, uttal och prosodi, har sociala och psykologiska innebörder. Han visade också att social prestige och språkinterna faktorer är fullt ut lika viktiga som samtalsintern konvergens och divergens för variation och förändring på ett makrosocialt plan.

Bengt Nordberg var medarbetare i Nationalencyklopedin och stod bland annat för artikeln »Språksociologi». Han var svensk representant i den redaktionella nämnden för årsboken Sociolinguistica, där han ansvarade för den svenska bibliografin, vilket han också gjorde i Sociolinguistic Bibliography of European Countries. När handboken Sociolinguistics, An International Handbook of the Science of Language and Society (1987-1988) skulle ges ut blev han ombedd att skriva ett kapitel om »Aims of Research and Methodologies».

Bengt Nordberg hade upparbetat ett stort nordiskt och internationellt nätverk. Många internationellt kända forskare besökte FUMS och Uppsala och fick inflytande på de studier som bedrevs. Under 1980-talet ledde han ett stort nordiskt forskningsprogram om urbanisering och lingvistisk förändring. I detta ingick framstående sociolingvister från Danmark, Finland, Norge och Sverige. Projektet utmynnade i den av honom redigerade volymen The Sociolinguistics of Urbanization: The Case of the Nordic Countries (1994).

Samtals- och interaktionsforskning var andra områden inom vilka Bengt Nordberg initierade projekt. Bland hans många projekt kan nämnas Ungdomars samtalsstil, Läkarens och lekmannens begreppsvärldar, Språk, åldrande och identitet, Samtalsspråkets grammatik och Nutida variation i svenskt talspråk. Det senare projektet tillkom i syfte att utarbeta läromedel för kurser inom universitetsundervisningen i svenska. I samarbete med Finska institutionen i Stockholm drevs vidare vid FUMS projektet Sverigefinnars två språkspråkbruk och attityder hos två generationer.

Utöver projektledning genomförde Bengt Nordberg också egen forskning i anknytning till studierna. Han skrev om onomatopoetiska uttryck och ungdomars samtalsstil, om talackommodation och språkstruktur, om verbsyntax i talspråk och - med fokus på institutionella samtal - om samtal till larmcentraler.

Bengt Nordbergs vetenskapliga produktion imponerar och renderade honom Svenska Akademiens språkforskarpris 2015.

Bengt Nordberg hade många förtroendeuppdrag. Han var medlem av Svenska språknämnden och ledamot i Forskningsnämnden för modern svenska. Han var styrelseledamot i Adolf Noreen-sällskapet och under drygt ett decennium redaktör för Språk och stil. Han ingick i styrelsen för Språkvårds- 
samfundet och var dess ordförande i sex år. Han var också medlem i redaktionskommittén för skriftserien Ord och stil.

Områdesgruppen för tal och interaktion, OFTI, var en annan organisation där Bengt Nordberg var engagerad, och 1993 stod han som värd för det årliga symposiet. Han var också med i organisationskommittéer för många konferenser, till exempel för Svenskans beskrivning 18 (1990) och för den internationella konferensen Discourse and the Professions (1992).

Bengt Nordberg var ansvarig för undervisningen i sociolingvistik i Uppsala. Han var handledare för många doktorander och också involverad i C- och D-studenters arbeten. Uppsatser och delstudier från olika projekt publicerades i FUMS rapportserie. Stor betydelse för utvecklingen av sociolingvistiken i Uppsala hade också den högklassiga seminarieserie som han ledde vid FUMS. Inbjudna var talare från olika svenska och nordiska lärosäten men också från universitet utanför Norden.

Bland Bengt Nordbergs förnämliga personliga egenskaper vill jag särskilt framhålla dem som han visade som föreståndare och ledare vid FUMS. Han var ihärdig och drivande men samtidigt vänlig och tillmötesgående. Han var mån om att verksamheten skulle växa och fortleva, vilket gjorde att han också var öppen för olika inriktningar inom fältet modern svenska, för studiet av såväl tal som skrift. FUMS kom därigenom med tiden att omfatta flera underavdelningar med egna rapportserier. Han drog till sig forskare och gav dem en plats i den arbetsgemenskap som FUMS innebar. Hans ledarskap var demokratiskt och han var lätt att samarbeta med. Ett framträdande drag i hans personlighet var hans omsorg om alla sina medarbetare. Som omtänksam chef startade han också en FUMS-kör och arrangerade, med familjen som funktionärer, årliga FUMS-mästerskap i orientering.

Bengt Nordberg hade en gedigen sakkunskap inom sina områden och arbetade omsorgsfullt. Hans eget skrivande är klart och stilistiskt högtstående. Många har haft Bengt Nordberg som handledare och textgranskare och vi kan alla intyga att han var en såväl noggrann som hänsynsfull läsare. 


\section{Författarna i detta nummer}

Bertils, Klara; fil.mast., doktorand i lingvistik, Institutionen för lingvistik och filologi, Uppsala universitet.

Bylin, Maria; fil.dr, språkvårdare i svenska, Språkrådet, Institutet för språk och folkminnen.

Eriksson, Olof; professor em. i franska med inriktning mot språkvetenskap, Linnéuniversitetet.

Grahn, Inga-Lill; fil.dr, postdoktor, Institut för språk och folkminnen, Dialekt-, namn- och folkminnesarkivet i Göteborg.

Gunnarsson, Britt-Louise; professor em. i modern svenska, särskilt sociolingvistik, Institutionen för nordiska språk, Uppsala universitet.

Huhtamäki, Martina; fil.dr, forskardoktor, Finskugriska och nordiska avdelningen, Helsingfors universitet, Finland.

Höder, Steffen; Professor für skandinavistische Sprachwissenschaft, Christian-Albrechts-Universität, Kiel, Tyskland.

Kahlin, Linda; docent, universitetslektor i svenska, Institutionen för kultur och lärande, Södertörns högskola.

Karlsson, Susanna; docent, universitetslektor, Institutionen för svenska språket, Göteborgs universitet.

Klang, Per; fil.mag., doktorand i nordiska språk, Institutionen för nordiska språk, Uppsala universitet.

Ledin, Per; professor i svenska, Institutionen för kultur och lärande, Södertörns högskola.

Lindström, Jan; professor i nordiska språk, Finskugriska och nordiska avdelningen, Helsingfors universitet, Finland.

Machin, David; professor i medie- och kommunikationsvetenskap, Institutionen för humaniora, utbildnings- och samhällsvetenskap, Örebro universitet.

Magnusson, Simon; fil.mast., doktorand i svenska, Institutionen för kultur och lärande, Södertörns högskola.

Melander, Björn; professor i svenska språket, Institutionen för nordiska språk, Uppsala universitet.

Nilsson, Jenny; docent i nordiska språk, forskningsarkivarie, Dialekt-, namnoch folkminnesarkivet i Göteborg (DAG), Institutet för språk och folkminnen.

Norrby, Catrin; professor i nordiska språk, Institutionen för svenska och flerspråkighet, Stockholms universitet. 
Nylund Skog, Susanne; docent i nordisk folkloristik och etnologi, forskare, Dialekt- och folkminnesarkivet i Uppsala (DFU), Institutet för språk och folkminnen.

Nyström Höög, Catharina; professor i svenska, Akademin Humaniora och medier, Högskolan Dalarna.

Olofsson, Joel; fil.dr, universitetsadjunkt i svenska som andraspråk, Avdelningen för utbildningsvetenskap och språk, Högskolan Väst.

Romanitan, Mihaela Oana; MD, PhD, Överläkare i neurologi, Södersjukhuset. Stroh-Wollin, Ulla; professor i nordiska språk, Institutionen för nordiska språk, Uppsala universitet.

Sörlin, Marie; fil.dr, universitetslektor i svenska språket, Institutionen för nordiska språk, Uppsala universitet.

Tykesson, Ingela; docent, universitetslektor i svenska, Institutionen för kultur och lärande, Södertörns högskola.

Wide, Camilla; professor i nordiska språk, Nordiska språk, Åbo universitet, Finland. 


\section{Förändringar i redaktionen för Språk och stil}

Catrin Norrby har efter ett antal år som redaktör för Språk och stil valt att lämna detta uppdrag. Redaktionen framför ett varmt tack för alla insatser för tidskriften! Hon ersätts i Adolf Noreen-sällskapets styrelse och som redaktör för Språk och stil av Sofie Henricson, Åbo Akademi.

Redaktionen för Språk och stil 